Neuere Lyrik

INTERKULTURELLE UND INTERDISZIPLINÄRE STUDIEN

Хенрике Шталь / Екатерина Евграшкина (ред./сост.)

\title{
Субъект в новейшей русскоязычной поэзии - теория и практика
}






\section{Neuere Lyrik}

INTERKULTURELLE UND INTERDISZIPLINÄRE STUDIEN

\section{Хенрике Шталь / Екатерина Евграшкина (ред./сост.) Субъект в новейшей русскоязычной поэзии - теория и практика}

В новейшей русскоязычной поэзии субъект снова стал актуальным, проявляя себя как одну из наиболее продуктивных и новаторски реализуемых категорий. Характерны формы субъекта лишь едва намеченного, либо непрерывно меняющегося, как Протей, либо выстраивающего себя заново под влиянием мгновения или ситуации. Общие парадигмы этих форм можно назвать «транссубъектностью», «метасубъектностью» и «сверхсубъектностью». Книга призвана дать толчок обновлению теории и методологии изучения субъектности в поэзии. Взаимодействие литературоведческой практики с лингвистическими, когнитивными теориями, с новейшей западной теорией лирики, а также с философскими концепциями делает возможным многосторонний подход к сложным феноменам современной русскоязычной поэзии.

\section{Редакторы}

Хенрике Шталь, профессор, заведующая кафедрой славянских литератур Трирского университета и директор Центра продвинутых исследований «Русскоязычная поэзия в транзите: поэтические формы обращения к границам жанра, языка, культуры и общества между Европой, Азией и Америкой» (ННИС).

Екатерина Евграшкина, кандидат филологических наук и сотрудник Центра продвинутых исследований «Русскоязычная поэзия в транзите: поэтические формы обращения к границам жанра, языка, культуры и общества между Европой, Азией и Америкой» (ННИС). 
Субъект в новейшей русскоязычной поэзии - теория и практика 


\title{
NEUERE LYRIK
}

Interkulturelle und interdisziplinäre Studien

\author{
Herausgegeben von \\ Henrieke Stahl, Dmitri Bak, Hermann Korte, \\ Hiroko Masumoto und Stephanie Sandler
}

BAND 4 
Хенрике Шталь, Екатерина Евграшкина (ред./сост.)

\section{Субъект в новейшей русскоязычной поэзии - теория и практика}




\title{
Bibliografische Information der Deutschen Nationalbibliothek
}

Die Deutsche Nationalbibliothek verzeichnet diese Publikation in der Deutschen Nationalbibliografie; detaillierte bibliografische

Daten sind im Internet über http://dnb.d-nb.de abrufbar.

DFG, Projekt „Typologie des Subjekts in der russischen Dichtung der Jahre 1990-2010“

Umschlaggestaltung: (C) Olaf Gloeckler, Atelier Platen, Friedberg Umschlagabbildung: Holle Frank

\author{
ISBN 978-3-631-77057-3 (Print) \\ E-ISBN 978-3-631-77058-0 (E-Book) \\ E-ISBN 978-3-631-77059-7 (EPUB) \\ E-ISBN 978-3-631-77060-3 (MOBI) \\ DOI $10.3726 / \mathrm{b} 14788$
}

PETER LANG

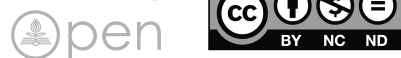

Open Access: Dieses Werk ist lizensiert unter der Creative

Commons Lizenz Namensnennung - Nicht kommerziell -

Keine Bearbeitungen 4.0 International (CC BY-NC-ND 4.0).

Den vollständigen Lizenztext finden Sie

unter: https://creativecommons.org/licenses/by-nc-nd/4.0/deed.de

(C) Henrieke Stahl, Ekaterina Evgrashkina, 2018

Peter Lang $\mathrm{GmbH}$

Internationaler Verlag der Wissenschaften

Peter Lang - Berlin · Bern · Bruxelles ·

New York $\cdot$ Oxford $\cdot$ Warszawa $\cdot$ Wien

Diese Publikation wurde begutachtet. www.peterlang.com 


\section{Содержание}

Хенрике Шталь / Екатерина Евграшкина (Трир)

Субъект в новейшей русскоязычной поэзии теория и практика

\section{К теории и типологии поэтического субъекта}

Хенрике Шталь (Трир)

Многоипостасная модель поэтического субъекта

Виллем Г. Вестстейн (Амстердам)

О проблеме фиктивности лирического субъекта

(на материале стихотворений Е. Шварц, О. Седаковой,

П. Барсковой и С. Кековой)

Владимир Новиков (Москва)

Два значения понятия «лирический герой» и их роль

для построения современной теории лирического субъекта

Сергей Бирюков (Галле)

Трансформация субъектности

Наталия Азарова (Москва)

Анализ многоязычия поэтического текста

как метод реконструкции субъекта

Наталья Фатеева (Москва)

К проблеме «номадического субъекта» в современной поэзии

Евгения Суслова (Москва)

Субъект и субъективация в новейшей русской поэзии:

подступы к типологии 
Ольга Соколова (Москва)

Отчужденный субъект в русской поэзии 2000-х гг.

Владимир Фещенко (Москва)

Дейксис как присутствие субъекта в поэтическом тексте:

теоретические подходы

Екатерина Евграшкина (Трир)

Игры с перспективой и «полагание» субъекта:

о дейксисе поэтического текста

Ольга Северская (Москва)

«Субъект» современной поэзии как

прагматическая переменная

Людмила Зубова (Санкт-Петербург)

Субъект и объект в современной поэзии

\section{Субъект в новейшей русской поэзии}

Роберт Ходель (Гамбург)

Поэтическая форма как фактор идентичности.

Сравнительный обзор русской лирики XX века

Юрий Орлиикий (Москва)

Соотношение лирического субъекта и типа стиха

в «вариативном» творчестве Сергея Завьялова

и Максима Амелина

Федор Двинятин (Санкт-Петербург)

Современные поэты-«не-поэты»:

от позиции и текста к субъектности

Марко Саббатини (Пиза)

Лирическое «мы» в творчестве Виктора Кривулина 1990-х гг. (анализ на примере книги стихов «Концерт по заявкам») 
Галина Заломкина (Самара)

Сопричастная субъективность в современной русской «непрозрачной» поэзии

Александра Третьякова (Трир)

Коммуникативные лирические отношения и способы выражения субъекта в поэзии Елены Зейферт

(на материале сборника «Веснег»)

Анна Гаврилюк (Трир)

Формы субъектности

в современной украинской гражданской поэзии

Ольга Северская (Москва)

Субъект лирический или публицистический?

(от чьего имени говорит новая социальная поэзия)

Александр Уланов (Самара)

Радикальная индивидуализация опыта:

субъект в поэзии А.Драгомощенко и А.Сен-Сенькова

Катина Бахарова (Трир)

Субъект в онейрических текстах Ольги Седаковой

и Елены Шварц (сравнительный анализ)

Валерий Гречко (Токио)

Лирический субъект в поэзии минимализма

Кирилл Корчагин (Москва)

Возвращение «мерцающего» субъекта:

московский концептуализм и поэзия 2000-2010-х годов

Марк Липовецкий (Боулдер)

«Цитатный» субъект: неоакмеизм, концептуализм, пост-концептуализм 
Александр Житенев (Воронеж)

Ready-made как опыт реконструкции лирического субъекта

Михаил Мартынов (Москва)

Особенности конструирования субъекта

в «поэзии вычеркиваний» 


\section{Хенрике Шталь / Екатерина Евграшкина (Трир)}

\section{Субъект в новейшей русскоязычной поэзии - теория и практика}

В настоящий сборник вошли статьи по итогам двух международных конференций: «Основы: теория лирического субъекта в контексте новейшей поэзии» (2-6 ноября 2015 г., Трирский университет) и «Типы субъекта и способы его репрезентации в новейшей поэзии (1990-2015 гг.)» (11-13 июля 2016 г., Институт языкознания и Институт русского языка им. В.В. Виноградова РАН). ${ }^{1}$ В конференциях приняли участие более 50 лингвистов и литературоведов из России, Германии, Италии, Нидерландов, Японии и США. Конференции были проведены в рамках трехлетнего немецко-российского проекта «Типология субъекта в русской поэзии 1990-2010-х гг.» (с 2015 по 2018 гг.), ${ }^{2}$ осуществленного при поддержке Немецкого научноисследовательского сообщества (DFG) и Российского гуманитарного научного фонда (РГНФ). Большинство участников проекта сотрудничают с кафедрой славистики Трирского университета уже с 2010 г., а на сегодняшний день входят в коллегию Центра продвинутых исследований «Русскоязычная поэзия в транзите» при Трирском университете ${ }^{3}$, также финансируемого НHИC (DFG). Отдельные статьи данного сборника написаны при поддержке этого Центра.

\section{О положении современной русской поэзии}

После крушения Советского союза и основания Российской Федерации русская литература прошла этап бурного развития, как в количественном, так и качественном отношениях, что позволяет говорить о ее новом расцвете в 1990 гг. Возникло множество различных художественных форм во всех литературных жанрах, характерной стала трансформация самих границ и функций родов литературы. Изменения в литературном пространстве, обусловленные, с одной стороны, социальными и экономическими

\footnotetext{
${ }^{1}$ Ряд статей этих конференций вошел в спецномер журнала „Russian literature“ под названием «Формы субъекта в новейшей русской поэзии». Номер в печати и должен выйти в 2019 г.

${ }^{2}$ Информация о проекте, программы конференций, фотоархив: www.lyrisches-subjektslavistik.uni-trier.de.

${ }^{3}$ См. информацию о Центре на сайте: www.lyrik-in-transition.uni-trier.de.
} 
последствиями, а с другой - новыми общественно-политическими задачами 2000-х гг., связанными с расширением возможностей благодаря развитию новых медийных средств и дигитализации всех сфер жизни, требуют пересмотра существующего теоретического и методологического инструментария гуманитарных наук, и в частности - филологии ${ }^{4}$. Поле литературы было подвержено сильным изменениям: вместо государственных литературных организаций образовалась литературная сцена с установкой, с одной стороны, на внутрилитературные, а с другой - на рыночные факторы, что привело к созданию новых функциональных связей литературы с обществом ${ }^{5}$, которые продолжали развиваться и трансформироваться с новой силой начиная с рубежа нового тысячелетия, как показывает, например, возникновение в поэзии эстетических дискурсивных стратегий в целях политической партиципации ${ }^{6}$.

В степени своего расцвета поэтические жанры не уступают эпическим, легче адаптирующимся к экономическим принципам новой эпохи, несмотря ни на финансовые проблемы, ни на общеотмеченную потерю «широкого» (массового) читателя ${ }^{7}$. За последние восемнадцать лет поэзия вышла из ниши и все более уверенно находит свой путь к молодому поколению и даже неинтеллектуальным слоям общества. Количество поэтов-непрофессионалов исчисляется тысячами; сайты поэзии и поэтри-слэмы, как и весь литературный ландшафт с широким спектром поэтических мероприятий, таких как чтения, конкурсы, фестивали, а также различные возможности для свободной, бесплатной или дешевой публикации в печатной или дигитальной формах образуют платформы, в том числе и независимые от столичных центров поэзии, в качестве которых все еще выступают, как и раньше, Москва и Санкт-Петербург. ${ }^{8}$ Ввиду этого развития российская литературная сцена создала стратегии профилирования и канонизации, которые при помощи рейтингов, присуждений премий, отбора публикаций важными литературными инстанциями, а также активной литературной

\footnotetext{
${ }^{4}$ Ср.: «Мы обсуждаем причины, почему то или иное явление, тот или иной автор, даже будучи популярными, могут оказаться за пределами изучения, „beyond the limits of scholarship“. Одна из важнейших причин заключается в том, что для интерпретации новых явлений буквально нет слов - нет терминологического и концептуального аппарата. Эти лакуны на деле приводят и к замалчиванию ярких авторов или произведений, и - в других случаях - к закреплению неверной терминологии. Сегодня, для того чтобы ввести значительную часть новейшей литературы в поле аналитики (не обязательно академической), требуется пересмотр нашего терминологического и методологического аппарата» (Кукулин 2008).

${ }^{5}$ См. более подробно: Menzel (2001).

${ }^{6}$ См. Майофис (2004); Корчагин $(2012,2013)$.

${ }^{7}$ См. Menzel (2000).

${ }^{8}$ Обзор новейшей поэзии дают следующие интернет-источники: http://www.rvb.ru/np/ index.htm, http://www.vavilon.ru/, http://www.litkarta.ru/ и др.
} 
критикой и научными исследованиями влияют на позиционирование автора в литературном пространстве, что в целом характерно и для поэзии. Селективным стратегиям противостоят мероприятия по культивированию широкого литературного многообразия, нацеленные, насколько это возможно, на отказ от нормативных критериев отбора. Неслучайно в связи с этим в русской литературной практике последних лет важна дискуссия о литературном каноне и теории поля, ставшая значимым предметом рефлексии в отечественной и зарубежной русистике. Другими актуальными темами дискуссий в русистике и славистике являются различные подходы к методологии истории литературы, нацеленные на развитие адекватных методов описания специфики литературного процесса с 1930 г. и его влияния на литературную ситуацию со времен Перестройки и по сегодняшний день. При этом проявляется тенденция к дифференцированному рассмотрению истории литературы по родам, что обусловлено высокой степенью ее сложности. 9

В общей истории современной литературы (со середины 1980-х гг.) поэзии - по примеру более ранних эпох - изначально была отведена маргинальная позиция: по сравнению с другими родами она в значительно меньшей степени принимается во внимание, и особенно это касается современной поэзии, говорить о которой часто предоставляется исключительно литературной критике. Русское литературоведение посвящает себя изучению современной поэзии в лице лишь немногих исследователей - несмотря на то, что на сегодняшний день она достигла такого уровня развития, который по части широты и многообразия поэтического спектра по сравнению с предыдущими эпохами истории русской литературы может быть охарактеризован как уникальный и беспрецедентный. ${ }^{10}$ В самой России поэзией занимаются прежде всего лингвисты. Это объясняется тем, что для современной русской поэзии характерна сверхсложная и многосторонняя работа с языком и многоязычием, а в русской лингвистике сохранилась живая традиция изучения поэзии и современной литературы в духе формализма и структурализма. В других странах также найдется сравнительно немного филологов, занимающихся русской современной поэзией, однако они, в отличие от российских исследователей, в основном литературоведы.

Принимая во внимание спектр упомянутых выше проблем и лакун, новейшие исследования ориентируются на историю литературы, обусловленную спецификой конкретного литературного рода и одновременно на-

\footnotetext{
${ }^{9}$ См. об этом подходе: Шталь / Рутц (2013), Рутц (2013). См. также проект по проблеме канона: „Reconfiguring the Canon of Twentieth Century Russian Poetry, 1991-2008“ (20102013): http://humanities.exeter.ac.uk/modernlanguages/russian/ research/russianpoetrycanon/. ${ }^{10}$ Подробный обзор исследований по данной теме был сделан нами во введениях к сборникам материалов конференций ННИС о современной русской поэзии 2010 и 2013 гг.: Шталь / Рутц (2013), Шталь / Рутц (ред., 2013); Stahl / Korte (2016), Stahl / Korte (2016, Hgg.).
} 
правленную на поиск трансжанровых перспектив исследования в теории и литературоведческой практике. В последние восемь лет сложилось поле исследования современной поэзии, принимающее во внимание как предшествующую историю литературы советского времени и Перестройки, так и другие роды литературы. Мы непосредственно участвовали в формировании этого поля исследования, организовав в 2010 и 2013 гг. две конференции, финансируемые ННИС, ${ }^{11}$ благодаря которым возникло международное научное сообщество по изучению современной поэзии, включившее также германистов и, в последнее время, специалистов по другим литературам. На этом сотрудничестве базируется и составляющий основу данной книги проект о типологии субъекта, реализуемый кафедрой славистики Трирского университета вместе с Институтом языкознания РАН и его Центром лингвистических исследований мировой поэзии. В настоящее время совместная работа сосредоточена в Центре исследований «Русскоязычная поэзия в транзите», финансируемом ННИС и поставившем себе целью развитие систематического подхода к описанию современной поэзии путем сравнительного анализа различных литератур Европы, Азии и Америки. ${ }^{12}$

Современная русская литература в целом и поэзия в частности характеризуются высокой степенью сложности и разнородности. В 1990-е гг. авторы и читатели как бы параллельно жили в пространстве частично изолированных, частично пересекающихся, но в основном конфликтующих «литератур». Этот раскол демонстрирует дальнейшее развитие литературной ситуации советского времени, когда возникли две параллельные и лишь точечно соприкасающиеся друг с другом «истории» русской литературы с 1930 г.: официальная vs. неофициальная / неподцензурная литература. ${ }^{13}$ Обе эти «литературы» располагали собственным пантеоном классиков, характерным жанровым спектром, алгоритмом взаимодействия с другими литературами и т.д. С Перестройкой на российскую литературную сцену вышла и литература русского зарубежья, т.е. эмигрантская литература; также усилилось внимание и к литературе других стран - в особенности Европы, Азии и Америки. На рубеже тысячелетий заявили о себе влияние на поэзию новых медиа, а также все более ощутимая на сегодняшний день транскультурная ${ }^{14}$ ее ориентация.

\footnotetext{
11 STA 1010/4 (Publikation: Шталь / Рутц (ред.) 2013); STA 1010/5-1 (Stahl / Korte (Hgg.) 2016). См. также хронику конференции: Евграшкина (2014).

${ }^{12}$ См. более подробно сайт: https://lyrik-in-transition.uni-trier.de/

${ }^{13}$ Кукулин (2010).

14 О понятии транскультурной литературы: Iljassova-Morger (2009). Понятие «транскультуральность» (,Transkulturalität“) относится к гибридным культурным образованиям или процессам трансформации (Binder et al. 2016), в то время как «интеркультуральность» (,Interkulturalität“") подразумевает дистанцирование и диалог, а гиперкультуральность („Нуреrkulturalität“") - освобождение от иерархически кодируемых форм пространства, времени и идентичности (Han 2005).
} 
В 1990-е гг. и на рубеже веков отдельные «истории» литературы обнаруживали тесную связь с проблемой поколений; сегодня данная проблема постепенно утрачивает свою актуальность, поскольку молодые авторы одновременно могут примыкать к различным более ранним традициям, так что многообразие стилей письма примерно с рубежа веков можно охарактеризовать скорее посредством концепта «одновременность неодновременного», нежели посредством констатации поколенческого и социального расслоения. ${ }^{15}$ Существуют единичные и находящиеся в постоянной трансформации стили письма, которые способствуют рассмотрению литературных групп как в первую очередь социального феномена вне связи с эстетикой. ${ }^{16}$ Такая ситуация значительно затрудняет обзор поэзии с начала 1990-х гг. ${ }^{17}$

Помимо этого, исследование стоит перед той проблемой, что для обзора недостаточно имеющихся на данный момент фундаментальных работ по отдельным авторским поэтикам, в то время как отдельным анализам не хватает контекстуализации и выявления более глубоких взаимосвязей. По сравнению с филологическими дисциплинами по другим языкам и литературам русистика обнаруживает и относительно явный дефицит развития теории и методологии, что касается прежде всего концептов лирики и поэзии.

Целью работ, составляющих данный сборник, является изучение освещенного выше круга проблем путем фокусированного обзора эстетического многообразия поэтического поля. Поскольку при актуальной литературной ситуации невозможно использовать в качестве упорядочивающего принципа для организации исследования границы между так называемыми группами и течениями, предлагается осуществить более глубокий анализ

15 Данный тезис был предложен Ильей Кукулиным на вышеупомянутой конференции ННИС в 2013 г.; в своем докладе он применил понятие «неодновременности» („Ungleichzeitigkeit“) Эрнста Блоха для описания развития литературного процесса, см. Kukulin (2016). См. также: «Применительно к современной русской поэзии точнее будет говорить не о направлениях, но об эстетических тенденциях, которые по-разному взаимодействуют в творчестве разных авторов» (Кукулин 2010).

${ }^{16}$ Ср. Давыдов (2017). Существуют проекты образования поэтических сообществ, например, по поколенческому или региональному принципам, или декларируется некоторая общая тенденция, которая лишь благодаря самой декларации может привести к образованию группы или направления (ср. «[...] само предшествование декларации осознанию некоторой общности - вопреки распространенному заблуждению - явление чрезвычайно распространенное [...]»; Давыдов 2017). Примером объявления тенденции с последующим образованием группировки являлась Московская концептуальная школа (МКШ) (см. там же: «[...] МКШ была сконструирована в отчасти декларативном, отчасти аналитическом тексте Бориса Гройса „Московский романтический концептуализм“ [...]»), а пример направления, объединившего поэтов с радикально разными поэтиками - так называемый «новый эпос» (термин Федора Сваровского для характеристики «эпизированной» поэзии 2000-х гг.). Об этом «манифесте» в журнале РЕЦ 2007 г. с декларативным отбором авторов и стихотворений на сайте polutona.ru см.: Кукулин (2008).

${ }^{17}$ Rutz (2011). 
отдельных репрезентативных произведений посредством некой общей и наиболее показательной для сравнения категории. В ходе обеих упомянутых конференций 2010 и 2013 гг. была доказана целесообразность типологического подхода, поднимающего вопрос об эстетических парадигмах по ту сторону социолитературного поля. ${ }^{18}$ Чтобы достичь наиболее высокой степени сопоставимости, в данном сборнике было решено сфокусировать внимание на одной избранной категории, с помощью которой могла бы быть разработана типология форм ее проявления. Такой показательной категорией был избран «субъект», поскольку, являясь фундаментальным понятием, он позволяет исследовать общее поле современной поэзии и функциональность ее отношения к миру и обществу, снова ставшую особо значимой начиная с рубежа веков.

\section{О лирике и поэзии}

«Лирика» относится к ряду тех проблематичных понятий, определение которых является непреходящей задачей теории литературы. Множатся попытки уклониться от «минимального определения» („Minimaldefinition“) лирики как «монологической речи в стихах» (,Einzelrede in Versen“) ${ }^{19}$, которое, безусловно, мало подходит для современной поэзии. Обусловленным «спектрами признаков» (,Merkmalsbündeln“), расплывчатым, но при этом принимающим во внимание специфику культур и эпох абстрактным моделям ${ }^{20}$ противостоят трансисторические и акультурные подходы, определяющие лирику как перформативную фикцию и «трансисторический» концепт в рамках учения о прототипах ${ }^{21}$ или как саморефлексивный языковой конструкт в рамках «метатеории» (,Display sprachlicher Medialität“ [дисплей языковой медиальности], „Katalysator ästhetischer Evidenz“ [катализатор эстетической очевидности] $)^{22}$, либо же в качестве анахронизма возводящие ее к магическим практикам ${ }^{23}$. Однако современная лирика породила формы, которые невозможно охватить ни с помощью некоего абстрактного «спектра признаков» из более ранних эпох, ни посредством соотнесения с неким (кажущимся) трансисторическим прототипом. Нередко такие тексты, как, например, лишенные субъекта или говорящего коллажи из обрывков речи и цитат, тексты без характерных для лирики формальных элементов (от рифмы до маркированных стилевых средств) и тем не менее названные

${ }^{18}$ Ср.: Шталь / Рутц (2013), Stahl / Korte (2016).

${ }^{19}$ Lamping (1989, S. 63); Völker (1997, S. 167).

${ }^{20}$ Cp. списки критериев в работах: Wolf (2005), Klotz (2011).

${ }^{21}$ Hempfer (2014, S. 10).

22 Zymner (2009; 2013, S. 7).

${ }^{23}$ Schlaffer (2012). Сp. с обзором новейших теорий лирики с XVIII в.: Zymner (2011). 
«стихотворениями», тексты, нивелирующие границы с другими классическими родами литературы, и т.д., тем не менее предъявляются автором как безусловно лирические или поэтические. Определения лирики и лирического субъекта, характерные для более ранних эпох, таким образом, не могут быть безоговорочно перенесены на тексты XX и тем более XXI веков.

Подход, принимающий во внимание взаимодействие авторского (само)определения и рецепции репродуцируемой либо же трансформированной нормы $^{24}$ со стороны автора и читателей, напротив, способствует адекватному восприятию транзиторных форм современной поэзии. Он позволяет описать формы, функции и процессы, не исключая заранее некоторого множества текстов на аксиологическом основании. В связи с этим настоящий сборник подводит к более широкому пониманию лирики, а в статьях предпочитается говорить о «поэзии» (текстах в стиховой форме) или более обобщенно о «поэтических текстах». Соглашаясь с П. Хюном и Ю. Шёнертом $^{25}$, мы исходим из предположения, что роды литературы представляют собой исторически сложившиеся и культурно обусловленные формы, изменения признаков и функций которых можно описать, не предполагая некоего трансисторического или метатеоретического концепта. Все тексты названного периода времени, маркированные - за счет места публикации, авторского определения или других сигналов для рецепции - как лирические или поэтические, служат, таким образом, объектом нашего исследования. Интересующий нас временной период охватывает поэзию с 1991 года, причем неотъемлемую часть исследования составляет ретроспективное обращение к предшествующей истории поэзии. Этот год следует понимать как приблизительное обозначение рубежа, который обусловлен исторической вехой развала СССР и принятием Конституции Российской Федерации.

\section{Субъект в поэзии}

Как в абстрактных моделях, так и в функциональных и эссенциалистских подходах с начала осмысления понятия рода лирический субъект рассматривается в качестве основополагающего или даже важнейшего конститутивного элемента. П. Хюн и Ю. Шёнерт ${ }^{26}$ указывают на то, что конвенциональное утверждение о стихотворении как «медиуме для само-артикуляции и само-конструировании говорящего» восходит уже к античности. Во времена усиленной рефлексии категории литературных родов - особенно в эпоху Ренессанса, а также в XVIII и раннем XIX веках - подчеркивалась неразрывная связь лирики с субъектом, как, например, у Гердера

\footnotetext{
${ }^{24}$ Более подробно об этом см. фундаментальный труд Харальда Фрике: Fricke (1981).

${ }^{25}$ Hühn / Schönert (2002, S. 289).

${ }^{26}$ Hühn / Schönert (2002, S. 290).
} 
(лирика как выражение чувств) или у Гегеля, оказавшего наибольшее влияние на дальнейшее восприятие лирики как поэтической формы выражения субъективного. ${ }^{27}$ Гегелевское определение «лирического» ${ }^{28}$ вновь и вновь «возвращается» в разнообразных вариантах - прежде всего в немецко- и русскоязычных пространствах. В XX веке сами поэты, как, например, Готфрид Бенн в своей влиятельной марбургской речи «Проблемы лирики» (1951) или Осип Мандельштам в эссе «О собеседнике» (1913), имевшем особое значение для Пауля Целана, пытались ставить и решать вопросы об отношениях авторства и лирического Я, поэтического языка и субъективной автономии, о соотношении с реальностью и о поэтическом «разрушении действительности» (,Wirklichkeitszertrümmerung“, G. Benn). После того как в модернизме (как известно, в качестве признаков этой эпохи Гуго Фридрих ${ }^{29}$ назвал деперсонализацию и дегуманизацию), а затем и с большей уверенностью в постмодернизме была констатирована «смерть» субъекта или, по крайней мере, его «исчезновение» ${ }^{30}$, многие авторы, особенно после 2000 г., снова задаются вопросом о категории «лирического Я» в современной поэзии. Субъект и субъективность, несмотря на приписываемую им анахроничность, в современной поэзии вновь становятся актуальными. В новейшей же теории лирики, напротив, проявляется тенденция к рассматриванию не только субъективности, но и самого субъекта как категорий, не являющихся определяющими с точки зрения литературных родов, и поэтому их больше не трактуют в рамках теорий лирики, в связи с чем замедляется и развитие методики исследования субъектных форм в поэзии.

Теория лирики XX века породила многочисленные модели определения субъекта, вследствие чего, соответственно, сложилась разнородная и многозначная терминология. ${ }^{31}$ Основной термин - «лирическое Я» - в 1910 г. был предложен Маргарете Зусман, в 1916 г. введен Оскаром Вальцелем в теоретический дискурс (хотя первое свидетельство относится уже к 1894 г.) и благодаря этой рецепции нашел свое широкое распространение во всем мире $^{32}$ (включая Россию, см. статью В. Новикова в данном сборнике). Изначально термин был призван различать «эмпирического» автора и манифестируемую в тексте инстанцию Я, которая выступает в текстопорождающей функции и тем самым располагает к идентификации с самим автором $^{33}$. «Лирическое Я», которому таким образом приписывались противо-

\footnotetext{
${ }^{27}$ Völker (1997, S. 164). Ср. также высказывания о Гегеле: Culler (2015, p. 92-109).

${ }^{28}$ Hegel (1970, S. 420).

${ }^{29}$ Friedrich (1985, S. 36, 172).

${ }^{30}$ Bürger / Bürger (2000).

${ }^{31}$ Cp. с обзором: Jaegle (1995, Kap. 2).

${ }^{32}$ См. более подробно: Borkowski / Winko (2011).

${ }^{33}$ Ср. об этом «имплицитном поэтическом пакте»: Fischer (2007, S. 72).
} 
речивые значения, так что Вальтер Килли ${ }^{34}$ уже в 1972 г. подчеркивал непригодность этого термина и рекомендовал отказаться от его употребления, по этой причине и на сегодняшний день не находит своего широкого применения в исследованиях по германистике. Также и в более позднее время неоднократно указывалось ${ }^{35}$ на терминологическую неоднозначность понятия «лирическое Я», в основе которой лежали различные способы его концептуализации.

С проблематизацией «лирического Я» появляются альтернативные понятия, которые, однако, остаются тесно связанными с определенными теориями и поэтому не находят широкого распространения. Эти понятия частично не покрывают значения, которые ранее отводились так называемому лирическому Я. Примеры таких новых терминов - «лирический субъект» („,lyrisches Subjekt“; Stierle 1979), «поэтическое Я» (,poetisches Ich“; Charpa 1985), «Я» (,das Ich“; Burdorf 1997), «„носитель“ лирического голоca» (,, Träger" der lyrischen Stimme“; Lüders 1965), «эксплицитная / имплицитная субъективность» (,explizite / implizite Subjektivität“; Müller 2004), «композиционный субъект», «субъект выражения / высказывания» („Kompositionssubjekt““, „Äußerungssubjekt“; Hühn 1995³6) или просто говорящий и адресант (Sprecher und Adressant). Сюда же относятся и другие понятия, обозначающие инстанции более высокого уровня: «самость» (,Selbst“; Peper 1998), «текстовый субъект» (,,Textsubjekt“ как параллель к «абстрактному автору» коммуникативной модели в нарратологии ${ }^{37}$ ), «имплицированный / подразумеваемый субъект» или «субъективность перспективы» (,,impliziertes Subjekt‘“38 oder „,Subjektivität der Perspektive“; Burdorf 1997) и т.д. В других странах формировались аналогичные, а также иные понятия.

В России терминология, как и теория лирики, в значительной степени оставались обозримыми. Понятийный ряд традиционно составляют «лирический субъект», «лирическое Я» с его ипостасями - «эмпирическим» и «поэтическим Я» ${ }^{39}$, а также «лирический» и «ролевой» «герой» и абстрактные инстанции «авторское сознание» и «образ автора / поэта»; лишь в недавнее время, вследствие рецепции европейских теорий лирики, терминология значительно расширилась. В русской филологии в основном представ-

\footnotetext{
${ }^{34}$ Killy (1972, S. 4).

${ }^{35}$ См. Burdorf (1997, S. 192). Л. Фёлькер (Völker 1997, S. 167) неоднозначно говорит о некой «терминологической фиксации „лирического Я“» (,terminologische Fixierung des ,lyrischen Ich““). Обзор истории употребительных понятий лирического Я дают, к примеру: Martínez (2002) и более детально: Borkowski / Winko (2011).

${ }^{36}$ Cp. Easthope (1983, pp. 43-45): ,subject of the enounced“/, „subject of enounciation“.

${ }^{37}$ Burdorf (1997, S. 194-195).

${ }^{38} \mathrm{Cp}$. Stephens (1982, pp. 60-62); это понятие нельзя путать с «имплицитным поэтом» (,implicit poet“; Wright 1960).

${ }^{39}$ Ковтунова (2006, с. 27).
} 
лены отдельные исследования о лирическом Я, субъекте или лирическом либо ролевом герое в поэтических произведениях различных признанных и преимущественно старых, нежели новых, классиков - притом чаще всего это диссертации ${ }^{40}$ (публикуемые в большинстве случаев лишь в виде авторефератов). Исследования по субъекту в современной поэзии в первую очередь направлены на авторов, чья поэтика оказалась под влиянием русского концептуализма, либо которые в 2010-х гг. представляют быстро набирающую в весе политическую поэзию ${ }^{41}$. Работы по субъекту можно также найти и среди русских лингвистических исследований современной поэзии. ${ }^{42}$

Ввиду большого числа различных теорий и терминологических систем, принятых в мировом научном сообществе, в предложенной книге не представляется возможным дать точные нормативные определения указанным терминам. Однако внимание, безусловно, уделяется тому, чтобы использование терминов было осознанным, причем в качестве ведущих критериев выступают, с одной стороны, ссылка на выбранную теоретическую модель и соответствующие методологические подходы, а с другой - их обоснованная адекватность феномену. Понятие «субъект» было выбрано в качестве общего для всего сборника, при этом оно, по аналогии с понятием «лирика», понимается широко и не определяется сугубо с позиции философии и теории познания, психологии и нейрофизиологии или теории поэзии и литературы, что позволяет внести в исследование множество понятий, закрепленных за определенными теориями, так что в равной степени могут быть изучены как конкретные формы, например, Я в стихотворении, выступающее в роли явного или скрытого говорящего, так и абстрактные концепты субъектности. Мы исходим из предположения о том, что для анализа современной поэзии с присущим ей разнообразием форм организации субъектного начала требуется и соответствующий, как можно более диверсифицированный, инструментарий, который еще требует своего дальнейшего развития.

Во многих исследованиях дается обзор авторитетным теориям лирического субъекта / Я, а также предпринимаются попытки типологизации их моделей (Borkowski / Winko 2011). ${ }^{43}$ При этом проявляется тенденция к возрастающей абстрактности типологий, которые обязаны, соответственно, предшествующим им подходам: к примеру, В. Мюллер суммирует 8 подходов (Müller 1979), М. Мартинез - 6 (Martínez 2002), а С. Шварц только 3 (Schwarz 2007). 3. Шидермайр (Schiedermair 2004) предлагает

\footnotetext{
40 См., например: Житенев (2008); Голынко-Вольфсон (2012); Корчагин (2013); а также диссертации: Нурмухамедова (2008); Штраус (2009); Зотеев (2011). Важные исследования по произведениям авторов предыдущих поколений: Бобров (1989); Мансков (1999); Романов (2004); Соколова (2006).

${ }^{41}$ Майофис (2003); Корчагин (2012, 2013).

${ }^{42}$ Например, Фатеева (2013).

${ }^{43}$ См. также Шталь (2016, с. 165-169).
} 
лингвистическую типологизацию, которая позволяет свести разнообразие моделей к основополагающей проблеме - восприятию языка. Исходя из этой идеи, мы предлагаем следующую категоризацию различных теорий: в том случае, если язык прежде всего понимается через отношения референции (I), антагонистичные линии теории о гипостазированном субъекте (Іа) и его отрицании (Ib) - в первую очередь в постструктуралистских и постмодернистских подходах - могут рассматриваться как оборотные стороны одной медали. ${ }^{44}$ Обе линии исходят из одного объекта референции - будь то онтическое или семантическое понимание / определение. При этом нормативно-мировоззренческие положения о природе субъекта (Я) в теории литературы интерполируются и проецируются на лирику. Принципиально иной тип образуют функциональные подходы (II), перенимающие и в некоторых случаях комбинирующие лингвопрагматические теории (IІа) или коммуникативные и рецептивные модели (IIb). Теория субъекта - одна из тех областей, в которых весомый вклад внесло языкознание, как русское, так и германское.

Модели типа Іа сосредотачиваются на статусе субъекта, чья идентичность, близость или удаленность от образа реального автора рассматриваются по-разному. После 1970 г. преобладают подходы, утверждающие разницу между автором и лирическим Я. Сюда можно отнести и советские исследования ${ }^{45}$. Возникшая путем элиминации авторского Я «лакуна» лирического Я / субъекта заполняется различными теоретическими конструктами в функции нового объекта референции. Это ведет к дифференциации различных инстанций и уровней Я / субъекта, охватывающих как конкретные формы, так и абстрактные концепты: например, определение лирического Я в теории познания как «единства трансцендентной структуры представления» (,Einheit der transzendentalen Vorstellungsstruktur ${ }^{646}$ ) или как ,,signature“447 - индивидуально-характерной формы выражения, в которой должен отражаться реальный автор. ${ }^{48}$ Независимо от языкового выражения «Я» либо замещающих его форм, эти подходы позволяют извлечь субъективность как матрицу текста из его формы (как центр восприятия / перспективации и продуктивную эстетическую форму). Возвращение эссенциализма можно наблюдать у А. Брема, рассматривающего лирику как уникальное и неподдающееся типологизации «выражение констелляции субъекта и мира» (,Ausdruck der Konstellation von Subjekt und Welt“449).

\footnotetext{
${ }^{44}$ Сходные положения см. в: Schiedermair (2004, S. 38).

${ }^{45}$ См., например: Сильман (1977, с. 76), а также исследования Гинзбург и Кормана.

${ }^{46}$ Peper (1972, S. 408).

${ }^{47}$ Perloff (1999).

${ }^{48}$ См.: Wright (1960, p. 83), а также: Müller (2011, S. 57, Sp. 1).

${ }^{49}$ Brehm (2013, S. 10).
} 
В процессе постструктуралистской семиотизации, отождествившей мир и текст, субъект уступил место субъективности как целенаправленно фиктивному конструкту (Ib), который с позиции философии языка или психоанализа был объявлен риторико-языковой структурой ${ }^{50}$, продуктом языка и неосознаваемых процессов. В то же время началось освоение постмодернистских теорий субъекта в теории литературы. Важными мерилами стали отрицание автономного и субстанционального субъекта и допущение лишь некоего воображаемого единства в действительности разнородного и децентрированного множества (Лакан, Кристева). Идеи французского постструктурализма и постмодернизма нашли свое распространение в России в 1990-е гг., хотя некоторые независимые идейные параллели, сложившиеся, однако, в иных условиях, можно усматривать уже в русском концептуализме ${ }^{51}$.

В известной степени антагонистичными по отношению к типам Ia / b выступают функциональные подходы (II), которые не наделяют идею / концепт субъекта определенным содержанием и от вопроса о «сущности лирического Я» переходят к анализу «употребления языковых средств» ${ }^{52}$ и прочих специфически эстетических приемов. Подходы (ІІа) ориентируются на лингвистику и анализируют в стихотворении главным образом структуру высказываний. Так, употребление личных местоимений вслед за Оскаром Вальцелем исследует Вольфганг Локеман (Lockemann 1973), а позже - Дитер Бурдор $\phi^{53}$; тот же предмет исследования актуален и в русской лингвистике. ${ }^{54}$ Другие подходы на лингвистической основе разрабатывают гипотезу о том, что субъектность может формироваться в тексте независимо от использования личных местоимений: например, в своей недавней работе Клаус Хэмпфер ${ }^{55}$ распознает «прототипическую структуру лирического высказывания» (,prototypische Struktur lyrischer Äußerung“) в «перформативной фикции» („Performativitätsfunktion“), т.е. в синхронности фиктивного, воображаемого речевого акта и самой оговоренной ситуации. ${ }^{56}$ Каспар Шпиннер (Spinner 1975) сводит вместе функциональную прагматику, позволяющую определить лирическое Я как «пустой дейксис» („Leerdeixis“), и положения рецептивной эстетики (Iser) о «пустом месте» („Leerstelle"). Лирическое Я понимается как функция в рецептивном процессе. Сюда же относится и теория 3. Шидермайр ${ }^{57}$, которая различает субъект

${ }^{50}$ Cp. Horn (1995, S. 302).

${ }^{51}$ См.: Эпштейн (2000 / 2005).

52 Burdorf (1997, S. 193).

${ }^{53}$ Burdorf (1997, Kap. 5.3).

${ }^{54}$ Ковтунова (2006).

${ }^{55}$ Hempfer (2014, S. 34).

56 О различении понятий „Performance“, „Performanz“ [перформанс, выступление] и „Performativität“ [перформативность] ср.: Hempfer (2011).

${ }^{57}$ Schiedermair (2004, S. 84). 
речевого акта и субъект, чье восприятие и опыт составляют содержание высказывания. Так она образует точку пересечения со второй функциональной линией, которая дифференцирует функциональные уровни субъекта в тексте и объединяет подходы, примыкающие к теории коммуникации и ее адаптации в нарратологии (IIb). Нарратологическая модель коммуникации с ее иерархией инстанций разных уровней неоднократно проецировалась на лирику. ${ }^{58}$ Однако подобные трансжанровые попытки не избежали критики. ${ }^{59}$ В этом контексте особое значение отводилось вопросу о визави адресанта, об адресате и читателе / слушателе / реципиенте. ${ }^{60}$ Эта инстанция таким же образом анализировалась по специфическим уровням коммуникативной модели (реальный, абстрактный / имплицитный, фиктивный адресат), в ней усматривали связующее звено между читателем и текстом и, наконец, даже продукт самого читателя. Именно подходы в русле теории дискурса (например, Stierle 1979 или Easthope 1983) в основном видят в читателе инстанцию, определяющую дискурс.

В основе этой книги лежат наблюдения, что в теориях лирического субъекта нередко проявляются особые предпочтения относительно определенных эпох, жанров и даже авторов и текстов, которые, соответственно, берутся в качестве примеров в первую очередь. Такие примеры демонстрируют идейную и / или формальную близость основным положениям соответствующих теорий - это в равной степени касается типов Іа и b, в то время как тип II ввиду своей функциональной направленности допускает более широкий спектр примеров. Однако проблема типа II связана в большинстве случаев с фактическим отсутствием содержательного высказывания о модели субъекта в поэтическом тексте. Функциональные подходы разделяют преобладающее сегодня в литературоведении сомнение в научности интерпретации. ${ }^{61}$

Это наблюдение подкрепляет положение теории науки о том, что теории и, соответственно, методы участвуют в формировании способов видения объекта и в значительной степени самого объекта. Если цель исследовательского процесса состоит в пополнении знаний об объекте, необходимо стремиться к известному согласованию подхода, метода и самого объекта. В таком случае не стоит отклонять эссенциалистские подходы как таковые, если они применяются к текстам, которые сами выстраиваются на эссенциалистской основе. Но принципиально необходимым представляется осознанное обращение со структурой, формой и функциями текста, учитывающее уровни коммуникативной модели. К тому же, как в прошлом в модернизме, так и сейчас в современной поэзии теория является «важной со-

\footnotetext{
${ }^{58}$ Grübel (1987), Bernhart (1993), Burdorf (1997), Schönert (1999), Hühn / Schönert (2002) и др.

${ }^{59}$ См., например: Müller (2004, S. 95).

${ }^{60} \mathrm{CM}$. типологию адресатов: Coenen-Mennemeier (2004).

${ }^{61}$ Cp.: Stahl (2013).
} 
ставной частью» ${ }^{62}$ : поэты создают тексты с оглядкой на определенные идеи, модели и теории, знание которых должно стать предпосылкой анализа.

По этой причине в основе данной книги лежит плюралистический подход, допускающий свободный выбор методов и теорий, а также развитие собственных концептов, но при этом настаивающий на убедительном обосновании этого выбора в соответствии с предметом исследования и поэтическими текстами и на интерсубъективной «прозрачности» анализа текстовых феноменов.

\section{Формы субъекта в современной русской поэзии}

В русле историко-литературной традиции со времен античности развивались различные формы лирического субъекта - от автобиографичного Я и воображаемого Я как маски, а также множественных личин Я (personae), до фрагментации, метаморфозы, растворения и замены конкретного субъекта голосами и т.д. - и его отношения к другим лирическим инстанциям различных уровней текста и вне текста (лирическое Ты, абстрактный автор, реальный автор). Современная поэзия демонстрирует осознанную игру с этими возможностями самой традиции и ссылающимися на нее теориями и моделями описания, так что в современной поэзии можно вести речь о своеобразной лирической метасубъектности. Новейшая поэзия создает различные формы синтеза разнородных и противоречивых традиционных типов лирического субъекта.

Как показывает содержание этого сборника, в современной поэзии можно выделить основные типы формирования субъекта, которые позволяют структурировать множество индивидуальных вариантов его поэтической реализации и сделать более наглядной их специфику. Современный спектр форм включает в себя три основных типа формирования субъекта: а) исчезновение / растворение / дисперсия субъекта, b) его [в основном мнимое] отсутствие и с) [новое] конституирование субъекта и субъективности.

Формы дезинтеграции субъекта (а) в поэтических текстах проявляются в виде множественных трансформаций, ролевых игр и маскарада, воображаемой дезориентации, плюрализма голосов, а также коллажей из фрагментов восприятия, цитат, аллюзий или реди-мейдов, которые ведут не только к упразднению говорящего, но и в крайних случаях к полному расфокусированию и деперспективации. Дезинтеграция субъекта остается актуальной и в новейшей поэзии и часто сопровождает распад поэтических форм (например, у Сергея Бирюкова, Ры Никоновой, Анны Альчук, Константина Кедрова, Елены Кацюбы; см. также статью С. Бирюкова в настоящем сборнике).

\footnotetext{
${ }^{62}$ Völker (1997, S. 163).
} 
Мнимое отсутствие и скрытое присутствие субъекта (b) можно обнаружить у авторов, дебютировавших в 1990-2000-е гг.: с одной стороны, отрицание автономного субъекта давно стало общим местом, а с другой - общественная ситуация требует, напротив, формирования самостоятельного субъекта как основы демократии. При этом авторы, работающие с осознанием исторических и общественных тенденций, как, например, Арсений Ровинский или Ника Скандиака, разделяют ощущение того, что субъект выпал из «исторического нарратива», образованного идеологиями, а также из самих социальных связей. Их ответом на это служит поэтическая проблематизация субъекта, чей «уход в тень» проявляется вплоть до его полного исчезновения в качестве осязаемой текстовой инстанции, а именно в отношении не только отсутствующих личных местоимений и соответствующих глагольных форм первого лица, но и самой возможности реконструировать центр перспективы высказывания. Однако существует и противоположная ситуация, когда имплицитный субъект осознанно формируется как текстовая инстанция на менее очевидном уровне аллюзий и композиции, либо как динамичная сила организации поэтической структуры в целом (ср. статьи К. Корчагина, М. Липовецкого, М. Мартынова в настоящем сборнике). Так, некоторые поэты оставляют субъект прозрачным для Другого, либо проектируют его отсутствие, но при этом он может появиться в языковом пространстве снова - не всегда в открытую - как голос и форма или прием (например, у Михаила Сухотина, Наталии Азаровой), либо как структурообразующая константа, выходящая за пределы конкретного текста - особенно в циклах и поэтических книгах.

Формы нового конституирования субъекта (с) обнаруживаются у авторов, в свете общей тенденции к его элиминации преобразующих поэзию в откровенно автобиографичный нарратив (Елена Фанайлова, Дмитрий Воденников, Тимур Кибиров и др.). Сильная позиция лирического Я, как это проявилось особенно явно начиная с рубежа веков в поэзии так называемой «новой искренности» ${ }^{63}$, часто сопровождает функциональные задачи, как, например, детабуизация некоторых явлений или общественная и политическая критика. Существует параллель между тенденцией к автобиографически маркированному Я и дигитальными медиа, в которых в качестве ответной меры по отношению к виртуальности выступает создание видимости аутентичности и индивидуальности, как это можно наблюдать в социальных сетях. Вообще говоря, откровенность некоторых современных поэтических текстов может (или должна) казаться популистской, и тем не менее при внимательном рассмотрении обнаруживается, что она не более чем симуляция, когда, к примеру, запускается в действие путем двойного отрицания или подчеркнутой нарочитости. Возрождение романтизирован-

${ }^{63}$ Rutten (2012). 
ных форм Я - по крайней мере, в профессиональной поэзии - было подорвано критикой и требует их переоценки.

Оба первых типа (a) и (b) обнаруживают также и переходные формы к новому конституированию субъекта (c): так, в политической поэзии имеет место сильная позиция Я-инстанций, которые, способствуя развитию концептуалистских практик и приемов (прежде всего, в духе Д.А. Пригова), демонстрируют различные формы отчуждения и комбинируют их с автобиографичными элементами (например, у Кирилла Медведева, Романа Осминкина, Эдуарда Лукоянова, Дмитрия Быкова ${ }^{64}$ ), или же растворяющийся субъект превращается в сложный, подвижный и трансформативный.

Особый вызов - в первую очередь для молодых авторов, вышедших на литературную сцену после рубежа веков - представляет собой «протеический» или «мерцающий» субъект, уходящий корнями в русский концептуализм (особенно в духе Д.А. Пригова). Этот субъект находится между двумя крайними позициями - отрицанием субъекта и его утверждением уклоняясь от сближения с каждой из них. Авторы, работающие с подобным субъектом, с одной стороны, избегают построения личностного субъекта, поскольку оно представляется им наивным, с другой - не отказываются от субъекта вовсе, будь на то этические, политические или антропологические и проч. причины. Образуются формы опосредованной, но тем не менее тотальной субъектности, а также возникающих ситуативно, изменчивых, множественных и открытых субъектов.

В целом обнаруживается, что для направлений современной поэзии, принципиально отличающихся друг от друга в отношении поэтологии, эстетики или идеологии, характерны формы лишь намеченного пунктиром, либо непрерывно меняющегося, как Протей, либо выстраивающего себя заново под влиянием мгновения или ситуации субъекта. ${ }^{65}$ Субъект проявляет себя спонтанно скорее как позиция, нежели как личность; в связи с этим вопрос «идентичности» для этой формы субъекта вторичен. Идентичность же выступает скорее в роли прагматической стратегии, нежели психологической проблемы. Субъект в таких стихотворениях определяется процессами субъективации (ср. статью Е. Сусловой в настоящем сборнике), обусловленными

${ }^{64} \mathrm{Cp.}$ Кузьмин (2001).

${ }^{65} \mathrm{Cp}$.: «Одной из самых ярких тенденций поэзии 2000-х стало развитие своего рода молекулярного смыслового анализа. Авторы с очень разной поэтикой составляют стихи из конфликтных, разнородных образов, мелодических фрагментов, аллюзий. [...] Поэтому переход от одного фрагмента к следующему легко становится личной микротравмой, свидетельствующей о преодолении комфортного, внутренне согласованного миропонимания. Интонационные сбои, повторяющиеся с не мотивированными на первый взгляд изменениями строки, - все это демонстрирует, что поэтическая речь в своем разворачивании как будто все время наталкивается на препятствия, и даже более того что при каждом таком столкновении говорящий должен немного пересоздать себя, чтобы иметь возможность говорить и двигаться (то есть жить) дальше» (Кукулин 2010). 
ситуацией и контекстом. Основным качеством этого субъекта является «определенная неопределенность»: намеченные конкретные черты одновременно предстают как опосредованные и принципиально изменчивые. Кажется, что поэзия после рубежа веков служит таким образом формированию парадигмы, которая объединяет в себе, с одной стороны, тягу к установлениям субъектности, с другой - (пост)модернистское упразднение и подчеркнутую сконструированность субъекта, что вместе с тем приводит к синтезу или метаморфозам традиционных поэтических форм субъекта.

\section{Структура книги}

Первую часть книги составляют статьи, которые, объединяя анализ современной поэзии с установкой на ее теоретическое осмысление, имеют целью разработку теоретических подходов и соответствующей методологии. При этом становится очевидной необходимость учитывать исторические и культурные контексты, а также изменения в них: субъект в поэзии нельзя рассматривать в отрыве от литературы и культуры соответствующего времени. Вторая часть сборника охватывает исследования субъектных форм в современной русской поэзии, причем особое внимание уделяется формам нового конституирования субъекта и формам перехода от растворения / отсутствия субъекта к его новому утверждению. ${ }^{66}$

В разделе «К теории и типологии поэтического субъекта» рассматриваются подходы и методы анализа форм субъектности с точки зрения теорий лирики и лингвистики.

Хенрике Шталь предлагает воспользоваться термином «поэтического субъекта» вместо «лирического» из-за неоднозначности и узости понятия «лирика» и предпочитает говорить о «субъекте» в качестве текстовой инстанции, формируемой по-разному на различных уровнях текста, что позволяет создать тонкий инструментарий для описания сложных субъектных структур и их соотношений между собой, а также с внетекстовыми формами авторской субъектности. В отличие от многих других, она относит «поэтический субъект» не к говорящему или адресанту, а к более абстрактной инстанции имплицитной субъектной структуры, которая может быть образована в разрез как с говорящим, так и с другими формами выражения реального автора. Фиктивность как говорящего, так и текстового субъекта подчеркивает Виллем Вестстейн на материале современной поэзии (О. Седакова, Е. Шварц, П. Барскова, С. Кекова): говорящий является элементом текстового пространства, автор же стоит вне его; даже при наличии

\footnotetext{
${ }^{66}$ Исследования по типологии субъекта в современной русской поэзии вошли в спецномер журнала „Russian Literature“ - «Формы субъекта в новейшей русской поэзии». Номер в печати и должен выйти в 2019 г.
} 
автоадресации или лирических нарративов, которые потенциально могут быть поняты в автобиографическом ключе, отождествление автора с говорящим или текстовым субъектом принципиально противоречит природе поэтического текста и должно рассматриваться как особый прием, нуждающийся в интерпретации. Владимир Новиков показывает, что разграничение автора и «я» (или говорящего в стихотворении), а также более емких понятий «героя» и «субъекта» восходит в русской традиции к Андрею Белому, который развивает понятие «лирический субъект» в противовес понятию «лирический герой», предложенному Юрием Тыняновым как форма присутствия авторской личности в стихотворном тексте. Представляя историю становления, развития и филологического применения терминов «лирический герой», «лирический субъект» и проч., Новиков указывает на продуктивность данных понятий также в анализе современной поэзии, отмечая, однако, необходимость их дифференцирования и использования с учетом широкого культурного пласта значений, приобретенных ими в русле филологических исследований многих десятилетий. Среди ставших классическими советских работ о субъекте в поэзии важную роль играют исследования Бориса Кормана, разработавшего понятия «собственно автор», «автор-повествователь», «лирический герой» и «ролевой герой». Сергей Бирюков расширяет его концепцию понятием Й. Ужаревича о лирическом «Сверх-Я», не только создающем текст, но и рефлектирующем его создание, и показывает, как это понятие помогает в анализе современной поэзии различать сложные формы удвоенной или умноженной субъектности, а также формы бессубъектной и так называемой имплицитной субъектности. Бирюков подчеркивает, что в современной поэзии развит широкий диапазон крайне индивидуальных форм субъектности, нуждающихся в тонком инструментарии анализа и описания расположенных между полюсами более традиционных и, напротив, авангардных форм. На основе анализа поэзии Ры Никоновой, Сергея Сигея и Елизаветы Мнацакановой Бирюков разрабатывает формы субъектности в неоавангарде и связывает их с обращением к опыту предшественников и поиском новой выразительности: традиционная субъектность отрицается, выводится за пределы текста, либо преобразуется по примеру смежных искусств - музыкального и изобразительного. На примере текстов К. Кедрова, Е. Кацюбы, В. Месяца, А. Таврова он рассматривает варианты трансформативной субъектности, утверждая невозможность ее полного преодоления: различные способы формальной деперсонализации не нивелируют субъективного видения.

Для современной поэзии характерно развитие форм распада единства четко отграниченного субъекта, ставшего подвижно-текучим, фрагментарным, множественным, прозрачным или практически неуловимым. Это касается в первую очередь традиционной категории адресанта (часто называемого «поэтическим» или «лирическим я», а также говорящим, но эти термины являются более узкими, чем адресант). Для описания форм адресанта языкознание 
предлагает методы анализа, которые адаптируются к потребностям современной поэзии и часто выходят за рамки традиционной лингвистики.

Наталия Азарова демонстрирует, каким образом дву- или многоязычие может быть рассмотрено как параметр для анализа проблемной субъектности в современной поэзии: оно позволяет определить адресанта как субъекта, «скользящего» между единством / целостностью и их невозможностью или разрушением / отрицанием. В основе анализа лежит выявление аутентичной и чужой речи, различных градаций своего / чужого / присвоенного в поэтическом высказывании, которые могут свидетельствовать о расщепленности / скрытости / неявленности субъекта. Таким образом, реконструкция субъекта возможна через последовательное исследование соотношения своей и чужой идентичности. Аналогично многоязычию в современной поэзии работает интертекстуальность: цитатность и аллюзии могут смещать перспективы адресанта и придавать ему подвижность. Постоянно движущегося и изменяющегося адресанта Наталья Фатеева определяет как «номадичного» (по Р. Брайдотти), так как этот субъект не может быть описан при помощи бинарных оппозиций и демонстрирует множество различий, центров, перспектив, а также их сдвигов, переходов в системе координат «кочующего» текста. Степень номадичности такого субъекта зависит от полноты представленности претекста, степени его узнаваемости и деформации (на примере С. Бирюкова, В. Павловой, В. Полозковой).

Уже сама работа с функциями языка обуславливает разные формы адресанта. Евгения Суслова, определяя субъект как базовую моделирующую функцию, а субъективность как процесс моделирования, предлагает типологию субъекта на основе отношений между [языковым] знаком и миром. По типу взаимодействия семантического, грамматического и функционального планов, а также по степени рефлексивности текста она различает четыре дискурсивные стратегии: репрезентирующую (Е. Шварц, В. Кривулин, О. Седакова и др.), референцирующую (В. Соснора, В. Бородин и др.), модализирующую (А. Альчук, Н. Азарова, А. Скидан и др.) и концептуализирующую (А. Драгомощенко, Г. Айги и др.). Обращаясь к когнитивной лингвистике, а также к понятию «расщепленного субъекта» у Лакана, Ольга Соколова расширяет лингвопоэтический анализ соотношения знака и мира рассмотрением точки наблюдения (point of view), выбранной говорящим относительно описанного объекта. При помощи этого инструментария Соколовой удается выявить, что для поэзии 1990-2010-х гг. оказывается характерным модус обретения себя / отчуждения от себя. Дисперсия собственного $я$ в отношениях с Другим и языком находит свое выражение в неконвенциональном использовании дейктических средств и в смене дейктического ядра, а невозможность самоопределения субъекта порождает неопределенную референцию: это попытка освободиться от статуса объекта для взглядов других. 
Дейксис как средство оформления субъектности ставится в центр трех следующих статей. Владимир Фещенко дает обзор языковедческих теорий дейксиса и проверяет их на адаптируемость к анализу поэзии, в которой, по его мнению, дейксис работает иначе, чем в других речевых актах, так как она в большей степени направлена на реализацию поэтической функции языка. На материале текстов В. Аристова он анализирует особенности функционирования дейктических средств в поле поэтического высказывания: так, в поэзии дейксис задается непосредственно последовательностью и организацией высказываний-строк, указательность определяет характер субъективности, а дополнительные параметры поэтический дейксис получает в случае перформативного чтения текста поэтом, сопровождаемого определенными интонациями, жестами и проч. Екатерина Евграшкина сосредотачивает свое внимание на нулевой референции, типичной для поэзии, в которой сам речевой акт является событием, придающим субъекту перформативный характер. Языковая конструируемость субъекта осмысливается метапоэтически в стихотворениях с выраженной метаязыковой составляющей, в которых само содержание «пустых» знаков (формальных носителей субъективности) становится предметом поэтической рефлексии. На примере русско- и немецкоязычных текстов, написанных в последние несколько десятилетий (Д. Воробьев, А. Глазова, П. Андрукович, Л. Зайлер, Л. Хаппель, Б. Кёлер и др.), она рассматривает особенности функционирования личных местоимений и индивидуальные формы «полагания субъекта», ориентируясь, прежде всего, на маркеры и единицы, определяющие пространственный и временной модусы индивидуального поэтического дейксиса. Она также исследует разнообразные формы смены пространственной и временной перспективы, ведущие к формированию сложной многоуровневой субъектности. Подобный анализ позволяет описать протеические формы открытости, неопределенности и подвижности субъекта, как они встречаются в особенности в современной герметичной поэзии. Анализ нулевого дейксиса местоимения «я», реализуемый Ольгой Северской, также сосредотачивается на растворенном субъекте, который образуется в самом процессе языковой автокоммуникации. На примере текстов И. Жданова, А. Драгомощенко, В. Кривулина и др. она последовательно доказывает взаимосвязь элементов $я, \mathrm{mbl}$, здесь и сейчас как переменных величин, способных принимать различные значения; при этом поэтическое Я маркирует присутствие говорящего и некой точки зрения. $Я$ - знак без референта - в поле поэтического высказывания характеризует его одновременно и как анонимное, и как сугубо личное.

Но не только дейксис приобретает в поэзии другие признаки и функции, нежели в стандартных формах коммуникации. В современной поэзии особенно отчетливо проявляется склонность к вольному обращению с языковыми нормами на всех уровнях и даже к радикальным языковым экспериментам. Людмила Зубова рассматривает эксперименты с нестандартными 
отношениями субъекта и объекта в современной русской поэзии, которые так же, как и вышеуказанные стратегии поэтического употребления дейксиса, приводят к формированию неоднозначности и неопределенности субъекта. Так, она устанавливает, что поэзия опосредует привычные представления об отношениях субъекта с объектом: в поэтическом высказывании выявляются тенденции к обмену актантами «субъект», «объект» и «инструмент», а также различные способы дистанцирования от субъекта «я» и его устранения.

В разделе «Субъект в новейшей русской поэзии» в центр изучения ставятся субъектные формы в определенных сегментах поэтического поля или в творчестве выбранных авторов, а также их соотношение с определенными поэтическими средствами, которые могут употребляться в качестве как противовеса выраженной субъективности, так и ее формального зеркала.

Сопоставляя русскую, немецкую, сербскохорватскую и польскую поэзию, Роберт Ходель рассматривает языковые, эстетические, идеологические и политические причины выбора между силлабо-тоническим стихосложением и свободным стихом. Устанавливается тот факт, что русская поэзия, в отличие от других, еще не исчерпала возможностей вариативного богатства силлабо-тонической системы, которая благодаря особенностям русского языка не только не ограничивает, но, напротив, создает плодотворную почву для развития новых форм, в том числе и открытого и подвижного субъекта, для формирования которого, оказывается, вовсе не обязателен вольный стих. Юрий Орлицкий также подчеркивает тесную связь субъектной структуры с природой стиха. Обращение С. Завьялова и М. Амелина к архаическим по своему генезису стиховым формам, по утверждению Орлицкого, с одной стороны, иллюстрирует сложный стиховой плюрализм и ритмическую гетероморфность современной поэзии, а с другой - формирование мультисубъектности, в условиях которой лирический субъект одновременно оказывается носителем традиций и новых функций, в совокупности формирующих его как инстанцию трансформативной культурной памяти. Традиционные поэтические средства особенно продуктивно продолжают развивать так называемые «поэты-непоэты», т.е. поэты, которые отказываются от активной саморепрезентации в современном социальном поле поэзии и от борьбы за позиционирование в нем, как это показывает Федор Двинятин. Однако и в их текстах субъектность характеризуется тенденцией к выбору модуса анонимности, иронии или маркированной стилизации - независимо от развития традиции, единство субъектного адресанта оказывается нереализуемым. Субъект, тем самым, становится центральной категорией поэзии, которая, в отличие от других классических форм, на сегодняшний день, безусловно, не остается неизменной.

Изменение субъектности в поэзии связано, как показывает случай Виктора Кривулина, с новой политической ситуацией постсоветской России, в которой основные ценности были подвержены трансформациям. Ощуще- 
ние отчужденности и всеобщей зыбкости основ отражается в фрагментации, умножении и процессуальности субъектных форм в поэзии. У Кривулина «я» растворяется и сливается с коллективным «мы». Этому коллективному субъекту Марко Саббатини отводит решающую роль в опреде-

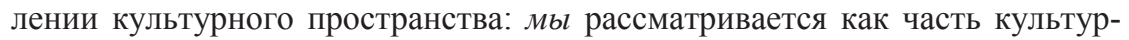
ного проекта и элемент поэтической историзации. Превращение $я$ в $\mathrm{Mbl}$ происходит в момент слияния своего и чужого пространств; в поэзии В. Кривулина поэтическое $\boldsymbol{м b l}$ формируется в пространстве Петербурга / Ленинграда и апеллирует к становлению и существованию неофициальной культуры. В целом в постсоветской поэзии по сравнению с предыдущей литературой можно наблюдать более широкое употребление местоимения «мы», которое, однако, принимает на себя разные функции. Кроме отчуждения и растворения это и формы слияния, не лишающие субъекта его автономности, а служащие эмпатическому вчувствованию, формированию сопричастности с Другим и преодолению границ с ним, что также ведет к развитию и других видов интерсубъективности. В подобных целях употребляется и деконструкция языковых норм в сложной или герметичной поэзии: из помехи сопричастности она становится запускающим ее кодом, как это показывает Галина Заломкина. Она выделяет в качестве характерных признаков «непрозрачной поэзии» многомерность взгляда и разнообразные языковые техники остранения, что в совокупности означает трудности в логическом, эмоциональном и эстетическом декодировании поэтических смыслов в соответствующих текстах (ср. А. Драгомощенко, Ш. Абдуллаев, А. Уланов и др.). Александра Третьякова на материале поэзии Елены Зейферт выделяет установку на коммуникативные отношения, для которых характерно сочувствие другому, причем субъект предстает целостным, хотя и неочевидным. Для ее поэзии имеет особое значение ориентация на адресата, что обуславливает преобладание эготивно-апеллятивного типа субъекта.

Усиленное внимание уделяется не только коммуникации с адресатом, но и форме «мы» в политической поэзии. Ольга Северская подчеркивает, что в современной поэзии происходит сближение с политикой, - с той разницей по сравнению с политической поэзией прошлого, что теперь она сама пытается участвовать в политическом дискурсе, присваивая себе его же признаки (ср. «новую социальную поэзию» П. Барсковой, К. Медведева, А. Скидана, Е. Фанайловой и др.). Поэтический текст перенимает ряд признаков современного публицистического стиля, включая идеологемы, ярко выраженную социальную оценочность, цитатность и средства иронии, авторскую субъективность и направленность авторской позиции на адресата и т.д. Однако несмотря на сильную установку на участие в политической коммуникации, субъект новой социальной поэзии не теряет своей лирической составляющей. В политически ангажированной поэзии «мы» употребляется также с идеологической функцией образования групп и отождествления с ними или, 
наоборот, в целях преодоления группового начала, связанного с заострением конфликтов и противостоянием враждебных лагерей, как показывает Анна Гаврилюк на выбранных примерах новейшей украинской поэзии, посвященной проблеме конфликта между Россией и Украиной.

В противоположность поэзии с коллективной или коммуникативной установкой Александр Уланов подчеркивает стремление к радикальной индивидуализации, характерное для другого сегмента новейшей поэзии. Субъектность выстраивается не на выражении чувств или размышлений, но как ярко индивидуальная перспектива восприятия себя и мира, как формы контакта с миром и другим человеком. Субъект текуч и открыт, но не лишен контуров, становясь в каждый момент другим, как это можно увидеть в поэзии Андрея Сен-Сенькова и Аркадия Драгомощенко. В явном виде («я») субъект практически отсутствует, происходит перенос тяжести на индивидуализацию события, которое рассматривается как событие-внея, а не событие-для-я. Согласно Уланову, поэтика указанных авторов - это «способы видеть», реализуемые средствами языка и литературы. Индивидуализация субъекта характерна также для поэзии Елены Шварц и Ольги Седаковой, хотя субъектность в их текстах формируется иначе. Катина Бахарова анализирует субъектность в творчестве обеих поэтесс на примере стихотворений на тему сна и утверждает, что открытый субъект у Седаковой текуч и прозрачен для других, тогда как у Шварц субъект внутренне расщеплен и распадается на несколько различных инстанций. Прозрачность субъекта может усиливаться до такой степени, что остается лишь сам акт коммуникации без месседжа, выдвигая субъектные инстанции адресанта и адресата сами по себе. Подобные остраненные субъектные формы Валерий Гречко исследует в поэзии минимализма (В. Некрасов, Бонифаций и др.). Для этого сегмента поэзии как раз характерны элиминация месседжа и обнажение коммуникативных приемов, содержанием которых становятся разнообразные формы поэтической интеракции участников, т.е. особого рода взаимодействия между субъектом и адресатом высказывания. Демонстрация механизмов коммуникации ведет к усиленному проявлению субъектности, хотя ее сущность и функции отличаются от таковой в нормативной и канонической поэзии.

Другой способ конструирования субъекта на основе дискурса развит в концептуализме и у его современных наследников. Субъект Пригова расщепляется на разные голоса, образованные посредством цитат, идеологем, клише, а также аллюзий на определенные дискурсы или стили. «Влипаясь» в разные дискурсы, субъект начинает «мерцать». Как показывает Кирилл Корчагин, приговский способ построения субъекта является вызовом для молодого поколения, в особенности для политически ангажированных поэтов постконцептуализма ${ }^{67}$, которые борются с этическим релятивизмом,

67 Этот термин восходит к работе Дмитрия Кузьмина (2001), см. также: Давыдов (2017). 
заложенным в концептуализме. Они стремятся к преодолению концептуализма с помощью его собственных средств двумя способами: с одной стороны, развивая некий «суперсубъект», в определенный момент останавливающий «мерцание», а с другой - демонстрируя шаткость любого идеологического основания высказывания, однако, с иной, нежели в концептуализме, целью - заострить утверждение определенного дискурса. Марк Липовецкий также подчеркивает, что функция цитатности в постконцептуализме изменилась, формируя субъектность между полюсами распада субъекта и приобретения им нового единства, которое, однако, учитывает проблемность и сомнительность единого субъекта. С опорой на ряд работ по роли цитат в современной литературе Марк Липовецкий рассматривает апроприацию «чужого слова» как воплощение нового типа мозаичной субъектности, при этом им особо выделяются две модели цитатности: неоакмеистская (цитата как аллегория исторической памяти в поэзии В. Кривулина и С. Стратановского) и концептуалистская (цитата как инструмент разрушения стереотипных связей и обнаружения их фиктивности в поэзии В. Некрасова, Д. Пригова, Л. Рубинштейна). В определенном сегменте поэзии 2000-х-2010-х гг. (М. Степанова, Е. Фанайлова, П. Барскова) происходит синтез данных тенденций, а вместе с тем формируется фрагментарный цитатный лирический субъект - вне диалога с прошлым и концептуализации истории - как современный анонимный поток сознания. Аналогичным образом поэты могут работать и с реди-мейдами. Александр Житенев показывает, как через их поэтический монтаж проявляется структурообразующая сила, формирующая определенную субъектность. Субъект в данном случае выступает в роли интерпретатора, он создает траектории чтения, позволяющие трактовать любой текст как построенный по принципу «текста в тексте»; работая с готовым материалом, он проявляет себя как создатель «резонансного пространства», в котором важна игра несовпадений между исходным и вторичным текстами, выявление исторической и эстетической дистанции. Даже в случае, когда этот субъект становится конкретным голосом, он может отличаться от самого автора. Особую форму поэтической работы с реди-мейдами представляют собой блэкауты, вычеркивающие, вымарывающие или выбеливающие блоки первичного текста. При этом субъект выбранного текста разрушается, однако самой активностью вычеркивания и отрицания определенных мест данного текста конституируется новый субъект, как это объясняет Михаил Мартынов на примерах А. Йоффе, Д. Серенко и А. Черкасова. Тексты-блэкауты, с одной стороны, манифестируют активное отсутствие субъекта, а с другой - обнаруживают его на периферии текстового пространства: в обрывках слов, в местах между колонками текста, в «случайных» знаках препинания и проч. Таким образом, эти тексты открывают незапланированные возможности текста, реализуя субъект как событие, и наполняют новыми содержаниями его кажущееся отсутствие. 
Именно блэкауты предоставляют веский аргумент в пользу тезиса о том, что отрицание или даже отсутствие субъекта не свидетельствуют о его настоящем отсутствии, но, напротив, формируют субъект как силу, определяющую текст в целом, т.е. косвенным образом субъект возвращается и в еще большей степени начинает господствовать над текстом, нежели традиционный субъект: он становится тотальным. И наоборот - проблематичным и сомнительным субъект оказывается в поэтических текстах, демонстрирующих процесс его расщепления и распада, как мы это можем наблюдать, например, у Пригова с его «мерцающим субъектом». Другой тип «сильного» субъекта - но не в смысле его единичности и тотальности - развивается в сложных и трансформативных поэтических формах. Этот субъект является нестойким, текучим, преходящим, множественным и открытым и выступает скорее как творческая сила и перформативное событие творческого акта, чем как определенное существо или хотя бы определенная смысловая позиция. Развитие подвижного субъекта может затрагивать все текстовые уровни: спектр распространяется от говорящего и адресанта вплоть до субъектных форм, скрытых в самой структурообразующей силе, причем эти формы разных уровней могут выстраиваться как гармонично содействующими, как и борющимися друг с другом - в том случае, когда сталкиваются перспективы, точки зрения и голоса, как, например, у Шварц с ее расслаивающимся по иерархическим уровням и разным инстанциям субъектом или в текстах с «номадическим» субъектом (см. статью Н. Фатеевой).

В современной поэзии вновь стала значимой связь с автором: или поэтический субъект полностью независим от автора, который может сам выступить как вымышленное лицо (см., например, случай Фаины Гримберг), и радикально отличается от него, или как раз наоборот. Но и сама личность автора может приобретать поэтические черты и оказываться субъектоммаской - в определенной связи с соответствующими стихотворными текстами, которую необходимо учитывать и осмыслять. Ни принципиальный отказ от связи форм поэтического субъекта с автором, ни простое отождествление с ним не могут полностью исчерпать ситуацию в современной поэзии. Решение этих вопросов - проблема уже не чистой теории, а методологии как развития инструментария для описания имеющихся в поэзии разнообразных форм. Сегодня сам автор может проявлять себя в модусе фиктивного, и в то же время он сам представляет субъекта в своей поэзии посредством чтения или перформативной инсценировки, т.е., таким образом, реализует себя в нем. Следует распознавать способы различения и описания как субъектности в самом поэтическом тексте, так и ее сложных взаимодействий с другими формами выявления субъектности автора. 
Материалы данной книги подтверждают тот факт, что «романтический» субъект лирики, призванный прежде всего выражать чувства и мысли и отраженный в «лирическом я», практически ушел из серьезной, эстетически взыскательной и в этом смысле «профессиональной» поэзии. Субъект стал проблемной категорией, но одновременно и категорией особенно продуктивной. Развивается множество форм субъектности, для описания которых традиционное литературоведение, а также языкознание не предоставляют достаточно развитого и тонкого инструментария анализа.

Современный поэтический субъект не в последнюю очередь является наследием экспериментов с субъектными формами XX века, особенно модернистской и авангардной традиций, а также поэзии андеграунда советского времени. Полагание субъекта складывается из взаимодействия разнородных и часто противоречивых факторов, а различия между отдельными уровнями текста, на которых субъект в той или иной форме находит свое выражение, приводят к тому, что он функционирует в нем как сложный многоуровневый элемент. Даже в случаях с формально отсутствующим субъектом можно говорить не столько о его полном нивелировании, сколько о новых неочевидных формах его проявления; даже в поэтическом коллаже голосов, лишенных Я, или в полифонических фрагментах, в которых невозможно соотнести высказывание с определенной субъектной позицией, субъект присутствует как комбинаторная и особым образом упорядочивающая инстанция; даже высказывание от первого лица, занимая видную позицию в современной поэзии, - скорее одна из форм преодоления и переосмысления «лирического я» классического типа. Содержательный и структурный планы многих современных поэтических текстов при помощи размыкания границ между Я и миром, телом, человечеством и метафизическими пространствами обнажают различные приемы преодоления этого Я, замкнутого в самом себе, а также создают формы текучести, гибкости и протеической трансформативности субъектности.

Общую парадигму этих разнообразных форм можно назвать «транссубъектностью» ${ }^{68}$ (относительно форм перехода), «метасубъектностью» (в отношении к осознанно построенной субъектности) или «сверхсубъектностью» (представленной скрытыми формами, превосходящими обычное самосознание и его выражение), так как эти формы основаны на осознании и вместе с тем преодолении заключенного в себе, декартовского субъекта. Преодоление его границ не обязательно означает потерю автономности и индивидуальности - примеры показывают, что может иметь место как раз

${ }^{68}$ Ср. у Кукулина: «Я уже предлагал заменить термин „новый эпос“ словосочетанием „Поэзия драматического кенозиса“ [Кукулин 2008; ред.], хотя и понимаю, что оно звучит менее выразительно и более громоздко. Можно назвать эту тенденцию и транссубъективной поэзией, то есть поэзией, связывающей разные „я“, разные типы субъекта» (Кукулин 2010). 
обратное. Новый субъект может как быть ослабленным, так и выступать сильным, однако сильным в отличных от коренящихся в самосознании формах центрированного субъекта. Поэтому мы предпочитаем говорить не о субъекте, а о субъектности: современная поэзия перешла, по крайней мере во многих ее сегментах, от субъекта к формам субъектности.

Книга призвана дать толчок обновлению теории и методологии изучения лирики, поэзии и субъектности в них, а также в художественных произведениях вообще. Плодотворна в этом плане работа именно с современной поэзией, представляющей собой вызов для проверки и дальнейшего развития филологических методов и теорий. Взаимодействие литературоведческой практики с лингвистическими, когнитивными теориями, с теорией лирики, а также с философскими концепциями делает возможным многосторонний подход к сложным феноменам современной поэзии.

\section{Литература}

Азарова, Н. (2012): Критерий «адресат» в установлении границ поэтического дискурса. // Арутюнова, Н. (сост.): Логический анализ языка. Адресация дискурса. М. 225-233.

Бобров, А. (1989): Лирический субъект и характерные процессы в лирике 80-х годов. М. Вестстейн, В. (1993): Лирический герой как прием // RussianLiterature. 34 (1), 1993. 95-108.

Голынко-Вольфсон, Д. (2012): Прикладная социальная поэзия: изобретения политического субъекта // Транслит. 10/11, 2012. 180-182.

Давыдов, Д. (2017): Концепция литературной группы в эпоху ее невозможности // Toronto Slavic Quarterly 61, 2017.

http://sites.utoronto.ca/tsq/61/Davydov61.pdf (07/08/2018).

Долар, М. (2012): По ту сторону интерпретации // Неприкосновенный запас. 85, 2012. 33-54.

Евграшкина, Е. (2014): Немецко-российская конференция «Поэзия на переломе: основные тенденции поэзии после 1989 года в России и Германии» // Новое литературное обозрение. 1 (125), 2014. 403-411. http://magazines.russ.ru/nlo/2014/125/45epr.html (02/08/2018).

Житенев, А. (2008): Лирический субъект новейшей русской поэзии: возможные аспекты анализа // Филологические этюды: Сб. науч. статей молодых ученых. 11 (1-2), 2008. Саратов. 113-117.

Зотеев, А. (2011): Лирический герой Елены Шварц и его трансформации в переводах на английский язык. Самара.

Ковтунова, И. (2006): Категория лица в языке поэзии // Красильникова, Е. (сост.): Поэтическая грамматика. Т. 1. М. 7-72.

Корчагин, К. (2012): Революция маски: о поэтике и политике Кирилла Медведева // OpenSpace.ru. http://os.colta.ru/literature/events/details/35834/ (02/08/2018).

Корчагин, К. (2013): «Маска сдирается вместе с кожей»: способы конструирования субъекта в политической поэзии 2010-х гг. // Новое литературное обозрение. 124, 2013. http://magazines.russ.ru/nlo/2013/124/17k.html (02/08/2018). 
Кузьмин, Д. (2001): Постконцептуализм (Как бы наброски к монографии) // Новое литературное обозрение. 50, 2001. 459-476.

Кукулин, И. (2008): От Сваровского к Жуковскому и обратно: О том, как метод исследования конструирует литературный канон // Новое литературное обозрение. 89. http://magazines.russ.ru/nlo/2008/89/ku16.html (06/08/2018).

Кукулин, И. (2010): Маятник одиночества: предварительные замечания о конструировании понятия «русская неподцензурная поэзия» // Филологические традиции в современном литературном и лингвистическом образовании: Сб. науч. статей. Вып. 9: В 2 тт. Т. 1. М. 242-252.

Майофис, М. (2003): «Не ослабевайте упражняться в мягкосердии»: Заметки о политической субъективности в современной русской поэзии // Новое литературное обозрение. 62, 2003. 323-339.

Мансков, С. (1999): Поэтический мир А. А. Тарковского: лирический субъект; категориальность; диалог сознаний. Барнаул.

Мегрелишвили, К. (2013): Ольга Седакова: «Чувство насущной необходимости русского Целана». Перевод как опыт расширения сознания // Шталь, Х. / Рутц, М. (сост.): Имидж, диалог, эксперимент: поля современной русской поэзии. Мюнхен. 451-461.

Нурмухамедова, Р. (2008): Лирический субъект в поэзии Тимура Кибирова. М.

Романов, И. (2004): Лирический герой поэзии И. Бродского. М.

Рутц, М. (2013): «Каноны» современной русской поэзии. Наблюдения и перспективы // Шталь, Х. / Рутц, М. (сост.): Имидж, диалог, эксперимент: поля современной русской поэзии. Мюнхен. 37-58.

Сильман, Т. (1977): Заметки о лирике. Л.

Соколова, Д. (2006): Лирический субъект и персонажи в стихотворениях Н.С. Гумилева. М.

Сучкова, Н. (2005): Лирический герой. М.

Фатеева, Н. (2009): Особенности языковой организации современных стихотворных текстов рубежа XX-XXI вв. // Менгель, С. / Фатеева, Н. (сост.): Динамика формы художественного текста: стих, проза, драма в конце XX - начале XXI века. Halle / Saale. 23-118.

Фатеева, Н. (2013): Грамматические девиации в глагольной сфере как основа обратимости ролей в лирической коммуникации // Плунгян, В. / Шестакова, Л. (сост.): Корпусный анализ русского стиха: Сборник научных статей. М. 142-157.

Шталь, Х. (2013): «Поминальная свеча» Елены Шварц - поэтика трансцендентирования // Шталь, Х. / Рутц, М. (сост.): Имидж, диалог, эксперимент: поля современной русской поэзии. Мюнхен. 435-449.

Шталь, Х. / Рутц, М. (2013): Имидж, диалог, эксперимент: поля современной русской поэзии // Шталь, Х. / Рутц, М. (сост.): Имидж, диалог, эксперимент: поля современной русской поэзии. Мюнхен. 3-34.

Шталь, Х. / Рутц, М. (сост., 2013): Имидж, диалог, эксперимент: поля современной русской поэзии. Мюнхен.

Шталь, Х. (2016): Опыт философского обоснования мета-теории поэтического субъекта: современное прочтение Генриха Барта // Азарова, Н. / Бочавер, С. (ред./сост.): Поэтический и философский дискурсы: история взаимодействия и современное состояние. М. 162-181. 
Штраус, А. (2005): Лирический герой (теоретический термин в современной поэтической практике) // Филолог. 6, 2005.

http://philolog.pspu.ru/module/magazine/do/mpub_6_122 (02/08/2018).

Штраус, А. (2009): Проблема лирического героя в современной поэзии: новые тенденции 1990-х-2000-х годов. Екатеринбург.

Эпштейн, М. (2000 / 2005): Постмодерн в России: литература и теория (2-ое переработанное издание: Постмодерн в русской литературе). М.

Bernhart, W. (1993): Überlegungen zur Lyriktheorie aus erzähltheoretischer Sicht. In: Foltinek, Herbert (Hg.): Tales and ,their telling difference“. Zur Theorie und Geschichte der Narrativik. Festschrift zum 70. Geburtstag von Franz K. Stanzel. Heidelberg. 359-375.

Binder, E. et al. (2016): Einleitung. In: Binder, E. et al. (Hgg.): Lyrik transkulturell. Würzburg. 9-36.

Block, F.W. (1999): Beobachtung des „Ich“: zum Zusammenhang von Subjektivität und Medien am Beispiel experimenteller Poesie. Bielefeld. 32-33.

Borkowski, J. / Winko, S. (2011): Wer spricht das Gedicht? Noch einmal zum Begriff , lyrisches Ich“ und zu seinen Ersetzungsvorschlägen. In: Bleumer, H. / Emmelius, C. (Hgg.): Lyrische Narrationen - narrative Lyrik. Gattungsinterferenzen in der mittelalterlichen Literatur. Berlin / New York. 43-77.

Brehm, A. (2013): „Lyrisches Ich“. Begriff und Praxis. Bielefeld.

Burdorf, D. (1997): Einführung in die Gedichtanalyse. Stuttgart / Weimar.

Bürger, P. / Bürger, Ch. (2000): Das Verschwinden des Subjekts. Das Denken des Lebens. Fragmente einer Geschichte der Subjektivität. Frankfurt a.M.

Charpa, U. (1985): Das poetische Ich - persona per quam. In: Poetica. 17, 1985. 149-169.

Coenen-Mennemeier, B. (2004): Das lyrische Du. Funktionen und Variationen einer poetischen Sprechsituation. Frankfurt a.M. u.a.

Culler, J. (2015): Theory of the Lyric. Cambridge.

Easthope, A. (1983): Poetry as Discourse. London.

Fischer, C. (2007): Der poetische Pakt. Rolle und Funktion des poetischen Ich in der Liebeslyrik bei Ovid, Petrarca, Ronsard, Shakespeare und Baudelaire. Heidelberg.

Fricke, H. (1981): Norm und Abweichung: Eine Philosophie der Literatur. München.

Friedrich, H. (1985): Die Struktur der modernen Lyrik. Von der Mitte des neunzehnten bis zur Mitte des zwanzigsten Jahrhunderts. Reinbek bei Hamburg.

Grübel, R. (1987): The Personal Pragmatic Institutions of Poetic Discourse. In: Zavala, I.M. / Diaz-Diocaretz, M. / van Dijk, Th.A. (eds.): Approaches to Discourse, Poetics and Psychiatry. Amsterdam. 149-170.

Hamburger, K. (1980): Die Logik der Dichtung (ungekürzte Auflage nach der 3. Auflage 1977). Frankfurt a.M. / Berlin / Wien.

Han, B.-Ch. (2005): Hyperkulturalität. Berlin.

Hegel, G.W.F. (1970): Werke in zwanzig Bänden. Bd. 15: Vorlesungen über die Ästhetik. Frankfurt a.M.

Hempfer, K.W. (2011): Performance, Performanz und Performativität. Einige Unterscheidungen zur Ausdifferenzierung eines Theoriefeldes. In: Hempfer, K.W. / Volbers, J. (Hgg.): Theorien des Performativen. Sprache - Wissen - Praxis. Eine kritische Bestandsaufnahme. Bielefeld. 13-41. 
Hempfer, K.W. (2014): Lyrik. Skizze einer systematischen Theorie. Stuttgart.

Horn, E. (1995): Subjektivität in der Lyrik: ,Erlebnis und Dichtung‘, ,lyrisches Ich‘. In: Pechlivanos, M. / Rieger, S. / Struck, W. / Weitz, M. (Hgg.): Einführung in die Literaturwissenschaft. Stuttgart / Weimar. 299-310.

Hühn, P. (1995): Geschichte der englischen Lyrik. Bd. 1. Tübingen / Basel.

Hühn, P. / Schönert, J. (2002): Zur narratologischen Analyse von Lyrik. In: Poetica. 34, 2002. 287-305.

Iljassova-Morger, O. (2009): Transkulturalität als Herausforderung für die Literaturwissenschaft und Literaturdidaktik. In: Das Wort. Germanistisches Jahrbuch Russland 2009. 37-57.

Jaegle, D. (1995): Das Subjekt im und als Gedicht: eine Theorie des lyrischen Text-Subjekts am Beispiel deutscher und englischer Gedichte des 17. Jahrhunderts. Stuttgart.

Kemper, D. (2008): Wissensarchäologie statt Bologna-Falle. Annäherungen an die russische Germanistik als Wissenschaft. In: Kemper, D. / Bäcker, I. (Hgg.): Deutsch-russische Germanistik. Ergebnisse, Perspektiven und Desiderate der Zusammenarbeit. Moskau. 46-65.

Killy, W. (1972): Elemente der Lyrik. München.

Klotz, V. (2011): Verskunst. Was ist, was kann ein lyrisches Gedicht? Bielefeld.

Korte, H. (2004a): Geschichte der deutschsprachigen Lyrik. Stuttgart.

Korte, H. (2004b): Zurückgekehrt in den Raum der Gedichte. Deutschsprachige Lyrik der 1990er Jahre, m.e. Auswahlbibliographie. Münster.

Krusche, D. (1993): Erinnern, Verstehen und die Rezeption kulturell distanter Texte. In: Wierlacher, A. (Hg.): Kulturthema Fremdheit. Leitbegriffe und Problemfelder kulturwissenschaftlicher Fremdheitsforschung. München. 433-449.

Kukulin, I. (2010a): Documentalist Strategies in Contemporary Russian Poetry. In: Russian Review. 69 (Oct), 2010. 585-614.

Kukulin, I. (2016): Zur Ungleichzeitigkeit der russischen Gegenwartsdichtung. In: Stahl, H. / Korte, H. (Hgg.): Gedichte schreiben in Zeiten der Umbrüche. Tendenzen der Lyrik seit 1989 in Russland und Deutschland. Leipzig. 93-113.

Lamping, D. (1989): Das lyrische Gedicht. Definitionen zu Theorie und Geschichte der Gattung. Göttingen.

Leitgeb, Ch. (2004): Zur Rhetorik deutschsprachiger Haikus. In: Sprachkunst. 35, 2004. 2. Halbband. 303-317.

Lockemann, W. (1973): Lyrik, Epik, Dramatik oder die totgesagte Trinität. Meisenheim an der Glan.

Lüders, E.M. (1965): Das lyrische Ich und das gezeichnete Ich. Zur späten Lyrik Gottfried Benns. In: Wirkendes Wort. 15, 1965. 361-385.

Martínez, M. (2002): Das lyrische Ich. Verteidigung eines umstrittenen Begriffs. In: Detering, H. (Hg.): Autorschaft. Positionen und Revisionen. Stuttgart. 376-389.

Menzel, B. (2000): Formen und Funktionen postsowjetischer Popularliteratur. In: Cheauré, E. (Hg.): Kunstmarkt und Kanonbildung. Tendenzen in der russischen Kultur heute. Berlin. 219-241.

Menzel, B. (2001): Bürgerkrieg um Worte. Die russische Literaturkritik der Perestrojka. Wien / Köln / Weimar.

Müller, W.G. (1979): Das lyrische Ich. Erscheinungsformen gattungseigentümlicher AutorSubjektivität in der englischen Lyrik. Heidelberg. 
Müller, W.G. (2004): Das Problem der Subjektivität der Lyrik und die Dichtung der Dinge und Orte. In: Nünning, A. (Hg.): Literaturwissenschaftliche Theorien, Modelle und Methoden. Eine Einführung. Trier. 93-105.

Müller, W.G. (2011): Das lyrische Ich. In: Lamping, L. (Hg.): Handbuch Lyrik. Theorie, Analyse, Geschichte. Stuttgart / Weimar. 56-58.

Peper, J. (1972): Transzendentale Struktur und lyrisches Ich. In: Deutsche Vierteljahrsschrift für Literaturwissenschaft und Geistesgeschichte. 46, 1972. 381-434.

Peper, J. (1998): Das transzendentale Selbstporträt der Subjektivität in der ästhetischen Einstellung, oder: Subjektivität ohne Subjekt. In: Fetz, R.L. et al. (Hgg.): Geschichte und Vorgeschichte der modernen Subjektivität: 2 Bde. Bd. 2. Berlin / New York. 1213-1248.

Perloff, M. (1999): Language Poetry and the Lyric Subject. Ron Silman's Albany, Susan Howe's Buffalo. In: Albany, Critical Inquiry. 25 (Spring), 1999. 405-434. http://marjorieperloff.com/stein-duchamp-picasso/silliman-howe/ (02/08/2018).

Pilz, D. (2007): Krisengeschöpfe. Zur Theorie und Methodologie der Objektiven Hermeneutik. Wiesbaden.

Rutz, M. (2011): Der „Bürgerkrieg um Worte“ geht weiter. Die Rezeption und Konzeption der russischen literarischen Postmoderne in russischsprachigen Lehrbüchern zur jüngeren Literaturgeschichte und Überblicksdarstellungen. In: Frieß, N. et al. (Hgg.): Wortmeldungen aus der jungen slavistischen Literaturwissenschaft. 10. Arbeitstreffen des JFSL, Trier 26.-28.03.2010. Potsdam. 461-476.

Rutten, E. (2012): Post-Communist Sincerity and Sorokin's „Thrilogy“. In: Wiener Slawistischer Almanach. Sonderband 79: Lange, B. / Weller, N. / Witte, G. (Hgg.): Die nicht mehr neuen Menschen. Russische Filme und Romane der Jahrtausendwende. München / Berlin / Wien. 27-55.

Schiedermair, S. (2004): „Lyrisches Ich“ und sprachliches „,ich“. Literarische Funktionen der Deixis. München.

Schlaffer, H. (2012): Geistersprache. Zweck und Mittel der Lyrik. München.

Schönert, J. (1999): Empirischer Autor, Impliziter Autor und Lyrisches Ich. In: Jannidis, F. / Lauer, G. / Martinez, M. / Winko, S. (Hgg.): Rückkehr des Autors. Zur Erneuerung eines umstrittenen Begriffs. Tübingen. 289-294.

Schwarz, S. (2007): Stimmen - Theorien lyrischen Sprechens. In: Geppert H.V. u.a. (Hgg.): Theorien der Literatur. Grundlagen und Perspektiven. Bd. 3. Tübingen. 91-123.

Spinner, K.H. (1975): Zur Struktur des lyrischen Ich. Frankfurt a. M.

Stahl, H. (2013): Interpretation als Dialog. Votum für eine strukturale Hermeneutik. In: Coincidentia. Zeitschrift für Europäische Geistesgeschichte. Beiheft 2: Schwaetzer, H. (Hg.): Bildung und Fragendes Denken. Bernkastel-Kues. 117-137.

Stahl, H. / Korte, H. (2016): Einleitung. In: Stahl, H. / Korte, H. (Hgg.): Gedichte schreiben in Zeiten der Umbrüche. Tendenzen der Lyrik seit 1989 in Russland und Deutschland. Leipzig. 13-49.

Stahl, H. / Korte, H. (Hgg.): Gedichte schreiben in Zeiten der Umbrüche. Tendenzen der Lyrik seit 1989 in Russland und Deutschland. Leipzig.

Stephens, A. (1982): Überlegungen zum lyrischen Ich. In: Elm, Th. / Hemmerich, G. (Hgg.): Zur Geschichtlichkeit der Moderne: der Begriff der literarischen Moderne in Theorie und Deutung. Ulrich Fülleborn zum 60. Geburtstag. München. 53-63.

Stierle, K. (1979): Die Identität des Gedichts - Hölderlin als Paradigma. In: Marquard, O. / Stierle, K. (Hgg.): Identität (Poetik und Hermeneutik VIII). München. 505-552. 
Straub, J. / Renn, J. (Hgg., 2002): Transistorische Identität. Der Prozesscharakter des modernen Selbst. Frankfurt a.M. / New York.

Völker, L. (1997): Gattungsdenken im Umbruch. Zum Lyrik-Diskurs der deutschen Literaturwissenschaft nach 1945. In: Völker, L. (Hg.): Von Celan bis Grünbein. Zur Situation der deutschen Lyrik im ausgehenden zwanzigsten Jahrhundert. Lille. 163-177.

Wolf, W. (2005): The Lyric. Problems of Definition and a Proposal for a Reconceptualization. In: Müller-Zettelmann, E. / Rubik, M. (Hgg.): Theory into Poetry. New Approaches to the Lyric. Amsterdam / New York. 21-56.

Wright, G.T. (1960): The Poet in the Poem. The Personae of Eliot, Yeats, and Pound. Berkeley / Los Angeles.

Zymner, R. (2009): Lyrik. Umriss und Begriff. Paderborn.

Zymner, R. (2011): Theorien der Lyrik seit dem 18. Jahrhundert. In: Lamping, D. (Hg.): Handbuch Lyrik. Theorie, Analyse, Geschichte. Stuttgart. 21-34.

Zymner, R. (2013): Funktionen der Lyrik. Münster.

Žerebin, A. (2005): Die andere Lektüre. Ein Plädoyer für fremdkulturelle Germanistik. In: Das Wort. Germanistisches Jahrbuch Russland 2005. 127-134. 
К теории и типологии поэтического субъекта 



\title{
Хенрике Шталь (Трир)
}

\section{Многоипостасная модель поэтического субъекта ${ }^{1}$}

\author{
Лирика или поэзия
}

Со всемирным расцветом поэзии в последнее время оживился и интерес к теории лирики, которая долго находилась в тени теорий нарративных и драматических жанров. ${ }^{2}$ В 2015 г. была создана платформа для изучения лирики International Network for the Study of Lyric ${ }^{3}$ и появилось несколько фундаментальных работ с попытками теоретически обосновать род лирики. ${ }^{4}$

В западной теории предпочитают пользоваться термином «лирика» вместо слова «поэзия», так как «поэзия» обязательно подразумевает версификацию, которая присутствует не в каждом лирическом произведении, а также не исчерпывает собой другие родовые признаки, к определению которых стремятся теоретики. ${ }^{5}$ Параллельно существуют несколько принципиально отличающихся друг от друга попыток определения лирики. Неко-

${ }^{1}$ В эту статью вошли в переработанной форме идеи и фрагменты следующих статей на ту же тему: Stahl (2017b), Шталь (2016), Шталь (2019b).

2 „Recent theoretical proposals do not focus on the catalogue of descriptive terminology (verse, metre etc.), but put particular emphasis on the most basic features and constituents of lyric. This growing scholarly engagement with lyric on a theoretical level raises the issue of defining the macro-genre [...]“ (Hillebrandt et al. 2017, p. 2). Лампинг еще в 2000 г. указывал на то, что уже поэзия модернизма стала спорным вопросом и пробным камнем новых теорий лирики (Lamping 2000, S. 231). Это тем более можно сказать о новейшей поэзии и современных теориях лирики.

${ }^{3}$ Cм. http://www.lyricology.org/ (09/07/2018).

${ }^{4}$ См., например: Zymner (2009, 2013), Schlaffer (2012), Rabaté (2013), Hempfer (2014), Ramazani (2014), Culler (2015), переизданная в обработанной форме книга Burdorf (2015), а также Fabb (2015) и спец-номер Journal of Literary Theory 11 (1): Theories of Lyric, 2017.

${ }^{5}$ См. об этой дискуссии: „Today the theory of lyric is fragmented along linguistic, national and disciplinary lines. This is apparent even in different traditions of naming and delineating the field. Some Anglo-American scholars have argued that the ,lyricization of poetry ' is a relatively recent development that replaced a panoply of different verse genres and forms with a single, ahistorical or timeless notion of lyric (Jackson / Prins 2014; Jackson 2012). ,Poetry“ formerly encompassed all forms of literature written in verse, but as ,poetry ‘ became restricted to short texts, a conceptual overlap with ,lyric' resulted. As a consequence, ,poetry' may be considered by some researchers as covering too many verified genres (e.g., epic), and, at the same time, as clashing with forms of lyric that show no signs of versification (cf. Zymner 2009, S. 59-72)“ (Hillebrandt et al. 2017, p. 2-3). 
торые представители этой новой волны сходятся во мнении в том, чтобы преодолеть, с одной стороны, общепринятое «минимальное определение» лирики как «единичной речи в стихах», ${ }^{6}$ а с другой - не менее распространенное стремление к составлению списка или «пучка признаков» ${ }^{7}$, абстрагируемых от образцов определенных культур и эпох. Эти списки остаются открытыми, т.е. могут дополняться в связи с изменениями, происходящими в лирике, но определение родовой принадлежности произведения по этим спискам не требует присутствия всех пунктов - достаточно определенного количества характерных особенностей, позволяющих соотнести данное явление с установленными родовыми признаками, гарантирующими узнаваемость рода и тем самым обосновывающими принадлежность к нему.

В отличие от таких подходов, некоторые новые теоретики пытаются сформулировать системное определение родового понятия. Например, романист Хемпфер усматривает главный признак лирики в фиктивной перформативности речи (,Performativitätsfiktion“) и придает ему системообразующее значение. ${ }^{8}$ Германист Шлаффер возводит признаки лирической речи к архаическим магическим практикам: лирика - «воспоминание об утраченном способе мышления и речи» (,Erinnerung an eine untergegangene Denk- und Sprechweise“"). ${ }^{9}$ Наиболее амбициозное определение лирики развивает компаративист Цимнер, претендуя на установление понятия рода, которое можно применить независимо от культурных и исторических специфик. Возведя модернистское понимание лирики в эталон, Цимнер рассматривает ее как «репрезентацию языка», как «экран языковой медиальности и катализатора эстетической эвиденции». В лирике «язык есть „творческий орган мысли“"», чем она, согласно Цимнеру, отличается от других жанров. ${ }^{10}$ Нормативная теория Цимнера позволяет определить не-

${ }^{6}$ „Einzelrede in Versen“, см.: Lamping (1989, S. 63); Völker (1997, S. 167).

7 „Merkmalsbündel“, см. списки признаков у: Wolf (2005), Klotz (2011).

${ }^{8}$ Hempfer (2014, S. 10). Cр. также: ,[...] eine systematische Lyriktheorie im Rahmen einer Performativitätstheorie zu konzipieren, wobei freilich kein Oppositionsverhältnis von Performativität und Textualität vorausgesetzt werden darf, sondern ein Performativitätskonzept, das ,Performativät' auch als Merkmal spezifischer Typen von Texten begreift. Eine solche performative Lyriktheorie möchte ich [...] zur Diskussion stellen.“ [(...) создать системную теорию лирики в рамках перформативной теории, причем в качестве предпосылки фигурировали бы не отношения оппозиции между перформативностью и текстуальностью, а некий концепт перформативности, осмысливающий «перформативность» в том числе и как признак особых типов текста. Такую перформативную теорию лирики (...) я хотел бы предложить для дискуссии] (Hempfer 2008, S. 57).

${ }^{9}$ Schlaffer (2012, S. 12).

${ }^{10}$ Zymner (2013, S. 8). Цимнер определяет лирику «как прежде всего графическую или фонетическую репрезентацию языка [...], особенность которой можно увидеть в том, что она является экраном языковой медиальности и катализатором эстетической эвиденции. [...] язык есть ,творческий орган мысли“, и это свойство отличает лирику по существу от других жанров $[\ldots] »(,[\ldots]$ als - vor allem: graphische oder phonische - Re- 
кое ядро признаков рода, по близости или отдаленности к которому можно классифицировать тексты, не учитывая их место в коммуникативной системе определенных эпох и культур.

Такие системные определения имеют свои недостатки. Например, исторически и культурно обусловленные изменения коммуникативной, а, следовательно, и жанровой системы, которые в определенное время и в соответствующем месте позволяют узнавать и создавать произведения в рамках определенного рода и жанра, уходят на задний план. Трансгрессивные, ненормативные формы принципиально оцениваются как исключение и позиционируются на полях или даже за пределами поля установленного родового понятия; подобное определение не помогает охватить жанровые особенности произведений и установить их место в уникальных ситуациях исторического развития.

Однако как раз для современной литературы снова характерны трансгрессивные и гибридные формы. Играя с узнаваемостью родовых и жанровых признаков, они их смешивают и одновременно стремятся к изменению границ традиционных родовых и жанровых определений, расширяя их также транскультурально. Устоявшиеся признаки и функции сдвигаются; то, что вчера было нормой, сегодня заменяется другими формами как актуальными эталонами жанра, т.е. эти формы выходят за пределы того, что вчера было признано в качестве образца жанра. Не только жанры подвержены эволюции, но и родовые понятия, границы между которыми снимаются - ведь и «роды» не существуют в виде онтологических идей, а являются - несмотря на их достаточную устойчивость - вымышленными и тем самым временно и культурно обусловленными категориями. ${ }^{11}$ Относительно «вечны» не роды или жанры, а сам язык и возможный спектр его использования (способы речи), который не исчерпывается и остается актуальным, хотя и по-разному распределяется по коммуникативным потребно-

präsentation von Sprache [...], deren generisch distinkte Besonderheit darin zu sehen ist, ein Display sprachlicher Medialität und dabei ein Katalysator ästhetischer Evidenz zu sein. [...] dass Sprache ein ,schöpferisches Organ des Gedankens“ ist, und diese Eigenschaft unterscheidet Lyrik im Kern von anderen Gattungen [...]“; Zymner 2013, S. 7).

11 Этот процесс может реализоваться вполне осознанно, см., например, у Степановой, которая в своем сборнике «Против лирики» (2017) авангардистски покушается на «самую суть» лирики с попыткой «умерщвления» «лирического поэта» и автора (в смысле текстовой инстанции) и тем самым ставит трансформацию субъектности в центр своей поэтики: «Похоже, на нынешнем этапе - а я подозреваю, что поэзия сохраняет себя только так - путем самоуничтожения, отсечения всего, что только что составляло ее неотъемлемую принадлежность, а то и самую суть - смысл лирики, ее новое дело жиз$н и$ состоит в попытке покушения на то, без чего она пока не умеет обходиться: на личность поэта. И поскольку поэзия вещь последовательная, если автор становится для нее проблемой, она должна с ним что-то сделать. Вопрос - что» (Степанова 2017, с. 420421). О «кенотичности» современной поэзии ср. у Кукулина (2008). 
стям и соответствующим им видам речевых актов и их манифестаций в продуктах речевой деятельности, среди которых находится и письменность.

Сегодня менее востребованы трансисторические и глобальные определения жанров, нежели развитие методологического инструментария, позволяющего описать изменения в использовании речевых функций и их распределении по родовым и жанровым формам на определенном этапе. Необходимо установить их отношение к конкретным, культурно и исторически устоявшимся нормам, на фоне которых понятия и рода, и жанров приобретают свои, относительно новые признаки.

По этой причине мы предлагаем говорить о «поэтических произведениях» и «поэзии», избегая родового определения. В данной статье говорится о «поэтических произведениях» в случаях, когда есть установка на художественную обработку языка, но отсутствует версификация в классическом смысле. В новейшей поэзии заметна тенденция к стихотворениям в прозе и к гибридным «прозостихам», которые, как и интермедиальные формы, выходят за пределы как родового понятия лирики, так и формального определения поэзии, но подаются с претензией на статус «поэзии».

К тому же в русском литературоведении родовое понятие лирики тесно связано с романтическими признаками, такими как субъективность (т.е. выражение психических и когнитивных аспектов субъекта), а также субъектность (т.е. присутствие субъекта, имплицитное или эксплицитно маркированное), и поэтому избегается как общее понятие. Новейший учебник исследовательской группы под руководством Наталии Азаровой посвящен как раз не лирике, а поэзии как более широкому понятию, в которое входят и лирические, и нарративные жанры в стихах. ${ }^{12}$ Однако здесь «лирическая

12 «В нарративных стихах внимание читателя сосредоточено на том, о чем рассказывает автор, в лирических - на том, как он рассказывает, на самой его речи. Поэтому для лирических стихов особенно важно понятие субъекта - того, кто говорит с нами с помощью поэтического текста и чьими глазами мы видим то, что в этом тексте изображено [...] Именно особенности субъекта создают неповторимый мир лирического стихотворения - хотя какая-то история может быть рассказана и в нем [...]» (Азарова et al. 2016, c. 21). В западной теории лирики распространено, напротив, четкое разграничение лирики от нарративных текстов, причем не по оппозиции субъект - объект речи, а по данности или отсутствию нарративности (понимаемой как опосредованная речь, передающая что-либо, часто пересказ какой-либо истории, т.е. представление некоторой очередности действий), см., например: „Nicht als lyrisch zu bezeichnen sind [...] zunächst einmal alle Gedichte, die durch die Struktur der Redevermittlung gekennzeichnet sind. Diese Struktur ist charakteristisch für epische Gedichte, als deren Prototyp das klassische Versepos gelten kann.“ [Все стихотворения, для которых характерна структура опосредованной речи, не могут рассматриваться в качестве лирических.] (Lamping 1989, S. 89). Поэтому баллады, а также эпиграммы, по Лампингу (там же), не являются лирическими стихотворениями. Общепринят в новых теориях также отказ как от субъективности, так и от самого субъекта как основного признака лирического, ср. в его же книге: „In einer umfassenden Definition der Lyrik ist also auf das Merkmal der Personalität ebenso zu verzichten 
поэзия» определяется по признаку фиксации на субъекте, а не на объекте речи, что представляет собой теоретический анахронизм. ${ }^{13}$ Возможно, установка учебника на субъект не случайна, так как он прежде всего обращается к современному материалу, а в новейшей поэзии именно субъект стал наиболее значимой и сложно обыгрываемой категорией, в которой авторы находят еще не исчерпанные возможности художественного выражения.

Данная статья имеет своей целью развитие инструментария для описания сложных субъектных форм, которые преимущественно встречаются в поэзии (но не только). Субъективность не рассматривается.

\section{Текстовой субъект и поэзия}

В России субъект до сих пор считается важной категорией как лирики, так и поэзии - в уже упомянутом новейшем учебнике группы Азаровой целая глава посвящена «поэтическому субъекту». В западных теориях лирики,

wie auf das der Subjektivität, weil das eine wie das andere - und erst recht das eine zusammen mit dem anderen - eine wenigstens aus heutiger Sicht nicht zu rechtfertigende Einschränkung des Begriffsinhalts zur Folge hätte.“ [В широком определении лирики надо отказаться от признака как персональности, так и субъективности, так как то и другое - и тем более то и другое вместе - по крайней мере с сегодняшней точки зрения означают неоправданное ограничение содержания понятия.] (Lamping 1989, S. 61). С точки зрения западных теорий лирики, по крайней мере в немецкой германистике и компаративистике, учебник «Поэзия» не соответствует современному уровню дискуссий даже конца 80-ых гг., не говоря уже о новейших теориях, как, например, Цимнера и других. Однако категорический отказ новых теоретиков лирики от субъекта идет вразрез с расцветом форм субъектности (а также субъективности) в новейшей поэзии, хотя, безусловно, ни субъектность, ни субъективность не являются исключительными признаками лирики.

${ }^{13}$ См. цитату в предыдущей ссылке (Азарова et al. 2016, с. 21). В русской теории лирики традиционно уделяется особое внимание субъекту (термин восходит еще к Андрею Белому, см. подробнее статью В. Новикова в настоящем сборнике). Ср., например, в ставшей классической книге Л. Гинзбург (цитируется по изданию 1997 г., воспроизводящему второе, расширенное издание 1974 г.): «Наряду с концепцией „непосредственного выражения“ издавна существовали и совсем другие определения лирики. При всем их многообразии, противоречивости, все они исходили обычно из признания особого положения субъекта, авторской личности в системе лирики, - что никоим образом не тождественно теориям прямых душевных излияний. [...] Специфика лирики в том, что человек присутствует в ней не только как автор, не только как объект изображения, но и как его субъект, включенный в эстетическую структуру произведения в качестве действенного ее элемента. При этом прямой разговор от имени лирического я нимало не обязателен. Авторский монолог - это лишь предельная лирическая форма. Лирика знает разные степени удаления от монологического типа, разные способы предметной и повествовательной зашифровки авторского сознания - от масок лирического героя до всевозможных „объективных“ сюжетов, персонажей, вещей, зашифровывающих лирическую личность именно с тем, чтобы она сквозь них просвечивала. В лирике активен субъект, но субъект лирики не обязательно индивидуален» (Гинзбург 1997, с. 9-10). 
однако, понятие субъекта стало весьма спорным. Многие теоретики избегают связи понятия «лирика» с субъективностью, признанной одним из главных свойств лирики, - в особенности после Гегеля и его известного определения лирики ${ }^{14}$ - но и с субъектностью, которая уже в античности считалась характерным свойством стихотворений ${ }^{15}$. Более того, они предлагают также устранить такие, ставшие в XX веке классическими, понятия, как «лирическое [поэтическое] я», «лирический [поэтический] субъект» ${ }^{16}$ и даже распространенное преимущественно в англоязычном мире «говорящий». Например, Рюдигер Цимнер переименовывает субъект высказывания или адресанта в «текстуальную фигурацию» („,Textfiguration“"17), так как субъект всегда создается в рамках текста. Адресант, или текстуальная фигурация, может быть маркирован (в виде персонажа или автора), скрыт (относительно автора) или вовсе отсутствовать. ${ }^{18}$

Цимнер ${ }^{19}$ полностью отрицает структурные формы субъекта в тексте как, в первую очередь, подход, переносящий нарратологическую теорию «абстрактного автора» на поэзию и вводящий «вместо эмпирического автора в тексте субъект», который действует «за спиной говорящего и фокализатора», т.е. подход, заменяющий реального автора текстовой, «структурирующей инстанцией»:

[...] я не понимаю, зачем необходимо предполагать существование абстрактного автора и к тому же скрывать его или лишь наблюдать его действия за чьими-нибудь спинами, и как это вообще возможно. ${ }^{20}$

Речь о субъектах или «я» осуждается как ненужное одушевление и онтологизация чисто текстовых феноменов. Таким образом, для Цимнера вообще оказывается лишним говорить о субъекте, тем более об «абстрактном авторе» или же «текстовом субъекте».

${ }^{14}$ Подробно о Гегеле см.: Culler (2015, p. 92-109). См. о значении гегелевской эстетики для теорий лирики, ставящих субъективность в центр внимания, например: Lamping (2000, S. 235-237).

${ }^{15}$ Hühn / Schönert (2002, с. 290) указывают на то, что традиция, усматривающая в стихотворении «среду для самоартикуляции и самоконститиурования говорящего („Меdium für die Selbst-Artikulation und Selbst-Konstitution des Sprechers“), восходит еще к античности.

${ }^{16}$ См. об истории понятия «лирическое я» и критической дискуссии на эту тему: Borkowski / Winko (2011).

${ }^{17}$ Zymner (2009, S. 20).

18 Там же.

${ }^{19}$ Zymner (2009).

${ }^{20}$, ,...] ich sehe nicht ein, weshalb man einen abstrakten Autor annehmen müßte und außerdem seine Machenschaften hinter irgendwelchen Rücken decken oder auch nur beobachten sollte und wie man es überhaupt könnte" (Zymner 2009, S. 18). 
Противоположную Цимнеру позицию занимает Дитер Бурдорф, который предлагает различать формы субъекта в поэтических текстах по аналогии с нарратологической коммуникативной моделью ${ }^{21}$. Он видит преимущество этого подхода в том, что он позволяет понять стихотворения как продукты коммуникативных актов реальных людей с определенной интенцией, выраженной в самом тексте и ждущей своей расшифровки читателем. Избегая отождествления текстовых инстанций с реальным лицом автора, Бурдорф подчеркивает, что в тексте осуществляется лишь «творческий порыв» автора. Этот «порыв» является структурирующей силой текстового целого и заменяет автора в тексте, т.е. «отпечаток» этого порыва в тексте есть не выражение реального субъекта, но сам «текстовой субъект», т.е. инстанция текста, связь которой с реальным автором прослеживается, но которая при этом не совпадает с ним. По этой причине Бурдорф отвергает возможность говорить об «абстрактном авторе». Текстовой субъект Бурдорф описывает как предполагаемого носителя интенции, выраженной в тексте, декодированной читателем и приписываемой им реальному автору:

Thus, the personal structure of poems cannot be described sufficiently by simply positing the articulated I in opposition to the real or empirical author, for he or she is not even part of the poem. As a work of literature, the text has detached itself from its factual producer. Nonetheless, the author's creative drive is represented in the text itself: he or she has become part of the poem as a structuring authority. If we don't wish to consider poems products of arbitrary powers or superhuman forces, and if we don't wish to cut off the connection between a poem and the human being who made it, we will have to define this structuring authority as a subject, so to speak as a placeholder for the empirical author in the text. This is the only method that allows us to ascribe a communicative intention to poems, an intention which has to be reflected in lyric analysis.

[...] I refer to this entity as the Textsubjekt ('textual subject'). In contrast to the 'implied' or 'abstract author', the term 'textual subject' brings certain benefits: Whereas the 'implied' or 'abstract author' remains unclear and indefinite with regard to its particular status and relation to the text, the 'textual subject' points to the fact that it is about a subjective, textual entity, constructed in and by the text. [...] The textual subject therefore has to be situated between the I speaking in the text and the factual producer of this text. It organizes a poem's perspective and directs the I without being identical with it. ${ }^{22}$

Для текстового субъекта, однако, имеет значение также то различие, которое Вольф Шмид устанавливает для абстрактного автора - его можно рассматривать как исключительно текстовую инстанцию и упускать из виду

21 Нарратологическая коммуникативная модель со своими уровнями и инстанциями (Schmid 2014a) неоднократно применялась к поэзии (например, Grübel 1987, Bernhart 1993, Schönert 1999, Hühn / Schönert 2002, Burdorf 2015). Однако это трансжанровое применение нарратологических установок было также и оспорено (см., например: Müller 2004, S. 95).

${ }^{22}$ Burdorf (2017, p. 25). 
возможные связи с автором, или наоборот, как «след конкретного автора в произведении» ${ }^{23}$.

Бурдорф, как и Шмид, считают эту инстанцию важнейшим смысловым пластом, содержащим интенцию текста. Шмид с полным правом подчеркивает, что этот смысл, созданный в этом пласте произведения, может отличаться от позиций самого автора, одновременно выраженных в других жанрах, в особенности нехудожественных, что объясняет необходимость устанавливать отношения между позициями, приписываемыми абстрактному и реальному авторам:

Contrary to the impression given by the term "author's image", the relation between the implied author and the real author should not be pictured in such a way that the former becomes a reflection or copy of the latter. [...] the implied author cannot be modelled as the mouthpiece of the real author. It is not unusual for authors to experiment with their world-views and put their beliefs to the test in their works. ${ }^{24}$

Мы с Бурдорфом предпочитаем говорить о текстовом субъекте именно изза этого возможного различия: субъект в тексте принципиально отделен от автора, так как он, во-первых, есть его продукт, созданный сознательно или бессознательно. А во-вторых, этот субъект скрыт в структуре текста и должен быть выявлен читателем, т.е. он не только инстанция текста, но одновременно и ее реконструкция читателем при помощи анализа и герменевтического акта понимания, в котором необходимо субъективное участие со стороны читателя (метод и подход к анализу, знание, а также когнитивные способности).

Хотя текстовой субъект может существовать, как и его терминологический двойник «абстрактный автор», во всех жанрах, он играет особую роль в произведениях с установкой на язык, т.е. в поэтических произведениях: усиленной саморефлексии субъекта Нового времени соответствует поэтическая (или эстетическая) функция языка (в понимании Романа Якобсона), именно в поэзии выходящая на передний план. Поэтому неслучайно именно в поэтических произведениях с единичной речью, т.е. с одним говорящим адресантом, мы находим примеры умноженной ролевой функции, которая относится к уровню не только говорящего, но и текстового субъекта, отличающегося как от говорящего, так и от самого

23 „Den abstrakten Autor kann man von zwei Seiten her bestimmen, vom Werk her und unter dem Aspekt des werktranszendenten konkreten Autors. In der ersten Perspektive ist der abstrakte Autor die Hypostase des das Werk prägenden Konstruktionsprinzips. In der zweiten Sichtweise ist er die Spur des konkreten Autors im Werk, sein immanenter Repräsentant." [Абстрактного автора можно определить с двух сторон: с позиции произведения и с позиции конкретного, но трансцендентного по отношению к своему произведению автора. В первом случае абстрактный автор является ипостасью конструктивного принципа произведения. Со второй точки зрения он является следом конкретного автора в произведении, его имманентным представителем.] (Schmid 2014a, S. 61).

${ }^{24}$ Schmid (2014b, p. 167-168.). 
автора. Пример такого многоипостасного субъекта можно найти в цикле Елены Шварц о монахине Лавинии. ${ }^{25}$

Но обращение к языку позволяет и вовсе элиминировать говорящего как носителя речевого акта, заменяя его композиционной формой самого языка, как мы это видим в визуальной поэзии. В таком случае адресант совпадает с языковой композицией или текстовым субъектом, скрытым в ней. В новейшей поэзии, напротив, наблюдается возврат сильного автобиографического субъекта - к примеру, на Ютубе подчеркивается именно тождество «поэта» с говорящим в тексте, когда сам поэт читает или, точнее, исполняет свой текст. ${ }^{26}$ Это тождество - игра с ролями субъекта, имеющая определенную функцию (например, подчеркивание политической позиции «аутентичностью» и «искренностью», которые на самом деле служат риторическим приемом). Вместе с отождествлением говорящего, текстового субъекта и самого автора, точнее его «имиджа», сформированного произведениями, а также его действиями в публичном пространстве, существует и противоположная тенденция к распылению субъекта в произведении, связанная с употреблением различных жанров и платформ авторской самопрезентации, к умножению, уничтожению и прочим разновидностям игр с субъектными формами. Эти игры не ограничены рамками одного текста и могут взаимодействовать с субъектными формами в других текстах, а также с внетекстовыми формами, как показывают, например, Дмитрий Пригов и его современные постконцептуалистские адепты вроде Романа Осминкина. ${ }^{27}$ Авторы как бы создают множество образов субъектов, которые могут, но не должны соотноситься с ними самими.

Для описания подобных сложных субъектных форм необходим более тонкий инструментарий, чем тот, что предлагают Цимнер или Бурдорф. Коммуникативная модель текстовых инстанций, а также вышеупомянутое распределение адресанта по четырем формам у Цимнера оказываются недостаточными для описания такого множества форм, в которые входит и игра с личностью реального автора, переходящая границы текста как художественного и как «фиктивного» продукта с так называемой действительностью, которая со своей стороны сама, в обратном процессе, становится материалом для художественных приемов.

25 См. более подробно: Шталь (2019b, в печати). Вымышленные текстовые субъекты под именами выдуманных авторов других национальностей в прозе создает, например, Фаина Гримберг. Ср.: «Далее я поняла, что работа от лица вымышленного автора дает мне очень многое. Особенности жизни той или иной общности легче раскрывались, когда говорили придуманные мною представители разных этнических групп: немец Якоб Ланг, турок Сабахатдин-Бора Этергюн, еврейка Марианна Бенлаид и другие» (Гримберг 2005).

${ }^{26}$ См., например, о виральном стихотворении Анастасии Дмитрук «Никогда мы не будем братьями» на Ютубе: Stahl (2015, 2017a).

${ }^{27}$ См. более подробно об этих примерах: Шталь (2019а, в печати). 
Во-первых, нужен подход для различения субъектных форм в самом поэтическом произведении, а также для установления их же отношения к другим субъектным формам в других произведениях автора или к его внетекстовым образам. Во-вторых, интенция или установка на передачу какого-либо смысла не позволяет определить форму самого субъекта: уход от простого централизованного единого субъекта связан с расцветом множества его форм. Именно множественная и многослойная форма субъекта в ее сложных соотношениях развита в новейшей поэзии. Втретьих, этим формам не обязательно соответствует «адресат», который в коммуникативной модели подразумевается для каждой формы адресанта. По этим причинам нужен другой подход, который выдвинет в фокус не коммуникативный акт с его носителями и смыслом, а самого субъекта и различение его возможных форм.

Мы предлагаем обосновать такой подход при помощи экзистенциальной философии Генриха Барта. Преимущество этого подхода состоит в том, что он позволяет описать и «автобиографические», или «реальные», субъектные формы наравне с художественными - все выражения субъекта необходимо понимать как «образы», реализующиеся в соотношениях различных явлений. Ни реальный, ни трансцендентный субъекты сами по себе не уловимы. Есть только трансцендентальная предпосылка для установления субъектных форм - как данных для восприятия, так и скрытых в структуре их соотношений и ждущих своего открытия в эстетическом созерцании. Субъект, по Барту, - это многослойная и подвижная соотнесенность явлений или форм выражения субъекта, управляемая скрытым принципом, обнаружение которого позволяет созерцать эту соотнесенность как таковую.

\section{«Субъект» как «Самость» в философии экзистенции Генриха Барта ${ }^{28}$}

Генрих Барт (1890-1965), философию экзистенции которого лишь сравнительно недавно открыли заново, ${ }^{29}$ еще в первой половине XX века заложил краеугольный камень для философии субъекта после постмодернизма, провозгласившего «исчезновение субъекта» и отрицавшего потребность в

\footnotetext{
28 Этот раздел воспроизводится в несколько измененной форме по статье: Шталь (2016, c. 169-174).

${ }^{29}$ Бокен ставит Генриха Барта в один ряд с Хайдеггером и Ясперсом, а Граф еще и с Сартром. См.: Graf (2008, S. 15); Bocken (2007, S. 139). См. о его центральном понятии «экзистеничи»: Grund (1999), Graf / Schwaetzer (Hgg., 2007). Первый номер бюллетеня общества Генриха Барта вышел в сентябре 1997 г. На сегодня вышло в целом 20 номеров (см.: http://www.heinrich-barth.ch/gesellschaft.html\#anchor_bulletin). Список научной литературы о Барте имеется на сайте общества:

http://www.heinrich-barth.ch/forschung.html (07/08/2018).
} 
философии субъекта вообще. ${ }^{30}$ Его подход выделяется тем, что объединяет трансцендентализм кантианского типа с экзистенциализмом и феноменологией. ${ }^{31}$ Тем самым, Барт избегает односторонности как эмпирического, так и рационального или метафизического направлений. Стремясь к обоснованию «основополагающих принципов индивидуума, Я, самости, личности» ${ }^{32}$, он сознательно обходит как гипостазирование субъекта ${ }^{33}$ или индивидуальности человека, так и его простое отрицание. ${ }^{34}$

Исходной точкой своей философии экзистенции Барт полагает насущную потребность обоснования понятия субъекта: если мы исходим из факта экзистенции человека, то «мы очевидно не можем избежать вопроса: кто или что актуализируется в экзистенциич? Как обстоит дело с AGENS [лат. ДЕЯТЕЛЕМ. - Х. Ш.]?» ${ }^{35}$

${ }^{30}$ К философии субъекта Барта можно отнести и оценку Графа: «Именно то, что могло стать одной из причин недостаточного внимания к Барту, делает его таким интересным для нас сегодня: его позиция между дискурсами. Ибо в то время, как современные дискуссии, возможно, и тут, и там несколько зашли в тупик, Барт обращает внимание на альтернативные констелляции мысли и может, таким образом, придать мышлению новые импульсы и указать новые пути». („Genau das, was die fehlende Beachtung Barths mit verursacht haben dürfte, macht ihn nun aber heute so interessant: seine Stellung zwischen den Diskursen. Denn wenn sich gegenwärtige Diskussionen da und dort vielleicht etwas festgefahren haben, so lenkt Barth die Aufmerksamkeit auf alternative Gedankenkonstellationen und ist so in der Lage, dem Denken neue Impulse zu geben und neue Wege zu weisen.") (Graf 2008, S. 14-15).

31 Сборник Зеппа и Вильдермута посвящен вопросу отношения философии Барта к феноменологии: Sepp / Wildermuth (2010).

32 ,grundlegende [...] Prinzipien des Individuums, des Ich, des Selbst, der Persönlichkeit“ (Barth 1965, S. 293).

33 «Несмотря на это, мы считаем необходимым не поддаться внушению гипостазирующего взгляда, слишком очевидно признанного в качестве общего консенсуса». („Nichtsdestoweniger sehen wir uns veranlaßt, uns der Suggestion einer hypostasierenden Auffassung, die nur allzu offenkundig von dem allgemeinen Consensus getragen wird, zu entziehen.") (Barth 1965, S. 301.)

34 «Нас могут заподозрить в том, что мы вступили на путь критической деконструкции [...] Но мы надеемся, что широко простирающаяся реализация хода наших мыслей [...] не приведет к негативному результату». (,Wir setzen uns dem Verdachte aus, den Weg einer kritischen Destruktion beschritten zu haben [...] Doch wir hoffen, daß uns die weit ausgreifende Durchführung unseres Gedankenganges [...] nicht zu einem negativen Ergebnisse führt.“) (Barth 1965, S. 303-304).

35 „D enn wir können offenbar der Frage nicht ausweichen: W e r oder w a s ist es, das sich in der Existenz aktualisiert? Wie steht es mit dem A G E N S ? “(Barth 2007, S. 87)

Важнейшие положения о субъекте в философии Барта освещены в одной из его лекций 1951-58 гг. «Экзистенциия в своем ,личном“ значении» (Barth 2007, S. 85-105) и в пятой главе «Индивидуальная экзистенция и личность»его главного произведения «Познание экзистенции» (Barth 1965, S. 298-359). 
Бартовская концепция субъекта открывает возможность охватить спектр форм субъекта между крайними полюсами утверждения некоторого единого субъекта до его полной неопределимости или отрицания и между всеобщим универсализмом и экстремальным индивидуализмом. При этом имеется возможность некоторого иерархического упорядочения форм субъекта, так как они определяются по разным уровням познания, которым они соответствуют.

Особенность философии Барта составляет ее эстетическая и герменевтическая установка. ${ }^{36}$ Единичный феномен открывается не познанию, а художественному созерцанию, способному охватить явление как сложное структурированное целое. Художник не сводит явление к понятию и не абстрагирует общее от единичного, но созерцает комплексное соотношение составляющих в самом явлении. Этот художественный подход делает возможным уразуметь человека как предельно индивидуального субъекта ${ }^{37}$ :

Лишь эстетическое уразумение, при котором понятие не опережает созериание, способно уразуметь человека в том, каким он выступает в явлении; в его интегральном, не сломленном проявлении. ${ }^{38}$

Эстетическое уразумение индивидуального явления для Барта - герменевтический акт интерпретации, позволяющей каждый раз по-новому и подругому, с другой точки зрения, из другой перспективы, увидеть явление, так что возможно бесконечное множество его восприятий. Выходит, что в Бартовской философии уразумение субъекта в явлении аналогично созданию и интерпретации художественного произведения.

Барт различает три уровня познания и, соответственно, субъекта. Первый уровень - человек как явление еще до его художественного восприятия. Явление охарактеризовано множеством деталей и внешним, преходящим единством, данным во времени и пространстве и поэтому постоянно меняющимся. Такое релятивное существование не имеет смысла и значения за пределами своего явления. На этом уровне не может быть речи о «субъекте» в смысле интегрального целого. Субъект как целое открывается лишь при том условии, что существует что-то вне и выше этой постоянно изменяющейся относительности:

${ }^{36}$ См.: Wildermuth (1990).

37 «Мы стоим тут перед противоположным всей эйдетической ясности и прозрачности полюсом: перед бытием единичного, как оно проявляется в явлении во всем своем наиболее полном способе бытия.» (,Wir stehen hier vor dem Gegenpol gegen alle eidetische Klarheit und Durchsichtigkeit: vor dem Sein des Einzelnen, wie er in seiner erfülltesten Seinsweise in die Erscheinung tritt.") (Barth 1965, S. 344).

38 „Nur das aesthetische Erfassen, in dem der Begriff der Anschau un nicht vorgreift, erfaßt den Menschen, wie erin die Erscheinung tritt; in seinem in te gra le n, u n g e b r o c h e n e n Erscheinen.“(Barth 2007, S. 88-89). 
Но остается одно насущное требование: отношение экзистенции к тому, что охватывает эту относительность; к чему-то непреходящему, что не затрагивается восходящими и нисходящими движениями экзистенции; к «принципу», расположенному по ту сторону высот и глубин экзистенциальной актуализации. ${ }^{39}$

Этот «принцип» не может быть «неким индивидуальным Я» ${ }^{40}$, платонически понятым «эйдосом» или онтологизированной душой: он есть лишь «принцип ,субъекта“ познания» ${ }^{41}$, который, подобно античному Логосу, есть всеобщее и универсальное условие возможности осмысленной и индивидуальной экзистенции. ${ }^{42}$ Аналогично кантовскому обоснованию познания трансцендентальным условием познания, субъект оказывается мыслимым только в том случае, когда представляется в отношении к «трансцендентальному Я». Этот «трансцендентальный субъект» «есть смыслопридающий принции актуализирующейся экзистенции. Как таковой он мыслим лишь в отнесенности к этой актуализации. С другой стороны, актуализация экзистенциального познания без отнесенности к своему трансцендентальному принципу теряет всякий смысл и всякое значение». ${ }^{43}$ «Субъект

39 „Es bleibt aber ein D e s i d e r a t : die Beziehung der Existenz auf ein i h r e R e lat i vität Übergreifendes; auf ein B e harrendes, das von dem Auf- und Absteigen der Bewegung der Existenz unberührt bleibt; auf ein ,Prinzip“, das j e n s e i t s der Höhen und Tiefen existenzieller Aktualisierung liegt.“ (Barth 2007, S. 94).

${ }^{40}$, ,k e i n individue 11 e s I c h “(Barth 2007, S. 98).

41 „Prinzip des ,Subjektes“ der Erkenntnis“ (Barth 2007, S. 97).

42 См. о различиях философии Барта от неокантианства и от Хайдеггера: Graf (2008, гл. 1 и 3). Отличие от Кантовского трансцендентализма, который Барт считает недостаточно критическим, таково: «Уже занятие проблемой вещи-в-себе [...] означает для Барта возврат к метафизике; то же самое касается тенденции Канта показать субъект познания предданным познанию. Поэтому Барт считает необходимым превзойти Канma». („Nur schon sein Sicheinlassen auf das Ding-an-sich-Problem [...] bedeutet für Barth einen Rückfall in die Metaphysik; nicht anders Kants Tendenz, das Subjekt der Erkenntnis als dieser vorgegeben erscheinen zu lassen. So ergibt sich für Barth die Notwendigkeit, über Kant hinauszugehen.") (Graf 2008, S. 174). Хофер справедливо указывает на то, что у Барта «Логос» становится «конститутивным принципом познания», и тем самым трансцендентальный подход незаметно переходит в «абсолютную трансцендентность» (Hofer 2010, S. 97). См. также: «[...] трансцендентально понятый в строго кантианском смысле Логос одновременно и трансцендентен, поскольку он не может быть до конца схваченным, понятым или овладеваемым». (,[...] dass der im strengen kantischen Sinne transzendental verstandene Logos zugleich transzendent ist, insofern er nicht im letzten erfassbar, verstehbar oder beherrschbar ist.") (Schwaetzer 2010, S. 116). Отношение Барта и Канта изучает более подробно: Hofer (2014).

Здесь проявляется христианская подоплека Барта, брата знаменитого протестантского теолога Карла Барта (1886-1968), см. об их отношениях: Danz (2007).

${ }^{43}$ Das transzendentale Ich ,ist ein s in $\mathrm{g}$ e be n d e s P r in z i p der sich aktualisierenden Existenz. Als solches ist es nur in B e zogenheit auf diese Aktualis i e rung denkbar. Andrerseits ve r li e r t die Aktualisierung existenzieller Erkenntnis o h n e Bezo- 
трансцендентального порядка», «TRANSCENDENS», является предпосылкой для самого понятия субъекта в явлении. ${ }^{44}$

Лишь на втором уровне, сопряженном между явлением и трансцендентальным порядком, открывается собственно субъект, который Барт называет «Самостью» в отличие от эмпирического и трансцендентального «Я». ${ }^{45}$ Эта «Самость» есть «интегрирующий момент» «актуализирующейся экзистенции» ${ }^{46}$, т.е. она выступает связью всех составляющих и их всестороннего соотношения, которую можно увидеть как образ (нем. Gestalt $^{47}$ ). «Самость» ни в коем случае нельзя определить как нечто особенное, эксплицитно данное:

Самость не является особой составной частью экзистенции; но она есть нечто относительное в том смысле, что может быть увидена каждый раз в ином содержании экзистенции. ${ }^{48}$

«Самость» есть структура, раскрытая интерпретирующим взглядом, направленным на смысловые соотношения всех единичных составляющих и их взаимосвязей в объекте. ${ }^{49}$ «Самость» никогда не может быть охвачена

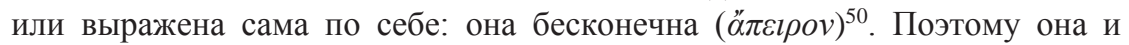

genheit auf ihr transzendentales Prinzip allen S i n n und alle B e d e u t u n g . " (Barth 2007, S. 103).

${ }^{44}$ Transzendentales Ich oder das Ich als TRANSCENDENS ist Voraussetzung des Selbst in diesem Sinne (Barth 2007, S. 95), „Subjekt transzendentaler Ordnung“ (Barth 2007, S. 95); „als das transzendental verstandene Subjekt des Existierens“ (Barth 2007, S. 95).

${ }^{45}$ Barth (2007, S. 89).

${ }^{46}$ Das Selbst ist das ,i n te grierende [... ] M o me n t “ „der sich aktualisierenden Ex is te n z" (Barth 2007, S. 93).

47 Барт говорит о „Gebilde“, „Gestalten der Erscheinung“ (нем.), образованиях или образах явлений (Barth 1965, S. 310), воспроизведенных художником как «свыше призванным интерпретатором» (,höchst berufener Interpret“) явлениях, в которых проявляется «настоящая экзистенция» (,,wirkliche Existenz“) (Barth 1965, S. 311).

48 „Das Selbst ist also n i c h t ein be s o n d e re r B e s t a n d t e i 1 der Existenz; sondern i n s of e r n ein Relatives, als es in i m m e r wi eder a n d e r m Gehalte der Existenz gesehen werden kann“ (Barth 2007, S. 94).

${ }^{49}$ Dieses findet sich ,in S i n n b e z i e h u n g e n, durch die sich die einzelnen Momente zu einem $\mathrm{Z}$ u s a $\mathrm{m}$ m e $\mathrm{n}$ h a n g e der Aktualisierung der Existenz aufbauen.“ (Barth 2007, S. 99).

Барт развивает понятие «Самости» в смысле «актуализации проявления-в-явлении, которое по существу ускользает от любого присутствия» („Denn die Aktualisierung des In-die-Erscheinung-Tretens entzieht sich wesensmäßig aller Präsenz.“; Barth 1965, S. 122). Ван Крекхофен называет эту «актуализацию проявления-в-явлении» «чистой феноменальностью» (Kerckhoven 2010, S. 61). См. также посвященный этой проблеме сборник: Hauff / Schweizer / Wildermuth (Hgg., 1990).

${ }^{50}$ Denn: „Das ,Selbst‘ wird ni e a 1 s s o 1 c he s erfaßbar und darstellbar“ (Barth 2007, S. 90). „Denn er ist ein , $\alpha \pi \varepsilon 1 \rho v^{*} “$ (Barth 2007, S. 90). 
остается «тайной» ${ }^{51}$, хотя и открытой для познания, приближающегося к ней в бесконечном процессе улавливания ее соотношений.

Индивидуальность субъекта осуществляется исключительно в художественном созерцании и интерпретации. Но эта интерпретация не является случайной или вольной, «субъективной» в отрицательном смысле, а диалогичной ${ }^{52}$, так как она обусловлена, с одной стороны, схватыванием взаимосвязей, создающих определенный образ, а с другой - точкой зрения воспринимающего структуру. ${ }^{53}$ Направленность интерпретирующего на восприятие «Самости» явления, существование которой обусловлено предпосылкой экзистенции «трансцендентального Я», гарантирует правдивость созданного образа. Что она есть сама в себе и существует ли она на самом деле - это неуместный вопрос, предполагающий не трансцендентальный, а трансцендентный, онтологизирующий подход. Спросить позволено лишь, в каких формах [Gestalten] она проявляется для взгляда. Субъект есть деятель, сознательные или бессознательные интенции которого осуществляются в его выражениях: они воспринимаются как «физиогномия» или «мимика» субъекта, который в них проявляется, но сам по себе остается непознаваем. ${ }^{54}$

${ }^{51}$ Der Mensch selbst, ,der uns in der Un s a g b arke it seiner Individualität als ein G e h e i m n i s anspricht.“"(Barth 2007, S. 89).

52 Диалогичные моменты в мышлении замечает и Грэтцель (Grätzel 2010).

${ }^{53}$ На эту особенность герменевтики Барта указывает и Граф. Всеобщую истину Барт замещает «экзистенциальной истиной» (см. главный труд Барта: «Познание экзистенции» (,Erkenntnis der Existenz“; Barth 1965), правдивость которой заключается в конкретной познавательной ситуации: «Относительно определенного аспекта экзистенциальная истина является такой же абсолютной и общей, как и теоретическая. Ее универсальность заключается в том, что каждый исторический миг находится в точно таком же непосредственном отношении к истине и может принципиально претендовать на то же право стать местом свидетельства об истине» („Die existentielle Wahrheit ist unter einem bestimmten Aspekt genauso absolut und allgemein wie die theoretische. Ihre Universalität liegt darin, dass jeder geschichtliche Augenblick in demselben, unmittelbaren Verhältnis zur Wahrheit steht und grundsätzlich dasselbe Recht für sich in Anspruch nehmen kann, zum Ort einer Wahrheitsbezeugung zu werden.“) (Graf 2010, S. 31). См. также: «Что философия должна работать дескриптивно-аналитическим способом и раскрывать структуры, давным-давно является само собой разумеющимся. Иначе спрашивается, каким образом философская мысль смогла бы претендовать на хотя бы последний остаток научности?» („Dass Philosophie deskriptiv-analytisch vorzugehen und Strukturen aufzuweisen hat, versteht sich längst von selber. Wie anders soll philosophisches Denken wenigstens einen letzten Rest an Wissenschaftlichkeit für sich beanspruchen?“) (Graf 2008, S. 168).

54 Такие понятия, как «физиогномия», «лик» или «жест», у Барта тесно связаны с центральным концептом «проявления-в-явлении», см. Barth (2007, S. 87, 89, 93, 98 и пр.). См. также: Wildermuth (1990, S. 233-242). 
Многоипостасная модель поэтического субъекта

Родство Бартовской концепции субъекта с искусством, а его иерархии трех уровней субъекта - с теорией коммуникативных пластов художественного текста делает ее привлекательной для описания субъекта в поэзии. С помощью его философии становится возможным развить модель для описания форм субъекта в художественных, собственно поэтических, произведениях, т.е. поэтического субъекта.

Эмпирический субъект, данный в явлениях, - это персонаж в тексте или также его адресант. Гипостазирование трансцендентального субъекта - достаточное условие для выявления субъекта в тексте как продукте автора. А «самость»- это текстовой субъект. Даже в том случае, когда автор отрицает его существование, субъект выявляется в структуре текста: он неизбежно присутствует как принцип построения или композиции текста (т.е. как текстовой субъект). Решающий момент - присутствие самого текста и направленность воспринимающего на принцип построения текста, т.е. восприятие текста как композиции и структурного целого (это не подразумевает, что текст обязательно должен обладать внутренне связанной структурой: пусть он будет хаосом, тогда этот хаос и есть принцип структурного целого).

Восприятие текстового субъекта есть его реконструкция в качестве открытия структурного целого, его формы и смысла, выраженного в нем. Выводы такой концепции нельзя обобщать и абстрагировать от текста напротив, необходимо искать индивидуальные особенности в структуре текста и демонстрировать или описывать их. Точка зрения или перспектива, с которой воспринимающий выявляет субъект текста, должна быть осознанной в качестве составляющего и крайне важного момента восприятия-реконструкции.

В отличие от коммуникативной модели, автор по модели Барта радикально отграничен от своего произведения, так как оно является возможностью его выявления, а сам автор остается вне этого выявления и как таковой принципиально не познаваем. Однако необходимо соотнести друг с другом разные его «самости», т.е. установленные образы субъекта автора в его разных выявлениях или выражениях. Субъект одного произведения должен быть сопоставлен с другими образами автора как в его художественных, так и нехудожественных формах выражения, чтобы установить специфику и место текстового субъекта в целом всех проявлений «самости» автора. При этом в каждом случае целесообразно различать и эксплицитно данный эмпирический субъект (говорящий, адресант), и эстетический или структурно данный, т.е. текстовой субъект, и устанавливать их соотношение. Соотнесение друг с другом «самостей» или эстетических субъектов разных выявлений автора позволяет, с одной стороны, выявить специфику отдельных субъектов, а с другой - установить образ субъекта 
самого автора как «реляционного субъекта», состоявшегося исключительно в соотношении всех его образов, данных во множестве их проявлений:

\section{I. В произведении: II. За пределами произведения:}

Адресант

Текстовой субъект

Автор как трансцендентальный и реальный субъект:

Совокупность произведений / продуктов:

\section{Адресант}

Текстовой субъект

\section{III. Соотномение I. $u$ II.:}

Реляционный субъект автора

Термин «поэтический субъект» можно отнести или к образу соотношения адресанта и текстового субъекта в рамках одного текста, или к реляционному субъекту автора, который реализуется во взаимоотношениях поэтического произведения с другими формами выражения автора (художественными и нехудожественными). Как показывают примеры, даже реляционный субъект автора может стать осознанным поэтическим проектом (Роман Осминкин). ${ }^{55}$

Преимущество этого подхода состоит в том, что он исходит из предположения о множестве различных субъектных форм отдельных произведений, т.е. привлекает внимание к возможности имагинативного характера даже текстового (Шварц) или реляционного (Осминкин) субъектов, которые могут быть такой же ролью или маской, что и персонаж в поэтическом произведении. Но это означает и то, что автобиографические формы выражения субъекта по существу не отличаются от художественных, - и в них есть такой же структурный субъект, ждущий своего открытия, как и в случае с текстовым субъектом. Фиктивность или автобиографичность, таким образом, можно более точно определить как градацию форм отношений между субъектными выражениями, созданными автором с функциональной установкой на то или на другое.

Итак, подобное обоснование изучения и описания поэтического субъекта означает следующее:

- предположение присутствия субъекта в каждом произведении обоснованно; субъект присутствует в текстах всех жанров; даже в драматическом тексте или визуальном произведении, в которых совсем нет или только слабо выражается инстанция рассказчика, лирического голоса и пр.;

- можно полностью учесть индивидуальность каждого произведения и формы выражения субъекта в нем;

- обоснованно преимущество структурно-герменевтического подхода ${ }^{56}$ к произведению, ведущего к познанию в качестве восприятия-реконструк-

\footnotetext{
${ }^{55}$ См. Шталь (2019а, в печати).

${ }^{56}$ Об этом см. более подробно: Stahl (2013).
} 
ции индивидуального облика субъекта и допускающего множество равно правдивых интерпретаций;

- можно учесть четыре главных формы субъекта - выраженный субъект (как составляющая текста: персонаж, говорящий / адресант), собственно субъект (как инстанция структур текста: «текстовой субъект»), трансиендентальный субъект - предполагаемый автор, гарантирующий субъектность, но проявляющий себя и в других формах или образах, которые равно необходимо познать, устанавливая их соотношения между собой, из чего и складывается четвертая форма субъекта: реляционный субъект автоpa. Этот четвертый субъект частично соответствует абстрактному автору с установкой не на текст, а на личность автора (по вышеприведенной формулировке Вольфа Шмида), но, в отличие от абстрактного автора, в него входят и другие субъектные выражения автора вне рамок данного текста. Произведения, а также другие формы выражения авторской инстанции могут в разной степени включать эти формы субъекта, по-разному оформлять их и организовывать их соотношение. На основе анализа общих принципов организации этих субъектных форм и их соотношений можно развить типологию субъекта в поэтических произведениях.

\section{Литература}

Азарова, Н. et al. (2016): Поэзия. Учебник. М.

Гинзбург, Л. (1997): О лирике. М.

Кукулин, И. (2008): От Сваровского к Жуковскому и обратно: О том, как метод исследования конструирует литературный канон // Новое литературное обозрение. 89, 2008. http://magazines.russ.ru/nlo/2008/89/ku16.html (06/08/2018).

Степанова, Мария (2017): Перемещенное лицо (вместо послесловия) (2012) // Степанова, Мария (2017): Против лирики. М. 412-433.

Шталь, Х. (2016): Опыт философского обоснования мета-теории поэтического субъекта: современное прочтение Генриха Барта // Азарова, Н. / Бочавер, С. (ред./сост.): Поэтический и философский дискурсы: история взаимодействия и современное состояние. М. 162-181.

Шталь, Х. (2019а, в печати): Партиципационная поэзия на Ютубе // Евграшкина, Е. / Шталь, Х. (ред./сост.): Субъект и лиминальность в современной русской литературе. Франкфурт-на-Майне.

Шталь, Х. (2019b, в печати): Типология субъекта в современной русской поэзии: теоретические основы // Russian Literature. Special Issue: Формы субъекта в современной русской поэзии / Под ред. Х. Шталь, Е. Евграшкиной. 
Barth, H. (1965): Erkenntnis der Existenz. Grundlinien einer philosophischen Systematik. Basel / Stuttgart.

Barth, H. (2007): Grundriß einer Philosophie der Existenz. Herausgegeben von Christian Graf, Cornelia Müller und Harald Schwaetzer. Regensburg.

Bernhart, W. (1993): Überlegungen zur Lyriktheorie aus erzähltheoretischer Sicht. In: Foltinek, H. (Hg.): Tales and „their telling difference“. Zur Theorie und Geschichte der Narrativik. Festschrift zum 70. Geburtstag von Franz K. Stanzel. Heidelberg. 359-375.

Bocken, I. (2007): Philosophie der Erscheinung und Psychologie der Weltanschauungen. In: Graf, Ch. / Schwaetzer, H. (Hgg.): Existenz. Genese, Umfeld und Facetten eines zentralen Begriffs bei Heinrich Barth. Regensburg. 139-161.

Borkowski, J. / Winko, S. (2011): Wer spricht das Gedicht? Noch einmal zum Begriff ,lyrisches Ich' und zu seinen Ersetzungsvorschlägen. In: Bleumer, H. / Emmelius, C. (Hgg.): Lyrische Narrationen - narrative Lyrik. Gattungsinterferenzen in der mittelalterlichen Literatur. Berlin / New York. 43-77.

Burdorf, D. (2015): Einführung in die Gedichtanalyse. Stuttgart.

Burdorf, D. (2017): The I and the Others: Articulations of Personality and Communication Structures in the Lyric. In: Journal of Literary Theory. 11 (1), 2017. 22-31.

Culler, J. (2015): Theory of the Lyric. Cambridge.

Danz, Ch. (2007): Ursprungsphilosophie und Theologiebegriff. Heinrich Barth im Kontext der dialektischen Theologie Karl Barths. In: Graf, Ch. / Schwaetzer, H. (Hgg.): Existenz. Genese, Umfeld und Facetten eines zentralen Begriffs bei Heinrich Barth. Regensburg. 105-122.

Fabb, N. (2015): What is Poetry? Language and Memory in the Poems of the World. Cambridge.

Graf, Ch. (2008): Ursprung und Krisis. Heinrich Barths existential-gnoseologischer Grundansatz in seiner Herausbildung und im Kontext neuerer Debatten. Basel.

Graf, Ch. (2010): Existentielle Wahrheit und Erkenntnis bei Heinrich Barth. In: Graf, Ch. / Schwaetzer, H. (Hgg.): Existenz. Genese, Umfeld und Facetten eines zentralen Begriffs bei Heinrich Barth. Regensburg. 17-44.

Graf, Ch. / Schwaetzer, H. (Hgg., 2007): Existenz. Genese, Umfeld und Facetten eines zentralen Begriffs bei Heinrich Barth. Regensburg.

Graf, Ch. / Schwaetzer, H. (Hgg., 2010): Existentielle Wahrheit. Heinrich Barths Philosophie im Spannungsfeld zwischen Wissenschaft, Kunst und christlichem Glauben. Regensburg.

Grätzel, S. (2010): Heinrich Barth und Michel Henry. In: Graf, Ch. / Schwaetzer, H. (Hgg.): Existenz. Genese, Umfeld und Facetten eines zentralen Begriffs bei Heinrich Barth. Regensburg. 45-58.

Grübel, R. (1987): The Personal Pragmatic Institutions of Poetic Discourse. In: Zavala, I.M. / Diaz-Diocaretz, M. / Van Dijk, Th. A. (eds.): Approaches to Discourse, Poetics and Psychiatry. Amsterdam. 149-170.

Grund, D. (1999): Erscheinung und Existenz. Die Bedeutung der Erscheinung für die Ansatzproblematik der transzendental begründeten Existenzphilosophie Heinrich Barths. Amsterdam / Atlanta.

Hauff, G. / Schweizer, H.R. / Wildermuth, A. (Hgg., 1990): IN ERSCHEINUNG TRETEN. Heinrich Barths Philosophie des Ästhetischen. Basel.

Hegel, G.W.F. (1970): Werke in zwanzig Bänden. Bd. 15: Vorlesungen über die Ästhetik. Frankfurt a.M. 
Hempfer, K.W. (2008): Überlegungen zur historischen Begründung einer systematischen Lyriktheorie. In: Hempfer, K.W. (Hg.): Sprachen der Lyrik: von der Antike bis zur digitalen Poesie. Für Gerhard Regn anlässlich seines 60. Geburtstags. Stuttgart. 33-60.

Hempfer, K.W. (2014): Lyrik. Skizze einer systematischen Theorie. Stuttgart.

Hillebrandt, C. et al. (2017): Theories of Lyric. In: Journal of Literary Theory. 11 (1), 2017. 1-11.

Hofer, M. (2010): Was heißt transzendentale Begründung der Existenz? In: Graf, Ch. / Schwaetzer, H. (Hgg.): Existenz. Genese, Umfeld und Facetten eines zentralen Begriffs bei Heinrich Barth. Regensburg. 89-102.

Hofer, M. (2014): Reine Anschauung. Heinrich Barth und Kant. In: Graf, Ch. / Schwaetzer, H. (Hgg.): Das Wirklichkeitsproblem in Transzendentalphilosophie und Metaphysik. Heinrich Barth im Kontext. Basel. 79-97.

Hühn, P. / Schönert, J. (2002): Zur narratologischen Analyse von Lyrik. In: Poetica. 34, 2002. 287-305.

Jackson, V. (2012): Lyric. In: Greene, R. et al. (eds.): The Princeton Encyclopedia of Poetry and Poetics. Princeton / Oxford. 826-834.

Jackson, V. / Prins, Y. (2014): General Introduction. In: Jackson, V. / Prins, Y. (eds.): The Lyric Theory Reader. A Critical Introduction. Baltimore. 1-8.

Klotz, V. (2011): Verskunst. Was ist, was kann ein lyrisches Gedicht? Bielefeld.

Lamping, D. (1989): Das lyrische Gedicht. Definitionen zu Theorie und Geschichte der Gattung. Göttingen.

Lamping, D. (2000): Moderne Lyrik als Herausforderung der Lyrik-Theorie. In: Rohmer, E. et al. (Hgg.): Texte, Bilder, Kontexte: interdisziplinäre Beiträge zu Literatur, Kunst, Ästhetik der Neuzeit. Heidelberg. 229-242.

Müller, W.G. (2004): Das Problem der Subjektivität der Lyrik und die Dichtung der Dinge und Orte. In: Nünning, A. (Hg.): Literaturwissenschaftliche Theorien, Modelle und Methoden. Eine Einführung. Trier. 93-105.

Rabaté, D. (2013): Gestes lyriques. Paris.

Ramazani, J. (2014): Poetry and its Others: News, Prayer, Song, and the Dialogue of Genres. Chicago.

Schlaffer, H. (2012): Geistersprache. Zweck und Mittel der Lyrik. München.

Schmid, W. (2014a): Elemente der Narratologie. Berlin / Boston.

Schmid, W. (2014b): Implied Author. In: Hühn, P. / Meister, J.Ch. / Pier, J. / Schmid, W. (eds.): Handbook of Narratology. Berlin / Boston. 161-173.

Schönert, J. (1999): Empirischer Autor, Impliziter Autor und Lyrisches Ich. In: Jannidis, F. / Lauer, G. / Martínez, M. / Winko, S. (Hgg.): Rückkehr des Autors. Zur Erneuerung eines umstrittenen Begriffs. Tübingen. 289-294.

Schwaetzer, H. (2010): Transzendentale Transzendenz - eine Annäherung via Kultur und Religion. In: Graf, Ch. / Schwaetzer, H. (Hgg.): Existenz. Genese, Umfeld und Facetten eines zentralen Begriffs bei Heinrich Barth. Regensburg. 103-122.

Sepp, H.R. / Wildermuth, A. (Hgg., 2010): Konzepte des Phänomenalen. Heinrich Barth Eugen Fin - Jan Potočka. Würzburg.

Stahl, H. (2013): Interpretation als Dialog. Votum für eine strukturale Hermeneutik. In: Coincidentia. Zeitschrift für Europäische Geistesgeschichte. Beiheft 2: Bildung und Fragendes Denken, herausgegeben von Harald Schwaetzer. Bernkastel-Kues. 117-137. 
Stahl, H. (2015): Poesie als politische Partizipation: Der virale poetopolitische Diskurs um Anastasija Dmitruks Videogedicht „Nikogda my ne budem brat'jami“ auf YouTube. In: Zeitschrift für slavische Philologie. 71 (2), 2015. 441-477.

Stahl, H. (2017a): Subject and Space in Political Viral Poetry concerning the Russia-UkraineCrisis. In: Hertel, R. / Soffel, Ch. (eds.): People and Cultures in Motion: Environment, Space, Subject and Humanities. Proceedings of an Interdisciplinary Conference. Taipei. 89-96.

Stahl, H. (2017b): Towards a Historical Typology of the Subject in Lyric Poetry. In: Journal of Literary Theory. 11 (1), 2017. 125-135.

Kerckhoven, G. van (2010): Epiphanie. Unstete phänomenologische Betrachtungen. In: Graf, Ch. / Schwaetzer, H. (Hgg.): Existenz. Genese, Umfeld und Facetten eines zentralen Begriffs bei Heinrich Barth. Regensburg. 59-88.

Völker, L. (1997): Gattungsdenken im Umbruch. Zum Lyrik-Diskurs der deutschen Literaturwissenschaft nach 1945. In: Ludwig, V. (Hg.): Von Celan bis Grünbein. Zur Situation der deutschen Lyrik im ausgehenden zwanzigsten Jahrhundert. Lille. 163-177.

Wildermuth, A. (1990): Philosophie des Ästhetischen. Das erscheinungsphilosophische Denken Heinrich Barths. In: Hauff, G. / Schweizer, H.R. / Wildermuth, A. (Hgg.): IN ERSCHEINUNG TRETEN. Heinrich Barths Philosophie des Ästhetischen. Basel. 205-260.

Wolf, W. (2005): The Lyric. Problems of Definition and a Proposal for a Reconceptualization. In: Müller-Zettelmann, E. / Rubik, M. (eds.): Theory into Poetry. New Approaches to the Lyric. Amsterdam / New York. 21-56.

Zymner, R. (2009): Lyrik. Umriss und Begriff. Paderborn.

Zymner, R. (2013): Funktionen der Lyrik. Münster. 



\section{О проблеме фиктивности лирического субъекта (на материале стихотворений Е. Шварц, О. Седаковой, П. Барсковой и С. Кековой)}

В 60-70-е гг. прошлого века, более полувека тому назад, структурализм стал доминировать в западном литературоведении. Структуралисты особенно интересовались теорией прозы, и на основе работ русских формалистов - В. Проппа, В. Шкловского, Б. Томашевского и других - создали новую отрасль литературоведения - так называемую нарратологию. Видные теоретики (во Франции - Р. Барт, А.Ж. Греймас, Ц. Тодоров, Ж. Женетт, ${ }^{1}$ в Америке - У. Бут, ${ }^{2}$ в Германии - В. Шмид ${ }^{3}$ ) писали статьи и книги о структуре нарративного текста и признаках художественного повествования. Среди центральных проблем были обсуждены теория точки зрения, перспективы или фокализации, и категоризация и типология различных повествовательных инстанций, в первую очередь рассказчика (повествователя, нарратора).

Структуралисты не уделяли особого внимания обязательному элементу любого повествования - персонажам, а также практически не занимались исследованием лирической поэзии. На мой взгляд, это объясняется тем, что анализ персонажей как психологических существ или «субъективности» как важного признака лирики в русле научного структурализма представлялся непродуктивным и потому бессмысленным. Кроме того, говорящий в стихотворении кажется намного менее сложным и интересным, нежели повествователь в прозе: он либо присутствует в рассказе, либо нет, либо является «надежным», либо нет, либо имеет собственную речь, либо говорит от лица одного из персонажей.

В наши дни еще можно встретить нарратологов, но очевидно, что время нарратологии прошло. Сейчас внимание научного литературоведческого сообщества сфокусировано не на прозе, а на поэзии, свидетельством чему являются международные конференции в Трире и Москве, целиком посвященные поэзии, а также тот факт, что ряд теоретиков, которые раньше писали преимущественно о прозе и общей теории литературы, в последнее время обратились к поэзии. Один из таких теоретиков - известный амери-

\footnotetext{
${ }^{1}$ См. особенно номера 4 (1964) и 8 (1966) журнала „Communications“ - «начало» структуралистической нарратологии во Франции.

2 Booth (1961).

${ }^{3}$ Schmid (1973).
} 
канский ученый Джонатан Каллер. Первая его книга, „Structuralist Poetics“, появилась в 1975 году. ${ }^{4}$ Как известно, на смену структурализму в литературоведение пришел метод деконструкции (Ж. Деррида и др.), и Каллер в начале 80-х гг. написал книгу „On Deconstruction: Theory and Criticism after Structuralism“. 5 Деконструкция также постепенно стала частью прошлого, и Каллер открыл для себя новый предмет исследования - лирическую поэзию, фактически не затронутую теоретиками в течение последних пятидесяти лет. В 2015 г. появилась его новая книга - „Theory of the Lyric“. ${ }^{6}$ В этой книге автор обсуждает различные проблемы лирики: от теории данного рода литературы и его истории, лирических структур, ритмики и рифмы до коммуникативной ситуации в лирическом стихотворении, т.е. инстанций говорящего и адресата. Для актуальной проблемы фиктивности / нефиктивности лирического «я» особенно интересно, что Каллер пишет о функции и роли лирического субъекта или лирического «я» в стихотворении.

Известно, что в романтической поэзии стихотворение считалось «исповедью души». Стихотворение - непосредственное выражение эмоций и чувств самого поэта; ${ }^{7}$ говорящий в стихотворении, очень часто проявляющий себя как «я», - сам поэт, и он не выдумает некую историю, но говорит о том, что действительно происходит в его душе.

В начале XX века, особенно в англо-американской критике, под влиянием таких поэтов, как Элиот и Паунд, возникла совсем другая теория. По этой теории, текст стихотворения не отчет о душевном переживании поэта, а фиктивное высказывание некоего специфического persona, отличного от самого поэта. Эта теория стала доминирующей во влиятельном американском течении новой критики (new criticism). ${ }^{8}$

Какова позиция Каллера? Он признает, что существуют стихотворения, в которых лирическое «я» действительно явно отличается от самого поэта, однако в долгой истории лирики подобное явление скорее составляет исключение. Он возвращается ко взглядам Гегеля о субъективности лирики и поддерживает теорию немецкой исследовательницы К. Хамбургер в том, ${ }^{9}$ что лирическое стихотворение является непосредственным сообщением какого-либо субъекта, а не формой репрезентации фиктивного высказывания. Другими словами, лирика, в отличие от художественной нарративной прозы, немиметична и нефиктивна. Это не означает, однако, что можно

${ }^{4}$ Culler (1975).

${ }^{5}$ Culler (1982).

${ }^{6}$ Culler (2015).

7 По известному высказыванию английского поэта У. Вордсворта во введении в сборнике „Lyrical Ballads“ (1800), , ,all good poetry is the spontaneous overflow of powerful feelings“" (cм. Brett / Jones 1991, p. 237).

${ }^{8}$ См. например Wimsatt (1954); Hamburger (1969).

${ }^{9}$ Hamburger (1957). 
отождествлять лирический субъект с самим поэтом. Субъект лирического высказывания не личность, но, как повествователь в романе или рассказе, лингвистическая инстанция, принадлежащая лирическому тексту. ${ }^{10}$

Несмотря на то, что лирический субъект - это не определенная личность, по Каллеру, существуют некие отношения между лирическим и биографическим субъектом, автором вне текста. Это отношение между лирическим «я» и поэтом можно охарактеризовать как логичную идентичность; опыт лирического субъекта не опыт поэта, но может быть идентичен ему. По сути говоря, не существует точного критерия, на основании которого мы могли бы отождествлять лирического субъекта с поэтом.

Действительно, опыт лирического субъекта может быть похож или даже идентичен опыту самого поэта, но мне кажется, что, если мы предполагаем, что лирический субъект является внутритекстовой инстанцией литературного произведения, созданного поэтом, он, в принципе, фиктивная инстанция. Поэт не сам говорит в своем тексте, но создает говорящую инстанцию, которая рассказывает о своем опыте, обращается к другой инстанции, адресату, выражает свои чувства и мысли и т.д. Этот говорящий существует в любом поэтическом тексте: ${ }^{11}$ иногда лишь как инстанция, формулирующая какую-либо сентенцию, иногда как фиктивная личность лирическое «я». Поэт ответствен за текст стихотворения и за создание говорящего внутри текста. Говорящий внутри текста ответствен за свои слова, и, по сути, совершенно неважно, выражает ли он взгляды или чувства поэта, или нет. Важно только, что он убедительно выражает некие взгляды и чувства, - так, что появляется художественно удовлетворительный результат. Поэт - творец этого результата, но этот результат не зависит от степени совпадения мыслей и чувств поэта и говорящего.

В повествовательной прозе рассказчик рассказывает, в лирическом стихотворении говорящий говорит. И рассказчик, и говорящий созданы автором как инстанции в художественном произведении, и поэтому они являются фиктивными инстанциями, они принадлежат тексту и не существуют вне его. Если говорящий в лирическом стихотворении - фиктивная инстанция, то значит, что все, что он говорит, в принципе фиктивно. Трудно, может быть, даже невозможно, узнать истинные мысли и чувства автора,

10 „Her [Käte Hamburger's] work is valuable in taking the essential first step of treating lyric enunciation not as the fictional imitation of an ordinary speech act but as a linguistic event of another type, an act of poetic enunciation which one can only attribute - why not? - to the poet, but a poet who remains in a biographical indeterminate relation to the claims of the poem itself" (Culler 2015, p. 109).

${ }^{11}$ В своей книге о лирике Каллер (там же, р. 124), обсуждая ритуалистические стихотворения, пишет, что существуют отдельные стихотворения без говорящего (,,in the case of individual lyrics that do not have speakers"). На мой взгляд, стихотворения без говорящих мы находим исключительно в визуальной поэзии. 
да это и не нужно: вполне достаточно слов говорящего, формирующих стихотворение, которое мы оцениваем как художественное произведение.

Данные положения я хотел бы проиллюстрировать на примере стихотворений четырех поэтов. Со всеми из них я знаком лично, так что при чтении их текстов у меня невольно возникают и образы авторов. Однако данный факт не имеет непосредственного влияния на анализ или оценку стихотворений. Кажется, вполне возможно отделить лирические «я» от эмпирических. Для понимания или оценивания литературного произведения не нужно знать биографию автора.

У Ольги Седаковой довольно много стихотворений, в которых звучит только голос говорящего и не появляется лирическое «я». Когда она пишет: «Кто любит слово, тот его и знает, / кто любит звук, тому он и звучит», ${ }^{12}$ - она, по всей вероятности, согласна с этими словами говорящего, однако для читателя не так важно знать это. Читатель прочитывает эти слова, оценивает их внутри контекста стихотворения - и либо соглашается с этим высказыванием, либо нет. Стихотворение не становится лучше или хуже, если читатель знает, что это личное мнение Седаковой.

В другом стихотворении («Тень») появляется лирическое «я»:

Я подошла к буфету: перебрать

смешные безделушки, а на деле

тайком от няни вынуть шоколад

из маминой коробки. Темный, длинный,

мне слаще сласти был испуг мой. Вдруг

я бросила коробку, позабыв

о том, что обнаружится пропажа.

И свет играл в неубранной постели.

И комната пестрела на глазах. ${ }^{13}$

Возможно, Седакова описывает здесь случай из своей жизни, но возможно и то, что все это придумано. Даже если Седакова утверждала бы, что это стихотворение содержит воспоминания о ее детстве, эти сведения могли бы быть интересны читателю, однако в любом случае они не должны влиять на его оценку стихотворения. Единственно важным представляется то, что слова говорящего (в данном случае - говорящей) художественно убедительны. В тексте стихотворения говорящая или лирическое «я» - фиктивная инстанция.

Фиктивность говорящего еще очевиднее в других стихотворениях Седаковой, например, в тексте «Нищие идут по дорогам»:

Хочу я Господа любить, как нищие его.

Хочу по городам ходить

\footnotetext{
${ }^{12}$ Седакова (2001, с. 316).

${ }^{13}$ Там же, с. 398.
} 
и Божьим именем просить,

и все узнать, и все забыть,

и как немой, заговорить

о красоте Его. ${ }^{14}$

Здесь уже труднее идентифицировать говорящего с поэтом, поскольку говорящий является по свей вероятности мужчиной («и как немой заговорить»). Сам поэт не присутствует в своем стихотворении, в нем только его «заместитель» - говорящий.

В большинстве стихотворений Елены Шварц говорящий - это некий «я». Часто этот «я» не появляется сразу, а незаметно вводится в текст стихотворения, причем само личное местоимение $я$ употребляется в косвенных падежах (меня или мне) или уступает место притяжательному местоимению (мой, моя).

Стамбул не пал, не пал Константинополь,

А с грохотом расшибся третий Рим,

На дне морей, под изумрудной коркой

В его развалинах, в золе горим.

Приливов не видать, теперь уж это ясно,

Но что они? На что мне Рим?

Мне мира мало, да и он опасен,

Он рухнул весь, мы в головне дрожим. ${ }^{15}$

Иногда «я» вводится только в конце текста, как, например, в стихотворении „Sorrow“; 16 иногда - как в стихотворении «Девятисвечник», ${ }^{17}$ которое состоит из девяти строф, - только один раз, посредством словоформы «мне», говорящий ссылается на самого себя. В данных случаях «я» фактически устраняется. ${ }^{18}$ Во многих других стихотворениях «я» называется сразу:

Я знаю, чего я хотела,

Теперь уж того не хочу,

Хотела я муки и славы

И в руки попасть палачу. ${ }^{19}$

Или:

Я не пойду на Страшный Суд -

Хотят - пускай несут.

Я шума не люблю и крика,

А там навряд ли будет тихо.

${ }^{14}$ Там же, с. 110.

15 Шварц (2002, с. 324).

${ }^{16}$ Там же, с. 355.

17 Там же, с. 312-313.

${ }^{18}$ Существуют разные способы устранения я. См. Ковтунова (2005, с. 45-70).

${ }^{19}$ Шварц (2002, с. 74). 
Одних простив, тех осудив,

Ужель останется один?

Осколок зеркала - я тут!

Я не пойду на Страшный Суд -

Хотят - пускай несут. ${ }^{20}$

Во всех этих примерах «я» - это просто «я», но есть и стихотворения, в которых некий «я» представляется фиктивной личностью. В известной поэме «Труды и дни Лавинии» ${ }^{21}$ говорящий - монахиня. Я, разумеется, не утверждаю, что автор вовсе не присутствует в своих произведениях, однако нет никакого основания отождествлять говорящего в стихотворении с поэтом.

Как в творчестве Шварц, так и в поэзии Полины Барсковой преобладают стихотворения, в которых говорящий проявляет себя как «я». Так как Барскова живет в Америке, не вызывает удивления тот факт, что ее лирическое «я» иногда тоже находится в американском городе, например, в Беркли (Berkeley):

Замечен мною был безумец,

Гроза берклийских улиток,

На голове черная диадема,

В руках - трезубец.

Он их подкарауливает на клумбах, возле калиток.

Он ловит их на газонах, и хрясть ногою... 22

Однако указание на местонахождение встречается достаточно редко. Кроме стихотворений с лирическим «я» у Барсковой довольно много текстов, в которых говорящий обращается к другому. Этот «ты», по всей вероятности, скрытое «я» («бедная П.»), и стихотворение, таким образом, представляет собой акт автокоммуникации, что часто характерно для поэзии:

Не поддавайся безумию, бедная П.,

Как бы оно ни пленяло тебя, ни пеняло тебе,

Как бы в волнительной, пестрой, щербатой толпе

Ни обращались, ни щурились милые А. и Б. -

Ты оставайся сидеть на трубе. ${ }^{23}$

В этом стихотворении говорящий ограничивается обращением, но чаще всего в тексте обнаруживаются и лирическое «я», и адресат.

Вот что я тебе скажу

Ты приснился мне во сне.

Засыпаю и гляжу

Это ты идешь ко мне.

Просыпаюсь и гляжу

\footnotetext{
20 Там же, с. 262.

${ }^{21}$ Там же, с. 169-221.

22 Barskova (2010, p. 22).

${ }^{23}$ Барскова (2010, с. 55).
} 
Пустота, болит рука,

Что прострелена тобой.

Безымянная река

Под балконом. Голубой

Страшный фартук мясника

В лавке - видно из окна. ${ }^{24}$

У Светланы Кековой есть стихотворения, в которых говорящий выступает в качестве лирического «я», но намного больше таких, в которых «я» отсутствует и говорящий вовсе не ссылается на самого себя.

Жизнь горит, как керосин, полыхает синим цветом.

В мертвом пламени осин воздух кажется предметом.

Мать устала, спать легла, ангел складывает крылья, сквозь немую пасть стекла взгляд проходит без усилья.

Копошится ночь в золе, исхудавшая, как кошка, остывает на столе кукурузная лепешка.

Только милостив Господь, и на маленьком погосте обретают снова плоть мертвецов сухие кости. ${ }^{25}$

Благодаря этой «общности» в ее стихотворениях мы часто встречаем личное местоимение «мы» вместо «я»:

Если жизнь становится смертным ложем, торжествует вновь пустоты утроба.

Мы лежим во тьме и понять не можем кто отвалит камень от двери гроба?

В помутневшем воздухе стерты грани между нашим раем и нашим адом. ${ }^{26}$

А иногда говорящий рассказывает, как повествователь в рассказе, вводя персонажей, время и место действия:

Два путника в узах печали брели в Эммаус

по пыльной дороге, заросшей травой у обочин.

Трава шелестела, и воздух был горек на вкус, каймой облаков был пустой небосвод оторочен. ${ }^{27}$

Когда Кекова вводит в текст религиозную тематику, я и автокоммуникативное $m b l$ обретают бо́льшую рельефность.

Прислушиваться к звездам я устала, но слышу то, что мне диктует Бог.

И мир в моей транскрипции неплох,

\footnotetext{
${ }^{24}$ Барскова (2007, с. 40).

${ }^{25}$ Кекова (1995, с. 20).

${ }^{26}$ Кекова (2001, с. 36).

27 Там же, с. 33.
} 
однако человеку не пристало

знать, что давно ослеп он и оглох. ${ }^{28}$

Ты стоишь перед Всевышним -

ангел, слово и число.

Наливаться кровью вишням

время, видимо, пришло. ${ }^{29}$

У каждого стихотворения - свой говорящий. Если мы сравниваем говорящих в разных стихотворениях одного поэта, мы можем сказать что-то о стиле поэта, о характерном для него употреблении слов и, если речь идет о лирическом «я», о возможных общих чертах этих «я». Но это не означает, что в отдельно взятом стихотворении мы можем отождествлять говорящего с поэтом. Говорящий принадлежит пространству художественного текста как созданный поэтом элемент этого текста. Сам же поэт остается вне его произведения.

\section{Литература}

Барскова, П. (2007): Бродячие музыканты. М.

Барскова, П. (2010): Прямое управление. СПб.

Кекова, С. (1995): Песочные часы. М. / СПб.

Кекова, С. (2001): На семи холмах. СПб.

Ковтунова, И. (2005): Категория лица в языки поэзии // Красильникова, Е. (ред.): Поэтическая грамматика. Т. 1. М. 45-70.

Седакова, О. (2001): Стихи. М.

Шварц, Е. (2002): Сочинения. Стихотворения. СПб.

Barskova, P. (2010): This Lamentable City. North Adams.

Booth, W. (1961): The Rhetoric of Fiction. Chicago.

Brett, R. / Jones, A. (eds., 1991): Lyrical Ballads. Wordsworth and Coleridge. The text of the 1798 edition with the editional 1800 poems and the Prefaces. Routledge / London / New York.

Culler, J. (1975): Structuralist Poetics. Ithaca / New York.

Culler, J. (1982): On Deconstruction: Theory and Criticism after Structuralism. Ithaca / New York.

Culler, J. (2015): Theory of the Lyric. Cambridge, Massachusetts.

Hamburger, K. (1957): Die Logik der Dichtung. Stuttgart.

Hamburger, M. (1969): The Truth of Poetry. Tensions in Modern Poetry from Baudelaire to the 1960s. London.

\footnotetext{
${ }^{28}$ Кекова (1995, с. 75).

${ }^{29}$ Там же, с. 62.
} 
Schmid, W. (1973): Der Textaufbau in den Erzählungen Dostoevskijs. München.

Wimsatt, W. (1954): The Verbal Icon. Studies in the Meaning of Poetry. Kentucky. 



\section{Владимир Новиков (Москва)}

\section{Два значения понятия «лирический герой» и их роль для построения современной теории лирического субъекта}

\section{1. Рождение понятия «лирический герой» в эссеистике Ю.Н. Тынянова}

Понятие «лирического героя» изначально отмечено внутренней антиномичностью, потенциальным совмещением в нем не только различных, но и взаимоисключающих значений. Оно появилось не как научный термин, а как образно-субъективная метафора в эссе Ю. Тынянова «Блок и Гейне», вошедшем в состав коллективного сборника «Об Александре Блоке», выпущенного в 1921 г. петроградским издательством «Картонный домик». Эта работа была прочитана автором в качестве доклада в октябре 1921 г. на научном заседании в Институте истории искусств.

Отношение Ю. Тынянова к Блоку было скорее полемическим, чем апологетическим. Воплощением эстетической новизны для Тынянова являлась поэзия Хлебникова. Возможности символистской поэтики представлялись критику исчерпанными. Отсюда - жесткое суждение в написанном тремя годами позже эссе «Промежуток» (1924):

У нас нет поэтов, которые не пережили бы смены своих течений. Смерть

Блока была слишком закономерной. ${ }^{1}$

В то же время Гейне всегда был близок Тынянову, над его стихами он много и увлеченно работал как переводчик. Сам обладавший несомненным стихотворческим талантом, Тынянов во многом реализовался как поэт именно в этих переводах. Перевоплощение в Гейне, применение его лирического «я» к себе самому было для Тынянова вполне органичным. К Блоку же отношение Тынянова было дистанционным, это для Тынянова поэтическая персона третьего лица, «он». Это обстоятельство прямым образом повлияло на зарождение в сознании поэта-исследователя такой конструкции, как «лирический герой».

Сопоставление двух поэтов - русского и немецкого - завершается следующим итогом:

Возникнув на закате течений, которыми они питались и которые собой закончили, разрабатывая тот же материал - личности и эмоции, - Блок и Гейне стоят на двух разных полюсах поэзии. Один строит свое искусство по признаку эмоциональности, другой - по признаку чистого слова. Примитивно-эмоциональная музыкальная форма, прообраз которой - романс, и лите-

\footnotetext{
${ }^{1}$ Тынянов (1977, с. 169).
} 
ратурный, словесный орнамент, высшим прообразом которого является арабеска. Поэтому столько споров вокруг Гейне, и при жизни, и после смерти, поэтому Блок бесспорен.

И если Гейне навсегда останется примером и образцом самодовлеющего словесного искусства, а знак его стоит над новой поэзией, то Блок являет пример крупного художника в подчиненном роде поэзии - эмоциональном. ${ }^{2}$

В таком, негативно-критическом контексте и появляется выражение «лирический герой»:

Блок - самая большая лирическая тема Блока. Это тема притягивает как тема романа еще новой, нерожденной (или неосознанной) формации. Этого лирического героя и оплакивает теперь Россия. ${ }^{3}$

То есть Тынянов считает слабостью поэзии Блока ее сосредоточенность на фигуре автора, а ее успех у читателей объясняет эстетической неискушенностью публики, которая воспринимает стихи как роман, а автора как живого человека:

[...] когда говорят о его поэзии, почти всегда за поэзией невольно подставляют человеческое лицо - и все полюбили лицо, а не искусство. ${ }^{4}$

«Лирический герой» в таком контексте - это, по сути, внеэстетическая реальность, способ нехудожественной манипуляции читательским сознанием.

Однако здесь мы имеем дело с одним парадоксом тыняновского научнохудожественного мышления, который зафиксирован Л.Я. Гинзбург:

Тынянов говорил, что бывают исследования, которые при правильном наблюдении фактов приводят к неправильным результатам, - и бывают такие, которые при неправильном наблюдении фактов приводят к правильным результатам. ${ }^{5}$

Готовя к печати сборник «Архаисты и новаторы» (1929), Тынянов переделывает статью, дает ей название «Блок». В предисловии поясняет:

Одна статья представляла собою искусственную параллель между одним новейшим русским поэтом и одним иностранным старым; второй член параллели я отбросил. ${ }^{6}$

В новой редакции отчетливо обнаружились «правильные результаты». Эмоциональность Блока уже не объявляется заведомым недостатком, а скорее предстает средством достижения эстетического эффекта. Совсем иной смысл приобретает и фраза, ставшая финальной:

Эмоциональные нити, которые идут непосредственно от поэзии Блока, стремятся сосредоточиться, воплотиться и приводят к человеческому лицу за нею. ${ }^{7}$

\footnotetext{
2 Тынянов (1921, с. 264).

3 Там же, с. 240.

${ }^{4}$ Тынянов (1977, с. 118-119).

${ }^{5}$ Гинзбург $(1982$, с. 351$)$.

${ }^{6}$ Тынянов (1977, с. 396).

${ }^{7}$ Там же, с. 123.
} 
«Человеческое лицо» - уже не просто лицо автора, но и - потенциально лицо некоего обобщенного человека.

Фраза «Этого лирического героя и оплакивает теперь Россия» в новой редакции предстает в таком виде: «Об этом лирическом герое и говорят сейчас». ${ }^{8}$ И дело не только в отходе от некрологического контекста, но и в том, что выражение «лирический герой» оказалось пригодным не только для одноразового употребления. И сама семантика его в дальнейшем претерпит значительную эволюцию.

2. «Лирический субъект» и «лирическое „я“»в литературоведческом сознании Андрея Белого. Дальнейшая судьба термина «лирический герой»

Вскоре после выхода тыняновской статьи Андрей Белый, готовя берлинское издание «Стихотворения» (1923), пишет в связи с «отделом» «Прежде и теперь» (входящим в состав раздела «Пепел»):

Стихотворения этого отдела обнимают ряд лет (от 1903 до 1916 г.); но я объединяю их вокруг темы «Пепла». Доминирующий лейтмотив этого цикла - взгляд на действительность, как на стилизованную картину; прошлое и настоящее кажутся одинаково далеки для себя потерявшей души; все только - маски; появление среди масок умершей действительности «домино» есть явление рока, отряхивающего пепел прошлого. Лирический субъект этого отдела - постепенно себя сознающий мертвец. ${ }^{9}$

А чуть ниже читаем:

В «Снежной Деве» собраны стихотворения, живописующие разочарование в любви; эта любовь, подмененная страстью, развеивается пургою; воспоминания об утраченном посещают субъекта поэзии $[\ldots]^{10}$

По мнению О. Ронена, термины «лирический субъект» и «субъект поэзии» возникли у Белого как полемическое противопоставлении тыняновскому «лирическому герою»:

Белый, сочувственно отозвавшийся о формальном методе в том предисловии к «Стихотворениям» 1923 г., где он употребил термин «лирический субъект», косвенно полемизировал с Тыняновым, когда заменил литературоведческий и литературно-биографический термин Тынянова философским, не совсем тождественным тыняновскому. ${ }^{11}$

Однако детализированной разработки понятие лирического субъекта тогда у Андрея Белого не получило, а через несколько лет он для рефлексии по поводу этого феномена воспользуется выражением «лирическое „я“»».

\footnotetext{
${ }^{8}$ Там же, с. 118.

${ }^{9}$ Белый (1994, с. 483).

10 Там же, с. 484.

${ }^{11}$ Ронен (2002).
} 
Примерно тогда же, когда Тынянов готовит к изданию сборник «Архаисты и новаторы», Андрей Белый в ноябре 1928 г. пишет в предисловии к новому изданию сборника своих стихов «Пепел» (оно выйдет в 1929 г.):

Композиция стихов в отделы являет самую тему «Пепла» в виде лирической поэмы в 4 частях: герой «Пепла» - шатун, бродяга, люмпен-пролетарий; нарисована его судьба; в «Глухой России» он ищет свободы и воли, а перед ним встают «Лихие места», «Глухая Россия» - лихое место.

Город? Но город 1908 года - «Мертвый город»; этот город рисует 2-й отдел; в отделе «В полях» - попытка отдаться деревенский природе: попытка к «Воздравие»; но она оканчивается в отделе «Злая деревня» полным «Заупокоем»; Россия 1904-1908 годов - кошмар; и «Бобыли», «Бродяги» именно потому, что «Бобыли» - сходят с ума: ноты безумия и анархического субъективизма правомерно отражены в этой «Драме» моего «Бродяги».

Прошу читателей не смешивать с ним меня: лирическое «я» есть «мы» зарисовываемых сознаний, а вовсе не «я» Б.Н. Бугаева (Андрея Белого), в 1908 году не бегавшего по полям, но изучавшего проблемы логики и стиховедения. ${ }^{12}$

Андрей Белый в данном случае выступает и как субъект и как объект исследования. Белый-литературовед, осмысляя тексты Белого-поэта, считает необходимым провести отчетливую границу между «лирическим ,я“"» стихов и личностью автора, его внехудожественным «я». «Лирическое „я““» трактуется им не как индивидуализированный, но как обобщенный художественный образ - «,мы“ зарисовываемых сознаний». Разграничение для поэтики резонное и познавательно необходимое. Оно эвристически плодотворно в той же мере, в какой для стиховедения оказалось плодотворным предпринятое Андреем Белым противопоставление метра и ритма.

Тынянов и Андрей Белый подошли к этому научному разграничению разными путями и с разных сторон. Тыняновское понятие «лирический герой» обозначает поэтическое «я» конкретное и индивидуализированное. Что же касается понятия «лирическое „я“‘ у Андрея Белого, то оно, наоборот, носит характер абстрактно-обобщенный. Что же касается дальнейшей судьбы нового понятия, то оно вошло в советское и постсоветское литературоведение в словесном оформлении Тынянова («лирический герой»), но в значении, близком к «лирическому „я“» в понимании Андрея Белого.

Сам термин был перенесен из модернистского контекста XX века на поэзию 1820-1840-х гг. Филологи стали говорить о лирическом герое применительно к Тютчеву, Веневитинову, Бенедиктову, Лермонтову. Это нашло теоретической обобщение у Л.Я. Гинзбург:

Лирический герой как особая форма выявления авторского сознания существовал впоследствии в разных литературных системах, но вышла эта форма из романтизма, порожденная одной из основных философских его предпосылок - убеждением в том, что искусство и жизнь в пределе стремятся к отождествлению и тождество это может распространиться на все, от вселен-

12 Белый (1994, с. 487-488). 
ной, которая, по учению Шеллинга, есть художественное произведение бога, до эстетически осознанной судьбы отдельного человека. ${ }^{13}$

У такого ретроспективного использования термина «лирический герой» есть резонные основания вследствие типологического сходства русского поэтического модернизма (особенно в его символистской разновидности) с поэтическим романтизмом XIX века. Однако в литературоведении существует тенденция к расширительному употреблению термина и применению его к творчеству любого поэта, к любому стихотворному произведению. Против этого возражала Л.Я. Гинзбург:

Термином «лирический герой» несомненно злоупотребляли. Под единую категорию лирического героя подводятся самые разные способы выражения авторского сознания, тем самым стирается их специфика, ускользает их познавательный смысл. В подлинной лирике всегда присутствует личность поэта, но говорить о лирическом герое имеет смысл тогда, когда она облекается устойчивыми чертами - биографическими, сюжетными». ${ }^{14}$

В связи с этим возникает необходимость в понятии, которое было бы шире понятия «лирический герой» и охватывало все «способы выражения авторского сознания». ${ }^{15}$ Такую роль призван сыграть термин «лирический субъект», исторически восходящий к Андрею Белому и приобретающий широкое распространение в филологии последних лет.

«Лирический субъект»- понятие общее, включающее в себя и различные формы существования «лирического героя». Лирический герой, как правило, предполагает присутствие в тексте местоименных или глагольных форм первого лица, в то время, как лирический субъект может обходиться без таковых. Лирический субъект не тождествен личности автора, и притом не вследствие каких-то частных несходств, а вследствие конститутивной нетождественности искусства и житейской реальности.

Вместе с тем понятие «лирического героя» сохраняет свою актуальность как форма присутствия авторской личности в стихотворном тексте. Разнообразие конкретных воплощений лирического героя пролегает между двумя полюсами. Полюсом индивидуализации, дезинтеграции («человеческое лицо» у Тынянова) и полюсом интеграции («,мы“ зарисовываемых сознаний» у Андрея Белого). Эвристическая ценность понятия «лирический герой» состоит в его аксиологической специфике, ибо о «лирическом герое» можно говорить только применительно к эстетически значимым текстам. В то время как «лирический субъект» - категория, характеризующая лирику как таковую, независимо от эстетического достоинства конкретных текстов.

\footnotetext{
${ }^{13}$ Гинзбург (1974, с. 148).

14 Там же, с. 144.

15 Там же.
} 
3. Морфология лирического героя в трудах М.В. Панова

Показательна в этом смысле эстетическая рефлексия выдающегося филолога М.В. Панова (1920-2001), ${ }^{16}$ который системно пользовался понятием «лирического героя» в построении своей истории русской поэзии. Панов, выступивший продолжателем опоязовской традиции и рассматривавший историю поэзии прежде всего как историю поэтических форм, разработал следующий алгоритм литературной эволюции. Поэтическая форма состоит из трех ярусов: звукового, словесного и образного. Эволюционные сдвиги начинаются со звукового яруса, затем процесс продолжается на словесном уровне и наконец переходит на образный ярус, где и представлен характерный для данного поэта (или поэтического течения) лирический герой. Таким образом «лирический герой» предстает не субъективной проекцией исследователя, но реальностью поэтической формы, органически связанной с ритмикой и языком.

Наиболее наглядно это продемонстрировано Пановым на примере поэзии Велимира Хлебникова. Здесь как основной футуристический прием анализируется сдвиг, причем у Хлебникова и Маяковского он носит различный характер: «Поэтика Маяковского агглютинативна, поэтика Хлебникова фузионна». ${ }^{17} \mathrm{~B}$ отличие от разорванности образно-композиционной и стиховой ткани у Маяковского - у Хлебникова «сдвиг пластичен». Отсюда - «неизменная подвижность», ${ }^{18}$ которую можно считать доминантой поэтики Хлебникова. Такая подвижность прослеживается и на уровне лирического героя.

Произведения поэта объединены образом лирического героя. Этот образ главное художественное открытие поэта. Образ изменчивый, вбирающий в себя различные облики, пластически сливающий их. Лирический герой Хлебникова - это пророк, ребенок, ученый, колдун, конструктор-изобретатель, невменяемый воин, бомж, как сказали бы сегодня, инопланетянин. И все эти ипостаси поэта перетекают одна в другую, совмещаются, пластически наслаиваются одна на другую [...] Необычность этой личности поражает читателя, но он не должен забывать, что она - создание искусства. ${ }^{19}$

Хотя Панов пользуется термином «лирический герой», к описанной им образной структуре вполне применимо было бы понятие «лирического субъекта», поскольку лирическое «я» Хлебникова не обладает теми «устойчивыми чертами» сюжетно-биографического свойства, которые, согласно Л.Я. Гинзбург, свойственны лирическому герою как таковому.

\footnotetext{
${ }^{16}$ Подробнее об этом ученом см. Новиков (2015).

17 Панов (2007, с. 500).

18 Там же, с. 502.

19 Там же, с. 518.
} 
Сложная и целостная структура хлебниковского лирического субъекта, описанная Пановым, находит историческое продолжение в новаторской поэзии конца XX - начала XXI вв. В этом отношении современная поэзия ближе к многоликому лирическому субъекту Хлебникова, чем к более определенному и очерченному лирическому герою Блока.

М.В. Панов был исследователем не только поэзии, но и литературы в целом. Он в своих лекциях применял категорию «лирический герой» и к научно-публицистической прозе, отмечая, что она становится литературным фактом в тех случаях, когда в ней присутствует «лирический герой», то есть образ автора, воплощенный в словесно-композиционной ткани произведения. Такое употребление выражения «лирический герой», конечно, носит условно-гиперболический характер, однако оно по-своему оправдано - с учетом той эссеистической природы, которая была ему свойственна у Тынянова.

4. Термины «лирический субъект» и «лирический герой» в применении к современной русской поэзии

Понятие «лирического героя», помимо прочего, обладает и определенным рецептивно-психологическим оттенком. Оно - в том виде, в котором устоялось к концу XX века, - предполагает возможность читательского перевоплощения в авторское «я» (показателен в этом смысле сборник эссе П. Вайля «Стихи про меня», где творчески осмысливаются стихи русских поэтов XVIII-XIX веков, отобранные по принципу субъективной близости их лирических «я» авторскому «я» эссеиста). На этом во многом базируется читательское восприятие русской лирики двух веков - условно говоря, от пушкинского «Недорого ценю я громкие права...» до «Век скоро кончится, но раньше кончусь я...» И. Бродского.

Поэзия начавшегося века пересматривает эту коммуникативную условность. Лирическое «я» здесь в целом тяготеет к дезинтеграции, за ним все меньше стоит потенциальное «мы», да и частотность местоименных и глагольных форм первого лица сокращается. Авторское сознание тяготеет к воплощению во всем тексте стихотворения, риторически-афористические конструкции становятся данью традиции, чаще даже литературной инерции. Здесь уместнее говорить о «лирическом субъекте», а понятие «лирического героя» учитывать как меру индивидуализации лирического «я».

Такая закономерность прослеживается в работе известных мастеров новаторской ориентации, ушедших из жизни в первом десятилетии XXI века и во многом определивших вектор нынешнего развития поэзии: Г. Айги, В. Кривулина, Е. Шварц, А. Парщикова, А. Драгомощенко. Их лирические «я» индивидуализированы, а потенциальная обобщенность, «интегрированность» выражается иначе, чем в поэзии декларативно-публицистиче- 
ского типа. Данные поэты тяготеют к тому, чтобы репрезентировать не социальную группу («мы»), но мироздание в целом. «Лирический герой» говорит не от имени многих читателей - он выступает посредником между читателем и миром.

Приведем примеры, в которых достаточно наглядно перемещение лирического «я» из центра поэтического пространства на его периферию - со стратегической целью оставить потенциального читателя один на один с миром.

\title{
Геннадий Айги:
}

горя - во времена жатвы

и углубляюсь я - в жатву: о этот

огонь - закалявший

терпенье отцов - как безвинность земли! -

и блистала страна Простотою

будто - звенела: в ее небеса восходили

смыслоназвания

Бедных Вещей - и прозрачность их доброприсутствия

сердце ковала того кто умом отдаляясь в пределы другие

ведал - о невозвращении

в этот очаг . . . . . . - отзвенело давно

в безымянности обще-пространства

то завершение круга - отсутствием

свето-основы: сиянья отцов запевавших плечами

как лицами неба и почвы! - и ныне

только молчание Слова

безликостью мира блистает . . . . . . . . - а было же

просто: ведь даже подобье шептанья несмелого

было - как личико-небо - повсюду глубокое

родное - без края ${ }^{20}$

\section{Виктор Кривулин:}

\section{Стихи в форме госгерба}

\author{
весь мир \\ весь мир которого нет \\ весь на экране как на ладони \\ поле гадания... что выпадает? валет \\ или шестерка треф - но вали вперед! \\ Хлопоты злая дорога худые кони \\ иные версты иные дни \\ берег твой дальний - \\ там и живу я \\ где вертухай виртуальный
}

${ }^{20}$ Айги (1991, с. 263). 
круговую песню поет сторожевую $^{21}$

\section{Елена Шварц:}

Воспоминание о Риме

Меня, как сухую ветвь, К Риму долго несла река, И очнулась я, чуть отпив Древле волчьего молока, Что сочится из всех щелей, Что от самых младых ногтей Каждый римлянин жадно пьет Из Волчицы, простершей над Градом Голубой и бездонный живот.

Вот я шла и брела под ним, Бормотала себе, и незримо Обломок жизни моей Прилепился к руинам Рима. ${ }^{22}$

\section{Алексей Парщиков:}

$* * *$

Жизнь моя на середине, хоть в дату втыкай циркуль.

Водораздел между реками Юга и Севера - вынутый километр.

Приняв его за туннель, ты чувствуешь, что выложены впритирку слои молекул, и взлетаешь на ковш под тобой обернувшихся недр... ${ }^{23}$

\section{Аркадий Драгомощенко:}

Я украл тебе строку из твоего же стихотворения смывая Марсель, старую бухту, суп на коленях вино и пейзаж, в котором смерть вполне дружелюбна и переходит по наследству, как сад инжира. Что по возвращении вернуть?.. ${ }^{24}$

В поэзии наших дней эта линия находит продолжение у Н. Азаровой, М. Амелина, В. Аристова, С. Бирюкова, В. Бородина, М. Гронаса, С. Завьялова, Е. Зейферт, К. Корчагина и др.

Приведем примеры из Н. Азаровой и из В. Аристова, которые свидетельствуют о той же поэтический стратегии.

\footnotetext{
${ }^{21}$ Кривулин (2001).

22 Шварц (2013, с. 30).

${ }^{23}$ Парщиков (2014, с. 163).

${ }^{24}$ Драгомощенко (2013).
} 


\section{Наталия Азарова:}

файл: обо мне

обычно я проводила вечность дома

не выходя смотря на не

смотря смотря до дремы дыр

до наступления сезонов

до удивления

насколько я горизонтальна

вид зрения вполслабости

перескажи мне эту невозможность

прекрати творить по живому

смотри смотри подушной духотой

моих людей двойная масса ${ }^{25}$

\section{Владимир Аристов:}

После дождя на детской площадке нет никого

только сизых четыре голубя

гуляют примерно в одном направлении

пересекаю косо их путь и я

Солнце! Волшебное солнце!

нарисованное детской рукой

замешенное на этом мокром песке

шевелится, наверное, здесь под землей ${ }^{26}$

Для поэтов такого склада говорить о себе - значит говорить о мироздании.

Такова в наши дни фундаментальная поэзия, работающая на обретение «нового зрения» и оставляющая в прошлом фигуру поэта как главного действующего лица.

Мы не касаемся отдельно иронической ревизии самого феномена лирического героя в стихах Д. Пригова, А. Еременко, Т. Кибирова (одна из книг которого шутливо называлась «Юбилей лирического героя»), И. Иртеньева, отчасти С. Гандлевского. Эта пародийно-ироническая линия заслуживает отдельного исследования. Отметим только основную историческую функцию этой поэтической тенденции - обнажение условности самой фигуры лирического героя и движение от монологического сознания к изображению мира, бесконечного в своих проявлениях и свободного от идейных доминант.

\footnotetext{
${ }^{25}$ Азарова (2014).

${ }^{26}$ Аристов (2013).
} 
Все сказанное выше не означает, однако, невозможности продолжения классической парадигмы, о которой можно говорить на примере крупнейшего лирика второй половины XX века В. Сосноры. Будучи безусловным авангардистом в отношении к слову, мастером, создавшим в высшей степени оригинальный и индивидуализированный поэтический язык, Соснора в построении авторского «я» сохранил верность романтически-модернистской традиции «лирического героя» как человека-поэта, вбирающего в себя все страдание мира, бросающего вызов Создателю: «Вы в Бога веруете, Бог?» («Закат в дождь» в книге «Хутор потерянный»). ${ }^{27}$ В стихотворении «Гамлет» (1979) поэт называет себя «безбилетником», ${ }^{28}$ устанавливая тем самым связь и с бунтом Ивана Карамазова и с цветаевским «Пора, пора, пора / Творцу вернуть билет». ${ }^{29}$

Конечно, можно говорить о «лирическом субъекте» в творчестве Сосноры - как стихотворном, так и прозаическом (сам поэт неоднократно говорил об отсутствии для него границы между поэзией и прозой; главная его поэтическая книга «Верховный час» (1979) и написанный годом позже роман «День Зверя» образуют своего рода дилогию). Но понятие «лирический герой» в изначальном, тыняновском смысле совершенно необходимо для вхождения в мир этого поэта. Только уловив выражение «человеческого лица», которое стоит за стихами («Я, с лицом не социальным»), ${ }^{30}$ можно обрести код для прочтения и интерпретации его «части речи». И читательское перевоплощение в авторское «я» становится необходимым условием коммуникации, для адекватного восприятия, например, трагической симфонии «Мой монгол» со следующим финалом:

Ремонтируя душу, как овчарню храня от волчат,

Суздаль - от Чингиз-хана, Плесков - от венчанья, как от веча - Новград, как от чуда - Москву... Отвечай!

Отвечаю:

- Это самопародия. Ах, извините, люблю

эволюцию литер «О»-«ЧА». Как бикфордов-свеча нагораю...

Пальцы в клавиши, как окурки вдавлю.

Не играю. ${ }^{31}$

Соснора, своего рода эстетический диссидент, чуждый и советскому, и «антисоветскому» менталитетам, и сегодня не вписывается в общую поэтическую картину, он остается «типическим исключением». Разработанная им модель поэтического сознания свидетельствует о том, что категория

\footnotetext{
${ }^{27}$ Соснора (2011, с. 615).

${ }^{28}$ Там же, с. 689.

${ }^{29}$ Цветаева (1983, с. 208).

${ }^{30}$ Соснора (2011, с. 667).

${ }^{31}$ Там же, с. 598.
} 
«лирический герой» не уходит в прошлое и может еще обрести новую актуализацию в творчестве поэтов новых поколений.

Подведем итог. Наблюдающийся в филологическом дискурсе переход к преимущественному использованию термина «лирический субъект» не отменяет эвристической значимости выражения «лирический герой», «эссеистического по происхождению», прочно связанного с определенной культурной традицией и обладающего определенным аксиологическим потенциалом. Научная типология лирического субъекта предполагает определенное количество подвидов и вариаций. При их выявлении и идентификации история «лирического героя» как феномена и как понятия может и должна быть учтена.

\section{Литература}

Айги, Г. (1991): Здесь: Избранные стихотворения. 1954-1988. М.

Азарова, Н. (2014): Раззавязывание. http://natalia-azarova.com/pdf/osn/5.pdf (24/05/2018).

Аристов, В. (2013): Из цикла «По нашему миру с тетрадью» // Новый мир. 3, 2013. http://magazines.russ.ru/novyi_mi/2013/3/a3.html (24/05/2018).

Белый, А. (1994): Авторские предисловия к сборникам стихотворений // Белый, А.: Собрание сочинений. Стихотворения и поэмы. М. 480-493.

Гинзбург, Л. (1974): О лирике. Л.

Гинзбург, Л. (1982): О старом и новом. Л.

Драгомощенко, А. (2013): Нейтральные высказывания: Стихотворения последних лет // Новое литературное обозрение. 3 (121), 2013. http://www.nlobooks.ru/node/3584 (24/05/2018).

Кривулин, В. (2001): Стихи юбилейного года. М. http://www.vavilon.ru/texts/krivulin4.html $(24 / 05 / 2018)$.

Новиков, В. (2015): По ту сторону успеха: Повесть о Михаиле Панове // Новый мир. 7, 2015. http://magazines.russ.ru/novyi_mi/2015/7/2nov.html (24/05/2018).

Панов, М. (2007): Труды по общему языкознанию и русскому языку. Т.2. М.

Парщиков, А. (2014): Дирижабли. М.

Ронен, О. (2002): «Блок и Гейне» // Звезда. 11, 2002. http://magazines.russ.ru/zvezda/ 2002/11/ronen.html (24/05/2018).

Соснора, В. (2011): Стихотворения. СПб.

Тынянов, Ю. (1921): Блок и Гейне // Об Александре Блоке. (Редактор не указан.) Петроград.

Тынянов, Ю. (1977): Поэтика. История литературы. Кино. М.

Цветаева, М. (1983): Стихотворения и поэмы: В 5 тт. Т. 3. New York.

Шварц, Е. (2013): Сочинения. Т. 5. СПб. 


\section{Сергей Бирюков (Галле)}

\section{Трансформации субъектности}

В настоящее время существуют различные виды субъектности в поэзии. С одной стороны, отмечается появление новых видов субъектности, а с другой - использование таких, которые можно назвать традиционными. Однако и эти виды подвергаются существенной трансформации. Это зависит, разумеется, от индивидуальности автора и от тех приемов, которые он использует при создании произведения. В данной работе выбор авторов обусловлен тем, что каждый из них находится в перманентном поиске средств выразительности. Субъектность не задана изначально, а вызревает и вырастает. Таким образом происходит возврат к фундаментальному значению «поэзии», как «творению».

В связи с этим исследователю необходимо, помимо собственно поэтических текстов, учитывать авторефлексивные тексты авторов, а то и побуждать авторов на создание таких текстов, задавая провоцирующие вопросы.

Я считаю, что в анализе современной поэзии важен не только взгляд со стороны - исследователя (литературоведа, лингвиста, культуролога), но и взгляд изнутри - самого создателя текстов. Трансформация происходит на уровне поэтического текста, но это значит, что в пре-тексте и за текстом происходят определенные трансформативные процессы, которые могут затрагивать и субъектность.

Классификацию традиционных форм субъектности представил в 70-е гг. прошлого века теоретик литературы Борис Корман (1922-1983), творчески связанный с московско-тартуской семиотической школой. В своем построении «теории автора» он опирался одновременно на идеи Ю.Н. Тынянова и М.М. Бахтина. Его подход основывался на четкой структуризации литературного пространства, в том числе в отношении «субъектных форм выражения авторского сознания». По Корману, субъекты могут быть следующие: «собственно автор», «автор-повествователь», «лирический герой», «ролевой герой». При этом «собственно автор» и «автор-повествователь» в своих текстовых проявлениях сближаются, а в случае с «ролевым героем» можно говорить о своего рода двусубъектности. ${ }^{1}$

\footnotetext{
${ }^{1}$ См. Корман (1982).
} 
Представляется, что в целом ряде случаев такая структурно-типологическая классификация может быть вполне применима к бытующим сегодня в русскоязычном пространстве поэтическим практикам.

В первую очередь это такие практики, которые основательно связаны с традиционным письмом. При этом традиция в данном случае понимается достаточно широко. Это и понимание роли поэта как создателя собственного мира (или миров), и владение различными поэтическими жанрами и способами письма, и, следовательно, различные способы представления субъектности.

Обратимся к деятельности поэтов, чье творчество достаточно репрезентативно представлено в современном литературном процессе. Это Елена Кацюба, Константин Кедров, Вадим Месяц и Андрей Тавров. Эти поэты активно действуют в поэтическом пространстве, кроме того, они занимаются авторефлексией и рефлексией по поводу творчества других авторов.

Константин Кедров предпочитает действовать от первого лица в авангардной и даже модернистской традиции позиционирования поэта как демиурга. Подобно тому, как он работает (играет) с различными стихоформами, он так же обыгрывает формы субъектности. К нему можно отнести определение хорватского теоретика Й. Ужаревича о лирическом «Сверх-Я» ${ }^{2}$, то есть Я, которое не только создает текст, но и в то же время ведет наблюдение над созданием текста. Такая степень субъектности характерна для некоторых авторов, осознанно работающих в экспериментальной поэтике.

В первую очередь для Елены Кацюбы, которая определяет свои действия в поэтическом пространстве как «лингвистический реализм». Это означает, что она следует за словом, которое имманентно является субъектом творчества. Поэт в данном случае предстает своеобразным скульптором слова и, в зависимости от фактуры слова - мягкой или твердой, лепит или вырубает словесную скульптуру.

Вадим Месяц в своем творчестве представляет различные трансформации субъектности. У него можно обнаружить все виды субъектности, обозначенные Б. Корманом. Месяц пишет и лирику от первого лица, выступает и как автор-повествователь в стихах на исторические и мифологические темы, и в качестве ролевого героя, когда пишет от лица другого(ой). Кроме того, он фактически входит в мир досубъектного (до-субъективного) творчества, когда пишет тексты, ориентированные на аутентичный песенный фольклор, или создает своеобразный новый эпос («Норумбега»).

Андрей Тавров, поэт, стилистически близкий к направлению метафористов, выделяется углублением в философско-теологические проблемы бытия. Его интересуют надличностные проблемы. В роли субъекта здесь скорее выступает собственно автор, который отрешается от субъективности в

\footnotetext{
${ }^{2}$ Užarević (1991, p. 132).
} 
пользу создания объективной картины мира. Вероятно, Тавров мог бы повторить слова Ницше из его «Рождения трагедии из духа музыки»:

Субъект, волящий и преследующий свои эгоистические цели индивид, мыслим только как противник искусства, а не его источник. ${ }^{3}$

Тавров создает целый ряд программных произведений, в которых манифестирует проект создания деперсонализированного, надиндивидуального искусства, обусловленного религиозными коннотациями.

\section{Константин Кедров}

«У поэта нет биографии - только вечность», - утверждает Константин Кедров в эссе о Хлебникове. В случае с Хлебниковым - это безусловная данность. Но и по отношению к поэтам в предельном приближении придется согласиться с этой максимой. В конечном счете мир, созданный поэтом, в абсолютном смысле принадлежит вечности. Хотя, конечно, можно складывать и биографии поэтов. Но Константин Кедров верен предназначению, он ищет и находит такие формы взаимодействия с мыслезёмом (воспользуемся хлебниковским словом), которые выводят его к действительно довольно рискованным кручам и обрывам времени.

Уже здесь в острой форме ставится вопрос о субъектности. Если у поэта нет биографии, не значит ли это, что он как субъект выступает в качестве ретранслятора некоторых идей, смыслов, которые внесубъектны?

Тут нам и придет на помощь мысль о «лирическом парадоксе», сформулированная Йосипом Ужаревичем. Он пишет:

Позиция лирического Сверх-Я вполне аналогична позиции кинокамеры по отношению к снятому фильму. [...] В этой полной связанности Сверх-Я со стихотворением как целым лежит смысл транспарадоксальности, т.е. эффект художественного катарсиса. Проблематика лирического Я и Сверх-Я включает два предельных случая: подчеркнутый персонализм и полную (но, в сущности, видимую) деперсонализацию. Между этими предельными случаями есть целая шкала возможностей структурных реализаций лирического субъекта. Здесь важно также подчеркнуть, что лирическое Я в тематическом и структурном смысле также является объектом лирики (а не только и не столько «субъектом»), как и все многообразные его состояния $[\ldots]^{4}$

В принципе парадокс Ужаревича, как мы увидим дальше, работает универсально. Но в отношении Кедрова и некоторых других поэтов авангардного направления он особенно актуален. Дело в том, что в поэтике ряда авторов, которых можно отнести к внеисторическому авангарду, как правило, можно заметить высокий уровень рефлективности. Эта рефлективность, аналитичность базируется (хотя и в разной степени) на освоенном

\footnotetext{
${ }^{3}$ Ницше (1990, с. 75).

${ }^{4}$ Užarević (1991, p. 132).
} 
наследии исторического авангарда, воспринятом как проекция. Тут работают разные включения. В случае с Кедровым эти включения фундаментального характера.

Константин Кедров - поэт, литературовед, философ - формировался во многом под влиянием хлебниковской поэтики и хлебниковского мировоззрения. В 1966 году на историко-филологическом факультете Казанского университета Кедров защитил диплом «Лобачевский - Хлебников - Эйнштейн». В дальнейшем Кедров посвятит Хлебникову ряд замечательных исследований.

Взаимодействуя с текстами Хлебникова, погружаясь в его миры, Кедров вырабатывает собственную оригинальную поэтику, приходит к открытию и утверждению метаметафоры, к пониманию «выворачивания» как фундаментальной основы поэтического процесса. Так построены многие его тексты, начиная с поэмы 1960 года «Бесконечная» и не заканчивая серией поэм под общим названием «Компьютер любви».

Говоря о поэтическом творчестве Кедрова, необходимо иметь в виду, что он является автором многих поэтологических и культурологических работ и прежде всего такой масштабной работы, как книга «Поэтический космос». В этой книге в наиболее фундированном виде изложены важнейшие положения поэтики, трактуемой Кедровым космологически и, разумеется, поэтически. Ближайший аналог, который возникает при чтении этой книги, Андрей Белый, остающийся поэтом и в прозе, и в своих теоретических изысканиях. ${ }^{5}$ Мировая мифология, теология, философия, литература, искусство, научные открытия - все это образует поэтическое тело текста.

«Выворачивание» - это собственно глобальная инверсия. В анаграммах и палиндромах наиболее явная. Но в то же время это и «выворачивание» субъекта, инверсия или трансформация субъекта. В одном из ранних произведений Кедров писал:

Человек оглянулся и увидел себя в себе.

Это было давно, в очень прошлом было давно.

Человек был другой, и другой был тоже другой,

Так они оглянулись, спрашивая друг друга.

Кто-то спрашивал, но ему отвечал другой,

И слушал уже другой,

И никто не мог понять,

Кто прошлый, кто настоящий.

Человек оглянулся и увидел себя в себе...

Я вышел к себе

Через - навстречу - от

И ушел под, воздвигая над. ${ }^{6}$

Автор диссертации о метаметафоре Евгения Князева пишет:

\footnotetext{
5 Темиршина (2001, с. 185-239).

${ }^{6}$ Цит. по https://www.stihi.ru/2009/07/26/3180 (12/12/2017).
} 
Стихотворение пронизано мотивом «зрения», обратного и разнонаправленного, открывающего перед человеком метафизическую реальность, в которой, оглядываясь назад, ты попадаешь в себя: внешнее оборачивается внутренним. В пространстве памяти человек выходит из себя нынешнего, не совпадая ни с одним своим прошлым Я. Каждый раз Я становится другим, так что принципиально невозможным оказывается диалог между ними. ${ }^{7}$

Итак, различные Я внутри одной личности ведут как будто к расподоблению субъекта, к многосубъектности. Но само осознание поэтом этой метаморфозы ведет к переформатированию.

В многосоставной и как будто самотрансформирующейся поэме «Компьютер любви» Кедров производит своего рода ревизию поэтического, уравнивая представления из различных, в обыденности несопоставимых категориальных рядов:

Небо - это высота взгляда

Взгляд - это глубина неба

Боль - это

прикосновение Бога

Бог - это

прикосновение боли

Выдох - это глубина вдоха

Вдох - это высота выдоха

Свет - это голос тишины

Тишина - это голос света

Тьма - это крик сияния

Сияние - это тишина тьмы

Радуга - это радость света

мысль - это немота души $[\ldots]^{8}$

Говорящий в данном случае крайне субъективен, но сами определения формульны, то есть претендуют на объективность. Таков объективносубъективный парадокс Кедрова.

\section{Елена Качюба}

Елена Кацюба, как уже сказано выше, исповедует «лингвистический реализм». Я обратился к поэтессе за разъяснениями, потому что это широкое понятие и трактовать его можно по-разному. Вот что ответила Елена:

Создание поэтического произведения осуществляется в пространстве и во времени. Это, в первую очередь, организация конкретного объема, внутри

\footnotetext{
7 Там же, см. также Князева (2000).

${ }^{8}$ Кедров (2005, с. 314).
} 
которого я нахожусь. Кроме того, текст имеет свою собственную историю и место в мире, которые я не создаю, а познаю. Поэтому я часто начинаю творить мир от начала своим, каждый раз разным способом. Например, с помощью зеркала:

Тогда сотворил Бог зеркало и отразился в нем Так Адам создан был, и Бог его любил, как самого себя Дал Бог Адаму зеркало, отразился Адам в зеркале так Ева явилась, и любил ее Адам, как самого себя.

Посмотрелись Адам и Ева друг в друга, как в зеркало, и появились у них дети, и Ева любила их больше самой себя, оттого дети любили только себя, и убил Каин Авеля. В гневе разбил Бог зеркало и развеял по свету. Оттого мы видим мир не как создал Бог, но как отражает зеркальный прах. ${ }^{9}$

Или с помощью лестницы:

Две птицы, соединенные крученым шнуром

Три птицы, соединенные медной цепочкой Четыре птицы, соединенные шелковым платком И многие другие соединенные лестницей из воздушных квадратов [...] Мир строился сверху вниз, как бы падая ниц с лестниц, страниц, ресниц $[\ldots]^{10}$

Или с помощью азбуки:

Алая и Белая розы - это А и Б любви далее - Война Глаз, Дар Евы, Желание, Забвение [...] в розарии азбуки, где Эхо Ютится и в конце всегда Я. ${ }^{11}$

Никакого переключения не происходит. Это как исполнение роли своего персонажа в спектакле. Каждый мой текст - это не что иное, как я сама в определенные мгновения, которые удалось остановить - оставить в первозданном виде, то есть, говоря фигурально, не превращая яблоко в компот или конфитюр. Я не тащу слово за собой - я сама следую за ним. Это я называю «лингвистический реализм». На мой взгляд, поэзия делает то, что Мефистофель запретил делать Фаусту, - останавливает мгновения. Фауст ученый, а не поэт, поэтому он с легкостью заключил этот договор. Ведь для ученого результат - только повод для дальнейшего исследования. Сего-

${ }^{9}$ Кацюба (1999, с. 23).

10 Там же, с. 30.

11 Там же, с. 7. 
дняшнее открытие завтра устареет. В мире чувств все иначе. Прекрасное мгновение, запечатленное поэтом, переживается снова и снова совершенно новыми людьми. ${ }^{12}$

Действительно, поэтесса следует за словом - но не только: она строит и собственное словесное здание, особенно когда работает с палиндромическим и анаграмматическим письмом. Здесь уже поэтесса сама становится исследователем - если не Фаустом, то лингвистической Софьей Ковалевской. Ее палиндромические сочинения, сверхпоэма «Свалка» и особенно два тома «Палиндромического словаря русского языка» прекрасные тому свидетельства. Субъектом в данном случае выступает поэт-исследователь. В «Словаре» Елена Кацюба проводит обследование генного пространства слова. Это и трактат, который может быть назван «Искусство палиндромической поэзии», и впечатляющее поэтическое произведение, созданное в новом жанре «словаря» (вспомним «Хазарский словарь» М. Павича). Это хорошо организованный ритмически текст. Но заслуга в этом не только поэта. Язык сам («лингвистический реализм»!) выступает в роли деятельного субъекта. Поэт и язык как будто вступают в соревнование в достижении лучшего результата. В данном случае оба побеждают. Словесные пермутации выводят на новый уровень.

Выдающийся польский русист Ежи Фарыно так писал о палиндромическом письме:

Обратное чтение превращает прежний план содержания (нормативное чтение) в план выражения для иного содержания. Это иное содержание и есть содержание семиотическое. Оно отвечает на вопрос: «что есть язык, как он устроен и что он значит?» ${ }^{13}$

Он говорит также о «пре-тексте» и «пост-тексте», о соединении в одном лице получателя и отправителя, слушателя в роли говорящего. ${ }^{14}$ Палиндромные образования и в самом деле как бы дешифруют нормативный текст, но в то же время они удваивают прямой текст.

Таким образом, мы можем говорить об удвоении субъектности в палиндромическом творчестве Елены Кацюбы.

\section{Вадим Месяи}

Поэт, прозаик, критик, переводчик, издатель, огранизатор литературного пространства Вадим Месяц в области поэзии работает в совершенно разных ключах, часто диаметрально противоположных. Он пишет лирические стихи, в которых получает возможность высказывания «лирическое я», высту-

\footnotetext{
12 Из материалов личной переписки.

${ }^{13}$ Faryno (1988, S. 54).

14 Там же, S. 55.
} 
пает как «ролевой герой», как «автор-повествователь». Его стихи, в которых мы встречаемся с «лирическим героем», традиционны в лучшем смысле этого слова. Они наследуют сразу нескольким традициям: здесь и русская классическая поэзия, и авангард, и различные европейские традиции - в частности, заметен сдвиг в сторону экспрессионизма. Например, такие стихи, в которых поэт предельно открыт и выступает от первого лица:

Неужели прошел год?

Я плохо помню, что было вчера, но как стоял в этой очереди год назад, помню до мелочей.

Такой же мороз, те же люди,

те же мысли, приходящие в голову.

Меня оборвали на полуслове, и сейчас я возвращаюсь к прежнему монологу, будто вернулся в прошлое.

Не было перелетов, других стран, гор и морей, ссор и праздников, разбитых машин, рождения дочери...

Даже менты кажутся мне знакомыми.

Храм архангела Михаила в березовой роще на берегу Оки. Новодел из красного кирпича, оживающий на глазах вместе с пришедшими людьми.

Очередь нетороплива.

Дыханье парит, приобретая округлые формы в солнечный день. Мы протягиваем пластиковые бутыли волонтерам, разливающим воду из двух почерневших цистерн, тихо поздравляем друг друга с праздником.

Вся жизнь - как очередь за святой водой. ${ }^{15}$

Как видим, личный опыт здесь совпадает с опытом других. Поэт не отделяет себя от других. Заключительная строка ставит афористическую точку. Применительно к этому поэту можно говорить о своеобразной борьбе с субъективностью и субъектностью. Он постоянно обращается к внесубъ-

${ }^{15}$ Месяц $(2015$, с. 5). 
ектным, коллективистским формам, как в случае с созданием неоэпоса («Норумбега», «Мифы о Хельвиге») или сочинением песен в «народном духе» (что отсылает к традиции XIX века, например, к Антону Дельвигу).

На мой вопрос о субъектности в его поэзии Вадим Месяц отвечает почти манифестно:

[...] Искусство должно ставить себе масштабные задачи, пусть даже невыполнимые, поэт должен преодолевать себя как человека, вытаскивать из своего опыта какие-то невероятные пласты... Я уверен, что путь от себя в сторону преодоления собственного «эго», расширения в космос, гораздо более продуктивен, чем усугубление своей индивидуальности. В народных песнях ярко выражен этот выход в коллективное бессознательное, и я пытаюсь писать песни, которые могут стать народными. ${ }^{16}$

Это высказывание чрезвычайно интересно и соприкосновением некоторых граней с идеями и воплощениями Велимира Хлебникова, который мыслил поэзию как возможность создания эпической картины мира, не только описывая мир, а воссоздавая и досоздавая. Его сверхповести и идея «Единой книги» красноречиво об этом свидетельствуют.

Но и в случае Хлебникова, и в случае Месяца мы сталкиваемся с парадоксом. Действительно, создается неоэпос. Но он не анонимный, а авторский! Мы знаем автора, и к тому же он комментирует собственное письмо.

В книге Месяца «Норумбега» помещены размышления автора - почти исследователя - и не только на тему эпоса, а также и попутно на многие другие темы. Житейское здесь переплетается с литературным. То есть автор отрицает субъективность, но его комментарии вступают в спор с его собственной позицией.

Такую позицию можно рассматривать как попытку уйти за пределы сегодняшнего, мгновенного, к неким вечным, традиционалистским устоям. Таким образом мы все-таки имеем дело с субъектом, который находится в поисках неких устойчивых координат. Мы все-таки видим перед собой поэта, который и в XXI веке не потерял своей романтической составляющей. Романтизм был обращен как раз к мифологии и создавал собственную мифологию. И это касается не только Уланда, а доходит до Вагнера и Ницше. В этом смысле интенции, которые развивает Месяц, вполне ницшеанского толка, со многими поправками, разумеется.

Поэт, как мы видим на примере Вадима Месяца, - постоянная величина, даже если старается выйти к самой объективной объективности.

В предисловии к «Норумбеге» академик Вяч. Вс. Иванов пишет:

Книга Вадима Месяца представляет собой сложное построение в духе нового Барокко. В ней современные опыты мифопоэтического эпоса причудливо соединяются с комментариями к нему, иногда основательными и ссылающимися на ученые труды, но часто и вовсе игровыми, где автор ускользает в

${ }^{16}$ Из материалов личной переписки. 
изгибы своих увлекательных воспоминаний о путешествиях в Непал или не менее экзотические части Азиатской России [...] «Постмодернистское» соединение самых разнородных фактов и вымыслов почти сбивает с толку отличного по возрасту читателя, имеющего только ограниченный опыт предыдущих поколений: я и цитаты из собственных писаний с трудом узнаю, когда они вплетаются в эту географическую и доисторическую мозаику. Те куски древних мифов и воплощавших их образов, которые в науке мы хотели понять умом, Вадим Месяц пробует оживить в эпосе, где им нужно вернуть хотя бы часть былого величия. А мне в поэтических частях книги близок дух серьезного беспокойства о будущем, гадания о предвидимом конце «железного века» - и расширение возможностей русского стиха, раздвигающего его в направлении, угаданном в поздних сочинениях Иосифа Бродского (содержащиеся в комментариях воспоминания о нем отступают на второй план по сравнению с продолжением его дела). ${ }^{17}$

Сам Вадим Месяц говорит о книге так:

«Норумбега», на мой взгляд, очень русская книга. Просто русскость не ограничивается одним лишь евразийством, пытается опираться на весь индоевропейский контекст. Отсюда: кельтские сказания, скандинавские саги, индийские веды. Это же родные русскому человеку вещи. Отчасти эта книжка о «варварстве». Так что я продолжаю «скифскую» линию нашей словесности. Мне действительно хотелось сделать так, чтобы поэзия была религиозной практикой $[\ldots]^{18}$

Тут возникает целый ряд парадоксов, в мягкой форме отмеченных также Вяч. Вс. Ивановым, которые, на мой взгляд, являются важным структурным элементом книги. Книга русская, по определению самого автора, написана на русском языке, неоэпос предположительно германский, но насыщен также многочисленными отсылами к древним эпосам разных народов. Кроме того, существенное пространство книги занимают авторские эссе, поданные то в виде источниковедческих работ, то в виде мемуаров и поэтических зарисовок. По сути дела, перед нами эпос личного мира поэта. Это его собственная история, поданная таким нестандартным образом. Это он заново проходит сквозь эпохи, верования, «варварским» методом все смешивая, чтобы вырваться из обыденности и в конечном счете достигнуть просветления (сатори).

[Учитель Цинюань замечал]: Тридцать лет назад, когда я начал изучать дзэн, я сказал: «Горы являются горами, реки являются реками». После того как я прикоснулся к истине дзэн под руководством хорошего наставника, я сказал: «Горы не являются горами, реки не являются реками». Но сейчас, когда я достиг состояния конечного покоя (которым является «просветление»), я говорю: «Горы действительно являются горами, реки действительно являются реками». ${ }^{19}$

\footnotetext{
${ }^{17}$ Иванов (2011, с. 5-6).

${ }^{18}$ Шабаева (2011).

${ }^{19}$ Цит. по https://otvet.mail.ru/question/88181184 (12/12/2017).
} 
Собственно, Вадим Месяц в частности возвращает поэзии ее исконную роль медитативной практики, переходя при этом на уровень «сверх-Я».

\section{Андрей Тавров}

Совершенно естественно будет здесь перейти к творчеству поэта, прозаика, эссеиста Андрея Таврова. Его книга «Зима Ахашвероша» вышла в 2008 году с предисловием Вадима Месяца. Этот текст Месяца, на мой взгляд, наиболее адекватно описывает, вплоть до проницания, творение Таврова и в целом его поэтическую практику, которую также можно назвать медитативной.

Книга построена как серия стихокартин, в которой сквозным мотивом проходят стихи с названием «Зима Ахашвероша» (всего их пять). Эти тексты я определяю именно как описания неких умозрительных картин, впрочем, напоминающих босховское и отчасти брейгелевское письмо (обращение именно к этим художникам характерно для метаметафористов). Описания насыщены и даже перенасыщены сюрреалистической образностью.

Приведу здесь первый из «зимних»:

ЗИМА АХАШВЕРОША

Зима Ахашвероша наступает. Галки

хлопочут в воздухе. Улица ведет к пустыне

с бензозаправкой. Витрина с «Рассо» взята не в фокус.

Не надо новых слов, этих достаточно. Галки

хлопочут в воздухе. И белей гусыни

взятый не в фокус снег. Зима Ахашвероша наступает.

Время, словно змея, жалит хвост попугая, сделанного из мармелада. Голуби роются на помойке.

Пуля блуждает внутри пожилого тела, вслепую ощупывая лабиринт руками - они красны.

Воздух сжимается в голубя и пускается врассыпную теперь он снежинка, блондинка и все такое.

Ахашверош стоит как снег, в гортани его - слово

о том, что поэзия знает больше

реки, расцветающей, что ни весна, берегами,

больше слов о конце и начале, великих и чуждых,

больше той, что после полуночи царапает вам лопатки,

больше той, с ложбинкой в паху, окруженной цветущей вишней.

Никто ничего не знает этой зимой.

Стынут рельсы, идут часы, самолеты летят домой.

Никто не видал кашалота, вынувшего кобелиный уд.

Не было ни ничто и ни всхлипа, мы растаяли сами в себе, медленно, как мармелад за щекой, в собственной теплой слюне, которой не осталось и на плевок. 
нежные они трогают волосы золотыми колокольцами дриады зеленые волнуют тебя голубиной песней вишневой с горчинкой умножают твой шаг как маятник заливы с парусом серебряным дышат бризом любимая здесь здесь она обнимая единорога за шею на солнечной в бризе веранде.. И пуля обрастает верблюдом с ракушкой пустой головы. ${ }^{20}$

Ахашверош у Таврова - это Агасфер, Вечный Жид. Поэтому нет ничего удивительного в том, что здесь приметы времен сдвинуты, соположены, сопоставлены. Вадим Месяц в своем анализе полагает, что Ахашверош у Таврова, закованный в собственном Я и осужденный до второго пришествия, ищет выхода, освобождения. Но оно ему недоступно. Говоря о других текстах книги, Месяц пишет о «темницах собственного я», в которые заключены герои. ${ }^{21}$

Здесь тоже парадокс. Поэт отказывается от субъектности, от говорения в первом лице. Он стремится нарисовать объективную картину. Но тем не менее мы постоянно видим здесь взгляд художника. Либо мы должны признать, что это некто, неизвестный нам, представляет эти картины. В этом состоит определенная драма художественного сознания, которое даже в своей искренней попытке деперсонализации не может освободиться от субъективного видения.

\section{II}

Касаясь проблемы субъекта в поэзии, мы затрагиваем множество сфер, в том числе это сфера поэтического поиска, обновления поэтического репертуара, образной системы, языка и, наконец, самой поэтической конструкции.

Поиск субъектности идет постоянно. Мы можем вспомнить об обращении поэтов нового времени к античности, обращении американских битников к восточной эзотерике и духовным практикам, обращении художников исторического авангарда к первобытным культурам, к фольклорным артефактам и т.д.

Авангардная поэзия второй половины XX века вполне естественно обратилась в поисках субъектности к своим предшественникам. Это был абсолютно сознательный ход. Французские, немецкие и русские авторы второй половины XX века прямо обращались к опыту исторического авангарда, вплоть до непосредственного взаимодействия с еще живыми авангардистами исторического периода (Анри Шопен - Рауль Хаусман, Геннадий Айги - Алексей Крученых, Сергей Сигей - Василиск Гнедов).

\footnotetext{
20 Тавров (2008, с.11).

${ }^{21}$ См. Месяц (2008, с. 5-8).
} 
В авангардной поэзии проблема субъекта особо обострена. Причины в каждом индивидуальном случае разные. Общей можем обозначить саму природу авангардного - нацеленность на поиск новой выразительности. В ряде случаев осознанность действий как именно авангардных приводит к сильной рефлексивности, что в свою очередь порождает особые формы поэтического искусства: комментирование текста, «инструктивные тексты» (С. Сигей), конструирование приемов, в конце концов выход за рамки вербального в визуальное и звуковое пространство. То есть этот поиск прямо попадает в область поэтологии.

Неовангард наряду с поиском собственной субъектности должен был заниматься (и еще продолжает) восстановлением фигур и текстов исторического авангарда. Это задает экстраординарную ситуацию, в которой исторический авангард становится объектом исследования, текстологической и издательской деятельности современных авангардистов (этой работой в разное время и в разной степени занимались Г. Айги, С. Сигей, Вл. Эрль, Б. Констриктор, А. Мирзаев и др., в том числе автор этих строк). Применительно к авторам исторического авангарда мы можем говорить о различных определениях субъекта. Здесь и лирический герой, и поэт в романтическом понимании, и варианты остранения. Эти позиции сохраняются и в неовангарде, с добавлением в ряде случаев рефлексии по отношению к персонажам и стилевым особенностям исторического авангарда.

Я буду говорить преимущественно об авторах, с которыми мне довелось общаться, о которых, как мне кажется, я имею некоторое представление, в том числе в плане субъектности. Хотя определить субъектность во всех этих случаях дело довольно сложное. Каждый из этих авторов резко индивидуален. Я поставил себе задачу сопоставления с историческим авангардом. Но это задача на самом деле довольно условная, поскольку не все авторы готовы мне ответить на вопрос о сопоставлении.

\section{Сергей Сигей, Ры Никонова}

Пожалуй, наиболее определенно о прямом взаимодействии с историческим авангардом можно говорить в случае Сергея Сигея (Сергей Всеволодович Сигов, 1947-2014). Сигей с ранней юности был увлечен футуризмом. Он не только читал все, что входило и выходило в футуризм, но и переписывал, перерабатывал футуристические тексты, визуальные работы и даже иконографию. Он выступал как аналитик текстов, а также самой идеологии отдельных авторов и движения в целом. Он работал как текстолог, комментатор, издатель произведений Игоря Бахтерева, Василиска Гнедова, Алексея Крученых, Сергея Подгаевского, Александра Туфанова. Практически весь возможный корпус русского авангарда был им тщательно изучен. Кроме того, Сигей непосредственно общался с Гнедовым и Бахтере- 
вым, а также с таким выдающимся знатоком авангарда как Н.И. Харджиев. Материалы, которые Сигей получал из первых рук, сразу же шли в работу - становились фундаментом самиздатского журнала «Транспонанс». В течение ряда лет этот уникальный журнал тиражом пять экземпляров Сигей делал вместе с женой - поэтессой и художницей Анной Ры Никоновой Таршис (1942-2014). Сергей Сигей и Ры Никонова также много занимались зарубежным авангардом, особенно дадаизмом и сюрреализмом, а также современными экспериментальными практиками. Не случайно они довольно органично вписались в международное движение мейл-арта, активно контактировали с зарубежными визуалистами. Независимо Сигей и Никонова проходили примерно такой же путь, который на Западе проходили поставангардные авторы. Опираясь на опыт предшественников, они этот опыт в существенной степени деконструировали. Справедлив вывод Ильи Кукуя, который он сделал, анализируя журнал «Транспонанс»:

Определяющими факторами авангардной поэтики для транс-поэтов были отнюдь не идея движения вперед и достижение нового состояния общества, а необходимость развития индивидуального поэтического языка. ${ }^{22}$

Во «фрагментах полной формы» Сигей специально акцентировал различные приемы, которыми он пользовался или только предполагал пользоваться: «афатическая поэзия», «аналогизация», «иероглифизм», «наложение стихотворного листа на лицо читателя», «ритмодинамический монтаж текста», «цифровая литература» и др. Характерна такая помета, сделанная Сигеем в 1975 году:

[...] никогда не забывать, что сочиняю поэзию после: трубадуров, малармэ, дзен-буддистов, шеербарта, моргенштерна, макаронических поэтов, гонгоры, кавалера марино, лили и люллия, плотина (невмешательство), дада поэтов, маринетти, японцев и китайцев [...]. ${ }^{23}$

На протяжении всей творческой деятельности Сигей постоянно в разных формах обращается к своим предшественникам, вплоть до того, что он работает непосредственно с текстами, как, например, в этом случае:

СОХРА ВЕЛИМИРНИКАВА

времыши камыши

на озере береге

где каменье временем

где время каменьем

где на берега где озере

гдевремы гдеменья камыши

на гдеозере бегдереге

священно гдеменьем шумящие гдеши

мыши времени шыши ${ }^{24}$

${ }^{22}$ Кукуй (2006, с. 227).

${ }^{23}$ Сигей (2006, с. 157).

${ }^{24}$ Segay (2005, S. 100). 
Как видим, Сигей обратился к раннему стихотворению В. Хлебникова (1908). Приведу его следом:

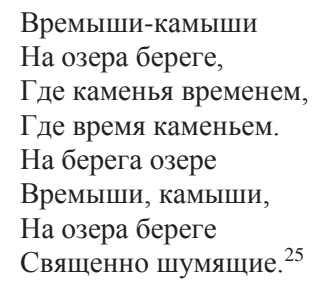

Текст Хлебникова прозрачен и сохраняет классическую стройность, чуть сдвинутую инверсией. Сигей же во второй половине своего текста доводит инверсивность до абсурда, переходящего в заумь. Таким образом выстраивая проекцию хлебниковского пути, помноженную на проекцию пути собственного. «Сохра» - то есть сохранение «велимирникова». Здесь современный поэт заумниченьем скрывает свою сентиментальность по отношению к Велимиру - вообще, может быть, к этому периоду времени, к которому он постоянно обращается.

Впрочем, сам Сигей вполне определенно высказывается в тексте под названием «Колба записок»:

будущел уже не описывает как

будетлянин,

он выражает.

будетляне поверхность

сверху разрабатывали,

будущелы ее же

изнутри.

исходная позиция -

опыты велимира первого.

хлебников - зазов,

будущелы за званых гостей

в его доме пируют,

хлебников - стол,

будущел - хлеб,

хлебников - пол,

будущел - пляска ${ }^{26}$

Понятно, что Хлебников - фундамент - основание всех поисков. Современный поэт, даже противопоставляя будущельство будетлянству все-таки не может уйти из-под влияния будетлянина - будущелы пируют в его доме. Ситуация достаточно конфликтная. Мы не могли сбрасывать наших предшественников с парохода современности хотя бы по той причине, что они не присутствовали в открытом пространстве, их произведения храни-

\footnotetext{
${ }^{25}$ Хлебников (2013, с. 39).

${ }^{26}$ Segay (2005, S. 102).
} 
лись впрок. И напротив - на нашу долю выпало заниматься их открытием. В то же время Сергей Сигей, Ры Никонова и другие авторы внеисторического авангарда пришли ведь со своей «пляской» - и ее надо было осуществить! Здесь налицо оказывалась как бы двусубъектность - необходимо было действовать от имени себя и от имени другого, включая в свои поиски «сохр».

Ры Никонова была менее склонна к тщательному изучению исторического авангарда. Будучи профессиональным музыкантом, она многое ловила со слуха, а визуальное мгновенно считывала оком художника. А дальше уже в ход шли перо, ручка пишмашинка, клей, ножницы, линейка, карандаш... Она создавала векторные стихи, координалы, архитекстуры, вкуумные и т.д. Джеральд Янечек насчитал тысячу форм. ${ }^{27}$ Но и она постоянно обращалась к творениям предшественников, вступая в диалог, часто самого радикального свойства. Ее увлекал радикализм формы Крученых, Терентьева, Зданевича, Чичерина, Туфанова. С ними она находила параллели, пересечения, точки отсчета и пересчета. Из обэриутов и Сигей и Никонова особенно чтили Игоря Бахтерева, с которым были знакомы и общались.

Игровое и ироническое, идущее от крученыховской линии, было особенно свойственно Ры Никоновой. Бабушкина фамилия в сочетании с придуманным грозным именем - лучшее тому подтверждение. Анна Александровна Таршис - это учительница детской музыкальной школы. А Ры Никонова - эпатажная авангардная художница, для которой законы искусства не писаны, она сама их создает. В частности, она пишет текст под названием «Любояз» - собрание неких максим о языке, об искусстве...

Обратим внимание на такое высказывание:

Умение скрыться за текстом - достовернейший показатель писательского мастерства. Зуд искренности, пророческое нетерпение приводит к обнажению наиболее дешевых участков мозга и только.

Без искусства нет искусства. ${ }^{28}$

Ры настолько искусно скрывается за текстом, что даже отказывается от текста вербального и переходит к визуальному, а затем и к пустотному или вакуумному. Казалось бы, таким образом она переходит от субъектности к некой объектности. Но это если за субъектность принимать индивидуальные (биографические в том числе) качества автора. От этих качеств Ры Никонова максимально отстраняется. Однако полностью спрятаться всетаки не удается. Все-таки остаются волевые качества, признаки стиля... Более того - радикальные нарушения канонов, изобретения форм ставят автора в исключительное положение. Фактически Никонова и Сигей находились в оппозиции не только к «классицизму» советской поэзии, но и к «классицизму» андеграунда. Но и в ситуации постсоветской они оказались противоположны так называемому мейнстриму. Толстые журналы дружно про-

${ }^{27}$ См. Янечек (1999).

${ }^{28}$ Никонова (2006а, с. 404). 
игнорировали существование этих авторов. Трудно представить, скажем, в «Новом мире» или «Знамени» такой, например, текст Ры Никоновой:

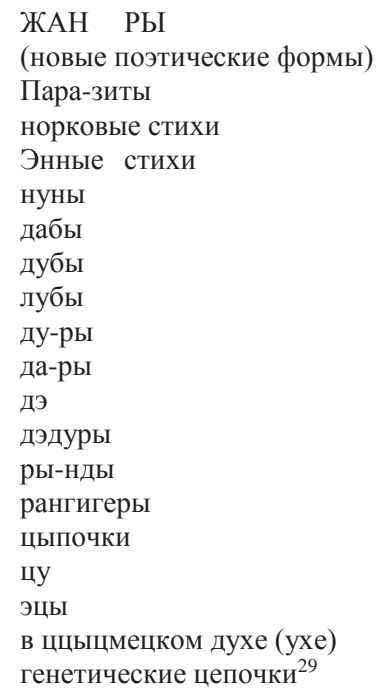

Характерно, что написано это в 1970 г., доработано в 2003 г. То есть Ры с невиданным упрямством отстаивала свое право на радикальную уникальность, принципиальное невписывание в литературный процесс. Одна из ее книг, выпущенная нашим общим издателем в Мадриде, Михаилом Евзлиным, называлась «Обструганное бревно поэзии». ${ }^{30}$

Называя себя транс-поэтами, Никонова и Сигей очень точно артикулировали направление вектора - в сторону трансформационной поэтики. Полагаю, им был бы близок тезис французского поэта, переводчика и теоретика Анри Мешонника:

Есть только один тип поэзии. Поэзия, которая трансформирует поэзию. Все остальное - подражание. Китч для богатых. ${ }^{31}$

Позицию, которую избрали Никонова и Сигей, можно охарактеризовать как безсубъектную субъектность. В их произведениях мы практически не встречаем местоимения первого лица, никаких переживаний «лирического героя» или «героини». Но в то же время «поэт» имеет высокую котировку. Однако в данном случае поэт далек от традиционного романтизма. Мы можем констатировать своеобразный романтизм делателя - художника в широком смысле, создающего новое искусство.

\footnotetext{
${ }^{29}$ Никонова (2006b, с. 330).

${ }^{30}$ Никонова (2002).

${ }^{31}$ Мешонник (2014, с. 117).
} 
Можно говорить об особом пути Елизаветы Мнацакановой. Профессиональный музыкант, в начале 50-х гг. она окончила Московскую консерваторию как пианист и теоретик, а затем аспирантуру. Мнацаканова вышла на глубокие органические соприкосновения стиха и музыки. Фактически ей удалось объединить две стихии: музыку и поэзию. И в этом случае можно наконец определенно сказать, что существует поэзия музыки и музыка поэзии. В течение нескольких десятилетий Мнацананова создает цельную систему музыкально движущегося стиха.

Для того чтобы понять принципы мнацакановского подхода, надо вспомнить, как строится музыка. Музыкальная ткань имеет такое же членение, что и словесная: слово (в музыке - мотив), фраза, предложение, период. Все эти термины взяты из арсенала ораторского искусства, то есть словесности.

Близость музыки и слова, родственность их происхождения - все это не требует особых доказательств. Бах не только писал гениальную музыку, но и профессионально владел риторикой и преподавал ее. Однако внутренние связи элементов в музыке иные, чем в словесном искусстве. Мнацаканова пишет словами, но эти слова добываются из музыки, протягиваются сквозь музыку, поэтому они иногда неузнаваемы, поэтому мы видим наплыв одних и тех же слов (на самом деле они разные!). Кстати, напомним о сходных приемах у Хлебникова, но как бы в обратной перспективе: разные слова как сходные. Недаром Хлебников хотел проверить законы времени «музыкальным ладом» и недаром он один из чтимых Мнацакановой поэтов.

Мнацаканова использует музыкальные формы развития материала, и от того, какие это формы, зависит художественный результат. Так, хоровое многоголосие в одной из частей развернутого цикла «У смерти в гостях» создает напряжение, сходное с народными заплачками, при этом происходит необычное звуковое перераспределение: консонанты приобретают вокалическое звучание, а вокализмы - консонантное (при отрывистом - стаккатном - произнесении). Очень важно здесь при чтении правильное распределение дыхания: подсказанное записью текста, дыхание подхватывается. Именно из всех этих составляющих и складывается произведение, обладающее большой эмоциональностью.

Прорастание лейтмотивов в лейттемы - характерный прием симфонического развития - постоянно используется Мнацакановой, но в книге „Das Buch Sabeth“332 он доведен до совершенства. Мы не знаем, какая музыка звучала поэту, когда он писал это произведение, полностью оно может воплотиться в голосе автора. Однако у нас остается и возможность собственной интерпретации - голосом.

\footnotetext{
${ }^{32}$ Мнацаканова (1988).
} 
Характерно, что звучание в книге Мнацакановой в конце концов становится настолько осязаемым, что переходит как бы в видимое - и тогда читателю является и почерк, и графические видения автора в цвете - это звуковые волны наконец воплотились. И если в словесном, в звучащем мире остановка все-таки возможна, то в графике поэт достигает действительно неостановимости движения.

И уже сама графика влияет на звуковое воплощение. Здесь действуют системы современного музыкального письма, которые используют в качестве темы не развернутую мелодию, а тембр, тембровые пятна, ритмические структуры, и тогда напластования отдельных слов, которые наплывают друг на друга, дают тембровый эффект кластера, а сама запись текста становится графически ощутимой, переходит в цветомузыку.

Музыка - слово - живопись - слово - музыка: так схематично и кольцеобразно можно записать это вечное движение поэтического мира Мнацакановой.

Все «содержание» «содержится» здесь. И вытянуть его отсюда невозможно другим инструментом, кроме чувства, настроенности. Инструмент восприятия и передачи должен быть настроен. И тогда наступает ясность ощущения, открывается внутреннее зрение, открывается внутренний слух. И становится ясным, почему «объект» сравнивается сам с собой (март сравнивается с мартом, например), потому что время протекает мгновенно, и в следующую секунду вещь, явление уже не равны только что названным. Уже произошли глобальные изменения, явление перешло в другую плоскость. Такой подход можно назвать мультипликационным, но учитывая при этом, что мультипликация в «мультиках» лишь физическое явление, а в поэзии - если не захват метафизического, то путь, приближение...

Вывод, который можно сделать из всего вышесказанного, что Е. Мнацаканова создает художественное пространство, подобно тому, как это делают художники и композиторы, то есть авторы, действующие вне словесности. ${ }^{33}$

В стихах поэтессы ощущается магическая, заклинательная сила. И в то же время это так просто - слова разъединяются или соединяются, как будто сами, как будто за этим не стоит воли автора. На самом деле автор как раз очень изощрен, настолько, что он исчезает, его не видно, это не пресловутая поструктуралистская «смерть автора». Автор, которого на самом деле никогда не было, спокойно может умирать. Совсем другое дело живой, дышащий автор. Он, конечно, ходит в обнимку со смертью, как всякий смертный, но он разговаривает со смертью. И здесь проявляется отчетливая субъектность. Сама Мнацаканова в разговоре со мной называла автором своих стихов, особенно книги „Das Buch Sabeth“, печаль, то есть

${ }^{33}$ Ср. Янечек (2006), Фещенко (2013). 
состояние! Но состояние по идее должно принадлежать кому-то. С большой долей вероятности можно предположить, что автору (тем более, если знать, что эта книга написана в марте-мае 1972 г., после того как Елизавета Мнацаканова перенесла в 1971 г. клиническую смерть). Однако в «нелирическом мире» (так бы я определил работу поэта, предпочитающего действовать композиторскими методами) автор передоверяет состояние некоему стороннему субъекту, а сам становится разработчиком главных и побочных тем и партий партитуры. Причудливый разброс слов и букв в книге, то сливающихся, то разлетающихся, цепь бесконечных секвенций - все это можно определить как партитурное письмо.

Если отрешиться от биографических моментов, то перед нами - прямое продолжение и развитие на новом этапе принципов авангардного письма. Это переразложение слова, словослияние, анаграмматизм. Здесь последовательно соблюдаются законы организации материала - тематизм, связность и протяженность музыкальной ткани, сотканной, однако, из слов. По форме такая ткань близка фольклорным заклинаниям и заплачкам, а также литургическому распеву. Вот один из примеров:

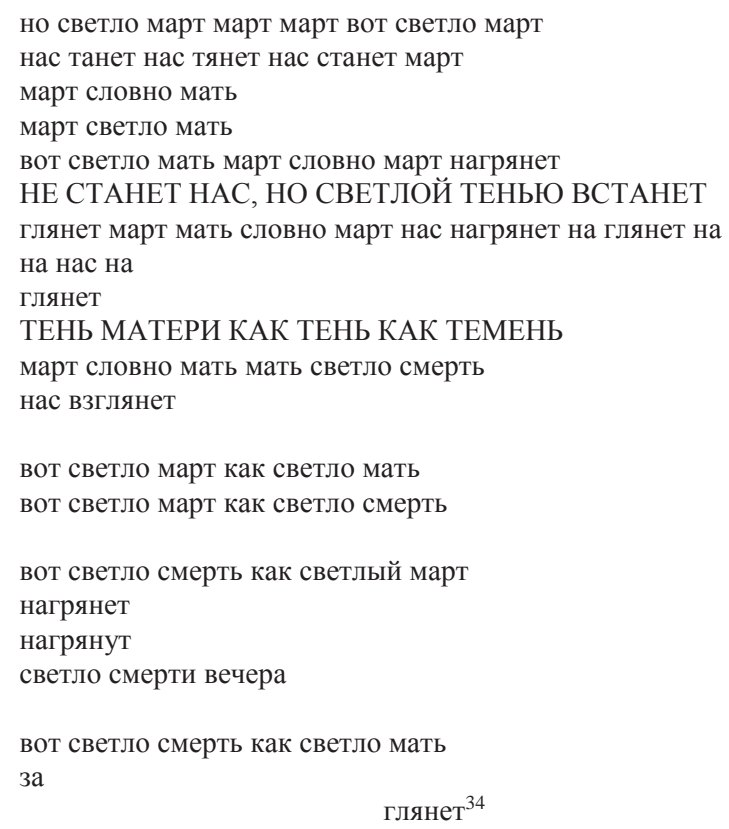

Авангардизм Мнацакановой в том, что она отказывается от традиционной стиховой и грамматической конструкции в пользу традиционной музыкальной структуры.

\footnotetext{
${ }^{34}$ Мнацаканова (1994, с. 50).
} 
Подчеркнутый перенос технологических принципов одного искусства в другое и есть настоящий авангардный подход. Другое дело, что самим автором это может не осознаваться, либо такая трактовка его может не устраивать. Но мы ведь имеем дело не с автором (в его естественных человеческих противоречиях), а с текстом.

Речь идет о книге Мнацакановой „Das Buch Sabeth“, то есть «Книге Завета», слово «завет» содержится и в латинизированном написании имени Елизаветы - ЭлиЗабет.

Но прочтем, что говорит сама поэтесса в предисловии к книге:

Эта книга о печали. Содержание книги - история встречи и расставания двух незнакомых людей, которые, собственно, никогда не виделись. Несмотря на это, они вспоминают друг о друге с тоской и болью. Когда они простились и расстались, чтобы никогда больше не встретиться, в их сердце медленно входит печаль, чтобы поселиться там навсегда.

Итак, печаль - важнейший протагонист всей этой истории. Печаль определяет действие, она играет главную роль. Печаль также подлинный автор данной книги.

Так что же это печаль? Какой смысл люди вкладывают в это слово?

Что касается слова. Во-первых, можно сказать: это не что иное, как движение сердца к моменту расставания; тому быстротечному моменту, который, не успев пройти мимо, уже закончен, навсегда вычеркнут из нашей жизни. Момент - теперь он медленно проплывает перед нашим мечтательным взором $[\ldots]$ он медленно бьется в нашем сознании, это медленный и торжественный ритм поступи смерти. Отныне этот ритм стал ритмом нашей жизни, он управляет нашим дыханием, подчиняет себе все движения мысли, гонит нас дальше и дальше, идет вместе с нами по жизни и сквозь всю нашу жизнь. ${ }^{35}$

Ритм поступи смерти сливается с ритмом поступи жизни, становится неотличим. Далее автор уравнивает печаль и смерть. Она говорит, что автором книги является печаль, но стихи вызваны «ритмом поступи смерти»...

Можно предположить, что изменение сознания обострило в Мнацакановой и свело воедино ее разнообразные дарования - профессионального музыканта, художника и поэта.

Не подводя итогов, можно констатировать, что в творчестве избранных мной поэтов мы встречаемся с очень яркими стилевыми особенностями, которые позволяют определить этих авторов как художников, которые находятся в поиске новой выразительности. По многим показанным выше признакам эти авторы продолжают и развивают традиции раннего авангарда в наиболее радикальных его проявлениях, в том числе это сказывается на отношениях с субъектностью. Субъектность традиционного плана отрицается, либо выводится за пределы текста, либо преобразуется, как это делается в смежных искусствах - музыкальном и изобразительном.

\footnotetext{
${ }^{35}$ Мнацаканова (1994, с. 36).
} 


\section{Литература}

Иванов, Вяч. Вс. (2011): Предисловие // Месяц, В.: Норумбега. М. 5-11.

Кацюба, Е. (1999): Красивые всегда правы. М.

Кедров, К. (2005): Компьютер любви // Диапазон. Антология современной немецкой и русской поэзии. Ред.: Елена Пахомова, Сергей Бирюков, Хендрик Джексон, Бернхард Замес, Константин Кедров. М. 314-316.

Князева, Е. (2000): Метареализм как направление: эстетические принципы и поэтика: автореф. дис. ...канд. филол. наук. Пермь. http:/www.dissercat.com/content/ metarealizm-kak-napravlenie-esteticheskie-printsipy-i-poetika (12/12/2017).

Корман, Б. (1982): Литературоведческие термины по проблеме автора. Ижевск.

Кукуй, И. (2006): Лаборатория авангарда: журнал «Транспонанс» // Russian Literature. 59 (2-4), 2006. 225-259.

Месяц, В. (2008): «Приведите крота...». Предисловие // Тавров, А.: Зима Ахашвероша. M. 5-8.

Месяц, В. (2015): Стихи четырнадцатого года. М.

Мешонник, А. (2014): Рифма и жизнь. Пер. с франц. О. Миричик-Сьоли. М.

Мнацаканова, Е. (1988): Das Buch Sabeth. Wien.

Мнацаканова, Е. (1994): Vita breve. Из пяти книг. Избранная лирика (1965-1994). Пермь.

Никонова, Ры (2002): Обструганное бревно поэзии. Мадрид.

Никонова, Ры (2006а): Любояз. Лубок для чтения вслух // Russian Literature. 59 (2-4), 2006. 404.

Никонова, Ры (2006b): Жан ры // Russian Literature. 59 (2-4), 2006. 330.

Ницше, Ф. (1990): Рождение трагедии из духа музыки // Ницше, Ф.: Сочинения в 2 тт. Т. 1. Пер. с нем. Г. Рачинского. М. 57-156.

Сигей, С. (2006): Фрагменты полной формы // Russian Literature. 59 (2-4), 2006. 157.

Тавров, А. (2008): Зима Ахашвероша. М.

Темиршина, О. (2001): Типология символизма: Андрей Белый и современная поэзия. М.

Фещенко, В. (2013): О современных «композиторах языка». «Тайная музыка слова Елизаветы Мнацакановой» // Шталь, Х. / Рутц, М. (сост./ред.): Имидж, диалог, эксперимент - поля современной русской поэзии. München / Berlin / Washington. 513-529.

Хлебников, В. (2013): Избранное / Сост. С. Бирюков, В. Перельмутер. М.

Шабаева, Т. (2011): Преодоление литературы: интервью с Вадимом Месяцем // Российская газета. 05/10/2011.

http://www.litkarta.ru/dossier/preodolenie-literatury/ dossier_1983/ (12/12/2017).

Янечек, Дж. (1999): Тысяча форм Ры Никоновой // Новое литературное обозрение. 35 , 1999. 283-319.

Янечек, Дж. (2006): Музыкальные процессы в стихотворениях Елизаветы Мнацакановой // Фатеева, Н. (отв. ред.): Художественный текст как динамическая система. М. 404-416.

Faryno, J. (1988): Паронимия - анаграмма - палиндром в поэтике авангарда. In: Wiener Slawistischer Almanach. Bd. 21. München. 37-61.

Segay, S. (2005): Formel vor. Gedichte auf Russisch. Itzehoe.

Užarević, J. (1991): Лирический парадокс. In: Russian Literature. 29 (1), 1991. 123-140. 


\section{Наталия Азарова (Москва)}

\section{Анализ многоязычия поэтического текста как метод реконструкции субъекта ${ }^{1}$}

Если попытаться определить (вернее, недоопределить) субъект в современной поэзии для удобства говорения о нем, то, видимо, мы имеем в виду поэтический субъект, который возникает во время чтения конкретного стихотворения, с одной стороны, и не существует за его пределами, а с другой стороны, в конструировании которого поэт принимает активное участие, что позволяет исследователю реконструировать следы этого участия. Такое понимание субъекта отражено в новом учебнике «Поэзия».2

Можно всецело согласиться с утверждением профессора Х. Шталь, что имеющиеся модели для определения лирики и субъекта как основного ее признака сталкиваются с той проблемой, что они преимущественно созданы на основе не современного, а более традиционного материала, и часто связаны со специальными теориями. ${ }^{3}$

Ставя себе задачу обновить теорию субъекта так, чтобы она могла стать основой описания субъекта новейшей поэзии, необходимо задаться вопросом о поисках формальных языковых параметров кроме традиционного анализа местоименной структуры поэтического текста, являющегося чуть ли не единственным принятым способом лингвистического анализа субъекта со времен знаменитой статьи Винокура о местоименной поэтике Баратынского, написанной еще в 40-е гг. прошлого века. ${ }^{4}$

Этот формальный показатель должен быть не произвольно выбранным, а релевантным для текстов новейшей поэзии последних тридцати лет. Таким параметром является полилингвизм текста, который может проявляться как в иноязычных инкрустациях, так и в оставленных следах в одном из языков, в поэтическом билингвизме авторов и в различных семиотических переходах на искусственные языки, графические символы и т.д.

Мы выдвигаем тезис, что межъязыковое взаимодействие как в любых вариантах полилингвизма текста, так и в варианте поэтического билингвизма автора всегда соотносится с категорией субъекта.

${ }^{1}$ Исследование выполнено при поддержке РГНФ (проект № 15-24-06003 «Типология субъекта в русской поэзии 1990-2010-х гг.»).

${ }^{2}$ Азарова / Корчагин / Кузьмин / Плунгян и др. (2016).

${ }^{3}$ Шталь (2015, с. 162).

${ }^{4}$ Винокур (1990). 
Отдельная и очень актуальная проблема для современной поэзии - это субъект переводного текста и способы его реконструкции: насколько в новейшей поэзии в ее формате Nachdichtung можно по переводам реконструировать наличие субъекта, соотносимого с материей языка перевода и языка оригинала. Или предположить, что скорее всего именно сопоставление оригинала и перевода может быть методом реконструкции субъекта и в том и в другом случае. Отдельный случай, когда субъект реконструируется на основании признания стратегии «неперевода» в мультиязыковых текстах.

Очевидными подступами к анализу субъекта в современной поэзии являются возможность реконструкции субъекта через разнообразные локусы, через выявление идентичности и чужой речи, интерречи и различных соотношений и градаций своего / чужого / присвоенного в речи, которые, так или иначе, могут свидетельствовать о расщепленности / скрытости / неявленности и т.д. субъекта.

Анализ межъязыкового взаимодействия может продуктивно соотноситься с этими параметрами. Он так или иначе:

- позволяет реконструировать субъект через пространство;

- дает возможность проблематизировать идентичность или выявить скользящую идентичность современного субъекта;

- соотносится со всем спектром проблем, связанных с чужой речью.

Необходимо уточнить, что речь идет не о построении однозначных моделей наличия / отсутствия межъязыкового взаимодействия и описания их функций, а об анализе межъязыкового взаимодействия отдельного текста, или отдельного автора, или группы авторов как одного из инструментов реконструкции субъекта. Но в любом случае реконструкция субъекта связана с проблемой понимания (интерпретации) и предполагает не упрощение, а создание некоторой параллельной тексту структуры, не «развертывание сложенного самолетика в чистый лист бумаги», а «развертывание бутона в цветок».

В известной работе С. Жижека «Щекотливый субъект» дается остроумная классификация методов академической борьбы с картезианским субъектом. Приведем ее полностью [выделение жирным шрифтом мое - Н.А.]:

Введение. Призрак бродит по западной Академии [...]

[...] призрак картезианского субъекта. Все академические силы объединились для священной травли этого призрака: (1) нью-эйджевый обскурантист (который хочет заменить «картезианскую парадигму» новым холистским подходом) и (2) постмодернистский де-конструктивист (для которого картезианский субъект является дискурсивным вымыслом, эффектом децентрированных текстуальных механизмов); (3) хабермасовский теоретик коммуникации (настаивающий на переходе от картезианской монологической субъективности к дискурсивной интерсубъективности) и (4) хайдеггерианский сторонник мышления бытия (подчеркивающий необходимость «преодоления» горизонта современной субъективности, наивысшим воплощением которой служит нынешний разрушительный нигилизм); (5) когнитивный ученый (пытающийся эмпирически доказать, что никакой 
уникальной сцены самости не существует, а есть только столпотворение соперничающих сил) и (6) глубинный эколог (обвиняющий картезианский механицистский материализм в том, что он предоставил философское основание для безжалостной эксплуатации природы); (7) критический (пост)марксист (настаивающий на том, что иллюзорная свобода буржуазного мыслящего субъекта укоренена в классовом делении) и (8) феминистка (которая замечает, что якобы бесполое cogito - это на самом деле мужское патриархальное образование).

Где та академическая ориентация, которую ее противники не ославили бы еще недостаточно преодоленным картезианским наследием ${ }^{5}$

Можно было бы расклассифицировать современную поэзию по способам противостояния картезианскому субъекту, предложенным Жижеком.

В частности, можно посмотреть, как в зависимости от способов устранения (расщепления) или размывания субъекта работает межъязыковое взаимодействие, а наряду с ним - междискурсивное взаимодействие и семиотические переходы. В этом случае основной была бы дискурсивно-коммуникативная парадигма, выдвижение на первый план межъязыкового взаимодействия как варианта чужой речи, интерречи и т.д. или когнитивная критика, представляющая межъязыковое взаимодействие как некие заданные ситуативные клише.

Мария Фаликман отмечает, что у европейца и у восточного человека (прежде всего, китайца) разные когнитивные рамки восприятия информации в тексте, в том числе и визуальные. ${ }^{6}$ В когнитивной науке информацию делят на фигуру и фон. Европеец видит гораздо четче фигуру (главное), и для него смазывается фон, который имеет второстепенное значение. А вот китаец, восточный человек, видит фон (периферию) и воспринимает эту информацию почти так же отчетливо, как и фигуру. В этом смысле восточное видение сродни женскому. У женщин более развито боковое, разнонаправленное, многопараметровое зрение. Отсюда и разное понимание субъекта. Если взять все подходы Жижека по критике и восстановлению субъекта, то все равно прослеживается европейская модель «расщепленность vs. целостность» (холизм, тоталитарность). В то же время, возможно, в последнее десятилетие мы можем подходить к субъекту, не обязательно собирая многопараметровость (в данном случае многоязычие) в единый конструкт, а с другой стороны, не обязательно настаивая на принципиальной невозможности этого собирания. Субъекта можно рассматривать, таким образом, в сосуществовании фона (периферии) и фигуры.

Оговорим одну важную общую закономерность поэзии XXI века (может быть, в 90-е гг. это не совсем так): если в тексте появляется одна инкрустация на каком-либо языке, то она, как правило, не бывает единичной, при-

\footnotetext{
5 Жижек (2014, с. 23).

${ }^{6}$ Фаликман / Коул (2014). См. также Kitayama / Duffy / Kawamura / Larsen (2003); Nisbett / Peng / Choi / Norenzayan (2001).
} 
чем последующие инкрустации с большой долей вероятности будут на других языках. Приведем пример максимальной формализации этой закономерности на коротком отрезке текста.

Пробуждение со словами

„Völkommen till Microsoft“", - единственным,

что не нуждается в переводе. ${ }^{7}$

Далее мы приведем самое предварительное описание возможных моделей соотношения многоязычия или субъективации:

1) Межъязыковое взаимодействие как манифестация идентичности, таким образом субъективация мыслится через идентичность, и многоязычные инкрустации подразумеваются как «свои», а не чужие, предлагают определенный круг адресатов и приписывают себя этому кругу.

Noblesse oblige. Старик совсем облез.

Чуть что - прыг-скок - и убегает в лес

Сидеть на пне, гудеть-бубнить аb ovo:

Разве мальчик в Останкине летом... И прочее...

То забывая слово,

То вспоминая... ${ }^{8}$

В стихотворении Дмитрия Веденяпина иноязычные вставки, входящие в тезаурус «обязательной образованности» интеллигента еще советского времени, работают на ностальгическую идентификацию субъекта в постсоветском пространстве.

Такая модель работает в основном как субкультурная идентификация.

Модель мультикультурализма, спроецированная на субъект, подразумевает обязательную принадлежность, приписывание себя к некоему кружку, меньшинству. В этом случае иноязычные инкрустации должны функционировать как способ не столько выявления идентичности субъекта, сколь подчеркивания самим субъектом своей идентичности. Английский язык в этом случае характеризует субъекта через коммуникативную модель - при адресации некоторой целевой и возрастной аудитории, знающей определенные цитаты или термины именно в английском варианте. Это, в основном, названия кинофильмов, музыкальных групп, песен, альбомов и т.д.

/reggae/

Когда взойдет великая Луна,

Мы позабудем наши имена,

И ша-ла-ла, и прочие дела,

Та-там, та-там.

То здесь, то там. Я собираю вещи, comin' thru the nite.

Я собираю вещи, comin' thru the nite.

В небе звездочка горит, сам с собою говорит.

\footnotetext{
${ }^{7}$ Скидан (2016, с. 152).

${ }^{8}$ Веденяпин (2009).
} 
- Человек ли ты? - Конечно же, nicht и nyet;

Здесь ни одна собака не застит свет,

Здесь вдоль обочин земля, трава и цветы,

Я со своим народом, ты со мною на «ты».

Рэггей - как надоела эта земля!

Чужая земля, где нет незаемных мелодий;

Будь верховой или пеший - под утро сигналят костры,

Соблюдают медленный шаг. Вот так.

Где же ты, где ты, где ты, родная страна,

Где же ты, где ты, где, кому ты нужна;

$\mathrm{O}$, все, что нужно мне,

Пускай его сгорает, сгорает на медленном огне.

Пускай его сгорает, здесь и там, comin' thru the nite,

Здесь и там, comin' thru the nite, waitin' occupate. ${ }^{9}$

2) Одним из важных способов реконструкции субъекта является субъективация в связи с разными типами и средствами передвижения (перемещения), нахождения в пространстве, что, в свою очередь, может быть описано не только традиционно использующимися дейктическими словами, а также изучением пространственной лексики, но и присутствием межъязыкового взаимодействия.

Пространственная (в смысле локуса, в смысле приписывания себя к определенному пространству или отделения себя от определенного пространства) или предметная субъективация. Многоязычие моделирует пространство.

Здесь возможно несколько вариантов. В первом пространство моделируется как чужое, экзотичное, «не свое».

Иноязычные инкрустации начинают выполнять декоративную функцию, призванную развлечь аудиторию либо туристическими цитациями (разнообразными названиями мест, предметов, одежды, еды и т.д., характерными речевыми штампами). Это проявляется в различного рода туристических иноязычных вставках, что, возможно, более характерно для поэзии 1990-х2000-х гг. (и субъект нацелен на осваивание или присвоение чужого, предметного, многоязычия) - времени освоения Европы - и менее характерно для поэзии нашего десятилетия.

[...] Пить чай еще светло, а пить caffè

уже темно. Что ль пожевать focaccia

c vitello freddo?.. На такой строфе

завязывать бы впору. Но пока что

меня несет мой Pegaso $[\ldots]^{10}$

Но возможно и гораздо более сложное и рефлексивное использование той же модели функционирования субъекта. Приведем стихотворение В. Ари-

\footnotetext{
${ }^{9}$ Шостаковская (2000).

${ }^{10}$ Строчков (2001, с. 53).
} 
стова «1-го мая в Милане» и его комментарий к иноязычным вставкам, сделанный по моей просьбе.

Улица Anton Chekhov

незаметно свернув

выводит на белую между стен улицу Монтале

Sul muro graffitti

На улицах я был один,

Как Первомай этот -

Праздник труда (festa lavoro)

Транспорт стоит и метро на приколе

Я был один прямоходящий

на солнечных площадях

мимо пролетали в скорлупках корпускул

обтекаемых светом машинах,

но даже сдавленный шепот не доходил из них

$[\ldots]$

сколько сделать еще протяжных шагов к месту, откуда можно найти весь городской горизонт

В тот же день - я не знал - в этот миг

ты навсегда покидала Москву

$[\ldots]$

Панорама с холма Милана

здесь не видна:

древо сухое на фоне зеркального банка

И наметают мороженое в кафельно-вафельный факел

у ипподрома galoppo. ${ }^{11}$

В этом стихотворении несколько фактов появления «чужого слова» $[\ldots]$ Первомай в детстве ассоциировался с долгожданным и самым радостным праздником, можно вспомнить, что помимо множества песен и стихов, посвященных празднику, мы учили на уроке английского (вот еще одна «инословесная» ассоциация): „The first of May - The heart of spring“. Оказавшись утром первого мая на миланской окраине, я был поражен абсолютным безлюдьем (то есть за те полчаса, что я шел, я не встретил ни одного человека!), это походило на некий сон - при яркой солнечности - своей изнанкой далекой, но отчетливой многолюдности и шумности тех первомаев... так что все движение по пустому городу напоминало перестроение атомарных предметов [...] Появление некоторых значимых иноязычных слов - разнословесные уровни были важны, чтобы в каком-то смысле уравновесить визуализацию

${ }^{11}$ Аристов (2002, с. 41-42). 
(для меня несомненную) [...] Следующая пара итальянских слов (в скобках) „festa lavoro“ - обозначает присутствие рефлективного уровня, неподогнанного под правильность (словосочетание лишь приблизительно правильно, существительное употреблено без артикля). Здесь это элемент внутренней речи и упомянутое «иноязычное» остранение подчеркивает наличие нескольких слоев сознания [...] „Galopро“ вопринимается как что-то непонятно-очевидное... Иноязычное слово здесь не только слышимо, но и зримо, оно отчетливо как очевидное иное бытие, и по сути не нуждается в переводе, поскольку обозначает элемент несомненного реального внешнего бытия [... $]^{12}$

Субъект этого стихотворения скорее «наблюдатель», который постоянно ищет точки опоры и подтверждения реальности видимого пространства. Он живет, вернее, медленно движется в мире атомарных предметов, и иноязычный текст приравнивается к этим атомарным предметам, а с другой стороны, иноязычные слова, как предметные, так и видоизмененные и интертекстуальные, взаимодействуют друг с другом, соединяя части разобщенной реальности, в которой литературная цитата оказывается более «своей», чем видимый мир. Так, „sul muro graffiti“ - это видоизмененная строчка из Монтале, которая в оригинале звучала как „sul muro graffito““ ${ }^{13}$

Отдельной темой, хотя и тесно связанной с предыдущими, в реконструкции субъекта современной поэзии может быть формирование концепта «чужой язык» как репрезентация опыта межкультурного взаимодействия, что может быть исследовано не только на непосредственно текстах, но и на опросах поэтов, что было мной осуществлено в статье. ${ }^{14}$

Второй вариант пространственной субъективации при помощи многоязычия предполагает ощущение чужого как своего, признание себя своим в чужом пространстве. Так, расцвет многоязычия в популярной культуре неожиданной концептуальностью звучит в цитировании в стихотворении Драгомощенко ${ }^{15}$ культовой «Касабланки», прецедентного текста XX века, по-английски (,We’ll always have Paris“), сообщая о том, что субъект стихотворения живет или долго жил в Америке и смотрит американские фильмы не в русском переводе, а в оригинале.

Для субъекта, живущего в объектной глобалистской реальности, любая иноязычная вставка мыслится как апроприированная, что отчетливее всего формализовано в постконцептуализме, например, у Нугатова:

\section{[...]}

возможна ли поэзия после adobe®photoshop®

и adobe®illustrator ${ }^{\circledR}$

поэзия после adobe®flash $®$

поэзия после autodesk®3ds max ${ }^{\circledR}$

\footnotetext{
${ }^{12}$ Из ответов на опрос.

${ }^{13}$ Montale (1925).

${ }^{14}$ См. Азарова (2015a).

15 Драгомощенко (2012, с. 80).
} 
поэзия после ipod®

поэзия после bluetooth ${ }^{\mathrm{TM}}$

поэзия после google ${ }^{\mathrm{TM}}$ youtube $\mathrm{TM}^{\mathrm{TM}}$

поэзия после blu-ray disc ${ }^{\mathrm{TM}}$

поэзия после playstation ${ }^{\circledR}$

поэзия после dolby®digital surround ${ }^{\circledR}[\ldots]^{16}$

3) Субъективация в «чужих голосах», что так или иначе соответствует либо критике субъекта с позиции постмодернистского конструктивизма, тогда межъязыковое взаимодействие выступает как текстовый механизм этой деконструкции, примером чего может служить поэзия А. Скидана, либо в хабермасовском варианте дискурсивной интерсубъективности, в котором межъязыковое взаимодействие может мыслиться как интерречь.

Для довольно большого круга современных поэтов, как явствует из высказывания В. Лехциера,

человеческая действительность - это действительность тотально речевая, хоровая, отчетливо не дифференцированная, не сегментированная тем или иным образом. Она предстает многоголосной сплошно-речевой, онтологически-гомогенной совокупностью речевых данностей, как стершихся, так и вполне живых. ${ }^{17}$

Отказ от идеи «внутренней речи» субъекта или заведомая апроприация чужого как собственного говорит о давлении на воображение в современной культуре, и, соответственно, о неспособности и нежелании формировать образ. Все делается для того, чтобы невозможно было вообразить «субъекта этого стиха», нарисовать картинку при непосредственном чтении. Но для исследователя существуют некоторые способы это сделать, при этом на вопрос, возможно ли говорить о субъекте вне политической ангажированности, мы должны ответить - очевидно, нет.

4) Нью-эйджевская парадигма и, соответственно, холистический подход к критике субъекта может находить прямое отражение в иноязычных инкрустациях, особенно когда речь идет о несуществующих языках.

Приведем характерную для своего времени цитату из письма Драгомощенко:

Даже разрушенные [...] даже несуществующие языки обещают изменения не только в том, что окружает, но и в тебе самом, в этот же миг, как бы он краток не был. Разве этого мало? чтобы обращаться к другим языкам или, на худой конец, их выдумывать ${ }^{18}$

Этой модели может служить его же стихотворение «Изучая язык Nuku-tutaha». В тяге к подчеркнуто неиндоевропейскому звучанию, в декларации к пристрастию к звукам несуществующих языков ощущается и некоторый

\footnotetext{
${ }^{16}$ Нугатов (2008, с. 58).

17 Лехциер (2015, с. 151).

18 Драгомощенко (из письма).
} 
«экологический привкус» эпохи „new age“ 90-х гг. Провозглашается вкус к разрушенным и несуществующим языкам, и многоязычие ставит знак равенства между изменениями в том, что окружает поэта, и изменениями в самом субъекте.
Птица полетит
Мальчик идет атрибутируя полет
Ты купаешься, птица полетит в полете
Над мальчиком у которого все времена
Сразу когда он купается входит в то
Что вчера было темное в свете звезд
Перед тем как погрузиться в воду
Он идет осененный крылом Бертрана Рассела
В сонме разбитой прибрежной воды
Он видел другого мальчика
Ne kitia he tama, kua kitia podsolnukh
Видишь к поверхности идут пузыри
Радужная оболочка песка искоса
Мальчик увидит его - to kitia a ia
Он бросил собаку что неожиданно
Собака ест птицу следовательно
Она парит в воздухе kua kai he kuli emanu
Ты съешь собаку без перевода
Пуля покидает тело сворачивается время
Птица видит мальчика собака летит -
Человек смертен искусство огромно ${ }^{19}$

5) Иноязычные вставки как модель множественной субъективации. Вопpoc: происходит это лишь внутри текста или мыслится как некоторая референция? В выделении множественной субъективации как отдельной модели есть некоторое нарушение таксономии. О множественной субъективации можно говорить не только как об отдельной модели. Она так или иначе появляется в тех текстах, где функционируют и другие модели.

У Драгомощенко иноязычные вставки - это намеренно созданные препятствия, и они отбрасывают к началу строки или к началу текста.

В этом смысле даже хорошо, чтобы иноязычный текст был непонятным или малопонятным. Зримый образ иностранного слова затрудняет читателю буквальное понимание даже «простых» русских слов, сообщая о том, что на самом деле свои слова не менее непонятные, и мы вряд ли знаем их «значения».

При множественной субъективации утверждается реальное или воображаемое родство языков, позволяющее субъекту балансировать между языками, или не укореняясь прочно ни в одном из них, или создавая пространство возможного неустойчивого выхода при обязательном возвращении в первый язык. Из письма К. Корчагина:

19 Драгомощенко (2009). 
Я очень часто использую материал чужих языков и для меня это может быть главное средство ввести в текст искусственное о(т)странение, а последнее в свою очередь нужно для того, чтобы прерывистый и расщепленный субъект моих текстов не смог ни в коем случае собрать себя; это дополнительные препятствия для такой «сборки», неустойчивости окружающего пространства, которое в то же время оказывается единым, хотя бы за счет наплывающих друг на друга языков. Однако единым вне субъекта - он словно вытолкнут из этой общности, т.к. все-таки привязан к одному языку, а с другими соотносится постольку, поскольку. ${ }^{20}$

Важным способом конструирования субъекта при помощи межъязыкового взаимодействия является хеджирование - обнаружение себя в той области, о которой хочется молчать, в том числе сакральной.

Иностранный язык, который всегда говорит и не говорит, понятен и не понятен одновременно может быть эффективным способом вербализации молчания. В стихотворении Айги «Заря: в перерывах сна» это небытие, точнее не-есть, ничто голоса дано по-французски néant de voix.

где есмь как золотую пыль -

как обрамленье красное приснившееся книги:

„néant de voix"-

от сердца высоко во сне над ним висящее -

о так сжигают есмь:

и жизнь - как некою его: умершею! -

она - разрозненною красною

как в плаче перерывы

мои теперь со сна! -

и лишь сознанье где-то сплавом ангельским

над тенью здесь затерянной -

иное

далеко ${ }^{21}$

В поэтике Айги отрицательное богословие (апофатика) предопределяет переход к иноязычной инкрустации: название стихотворения «Запись: ароphatic» можно воспринимать как своеобразную формулу перехода на другой язык. Любопытно, что слово „арорһаtic“, записанное латиницей, в сознании читателя прямо не ассоциируется ни с одним иностранным языком: хотя формально ,арорhatic“ в такой орфографии, как у Айги, - это английское слово, совершенно неочевидно, что поэт здесь имел в виду английский язык. Скорее всего, это некое слово, которое будучи понятным, относится ко всем языкам и ни к одному конкретно, а с другой стороны, написание латиницей позволяет достичь необходимой степени остранения.

Надъязыковая латиница слова „арорhаtic“ здесь выступает как способ кодирования запретной в разных смыслах как социальной, так и сакральной субъективации. ${ }^{22}$

\footnotetext{
${ }^{20}$ Письмо от 13/11/2011.

${ }^{21}$ Айги (1992, с. 96).
} 
Смешение языков (code-switching) часто используется билингвами в практике хеджирования, то есть де-интенсификации табуированной информации или подачи ее в размытом, неопределенном виде, в виде „sort of" («вроде»).

Но хеджирование используется не только билингвами.

КВА?

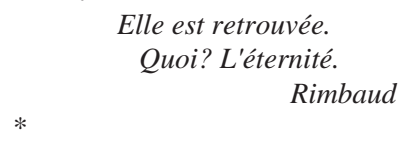

Вот и «вечность», вот и «ква».

И чего там? Ничего там, и чему ни скажешь «хва!», знай, болтайся по болотам $[\ldots]^{23}$

6) Межъязыковое взаимодействие как отражение утопии, либо идеального языка, при этом может признаваться невозможность его построения как системы, что в той или иной степени соответствует хайдеггеровской «мечте о языке». Но и признанию относительной возможности коммуникации.

По Хайдеггеру, подлинной проблемой является технологический способ отношения ко всему, что нас окружает. ${ }^{24}$ Подобный субъект не только ощущает классическое противоречие между подлинным бытием в мире и das Man, но и пытается совместить, казалось бы, несовместимые выходы из этого противоречия - в решительную экзистенциальность с одной стороны, и в традицию метафизической онтологии, вплоть до теологии - с другой. Как здесь работает многоязычие?

Выбираются так называемые «двуязычные» слова, например, «роза» („Rose“), которые возвещают преодоление границы языков и возможность одновременного присутствия в разных языках и между ними.

В пантеистической поэтике Айги субъект растворяется в среднем роде и неличных формах нейтрализации как гендерной оппозиции, так и оппозиции «одушевленное / неодушевленное»; нейтрализуется частеречная принадлежность, и на первый план выступает визуальная информация, благодаря чему текст частично иконизируется. Возникает приоритет зрительного восприятия, и слово отрывается от конкретной языковой принадлежности. Это характерный для Айги прием, когда слово, превращаясь в иероглиф, парит между языками, как бы не относится ни к одному национальному языку. В таком иконизированном тексте, обеспечивающем абсолютную переводимость через нейтрализацию категорий, возникает возможность восприятия

\footnotetext{
22 Подробнее об этом см. Азарова (2016).

${ }^{23}$ Булатовский (2008).

${ }^{24}$ Включая язык, что прежде всего актуально для Айги, и исследования субъекта, что сегодня актуально для нас.
} 
иностранного текста (иностранного слова) без перевода. Для него первостепенен звуковой образ чужого слова и чужого языка, и его визуальный образ.

Для билингва Айги характерна принципиальная легкость введения третьего языка и легкость обращения с чужими языками.

Переход поэта-билингва к другим языкам, которых всегда больше, чем два, совершается по-другому, чем у поэта-монолингва. Если в поэзии монолингвов (Владимира Аристова, Аркадия Драгомощенко и др.) обращение к многоязычию ведет к изменению самого субъекта и того, что его окружает (или обещает эти изменения), а переход с языка на язык увеличивает не только многозначность слов, но и «многозначность субъекта», то у Айги множественной субъективации себя в связи с другим языком не происходит.

Если монолингв мыслит себя в другом языке, другого себя, то для билингва другие языки могут быть мостом в надъязык, а субъективация предполагает утопию надъязыка, отражающего довавилонский прото-гул. ${ }^{25}$

Субъект Айги живет в мире, с одной стороны, сконструированном как современный ему хайдеггеровский конечный исторический горизонт размыкания бытия, а с другой стороны, в мире, который антропоцентричен, но еще не субъективен, то есть досовременен, и универсальный язык (надъязык) тоже может мыслиться в дизъюнктивном синтезе этих двух представлений о мире.

7) В поэзии Драгомощенко множественная субъективация и мечта о надъязыке удивительным образом сочетаются, что является особенно актуальным и продуктивным для поэзии 2010-х гг.

Сегодня речь идет о возвращении субъекта в поэзию, то есть о возвращении Я в поэзию, но Я, значительно отличающегося от принятого в метатекстах XX века.

Поэты действуют в рамках тенденции преодоления ограниченности одного языка при помощи межъязыкового взаимодействия, в том числе путем преодоления диктата родной языковой картины мира, мифа о самодостаточности одного национального языка.

У Драгомощенко механизм, запущенный одной иноязычной инкрустацией, приводит к выстраиванию особого пространства, в котором опорными точками служат «куски» других языков, и отнюдь не обязательно европейских.

Иноязычные инкрустации и межъязыковые переходы у Драгомощенко, как и у целого ряда более молодых поэтов, - это не эксперимент, они не вызывают возражения и не кажутся каламбуром, т.е. игрой на столкновении

25 «Ловушкой, которой необходимо избежать здесь, является ускорение онтологизации этой „речи-в-себе“ [...] как если бы эта „речь avant la lettre“ действительно существовала как другой, более фундаментальный и полностью конституированный язык, сводящий нормальный, „явный“ язык к его вторичному поверхностному отражению [...] эта другая проторечь остается виртуальной» (Жижек 2014, с. 91). 
значений. В этой антикаламбурности и отсутствии противопоставления языков - принципиальное отличие от традиции «макаронического стиха». ${ }^{26}$

Или уподобясь червю, приползти

По извилистому описанию розы, оставляя в итоге:

лишь только is... ${ }^{27}$

из rose is -

Образ идеального языка у Драгомощенко все-таки возникает и выстраивается вместо, казалось бы, изначально заявленной борьбы с правилами языка. Это идеальный язык, в котором, с одной стороны, любое соотношение знака и значения подвергается сомнению, а с другой - коммуникация все же возможна, и коммуникация эта может быть межъязыковой и надъязыковой.

Множественная субъективация оказывается возможной в пространствах, создаваемых интерференцией, вторжением, наложением языков.

Субъект Ники Скандиаки живет в пространстве не только межъязыковых, но и семиотических переходов, в частности, на языке программирования:

[...] systemic contamination

contained? yams, yams.

hurts (and?) yams. [roadside monk]

impressive: сенсорная [афазия], контактно-усталостный [износ]

тяжеловесная женская доля, / - - / -, / - - /

?мерцающее молоко

очередь / выстрел из огнемета / шквал огня

мерцающее устройство

(flickering device) $[\ldots]^{28}$

В поэзии Ники Скандиаки мы видим возврат к утопии универсального языка как сложнопростроенного семиотического феномена (из отрывков и обрывков), но в отличие от Айги и даже Драгомощенко, здесь нет даже намерения превращения подобного языка в систему. Это вербализация и невербализация одновременно. Это сохранение межъязыкового взаимодействия в рамках дискурсивной практики, проецирующейся на мечту об универсальном языке.

Мне бы хотелось завершить статью замечанием о том, что в некоторых случаях мы говорим о субъекте, в некоторых случаях о поэтическом субъекте, скользящем субъекте, скользящей идентичности, не проводя строгих

${ }^{26}$ Ср. из стихотворения Д. Веденяпина:

Après nous le déluge

маркиза де Помпадур

Зачем нам, товарищ начальник,

Вся эта унылая чушь?

Ведь даже у бабы-на-чайник

В глазах: после нас хоть déluge. [...] (Веденяпин 2015).

27 Драгомощенко (2012, с. 181).

${ }^{28}$ Скандиака (2006). 
дефиниций между этими терминами (даже образ автора или концепт автора оказывается порой не лишним), но при этом непоследовательность и некоторая избыточность нашего понятийного аппарата как раз подтверждает то, что наша мысль - это не просто академическая логическая игра, она способна соотноситься с действительной сложностью современной реальности субъективации.

\section{Литература}

Азарова, Н. (2015a): Формирование концепта «чужой язык» как репрезентация опыта межкультурного взаимодействия // Вопросы когнитивной лингвистики. 4 (45), 2015. 23-29.

Азарова, Н. (2015b): Межъязыковое взаимодействие в поэзии Драгомощенко // Новое литературное обозрение. 131 (1), 2015. http://www.nlobooks.ru/node/5847 (18/10/2015).

Азарова, Н. (2016): Многоязычие Айги и языки-посредники // Russian Literature. 79/80, 2016. 29-44.

Азарова, Н. / Корчагин, К. / Кузьмин, Д. / Плунгян, В. и др. (2016): Поэзия: Учебник. М.

Айги, Г. (1992): Стихи разных лет. М.

Аристов, В. (2002): Иная река: Пятая книга стихов. М. / СПб.

Булатовский, И. (2008): Ква? // Воздух. 1, 2008. http://www.litkarta.ru/projects/ vozdukh/issues/2008-1/bulatovsky/ (18/10/2015).

Веденяпин, Д. (2009): Одесса-63 // Воздух. 1-2, 2009. http://www.litkarta.ru/projects/ vozdukh/issues/2009-1-2/vedeniapin/view_print/ (18/10/2015).

Веденяпин, Д. (2015): Après nous le déluge // Флейта Европы. 1, 2006. http://www.igraigr.com/vedenyapin.htm (18/10/2015).

Винокур, Г. (1990): Я и ты в лирике Баратынского (Из этюдов о русском поэтическом языке) // Винокур, Г.: Филологические исследования: Лингвистика и поэтика. М. 241-249, 357-362 (комментарии).

Драгомощенко, А. (2009): Поскольку люблю скрип рам // Знамя. 8, 2009. http://magazines.russ.ru/znamia/2009/8/dra3.html (18/10/2015).

Драгомощенко, А. (2012): Тавтология: Стихотворения, эссе. М.

Жижек, С. (2014): Щекотливый субъект: отсутствующий центр политической онтологии / Пер. с англ. С. Щукиной. М.

Лехциер, В. (2015): Поэзия в эпоху постметафизического мышления // Азарова, Н. / Бочавер, С. (сост., ред.): Поэтический и философский дискурсы: история взаимодействия и современное состояние: Сб. ст. М. 144-161.

Нугатов, В. (2008): В обратную сторону // Воздух. 2, 2008. http://www.litkarta.ru/projects/ vozdukh/issues/2008-2/nugatov/ (18/10/2015).

Скандиака, Н. (2006): Немножко дней // Воздух. 1, 2006. http://www.litkarta.ru/projects/ vozdukh/issues/2006-1/skandiaka/ (18/10/2015).

Скидан, А. (2016) Membra disjecta. СПб.

Строчков, В. (2001): Ворчливая ностальгиана // Журнал Клуба литературного перформанса и салона «Премьера». 51-56. 
Фаликман, М. / Коул, М. (2014): «Культурная революция» в когнитивной науке: от нейронной пластичности до генетических механизмов приобретения культурного опыта // Культурно-историческая психология. 10 (3), 2014. 4-18.

Шостаковская, И. (2000): /reggae/// Вавилон: вестник молодой литературы. 7 (23), 2000. M. http://vavilon.ru/metatext/vavilon7/shostakovskaya.html (18/10/2015).

Шталь, Х. (2015): Опыт философского обоснования мета-теории поэтического субъекта: современное прочтение Генриха Барта // Азарова, Н. / Бочавер, С. (сост., ред.): Поэтический и философский дискурсы: история взаимодействия и современное состояние: Сб. ст. М. 162-181.

Kitayama, S. / Duffy, S. / Kawamura, T. / Larsen, J. (2003): Perceiving an object and its context in different cultures: a cultural look at new look. In: Psychological Science. 14 (3), 2003. 201-206.

Montale, E. (1925): Sul muro graffito. http://www.la-poesia.it/poesie-del-900/eugeniomontale-sul-muro-grafito-1116-1.html (18/10/2015).

Nisbett, R. / Peng, K. / Choi, I. / Norenzayan, A. (2001): Culture and systems of thought: holistic versus analytic cognition. In: Psychological Review. 108 (2), 2001. 291-310. 



\section{Наталья Фатеева (Москва)}

\section{К проблеме «номадического субъекта» в современной поэзии}

Объекта эстетические свойства в конце концов зависят от субъекта. Субъект читает Деррида и Гройса и погружен в проблемы интертекста. ${ }^{1}$

Понятия «номадического интеллекта» и «номадического субъекта» стали благодаря Рози Брайдотти (ее работе «Путем номадизма»²) широко использоваться в феминистической литературе. Сами же эти понятия безусловно связаны с концепцией «номадического мышления» и «номадическими» текстовыми стратегиями Ж. Делеза (номадическое и ризоматическое письмо). Сущность их состоит в том, что латинский термин «номадизм», буквально означающий «кочевничество», в переносном значении был применен к новой форме субъектности, построенной на множественности различий и отсутствии иерархии, а также снятии системы четких оппозиций. Такая конфигурация отражает стремление к идентичности, состоящей из переходов, последовательных сдвигов, смен координат, а также «множественность центров, смещение перспектив, путаницу точек зрения» ${ }^{3}$ как неизбежный способ движения мысли.

Российские феминистки (Е. Здравомыслова и А. Темкина), создавая на русском языке антологию гендерных исследований, предложили также термин «номадическое авторство», который отражает тот факт, что перевод феминистических текстов с языка на язык всегда «дискурсивно ситуативен» и заставляет переводчика искать адекватные эквиваленты в своей культуре и языке. ${ }^{4}$ По их мнению, понятие номадичности автора производно от концепции интертекстуальности, которая подразумевает «кочевание» текста из контекста в контекст. В этом смысле, и перевод, и оригинал находятся в зависимости от предшествующих текстов и их смыслов, а автор только транслирует социальные и культурные коды. Тогда понятия первичного и вторичного текста (оригинала и перевода) становятся неопределенными, и не могут по идее принадлежать только одному автору -

\footnotetext{
${ }^{1}$ Кибиров (1998).

2 Перевод этой статьи из книги Р. Брайдотти (см. Braidotti 1994) опубликован в Жеребкин (ред., 2001): см. Брайдотти (2001).

3 Делез (1998, с. 78).

4 Здравомыслова / Темкина (2000, с. 23 и далее).
} 
они являются результатом «постоянной интерпретации, происходящей в процессе чтения, письма, перевода и нового чтения». ${ }^{5}$ Так, более ранние тексты становятся зависимыми от своих последующих трансформаций, поэтому «соавторами» дискурсивности становятся все действующие лица этой цепочки, которые возвращаются к этим текстам, изменяя тем самым и весь полигенетический дискурс.

Нам кажется, что такое отношение дискурсивности применимо вообще к интертекстуальности в ее широком понимании. В статье «интертекстуальность» будет рассмотрена во всех ее типологических проявлениях именно с позиции авторского или субъектного номадизма. Моя статья не будет связана с собственно переводом. Будут проанализированы поэтические тексты последнего времени, в которых интертекстуальные заимствования позволяют говорить о подвижном понимании «авторской идентичности», включая гендерный аспект. Кроме того, как проявление субъектного номадизма будет рассмотрена подвижность субъектной перспективы текста, которая позволяет переход от неявного выражения субъектности к маркированным формам.

Возьмем, к примеру, центонный текст Веры Павловой:

Могла ли Биче, словно Дант, творить,

как желтый одуванчик у забора?

Я научила женщин говорить,

Когда б вы знали, из какого сора. ${ }^{6}$

Он полностью состоит из строк двух стихотворений А. Ахматовой из цикла «Тайны ремесла» (1936-1960) - это седьмой текст цикла под названием «Эпиграмма»:

Могла ли Биче словно Дант творить,

Или Лаура жар любви восславить?

Я научила женщин говорить...

Но, боже, как их замолчать заставить. ${ }^{7}$

И второе четверостишье второго стихотворения цикла «Мне ни к чему одические рати...»:

Когда б вы знали, из какого сора

Растут стихи, не ведая стыда,

Как желтый одуванчик у забора,

Как лопухи и лебеда. ${ }^{8}$

Павлова составляет свое стихотворение из первой и третьей строки первого четверостишья и первой и третьей строки второго, перестраивая их так, чтобы получилась перекрестная рифмовка. Встает вопрос, кто является субъектом ее нового четверостишия, поскольку из-за узнаваемости строк

\footnotetext{
5 Там же.

${ }^{6}$ Павлова (1998).

${ }^{7}$ Ахматова (1986, с. 193).

${ }^{8}$ Там же, с. 190.
} 
мы однозначно соотносим этот текст с ахматовским, где субъектом, выраженным местоимением Я, является лирическая героиня Ахматовой. Можно ли утверждать, что субъект в этом случае представляет собой подвижную «номадическую» категорию, так как на долю «субъекта» Павловой выпадает лишь функция перекомпоновки строк своей предшественницы, и речь не может идти о присвоении «чужого» текста? В данном случае никак не изменяется гендерная идентичность субъекта. Меняется только смысл строк центонного стихотворения: вопрос об умении творить, как Дант, включает в себя сравнение как желтый одуванчик у забора, что снижает статус самого акта творчества; получает характеристику и сам объект, которого лирическая героиня обучает говорить - Когда б вы знали, из какого сора. Эта смена проекции все же заставляет думать, что субъект стихотворения Павловой также проявляет свою «субъектную» сущность, при этом не отменяя субъекта заимствованного текста, в котором также говорится о необычности объекта творчества: По мне, в стихах все быть должно некстати, / Не так, как у людей. ${ }^{9}$ Значит, наше предположение о «номадичности» субъекта оказалось правильным. Встает также вопрос, изменяется ли ретроспективно смысл ахматовских текстов: видимо, да, поскольку Павлова меняет серьезную тональность этих текстов на ироническую, придавая этим высказываниям статус легкомысленности, которая изначально им не была присуща.

Проанализируем еще один текст Веры Павловой:

Свеча горела на столе, а мы старались так улечься, чтоб на какой-то потолок ложились тени. Бесполезно!

Разве что стоя над столом, о стол руками опираясь и нависая над свечой, так - да. Но только рук скрещенья. ${ }^{10}$

В данном стихотворении обыгрывается стихотворение «Зимняя ночь» (1946) Пастернака, а именно, его строки:

$[\ldots]$

Свеча горела на столе,

Свеча горела.

На озаренный потолок

Ложились тени,

Скрещенья рук, скрещенья ног, Судьбы скрещенья. ${ }^{11}$

\footnotetext{
${ }^{9}$ Там же.

${ }^{10}$ Павлова (1997).

${ }^{11}$ Пастернак (1990, с. 526).
} 
Субъект стихотворения Павловой от первого лица говорит о том, что, пытаясь с партнером найти то положение рук и ног по отношению к свече, которое изображено в стихотворении Пастернака, терпит неудачу. По всей вероятности, не зная пастернаковского текста, это стихотворение нельзя понять адекватно - оно все состоит из его цитат как точных, так и преобразованных. Можем ли мы говорить о номадическом субъекте в данном случае? Ведь интертекстуальность, следуя определению И.В. Арнольд, это «включение в текст либо целых других текстов с иным субъектом речи, либо их фрагментов в виде маркированных или немаркированных, преобразованных или неизмененных цитат, аллюзий, реминисценций». ${ }^{12}$ Действительно, здесь иной субъект, по всей вероятности, женского пола, но без апелляции к пастернаковскому субъекту, который лишь представлен «голосом», невозможно вообразить описываемую ситуацию. Скорее всего, нам придется признать, что субъект, претерпевший гендерную метаморфозу, здесь также является номадическим. Как этот павловский текст ретроспективно влияет на восприятие пастернаковского? Конечно, как и в первом случае, он заставляет его понимать в ироническом регистре, который ему изначально не свойственен.

Обратимся теперь к тексту Веры Полозковой, не являющемуся по существу центонным, но содержащему несколько интертекстуальных маркеров, непосредственно соотнесенных с Я субъекта:

Я твой щен: я скулю, я тычусь в плечо незряче,

Рвусь на звук поцелуя, тембр - что мглы бездонней;

Я твой глупый пингвин - я робко прячу

Свое тело в утесах теплых твоих ладоней;

Я картограф твой: глаз - Атлантикой, скулу - степью,

А затылок - полярным кругом: там льды; that's it.

Я ученый: мне инфицировали бестебье.

Тебядефицит.

Ты встаешь рыбной костью в горле моем - мол, вот он я.

Рвешь сетчатку мне - как брусчатку молотит взвод.

И - надцатого мартобря - я опять животное,

Кем-то подло раненное в живот. ${ }^{13}$

Первый маркер я твой щен отсылает к шутливому прозвищу Маяковского, которое ему дала Лиля Брик: этим прозвищем он подписывал телеграммы и записки, обращенные к Лиле, называя ее ласково Киса, Кисик, а также рисовал щенка вместо подписи. Известно также, что когда Маяковский подобрал щенка, то его тоже назвал Щеном, ${ }^{14}$ что получило отражение в поэме «Хорошо!»: «Двенадцать / квадратных аршин жилья. / Четверо / в по-

\footnotetext{
12 Арнольд (1999, с. 346).

13 Полозкова (2005). Шрифтовые выделения мои, Н.Ф.

${ }^{14}$ Брик (2003, с. 141-148).
} 
мещении - / Лиля, / Ося, / я / и собака / Щеник». ${ }^{15} \mathrm{~B}$ тексте Полозковой $я$ твой щеен вносит тему мучительной любви, которая отличала отношения поэта с Л. Брик, но меняет гендерные роли (хотя в тексте нет прямых указаний на то, что текст написан от лица женщины). Второй интерекстуальный маркер отсылает к программной «Песне о буревестнике» М. Горького («Глупый пингвин робко прячет тело жирное в утесах...»), ${ }^{16}$ однако негативный план горьковской строки заменен здесь на положительный: лирический субъект, обращаясь к адресату, называет себя «твоим глупым пингвином», который прячет тело не в холодных утесах, а в теплых ладонях возлюбленного, находясь где-то между Атлантикой, степью и полярным кругом. Третий маркер - надияатое мартобря - соотносит текст с «Записками сумасшедшего» Н. Гоголя, а также со стихотворением «Ниоткуда с любовью...» И. Бродского («Ниоткуда с любовью, надцатого мартобря, / дорогой, уважаемый, милая, но неважно / даже кто, ибо черт лица, говоря / откровенно, не вспомнить[...]»); ${ }^{17}$ он вводится, чтобы показать степень болезненности переживаний субъекта, которому инфицировали бестебье и болезнь тебядефицит. Заканчивается текст тем, что лирическое Я вновь ощущает себя животным, но уже раненным в живот, что является отсылкой к «Поэме конца» М. Цветаевой, когда она пишет о расставании с любимым: «Я не более чем животное, / Кем-то раненное в живот». ${ }^{18}$

Как влияют на наше восприятие субъекта все эти интертекстуальные параллели? Видимо, влияние выражается в том, что они, наслаиваясь друг на друга, расширяют субъектное пространство стихотворения Полозковой, заставляя читателя воспринимать его как полигенетическое, т.е. в соотнесении с субъектами прецедентных текстов. Является ли в этом случае авторство номадическим? Вероятно, нет, потому что эти интертекстуальные фрагменты встроены в конструкции с субъектом, выраженным первым лицом единственного числа, которые задают коммуникативную рамку Я-Ты. Это позволяет субъекту нашего текста как бы присвоить их.

Рассмотрим еще один текст, который сложнее предыдущих тем, что он целиком является перепевом целого стихотворения - мы имеем в виду стихотворение Андрея Родионова «Девочки пели в масках в церковном хоре...», соответственно, исходным образцом для него выступает стихотворение А. Блока «Девушка пела в церковном хоре...» (1905). Родионов меняет тональность своего текста по отношению к блоковскому - она становится трагической, но с оттенком иронии:

\footnotetext{
${ }^{15}$ Маяковский (1969, с. 567).

${ }^{16}$ Горький (1901).

${ }^{17}$ Бродский (1990, с. 52). Ср. строки стихотворения Полозковой «Наскальное»: «Я хочу быть немного Бродским - / Ни единого слова зря» (Полозкова 2004).

${ }^{18}$ Цветаева (1994, с. 42).
} 
Девочки пели в масках в церковном хоре.

Богородица, выгони Путина вон.

У Надежды Толоконниковой плакал ребенок,

А Достоевский не велел, чтобы плакал он.

И храм был страшен, как панк-молебен,

И их тогда отвели в тюрьму,

Красиво одетых нежных царевен

Под масками слез не видать никому.

Все плакали тихо, но вой был жуток, И лишь далеко в кирпичном Кремле

Причастный к тайнам плакал Путин,

На что Федор Михалыч как раз положительно смотрел. ${ }^{19}$

Как мы видим, в этом тексте нет выраженного субъекта, субъект представлен только «голосом», который направляет развитие текста. Текст же развивается по новому сценарию - обыгрывается история группы «ПуссиРайт», девочки которой также пели в храме, но совсем о другом, чем блоковская девушка («О всех усталых в чужом краю, / O всех кораблях, ушедших в море, / O всех, забывших радость свою»). ${ }^{20}$ Причем в мелодическую канву блоковского текста вводится и ссылка на Достоевского о плаче (слезе) ребенка, ${ }^{21}$ обыгрывающая слова блоковского текста Причастный тайнам, - плакал ребенок. В тексте Родионова сначала действительно плачет ребенок Надежды Толоконниковой, а в конце причастным к тайне выступает плачущий Путин, что получает одобрение Достоевского (На что Федор Михалыч как раз положительно смотрел).

Вся сила воздействия этого текста заключается в том, что за ним стоит контрастный блоковский текст. Голос субъекта родионовского текста, излагающий современную историю, как бы переворачивает блоковский текст наизнанку, вписывая ее в современный политический контекст. Можно ли говорить о номадическом авторстве в этом случае? Видимо, да, поскольку без интертекстуального контраста родионовский текст воспринимается с потерей метрического образца и культурного контекста. При этом ретроспективно блоковский текст не изменяет своей «просветленной» тональности, она лишь рельефнее высвечивает измененный вариант современного текста, придавая и ему некоторую возвышенную тональность.

\footnotetext{
19 Родионов (2012).

${ }^{20}$ Блок (1960, с. 79).

${ }^{21}$ Слова Ивана Карамазова: «Да весь мир познания не стоит тогда этих слезок ребеночка к «боженьке» [...] Пока еще время, спешу оградить себя, а потому от высшей гармонии совершенно отказываюсь. Не стоит она слезинки хотя бы одного только того замученного ребенка, который бил себя кулачонком в грудь и молился в зловонной конуре неискупленными слезами своими к «боженьке»!» (ч. 2, кн. 5, гл. «Бунт», «Братья Карамазовы»; Достоевский 1958, с. 307).
} 
Этот текст демонстрирует, что «соотнесенность с образцом, его воспроизведение при одновременном искажении и осмеянии расчищают пространство для новаторства, творческого вымысла и самовыражения». ${ }^{22}$

Обратимся еще к одному стихотворению, в котором по контрасту с другими текстами очень важно звуковое начало. Это стихотворение С. Бирюкова, посвященное Тютчеву:

Тютчев

Чуть-чуть

Туч тюч

Тут и тут

Тют

Чев

Мысль изреченная есть ложь

Мысль изреченная есть вошь

Мысль изреченная ничтож

Мысль изреченная есть тож

Мысль изреченная есть что ж

Мысль из(реченная) ни что ж

Мысль из-реч-енная есть нож

Веч тют

Весь тут

Туч чуть

Чутев

Чутчев

Чев туч чев

Веч чев чуть

Тюююютчеев. ${ }^{23}$

Оно показательно как вариация на тему хлебниковского «Тютчева туч». ${ }^{24}$ Здесь Бирюков выстраивает всевозможные комбинации из имеющихся слогов веч тют, весь тут, туч чуть, чучев, чутчев, чев туч чев, расширяя ассоциативное поле стиха; при этом параллельно с заумными звуковыми импровизациями метаморфозам подвергается и знаменитая строка Тютчева «Мысль изреченная есть ложь», которая сначала доходит до стадии Мысль изреченная ничтож, а затем превращается в Мысль изреченная есть нож, переводя все высказывание в интертекстуальный регистр: ср. «Кинжал» (1837) и «Поэт» (1837) М. Лермонтова, «Кинжальные слова» (1899) К. Бальмонта, «Сабля» (1929) Д. Хармса и др.

Сам Бирюков подчеркивает свою особую связь с Тютчевым и его стихотворением, а также с тем, как Тютчева видит Хлебников, в статье «Тютчев

\footnotetext{
22 Пьеге-Гро (2008, с. 165).

${ }^{23}$ Бирюков (2009, с. 27).

24 Это слова Рыжего поэта из драмы В. Хлебникова «Маркиза Дэзес»: «О Тютчев туч! какой загадке, / Плывешь один, вверху внемля?» (Хлебников 1986, с. 410).
} 
как текст». ${ }^{25}$ В этой статье, посвященной «Silentium!» Тютчева, он делает акцент на его звуковой организации, выделяя в его строении доминирующую $M$ и ключевые слова, замыкающие круг: молчи - мечты - безмолвно молчи. Поэт также отмечает родство своего текста со стихотворением Хлебникова «О достоевскиймо бегущей тучи...», ${ }^{26}$ где последние две строки посвящены Тютчеву:

Ночь смотрится, как Тютчев,

Замерное безмерным полня. ${ }^{27}$

Кончается же эта статья приведенным выше текстом самого Бирюкова. Все это говорит о том, что тютчевский текст подвергается у Бирюкова метаязыковой рефлексии, которая и послужила основой для создания собственного стихотворения. Что касается субъектной организации, то у Тютчева мы имеем имплицитного субъекта первого лица, который адресует свой текст некоему обобщенному Ты, что подразумевает и автоадресацию. У Бирюкова субъект представлен только «голосом», он и воспроизводится поэтом при чтении своих стихотворений. Можем ли мы говорить о номадическом субъекте в этом случае, принимая во внимание, что посредником в этой коммуникации является субъект хлебниковских пьесы и стихотворения?

Скорее всего, нет однозначного ответа на этот вопрос. Положительный ответ на этот вопрос предполагает, что текст атрибутирован: цитата и фамилия Тютчева однозначно соотносят текст с великим поэтом, а вариации звукового облика фамилии соотносят текст с хлебниковским. Отрицательный ответ учитывает то, что фамилия Тютчева и его знаменитая строка подверглись значительной формальной деформации; сама же тютчевская строка представляет собой уже афоризм и может не соотноситься собственно с Тютчевым. Однако в тексте безусловно присутствует полигенетичность, которая вскрывается самим поэтом.

И наконец, рассмотрим еще одно стихотворение Александра Левина, которое представляет собой пародию на пушкинское стихотворение «Я Вас любил...» и которое во всех смыслах является «крайним»:

СТИХОТВОРЕНИЕ, НАПИСАННОЕ

ПРИ ПОМОЩИ ПРОГРАММЫ

RUSSIAN WORD CONSTRUCTOR

Я вас клубил. Клубовь еще медвежет

в грузди моей укислым солобьём,

\footnotetext{
${ }^{25}$ Бирюков (2003).

${ }^{26}$ Начало этого текста также подверглось трансформациям у С. Бирюкова в стихотворении «Реконструкция (вариационный метод)» с эпиграфом «О достоевскиймо» Велимир Хлебников (см. Бирюков 2013, с. 89); самому же Тютчеву посвящено еще стихотворение «Путь Тютчева»: «дорогой Тютчева / в пути / Selentium ты перечти» (Бирюков 2015, с. 31).

${ }^{27}$ Хлебников (1986, с. 54).
} 
но пасть она вам жальше не обрежет.

Я не шучу вежасностью пи-эм.

Лженою вас своей не оформляю.

Пеньюров ваших снятых соблазня меня мутит, как мрачка наливная, как целкая и чаркая лжизня.

Вы мне никтоль, никтовая мутница.

В груди моей фугас, но не совсем.

Ах, мне увы!.. Я, эфират в ресницах, для вас хищаю вовый полисем!..

Я вас клубил так флейтисто и плотско то плылостью, то умствием томим, я вас клубил так адско и улетско, как флаг вам в рук голимой быть другим. ${ }^{28}$

Мы знаем, что одна из переиначенных версий пушкинского стихотворения принадлежит И. Бродскому, но в ней, хотя оно иронично по своей сути, выдержана все же дистанция по отношению к исходному образцу, и субъект берет на себя ответственность за все высказанные слова:

Я вас любил. Любовь ещё (возможно, что просто боль) сверлит мои мозги, Всё разлетелось к чёрту, на куски.

Я застрелиться пробовал, но сложно с оружием. И далее, виски:

в который вдарить? Портила не дрожь, но задумчивость. Чёрт! всё не по-людски!

Я Вас любил так сильно, безнадежно, как дай Вам бог другими - но не даст! Он, будучи на многое горазд, не сотворит - по Пармениду - дважды сей жар в груди, ширококостный хруст, чтоб пломбы в пасти плавились от жажды коснуться - «бюст» зачеркиваю - уст! $!^{29}$

Анализируя это стихотворение, А.К. Жолковский отмечает, что Бродский усиливает уступительные оговорки Пушкина (быть может, не совсем), вводя в свой текст конструкции с отрицательными частицами «не» и противительным союзом «но», ставя их в ключевые позиции текста. ${ }^{30}$ «Противительность» у Бродского также усиливается тем, что признание обращено к статуе (это один из «Двадцати сонетов к Марии Стюарт»).

28 Левин (2001, с. 39).

${ }^{29}$ Бродский (1995, с. 73).

30 Жолковский (1994, с. 28). 
Стихотворение же Левина представлено автором как написанное с помощью компьютерной программы. Что в этом случае можно сказать о субъекте? Является ли он организующей инстанцией стихотворения, либо его функции переданы компьютерной программе? Скорее всего, мы имеем дело с переходным явлением, тем более что его текст напоминает «глокую куздру» Л.В. Щербы. Само пушкинское стихотворение состоит из 8 строк, у Левина их вдвое больше (у Бродского - 14). Особый интерес представляет последнее четверостишье, которое по структурной схеме более всего совпадает со второй частью пушкинского стихотворения. Его трансформации приписаны Word Constructor, но пародийность не обнаруживалась бы, если бы мы не знали исходного образца. Такая трансформация по идее должна показать, что бездумное заучивание пушкинских строк столь же вредно, как и их искажение бездушной машиной. Можно ли говорить о номадическом субъекте в этом случае? Скорее всего, да, так как компьютеризированный субъект у Левина опирается на исходную пушкинскую модель, а также учитывает, что однажды у Бродского эта модель уже была нарушена.

Итак, мы показали различные способы организации субъектной перспективы текста, когда в связи с интертекстульностью встает вопрос о его полигенетичности и номадичности. Можно сделать вывод о том, что степень номадичности субъекта зависит от полноты представленного претекста, от степени его узнаваемости или деформированности, и в целом от установки субъекта анализируемого текста.

\section{Литература}

Арнольд, И. (1999): Семантика. Стилистика. Интертекстуальность. СПб.

Ахматова, А. (1986): Сочинения. Стихотворения и поэмы. Т. 1. М.

Бирюков, С. (2003): Тютчев как текст // Toronto Slavic Quarterly. 6, 2003. http://sites.utoronto.ca/tsq/06/biryukov06.shtml (26/08/2016).

Бирюков, С. (2009): POE $\sum I \sum$ ПОЭЗИС POESIS. Стихи, композиции, визуалы, серийная техника. М.

Бирюков, С. (2013): Звучарность. М.

Бирюков, С. (2015): Knig beg. М.

Блок, А. (1960): Собрание сочинений в 8-ми тт. Т. 2. М. / Л.

Брайдотти, Р. (2001): Путем номадизма // Жеребкин, С. (ред.): Введение в гендерные исследования. Часть II. Хрестоматия. Харьков / СПб. 136-163.

Брик, Л. (2003): Пристрастные рассказы. М.

Бродский, И. (1990): Осенний крик ястреба. Стихотворения 1962-1989 гг. Л.

Бродский, И. (1995): Пересеченная местность. Путешествия с комментариями. М.

Горький, М. (1901): Песня о Буревестнике. http://ilibrary.ru/text/1493/p.1/index.html $(26 / 08 / 2016)$. 
Делёз, Ж. (1998): Различие и повторение-. Пер. с фр. Н. Маньковской, Э. Юровской. СПб. Достоевский, Ф. (1958): Собрание сочинений. Т. 9. М.

Жеребкин, С. (ред., 2001): Введение в гендерные исследования. Часть II. Хрестоматия. Харьков / СПб.

Жолковский, А. (1994): Блуждающие сны и другие работы. М.

Здравомыслова, Е. / Темкина, А. (2005): Введение. Феминистский перевод: текст, автор, дискурс // Здравомыслова, Е. / Темкина, А. (ред.): Хрестоматия феминистских текстов. Переводы. СПб. 5-28.

Кибиров, Т. (1998) Умничанье. http://lit.peoples.ru/poetry/timur_kibirov_zapoev/poem_172 08.shtml (12/01/2018).

Левин, А. (2001): Орфей необязательный. Вторая книга стихов. М.

Маяковский, В. (1969): Стихотворения. Поэмы. Пьесы. М.

Павлова, В. (1997): Свеча горела на столе... http://www.verapavlova.ru/books/sky.html $(26 / 08 / 2016)$.

Павлова, В. (1998): Могла ли Биче, словно Дант, творить... http://www.verapavlova.ru/ books/3book.html (26/08/2016).

Пастернак, Б. (1990): Собрание сочинений в пяти тт. Т. 3 М.

Полозкова, В. (2004): Наскальное. http://modernpoetry.ru/contemporary/vera-polozkovanepoemanie\#nepoemanie1 (26/08/2016).

Полозкова, В. (2005): Я твой щен: я скулю, я тычусь в плечо незряче... http://modern poetry.ru/contemporary/vera-polozkova-nepoemanie\#nepoemanie1 (26/08/2016).

Пьеге-Гро, Н. (2008): Введение в теорию интертекстуальности. Пер. с франц. Г. Косикова. М.

Родионов, А. (2012): Девочки пели в масках в церковном хоре... http://arodionoff.livejournal.com/276561.html (26/08/2016).

Хлебников, В. (1986): Творения. М.

Цветаева, М. (1994): Собрание сочинений в семи тт. Т. 3. М.

Braidotti, R. (1994): By Way of Nomadism. In: Braidotti, R.: Nomadic Subjects: Embodiment and Sexual Difference in Contemporary Feminist Theory. New York. 15-36. 



\section{Евгения Суслова (Нижний Новгород)}

\section{Субъект и субъективация в новейшей русской поэзии: подступы к типологии}

Вопросы субъективации рассматриваются в различных сферах филологического знания: в поэтике, поэтической грамматике, прагматике, теории языковой личности, семантике, лингвистике текста, коммуникативной грамматике, функциональной лингвистике, семиотике и др. Зачастую исследования явления субъективации либо сужаются до описания конкретных языковых фактов (лингвистический перекос), либо производится расширение до понятия «личности», «телесности» и т.п. В последнем случае субъект описывается не как одна из категорий лингвопоэтики, а как компонент содержания поэтического текста наряду с другими (литературоведческий перекос):

Специализируясь на передаче самых конкретных форм душевной жизни (притом в ее наиболее интенсивных стадиях), лирика по изначальной своей установке безымянна. Лирическому герою, исходя из глубины и конкретной единичности изображаемой ситуации, нет надобности называть ни себя, ни кого бы то ни было из участников лирического сюжета по имени. Достаточно, чтобы были упомянуты «я», «ты», «он», «она» и т.д. ${ }^{1}$

В словарях субъектность понимается как «глобальная интегрирующая категория текста», а такие термины, как субъектность речи, субъектность текста, авторизация, субъектная организация текста понимаются как синонимы. ${ }^{2}$

С точки зрения исторической поэтики выделяются три типа субъекта: синкретический, жанровый и лично-творческий. ${ }^{3} \mathrm{~B}$ теоретической поэтике разработаны три классические категории для описания типов субъективации: лирический герой, лирическое «я», лирический субъект. В основе этого разделения лежит критерий эксплицированности субъектной составляющей.

Л.Я. Гинзбург подчеркивает, что «термином лирический герой несомненно злоупотребляли [...] говорить о лирическом герое имеет смысл тогда, когда она [личность поэта] облекается устойчивыми чертами - биографическими, сюжетными». ${ }^{4}$ Л.Я. Гинзбург связывает актуализацию категории лирического героя с поэзией эпохи романтизма: в XIX веке «индивидуализация лирики разрушала канонические формы. Она предопредели-

\footnotetext{
${ }^{1}$ Сильман (1977, с. 37).

${ }^{2}$ Кожина (2003 (ред.), с. 517-518).

${ }^{3}$ Бройтман (2008, с. 113).

${ }^{4}$ Гинзбург (1997, с. 155).
} 
ла все возрастающее значение индивидуального контекста (вместо контекстов устойчивых стилей)». ${ }^{5}$

Сам термин «лирический герой» впервые появляется у Ю.Н. Тынянова в статье о Блоке. Лирическое «я» близко к фигуре говорящего, при этом не является «объектом для себя». ${ }^{6}$ Термин лирическое «я» введен в науку М. Зусман в работе 1910 г., ${ }^{7}$ использовался И. Анненским. «Характеристика лирического я - грамматически выраженное лицо», присутствующее «в тексте как ,я“ или „мы“, которому принадлежит речь. [...] На первом плане не он сам, а какое-то событие, обстоятельство, ситуация, явление». ${ }^{8}$ Лирический субъект задается преимущественно «единством авторского сознания». ${ }^{9}$

В поэтике выделяются коммуникативный и прагматический аспекты субъективации. Здесь для нашего исследования значимыми оказываются переход от коммуникативности к автокоммуникативности (медитативная лирика) и тот факт, что коммуникативная структура, утопленная «внутрь» текста, усложняет его рефлексивную структуру, в результате чего субъективация становится имплицитной.

Субъектная ориентация текста связана с первичной семиотической системой - языком и, как его реализацией, речью. Э. Бенвенист показывает, что субъект не просто проявляется в речи, но конституируется речевым актом: «я» имеет референтную соотнесенность с актом индивидуальной речи, в котором оно произносится и в котором оно обозначает говорящего. Этот термин может быть идентифицирован только в «единовременном акте речи» (instance de discours), имеющем только текущую референтную соотнесенность. ${ }^{10}$ Без языка и речи нет и субъекта. Этот тезис позволяет поставить вопрос о связи когнитивного потенциала новейшей поэзии и отсутствия прямой выраженности субъекта на уровне лексики. В коммуникативной грамматике субъект осмысляется в «субъектной перспективе высказывания» и реализуется через «субъектную сферу». ${ }^{11}$

Ю.Н. Караулов выделяет три уровня языковой личности:

Структура языковой личности представляется состоящей из трех уровней: 1) вербально-семантического, предполагающего для носителя нормальное владение естественным языком, а для исследователя - традиционное описание формальных средств выражения определенных значений; 2) когнитивного, единицами которого являются понятия, идеи, концепты, складывающиеся у каждой языковой индивидуальности в более или менее упорядоченную, более

\footnotetext{
${ }^{5}$ Там же, с. 51.

${ }^{6}$ Корман (1982, c. 13).

${ }^{7}$ CM. Susman (1910, S. 16-19).

${ }^{8}$ Корман (1982, с. 13).

${ }^{9}$ Гинзбург (1997, с. 149).

${ }^{10}$ Бенвенист (1974, с. 295-296).

11 Золотова / Онипенко / Сидорова (2004, с. 229-251).
} 
или менее систематизированную картину мира, отражающую иерархию ценностей. Когнитивный уровень устройства языковой личности и ее анализа предполагает расширение значения и переход к знаниям, а значит, охватывает интеллектуальную сферу личности, давая исследователю выход через язык, через процессы говорения и понимания - к знанию, сознанию, процессам познания человека; 3 ) прагматического, заключающего цели, мотивы, интересы, установки и интенциональности. Этот уровень обеспечивает в анализе языковой личности закономерный и обусловленный переход от оценок ее речевой деятельности к осмыслению реальной деятельности в мире. ${ }^{12}$

Это достаточно интересно, так как можно говорить о типе субъективации как об актуализации доминантного уровня и доминантной референтной области, к которой отсылает поэтический текст. Так, например, М.И. Шапир отмечал прагматическую направленность поэзии авангарда. ${ }^{13}$ Для поэзии второй половины XX века - начала XXI века в актуальном поле оказывается переход от вербально-семантического (в терминах Ю.Н. Караулова) к когнитивному плану.

Для разработки проблемы экплицированности / имплицированности субъекта чрезвычайно значимы работы Ю.Д. Апресяна, описавшего дейктическую систему как сферу концептуализации говорящего:

Дейктическая лексика эгоцентрична [...] Фигура говорящего организует и семантическое пространство высказывания, и систему дейктических слов языка. С одной стороны, фигура говорящего является тем ориентиром, относительно которого в акте коммуникации ведется отсчет времени и пространства. С другой стороны, ссылка на фигуру говорящего образует ядро толкования двух основных пространственных и временных дейктических слов естественных языков - здесь и сейчас, а через них - и всех остальных. ${ }^{14}$

Е.В. Падучева развивает идею Ю.Д. Апресяна о разграничении говорящего и Наблюдателя, определяя последнего как «нулевой знак с дейктическим значением», который выступает как «показатель вторичного дейксиса». Наблюдатель также определяется как «местодержатель» (place-holder) и «субъект восприятия, дейксиса и сознания». ${ }^{15}$

Оппозиция говорящего и Наблюдателя так же, как и классификация, принятая в поэтике, ставит вопрос о степени эксплицированности / имплицированности субъекта. Наблюдатель выступает как категория текста, в то время как говорящий - как категория высказывания. Если говорящий - это, прежде всего, субъект языка и речи, то Наблюдатель - это субъект сознания. Пограничной зоной между двумя этими модальностями служит поле дейксиса. К исследованиям о дейксисе примыкают работы в русле грамматики и поэтической грамматики о местоимениях и категории лица в поэзии.

\footnotetext{
12 Караулов (1989).

13 Шапир (1995, с. 136-143).

14 Апресян (1995, с. 631).

${ }^{15}$ См. Падучева (2006).
} 
Большое значение для нашего исследования имеет изучение функционально-семантических полей и, прежде всего, поля персональности. А.В. Бондарко отмечает, что

$[\ldots]$ соотношение центра поля и периферии в структуре ФСП характеризуется совокупностью следующий признаков: а) максимальная концентрация базисных семантических признаков, определяющих качественную специфику данного ФСП (центр) - разреженность таких признаков (периферия); б) сосредоточение связей языковых единиц, участие в максимальном числе оппозиций (центр) - рассредоточение - «сетки связей», их ослабление, проявление той или иной степени изолированности (периферия); в) наибольшая специализированность данного языкового средства или системы средств по отношению к реализации определенных семантических функций (центр) меньшая степень специализации (периферия). ${ }^{16}$

А.В. Бондарко определяет поле персональности как моноцентрическое, то есть обладающее ярко выраженным центром и периферией. К центру относятся личные местоимения, а к периферии - сфера третьего лица, семантика обобщенноличности, неопределенноличности и безличности (по направлению к периферии). В периферийной зоне возможно «скольжение референта». ${ }^{17}$ Это указывает на такое свойство организации текста, при котором чем дальше от центра, тем сложнее сфокусироваться в определенной референтной области, чем дальше, тем более размытым становится референт, поэтому, чтобы понять, о чем идет речь, нужен бо́льший фрагмент текста. Этот момент мы также учитываем при систематизации типов субъективации.

Лингвопоэтика и историческая лингвопоэтика, на наш взгляд, нуждаются в категории субъекта именно как категории текста. Итак, опираясь на вышесказанное, можно заключить, что субъект поэтического текста рассматривается как базовая моделирующая функция, а процесс моделирования - как субъективация. При разработке этой категории мы, опираясь на рассмотренные работы, полагаем, что в первую очередь важно учитывать несколько признаков: степень эксплицированности / имплицированности субъекта, степень расчлененности / нерасчлененности референции и доминантную референтную область (мир, знак, сознание), уровень реализации субъекта (лексика, грамматика, текст), интенциональность, которая проявляется как установка на предметность / установка на отношение, тяготение к синтагматической реализации / тяготение к парадигматической реализации (предельным выражением парадигматичности является организация по принципу поля). После осуществления этой процедуры нам важно проанализировать, каковы собственно языковые реализации того или иного субъекта в поэтическом тексте. Заметим, что в этой статье мы рассматриваем именно внутреннюю парадигматизацию поэтического текста, а смежные явления (визуальная поэзия,

\footnotetext{
${ }^{16}$ Бондарко (1991 (ред.), с. 6).

17 Там же, с. 86.
} 
эксперименты в области комбинаторики, поэтические упражнения в сериальности и т.п.) требуют отдельного рассмотрения.

Ю. Кристева, описывая динамическую структуру субъектности в современной поэзии, констатирует наличие «зерологического» субъекта, который «не зависит ни от какого знака», а «отношение знака к денотату сводится к нулю». ${ }^{18}$

Систематизацию, предлагаемую ниже, мы называем, вслед за А.В. Бондарко, функционально-семантической, так как типы субъективации выделяются в ней на основании вышеперечисленных критериев именно в отношении их базовой функциональной принадлежности. Мы предлагаем описание четырех типов субъектов поэтического текста: репрезентирующзего, референцииующего, модализирующего и концептуализирующего. Названия эти громоздки, но они необходимы, чтобы отразить идею, что субъект задает определенную рефлексивную структуру текста посредством доминантной процедуры в процессе текстопорождения; именно эта процедура определяет базовый уровень содержания поэтического текста.

Первый тип субъективации, актуализирующий отношение знак (мир), мы называем репрезентирующим. Он связан с нулевой степенью рефлексивности, так как для этого типа субъективации сохраняется релевантным отношение $\mathrm{S} \rightarrow$ О. Отличием от субъекта, традиционно называемого в поэтике «лирическим героем», будет степень условности мира, о котором в тексте идет речь, «каркасность» повествования. Общая установка на линейное развертывание повествования и синтагматическая ориентация, экплицированность субъекта посредством центра поля персональности и доминантная референтная область мир также характерны для этого типа субъективации. Языковым уровнем, на котором репрезентирующий субъект проявляется в большей степени, выступает лексика, в то время как синтаксис «затушевывается». Поэтическим текстам, в которых структурообразующим фактором будет репрезентирующий субъект, свойственна расчлененная референция и ориентация на предмет.

Второй тип субъекта, задающего диапазон знак (мир ↔знак), мы обозначили как референцирующий. Субъект, близкий к этому типу, появляется в эпоху авангарда, когда ставится вопрос о соотношении мира и знака. Для референцирующего типа характерна общая ориентация на отношение (предмет $\rightarrow$ процесс), наблюдается движение к парадигмизации текста и импликации субъекта посредством движения к периферии поля персональности, а также «скачки» от центра к периферии - и обратно. Субъект реализуется на уровне ограниченного контекста (высказывания), но высказывания, так как есть движение в сторону парадигматики, вступают в более тесные взаимоотношения друг с другом. Доминантные референтные области - мир и знак

\footnotetext{
${ }^{18}$ Кристева (2004, с. 287-288).
} 
(по отдельности и в их взаимоотношении). Такой субъект активно реализуется и в аспекте лексики, и в аспекте грамматики, актуализируя отношения между этими двумя ярусами языка. Чрезвычайно активна фразеология. Референция преимущественно расчлененная, а тенденция к нерасчлененной референции проявляется на уровне негации, когда референт отрицается или для него не существует прототипа в мире привычных предметов. Степень рефлексивности начинает постепенно нарастать.

Третий тип субъективации фокусируется на нашей шкале в точке знак (знак) и связан уже с гораздо большей степенью имплицированности субъекта (он близок к тому, что в поэтике называется лирический субъект и находится между говорящим и Наблюдателем в семантике). Такой тип субъективации связан, прежде всего, с коннотативным полем и реализуется как задающий специфическую модальность (процесс $\rightarrow$ коннотация), поэтому мы назвали его модализирующим. Субъект этого типа задает семиотический предел, поэтому реализуется чаще всего на уровне грамматики (дейксис, синтаксис и т.д.), при этом внимание от лексики смещается в сторону фразеологии, а лексический уровень становится пассивным. Доминантная референтная область - знак, и, как частный случай проявления, наблюдается смещение от зоны языка к зоне мышления. Увеличивается нерасчлененность референции, в результате чего для выявления субъекта требуется больший по объему контекст. В случае модализирующего субъекта мы видим еще более сильное тяготение к парадигматической организации, в то время как синтагматика перестает иметь определяющее значение.

Концептуализирующий - четвертый тип субъективации, где рефлексивность максимальна. Фокусировка происходит на отрезке знак (знак $\leftrightarrow$ сознание). Примеры этого типа как раз и относятся к таким поэтическим текстам, в которых не всегда понятно, «о чем собственно идет речь». Это связано с нерасчлененностью референции, проявляющейся на уровне текста, а не на уровне отдельных высказываний (или референция на уровне отдельных высказываний не совпадает с референцией на уровне целого текста). Основная ориентация этого типа субъективации направлена на отношение, которое проявляется в установлении связи между областью сознания и ее знаковыми реализациями. Так как сознание не схватывается знаковыми конфигурациями, авторы используют аппарат образов-схем. Тексты такого типа можно назвать концептнылм письмом, то есть письмом концептами или письмом, направленным на формирование сингулярного концепта отдельно взятой единицы опыта. Концептуализирующий субъект может задавать организацию поэтического текста по принципу поля (коннотация $\rightarrow$ пространство), когда оппозиция между синтагматикой и парадигматикой перестает быть релевантной.

Для поэтических текстов, в которых определяющим фактором оказывается структура репрезентирующего субъекта, актуально объектное осмысление «я» (схема $\mathrm{S} \rightarrow \mathrm{S}(\mathrm{O})$ ) прежде всего на лексико-семантическом уровне. 
Говоря иными словами, происходит тематизация «я». К авторам второй половины XX века - начала XXI века, у которых появляются стихотворения с такой организацией, можно отнести Е. Шварц, В. Кривулина, О. Седакову, О. Юрьева, В. Аристова, А. Афанасьеву, П. Барскову, В. Гандельсмана, Л. Аронзона, К. Капович, А. Левина, Т. Кибирова, В. Павлову, А. Порвина, М. Степанову, И. Жданова и др. Нужно подчеркнуть, что каждое стихотворение требует отдельного рассмотрения, потому что авторы могут как ориентироваться на один тип текстообразования, так и работать с чрезвычайно разными стратегиями, как, например, Л. Аронзон, отличающийся широким диапазоном поэтик.

Поэтические тексты этого типа характеризуются синтагматической плотностью, в них преобладает импульс линейного развертывания в рамках описания или свернутого повествования. Чаще всего, субъективация связана с действием центра поля персональности: актуализируются местоимения первого и второго лица, возвратные местоимения, притяжательные местоимения, двухсоставные полные и односоставные личные предложения. Наблюдается системная противопоставленность первого, второго / третьего лица, которая знаменует собой движение к периферии поля персональности):

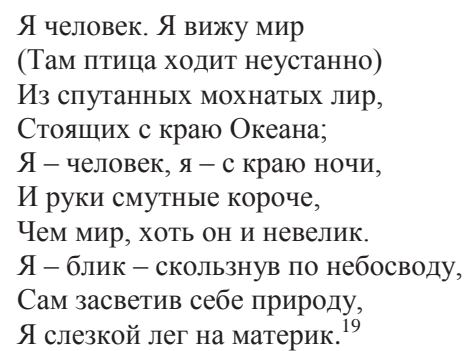

На уровне текста нарастание противопоставления субъекта и объекта и переход от позиции субъекта к позиции объекта может происходить благодаря использованию тире. В строке «Я человек. Я вижу мир» обозначено отношение через семантику зрения. Здесь имплицировано определение: человек - этот тот, кто видит мир. В строке «Я - человек, я - с краю ночи» при повторе появляется тире, которое нормативно только в том случае, если есть противопоставление. Здесь уже происходит синтаксическая экспликация тавтологического определения. В строке «Я - блик - скользнув по небосводу» возникает определение субъекта как блика, то есть того, что можно видеть. В процессе уточнения собственной природы субъект в стихотворении О. Юрьева проходит путь: mom, кто видит $\rightarrow$ mom, кого можно увидеть (то, что можно увидеть), то есть $я \rightarrow$ мир: «Сам засветив себе природу, / Я слезкой лег на материк».

${ }^{19}$ Юрьев (2004). 
На лексико-семантическом уровне может быть задана тема телесного разрушения, исчезновения, любого другого типа деструкции, связанной с рефлексами авангардного языка, но на уровне субъектно-объектной схемы абсолютно четко будет сохраняться репрезентирующий тип:

Я исчезаю по частям.

Вчера моя нога

Не вышла ужинать к гостям,

Лишившись пирога.

Сегодня в зеркало смотрю,

На месте лба - тайга.

Когда пропал мой верный нос,

Я поняла без слов,

Что в темноту его унес

Коварный Ковалев. ${ }^{20}$

Чтобы осуществился переход к другому типу субъективации, обязательно должны возникнуть изменения на уровне грамматики. Для репрезентирующего субъекта традиционно использование риторических фигур, направленных на модификации в области семантики. Такими средством чаще всего становятся метафора и сравнение. Уровень фразеологизации обычно оказывается незадействованным, в текстах наблюдается свободное связывание слов. Оппозиция мир ↔ знак непосредственно тематизируется, то есть служит содержанию сообщения и не выходит за рамки семантики.

В поэтических текстах, конституированных референцирующим типом субъекта, имеет место «языковой взрыв», приводящий к ряду лексикограмматических следствий. Возникновение этого типа субъективации относится к периоду семиотического авангарда, так как он проблематизирует границу мир ↔ знак. К поэтам первой половины $\mathrm{XX}$ века, многие поэтические тексты которых были организованы таким способом, можно отнести, например, М. Цветаеву, В. Маяковского, В. Хлебникова. Среди поэтов второй половины XX века - начала XXI века можно назвать Е. Хорвата, В. Соснору, Т. Дунченко, В. Бородина, А. Горенко и др.

Для текстов такой внутренней структуры характерны размывание границы между местоимением первого лица ед. ч. и третьего лица ед. ч., так как разрушается оппозиция, выраженная схемой $\mathrm{S} \rightarrow \mathrm{S}(\mathrm{O})$, свойственная репрезентирующему типу, а также другие проявления деформации залоговости, возвратности, глагольной валентности. На уровне местоименной поэтики происходит расслоение референцирующего субъекта (по терминологии Ю.Д. Апресяна) на говорящего и наблюдателя:

Я отвернусь, как латинское R, к стенке пустой. Не ищи идеала в жизни. Ты сам для кого-то пример, так завернувшись в свое одеяло,

${ }^{20}$ Барскова (2005). 
как завернулся. А, впрочем, к чему

здесь обращенье? К кому обращаться -

уж не к себе ли? И вправду, ему

нечего кем-то еще обольщаться $[\ldots]^{21}$

$\mathrm{R}$ - зеркально перевернутый двойник Я. Оппозиция поддерживается тем, что строка замыкается в начале и в конце этими знаками, вследствие чего возникает идеографический план симметрии или отражения. Поворот Я связан также с внутренним поворотом - рефлексией субъекта, знаком которой может также служить латинское R. От «я» мы переходим к «ты», a затем и к местоимению третьего лица ед. ч. «ему». Общее смысловое движение задается наложением семантических полей ключевых глаголов «отвернусь - завернувшись - завернулся - обращаться», так или иначе связанных с семантикой оборачивания. Оборачивание соотносится с временной перспективой стихотворения: «я» относится к плану будущего времени, «ты»- к прошедшему, а личное местоимение в косвенной форме «ему» используется в инфинитивной конструкции. А. Жолковский отмечает, что инфинитивные конструкции связаны с мотивами «альтернативности и небытия». ${ }^{22}$ Такое движение я $\rightarrow$ он не овнешняет, а овнутряет понимание о субъекте, освобождающееся от привязанности к предметности и наглядности. В другом стихотворении Е. Хорвата:

Мы хитрости своей стыдимся, но Аполлону не сдадимся

и в том неизъяснимый смак, что «Я» шагающая буква, и связки травм моя обувка, и на песке не след, но знак. ${ }^{23}$

На синтаксическом уровне референцирующий субъект реализуется в компрессии конструкций, при этом непосредственно не выражается. Тексты такого типа характеризуются движением в сторону периферии ФСП:

кости глото́к костей водная голова вычертит струн гостей вора и на лаваш лестница упадет улица пережмет яблоком голубым яблоком голубым имя зверей звенит воздуха головной мозг через тридцать лет яблочный нитяной вышедший из-под рук утреннего луча вымерший изумруд го́ловы без ключа

вылетели внутри времени голосят ходят по две - по три маются на сносях сносят себя собой вымерзшие орут мокнут и тают в бой выжженный изумруд

\footnotetext{
${ }^{21}$ Хорват (2005).

22 Жолковский (2000).

${ }^{23}$ Хорват (2005, с. 4$)$.
} 
о́строва голубей нет голубей его палицы и грубей пальцев и ничего не обретает плоть прежде чем стать своим остовом говорю и исчезаю с ним. ${ }^{24}$

Стихотворение В. Бородина построено на эллиптических конструкциях и дистанцировании синтаксически связанных слов, как, например, во фрагменте «го́ловы без ключа / вылетели внутри времени голосят / ходят по двепо три маются на сносях / сносят себя собой» восстанавливается пропозиция «го́ловы ходят по две - по три». В стихотворении доминирует корпоральная лексика, которая связана с метонимическим смещением. Для референцирующего субъекта в целом характерна метонимическая динамика. Противопоставленными оказываются развернутые и эллиптичные высказывания. Развернутым высказыванием заканчивается стихотворение с семантикой речи: «и ничего / не обретает плоть прежде чем стать своим / остовом говорю и исчезаю с ним». Референцирующий субъект здесь интериоризирован, поэтому возникают грамматическое сгущение, близкое к архаическому нанизыванию, и уплотнение слов, однокоренных или близких по звучанию (тексты такой организации тяготеют в паронимической аттракции).

Актуализация возвратного местоимения «себя» в этом типе текстообразования связано с конструированием мира, обращенного внутрь. «Себя»это оператор пространственных трансформаций. Другим маркером такой обращенности служит в тексте многократное повторение одних и тех же синтаксических конструкций определения по модели «я (есть)...». Актуализация местоимения «сам» (этимологически восходящего к слову со значением «один») в разных значениях также характерна для поэтических текстов с референцирующим субъектом. Проникание признаков одних предметов в другие приводит к грамматическому нарушению употребления возвратных компонентов высказывания:

Небце синее косое

дурно глянется в меня

поделись-ка ты со мною

полстраною и коня ${ }^{25}$

Л.В. Зубова отмечает, что

[...] поэтические эксперименты с деформацией валентной структуры глаголов (это касается и синтаксической, и семантической валентности) свидетельствуют о значительном изобразительном и когнитивном потенциале валентных свойств глаголов. ${ }^{26}$

В стихотворении А. Горенко присутствует нарушение как грамматической, так и семантической валентности. Вероятно, глагол «глянется» ассоцииру-

${ }^{24}$ Бородин (2008, с. 11).

${ }^{25}$ Горенко (2003).

26 Зубова (2009, с. 54). 
ется с глаголом «глядеться», который, в отличие от использованного поэтом, допускает возвратную форму. Такая замена поддерживается строкой «дурно глянется в меня», то есть «посмотрит в меня, как будто я зеркальце», так как существует устойчивое выражение «глядеться в зеркальце». Реконструируемая метафора «небо - зеркало» реализуется в слове «небце», соединяющем в себе и небо, и зеркальце. В стихотворении «небце» смотрит в субъекта, а не наоборот, вследствие чего свойствами зеркала наделяется референцирующий субъект А. Горенко. Здесь актуализируется другая метафора: «сознание - зеркало». Наречие «дурно» возникает благодаря грамматической компрессии: существует фразеологизированное выражение «дурно выглядеть», поэтому строка «дурно глянется в меня» может быть понята как соединяющая в себе два акта действия: «посмотреть» и «увидеть, что выглядит дурно», тем более «небце» употреблено с эпитетом «косое». В стихотворении А. Горенко возникает семантика взаимности: в случае, когда субъект смотрит в небо, небо тоже в него смотрит, поэтому можно говорить не о субъектно-объектной схеме, а о процессе, ведущем к устранению разрыва между внешним и внутренним.

Модализирующий субъект, третий выделяемый нами тип субъективации, более других связан с категориями языка и находится ближе всего к тому, что Ю.Д. Апресян и Е.В. Падучева называют Наблюдателем. Он может не иметь прямых экспликаций в тексте. Этот тип субъективации связан с традицией обэриутов (прежде всего, с опытами Д. Хармса), а именно с активизацией понятийного компонента в поэтическом тексте, цель которого - «раскрыть отношение между мыслью, языком и миром» ${ }^{27}$ посредством описания предмета, на котором сфокусирован взгляд. Во второй половине XX века - начале XXI века тексты с таким типом субъективации можно найти у А. Альчук, А. Монастырского, Л. Рубинштейна, П. Андрукович, Я. Сатуновского, Н. Азаровой, Д. Гатиной, Д. Давыдова, А. Скидана, В. Некрасова и др. В текстах с модализирующим субъектом актуализируется коннотативный план. Если репрезентирующий тип субъективации, по большей части, связан с денотативным планом, то модализирующий тип субъективации - с коннотативным.

Если для предыдущих типов субъективации наиболее значимым было отношение мир ↔знак, то в поэтических текстах с модализирующим типом субъективации проблематизируются отношения языка и мышления, что может быть выражено на уровне грамматики или коннотации текста. Если в двух предыдущих стратегиях текстообразования единицей поэтического текста можно считать слово, то для текстов с модализирующим субъектом такой единицей служит синтагма. Парадигматизация выходит на первый план по сравнению с синтагматизацией (ослабляется действие локальной

\footnotetext{
${ }^{27}$ Валиева (2007, с. 6).
} 
связности). Модализирующий субъект может быть полностью имплицирован и «просвечивать» только как средство связи речевых контекстов:
может быть
вопрос в степени
действительно показаться
не будет ли чрезмерным спросить
во всяком случае
согласно эстетике
тем не менее
следует ли нам сожалеть
готов поверить
все что он пытался сказать
вы ничего не забыли
если мои воспоминания
об искусстве точны
выражать нечего
выражать нечем
нет желания выражать
впрочем
говоря логически
никакая. ${ }^{28}$

Основной прием в текстах с модализирующим субъектом - это схематизация: чтобы понять речь, нужно схематизировать речевой акт. Стихотворение фактически становится наглядной моделью, играющей важную роль в процессе познания. Если для репрезентирующего субъекта характерна устойчивость одной точки зрения, для реферирующего возможны ее смещения, то для модализирующего субъекта характерно неразличение одной / многих точек зрения.

Для поэтических текстов с концептуализирующим субъектом наиболее характерным признаком является нерасчлененность референта: мы не понимаем, к чему именно текст отсылает, потому что центральной проблемой высказывания является «проблема перехода смысла в значение». ${ }^{29}$ Истоки в русскоязычной традиции можно увидеть в поэзии поставангарда, в частности, в поэзии А. Введенского. Во второй половине XX века - начале XXI

\footnotetext{
${ }^{28}$ Скидан (2005, с. 30).

29 Лурия (1979, с. 193).
} 
века можно назвать некоторые тексты Г. Айги, А. Драгомощенко, Н. Сафонова, С. Огурцова, Д. Ларионова и др. В поэтических текстах с концептуализирующим субъектом большую роль играет пространственная организация семантического плана, которая приводит к тому, что повторяющиеся элементы по организации значения приближаются к значению концептов:

И тут я сказал декупаж дилеммы вырваны брошены в рамках внутренней речи клеммы плавились так.

Аффекты анафоры торопливы и ты, офелия-трата, ведешься по следу.

N. с несчастным сознанием плюс S. на Z. минус слэш. Скользкий каменный берег вне эксклюзива инсайта.

Свернувшись под слоем слепой информации, преодолевшие символизм, ссыпая сыпь страха до завтра. ${ }^{30}$

В этом тексте Дениса Ларионова проявляется сильная тенденция к семантической нелинейности, синтагматические и парадигматические отношения оказываются в равной степени важны, референциальная область размыта, при этом имеет место смысловое сжатие.

Таким образом, четыре типа субъективации как четыре дискурсивные стратегии могут рассмотриваться как базовые точки некой общей оси, на которой возможны различные градации. Это подход позволяет связать семантический, грамматический и функциональный планы, позволяя увидеть, как коммуникативная (пусть и бессознательная) установка поэта влияет на логику развертывания поэтического текста.

\section{Литература}

Апресян, Ю. (1995): Дейксис в лексике и грамматике и наивная модель мира // Апресян, Ю.: Избранные труды: В 2 тт. Т. 2.: Интегральное описание языка и системная лексикография. М. 629-650.

Барскова, П. (2005): Бразильские сцены. М. / Тверь. http://www.vavilon.ru/texts/prim/ barskova5.html (5/02/2018).

Бенвенист, Э. (1974): Общая лингвистика / Пер. с франц. Ю. Караулова и др. М.

Бондарко, А. (ред., 1991): Теория функциональной грамматики: Персональность. Залоговость. СПб.

Бородин, В. (2008): Луч. Парус: Первая книга стихов. М.

Бройтман, С. (2008): Лирический субъект // Тамарченко, Н. (ред.): Поэтика: словарь актуальных терминов и понятий. М. 113-114.

Валиева, Ю. (2007): Игра в бессмыслицу: поэтический мир Александра Введенского. СПб.

30 Ларионов (2010). 
Гинзбург, Л. (1997): О лирике. М.

Горенко, А. (2003): Праздник неспелого хлеба. М. http://www.vavilon.ru/texts/gorenko1. html (5/02/2018).

Жолковский, А. (2000): Бродский и инфинитивное письмо // Новое литературное обозрение. 45, 2000. http://magazines.russ.ru/nlo/2000/45/-20.html (5/02/2018).

Золотова, Г. / Онипенко, Н. / Сидорова, М. (2004): Коммуникативная грамматика русского языка. М.

Зубова, Л. (2009): Глагольная валентность в поэтическом познании мира // Язык как медиатор между знанием и искусством: Сб. докладов Международного научного семинара. М. 39-55.

Караулов, Ю. (1989): Русская языковая личность и задачи ее изучения http://destructioen.narod.ru/karaulov_jasikovaja_lichnost.htm (5/02/2018).

Кожина, М. (ред., 2003): Стилистический энциклопедический словарь русского языка. М.

Корман, Б. (1982): Литературоведческие термины по проблеме автора. Ижевск.

Кристева, Ю. (2004): Избранные труды: Разрушение поэтики. М.

Ларионов, Д. (2010): Стихотворения // TextOnly. 2, 2010. http://textonly.ru/votum/?issue= $32 \&$ article $=33400(5 / 02 / 2018)$.

Лурия, А. (1979): Язык и сознание. М.

Падучева, Е. (2006): Наблюдатель: типология и возможные трактовки // Компьютерная лингвистика и интеллектуальные технологии: труды междунар. конф. «Диалог-2006»; Бекасово, 31 мая - 4 июня 2006 г. М. 403-414.

Сильман, Т. (1977): Заметки о лирике. Л.

Скидан, А. (2005): Красное смещение. М. / Тверь. http://www.vavilon.ru/texts/skidan10. html (5/02/2018).

Хорват, Е. (1980): Я отвернусь, как латинское R... http://rvb.ru/np/publication/01text/ 48/01 horvat.htm (5/02/2018).

Хорват, Е. (2005): Раскатанный слепок лица: Стихи, проза, письма. М.

Шапир, М. (1995): Эстетический опыт ХХ века: авангард или постмодерн // Philologica. 3-4, 1995. 135-152.

Юрьев, О. (2004): Избранные стихи и хоры. М. http://www.vavilon.ru/texts/prim/yuriev32.html (5/02/2018).

Susman, M. (1910): Das Wesen der modernen deutschen Lyrik. Stuttgart. 


\section{Ольга Соколова (Москва)}

\section{Отчужденный субъект в русской поэзии 2000-х гг. ${ }^{1}$}

Специфика формирования субъекта и поэтической субъективности - одна из наиболее актуальных проблем современной филологии, для решения которой используются различные подходы. Повышение интереса к проблеме субъекта может быть связано с необходимостью осмысления нового поворота, наблюдаемого в современной поэзии вслед за революционным отказом от миметического изображения, произошедшим в начале XX века. Среди ключевых характеристик произошедшего в начале XX века переворота исследователи выделяют создание форм искусства, ориентированных на разрушение миметической иллюзии. Борьба авангарда с системностью и синтагматической структурной схемой выразилась в противопоставлении органического и неорганического произведений. ${ }^{2}$ Если в органическом произведении «отдельные части и целое представляют собой диалектическое единство», адекватное прочтение которого «описывается герменевтическим кругом» понимания целого на основе частей, а частей - на основе целого, то в неорганическом произведении части «,эмансипируются“" от тяготеющего над ними целого», при этом решающее значение имеет не последовательность и особенность событий, а лежащий в их основе конструктивный принцип. ${ }^{3}$

Описанные принципы деиерархизации, конструктивности и полисемантичности могут быть спроецированы на не-миметическое искусство XX века в целом, для которого было характерно отрицание устоявшихся культурных канонов, стилевых формаций и нарушение языковых, эстетических и коммуникативных конвенций. В отличие от предшествующего искусства, авангардные тексты отличались изменением структуры субъекта, сочетающей установку на деперсонализацию, аннигиляцию лирического «я» (ср. направления беспредметного искусства) и максимальную его акцентуацию, вплоть до лишенных конкретности гиперболизированных форм (ср. эгофутуризм, отдельные тексты кубофутуристов).

На современном этапе происходит преодоление сложившихся принципов организации текста и формирования субъекта, в связи с чем актуаль-

\footnotetext{
${ }^{1}$ Исследование выполнено за счет гранта Российского научного фонда (проект №14-2800130) в Институте языкознания РАН.

2 Бюргер (2014).

3 Там же, с. 124.
} 
ным представляется обращение к анализу субъекта как ключевой категории поэтического текста. Однако «современность» представляется неоднородным пространством, организованным сменой координат: от модернизма и авангарда начала XX века - к постутопическому периоду постмодернизма второй половины XX века - и новым поворотам, наблюдаемым на современном этапе смены веков, основные черты которого связываются исследователями с экономическими переменами, вхождением в медиапространство и дигитализацией, ${ }^{4}$ а также с движением между двумя полюсами: авангардным и религиозно-мистическим. ${ }^{5}$

Соответственно, анализ субъекта современных поэтических текстов может быть осуществлен с учетом формирования новой оптики и поиска новых методов ее фокусировки. ${ }^{6}$ Одним из ключей к пониманию субъекта является обращение к поэтическому видению, или к поэтической точке обзора, что связано с традиционным терминологическим определением лирического субъекта как «носителя речи, а также основной (объемлющей) точки зрения на мир и оценки в лирическом художественном произведении». ${ }^{7}$ Трансформация поэтической оптики - от нерасчлененности в фольклоре «я» и «другого» к «двуплановому видению себя и изнутри, и со стороны» с точки зрения до конца не объективируемого «другого» в лирике XIX-XX веков ${ }^{8}$ и вплоть до аннигиляции («минус-я») или, напротив, максимального акцентирования «я» как репрезентанта «другого» в авангарде («я-все») - позволяет поставить вопрос о формировании поэтической точки зрения на современном этапе.

Учитывая пристальное внимание к вопросу взгляда, участвующего в процессе обретения себя / отчуждения от себя, сформулированного в психоаналитической оптике Ж. Лакана, мы обратимся к его теории в аспекте участия перспективы (точки зрения / обзора) в организации поэтического субъекта. Интересующая нас проблема соотношения субъекта и объекта раскрывается у Ж. Лакана в связи с вопросом об идентификации и трансформации субъекта, соотносящего себя с неким образом (удовольствие, связанное с видением себя ребенком в зеркале), что приводит к катастрофическому прозрению бытия «один на один с собой» и драматическому осознанию раздвоенности («Я-там», «Я-здесь»), ибо «я сам по себе есть только вне себя». ${ }^{9}$ Собственное $я$ субъекта - это и Другой, и чужое $я$,

${ }^{4}$ Шталь / Рутц (2013, с. 5).

${ }^{5}$ Вестстейн (2013, с. 63).

6 Ср. различные междисциплинарные подходы к анализу современной поэзии: в социологическом (Рутц 2013), философском (Азарова 2010; Шталь 2013; Белоус 2013) и др. аспектах.

${ }^{7}$ Бройтман (2008, с. 112-113).

${ }^{8}$ Там же, с. 114.

9 Лакан (1998, с. 62). 
отчужденное от него, поскольку процедура отчуждения является результатом включения в собственную психическую структуру внешнего.

Согласно Ж. Лакану, взгляд выступает в роли «привилегированного объекта»:

В отношениях, определяемых зрением, объект, от которого зависит фантазм, на котором повис мерцающий, колеблющийся субъект, - это взгляд. Его привилегированность - как и то, благодаря чему субъект так долго мог заблуждаться, себя в этой зависимости полагая, - связана с самой структурой его. ${ }^{10}$

Именно «неуловимость» и «эфемерность» взгляда формирует иллюзию сознания, «будто оно видит, как оно себя видит». ${ }^{11}$ Субъект воображает, словно он является источником видения и может управлять им, будучи при этом объектом для взглядов других, для которых он становится зрелищем. Более того, взгляд - это не средство, с помощью которого субъект господствует над объектом, напротив, объект обладает господством над взглядом, субъект же наслаждается не процессом контроля или идентификации, а захваченностью объектом-взглядом. ${ }^{12}$

Применительно к поэтическому видению можно обозначить такую процедуру как совмещение дистанцированного наблюдения субъекта за объектом с неизбежной «захваченностью» этим объектом, становящимся источником искомого опыта поэзии. ${ }^{13}$ «Разделенный» субъект поэтического текста становится зрелищем для самого себя, поэтому здесь можно говорить не о пассивной «захваченности» объектом взгляда, а о рефлексивности точки зрения поэта, которая, будучи обращена на себя, становится авторефлексивной.

Говоря об особенности поэтической точки зрения, необходимо отметить, что понятие перспективы возникает в области изобразительных искусств и определяет оптическое изменение форм, размеров, окраски и пропорций предметов на расстоянии. Войдя в область социальных и гуманитарных наук, перспектива начинает обозначать позицию, или точку зрения, наблюдателя / говорящего по отношению к описываемому объекту. Процесс выстраивания точки зрения говорящего при интерпретации объекта определяется как перспективизация.

Перспектива и точка зрения являются одними из базовых в нарратологии и в когнитивной лингвистике. В нарратологии выделяются несколько подходов к определению точки зрения (англ. point of view). Согласно Б.А.

\footnotetext{
10 Лакан (2004, с. 93).

11 Там же.

12 McGowan (2003, p. 33).

${ }^{13}$ Ср. с высказыванием Ф. Лаку-Лабарта о поэзии П. Целана как опыте, понимаемом в точном этимологическом значении experiri - «прохождение через опасность» - и ни в коем случае не в значении «доподлинно случившегося, имевшего место в жизни» (Лаку-Лабарт 2015, с. 28).
} 
Успенскому, под точками зрения понимаются позиции, с которых ведется повествование в художественном произведении, и они рассматриваются «в идейно-ценностном плане, в плане пространственно-временной позиции лица, производящего описание событий (т.е. фиксации его позиции в пространственных и временных координатах), в чисто лингвистическом смысле (ср., например, такое явление, как «несобственно-прямая речь»)», что соответствует плану идеологии, плану фразеологии, плану пространственно-временно́й характеристики и плану психологии. ${ }^{14}$ Во избежание визуальных коннотаций, свойственных термину точка зрения, Ж. Женетт вводит термин фокализация (фр. focalisation - фокусирование), который восходит к понятию К. Брукса и Р.П. Уоррена фокус наррации (англ. focus of narration) и понимается в значении, близком к принятому Б. А. Успенским: организация выраженной в повествовании точки зрения, предполагающей донесение ее до зрителя или читателя. ${ }^{15}$ В. Шмид дает следующее определение точки зрения - это «образуемый внешними и внутренними факторами узел условий, влияющих на восприятие и передачу событий», а под перспективой (нем. Perspektive 'перспектива' или Erzähl perspektive 'повествовательная перспектива') понимает «отношение между [...] точкой зрения и событиями». ${ }^{16}$ При этом, согласно В. Шмиду, объектом точки зрения могут быть повествуемые события, она включает в себя акты восприятия и передачи событий, различение которых необходимо, поскольку сообщение событий нарратором может отличаться от того, как он их воспринимает, а также различные планы (пространственный, идеологический, временной, языковой и перцептивный). ${ }^{17}$

Перспективизация, или перспектива (англ. perspectivization, perspective) в когнитивной лингвистике является дискурсивным механизмом конструирования объекта ${ }^{18}$ с точки обзора говорящего / наблюдателя с учетом точек обзора других участников коммуникации и позволяет воспринимать реальность с учетом разных точек обзора. ${ }^{19}$ Теория точки наблюдения, точки зрения, или точки обзора (англ. vantage theory), сформулированная

${ }^{14}$ Успенский (1995, с. 9, 15).

15 Женетт (1998, с. 205).

${ }^{16}$ Шмид (2003, с. 121).

${ }^{17}$ Там же, с. 121-126.

18 Конструирование и перспективизация являются базовыми когнитивными процессами, лежащими в основе прагматического конструирования. Конструирование (англ. construal) как способность выбора отправителем определенных способов выражения информации постулирует активную роль говорящего в организации «своего мира» (Тауlor 1995, p. 4) и опирается на механизмы акцентирования, или фокусирования, и сдвига, или дефокусирования / перефокусирования. В основе этих механизмов лежат базовые принципы существования и развития языка - установка на стабилизацию, упорядочивание и мобилизацию, расширение возможностей.

${ }^{19}$ См. Langacker (1987, p. 126); Ирисханова (2014, с. 56). 
Р. Маклори при обращении к проблеме категоризации цвета в языке (эта категория возникает на пересечении устойчивых координат, таких как яркость, насыщенность, оттенок, и подвижных, основанных на индивидуальном восприятии цветовых сигналов), представляет собой

[...] связь между фиксированной и подвижной координатами в окружающем физическом пространстве и способами его восприятия и познания. Пересечение координат во внешней реальности и в сознании образует точку зрения. ${ }^{20}$

Несмотря на наличие общих черт в понимании перспективы и точки зрения (обзора) в нарратологии и в когнитивной лингвистике (субъективная точка зрения повествователя и субъективация говорящего; выделение субъектных «слоев», или «сфер», и разных форм адресованности текста в зависимости от разграничения точек зрения), можно выделить и некоторые особенности, характерные для когнитивного подхода и представляющие интерес при анализе поэтического текста. Во-первых, ориентация говорящего при конструировании объекта на точки обзора других участников коммуникации и координация с ними, а также с коммуникативной ситуацией. Во-вторых, прагматический аспект перспективизации, направленный на изучение субъективных и актуальных (протекающих в данный момент) закономерностей функционирования языковых единиц, что определяется необходимостью «запечатлеть момент непосредственного восприятия поэтом явлений мира внешнего и внутреннего». ${ }^{21}$ В-третьих, динамичность перспективы, выстраивание которой сходно с ориентированием в пространстве и перемещением между фиксированными и подвижными координатами.

Учитывая такие факторы поэтического дискурса как автокоммуникативность, ${ }^{22}$ когда в роли и отправителя, и получателя информации выступает поэтический субъект; «синхронность», характерную для адресата-слушателя $^{23}$ и отражающую установку на преодоление границ между письменным и устным модусами с целью преодоления пространственно-временной дистанции; а также смысловую динамику и множественность интерпретаций, продуктивным для анализа точки обзора поэтического субъекта видится обращение к когнитивно-прагматическому подходу.

Если когнитивным механизмом, лежащим в основе традиционной коммуникации, является точка зрения, или точка обзора, то можно обозначить механизм, характерный для поэтической автокоммуникации, как размывание точки обзора, поскольку здесь в процессе конструирования образа объекта и выстраивания перспективы участвует только отправитель, выступающий и в роли получателя. Пользуясь терминологией Ж. Лакана, можно сказать, что, если традиционная коммуникация связана с интегрированием

\footnotetext{
${ }^{20}$ MacLaury (1995, p. 269).

${ }^{21}$ Ковтунова (2006, с. 8).

22 Лотман (1992, с. 76-77).

${ }^{23}$ Падучева (2010, с. 214).
} 
себя в символическую систему языка и, следовательно, «реализацией» субъекта посредством речи, что опирается на существование Другого, ${ }^{24}$ то в автокоммуникации интеграция в символическую систему языка связана с поиском единства, где субъект идентифицирует себя с Другим (внешней точкой обзора), и, одновременно, дистанцируется от него. Он выстраивает перспективу, в которую вводятся разные точки обзора, обладающие гипотетической способностью сойтись в одну точку при определенном ракурсе.

В тексте «задевают смутно касаясь кружат» К. Корчагина (2012) отмечается повышение автокоммуникативности за счет совмещения показателей прагматической определенности и неопределенности (неопределенные местоимения, синтаксическая компрессия и синтаксическая редукция). Маркерами прагматической неопределенности здесь становятся неопределенные местоимения, среди основных «функций» которых выделяется указание на неизвестность референта участникам коммуникативной ситуации. Они выступают в роли пропусков слов, своеобразных лакун, концептуализированных в тексте:

задевают смутно касаясь кружат

какие-то точки и пелена за ними

и не то что надвигается но как-то

вплотную кто бы ни появился

поднимаются кверху колонны хотя. ${ }^{25}$

Здесь отмечается «движение» по семантической карте ${ }^{26}$ от референтных местоимений какие-то, как-то, отсылающих к конкретным объектам, существующим в реальной действительности, к нереферентному местоимению кто бы ни, обладающему отрицательной поляризацией и тяготеющему к отрицательному контексту. Такая направленность маркирует стремление автора к разрушению референциальных связей между именами и объектами в реальной действительности. Пропуски слов и замена их неопределенными местоимениями становятся аттракторами, притягивающими внимание читателя и инициирующими его стремление разгадать скрытую пресуппозицию: какие-то точки и пелена за ними / и не то что надвигается но как-то / вплотную.

Интересно отметить отличие неопределенной референции в текстах начала XX века и начала XXI века. Так, в стихотворении «Послушайте!» В. Маяковского (1914) наблюдается отличный от предыдущего текста вектор движения по семантической карте:

Послушайте! Ведь, если звезды зажигают -

значит - это кому-нибудь нужно?

24 Лакан (1999, с. 332).

${ }^{25}$ Корчагин (2012).

${ }^{26}$ Классификация местоимений русского языка, предложенная М. Хаспельматом (Haspelmath 1997). 
Значит - кто-то хочет, чтобы они были?

Значит - кто-то называет эти плевочки жемчужиной ${ }^{27}$

Точкой отсчета здесь становится нереферентное местоимение в ирреальной предикации. В тексте Маяковского к такому «невыбранному» референту относится местоимение кому-нибудь. Далее употребление референтного, неизвестного говорящему местоимения кто-то обозначает движение к большей степени определенности, что маркируется повторным употреблением его в тексте. Затем в текст вводится местоимение кому-то, наделяемое свойствами референтности и известности говорящему:
А после
ходит тревожный,
но спокойный наружно.
Говорит кому-то:
«Ведь теперь тебе ничего?
Не страшно?
Да?!» ${ }^{28}$

Возможность обозначения местоимения кому-то как известного говорящему возникает в связи с детализацией коммуникативной ситуации успокоения, оформленной с помощью вопросительных конструкций и употребления личного местоимения тебе. Переход от местоимения, употребленного в нереферентной функции, к референтному местоимению отражает стремление автора к созданию первичного шокового, «остраняющего» эффекта, направленного на читателя. В дальнейшем ситуация меняется для отправителя сообщения, обретая некую прагматическую определенность, но остается по-прежнему неизвестной читателю, благодаря чему подчеркивается контрастность оппозиции «поэт - читатель», характерной для авангардной коммуникации (ср. с понятием «эстетической вещи» или «минус-адресата»). ${ }^{29}$

Хотя оба текста используют неопределенные местоимения для создания эффекта ускользающей, не(до)оформленной поэтической ситуации, здесь необходимо разграничивать использование неопределенности как приема остранения и формирование неопределенной ситуации с помощью неопределенных форм. ${ }^{30}$ Если в тексте Маяковского поэт выступает в роли демиурга, способного с легкостью изменить координаты ситуации и степень ее определенности и доминирующего над читателем в ситуации «отрицательной коммуникации», то текст Корчагина пронизан постутопическим ощущением неопределенности реальности и распадения связей между ее объектами и отсылающими к ним словами.

\footnotetext{
${ }^{27}$ Маяковский (1955, с. 60).

${ }^{28}$ Там же.

${ }^{29}$ Подробнее об авангардной коммуникации см.: Шапир (1995); Соколова (2015).

${ }^{30} \mathrm{Cp}$. с различными подходами к формированию неопределенности в поэтических системах У. Стивенса и Т.С. Элиота (Perloff 1999, p. 21-22).
} 
Эффект распадения связей не только между именем и объектом, но и связей внутри самого поэтического субъекта возникает за счет смены дейктического центра. Говоря о персональном дейксисе относительно конструирования точки обзора поэтическим субъектом, важно отметить, что в поэтическом тексте

[...] прямой разговор от имени лирического я нимало не обязателен. Ведь в лирике авторское сознание может быть выражено в самых разных формах - от персонифицированного лирического героя до абстрактного образа поэта, включенного в классические жанры, и, с другой стороны, до всевозможных «объективных» сюжетов, персонажей, предметов, зашифровывающих лирического субъекта именно с тем, чтобы он продолжал сквозь них просвечивать. ${ }^{31}$

Принимая во внимание особенность перспективизации в поэтическом тексте, которая строится на совмещении дистанцированного наблюдения субъекта за объектом и «захваченности» этим объектом, осуществляемой не пассивно, а рефлексивно и авторефлексивно, можно интерпретировать все грамматические формы лица (личные и притяжательные местоимения, личные формы глагола) как «ипостаси» поэтического субъекта.

Отстраненное обозначение субъекта местоимением множественного числа третьего лица (не дает им горящий пух во весь), ${ }^{32}$ в которой субъект сам отчуждается от себя, создавая даже не $m b l-$, а максимально дистанцированную они-форму, сменяется формой псевдо-единения субъекта и объекта, отправителя и получателя сообщения (будет нас трое и спинь соприкоснутся; на уже не принадлежащей нам высоте). Псевдо-единение связано с нестандартным употреблением поэтического $\mathrm{Mbl}^{33}$ которое обозначает не общность поэта и читателя либо круг близких людей, но, возникая в конструкции с гипотетическим значением (даже если / будет нас трое), выражает такое состояние альтернативного мира, которое не может быть реализовано в данной ситуации. Эта невозможность любой формы мы связана с отчуждением самого поэтического $я$, одновременно находящегося на двух полюсах $(\text { они }-M b l)^{34}$ и не принадлежащего ни одному из этих полюсов.

Выражение децентрированной, распадающейся коммуникативной ситуации в современной поэзии часто реализуется с помощью сдвига дейктического центра. Например, в тексте «Другой фотограф» (2009) Д. Григорьева авангардный поэтический дискурс балансирует на грани монологической (способ оформления) и диалогической (маркеры персонального дейксиса) речи. Оппозиция «я - не я» выражается с помощью дейктических средств и организует диалог, который является композиционным центром текста:

\footnotetext{
${ }^{31}$ Гинзбург (1964, с. 5-6).

32 Здесь и далее примеры из текста «задевают смутно касаясь кружат» (Корчагин 2012).

${ }^{33}$ О поэтическом мы см.: Левин (1998); Азарова (2019).

${ }^{34} \mathrm{Cp}$. противопоставление проксимального и экстремального дейксиса (Апресян 1986, c. 275).
} 
Я снимал разрушенное небо, синие кирпичи, снежные заплаты, Я снимал то, чего не было, так говорит и щелкает аппаратом. -

Вот снимок девушки, вот дорога, над ними сплошные дожди, я могу даже снять Бога, Только ты отсюда уйди:

ты не влезаешь в кадр, нарушаешь композицию, закрываешь вид, тебе здесь делать нечего», так он мне говорит...

А потом щелкает в траве кузнечиком, листьями над головой шумит. ${ }^{35}$

Дейктические средства обозначают смену дейктического центра как принцип структурирования субъекта текста. «Динамика дейксиса» организует смену фокусов: общая точка обзора (Я снимал разрушенное небо; Я снимал то, чего не было), задаваемая отправителем как субъектом коммуникации, меняется, перемещаясь от обобщенного $Я$ адресата и адресанта к дистанцированию их посредством глагольных форм третьего лица (так говорит и щелкает аппаратом). Дальнейший переход от $Я$ к я приводит к очередной смене перспективы с помощью снижения «сакрального статуса» субъекта. Написанное с прописной буквы местоимение $Я$, которое изначально задавало общую точку обзора и коммуникации, становится точкой бифуркации при переходе от прописного написания «сакрального» $Я$ - к строчному «профанному» я. Описывая соотношение пары $T b l-m b l$, Н.M. Азарова отмечает наличие «некоего паритета грамматических и лексических значений, а также снятие оппозиции $m b l-T b l$ на основе концептуализации грамматической семантики (семантики адресата)». ${ }^{36}$ Таким образом, амбивалентность пары $Я$ - $я$ включает как противопоставление сакрального профанного, так и схождение их в точке адресата и адресанта (диалог отправителя с самим собой и с получателем).

Постоянная смена шифтеров маркирует изменение точки обзора адресанта и невозможность фокусирования определенной точки обзора адресатом. Постоянная динамика точки обзора выражает основные цели отправителя поиск и невозможность окончательного структурирования субъектом собственного я и сдвиг сфокусированной точки обзора адресата за границы текста - на реальность, воспринимаемую как зыбкая и неустойчивая.

\footnotetext{
${ }^{35}$ Григорьев (2009, с. 65).

${ }^{36}$ Азарова (2010, с. 121).
} 
В книге „Spolia“ (2015) M. Степановой ключевым приемом становится неконвенциональное использования дейктических элементов в недейктической функции:

если собрать в кучу,

было сказано вот что -

она не способна говорить за себя,

потому в ее стихах обязательны рифмы

и фальсифицируются отжившие формы [...]

где ее я, положите его на блюдо

почему она говорит голосами

(присвоенными, в кавычках:

у кого нет я, ничего присвоить не может,

у кого нет я, будет ходить побираться, подражать углу, коту, майонезной банке, и все равно никто ему не поверит)

я бублик, я бублик, говорит без-себя-говорящий.

у кого внутри творожок, у меня другое

у кого внутри огого, натура, культура,

картофельные оладьи, горячие камни,

а у меня дырка, пустая яма

я земля, провожаю своих питомцев [...]

у кого нет $\mathbf{я}$,

может позволить себе не-явку,

хощет отправиться на свободку. ${ }^{37}$

Вероятно, в тексте воспроизводится коммуникативная ситуация экзамена в Литературном институте, которая символически выражается как агональная ситуация за счет формирования оппозиции ближнего (проксимального) и дальнего (экстремального) дейксиса ( $я-$ она), усложняемой с помощью неконвенционального использования маркера персонального дейксиса $я$ в недейктической функции.

Изначально в тексте создается эффект распадения я на форму третьего лица она, возвратное местоимение себя и притяжательное ее (она не способна говорить за себя, / потому в ее стихах обязательны рифмы). Это распадение целостности выявляется из контекста, когда неспособность говорить обозначает даже не молчание, но неправильную форму говорения рифмами, т.е. не принятую в данной дискурсивной ситуации проекцию своего я через воспроизведение чужих смыслов. Рифма, обладающая свойствами регулярности, заданной схематичности, с одной стороны, становится знаком отжившей поэтической формы, но, с другой, обнажает проблему саморефлексии субъекта,

${ }^{37}$ Степанова (2015). 
возникающую в ситуации сопротивления формы. Эта неспособность говорить за себя и приводит к диссонансу, внутреннему конфликту, лежащему у истоков заданного в стихотворении движения от целостности, не знающей дифференциации, к разграничению различных аспектов своего $я$.

Близкая ситуация «пробуждения» поэтического я от «солипсистского самоотражения» анализируется на материале поэзии Е. Шварц в работе X. Шталь. ${ }^{38}$ Это позволяет сделать вывод, с одной стороны, о наличии общей тенденции к «принятию инаковости, замещающей первоначально предположенную им [лирическим я] имманентность», характерной для современной поэзии, ${ }^{39}$ но, с другой, о последующем стремлении к преодолению этого разрыва (у Е. Шварц) и, напротив, усугублению его (у М. Степановой).

Интенциональность поэтического субъекта реализуется за счет употребления маркера персонального дейксиса $(я)$ в недейктической функции (2де ее я, положите его на блюдо; у кого нет $я$, ничего присвоить не может, / у кого нет я, будет ходить побираться), использования интертекстуальных элементов (я земля, провожаю своих питомцев), фраз, сходных с «речевой разорванностью» душевнобольных, или «шизофазией» (я бублик, $\boldsymbol{я}$ бублик). Оксюморонное определение говорит без-себя-говорящий может быть интерпретировано как характеристика субъекта, формирующегося в ситуации одновременного отказа-от-говорения и невозможности не-говорения. Говорение оказывается своеобразной поэтической оптикой, противопоставленной молчанию как дословесной недифференцированной целостности, той перспективой, благодаря которой субъект может дистанцироваться от своего $я$ и, одновременно, утратой собственного $я$, его «выговариванием». Неразрывность и процессуальность обретения себя и отчуждения от себя, самоидентификации и дистанциирования подчеркивается словообразовательными (компрессивная «словесная конструкция», образованная с помощью дефисов) и грамматическими средствами (причастие) самоопределения субъекта: без-себя-говорящчий.

Проведенный анализ позволяет выделить определенный тип субъекта, характерный для ряда поэтов и отражающий одну из тенденций поэзии 1990-х - 2010-х гг. Обозначение такого субъекта как отчужденного опирается на особую оптику, формируемую относительно базовой поэтической автокоммуникации и когнитивного механизма размывания точки зрения. Употребление термина отчужденный восходит к лакановскому понятию отчуждения, являющемуся результатом «расщепления» субъекта, которое происходит в результате выбора между смыслом (произведенным означающим) и бытием. ${ }^{40}$ Отчужденный субъект, по Ж. Лакану, выбирает смысл, в силу чего ли-

\footnotetext{
${ }^{38}$ Шталь (2013, с. 439).

39 Там же.

40 Лакан (2004, с. 275).
} 
шается биологического опыта, т.е. внутреннего, чувственного функционирования. Платой за выбор смысла становится «пропажа субъекта, его мерцание, смысловые провалы», ${ }^{41}$ что связано с господством означающего.

Вслед за отказом от миметической иллюзии в искусстве начала XX века отказ от иллюзии целостности, возникший уже в начале прошлого столетия, проецируется и на структуру субъекта. В современной ситуации девальвации означающего субъект уже не стремится к поиску целостности, но находится в состоянии сознательной дисперсии собственного я в отношениях и с Другим, и с языком. Это отчуждение означает уже не только расщепление мышления и бытия, участвующее в учреждении субъекта, но расщепление самоидентификации и дистанцирования (ср. неконвенциональное использование дейктических элементов у М. Степановой), разделение субъекта лингвистическим выбором самоопределения (ср. смена дейктического центра у Д. Григорьева). Невозможность определения субъекта в категориях собственного самосознания приводит, по Ж. Лакану, к необходимости вовлечения точки обзора Другого, задающего перспективу внешнего поля. Но в современной поэзии и эта перспектива деформируется, становясь максимально неопределенной (ср. неопределенную референцию у К. Корчагина), нарушая возможность самоопределения субъекта как в отношении к Другому, так и в цепочке означающих.

Выявленные способы формирования субъекта связаны как с его попыткой освободиться от статуса зрелища - объекта для взглядов других, так и с дальнейшим движением по траектории утраты господства не только над означающим, но и над собственной точкой обзора (или взглядом), выступающей в роли доминирующего оптического и смыслообразующего инструмента.

\section{Литература}

Азарова, Н. (2010): Язык философии и язык поэзии - движение навстречу (грамматика, лексика, текст). М.

Азарова, Н. (2019): Новые проблемы старого «мы» // Russian Literature: Формы субъекта в новейшей русской поэзии (спец. вып.) [в печати для 2019 г.].

Апресян, Ю. (1986): Дейксис в лексике и грамматике и наивная модель мира // Семиотика и информатика. Вып. 28. М. 5-33.

Белоус, В. (2013): От символизма к концептуализму и... далее (Поэтическое самовыражение как форма современного сознания) // Шталь Х. / Рутц, М. (ред.): Имидж, диалог, эксперимент - поля современной русской поэзии. München / Berlin / Washington 261-272.

Бройтман, С. (2008): Лирический субъект // Тамарченко, Н. (ред.): Поэтика: словарь актуальных терминов и понятий. М. 112-114.

${ }^{41}$ Там же, с. 263. 
Бюргер, П. (2014): Теория авангарда. Пер. с нем. С. Ташкенова. М.

Вестстейн, В. (2013): «Бронзовый век» русской поэзии: кто войдет в канон? // Шталь Х. / Рутц, М. (ред.): Имидж, диалог, эксперимент - поля современной русской поэзии. München / Berlin / Washington. 59-63.

Григорьев, Д. (2009): Другой Фотограф. М.

Гинзбург, Л. (1964): О лирике. М. / Л.

Женетт, Ж. (1998): Фигуры. В 2 тт. Т. 1. Пер. с франц. Е. Васильевой, Е. Гальцовой, С. Зенкина и др. М.

Ирисханова, О. (2014): Игры фокуса в языке: семантика, синтаксис и прагматика дефокусирования. М.

Ковтунова, И. (2006): Категория лица в языке поэзии // Красильникова, Е. (отв. ред.): Поэтическая грамматика. Т. 1. М. 7-72.

Корчагин, К. (2012): Лучникам и гоплитам // Воздух. 3-4, 2012. http://www.litkarta.ru/ projects/vozdukh/issues/2012-3-4/korchagin/view_print/ (5/02/2018).

Лакан, Ж. (1998): Работы Фрейда по технике психоанализа. Семинары: Кн. 1. Пер. с франц. М. Титовой, А. Черноглазова. М.

Лакан, Ж. (1999): «Я» в теории Фрейда и в технике психоанализа. Семинары: Кн. 2. Пер. с франц. А. Черноглазова. М.

Лакан, Ж. (2004): Четыре основные понятия психоанализа. Семинары: Кн. 11. Пер. с франц. А. Черноглазова. М.

Лаку-Лабарт, Ф. (2015): Поэзия как опыт. Пер. с франц. Н. Мавлевич. М.

Левин, Ю. (1998): Избранные труды. Поэтика. Семиотика. М.

Лотман, Ю. (1992): Избранные статьи: В 3 тт. Т. 1.: Статьи по семиотике и топологии культуры. Таллин.

Маяковский, В. (1955): Полное собрание сочинений: В 13 тт. Т. 1. М.

Падучева, Е. (2010): Семантические исследования: Семантика времени и вида в русском языке. Семантика нарратива. М.

Рутц, М. (2013): «Каноны» современной русской поэзии. Наблюдения и перспективы // Шталь Х. / Рутц, М. (ред.): Имидж, диалог, эксперимент - поля современной русской поэзии. München / Berlin / Washington. 37-58.

Соколова, О. (2015): Дискурсы активного воздействия: теория и типология: Дис. докт. филол. наук. М.

Степанова, М. (2015): Spolia. M. http://gefter.ru/archive/12647 (2/02/2018).

Успенский, Б. (1995): Поэтика композиции // Успенский, Б.: Семиотика искусства. М. 9-218.

Шапир, М. (1995): Эстетический опыт XX века: авангард и постмодернизм // Philologica. T. 2 (3-4), 1995. 136-143.

Шмид, В. (2003): Нарратология. М.

Шталь, Х. (2013): «Поминальная свеча» Елены Шварц - поэтика трансцендентирования // Шталь Х. / Рутц, М. (ред.): Имидж, диалог, эксперимент - поля современной русской поэзии. München / Berlin / Washington. 435-450.

Шталь, Х. / Рутц, М. (2013): Имидж, диалог, эксперимент - поля современной русской поэзии // Шталь Х. / Рутц, М. (ред.): Имидж, диалог, эксперимент - поля современной русской поэзии. München / Berlin / Washington. 3-34. 
Haspelmath, M. (1997): Indefinite pronouns. Oxford.

Langacker, R. (1987): Foundations of Cognitive Grammar. Vol. 1. Stanford.

MacLaury, R. (1995): Vantage theory. In: Taylor, J. et al. (eds.): Language and the Cognitive Construal of the World. Berlin / New York. 231-276.

McGowan, T. (2003): Looking for the gaze: Lacanian film theory and its vicissitudes. In: Cinema Journal. Vol. 42 (3), 2003. 27-47.

Perloff, M. (1999): The Poetics of Indeterminacy: Rimbaud to Cage. Evanston, Illinois.

Taylor, J. (1995): Introduction: on constructing the world. In: Taylor, J. et al. (eds.): Language and the Cognitive Construal of the World. Berlin / New York. 1-21. 


\section{Владимир Фещенко (Москва)}

\section{Дейксис как присутствие субъекта в поэтическом тексте: теоретические подходы ${ }^{1}$}

Одним из инструментов формирования субъективности любого высказывания или текста служит дейксис. Ведь именно он «собирает» субъекта из разрозненных слов и фраз в процессе речепорождения. Именно он привязывает языковые выражения к конкретным простанственно-временным координатам и живым субъектам речи, делая каждое коммуникативное событие уникальным и человекомерным. В данной статье мы предложим обзор существующих учений о дейксисе в лингвистике и наметим способы применения дейктических категорий к поэтическому высказыванию и тексту.

Классические теории дейксиса, субъекта и перформативности в языке

Дейксис изучается в рамках теории перформативности как проявления субъекта высказывания в его речевом действии. В современной лингвистике дейксис определяется как

использование языковых выражений и других знаков, которые могут быть проинтерпретированы лишь при помощи обращения к физическим координатам коммуникативного акта - его участникам, его месту и времени. ${ }^{2}$

Будучи универсальным свойством языка, дейксис выражается в каждом конкретном языке по-своему, особым репертуаром грамматических и лексических средств. Однако реально он становится действующим механизмом только в конкретном языковом употреблении, в дискурсе. Теория дискурса же начала развиваться в XX веке как раз на основе понятия дейксиса как перформативного момента в функционировании высказывания.

Первым, кто обратил внимание на особый разряд слов в языке, ответственных за репрезентацию субъекта, был немецкий индоевропеист К. Бругман. В статье о демонстративах в индогерманских языках ${ }^{3}$ он выделил четыре способа указания в языке: указание на говорящего (Ich-дейксис), указание на слушающего (Du-дейксис), а также der-дейксис и jenerдейксис. При этом Бругман отмечал, что обилие таких демонстративов

${ }^{1}$ Статья выполнена в рамках гранта РГНФ № 15-24-06063 «Типология субъекта в русской поэзии 1990-2010-х».

2 Кибрик (http).

${ }^{3}$ Brugman (1904). 
особо характерно для такого литературного жанра, как драматургический текст. О лирической поэзии речь здесь не заходит.

Классификация К. Бругмана в дальнейшем развивается его соотечественником К. Бюлером в учении об «указательном поле языка». Им была обозначена базовая схема дейксиса в языке, состоящая из трех компонентов: «я здесь - сейчас». Схождение этих компонентов в акте высказывания отмечает «исходную точку отсчета» субъективности, называемую Бюлером origo:

Имея в качестве исходной точку Origo наглядного здесь, можно осуществить языковое указание на все другие позиции, если исходной будет точка Origo сейчас - на все другие моменты времени. ${ }^{4}$

То же самое касается показателя индивида (я), по отношению к которому в речевом высказывании выстраиваются все остальные индивиды, участвующие в коммуникации. Бюлер далее выделяет три способа указательности в языке: 1) наглядное указание (demonstratio ad oculos), т.е. отсылка к реальности в момент высказывания, 2) дейксис к воображаемому, т.е. отсылка к чему-то в данный момент не присутствующему в момент высказывания, но мысленно представляемому, 3) анафору, т.е. отсылку к каким-либо другим элементам высказывания. Бюлеровская теория указательности строится на анализе повседневного языка и не содержит каких-либо литературных примеров. Лишь однажды он апеллирует к поэзии, но только с целью уравнять полномочия дейксиса в обыденной и поэтической речи:

Дейксис - это поведение в сфере речевых действий kat' ехоchen, и он остается таковым, если оказывается на службе поэзии. ${ }^{5}$

Далее этого замечания немецкий лингвист не идет. Современные расширения бюлеровской теории дейксиса (например, работы Дж. Лайонза, Ч. Филлмора, Ю.Д. Апресяна, Е.В. Падучевой, А.А. Кибрика, Т.В. Булыгиной, С.А. Крылова, Б.А. Успенского) также не содержат случаев обращения к поэтическому языку.

Со стороны семиотики к явлению, аналогичному дейксису, пришел в своем учении Ч.С. Пирс. Его классификация знаков содержит три типа: знаки-символы, знаки-иконы и знаки-индексы. Последние как раз и соответствуют тому, что К. Бюлер назвал «указательным полем языка». Подлинными знаками-индексами Пирс назвал личные и указательные местоимения. Приводя в пример фразу «на расстоянии тысячи ярдов отсюда», Пирс отмечает, что «отсюда» является таким типом знака, ибо зависит от конкретного расположения субъекта в момент произнесения этой фразы. Индексальность как свойство знаков была положена в основу «прагматического» измерения языка Ч.У. Морриса, того, которое соотносит знаки с говорящим субъектом. В этих учениях мы также не встречаем каких-либо комментариев по поводу поэзии как формы проявления субъективности в

\footnotetext{
${ }^{4}$ Бюлер (1993, с. 99).

5 Там же, с. 153.
} 
языке. Пожалуй, единственное замечание Морриса о поэзии касается лишь ее ориентированности на оценочность, в отличие от языка науки:

Лирическая поэзия обладает синтаксисом и использует слова, означающие вещи, но ее синтаксис и слова действуют таким образом, что для читателя на первый план выступают ценности и оценки. ${ }^{6}$

Здесь лишь косвенно намекается на домининанту субъективности в поэтическом семиозисе.

Еще одним шагом к выявлению субъективности в языке стала теория Э. Бенвениста. Без обращения к понятию дейксиса он по сути формулирует более общий вариант теории субъекта в языке. Согласно Бенвенисту, именно в языке человек конституируется как субъект. Так же, как и К. Бюлер, как и Ч.С. Пирс, он обращается к примерам личных местоимений как первейших носителей субъективности. Но, в отличие от своих предшественников, акцентирует не язык вообще, а дискурс, единовременный акт индивидуальной речи. Именно в дискурсе, а не в языке как системе, можно в полной мере говорить о проявлении субъективности. Бенвенист называет тот класс слов, который по Бюлеру является дейктическим, и который ранее Б. Расселом был назван «эгоцентрическими словами» - «аутореферентными» словами ${ }^{7}$. Они отсылают только к тому субъекту, который их произносит здесь и сейчас. Хотя Бенвенист в своих поздних работах обращался к анализу поэтических текстов (в частности, Ш. Бодлера), его выводы о природе поэтической речи ограничились лишь замечаниями об особом референциальном мире поэтического высказывания, без каких-либо наблюдений над субъективностью в поэтическом языке. С другой стороны, такой глубокий исследователь поэтической речи, как Р.О. Якобсон, не оставил никаких замечаний об употребимости «шифтеров» (его аналог дейктических слов) в поэтических текстах. С третьей же стороны, французского философа А. Мешонника, наследующего традиции Бенвениста, субъективность в поэзии интересует за пределами языка, с точки зрения довольно мистически понимаемого понятия «ритма» ${ }^{8}$.

Не встречаем мы каких-либо соображений о природе поэтического высказывания и у другого родоначальника лингвистической прагматики Дж. Остина. Вводя свою классификацию «перформативов», он специально оговаривает, что «поэтическое использование языка» не может являться иллокутивным. Более того, Остин, кажется, даже подсмеивается над попытками интерпретации поэтического высказывания в терминах философии языка. Анализируя фразу «Go and catch a falling star» из стиха Джона Донна, он недоумевает как возможно вообще осуществление подобного действия, «поймать падающую звезду». И даже уничижительно называет это «пара-

\footnotetext{
${ }^{6}$ Моррис (2001, с. 96).

${ }^{7}$ Бенвенист (2002, с. 297).

${ }^{8}$ Мешонник (2014).
} 
зитическим, несерьезным и ненормальным употреблением языка», вменяя это, например, Уитмену, который «призывает парить орла свободы» ${ }^{9}$. На этом размышление Остина о поэзии останавливается. Тем не менее, его теория уже спустя несколько десятилетий вдохновила исследователей на изучение речевых актов в изобразительном искусстве (Т. де Дюв $\left.{ }^{10}\right)$ и литературе (Дж. Хиллис Миллер), впрочем, не в поэзии, а в прозе (на примере романов Г. Джеймса) $)^{11}$.

В рамках теории языка синтез всех указанных выше прагматически ориентированных философий языка был осуществлен в книге Ю.С. Степанова 1985 г. «В трехмерном пространстве языка». Выражение прагматического подхода к языку здесь формулируется в понятии «дектики». Степанов производит этот термин от неродственного «дейксису» (от греч. deiknumi «указываю»), но близкого по ему звучанию греческого слова dechomai («принимаю в себя», «воспринимаю»). Тем самым бругмановский термин как бы наполняется своей внутренней формой, объединяя смыслы «указательности» и «присваивания» языка говорящим. Дектикой называется то измерение языка, которое связано с отношением слова к субъекту речи. Для такой парадигмы важнейшим оказывается понятие «субъекта». При этом Степанов, развивая идеи Э. Бенвениста, вводит дополнительные уровни субъективности в свой анализ:

Одна из основных линий новой интерпретации высказывания - это расслоение «Я» говорящего на «Я» как подлежащее предложения, «Я» как субъект речи, «Я» как внутреннее «Эго», которое контролирует самого субъекта. И параллельно этому расслаивается сама прагматика: на элементарную часть «локацию» «Я» в пространстве и времени, на более сложную часть - «локацию» «Я» (уже «Я» осложненного как субъект речи) в отношении к акту говорения, на «локацию» высших порядков - отношение говорящего «Я» к его внутреннему «Эго», которое знает цели говорящего и его намерения лгать или говорить правду и т.д. ${ }^{12}$

К подобному разграничению «слоев» субъекта Степанова подталкивает опыт литературы, в частности, расслоение авторского «я» в нарративе М. Пруста. Здесь же дается намек на существование особой, «дектической» поэтики в литературе Нового времени. И хотя поэтических примеров как таковых в книге не присутствует, Степанов для указания на эту проблему приводит стих Г. Гейне: „Sie liebten sich beide, doch keiner // Wollt' es dem andern gestehn“, и его вольное переложение М. Лермонтовым, как штрих к иллюстрации сложной субъективности в поэтическом высказывании, свойственной уже романтизму.

\footnotetext{
${ }^{9}$ Austin (1962, c. 104).

${ }^{10}$ Дюв (2015).

${ }^{11}$ Hillis Miller (2001).

${ }^{12}$ Степанов (2010, с. 217-218).
} 
Из этого краткого обзора классических теорий дейксиса, субъективности и перформативности можно заключить, что поэтическое высказывание либо оставлялось за скобками лингвистического анализа (у К. Бюлера и Э. Бенвениста), либо вызывало отторжение своей «несерьезностью» (у Дж. Остина), либо же вписывалось не как специфически поэтическое в «дектическую» парадигму языка (у Ю.С. Степанова). Тем не менее, при разработке теории субъективности применительно к поэзии стоит учитывать общие принципы соотношения высказывания и субъекта, сформулированные в классических работах по языкознанию и философии языка.

\section{Некоторые попытки применения понятия дейксиса к поэтическим текстам}

Определенным аналогом лингвистического явления дейксиса в терминах литературоведения выступает уже классическое понятие «лирического я». Специфика именно поэтической субъективности была резюмирована в этих терминах Л.Я. Гинзбург:

Специфика лирики в том, что человек присутствует в ней не только как автор, не только как объект изображения, но и как его субъект, включенный в эстетическую структуру произведения в качестве действенного ее элемента. При этом прямой разговор от имени лирического я нимало не обязателен. Авторский монолог - это лишь предельная лирическая форма. ${ }^{13}$

В немецкой литературной теории о «поэтическом субъекте»и «лирическом субъекте» как отличном от авторской личности много писал Г. Фридрих, отмечая изменения в субъективации поэтического «я», начиная с поэзии модернизма. Так, относительно А. Рембо и его фразы «я - это другой» он пишет о несовпадении реального биографического «я» и «я» как функции поэтического высказывания:

Субъект поэтической визии - не эмпирическое «я». Другие власти проступают на его место, власти из глубины предличностного характера и направленной мощи [...] «Я» Рембо в его диссонантной многозначности есть результат той оперативной трансформации индивида [...] Художественное «я» может надеть любые маски, распространиться на любые эпохи, народы, способы экзистенции [...] Начиная с Рембо утвердилось анормальное разделение между художественным субъектом и эмпирическим «я», которое в нашу эпоху легко обнаруживается у Эзры Паунда и Сен-Жон Перса, что делает невозможным трактовку современной лирики как биографического высказывания. ${ }^{14}$

Фридрих также делает важные замечания, касающиеся языка новой европейской поэзии, однако, не прибегая к собственно лингвистическим анализам.

Литературоведами продуктивно изучаются различные формы присутствия субъекта в литературном произведении на уровне соотношения «ав-

\footnotetext{
${ }^{13}$ Гинзбург (1997, с. 10).

${ }^{14}$ Фридрих (2010, с. 75 , с. 84-85).
} 
тор-герой-читатель». Между тем случаи исследования языковых способов конструирования субъекта немногочисленны. Те немногие обращения к интересующей нас теме, естественно, базируются на общелингвистических постулатах перформативной парадигмы.

К примеру, о функциях шифтеров в поэтическом языке высказывался Вяч. Вс. Иванов, приводя случаи дейктического выражения категории «определенности-неопределенности». Он же отмечал возросшую роль дейксиса в поэзии XX в., которая сосредоточена на «выражении личности поэта в минуту самого акта поэтической речи» ${ }^{15}$. И.И. Ковтунова рассматривала местоименную поэтику как преимущественно лирико-поэтическую разновидность дейксиса. Согласно ее подходу, «дейктические местоимения в поэтических текстах, устанавливая точку зрения воспринимающего, создают образ восприятия мира» ${ }^{16}$. В этом направлении были предприняты некоторые конкретные анализы форм присутствия субъекта в поэтическом высказывании. Так, в статье Н.М. Азаровой об одной строчке «В этот день голубых медведей» Хлебникова делается важный вывод о том, что поэтический дейксис в интерпретации философа (в данном случае, Я.С. Друскина) обретает экзистенциальное измерение. ${ }^{17}$ Наконец, к дейксису относится напрямую проблема адресации поэтического дискурса. Точнее сказать, адресация входит в дейксис как один из компонентов высказывания (о чем писали М.М. Бахтин и И.И. Ковтунова). Ряд статей из недавнего выпуска серии «Логический анализ языка» разрабатывает эту проблему на материале отдельных поэтических текстов. ${ }^{18}$

Отдельно стоило бы отметить работу британского исследователя К. Грина, посвященную проблеме дейксиса в поэтическом тексте. ${ }^{19}$ Данный труд - попытка систематического и последовательно лингвистического подхода к функционированию разнообразных дейктических категорий в поэтическом тексте. Базируясь на солидной проработке дейктических понятий в лингвистической прагматике, автор строит свою аргументацию на главном тезисе: инстанция Я в поэзии является точкой отсчета для пространственно-временных координат дейктического контекста. Дейктическим контекстом является при этом не внешний контекст высказывания, а само пространство поэтического текста, тот мир, который создается каждый раз заново в каждом конкретном стихотворении. Тем самым Грин отвергает позицию, согласно которой поэтический мир является лишь подобием мира референциального, притом подобием проблематичным для линвистического анализа (точка зрения К. Бюлера, Дж. Остина и даже отчасти

\footnotetext{
${ }^{15}$ Иванов (1979, с. 106).

${ }^{16}$ Ковтунова (1986, с. 26).

17 Азарова (2008).

18 Арутюнова (отв. ред., 2012).

${ }^{19}$ Green (1992).
} 
Э. Бенвениста). Origo поэтического текста (то есть схождение в одной точке координат «здесь - сейчас - я») каждый раз задается с нуля, без необходимой привязки к референтному миру, и уже разворачивание поэтического текста в целом определяет позиции относительно этого origo, а отнюдь не законы референтного мира. Когда мы начинаем говорить в обыденной речи, как правило, origo совершенно очевидно (каждый из говорящих знает кто он, и кто его собеседник, где и когда он говорит). В прозаическом тексте это может быть уже не столь очевидно, но тем не менее, сам принцип наррации строится на знании, о ком идет речь, в какой момент времени и в каком пространстве. В лирической поэзии этот origo может являться неизвестным, и, стало быть, дейксис не предопределяется заранее знанием читателя, но конституируется в самой организации текста. По выражению исследователя, «дейксис сам пишет поэтический текст» ${ }^{20}$. Один из примеров, который подробно разбирает Грин, - стихотворение Р. Фроста „Stopping by Woods on a Snowy Evening":

Whose woods these are I think I know.

His house is in the village though;

He will not see me stopping here

To watch his woods fill up with snow. ${ }^{21}$

Это лишь первое четверостишие текста, но здесь уже видно, как на границе определенности и неопределенности работает дейксис на разных уровнях. Грин указывает, во-первых, на соотношение заглавия и первой строки, которое проблематизирует origo. Первая строчка практически целиком состоит из дейктических маркеров, но их привязка к субъекту стиха выясняется только к концу текста.

К. Грин предпринимает диахронический анализ функционирования дейксиса на материале небольшой выборки английских поэтов от елизаветинских времен до модернизма Э. Паунда. Таким образом, прослеживаются изменения в использовании дейксиса в разные эпохи и в разных поэтиках. Каждое стихотворение анализируется по единому набору дейктических параметров: 1) референциальный дейксис (указание на конкретные референты), 2) origo-дейксис (указание на точку отсчета «здесь - сейчас - я», 3) пространственно-временной дейксис (привязка к месту и времени), 4) субъективный дейксис (указание на роли субъектов в тексте, включая автора и читателя), 5) дискурсивный дейксис (указание на само производство высказывания, 6) синтактический дейксис (связность и анафора). В совокупности все эти параметры, или виды дейксиса составляют так называемую «прагматическую рамку, или схему» стихотворения. Представляется, что для анализа современной русской и немецкой поэзии эта методика

\footnotetext{
20 Там же, с. 48 .

21 Там же, с. 52.
} 
анализа дейктической структуры текста может быть одной из продуктивных в поисках сущности субъективности в стихе. ${ }^{22}$

Кратко упомянем еще одну перспективу изучения дейксиса в поэзии. Она связана с когнитивными исследованиями языка. В когнитивной поэтике дейксис рассматривается как один из способов репрезентации знания. Так, П. Стокуэлл разделяет текстовый дейксис и когнитивный дейксис. ${ }^{23}$ Первый отвечает за связность самой формы представления знаний в художественном тексте, а второй за те фреймы, которые форматируют знания на содержательном уровне высказываний. Теория дейктических сдвигов (deictic shifts theory) моделирует общее восприятие читателя, «погружающегося» в литературный текст, как того читателя, который занимает определенную познавательную позицию внутри мысленно конструируемого мира текста. Эта имагинативная способность и есть дейктический сдвиг, позволяющий читателю понимать дейктические выражения, относящиеся к сдвигаемому дейктическому центру. ${ }^{24}$ В основном теория дейктических сдвигов применяется к прозаическим произведениям, и она сообщает нам скорее и больше о механизмах чтения как когнитивного процесса, имея меньшее отношение к субъективности поэтического текста. Тем не менее, некоторые положения когнитивной теории относительно фокусировки и дефокусировки языковых единиц в тексте могут помочь в описании сложной субъектно-объектной структуры современной поэзии.

Возможные пути изучения поэтического дейксиса применительно к современной поэзии

Учитывая все вышеизложенные классические теории высказывания и более современные подходы к изучению поэтического дейксиса, можно было бы предложить некоторые методологические очертания дейктического анализа поэтического текста. Такой анализ, основывающийся на исключительно языковых данных текста, мог бы стать частью общей программы исследования субъективности в современной поэтической практике. ${ }^{25}$ Отметим вкратце несколько пунктов предлагаемого подхода.

\footnotetext{
22 См. также другое издание под редакцией этого автора: Green (ed., 1995), представляющее собой сборник статей на тему дейксиса в художественных текстах, а также специальный выпуск журнала „Arethusa“, посвященный проблеме дейксиса в древнегреческой лирической поэзии (Felson (ed.) 2004).

${ }^{23}$ Stockwell (2002).

${ }^{24}$ См. также Schiedermaier (2004); Tsur (2008); Ахапкин (2012).

25 Некоторые черты такого анализа применительно к экспериментальной американской поэзии предложены в нашей публикации: Фещенко (2015).
} 
Дейксис в поэзии играет повышенную роль, чем в прозе, поскольку указательное поле языка в стихотворной речи намеренно организуется и ритмизуется. В результате дейктические элементы языка и текста подвергаются сгущению. Это обстоятельство было отмечено И.И. Ковтуновой на примере местоимения «так»:

Единство и теснота стихового ряда здесь особенно ощутимы как факторы, организующие поэтическую семантику. Они усиливают дейктическое значение слова так в предложениях, смысл которых приобретает до некоторой степени самодовлеющий характер - благодаря пунктуационному обособлению и ослабеванию линейной семантической связанности». ${ }^{26}$

Рассмотрим следующее стихотворение В. Аристова:

Может быть в северных странах

Светофоры стрекочут

И ночи светлы.

Но у нас, где на перекрёстках

Скрещён красный свет в темноте

Здесь в Хамовниках мягких

Я не спас тебя той июльскою ночью

Я не спас тебя

Мы все спасли нас 27

Представим, что данное стихотворение было бы изложено прозой, например, так:

Может быть, в северных странах светофоры стрекочут, и ночи светлы. Но у нас, где на перекрестках скрещен красный свет в темноте, здесь в Хамовниках мягких я не спас тебя той июльскою ночью. Я не спас тебя. Мы все спасли нас.

В прозаическом фрагменте такие дейктические маркеры, как «может быть», «в странах», «у нас», «здесь в Хамовниках», «я не спас тебя», «той ночью», «мы спасли нас» задавали бы совсем иную, линейно-синтагматическую линию согласования субъектов, объектов и предикатов. Первая фраза вполне однозначно указывала бы на модальность для всего предложения: «может быть, то и другое». Тогда как при стихотворном разбиении эта модальность имеет многозначные векторы предикации. Например, первая строчка может читаться не только как конструкция с вводным модальным «может быть», а и как безлично-бессубъектное высказывание о том, что «в северных странах (нечто) может быть» (учитывая отсутствие запятой после может быть). В последних строчках повторенное отдельными стихами «я не спас тебя» задает дейктический сдвиг: «я не спас тебя той июльской ночью» и «я не спас тебя вообще» притом, что это могут быть разные я (разные голоса). При таком прочтении последняя строка «мы все спасли нас» обретала бы смысл, как будто бы неясный, если чи-

\footnotetext{
${ }^{26}$ Ковтунова (1986, с. 58).

${ }^{27}$ Аристов (2008, с. 20).
} 
тать эту последнюю строчку прямолинейно. Как можно говорить о «я» и «ты» собирательным «мы все»?.. Но если иметь в виду разные «я» в предшествующих строчках, то этот собирательный смысл «все» становится прозрачнее. Таким образом, дейксис в стиховой речи динамизирует субъективную структуру текста, и, значит, его прагматический смысл.

Вообще, можно рассматривать отдельные строки стихотворного текста как отдельные микровысказывания, составляющие часть макровысказывания - целого текста или его фрагмента. При таком взгляде все стихотворение может рассматриваться как коммуникативное целое, составленное из коммуникативных фрагментов. И именно переходы между этими фрагментами, соотносящимися между собой нелинейными связями в структуре текста в виде строк-высказываний, будут маркировать дейктические сдвиги. Разумеется, если смотреть на стих подобным образом, большинство таких микровысказываний будут выглядеть неоконченными (как высказывание «может быть в северных странах»), но именно их неоконченность будет создавать особый дейксис, не свойственный дейксису прозаической речи. Собственно, при таком подходе соблюдается основной принцип организации стихотворной речи, сформулированный Р.О. Якобсоном (перенесение с оси селекции на ось комбинации) и подтвержденный М.И. Шапиром в его определении стиха как «сквозных парадигматических членений». В данном же случае парадигматическим членениям подвергается дейксис, т.е. указательное поле текста.

Точкой отсчета субъектно-объектной структуры поэтического текста признается не «я» («эго»), a origo, т.е. «я» в конкретном «здесь» и «сейчас» (или в терминологии И.И. Ковтуновой, «точка зрения» или «центр восприятия»). При этом движения от этой точки отчета в любой из этих трех позиций каждый раз сдвигают origo, в результате чего образуется динамическая субъектная структура текста. В стихотворении В. Аристова это можно проследить следующим образом:

Может быть в северных странах (нулевой субъект, модальность возможности, пространственный дейксис-1)

Светофоры стрекочут (нет дейксиса)

И ночи светлы. (нет дейксиса)

Но у нас, где на перекрёстках (субъективный дейксис-мы-1, пространственный дейксис-2)

Скрещён красный свет в темноте (нет дейксиса)

Здесь в Хамовниках мягких (уточняющий пространственный дейксис-2)

Я не спас тебя той июльскою ночью (субъективный дейксис-я-1, субъективный дейксис-ты-1, временной дейксис-1)

Я не спас тебя (субъективный дейксис-я-2, субъективный дейксис-ты-2, нулевой временной дейксис)

Мы все спасли нас (субъективный дейксис-мы-2, удвоенный рефлексивной конструкцией) 
Точка отсчета (origo) появляется лишь в четвертой строчке, и начинает претерпевать изменения далее по ходу стихотворения. При этом то, что предшествует origo (первые четыре строчки), в смысловом плане противостоит следующей части (безличный дейксис дальнего пространства сложному личному дейксису ближнего пространства и дальнего времени), что указывает на многонаправленные трактории дейксиса в стихе. Дейксис с самого начала текста выступает как «неизвестное» или «множество неизвестных» (отсутствие экспозиций, наррации, обыденной логической связности). Поэтический дейксис не предзадан, а задается самой последовательностью и организацией высказываний-строк. Разумеется, подобный дейктический разбор стихотворения остается не полным без других координат анализа - синтаксического (связь соседствующих слов между собой) и семантического (установление референции конкретных элементов стиха к внеположному тексту миру, т.е. конкретные исторические обстоятельства создания стихотворения). Однако анализ внутритекстового дейксиса самого по себе уже способен зафиксировать динамику субъектности, характерную для данного конкретного текста или поэтики данного автора.

Если рассматривать поэтическое высказывание как разновидность высказывания вообще, необходимо признать, что перформативы в поэзии осуществляют прежде всего самореферентную функцию - производят действия при помощи слов, но действия внутри самого языка и текста, воздействуя на язык и текст как таковой. Так, заключительная строчка из стихотворения В. Аристова «Мы все спасли нас» производит действие по сборке всех я- и мы-дейксисов всего стихотворения. «Мы все» здесь - не то же самое, что «мы все» в обыденной коммуникации. В данном тексте «мы все» - это все «я» и «ты» во всех временных и пространственных координатах, размеченных в стихотворении. То есть референтом «мы все» являются не конкретные личности, объединенные чем-то общим, а все те эгоцентрические слова, предшествующие финальному «мы все». Стало быть, поэтический дейксис является предельной манифестацией принципа речи, «обращенной на саму себя», поэтической функции языка.

При анализе дейктического измерения текста целесообразно было бы там, где это возможно, принимать во внимание авторефлексию самого поэта. Иногда такая рефлексия указывает на специфику дейксиса в текстах автора, хотя порой и расходится в частностях в поэтической практике. Так, в своих эссе В. Аристов подчеркивает ориентированность лирической поэзии на формулу «я есмь», в отличие от прозы с ее формулой «ты есть» и драмы с ее «мы есть». ${ }^{28}$ Но как мы видели в приведенном стихе, все три эти формулы задействуются автором в данном стихе. Но по всей видимости, именно синтез этих трех субъективностей и пытается осуществить Аристов в стихотворных опытах.

${ }^{28}$ Напр., в Аристов (2010). 
В стихотворении, в котором расположение строк на листе нерегулярно (фигурные стихи, отточия, пробелы, зигзаги, пустые фрагменты текста и т.п.), дейксис обретает дополнительный фактор. В таком стихе пространственный дейксис будет работать не только на уровне семантики слов, но и на уровне локализации слов в пространстве текста. Поэтические микровысказывания тут могут составляться из самых разных констелляций слов, букв, иных типографских знаков (у В. Аристова см. особенно стихотворения «Реставрация скатерти», «Созерцание деревца», «Поездка на острова», «Одна балканская страна» и др. ${ }^{29}$. Соответственно, в музыкально-ориентированной поэзии будет активизироваться дейксис временной (как, например, в поэзии Е. Мнацакановой).

Наконец, укажем на еще один важный аспект указательности как выражения субъективности в поэтическом высказывании. Речь идет о случаях, когда внутрилингвистический и внутритекстовый дейксис письменного текста сопровождается дейксисом экстралингвистическим. Это может быть жест, голос, движение. Подобное имеет место в случае исполнения поэтического текста или в случае поэтического перформанса. Так, на примере отдельных текстов В. Аристова можно было бы обратиться к их звучащему исполнению. Ведь подчас расстановка пауз и акцентуация звучащего стиха отличаются от письменного варианта текста, и макровысказывания могут члениться на микровысказывания иначе. Возможно, в некоторых случаях, отличались бы и дейктические связи в разных вариантах текста.

Эти положения могут служить одним из возможных способов анализа присутствия субъекта в современной поэзии. Разумеется, чисто лингвистический анализ поэтического дейксиса должен дополняться другими методами изучения субъективности (принятыми или разрабатываемыми в настоящее время в литературоведении, теории дискурса, философии).

\section{Литература}

Азарова, Н. (2008): Две странички Якова Друскина о хлебниковских «Медведях» // Лощилов, И. Е. (ред.): Интерпретация и авангард: межвузовский сборник научный трудов. Новосибирск. 56-67.

Аристов, В. (2008): Месторождение. М.

Аристов, В. (2010): Эссе: онтологические установки и формальные границы // НЛО. 4 (104), 2010. M. 84-108.

Арутюнова, Н. (отв. ред., 2012): Логический. анализ языка. Адресация дискурса. М.

Ахапкин, Д. (2012): Когнитивная поэтика и проблема дейксиса в художественном тексте // Когнитивные исследования: Сборник научных трудов. Вып. 5. М. 252-266.

${ }^{29}$ Аристов (2008). 
Бюлер, К. (1993): Теория языка: Репрезентативная функция языка. Пер. с нем. под общ. ред. Т. В. Булыгиной. М.

Бенвенист, Э. (2002): Общая лингвистика. Пер. с франц. Ю. Караулова, В. Мурат, И. Барышева и др. М.

Гинзбург, Л. (1997): О лирике. М.

Дюв, Т. де (2015): Артефакт. Пер. с франц. П. Арсеньева // Транслит. 17, 2015. СПб. 24-47.

Иванов, Вяч. (1979): Категория определенности-неопределенности и шифтеры // Николаева, Т. М. (Отв. ред.): Категория определенности-неопределенности в славянских и балтийских языках. М. 95-99.

Кибрик, А. (http): Дейксис // Энциклопедия «Кругосвет». www.krugosvet.ru/enc/gumani tarnye_nauki/lingvistika/DEKSIS.html (15/06/2014).

Ковтунова, И. (1986): Поэтический синтаксис. М.

Мешонник, А. (2014): Рифма и жизнь. М.

Моррис, Ч. (2001): Основания теории знаков // Степанов, Ю. (сост.): Семиотика: Антология. М. 129-143.

Степанов, Ю. (2010): В трехмерном пространстве языка: Семиотические проблемы лингвистики, философии, искусства. М.

Фещенко, В. (2015): Телесный дейксис в экспериментальной поэзии: опыт Э.Э. Каммингса // НЛО. 5 (135), 2015. М. 43-55.

Фридрих, Г. (2010). Структура современной лирики. От Бодлера до середины двадцатого столетия. Пер. с нем. Е. Головина. М.

Austin, J. (1962): How to Do Things with Words. Oxford.

Brugmann, K. (1904): Die Demonstrativpronomina der indogermanischen Sprachen. Eine bedeutungsgeschichtliche Untersuchung. Leipzig.

Felson, N. (ed., 2004): Special Issue: The Poetics of Deixis in Alcman, Pindar, and Other Lyric. In: Arethusa. Volume 37. Number 3.

Green, K. (1992): A Study of Deixis in Relation to Lyric Poetry. Sheffield.

Green, K. (ed., 1995): New Essays in Deixis. Discourse, Narrative, Literature. Amsterdam / Atlanta, GA.

Hillis Miller, J. (2001): Speech Acts in Literature. Stanford.

Schiedermaier S. (2004): „Lyrisches Ich“ und sprachliches ,ich“. Literarische Funktionen der Deixis. München.

Stockwell, P. (2002): Cognitive Poetics. An Introduction. London.

Tsur, R. (2008): Toward a Theory of Cognitive Poetics. Brighton / Portland. 



\section{Екатерина Евграшкина (Трир)}

\section{Игры с перспективой и «полагание» субъекта: о дейксисе поэтического текста}

Субъект поэтического текста - текстовая инстанциия, которая находит свое непосредственное выражение благодаря знакам субъекта. Указаниями на субъект являются некоторые знаки естественного языка - прежде всего, личные и притяжательные местоимения. По Э. Бенвенисту, «я - это индивид, который производит данный речевой акт, содержащий акт производства языковой формы я». ${ }^{1} \mathrm{OH}$ также подчеркивает, что «я не может быть идентифицировано иначе как посредством речевого акта, который его содержит, и только посредством его; оно действительно только в том единовременном речевом акте, в котором оно производится». ${ }^{2}$

$Я$, таким образом, принадлежит к реальности речевого высказывания как и $T b l$, которое в его взаимосвязи с $Я$ получает симметричное определение: «mbl - [это] индивид, к которому обращаются в данном речевом акте, содержащем акт производства языковой формы $m b l »{ }^{3}$ Семиотик У. Волли также указывает на взаимообратимые отношения (Wechselbeziehung) субъектов, выраженных местоимениями я и $\mathrm{mbl}^{4}{ }^{4}$

Так как литературная коммуникация опосредована, связь между пишущим и формами $Я$ в его письме также будет относительной. При чтении текста реципиент обычно не воспринимает его автора как некое лицо, присутствующее здесь и сейчас, и не ведет с ним непосредственного диалога. Нарративные тексты предполагают присутствие многих инстанций $Я$, как то рассказчик, наблюдатель и проч., 5 однако они обычно исключают их непосредственную идентификацию с $Я$ реального автора. ${ }^{6}$ В поэзии, дискурсивной константой которой является смысловая неопределенность, данные нарративные инстанции $Я$ нередко отсутствуют, а $Я$ обретает статус $c$ мысслового конструкта, для которого функциональное определение Э. Бенвениста фактически неприложимо. Поэтическое $Я$ может рассматриваться

${ }^{1}$ Бенвенист (1974, с. 287).

2 Там же, с. 286.

${ }^{3}$ Там же, с. 287.

${ }^{4}$ См. Volli (2002, S. 36).

${ }^{5}$ См. о знаках субъекта в нарративных дискурсах: Данилова (2001).

6 Это касается, прежде всего, художественных неавтобиографических текстов, однако и автобиографии, ввиду их включения в особый дискурсивный контекст, релятивируют идентификацию автора и автобиографического $Я$. 
как конкретный единичный акт производства языковой формы $Я$, однако оно не отсылает к непосредственному речевому акту реально существующего лица (или даже лица фиктивного, вымышленного). Языковая перформативность поэзии позволяет говорить о поэтическом тексте как об особом и в узком смысле анонимном речевом акте, референтом которого является он сам как некое событие языка, а его субъект при этом обретает статус перформативного элемента.

Поэтико-перформативный потенциал местоимений в поэзии часто реализуется посредством метаязыковых элементов. Так, например, в стихотворении Лиобы Хаппель (Lioba Happel, род. 1957) ich [я] находит свое текстовое определение благодаря ряду придаточных относительных - это пример отчужденного поэтического субъекта:

in deiner zukunft erlosch ich

ich die ich ich war ich die ich rief

ich die ich lange rief ich die ich deinen tod sah

ich die ich sang tanzte brot ass

o mein geliebtes mädchen in china

ich die ich du bin

ich die ich deine schönheit liebte ${ }^{7}$

в твоем будушем я потухла

я та я что была я что я звала

я что долго звала я что видела твою смерть

я что я пела танцевала хлеб ела

о моя любимая девочка в китае

я та я что ты

я та я что твою красоту любила

В данном стихотворении происходит крайняя релятивизация знака субъекта я: отсутствует конвенциональная синтагма, включающая в себя личное местоимение и соответствующую глагольную форму, вместо этого местоимение сопровождает длинный ряд придаточных относительных, которые призваны придать я определенное содержание. Остранение происходит посредством прямой идентификации ich [я] и du [ты] (,,ich die ich du bin“ [я та я что ты]), причем это единственный случай употребления настоящего времени (точнее, «вневременной» формы глагола-связки sein [быть]) по отношению к преобладающим формам претерита (war [была], rief [звала], sah [видела] и т.д.). Относительными предстают также сами действия субъекта: в первой

${ }^{7}$ Happel (2009, S. 15). 
строке обстоятельство, семантически связанное с будущим временем, примыкает к предикату, выраженному претеритом (,,in deiner zukunft erlosch ich“" [в твоем будущем я потухла]). Релятивизация становится общей смысловой доминантой текста; предмет поэтической рефлексии в данном случае - поиск возможностей наполнить содержанием пустой знак субъекта, однако характерные уточнения посредством придаточных относительных лишь подчеркивают его неопределенность и даже неопределимость: поэтический субъект не становится конкретным и осязаемым.

Метаязыковая рефлексия на предмет знаков субъекта в немецком языке является непосредственной темой следующих текстов Йоко Тавады (Yōko Tawada, род. 1960), пишущей на японском и немецком языках. В одном из стихотворений Й. Тавада проблематизирует отсутствие грамматической оппозиции по отношению к $я$ на фоне оппозиции $b b l-m b l$ :

\section{Die zweite Person Ich}

Als ich dich noch siezte, sagte ich ich und meinte damit mich.

Seit gestern duze ich dich, weiß aber noch nicht, wie ich mich umbenennen soll. ${ }^{8}$

\section{Я во втором лице}

Когда обращалась к тебе на «вы», говорила «я», имея в виду

себя.

Со вчерашнего дня говорю тебе «ты», но все еще не знаю, как мне себя переименовать.

Преодоление коммуникативной дистанции в отношениях двух субъектов, дискурсивно закрепленное переходом на $m b l$, может быть значимым и для $я$ каждого из субъектов, предполагая некие изменения в нем самом в связи с новыми дискурсивными обстоятельствами. Однако язык оказывается беспомощным, чтобы зафиксировать эти изменения я в самом знаке: таким образом, в данном тексте проблематизируется статичность конвенционального языкового знака субъекта - и необходимость его переименования в рамках поэтического текста.

В другом примере поэтизируется заполнение пустых знаков субъекта в их непосредственной соотнесенности с речевым процессом и определенным референтом (в данном случае через указание на пол):

\section{Die zweite Person}

Du hast ein Geschlecht.

„Du“ hat kein Genus.

Du da!

\footnotetext{
${ }^{8}$ Tawada (2011, S. 8).
} 
Meinst du mich?

$\mathrm{Ja}$ !

Dann ist dein ,du“ heute weiblich. $[\ldots]^{9}$

\section{Второе лицо}

У тебя есть пол.

«Ты» не имеет рода.

Эй, ты!

Это ты мне?

Да!

Тогда твое «ты» сегодня женщина. [...]

Еще в одном случае проблематизируется известная относительность универсальности знаков субъекта - посредством указания на их неуместность в некоторых социальных контекстах (таким образом, эти знаки становятся косвенными носителями определенной семантики):

$[\ldots]$

„Ich“ muss keine Steuern zahlen, denn ICH ist kein bürgerlicher Name.

„Du“ musst nicht zur Bundeswehr. Ein Soldat, der DU heißt, tötet nicht. ${ }^{10}$

$[\ldots]$

«Я» не нужно платить налоги, ведь Я - это не гражданское имя.

«Ты» не нужно идти в бундесвер. Солдат, которого зовут ТЫ, не станет убивать.

Можно найти много примеров метаязыковой рефлексии на предмет сущности и значения знаков субъекта в поэтическом тексте - как в немецкой, так и в русской поэзии. Так, в качестве метода остранения может выступать грамматический нонсенс - в случаях, когда личное местоимение первого лица единственного числа «согласуется» с «объективирующей» глагольной формой третьего лица: ${ }^{11}$ «я врет в каждой букве» ${ }^{12}$ (cp. с аналогичным примером из немецкой поэзии: ,in der Lukács-Konditorei / sitzt ich und schreibt ${ }^{\text {‘13 }}$ [в кондитерской Лукача сидит я и пишет]).

\footnotetext{
${ }^{9}$ Там же, S. 23.

10 Там же, S. 24.

11 Примечательно, что и в русском, и в немецком языках формы прошедшего времени для первого и третьего лица единственного числа совпадают: тем самым в своем «прошлом» $Я$ некоторым образом «объективируется». Однако того же нельзя сказать о формах настоящего времени в обоих языках: непосредственно здесь и сейчас действующее $Я$ отмечено индивидуальными грамматическими формами глагола, в настоящем оно именно субъект действия.

12 Воробьев (2015, с. 61).

${ }^{13}$ Köhler (1991, S. 13).
} 
Другая возможность метаязыкового очуждения основывается на апофатическом отрицании знаков субъекта: «как в тот раз, когда не я мне, не тыты / не не-ты, не не-не-ты, когда ты [...]». ${ }^{14}$

В отношении семантической неопределенности и семиотической относительности знаков субъекта характеристика личных местоимений как «универсальных» и «пустых» знаков, предложенная Р. Бартом, ${ }^{15}$ кажется особенно релевантной для поэзии. «Пустые» или «универсальные» знаки (местоимения, местоименные наречия, артикли и проч.) получают свое содержание, встраиваясь в семиотическую систему текста и устанавливая связь с неким референтом внутри «возможного мира» художественного текста. В поэзии местоимения при этом часто имеют самореферентную функцию и являются элементами-заменителями (Platzhalter) соответствующих субъектных позиций в тексте, участвующих в перспективации текста и формировании дейксиса.

Мир, состоящий из четырех измерений, включающих три пространственных и одно временное, а также необходимость ориентироваться в этом мире являются неотъемлемой частью человеческого бытия, а потому находят разнообразные формы отражения и в языке. Дискурсивные узльл ориентирования включают в себя прежде всего пространственный и временной аспекты и имеют прагматическую направленность; их формирование определяется конкретной личной перспективой говорящего.

По теории К. Бюлера, ${ }^{16}$ система ориентации субъекта $Я$-Здесь-Сейчас (Hier-Jetzt-Ich-Origo) образует дейктический центр. Однако в речевом потоке центр может смещаться. Соответствующие дейктические выражения, указывающие на временные точки и отрезки, пространственное расположение и действующих в нем субъектов, функционируют в рамках конкретной речевой ситуации в непосредственном конструировании действительности $^{17}$ и отсылают к уже сказанному или предвосхищают то, что еще только должно быть сказано. С точки зрения семиотики, дейктические выражения являются знаками-индексами и служат скорее средствами когезии, а не когерентности.

Дейксис складывается из нескольких измерений, которые можно обозначить как пространственное (локальное, или объективное), временное (темпоральное) и личное (субъективное). Несмотря на отсутствие непосредственной интеракции в художественном дискурсе, понятие дейксиса остается релевантным и для него: в данном случае дейксис становится основой

\footnotetext{
${ }^{14}$ Глазова (2008, с. 105).

${ }^{15}$ Барт (2002, c. 141).

${ }^{16}$ Bühler (1978).

${ }^{17}$ Больше о сущности дейксиса см. Падучева (1985), Fricke (2007).
} 
наррации $^{18}$ и обретает новое качество дискурсивного или текстового дейксиса. Однако поэзия имеет иную нарративную природу (хотя в поэтическом тексте могут присутствовать нарративные элементы, близкие по форме эпическим) - это дает основание предполагать, что предложенная К. Бюлером система Origo, задающая временные и пространственные координаты бытия субъекта, будет иначе функционировать в поэтических дискурсивных процессах.

Особый интерес в связи с данной проблемой представляет собой текст К. Элиха „Deixis und Dichtung - Linguistische Überlegungen“ [Дейксис и поэзия - лингвистические соображения]. К. Элих указывает на то, что именно в поэзии дейксис представляет собой «специфическую проблему», а его структура может быть освоена лишь в том случае, если саму поэзию рассматривать как «особый тип речевого действия». ${ }^{19}$ Характер использования языковых средств дейксиса определяется независимостью речевого действия от коммуникативной ситуации, его растяжимостью (Zerdehnung), a также особенностями процесса текстуализации (Vertextung) в различных формах поэзии (Verfahren der Dichtung). ${ }^{20}$

В своем исследовании К. Элих обращается к дейктическим средствам немецкого языка и показывает на примерах одного стихотворения и одного прозаического текста П. Целана (соответственно, из сборников „Niemandsrose“ [Ничья роза, 1963] и „Meridian“ [Меридиан, 1961]), как дейктические структуры различных типов функционируют в определенном авторском дискурсе и как они выражены средствами языка. Принципиально важным для исследования поэзии представляется следующее высказывание К. Элиха о дейктической плотности (Deixis-Dichte):

Der Einsatz deiktischer Ausdrucksmittel eröffnet dem Autor einen anderen $\mathrm{Zu}-$ gang zum mentalen Bereich seines zum Leser transformierten Hörers, als ihn der Einsatz nennender Prozeduren, also Nutzung von Ausdrücken des Symbolfeldes, gestattet. Wird auf deiktische Ausdrucksmittel im erheblichen Umfang verzichtet, so verliert sich die Möglichkeit des direkten Eingriffs in die Fokussierungs- und Orientierungsmöglichkeiten des Lesers. ${ }^{21}$

Благодаря дейктическим средствам выражения, автору открывается иной доступ к ментальной сфере его слушателя-читателя, нежели в актах номинации (т.е. при использовании выражений, принадлежащих к символическому полю значений). При существенном отказе от дейктических средств выражения теряется возможность непосредственного воздействия на процессы ориентирования и фокусирования читателя.

18 О функциональности дейктической системы Origo в нарративных дискурсах см. Данилова (2001).

${ }^{19}$ Ehlich (2009, S. 67).

${ }^{20}$ Там же, S. 71.

21 Там же, S. 73. 
Значение имеет не столько концентрация дейктических указаний, сколько их контекстуальная целесообразность и функциональность. Поэзии, проявляющей тенденцию к культивированию смысловой неопределенности, присущи нестабильные референциальные отношения, что может стать причиной нарушения равновесия текстового дейксиса и потенциальной дезинтеграции дейктических модусов (личного, временного и пространственного). Исходя из этого, можно предположить, что на семиотическом уровне субъектные позиции, выраженные соответствующими знаками субъекта, определяются в большой степени (или даже исключительно) пространственным (или объективным) и временным дейктическими модусами. Это означает, что временной и пространственный модусы потенциально могут участвовать в конституировании субъекта, а не ограничиваться описанием бытийственных координат некоего пред-данного и автономного субъекта. В этом смысле формула Origo трансформируется в (некое)-Я-посредсmвом-Здесь-и-Сейчас.

Подобный подход к функционированию поэтического дейксиса вряд ли применим к нарративной или эмоционально-экспрессивной лирике, предполагающим существование некоего относительно автономного субъекта, т.е. некоего $Я$, которое является непосредственным источником рефлексии и транслирует собственное видение мира и себя в нем. В герметичной поэзии субъект либо ставит самого себя под вопрос, либо оказывается частично или полностью дезинтегрированным во времени и пространстве, либо вовсе отсутствует (в том случае, когда субъектные позиции в тексте не эксплицированы и лишь подразумеваются). В данном случае «пустота» универсального знака (прежде всего личного местоимения, воязыковляющего категорию субъективности) заполняется в интерактивном процессе письма: конституирование субъекта происходит здесь и сейчас, причем на характер субъективации влияют разнообразные внутритекстовые взаимосвязи, в том числе и эксплицированные пространственный и временной модусы.

Конституирование субъекта само может стать предметом поэтической рефлексии, как мы уже видели на примере текста Л. Хаппель. С этой точки зрения, поэтический сборник Барбары Кёлер (Barbara Köhler, род. 1959) „Deutsches Roulette“22 [Немецкая рулетка], особенно его первые две части, может рассматриваться как своеобразный поэтический эксперимент. Локализация в ряде текстов связана с пространством перед, позади и внутри зеркала, которое, в свою очередь, имеет долгую культурную традицию в качестве артефакта, непосредственно отражающего субъекта и побуждающего его к саморефлексии. К пространственным маркерам в текстах относятся ключевые слова расстояние (Abstand), граница (Grenze), переход (Übergang) и т.д., а также дейктические указания, уточняющие положение субъекта по отношению к зеркалу. Зеркальное отражение становится простран-

${ }^{22}$ Köhler (1991). 
ственным средством трансформащии субъекта, а также его фрагментаризациии и даже отрицания.

Иначе конституирование субъекта происходит в следующем стихотворении Лутца Зайлера (Lutz Seiler, род. 1963):

\section{beton}

zwei graue aufmerksame kinder lehnten

oben im portal das eine

hielt die anstalt in den armen das

andere las es war einmal

$\mathrm{zu}$ früh an jedem morgen und

ein sehnen das

sich selbst nicht kannte ab-

gekniet im katzensilber im granit

der grossen schotterfläche du

bist mîn so standen wir und schauten

hoch für immer ab-

getauscht mit schwerer tinte an

den fingerspitzen spastischen

kapuzen-küssen ich

bin dîn: aus kies, zement, armierungseisen. ${ }^{23}$

\section{бетон}

двое серых внимательных детей облокотились

на высоте портала один

все здание держал в руках

другой читал про жили-были

так каждым ранним утром и

тоска саму

себя не знавшая колени преклонила

вглубь плит из гравия в гранит

кошачье серебро $m b l$

моя так мы стояли и смотрели

наверх всегда внизу

обмениваясь тяжелыми чернилами на

пальцах судорожными

поцелуями под капюшоном $я$

твой: из цемента, гравия, железа арматуры

${ }^{23}$ Seiler (2003, S. 49). 
Пространственные маркеры paccblnaны по всему тексту, с ними связано и упоминание некоего заведения (Anstalt), также перечислены различные строительные материалы, из которых это пространство слагается (beton [бетон], granit [гранит], katzensilber [«кошачье серебро», слюда], kies [щебень, гравий], eisen [железо], zement [цемент]). Что касается восприятия пространства, то могут быть отмечены по крайней мере две перспективы: верхняя (oben, im Portal [сверху в портале]) и нижняя, откуда направлен взгляд (,so standen wir und schauten / hoch“" [так мы стояли и смотрели наверх]). Смысловая неопределенность, имманентная данному тексту, имеет, однако, свои границы: так, например, при первом прочтении можно с большой степенью уверенности утверждать, что это любовное стихотворение (ср. признаки любовного сценария: kapuzen-küsse [поцелуи под капюшоном], „du bist mîn - ich bin dîn“" [ты моя - я твой] и др.). Однако внимание к упомянутым текстуальным перспективам и пространственно-объективным маркерам помогает установить факт наличия автоинтертекстуальных связей данного стихотворения с рассказом Л. Зайлера „Kapuzenkuss“24 [Поцелуй под капюшоном], что, в свою очередь, открывает доступ к более глубоким смысловым пластам поэтического текста. Рассказ ведется от лица мальчика, и в нем повествуется о первой обоюдной влюбленности двух школьников под молчаливым «покровительством» и «благословением» скульптуры, размещенной в портале школы:

[...] Die einzigen, denen ich am Morgen begegnete, waren die beiden braunen Steinkinder über dem Eingang zur Schule. [...] bei den Kindern im Portal handele es sich um Hans und Margarethe, die früheren Hänsel und Gretel. Sie seien die Wappenkinder der Anstalt gewesen. [...] Im Portal befand sich ein großes ovales Fenster, an dessen Einfassung die beiden Steinkinder lehnten, links Margarethe, rechts Hans $[\ldots]^{25}$

[...] Первыми, кого я встречал утром, были два коричневых каменных ребенка над входом в здание школы. [...] детьми этими были Ганс и Маргарете, в прошлом - Гензель и Гретель. Они были символом здания. [...] В портале было большое овальное окно, и оба ребенка облокачивались на его выступ: слева - Маргарете, справа - Ганс [...]

Графический маркер в поэтическом тексте (курсив), который у Л. Зайлера и в других произведениях в основном маркирует пространство интертекста, во второй строфе отсылает к традиционному сказочному зачину „еs war einmal““ (дословно «был некогда...», аналог в русской культуре - «жилбыл»), а далее - к средневековому тексту неизвестного автора, написанному на средневерхненемецком и восходящему к XIII веку - „du bist mîn, ich

\footnotetext{
${ }^{24}$ Seiler (2009, S. 59-109).

25 там же, S. 62.
} 
bin dîn“ [ты - моя, я - твой $]^{26}$ - до сих пор данный текст считается одним из старейших любовных стихотворений на немецком языке.

Обозначенные интертекстуальные связи непосредственно влияют на формирование субъективной перспективы в тексте. Возникает по крайней мере одна субъектная оппозиция, противопоставляющая коллективный субъект wir [мы] и два автономных, графически маркированных субъекта ich [я] и du [ты], которые, однако, вступают в отношения взаимопринадлежности, эксплицитно выраженной в тексте посредством притяжательных местоимений (я - твой, ты - моя - или наоборот). Данная субъектная оппозиция может, однако, рассматриваться и через призму идентификации, поскольку $\boldsymbol{м b l}$ складывается из я и $\mathbf{m b l}$. В общем интерпретативном контексте

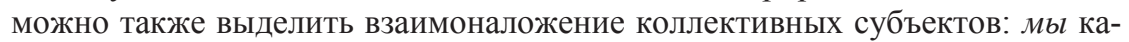
менных детей в портале и $\boldsymbol{M b l}$ тех, кто смотрит на них снизу, - и, вполне вероятно, идентифицирует себя с ними.

В современной русской поэзии субъект и характер его присутствия в поэтическом тексте также нередко становятся предметом поэтической рефлексии. Так, я в некоторых текстах Полины Андрукович (род. 1969) ставит себя под вопрос, выnaдает из заданных пространственных координат:

«весь день я провёл во мшанике,

но мшаника не было, поезд

остановился

на половине.» 27

Глагольная форма прошедшего времени (провел) локализует положение субъекта (во мшанике) и указывает на некий промежуток времени (весь день). Однако возникает некоторое противоречие, поскольку пространство лишено тех объективных признаков, которые были обозначены с позиции субъекта („но мшаника не было“), т.е. субъект воспринимал себя в некой отсутствующей точке пространства. Другой вариант интерпретации рассматривает некую воображаемую локализацию субъекта, которую, однако, сам субъект воспринимает как реальную. В этом случае имагинативное не совпадает с объективным, и в этом смысле поезд становится символом их несовпадения, поскольку он, объект поэтической объективной реальности, не достигает своей цели - мшаника, т.е. пространства имагинации. И в том, и в другом случае противоречия основываются на расхождении пространственного восприятия субъектом и самого пространства - и ставят под сомнение либо объективность пространства, либо самого субъекта.

В большинстве текстов поэтического сборника «Зимняя медицина» ${ }^{28}$ (2015) Дмитрия Воробьева (род. 1979) практически отсутствуют знаки

${ }^{26}$ См. стихотворение и комментарий к нему: http://www1.uni-frankfurt.de/fb/fb10/IDLD/ ADL/mitglieder/schuhmann/30_Du_bist_m_n_pdf.pdf (25/05/2017).

${ }^{27}$ Андрукович $(2014$, с. 39).

${ }^{28}$ Воробьев (2015). 
субъекта. Однако в тех случаях, когда личное местоимение $я$ все же обнаруживается, оно часто согласуется с несоответствующей грамматической формой глагола:

[...] я мечтает говорить точно

просто

страница не найдена ${ }^{29}$

[...] а когда я вернется куда

а когда я вернется зачем

а когда я вернется постой

$[\ldots]^{30}$

«Объективирующая» глагольная форма, остранивающая позицию субъекта, позволяет рассматривать $я$ как некий сторонний, автономный предмет, само присутствие и необходимость которого подвергаются сомнению (ср. вопросы куда, зачем и императив, сдерживающий возвращение $я$ - поcmoй). В другом примере очуждение я происходит благодаря согласованию с глагольной формой среднего рода, за счет чего я теряет свой пол: «я стало таким несносным». ${ }^{31}$

Для следующего текста релевантными дейктическими средствами означивания субъектных позиций являются указательные местоимения, а сами субъектные позиции определяются соотношением с пространственными и временными координатами:

Тот который падает в снег

пока тот

который падает в снег

ещё стоит

и тот

который падает в снег

еще поёт

слёг

который падает в снег

в снег

который падает в снег

\footnotetext{
${ }^{29}$ Там же, с. 57.

30 Там же, с. 49.

31 Там же, с. 53.
} 
который падает в снег

который падает ${ }^{32}$

Примечательна структурная идентификация того, который naдаem в снег и самого снега, который nадает в снег. «Объективированный» субъект под конец исчезает, пропадая под снегом и не оставляя никаких следов.

Итак, в рамках поэтического текста индексальные знаки участвуют в формировании дейксиса, однако их указательная функция полностью определяется и ограничивается данным конкретным текстом. То же самое касается и знаков субъекта: поэтический субъект в контексте смысловой неопределенности как дискурсивной доминанты - это прежде всего текстовая инстанция, конструкт, лишенный конкретного референта. К знакам субъекта относятся личные местоимения, в поэтическом тексте они являются знаками-заменителями субъектных позиций; маркируя личную перспективу, они, тем не менее, не являются непосредственной точкой отсчета дейктического центра. Субъект в герметичной поэзии часто становится перформативным элементом, его конституирование осуществляется посредством взаимодействия темпорального и локального дейктических модусов, сообщающих ему определенное содержание, что исключает существование пред-данного субъекта. Сам процесс конституирования субъекта может стать предметом поэтической рефлексии, в этом случае в тексте будет ярко выражен метаязыковой уровень, проблематизирующий значение «пустых» знаков - потенциальных носителей субъективности; за счет различных методов остранения, имеющих метаязыковую основу, значение и содержание знаков субъекта релятивируются. Эффекты остранения имеют и «объективирующую» функцию: субъект предстает в качестве локализованного объекта, который, однако, потенциально сохраняет связь со своей субъектной позицией. Для множества герметичных поэтических текстов характерен и полный отказ от знаков субъекта.

Таким образом, конституирование поэтического субъекта коррелирует с особым функционированием дейксиса в поэтическом дискурсе: субъект может быть неопределен, неясен, недостоверен, сомнителен, дезинтегрирован или вовсе устранен - он подвижен и подвержен изменениям, это своеобразный Протей - в таком же подвижном, текучем «возможном мире» поэтического текста.

32 Там же, с. 10. 


\section{Литература}

Андрукович, П. (2014): Вместо этого мира. М.

Барт, Р. (2002): Ролан Барт о Ролане Барте. Пер. с франц. С. Зенкина. М.

Бенвенист, Э. (1974): Общая лингвистика. Под редакцией, с вступительной статьей и комментарием Ю. С. Степанова. М.

Воробьев, Д. (2015): Зимняя медицина. Чебоксары.

Глазова, А. (2008): Петля. Невполовину. М.

Данилова, Н. (2001): Знаки субъекта в дискурсе. Самара.

Падучева, Е. (1985): Высказывание и его соотнесенность с действительностью. М.

Bühler, K. (1978): Sprachtheorie. Die Darstellungsfunktion der Sprache. Frankfurt / Berlin / Wien.

Ehlich, K. (2009): Deixis und Dichtung - Linguistische Überlegungen. In: Dannerer, M. / Mauser, P. / Scheutz, H. / Weiss, A. (Hgg.): Gesprochen - geschrieben - gedichtet. Variation und Transformation von Sprache. Berlin. 67-79.

Fricke, E. (2007): Origo, Geste und Raum - Lokaldeixis im Deutschen. Berlin / New York.

Happel, L. (2009): Land ohne Land: Gediche. Unterschächen.

Köhler, B. (1991): Deutsches Roulette: Gedichte. Frankfurt a.M.

Seiler, L. (2003): vierzig kilometer nacht: Gedichte. Frankfurt a.M.

Seiler, L. (2009): Die Zeitwaage: Erzählungen. Frankfurt a.M.

Tawada, Y. (2011): Abenteuer der deutschen Grammatik. Tübingen.

Volli, U. (2002): Semiotik. Eine Einführung in ihre Grundbegriffe. Tübingen. 



\section{Ольга Северская (Москва)}

\section{«Субъект» современной поэзии как прагматическая переменная}

Применительно к современной поэзии довольно часто звучит тезис о «растворении субъекта», отсутствии в текстах ярко выраженного личностного начала. Например, Л. Оборин замечает:

Поэты отказываются говорить и становятся оптикой. ${ }^{1}$

Действительно, поэтическое «я» сегодня оказывается знаком без референ$\mathrm{Ta}^{2}{ }^{2}$ а потому более, чем когда-либо может присваиваться любым говорящим, делая лирическое высказывание одновременно и сугубо личным, и анонимным, «ничьим».

В этих случаях можно говорить о «Я» как о прагматической переменной, ${ }^{3}$ которая, наряду с другими - «ТЫ», «ЗДЕСЬ» и «СЕЙЧАС», - не обладает семантической «полновесностью», однако, отождествляя объекты, события, пространственно-временные отрезки, указывает на присутствие в тексте говорящего и его точку зрения. ${ }^{4}$ А значит, позволяет обрисовать те области текста, которые оказываются значимыми для интерпретации заложенного в нем авторского сообщения о мире.

Собственно, именно они помогают автору и читателю достичь согласия в пресуппозиции, при котором отправная точка интерпретации совпадает с определенной пространственно-временной точкой повествования. Это достигается мысленным введением адресата в ситуацию непосредственного общения. Она моделируется языковыми средствами, «фиксирующими центр восприятия и очерчивающими некоторый микромир, находящийся в

1 Это мнение он высказал в ходе дискуссии о новой поэтической субъективности, которую организовал журнал «Знамя» (цит. по: Чупринин 2012). Та же мысль присутствует в предложенных участниками диспута понятиях «анонимности говорящего» (Б. Кенжеев), «фиктивных фигур авторства» (М. Степанова), «литературной псевдонимии» (И. Роднянская). Подробнее об этом сказано в Северская (2018).

${ }^{2}$ Как замечает Фарино, «безреферентность, условность лирического „я“ ведет к тому, что реципиент такого высказывания легко принимает это „я“ на себя, идентифицируется с ним», а «статус лирического „я“ подобен статусу не речевого „я“, а „я“ языкового» (Фарино 2004, с. 155).

${ }^{3}$ Напомним, что прагматическими называются переменные, которые входят в смысл большинства предложений и определяют то, что принято называть индексом, или точкой, референции (Падучева 1985, с. 39-40).

${ }^{4}$ Падучева (1996, с. 258-259). 
поле непосредственного наблюдения». ${ }^{5}$ В силу автореферентности поэтического высказывания, непосредственно данными (как бы «наблюдаемыми») предстают референтные ситуации, выделенные в пространстве означающих с помощью речевых жестов. Среди прочих способов актуализации ${ }^{6}$ особое место занимает непосредственное указание на тот или иной коммуникативный контекст.

Читатель может стать «свидетелем» некого речевого акта. Либо происходящего «здесь» и «сейчас» (по отношению к миру текста), либо имевшего место «там» и «тогда» (по отношению к нынешней позиции автора и читателя, в одном из возможных состояний текстового мира), что подчеркивается употреблением глагольных форм, соответственно, в настоящем или в прошедшем времени, иногда в сочетании с воспроизведением прямой или косвенной речи «чужого» разговора. ${ }^{7}$ Но при этом автор и читатель наблюдают за тем, что говорилось «там» и «тогда», из одной и той же точки, маркированной координатами «Я», «ТЫ», «ЗДЕСЬ» и «СЕЙЧАС»: 'я здесь и сейчас рассказываю тебе о неком разговоре' - это значение можно приписать авторской речи, 'я здесь и сейчас слышу и воспринимаю твой рассказ о некоем разговоре' - читательской.

Побуждение читателя вступить в коммуникацию с автором выражается либо с помощью адресованного всем и каждому риторического вопроса (например: А. Парщиков, «Мемуарный реквием»; И. Жданов, «Дом»); либо с помощью императива, приглашающего читателя осуществить свой речевой акт: Попробуй мне сказать... (И. Жданов, «Фоторобот запретного мира»); Поговори со мной... (С. Гандлевский, «А вот и снег. Есть русские слова...»). ${ }^{8}$

Пожалуй, самым явным указанием на то, что коммуникация происходит «здесь» и «сейчас», служат актуализированные в контексте поэтического высказывания прагматические переменные «Я» и «ТЫ» в сочетании с глаголами говорения и восприятия в перформативном употреблении: $\boldsymbol{Я}$ говорю о простых вещзах (М. Айзенберг, «Сад им. Баумана»); И что бы ни сказал ты - [...] $\boldsymbol{я}$ - говорю тебе (В. Аристов, «Стихотворение в трех частях»); я говорю после твоего слова [...] ты спрашиваешь меня что есть

\footnotetext{
${ }^{5}$ Ковтунова (1986, с. 4, а также с. 11).

${ }^{6}$ К ним относятся иконическое выделение референта с помощью звукосмыслового повтора, прямое указание на референт или референтную ситуацию, которое активизирует фоновые знания и устойчивые представления, формирующие интерпретационный фрейм, а также реализация прагматических переменных (Северская 2013a, с. 126-139).

7 Об этом говорят примеры «портретирования» речевых актов А. Парщиковым, С. Соловьевым, с одной стороны, или воспроизведение их в контексте авторской речи А. Драгомощенко, Н. Искренко и Т. Щербиной - с другой, которые уже становились предметом анализа (там же, с. 133-134).

8 Здесь и далее цитаты приводятся по поисковому контенту поэтического подкорпуса Национального корпуса русского языка (http://ruscorpora.ru/search-poetic.html, 30/01/2018).
} 
истина и я говорю тебе дзен ты / спрашиваешь в чем заключается истина и я говорю тебе в / шепоте (Е. Даенин, «Приближение к Дзен»); Что я сказал? Повтори (А. Драгомощенко, «Кондратий Теокопокулос на перекрестке в ожидании гостя»); [...] я тебя окликаю [...] (А. Драгомощенко, «Эротизм») ${ }^{9}$ и т.п.

Нередко высказывания с прагматическими переменными «Я» и «ТЫ» указывают читателю на наличие прецедента «говорения того же самого»: Подсолнухи Ван Гог Опять аукцион / я список лотов дочитал до середины / и вышел вон / из недокупленной надышанной картины (В. Кривулин, «Подсолнухи»), - здесь не только первая строка (благодаря сходству ритма и синтаксической структуры) отсылает к прецедентному тексту О. Мандельштама «Бессонница, Гомер, тугие паруса...», но и практически полностью совпадает описание акта восприятия с говорящим некого текста. Различается только его содержание: список кораблей в тексте-источнике и список лотов в заимствующем тексте, но различие это не существенное, так как лот - это не только 'аукционный товар', но и 'навигационный прибор для измерения глубин с борта судна' ${ }^{10}$ Таким образом, мандельштамовские корабли и кривулинские лоты оказываются метонимически связанными в одной поэтической ситуации, а списки, в которых они упоминаются, указывают на один речевой акт, точнее - на его начало и конец (один поэт прочел - 'читая, воспринял' - список, другой его дочитал 'окончил чтение, довел его до конца или какого-либо предела'). При этом сам акт чтения предполагает наличие «первосказания» ${ }^{11}$ и его присвоения, т.е. совпадения двух точек референции в прагматически переменном «Я»: читать значит 'воспринимать что-либо написанное или напечатанное, произнося вслух или воспроизводя про себя’. «Я» прецедентного текста превращается в имплицитное «ТЫ», с которым и вступает в коммуникацию «Я» текста-реципиента. ${ }^{12}$ Так создается то, что Ковтунова предлагает называть «открытым ассоциативным образным рядом». ${ }^{13}$

\footnotetext{
${ }^{9}$ При этом воспроизводится не только устная, но и письменная речь, ср.: Странно, / будто я пишу тебе на тот полусвет (С. Соловьев, «Стекло»); Перевернуты строки, / Которые я пытаюсь прочесть (В. Аристов, «Дом Платона»).

10 Формулировки контекстных смыслов здесь и далее вытекают из значений, приписываемых соответствующим словам в «Большом толковом словаре русского языка» (Кузнецов 2008).

11 Золян «первосказавшим» называет реального автора или персонаж, которому приписывается высказывание в мире текста, и замечает, что в поэтическом тексте с «Я» может отождествляться любой из «говорящих одно и то же» (Золян 1988, с. 26).

12 Прием расщепления референции «Я» с помощью отсылки к прецедентному тексту используется современными поэтами довольно часто. В частности, об этом говорит и пример из «Появления героя» Л. Рубинштейна: Ну что я вам могу сказать! [...] Послушай, что я написал, где «Я» ассоциируется и с говорящим «ЗДЕСЬ» и «СЕЙЧАС»,
} 
Некоторые поэтические школы (например, школа метареализма) прямо декларируют «прозрачность» и «проницаемость» субъектной позиции, помещая адресата и адресанта, «тебя» $и$ «меня» - в «соты полые предложения», в «пробел между словами» (А. Драгомощенко, «Эротизм»), ${ }^{14}$ а также в заимозависимость индексов референции: зря я ищу тебя, собой не являясь (А. Парщиков, «Бегство-2»); Расстояние между тобой и мной - это и есть ты. [...] И когда ты стоишь предо мной, рассуждая о том и о сем, / я как будто составлен тобой из осколков твоей немоты (И. Жданов, «Расстояние между тобой и мной...»). ${ }^{15}$ Другие же воздерживаются от подобных деклараций, но строят дейктическую систему своих текстов, основываясь на том же понимании «растворенной субъективности», ${ }^{16}$ «прозрачности», которой поэты наделяют не имена, а местоимения. ${ }^{17}$

Можно говорить и о том, что сами поэты осознают множественность возможных для этого знака референций, что также легко подтверждается: я раздвоюсь (А. Еременко, «Вдоль коридора зажигая свет...»), я фантом и чья-то часть (И. Жданов, «Попробуй мне сказать, что я фантом...»); [...] отпущено поровну всем, и ты понимаешь, что не в означивании дело, но в исключении (А. Драгомощенко, «Кондратий Теотокопулос на перекрестке...»). Иногда даже создается впечатление, что «я»-субъект испытывает некий «кризис самоидентификации»: [...] я неразличим [...] (И. Жданов, «Область неразменного владенья...»); [...] я не тот, кто (А. Драгомощенко, «Кондратий Теотокопулос пишет письмо сыну»); Но у каких менял / взамен себя как есть я получу - меня? (И. Кутик, «Вступле-

и с пушкинской Татьяной (Я к вам пишу - Чего же боле? Что я могу еще сказать?) и Пушкиным как «говорящими одно и то же» (Северская 2013a, с. 136-137).

${ }^{13}$ Ковтунова (1979, с. 267).

${ }^{14} \mathrm{O}$ прозрачности и проницаемости А. Драгомощенко пишет часто, например: Звездное роение в абсолютной прозрачности субъекта и объекта. [...] Я наклоняюсь к тебе («О фабуле разветвляющегося города»); «Я» не нуждается в действующих лицах. Поэтому ты - только ты, $\boldsymbol{я}$ - только я, исчезающие в проницаемости («Продолжали быть...»).

15 При этом не все поэтики можно назвать я-центричными: чаще всего местоимение 1го лица используют И. Жданов (2,7 употреблений на страницу текста), С. Соловьев $(1,9)$, А. Парщиков $(1,7)$, у последних двух преобладает все же конкретно-референтное $я$, что объясняется установкой на изобразительность, и А. Драгомощенко $(1,5)$, который преимущественно рассматривает $я$ как языковой феномен; значительно реже $я$ встречается у В. Аристова и И. Кутика (в среднем - 1 употребление на страницу); а Е. Даенин обходится практически без местоимений (его коэффициент - 0,3).

16 Судя по примерам из поэтического подкорпуса Национального корпуса русского языка, это характерно и для отдельных поэтик, ср. у В. Кривулина: $\boldsymbol{я}$ ли, [...] став чертою / линией от «я» до «ты»? .. («Знали прикуп, жили в Сочи...»); $\boldsymbol{я}$ - подобье адресата («Одические строфы»).

$17 \mathrm{O}$ «прозрачности» как «проницаемости» и соотношении этого представления с концепцией «прозрачности» языкового знака Э. Гуссерля уже однажды говорилось (Северская 2013b). 
ние»). ${ }^{18}$ Проективность референции обусловливается сменой точки зрения, при этом вектор проекции может как объективировать субъект: $\boldsymbol{Я}$ смотрю на свет и себя стыжсусь (М. Айзенберг, «На ходу превращается прежний сон...»), так и наделять объект восприятия субъективностью: $\boldsymbol{\boldsymbol { A }}$ - всего лишь проблеск глазного дна (И. Жданов, «На новый год»).

Прежде всего, «Я» при таком понимании - это и не 'обозначение говорящим самого себя', и не 'обозначение сознаваемой человеком собственной сущности, самого себя как личности, индивидуума', а скорее некий пустой знак, готовый вобрать в себя любой смысл. Этому есть множество подтверждений, приведем лишь самые яркие примеры: $\boldsymbol{я}$ человек пустой (М. Айзенберг, «За ночь кровля почти промокла...»); я чувствовал рождение Пустыни / где смерчевый столбняк приблизился ко мне (В. Кривулин, «Столбняк в пустыне»); наряду с «пустотностью» упоминается и «нулевое проявление» «Я»: меня как будто нету (В. Кривулин, „Allegro vivace“"); Меня никто не знает. / Меня как будто нет (И. Жданов, «Крещение»). ${ }^{19}$

Интересно, но ожидаемо, что пустота знака «я»-субъекта заполняется речью в различных ее проявлениях: Кто я здесь? [...] любое слово (М. Айзенберг, «Если кто исчез удачно...»); $\boldsymbol{я}$ [...] как бы на полях письма / неразборчивое слово (В. Кривулин, «Хоть бы кто-нибудь хороший»); Что $\boldsymbol{я}$ ? сnазмы горловые / хрипота ли? (В. Кривулин, «Сумерки в бассейне»). Но и «я»субъект способен наполнять пустоту содержанием и вербализоваться, например, занимая пазы отверстых голосов (И. Жданов, «Мастер»). Когда «я» обретает голос и способность произносить слова, начинается автокоммуникация: И сам с собой минут на пять вась-вась / я (С. Гандлевский, «Мне нравится смотреть...»); Что я услышу, когда закричу? (М. Айзенберг, «Надо мной стоит человек-гора...»), либо обмен речевыми актами.

В некоторых случаях это совпадает. Иллюстрацией могут послужить следующие строки: И, собирая речь свою по капле, / я повторяю (А. Еременко, «Дума»). С одной стороны, речь черпается «я»-субъектом из реки слов: в тексте актуализируется и стереотипное поэтическое сопоставление речи и реки, и общеязыковое представление о текучести речи, в соответствии с которым речь льется, слова же цеедт, выдавливают из себя по капле. Иначе говоря, «я»-субъект заимствует высказывания предшественников и повторяет их в своем речевом акте. С другой стороны, подразуме-

\footnotetext{
18 Для «самоопределения» говорящему «я»-субъекту порой требуется «собеседник», т.е. некое «ты», которое может находиться и в мире с другими пространственно-временными координатами: Нащупать бы себя. Я слухом ночь тревожу, / но нет, притихла ночь, не верит ни на грош (И. Жданов, «Крещение»), - с одной стороны, коммуникация с ночью осуществляется «здесь» и «сейчас», с другой - «я»-субъект находится в «этом» мире, тогда как «ты»-субъект представляет мир «тот».

19 О преобразовании философского концепта «пустоты» в поэтический убедительно рассуждает Н.М. Азарова (Азарова 2013).
} 
вается, что слова, которые «я»-субъект произносит, особым образом распределяются во времени. Это подтверждает одним из своих значений глагол повторить - 'сказать еще раз то же самое'. Таким образом, «Я» говорит с нами «ЗДЕСЬ» и «СЕЙЧАС», но его локализация векторно двунаправлена и открыта: к «ТАМ» и «ТОГДА» в прошлом (эксплицитно - собирать можно только то, что уже имеется к моменту речи) и в будущем (имплицитно, потенциально - повторение может быть неоднократным). ${ }^{20}$

Что касается актуализации во времени и пространстве, то полезно будет проанализировать, как местоимения «Я» и «ТЫ» ведут себя в микроконтекстах, содержащих «эгоцентрические» (т. е. указывающие на «Я» высказывания) элементы дейксиса: именно они выделяют поле восприятия, общее для адресанта и адресата сообщения.

В норме «Я» должно определяться координатами «ЗДЕСЬ» и «СЕЙЧАС», - даже когда «я»-субъект использует прошедшее или будущее время, он находится именно в этой временной точке, по отношению к которой все и определяется. И именно в этой точке должен оказаться «ты»-субъект, чтобы правильно определить коммуникативную перспективу. В поэтическом тексте «ЗДЕСЬ» превалирует над «СЕЙЧАС», так как указывает, в соответствии со словарным значением лексемы, на место, время и обстоятельства речи, обозначая хронотоп, как в следующем примере: Мне здесь nять, - брякнул гений. Mьл отдали должное снимку (С. Гандлевский, «Вот когда человек средних лет...»). С этой координатой связаны и другие эгоцентрические слова, в частности, указательные местоимения этот, эта, это, выделяющие нечто близкое в пространственном или временном отношении: $\boldsymbol{Я ~ е д и н с т в е н н ы и ̆ ~ с в и д е т е л ь : ~ Э т а ~ м е с т н о с т ь ~ м н е ~ з н а к о м а ~ ( М . ~}$ Айзенберг, «Приникает к темной яви...»). Эффект приближения реальности к говорящему достигается и с помощью реализации метафор, сравнений и иных образных выражений с использованием притяжательных местоимений 1-го лица: Это мне мой кот наплакал, наилучший из котов (М. Айзенберг, «Потихоньку речь течет...»).

Впрочем, не всегда это приближение именно к «я»-субъекту: неизвестно я или не-я / это видит из толпь [...] (В. Кривулин, «Сонет с обратной перспективой»). И не всегда он оказывается здесь, т.е. в этом месте: Я приезжий, я нездешний (М. Айзенберг, «Я приезжий, я нездешний...»); ${ }^{21} \mathrm{a}$

\footnotetext{
20 «Здесь» и «сейчас» обычно связывают с сенсорным, а «там» и «тогда» с эпистемическим восприятием (Руднев 1966, с. 29). Определяемые соответствующими координатами высказывания в представлении читателя связываются метафорически или метонимически: посредством этого «говорящий (следовательно, всякий человек) последовательно вычленяет из мира, определяемого координатами „я“-,,здесь“-,,сейчас“ - из тесного круга, прилегающего к его телу и совпадающего с моментом его речи, другие миры» (Степанов 1985, с. 229).

${ }^{21}$ Ср.: [...] это не здесь [...] (А. Драгомощенко, «Эротизм»).
} 
иногда не может себя в этой точке пространства обнаружить: где я? где $\boldsymbol{я}$ здесь? (В. Кривулин, «Повод высказаться»); где-то [...] я [...] раздавалось (И. Жданов, «Мастер»). Чрезвычайно интересно используются в современных поэтических текстах местоименные наречия цели и следствия: сохраняя свою цельнооформленность и основное значение, они переосмысливаются, вступая во взаимодействие с пространственными координатами. Так, в зачем за счет оживления внутренней формы акцентируется признак соположения в пространстве двух сущностей: зачем я здесь (В. Кривулин, «По Твоему слову»), - «я»-субъект как будто оказывается за или рядом с другим говорящим, «уступая» ему свою «законную» позицию; в данном случае в точке поэтического пространства, определяемой координатой «ЗДЕСЬ», звучит и Голос Бога, а «ЗДЕСЬ» становится точкой совмещения двух миров, фокусом интерпретации, точкой развития возможного диалога. Нечто похожее происходит и в другом случае: Мне не туда, я не затем (М. Айзенберг, «Вот пух: он так же сам собой...»), с той разницей, что тут речь об отдаленной перспективе с координатой «ТАМ». ${ }^{22}$

В большинстве случаев можно говорить о смещении дейктических координат, например, об актуализации «Я» в областях поэтического мира с координатами «ТАМ» и «ТОГДА», обычно приписываемых «ТЫ» (и наоборот). В том числе в областях, не названных прямо, но определяемых как те или иные по косвенным признакам (в частности, по лексико-семантическим соответствиям и оппозициям).

Как показывает Национальный корпус русского языка, в современной поэзии на то, что «Я» находится именно «ЗДЕСЬ», указывают, прежде всего, такие лексемы, как тело, земля, песок, холмы, река, лес, роща, поле, ромашки, муравьи и т.п.; с координатой «ТАМ» связаны горы, небо, облака, ветер, птицьы, тишина, немота, сон, память, мысли, душа, пустьлня, ночь, холод(ок), могила, что согласуется с традиционным поэтическим противопоставлением этого, сего и того мира.

Поэтическое «Я» хорошо чувствует себя как в «этом»: Цветьл увядиие, я так люблю смотреть / в пространство, ограниченное слева / ромашками (А. Еременко, «Вечерний сонет»), так и в «том» мирах: Еще природы вечная одыика / надеется, что я ее прочту (М. Айзенберг, «Еще блеснет, теряя осторожность...»), - это высказывание, при кажущейся «здешности» и

${ }^{22}$ Ср. у М. Айзенберга: Кто мне вслед обронит слово [...]? «Я»-субъект различим в отдаленной перспективе, он удаляется от точки актуализации, а «здесь» и «сейчас» говорит кто-то другой - mbl, он, она, они, обычно находящиеся «там» и «тогда», но эта точка референции немедленно трансформируется в свою противоположность, как только меняется перспектива воображаемого диалога и «я»-субъект улавливает оброненное слово, как уже где-то и когда-то прозвучавшее. 
«сиюминутности», звучит (как следует из текста) там, «где только шум и шорох, или крик, а голос человека неуместен». ${ }^{23}$

Можно наблюдать и пространственно-временное расщепление референции, поскольку в одном контексте могут совмещаться два плана - ближняя и дальняя перспективы: В жизни я много чего забыл, / но помню тот яркий осенний день - / озноб тополей на сентябрьском ветру, синее небо [...] (С. Гандлевский, «Когда я был молод...»); потолок - уже небо хотя штукатурка в лоскутьях / небо, конечно, иначе кому я молюсь (В. Кривулин, «Ослепленный Блок»). В первом примере на нечто, что когда-то было, но к моменту речи прошло, указывает глагол забыть - 'оставить в прошлом, упустить из виду / не взять с собой', в то время как глагол помнить переводит план прошлого в план настоящего и - в возможной перспективе - будущего. При этом тополя - это атрибут земного, «сего» мира, а небо - это уже мир «тот». Во втором случае граница между небом и землей проходит по потолку: вертикаль объединяет небесный свод мироздания и свод здания.

Иногда поэт использует координату «ЗДЕСЬ», выделяя ею в фокусе контраста предмет речи и поэтического осмысления: Местами Тибр серебряный, но пробы / не видно из-за быстрого теченья. / Я был здесь триждbl. Хочется еще (С. Гандлевский, «Вот римлянка...»), - в норме должно было бы быть там, но здесь подает читателю Тибр как на ладони.

«ЗДЕСЬ» как фокус контраста может и не присутствовать в тексте эксплицитно. Но легко восстанавливается в соотношении с координатой «ТАМ», от которой «я»-субъект дистанцируется, как в следующем примере из «Взгляда» И. Жданова:

В воронке взгляда гибнет муравей,

в снегу сыпучем простирая лапки

к поверхности, которой больше нет.

Там нет меня. Над горизонтом слова взойдут деревья и к нему примерзнут я никогда их не смогу догнать, -

«ТАМ» и «ТОГДА» относятся как к прошлому, так и к будущему, а поскольку «я»-субъекта там нет, то методом исключения он обнаруживается «ЗДЕСЬ» и «СЕЙЧАС», откуда и берут начало две отдаленные перспективы.

В большинстве случаев мы имеем дело с пограничными ситуациями и взаимопроницаемостью пространств, а «я»-субъект может переходить границу в разных направлениях: побывав «там», оказаться «здесь», находясь «здесь», обращаться к тому, что «там», чувствовать себя «там», как «здесь» и т.д. ${ }^{24}$ Не случайно и довольно частое употребление форм где-то, где-то

\footnotetext{
${ }^{23}$ Об этом говорят такие словесные «маркеры», как память, сон, заочность, у ямы на краю (*на краю могиль), утрата, духи, безголосые, слепье, глухие дни, облачная завеса и т.п.

${ }^{24}$ И кажется, такие перемещения ему жизненно необходимы, ср.: Я умру здесь, сомкнув створы «сейчас» (А. Драгомощенко, «Возможность исключения»).
} 
здесь, где-то там. «Тот» мир, как и «этот», обнаруживается рядом, возле, вокруг той части поэтического пространства, той точки, с которой соотносится «Я». При этом «я»-субъект может впускать тот мир в этот, «здешний»: Я окна открыл. Пусть ветер гуляет по комнатам (А. Еременко, «Хоку»); или же вбирать мир в себя, как у И. Жданова: и мир во мне очнется, и шевельнется звук («Контрапункт»); горы во мне продолжают расти («Полустанок...»); вода, как будто к разговорам / полузаснувших рыб прислуииваясь, [...] льется сквозь меня («Крещение»). Интересно и то, что внутреннее пространство ассоциируется, прежде всего, с домом: дома - это и значит «ЗДЕСЬ». ${ }^{25}$

Как можно было убедиться, «Я» в современных поэтических текстах действительно становится некой переменной величиной, способной принимать различные значения. При этом «Я» оказывается принципиально диалогичным: как отмечал Е. Фарино, «я» может быть употреблено только при обращении к кому-то, кто предстанет как «ты» и, став «эхом» говорящего, в свою очередь обозначит себя, обращаясь к нему, как «я». ${ }^{26}$ Если воспринимать речь как поток, то не скажешь лучше И. Жданова, который в «Плыли и мы в берегах...» так сформулировал свое отношение к новой субъективности: Больше того, чем я не был и что я такое, / в этом потоке я быть не могу и не стану...

\section{Литература}

Азарова, Н. (2013): Как современная поэзия осваивает традиционную и новую философскую лексику // Шталь, Х. / Рутц, М. (ред.): Имидж, диалог, эксперимент - поля современной русской поэзии. München / Berlin / Washington. 209-230.

Золян, С. (1988): Поэтическая семантика и семантико-композиционная организация поэтического текста. Ереван.

Ковтунова, И. (1979): Структура художественного текста и новая информация // Золотова, Г.А. (отв. ред.): Синтаксис текста. М. 276-288.

Ковтунова, И. (1986): Поэтическая речь как форма коммуникации // Вопросы языкознания. 1, 1986. 3-13.

Кузнецов, С. (ред., 2008): Большой толковый словарь русского языка. СПб. / М. http://www.gramota.ru/slovari/info/bts/ (2/02/2018).

Национальный корпус русского языка. Поэтический корпус. http://ruscorpora.ru/searchpoetic.html (15/09/2016).

Падучева, Е. (1985): Высказывание и его соотнесенность с действительностью. М.

25 По всей вероятности, это связано с хайдеггеровским образом «дома языка» и введенным им различением «здешности» и «здесь-бытия» (Хайдеггер 1993, с. 264).

${ }^{26}$ Фарино (2004, с. 608). 
Падучева, Е. (1996): Семантика нарратива // Падучева, Е.: Семантические исследования (Семантика времени и вида в русском языке. Семантика нарратива). М. 195-418.

Руднев, В. (1996): Теоретико-лингвистический анализ художественного дискурса. М.

Северская, О. (2013а): Поэтическое высказывание и смысловая композиция текста (структурный и коммуникативный аспекты) // Красильникова, Е. (отв. ред.): Поэтическая грамматика. Т. 2. М. 122-176.

Северская, О. (2013b): Лингвистическая философия метареализма (поэзия и поэтическая метатеория) // Шталь, Х. / Рутц, М. (ред.): Имидж, диалог, эксперимент - поля современной русской поэзии. München / Berlin / Washington. 91-117.

Северская, О. (2018): Субъект лирический или публицистический? От чьего имени говорит новая социальная поэзия // Шталь, Х. / Евграшкина, Е. (ред./сост.): Субъект в новейшей русскоязычной поэзии - теория и практика. Frankfurt a.M. 325-341.

Степанов, Ю. (1985): В трехмерном пространстве языка. М.

Фарино, Е. (2004): Введение в литературоведение: Учебное пособие. СПб.

Хайдеггер, М. (1993): Время и бытие: Статьи и выступления. Пер. с нем. В. Бибихина. М.

Чупринин, С. (2012): Стихи без героя? Приглашение к дискуссии // Знамя. 11, 2012. http://magazines.russ.ru/znamia/2012/11/c11-pr.html (30/01/2018). 


\section{Людмила Зубова (Санкт-Петербург)}

\section{Субъект и объект в современной поэзии}

Человек на протяжении всей его жизни задумывается о том, в каких ситуациях он является субъектом, а в каких объектом, когда и почему он становится исполнителем чьей-то воли (инструментом), то есть в каких отношениях он находится с другими людьми, с природой, историей. И, конечно, рефлексия на эту тему - постоянный предмет философии, психологии, искусства.

В статье рассматриваются эксперименты современных поэтов (начиная со второй половины XX века), направленные на такое употребление языковых единиц, которое не соответствует привычным представлениям о субъекте и объекте и некоторых других участниках денотативной ситуации (инструменте, адресате), а часто и прямо противоположно привычным представлениям.

Это явление анализируется в статье на примерах, связанных преимущественно с категориями залога, лица, одушевленности, падежа, но затрагиваются и некоторые периферийные способы выражения субъектно-объектной оппозиции. ${ }^{1}$

Структура статьи основана на тех процессах, которые наблюдаются при анализе поэтических вольностей в функционально-семантическом поле объектности-субъектности и смежных участках других функционально-семантических полей.

Перечислю эти процессы и соответствующие разделы статьи:

1. Обмен участников ситуации актантами «субъект», «объект», «инструмент».

2. Дистанцирование от субъекта «я» и его устранение.

3. Устранение противоречий между грамматикой и семантикой актантов.

4. Создание неоднозначности на основе грамматической полисемии.

\footnotetext{
${ }^{1}$ Поскольку тема субъекта и объекта проявляется в разных грамматических категориях, некоторые примеры и фрагменты их анализа рассматриваются в книге: Зубова (2010) и статьях: Зубова (2004; 2009; 2012a; 2012b, 2012c; 2015).
} 


\section{1. Обмен участников ситуации актантами}

«субъект», «объект», «инструмент»

Смешение субъекта с объектом - одна из главных тем экзистенциальной философии, отраженной искусством XX века:

Субъект и объект эквивалентны, что составляет логическое содержание нашей современности. ${ }^{2}$

Оппозиции субъект / объект, активность / пассивность - центральные для самоидентификации поэта. Для многих современных авторов, особенно вольно обращающихся с языковой нормой, характерно убеждение в том, что их право на поэтические вольности определяется не властью над языком, а подчиненностью языку, ${ }^{3}$ только не как норме, а как стихии. ${ }^{4}$

Так, в стихотворении Веры Павловой оказывается, что книга пишет автора, а в стихотворении Александра Кабанова - что книга читает автора.

Вечерний свет и вечерний звон -

соавторы книги этой.

Ее цитирует сладкий сон,

чтоб не захотелось рассвета.

Она раздувает пламя твое

и брызжет оно, и пышет,

и ты считаешь, что пишешь еe, когда она тебя пишет. ${ }^{5}$

\footnotetext{
${ }^{2}$ Смирнов (1994, с. 12).
}

${ }^{3}$ Представление о первичности языка имеет глубокую основу в мировой культуре: «Слиянность, неразложимое единство, взаимозаменимость в практике ритуального действа имени и вещи - органическая часть образной системы мифологической картины мира, для которой вообще был характерен образный синкретизм, субъектно-объектное единство. Миф же о творении мира словом принадлежит также к числу основных, коренных индоевропейских мифов» (Резанова 1999, с. 86).

${ }^{4}$ Наиболее выразительно это было сказано в Нобелевской лекции Иосифа Бродского: «Кто-кто, а поэт всегда знает, что то, что в просторечии именуется голосом Музы, есть на самом деле диктат языка; что не язык является его инструментом, а он - средством языка к продолжению своего существования [...] независимо от соображений, по которым он берется за перо [...] немедленное последствие этого предприятия - ощущение вступления в прямой контакт с языком, точнее ощущение немедленного впадения в зависимость от оного, от всего, что на нем уже высказано, написано, осуществлено. Зависимость эта - абсолютная, деспотическая, но она же и раскрепощает. Ибо, будучи всегда старше, чем писатель, язык обладает еще колоссальной центробежной энергией, сообщаемой ему его временным потенциалом - то есть всем лежащим впереди временем» (Бродский 1998, с. 15).

5 «Эту книгу читает вслух...» (Павлова 1999). Здесь и далее выделение мое - Л.3. 
Крымско-татарское иго вновь из бутылки хлебнешь.

Рядом раскрытая книга душно. И вряд ли уснешь.

Воблы сушеная фишка в черном квадрате окна. Спи, моя старая книжка, пусть тебе снится весна.

Винница, пьяная Ницца, все, что угодно судьбе... Только не с мясом страница, только не пепел в трубе.

Гул пролетевшего МИГа, утра зазубренный край...

Спи моя старая книга, больше меня не читай. ${ }^{6}$

В обоих случаях речь идет о том, что человек сформирован тем, что он написал в своих книгах. У В. Павловой изображается процесс становления человека, а у А. Кабанова говорится о том, что человек не может быть адекватно понят судя по тому, что им было написано давно: ранее написанное уже не вполне соответствует новому состоянию человека и препятствует дальнейшему развитию личности.

Следующий текст с переосмыслением субъектно-объектных отношений выразительно демонстрирует обмен актантов высоким и низким рангами:

В весенний сумрак

Под грузом сумок

С едою, купленной впрок.

И мой со мною, и мой со мною сурок.

...А как все это кончится, камни сточатся,

Отговорит и рощица, и пророчица,

Автомобили втянутся гаражами,

Гости - вокзалами, залами, этажами,

Шляпы - коробками, сны и сигары - ртами,

Все поменяются шубами и местами,

В час, когда будет можно все то, что хочется,

С ветхой единой-плоти одежды сбросив,

Что они сделают? сняв убор из колосьев

С женской родной седеющей головы?

Лягут лежать как псы

${ }^{6}$ «(Колыбельная для книги)» (Кабанов 2005, с. 58). 
и

Будут лежать, как львы. ${ }^{7}$

Здесь субъектно-объектная перевернутость утверждает приоритет мира вещей по отношению к человеку. В этом тексте изображается ситуация за пределами жизни персонажей. Вещи оказываются долговечнее людей, к вещам переходит роль субъектов, но и в этом случае наблюдается обмен ролями уже между предметами: обнаруживается, что не гаражи предназначены для автомобилей, а автомобили для гаражей, не коробки для шляп, а шляпы для коробок. И люди (гости) предназначены для вокзалов. Со всей очевидностью в этом тексте представлено понижение главных участников ситуации в ранге и повышение второстепенных.

Обращенность субъектно-объектных отношений приводит к олицетворению предметов.

А. В. Бондарко пишет:

Между функциями С[убъекта] / О[бъекта] и различием одушевленности / неодушевленности существует определенное распределение, заключающееся в том, что признак «одушевленность» сочетается преимущественно с функцией С[убъекта], а признак «неодушевленность»- преимущественно с функцией О[бъекта]. [...] Обмен ролями - когда неодушевленный предмет выступает в качестве подлежащего в именительном падеже, а одушевленное существо - как прямое дополнение в винительном падеже - ведет соответственно к известному оттенку персонификации. ${ }^{8}$

В рассмотренном тексте дополнение выражено не винительным, а творительным падежом, и от этого персонификация оказывается еще более выразительной.

В тексте М. Степановой можно видеть не только одушевление предметов, типичное для поэзии вообще, но и явление глубоко архетипическое:

[...] языческие ритуалы в целом ряде случаев определяются представлением о перевернутости связей потустороннего (загробного) мира [...] оба мира посюсторонний и потусторонний - как бы видят друг друга в зеркальном отображении $[. .$.$] перевернутость поведения выступает как естественное и$ необходимое условие действенного общения с потусторонним миром или его представителями. ${ }^{9}$

В стихотворении Давида Паташинского люди предстают инструментами неизвестно кого (в структуре неопределенно-личных предложений):

порцию невезухи кто еще нас поймет

были мы люди-мухи нами любили мед

были мы люди-суки были глаза сухи

ты не давай мне руки не подавай руки

7 «Свадьба принца Чарльза и Камиллы Паркер-Боулз в прямой трансляции немецкого канала RTL» (Степанова 2006).

${ }^{8}$ Бондарко (1992, с. 49).

${ }^{9}$ Успенский (1994, с. 321, 323). 
утренней укоризной сморщенное лицо

были глаза как призмы свернутые в кольцо

наша душа - потемки вытертые до дыр

были мы люди-терки нами строгали сыр

нами вино лакали нами давили тлю

этими вот руками что я тебя люблю ${ }^{10}$

В этом случае преобразование субъектно-объектных отношений вместе с дефисными конструкциями люди-мухи, люди-терки указывает на зависимость человека от обстоятельств жизни.

О том, что человек - не главный в природе, он даже не объект, а инструмент, сообщается и в таком стихотворении:

Толстый комар пролетел, засмеялся и вышел,

Хлопнув ладонью моей по запредельной щеке.

Снова в глазах тишина, и таращатся голые окна,

К мирной постели моей пасть разевая свою. ${ }^{11}$

Комар здесь персонифицирован и на лексическом уровне: он назван толстым, а не крупным, о нем говорится, что он засмеялся и вышел (а не вылетел). И окна здесь таращатся и разевают пасть - рисуется вполне сказочная картина, в которой активными субъектами оказываются все кроме человека. Человек же здесь представлен метонимически: только ладонью, причем и ладонью он не сам распоряжается.

В следующем стихотворении говорится о распределении семейных ролей:

Уже который год, лишь вечер настает, как пара лошадей, мы дружно ходим цугом.

Я штопаю носки, ты чинишь дисковод.

Да что ж это с тобой мы делаем друг другом?!

Ты моешь мной полы, стираешь мной белье, Готовишь мной на стол, когда приходят гости, А я тобой смотрю, как мент гнобит жулье, Чиню тобою кран и забиваю гвозди.

Потом ты мной родишь двоих-троих парней, Ты выкормишь их мной и вырастишь на славу, А я тобой куплю сперва, что помодней, Потом авто, гараж и пони на забаву.

И годы - чередой, а мы-то вразнобой

Все чешем чехардой, усердны и упрямы.

Ты будешь мной любить, а я любить тобой, Друг другом застолбив Канары и Багамы...

10 «Немного цвета» (Паташинский 2006, с. 72).

11 «Ночь через форточку воет тихонько в квартире...» (Кучерявкин 2001, с. 122). 
Однажды ты поймешь, что твой черед настал,

Что жизнь уже прошла, и не переиначишь,

Но так же, как любил, и так же, как дышал,

Ты мною смерть свою оплатишь и оплачешь. ${ }^{12}$

В семейной жизни муж и жена нередко спорят (или, по крайней мере, задумываются) о том, кто что должен делать, кто кого и как использует. Эта тема развита Марией Ордынской в подробностях. Намек на конфликт содержится в строчках: И годы - чередой, а мы-то вразнобой / Все чешем чехардой, усердны и упрямы. Однако именно в радикальной трансформации субъектности и инструментальности изображена гармония семейных отношений.

Клишированное сочетание друг с другом преобразуется в авторское друг другом. Может быть, это связано с тем, что предлог с представлялся неуместным при жизни вразнобой, как сказано в стихотворении.

Аномалия глагольного управления в сочетании друг другом ${ }^{13}$ при детальном развертывании темы повлекла за собой и другие грамматические сдвиги, относящиеся к управлению глаголов. Норма сочетаемости (точнее, узус, так как подобная норма нигде не зафиксирована) не предусматривает инструментальной валентности глаголов, представленных авторскими сочетаниями: готовишь мной, тобой смотрю, ${ }^{14}$ мной родишь, тобой куплю, мной любить. ${ }^{15}$

Преобразование непереходных глаголов в переходные нередко заполняет лакуны в системе субъектно-объектных бинарных оппозиций, например, в таких текстах:

Чей праздник здесь жил, волосами звеня?

Чьи флейты мистерий? Чьи магий мантильи?..

Меня не любили - болели меня...

(Чье сердце столиц?) ... и, естественно, мстили. ${ }^{16}$

Ты веришь в Бога? Он меня живет минуя тело спящими ночами а в комнате - московский снег идет и девушка проходит между нами ${ }^{17}$

12 «Уже который год, лишь вечер настает...» (Ордынская 2008, с. 131).

${ }^{13}$ Сочетание друг другом в норме возможно, но только не с глаголом делать, а в предложениях типа мы довольны (не довольны) друг другом, они гордятся друг другом. Вероятно, предикат в таких случаях должен указывать на состояние, а не на действие.

14 Творительный падеж при глаголе смотреть возможен только в плеонастическом сочетании смотреть глазами или в метафорах типа смотреть волком.

15 Впрочем, творительный падеж при глаголе любить имеется во фразеологическом сочетании любить всей душой.

16 «Хутор потерянный» (Соснора 2006, с. 603).

17 «Новая Эллада» (Поляков 2003, с. 121). 
Первый из этих примеров примечателен тем, что импульсом к транзитивации глагола болеть, возможно, является рифма жалели - болели. Предположительно, механизм сдвига таков: *не жалели меня $\rightarrow$ болели меня. Синонимия слов любить и жалеть в русском языке, особенно в просторечии и диалектах, хорошо известна. В таком случае аномальное управление порождено стиховой структурой.

Импульсом сдвига во втором примере являются не внутриязыковые ассоциации, а, скорее всего, исключительно когнитивная потребность заполнить лексико-грамматическую лакуну:

Бога вообще нельзя понять вне грамматики и метафизики переходности [...]

Бог не просто нас творит в начале и спасает в конце (если мы сами того захотим), но он есть действующее начало во всем, что составляет наше существование. Поэтому и можно сказать, что он нас существует. ${ }^{18}$

\section{2. Дистанцирование от субъекта «я» и его устранение}

Устранение субъекта - одна из главных установок постмодернизма. ${ }^{19}$ Выражения смерть автора, смерть субъекта, восходящие к статье Р. Барта, впервые опубликованной в 1967 г., ${ }^{20}$ часто употребляются в критике и литературоведении не только метафорически, но и терминологически. $^{21}$

В современной поэзии устранение субъекта часто выражается на грамматическом уровне - либо неупотреблением местоимения $я$ и глагольных форм 1-го лица единственного числа, либо рассогласованием глагола с местоимением $я$.

На практике это выглядит, например, так (в ситуации объяснения в любви):

Ах, Наталья, idol mio,

истукан и идол!..

Горько плачет супер-эго, голосит либидо!

18 Эпштейн (2007).

${ }^{19}$ Постмодернизм понимается не как направление, а как ведущая тенденция в мировосприятии, свойственная второй половине XX века.

${ }^{20}$ Барт (1994).

21 «,СМЕРТЬ АВТОРА“ - парадигмальная фигура постмодернистской текстологии, фиксирующая идею самодвижения текста как самодостаточной процедуры смыслопорождения» (Грицанов / Можейко 2001, с. 771).

«,СМЕРТЬ СУБЪЕКТА“ - метафорический термин для обозначения одного из двух полюсов амбивалентной тенденции размывания определенности субъект-объектной оппозиции в рамках постмодернистской программы преодоления традиции бинаризма, фиксирующий отказ постмодернистского типа философствования от презумпции субъекта в любых версиях его артикуляции (ино- , поли- и, наконец, бес-субъектность „непознаваемого субъекта“ эпохи постмодерна)» (там же, с. 80). 


\section{Говорит мое либидо}

\section{твоему либидо:}

«До каких же пор, скажите,

мне терпеть обиды?» ${ }^{22}$

Ирония Кибирова здесь направлена и на себя, и на учение Зигмунда Фрейда о психоанализе, который объясняет поведение и чувства человека бессознательным. Ироническая тональность текста усиливается тем, что маркером отстраненности становится не только сам термин либидо, но и средний род этого термина. Автор как бы снимает с себя ответственность за свои чувства, но при этом он воспроизводит традиционный образ любви как стихийной силы.

При рассогласовании глагольной формы с местоимением демонстрируется раздвоенность сознания, когда субъект высказывания смотрит на себя как на объект: ${ }^{23}$

Зато я никому не должен никто поутру не кричит и в два часа и в полдругого зайдет ли кто - а я лежит ${ }^{24}$

Это дерево губить что-то неохота, ветром по небу трубить вот по мне работа.

Он гудит себе гудит, веточки качает. На пенечке кто сидит?

Я сидит, скучает. ${ }^{25}$

наигравшись в привиденья снег утратил прежний вид рухнул навзничь без движенья он - лежит, а я - летит

\section{я плывет со мною рядом}

приглашая всех в полет и с небес лукавым взглядом знак условный подает ${ }^{26}$

22 «Ах, Наталья, idol mio...» (Кибиров 2000, с. 25).

23 «Постмодернистская психика в целом симбиотична [...] У симбиотика с его авторефлексированием нет иного положения в мире, кроме метапозиции» (Смирнов 1994, с. 317).

24 «Я был веселая фигура...» (Лимонов 2003, с. 95).

25 «Песенка» (Лосев 1999, с. 65).

26 «Неошагаловский полет» (Гецевич 1995, с. 14). 
Подобный аграмматизм, который у современных поэтов встречается очень часто, имеет основание во вполне нормативных языковых структурах с субстантивированным местоимением «я» (ср. выражения: авторское «я», поэт отстраняется от своего «я»), а также в высказываниях типа Мама тебе не разрешает (если это говорит сама мать). Кроме того, употребление глагола в 3-м лице при местоимении в 1-м хранит в себе историческую память о структуре высказывания: в древнерусских текстах широко представлены этикетные формулы типа $я$, Федька, челом бьет. Такая синтаксическая контаминация 1-го и 3-го лица демонстрирует, что пишущий переключается с обозначения себя как субъекта речи на обозначение себя как объекта восприятия.

Устранение субъекта, преобразование его в объект получается и при употреблении форм местоимений меня, мне вместо себя, себе, и при замене притяжательного местоимения мой падежной формой меня. Оба этих способа представлены в контекстах, изображающих отделение души от тела:

Усомнившись в себе, поднося свои руки к глазам,

я смотрю на того, кто я сам:

пальцы имеют длину, в основании пальцев -

по валуну,

ногти, на каждом - страна восходящего солнца,

в венах блуждает голубизна.

Как мне видеть меня после смерти меня,

даже если душа вознесется ${ }^{27}$

Вероятно, нормативное требование кореферентности местоимения себя с подлежащим исключает отнесение местоимения меня к субъекту я, хотя и местоимение меня в этом случае тоже вполне кореферентно. Нарушение этой нормы в тексте Гандельсмана указывает на то, что местоимение меня не должно быть кореферентно с подлежащим $я$.

Замена выражения после моей смерти на выражение после смерти меня усиливает отчуждение - вероятно потому, что притяжательное местоимение указывает на принадлежность кому-либо, а после смерти человеку уже ничто не принадлежит.

В следующем примере родительный падеж местоимения себя в сочетании мордочку себя заменяет нормативное притяжательное местоимение мою.

Заходя в ванную, внезапно в зеркале замечаю

забавную мордочку себя. Становясь большими,

утро в чужой стране начинаем с чая,

заканчивая в машине. ${ }^{28}$

Если слово себя в качестве объектного глагольного актанта вполне нормативно (вижу себя, упрекаю себя), то употребление этого местоимения как

27 «Вступление» [из цикла «Шум Земли»] (Гандельсман 1998, с. 6).

28 «Заходя в ванную, внезапно в зеркале замечаю...» (Паташинский 2006, с. 71). 
генитива в определительной функции при существительном оказывается резкой аномалией. На то, что субъект высказывания демонстрирует себя как наблюдателя за собой, указывают и лексическое значение прилагательного забавную, и диминутив мордочку. Следовательно, и эти языковые средства, очевидно периферийные для функционально-семантического поля субъектности / объектности способны выполнять функцию преобразования субъекта в объект.

Средством дистанцирования субъекта речи от своей субъектности является и архаическое местоимение аз, позволяющее воспринимать это слово как указание и на 1-е и на 3-е лицо одновременно:

Дом, в котором угрюмый аз

Не связал ни одной из обещанных дому фраз,

Только вялые длани,

Повторяя растерянно: как пустые копилки, тряс,

- Слава. Слава. Слава. ${ }^{29}$

Несмотря на то, что глагол прошедшего времени не маркирует отстранения субъекта, так как не изменяется по лицам, это отстранение оказывается все же выраженным: определение угрюмый естественно во фразе только если персонаж представлен как объект, описываемый внешним наблюдателем.

Другие примеры с отстраняющим местоимением аз разной степени ироничности:

Чей колокол - клюква? Чей аз - из меня?

Так узнику Эльбы - три крапа, три карты. ${ }^{30}$

Выезжали из дома всегда поутру.

С первым светом, по гулким проспектам.

$$
\text { [...] }
$$

И на заднем сиденьи собака.

Да, на заднем в обнимку собака и аз,

Как двухглавый орел на монете,

В обоюдные стороны впялили глаз:

Только пальцем туда поманите ${ }^{31}$

Кто - мышь для упыря? Бутыль наливки,

Охват крыла, очарованье глаз?

Подруга дней, к которой тайный лаз,

На блюдечке оставленные сливки?

29 «Дом, в котором сегодня ждут...» (Лейкин 1991, с. 76).

30 «Хутор потерянный» (Соснора 2006, с. 102).

31 «Собака» (Степанова 2001, с. 26). 
Готовая, как форма для отливки,

Сижу, сложимши лапки, бедный аз.

На передплечье светятся прививки

Предшественных и будущих проказ ${ }^{32}$

В следующем тексте средством преобразования субъекта в объект становится преодоление лексических ограничений на образование форм лица:

Я - я опять. Не кто-нибудь иной,

А я: никто еще не квартирует,

И некто «я» передо мной шурует,

Как я маячу за своей спиной. ${ }^{33}$

Чтоб, неразумное, не голосило,

Телу пальто покупается в талью.

Я под сорочкой зияю, как сито,

Перед горящей ночами плитою. ${ }^{34}$

Всё зияю... И я, и ее

Зазвеневшее сердце пустое...

Ой, зима, все толкуешь свое?

Ой, толчешься все в сухостое...? ${ }^{35}$

Смотрю вослед своей душе,

как в сумерках на убыль света,

отсутствую и брезжу где-то -

то ли еще, то ли уже. ${ }^{36}$

С неладой-жизнью пребывая рядом,

я обнимаюсь неуемным взглядом,

как лядвеи огромным, и всем стадом

усталым слягу, голову сложу

под этот взгляд, где брежу и блажу,

где еле брезжу, жалобно и нежно,

где чуть ворочаюсь, брезгливо и небрежно... ${ }^{37}$

Ю.Д. Апресян и Е.В. Падучева показали, что в лексическую семантику подобных глаголов входит компонент «врожденный наблюдатель»:

Врожденный наблюдатель имеется у глаголов, выражающих наблюдаемый признак предмета: цвет (белеть, чернеть), форму (маячить, торчать), звучание (раздаться, раздаваться). ${ }^{38}$

32 «20 сонетов к М.» (Степанова 2001b, с. 48).

33 «Я» (Ожиганов 2015, с. 63).

34 «Чтоб, неразумное, не голосило...» (Степанова 2001а, с. 21).

35 «Все зияю... И я, и ее...» (Юрьев 2004, с. 34).

36 «Путник» (Ахмадулина 1995, с. 88).

${ }^{37}$ «Я с жизнью рядом...» (Петров 1994, с. 189).

${ }^{38}$ Падучева (2004, с. 214). 
В первом из этой группы примеров маркерами преобразования субъекта в объект являются и выражение И некто «я», и локализация передо мной, и глагол шурует, сконцентрированные в одной строке, а также начало строфы $Я-я$ опять - с очевидной пресуппозицией иного состояния.

\section{3. Устранение противоречий между грамматикой и семантикой актантов}

Употребление в тексте безличных глаголов, по своей семантике не указывающих на субъект, весьма способствует трансформациям, связанным с субъектом и объектом, активом и пассивом, например:

Я сегодня проснулся от слез. Слезы блестели

в капле лампы ночной, потому что горела.

Видно, вчера не заметилось, как заснулось.

Вот и приснилось. И лампа без толку играла ${ }^{39}$

В этом случае представление о грамматической активности предикатов не заметилось, заснулось противоречит представлению о семантической активности субъекта, и постфикс -ся, превращая личные глаголы в безличные, устраняет конфликт между грамматическим активом глаголов и их семантическим пассивом.

В следующем контексте с окказиональной безличностью (без изменения внешнего облика глагола) автор отказывает в субъектности тому, кого он называет словом никто и чье действие отрицает:

Рожа наружу, внутри никого,

вот он, юрод на ходулях, сшит он

из кровоточащей телячьей кожи,

это идет мое право мычать и право качаться

налево, вправо,

вземь, вниз, из.

Занавески. Они шевелятся,

рассвет наружу, внутри никого,

никого не лезет в окно,

занавески кружатся и крошатся,

в них осыпается шелуха, отпадает известка.

Занавески стоят стеной,

за ними стоит иное. ${ }^{40}$

Пример может быть объяснен такими словами А.В. Бондарко:

Субъектность, находящая выражение в формах косвенных падежей (например, Ee здесь не было), всегда так или иначе «снижается в ранге» по сравнению с субъектностью, выраженной подлежащим в форме им. падежа (ср.: Она здесь только что была), потому что на денотативно-понятийную основу

39 «Я сегодня проснулся от слёз ...» (Иконников-Галицкий 1998, с. 51).

40 «Рожа наружу, внутри никого...» (Боярских 2009, с. 110). 
семантики С[убъекта] наслаивается тот или иной оттенок объектной языковой интерпретации, связанной с формой дополнения. ${ }^{41}$

Е.В. Падучева обращает внимание на то, что в конструкциях типа Коли нет (не было) в Москве «генитив приравнивает наблюдаемое отсутствие к несуществованию». ${ }^{42}$ В тексте Е. Боярских глагол лезет - не экзистенциальный, это глагол активного действия (движения), то есть семантика сочетания никого не лезет противоречит отрицанию и действия, и самого действующего субъекта. При этом семантический компонент наблюдаемости усиливается, укрупняется, а само отрицание, может быть, как раз из-за его обостренной экспрессивности, ставится под сомнение: картина слишком отчетливо изображает лезущего - тем более что занавески кружатся и крошатся, а заканчивается стихотворение строкой за ними стоит иное.

Рассмотрим такой пример со сгущением страдательных причастий прошедшего времени:

Ладонь кем-то улещена.

Лицо кем-то ошарено.

Ты мною намерещена,

Ты мною накошмарена. ${ }^{43}$

По формулировке В.А. Плунгяна, «граммемы залога маркируют переключение внимания говорящего, тот „кадр“, в фокус которого поочередно попадают разные участники ситуации». ${ }^{44}$

Здесь в фокус внимания попадает семантический объект, названный словом $m b l$, и становится синтаксическим подлежащим (синтаксическим субъектом, противоречащим логическому субъекту). В этом случае можно было бы говорить о сопряженной субъектности, о которой писал А.В. Бондарко: сопряженная субъектность состоит в том, что функция субъекта состояния совмещена с функцией объекта действия, как в сочетании ботинки начищены. ${ }^{45}$

Грамматическая структура в приведенном примере побуждает видеть субъект состояния в актанте $m b l$. Но логика ситуации, а точнее, лексические значения результативных причастий препятствуют такому восприятию. Некто она (mbl) мерещится не сама себе, а субъекту высказывания, и кошмар испытывает именно он, а не она. Но можно ли кого-то назвать субъектом действия мерещится? Логически - он явный пациенс, а не агенс, следовательно, и субъект состояния - он, а не она. Казалось бы, это противоречит теоретическому положению о сопряженной субъектности. На поверхностном уровне - да, но если задуматься о смысле поэтического высказывания, можно интерпретировать текст так: в результате постоянных мыслей

\footnotetext{
${ }^{41}$ Бондарко (1992, с. 48).

42 Падучева (2006, с. 105).

43 «Ладонь кем-то улещена...» (Власов 1994, с. 34).

${ }^{44}$ Плунгян (2000, с. 195).

${ }^{45}$ Бондарко (1992, с. 46).
} 
автора-персонажа его любимая изменяется в его сознании, превращаясь в то, что мерещится и становится кошмаром (или персонажем кошмарных снов). То есть она действительно оказывается субъектом состояния.

Этот пример затрагивает и категорию переходности, поскольку промежуточным звеном между нормативным глаголом мерещзиться и авторскими причастиями намерещена, накошмарена являются имплицитные окказионализмы намерешить, накошмарить. К современному жаргонному слову кошмарить в значении 'запугивать, устрашать' этот текст не имеет отношения, но примечательно, что в жаргоне такой глагол возник, осуществив словообразовательную потенцию, сходную с той, которая реализована в стихотворении.

\section{4. Создание неоднозначности на основе грамматической полисемии}

В следующем тексте автор устраняет возвратный постфикс слова колотится, и в результате этой деформации возникает грамматическая многозначность глагола:

Гулкий филин, обозначивая соседство,

рядом со мной на кипарис уселся.

Рука у груди - самое лучшее средство,

если неровно колотит сердце

с той стороны стеклянной клетушки.

А земля полна клевера или кашки.

Иногда мне становится так душно,

что становится страшно ${ }^{46}$

Здесь глагол колотит можно понимать и как глагол действительного залога, то есть как предикат, отнесенный к субъекту сердие, и как безличный глагол, при котором актантом сердце обозначен объект воздействия, и как член потенциальной синонимической пары колотит - колотится (ср.: узуальную синонимическую пару стучит - стучится).

Грамматическая неоднозначность, создающая субъектно-объектный синкретизм, наблюдается и в таких строчках:

Я б выучил гэльский на птичьих утесах,

Где воздух знобит от мелькания чаек.

Я знал бы ответы на ваши вопросы,

Которые вы задаете случайно. ${ }^{47}$

Исходя из презумпции безличности, в норме имманентно свойственной глаголу знобить, слово воздух в сочетании воздух знобит следует понимать как обозначение объекта винительным падежом существительного (с инверсией подлежащего и дополнения). Но все же есть и альтернатива восприятия, тем более что у того же автора встречается несомненная трансформация

46 «Небо наклонилось...» (Паташинский 2006, с. 69).

47 «И я мог бродить...» (Дидусенко 2006, с. 208). 
безличного глагола в личный: И крепко дымиалось: ещче и ещзе! / Морозило. Осень знобила плечо. ${ }^{48}$

Совпадение страдательных причастий настоящего времени с личной глагольной формой 1-го лица множественного числа выполняет художественную функцию в таком тексте:

И, просекаемый сейчас,

Терновник мглист,

И еле слышим мягкий смех,

Чуть видим лик. ${ }^{49}$

На такую омонимию обратила внимание Н.М. Азарова. В результате анализа многочисленных примеров она выдвинула гипотезу:

Возможно усмотреть в русском философском и поэтическом текстах наличие регулярного сопряжения категории лица с категорией залога в неличной форме на -ем/-им под влиянием или в ситуации непосредственной близости с личной формой первого лица множественного числа глагола, что ведет к имплицированию категории лица (персональности) в форме на -ем/-им. ${ }^{50}$

В своем исследовании Н.М. Азарова опирается на такое положение А.В. Бондарко:

Отношение к лицу может быть либо относительно самостоятельной характеристикой высказывания, или некоторого его элемента, либо характеристикой, сопряженной с какой-то иной семантической категорией, например, посессивной (мой дом). В некоторых языках возможно сопряжение категории лица и с иными семантическими категориями. ${ }^{51}$

Фокусируя внимание на теме «субъект и объект», добавлю, что в этом случае личными формами глаголов сльишим, видим обозначен грамматический актив, а, следовательно, существительными смех, лик обозначены объекты сенсорного восприятия. Если же интерпретировать слова сльлиим, видим как страдательные причастия, то существительные смех, лик оказываются обозначением грамматических субъектов. Конечно, в ранговой иерархии актантов приоритетен актант $\boldsymbol{M b l}$, но его неэксплицированность местоимением заставляет читателя воспринимать слова сльиим, видим как равноправные в своей грамматической двойственности.

Много примеров грамматической неоднозначности связано с категорией падежа. Например, значения именительного и родительного падежей совмещены в таком контексте:

Повсеместно окрест ни светло, ни темно,

И в созвучии: око - икона - окно, -

Обещание вещего знака,

Словно все, что случится, лежит на кону...

48 «Был месяц растущий, растущий туда...» (Дидусенко 2006).

49 «Полезно опусканье глаз...» (Вольф 2001, с. 42).

${ }^{50}$ Азарова (2010, с. 167).

${ }^{51}$ Бондарко (2002, с. 544). 
И, поодаль застывши, молчит на луну

Осторожная злая собака. ${ }^{52}$

Строку обещзание вещчего знака можно понять по-разному: и 'созвучие дает сигнал о вещем знаке' и 'вещий знак обнаруживается созвучием'. Двойственность эта смысловая, она направлена на объединенное восприятие субъекта и объекта обещания. К синкретизму объектного и субъектного значений родительного падежа располагает одновременная реализация и субъектной, и объектной валентности отглагольного существительного. Заметим, что автор, перечисляя этимологически родственные слова око, икона, окно, придает статус знака именно звуковому сходству и при этом ставит рядом другие, еще более созвучные исторически однокоренные слова обещзание и вещего.

В стихах Андрея Битова омонимия именительного и винительного падежей, которая иногда препятствует различению субъекта и объекта, становится предметом языковой рефлексии:

Часы без стрелок - завожу их вновь,

И аккуратность заменяет точность.

Смерть побеждает, как всегда, любовь...

Но кто кого? Грамматики порочность. ${ }^{53}$

А Давид Паташинский использует затрудненность такого различения, деформируя известное изречение цель оправдывает средство, воспринимая которое мы обычно не сомневаемся, что в нем подлежащим является слово цุель, а прямым дополнением - слово средство.

Утром любят взять за сердце, камень сердца согревая, утром дети пьют густое голубое молоко,

цель выдумывает средство, а судьба у нас такая

доживать, что дали, стоя, если плакать нелегко. ${ }^{54}$

Автор, разрушая фразеологизм замещением сказуемого и вставляя фразу в поэтический контекст, заставляет читателя задуматься о том, что все-таки первично - цель или средство. Стиховая структура здесь особенно релевантна: если в практической речи ранг актантов может зависеть от порядка

52 «Полнолунье» (Перельмутер 1997, с. 87).

53 «Рассвет» [стихи Ленечки из повести «Лес»] (Битов 1997, с. 36).

54 «Утром каменные люди любят взять меня за сердце...» (Паташинский 2006). 
слов, ${ }^{55}$ то в поэзии инверсия является нормой, ${ }^{56}$ следовательно, слово цель во фрагменте цеель выдумывает средство способно быть и подлежащим, и дополнением, выдвинутым в начало высказывания.

Полисемия дательного падежа, который может быть и дательным субъекта и дательным адресата, располагает к объединению этих значений, например, в таком стихотворении:

этим - купанным на кухне в оцинкованных корытах

со младенчества играющим у церкви без креста

не писать на Пасху золотых открыток

серебристой корюшки не ловить с моста

оловянная свинцовая а то и в каплях ртути

их несла погода спеленав сукном

а теперь и некому просто помянуть их

голубиным словом на полуродном

языке церковном языке огней

отраженных волнами с такой холодной силой

что прижаться хочется крепче и больней

к ручке двери - двери бронзовой двустворчатой резной

где изображен свидетель шестикрылый

их небытия их жизни жестяной ${ }^{57}$

Виктор Кривулин пишет о погибших солдатах. Название стихотворения «Эти» фонетически (и рифменно) подобно слову дети. Слова в оиинкованных корытах, помещенные в первую строку, при развертывании текста вызывают в сознании картину похорон в цинковых гробах.

При совпадении двух значений дательного падежа множественного числа (этим [...] не писать на Пасху золотых открыток) местоимение этим может быть понято как указание и на субъект, и на адресата (т. е. быть и агенсом, и бенефактивом): ‘они не будут писать открыток' и 'никто не будет писать им открыток', 'они не будут ловить корюшку' и 'для них никто не будет ловить корюшку'.

А в следующем тексте совмещение агенса и бенефактива в дательном падеже слова Богу становится возможным благодаря безличному глаголу,

55 «Подлежащее в большей степени, чем другие И[менные] Г[руппы] в предложении, способно находиться в центре внимания участников речевого акта, соответственно оно имеет и высший коммуникативный ранг. Дополнение способно к этому в меньшей степени. Если оно все-таки находится в центре внимания, то это приходится выражать особыми средствами, например, не совсем обычным порядком слов, при котором дополнение стоит в начале предложения» (Тестелец 2001, с. 420).

${ }^{56}$ И.И. Ковтунова указала на принципиальное отличие измененного порядка слов в поэзии и прозе: в прозе инверсии стилистически маркированы актуальным членением предложения, фразовой интонацией, а в стихах они являются нормой и стилистически не маркированы, так как фразовое членение поэтических текстов подавляется ритмическим (Ковтунова 1992, с. 195-198).

57 «Эти» (Кривулин 1988, с. 7). 
нейтрализующему те различия в обозначении субъекта и адресата, которые были бы выражены разными падежами при употреблении личных форм глагола (кто-то улььбался Богу или ульљбался Бог).

Под это дело хорошо спалось

В пустом дому, что был через дорогу,

И думалось, и мнилось, и пилось,

И без ехидства улыбалось Богу. ${ }^{58}$

Конечно, читатель волен выбирать одно из значений, считая омонимию или полисемию помехой для точного восприятия. Но все же в поэтическом тексте неточность не обедняет, а обогащает текст. Можно заметить, что если лексическая полисемия давно освоена - не только как основа игровых приемов, но и как средство серьезного высказывания, то в поэзии конца XX начала XXI века активно осваивается грамматическая полисемия. Авторы иногда сознательно, иногда интуитивно - предлагают нам или не вникать, или, напротив, вникать в противоречия и считать эти противоречия мнимыми.

Современная филология уделяет большое внимание осмыслению неточности и неопределенности в различных речевых жанрах и в эволюции языка (Ю.М. Лотман, ${ }^{59}$ И.И. Ковтунова, ${ }^{60}$ М.Л. Гаспаров ${ }^{61}$ и др.). И здесь важно то, что поэзия в своей лингвистической смелости не только выявляет тенденции развития языка, но и во многом опережает это развитие.

58 «Ночь напролет и зиму бесперечь...» (Знаменская 1997, с. 77).

59 «Функция тропа как механизма семантической неопределенности обусловила то, что в явной форме, на поверхности культуры, он проявляется в системах, ориентированных на сложность, неоднозначность или невыразимость истины» (Лотман 1996, с. 58).

60 «[...] суммируя виды неопределенности в поэтическом языке, в числе главных можно назвать следующие: в плане познавательных категорий и познавательной позиции автора неопределенность чувства, ситуации, субъекта, места, времени, действия, объекта действия, точки зрения; в плане языковых категорий и связей (точнее - когнитивно-языковых) - неопределенность значения слова, неопределенность отнесенности признака (между этими двумя видами неопределенности и тропами границы размыты), неопределенность логикосинтаксических отношений, неопределенность предмета речи (темы); в плане поэтической коммуникации - неопределенность говорящего и адресата. Все эти виды неопределенности проявляются на уровне тропики, лексической семантики, семантико-синтаксических связей, синтаксиса текста» (Ковтунова 1993, с. 113).

${ }^{61}$ По мнению М.Л. Гаспарова, в поэзии ХХ века появился новый троп - антиэмфаза расширение и размывание значения слов; «из-за этой опоры на новый троп, на антиэмфазу, от традиционной к современной поэтике меняется само соотношение между обычным языком и поэтическим языком. Там поэтический язык лишь продолжал обычный язык, надстраиваясь над ним добавочным слоем выразительных средств, - здесь поэтический язык противопоставляется обычному, вторгаясь в него иной структурой выразительных средств. [...] В обычном языке слово моносемизируется контекстом - в поэтическом предложении и целый контекст полисемизируется эстетической изоляцией» (Гаспаров 1986, с. 191). 


\section{Заключение}

Заканчивая статью, приведу цитату из работ А.В. Бондарко:

По существу средства, обычно рассматриваемые в разных главах грамматических описаний, - субъектно-объектные элементы синтаксических структур, субъектно-объектное ядро категории падежа, грамматические категории лица глагола и местоимения, категория залога, лексико-грамматические разряды переходности / непереходности, возвратности / невозвратности, одушевленности / неодушевленности, лица / не-лица - представляют собой элементы единой системы субъектно-объектных отношений. ${ }^{62}$

Я видела свою задачу в том, чтобы показать эту систему в ее динамике, ускоренной художественными функциями языковых элементов.

\section{Литература}

Азарова, Н. (2010): Язык философии и язык поэзии - движение навстречу (грамматика, лексика, текст). М.

Ахмадулина, Б. (1995): Гряда камней. Стихотворения 1957-1992. М.

Барт, Р. (1994): Смерть автора // Барт, Р.: Избранные работы: Семиотика. Поэтика. М. 384-391.

Битов, А. (1997): В четверг после дождя. СПб.

Бондарко, А. (1983): Принципы функциональной грамматики и вопросы аспектологии. Л.

Бондарко, А. (1992): Субъектно-предикатно-объектные ситуации // Бондарко, А. (ред.): Теория функциональной грамматики: Субъектность. Объектность. Коммуникативная перспектива высказывания. Определенность / Неопределенность. СПб. 29-71.

Бондарко, А. (2002): Теория значения в функциональной грамматике. М.

Боярских, Е. (2009): Женщина из Кимея. М.

Бродский, И. (1998): Нобелевская лекция // Бродский, И.: Сочинения: В 8 тт. Т. 1. СПб. 5-16.

Власов, Е. (1994): Знаменитая книга. СПб.

Вольф, С. (2001): Розовощекий павлин. М.

Гандельсман, В. (1998): Эдип. СПб. / Нью-Йорк.

Гаспаров, М. (1986): Историческая поэтика и сравнительное стиховедение (проблема сравнительной метрики) // Мелетинский, E.M. et al.: Историческая поэтика: Итоги и перспективы. М. 188-209.

Гецевич, Г. (1995): Стихи. М.

Грицанов, А. / Можейко, М. (2001): Постмодернизм. Энциклопедия. Минск.

Дидусенко, М. (2006): Из нищенской руды. М.

Знаменская, И. (1997): Глаз вопиющего. СПб.

${ }^{62}$ Бондарко (1983, с. 44). 
Зубова, Л. (2004): Я? (Проблема персональности в современной поэзии) // Grelz, K. / Witt, S. (eds.): Telling forms. 30 essays in honor of Peter Alberg Jensen. Stockholm. 402-415.

Зубова, Л. (2009): Глагольная валентность в поэтическом познании мира // Фатеева, Н. (ред.): Язык как медиатор между знанием и искусством. Сборник докладов международного научного семинара «Проблемы междисциплинарных исследований художественного текста». М. 39-55.

Зубова, Л. (2010): Языки современной поэзии. М.

Зубова, Л. (2012а): Конфликт между грамматикой и лексикой в современной поэзии // Абдулхакова, Л. / Копосов, Д. (ред.): Русский язык: функционирование и развитие (к 85-летию со дня рождения заслуженного деятеля науки РФ проф. В.М. Маркова): материалы Международной научной конференции (Казань, 18-21 апреля 2012 г.). Т. 2. Казань. 278-285.

Зубова, Л. (2012b): Возвратность в функционально-семантическом поле залоговости как объект поэтических экспериментов // Воейкова, М. (ред.): От формы к значению, от значения к форме: Сб. ст. в честь 80-летия А.В. Бондарко. М. 208-228.

Зубова, Л. (2012 с): Одушевленное и неодушевленное в современной поэзии // Вяткина, С. / Руднев, Д. (отв. ред.): Грамматика и стилистика русского языка в синхронии и диахронии: очерки. СПб. 435-457.

Зубова, Л. (2015): Неузуальные страдательные причастия настоящего времени в современной поэзии // Казанский, Н. (отв. ред.): ActaLinguisticaPetropolitana. Труды Института лингвистических исследований РАН. Т. 11. Ч. 1.: Воейкова, М. / Сосновцева, Е. (ред.): Категории имени и глагола в системе функциональной грамматики. СПб. 63-82.

Иконников-Галицкий, А. (1998): Өавор. СПб.

Кабанов, А. (2005): Крысолов. СПб.

Кибиров, Т. (2000): Amour, exil... СПб.

Ковтунова, И. (1992): Современный русский язык. Порядок слов и актуальное членение предложения. М.

Ковтунова, И. (1993): Принцип неполной определенности и формы его грамматического выражения в поэтическом языке XX века // Красильникова Е. В. (отв. Ред.): Очерки истории языка русской поэзии XX века. Грамматические категории. Синтаксис текста. М. 106-154.

Кривулин, В. (1998): Купание в иордани. СПб.

Кучерявкин, В. (2001): Треножник. СПб.

Лейкин, В. (1991): Образы и подобия. Л.

Лимонов, Э. (2003): Стихотворения. М.

Лосев, Л. (1999): Стихотворения из четырех книг. СПб.

Лотман, Ю. (1996): Внутри мыслящих миров. Человек - текст - семиосфера - история. М.

Ожиганов, А. (2015): Два введения в Игру стеклянных бус (венок сонетов) // Komaromi, A. (ed.; Electronic Archive Project for the Study of Dissidence and Samizdat): The Samizdat Journal 37 [Transcript based on the copy of ,37“ № 5 (1976) at the Historical Archive, Institute for the Study of Eastern Europe, University of Bremen, F. 75]. Toronto. https://samizdatcollections.library.utoronto.ca/islandora/object/samizdat\%3A37_5/datastream/PDF/view (8/05/2018).

Ордынская, М. (2008): Уже который год, лишь вечер настает... // ЛИТО Вячеслава Лейкина. 23. СПб. 131. 
Павлова, В. (1999): Из книги «Площадь соловецких юнг»// Волга. 8, 1999. http://magazines.russ.ru/volga/1999/8/pavl.html (8/05/2018).

Падучева, Е. (2004): Динамические модели в семантике лексики. М.

Падучева, Е. (2006): Диатеза, генитив отрицания, наблюдатель // Храковский, В. С. / Дмитренко, С. Ю. / Заика, Н. М. (редколл.): Проблемы типологии и общей лингвистики. Международная конференция, посвященная 100-летию со дня рождения проф. А.А. Холодовича. СПб. 103-109.

Паташинский, Д. (2006): Немного цвета. СПб.

Перельмутер, В. (1997): Пятилистник. М.

Петров, С. (1994): Я с жизнью рядом // Камера хранения: Литературный альманах. Вып. четвертый. СПб.

Плунгян, В. (2000): Общая морфология. Введение в проблематику. М.

Поляков, А. (2003): Для тех, кто спит. М.

Резанова, 3. (1999): Язык и человек: субъектно-объектные отношения (варианты интерпретации в европейской культурной традиции) // Вестник Томского государственного университета. 268, 1999. 86-89.

Смирнов, И. (1994): Психодиахронологика. Психоистория русской литературы от романтизма до наших дней. М.

Соснора, В. (2006): Стихотворения. СПб.

Степанова, М. (2001a): О близнецах. М.

Степанова, М. (2001b): Песни северных южан: Стихи. М. / Тверь.

Степанова, М. (2005): Физиология и Малая История. М.

Степанова, М. (2006): O // http://znamlit.ru/publication.php?id=3054 (8/05/2018).

Тестелец, Я. (2001): Введение в общий синтаксис. М.

Успенский, Б. (1994): Анти-поведение в культуре Древней Руси // Успенский, Б.: Избранные труды. Т. 1. М. 320-332.

Эпштейн, М. (2007): О творческом потенциале русского языка: Грамматика переходности и транзитивное общество // Знамя. 3, 2007. 193-208.

http://znamlit.ru/publication.php?id=3230 (8/05/2018).

Юрьев, О. (2004): Избранные стихи и хоры. М. 

Субъект в новейшей русской поэзии 



\section{Роберт Ходель (Гамбург)}

\section{Поэтическая форма как фактор идентичности. Сравнительный обзор русской лирики XX века}

Лирика как самый «субъективный вид литературы» отказывается как от «объективности в изображении события» прозы, так и от объективности представления действующих лиц в драме, ради выражения непосредственных чувств с помощью особого художественно организованного языка. ${ }^{1}$ Эта субъективная природа лирики находит свое отражение даже в чисто грамматическом аспекте: если классическое повествование от третьего лица компенсирует отсутствие традиционной (полноценной) речевой ситуации, при которой «говорящий» и «слушающий» находятся в одном месте, с помощью вытеснения эгоцентрических элементов, то лирический текст «делает вид», ${ }^{2}$ будто эта ситуация действительно имеет место. Поэтому лирическое «я» может непосредственно обращаться к лирическому «ты», а дейктические элементы типа это, здесь и сейчас не нуждаются в лирическом тексте в каких-то пояснениях. Неслучайно Е. Падучева подчеркивает относительность границы между лирическим «я» и автором:

Поэтому, между прочим, диегетический мир лирического текста легко отождествляется с реальным; в самом деле, для этого достаточно, чтобы лирический герой стихотворения отождествлялся с его автором. ${ }^{3}$

Исходя из этого, можно предположить, что как раз субъективное изображение реальности в лирике предполагает достаточно строгую организацию выразительных средств. Такая организация защищает автора от той субъективности, которая может восприниматься как ограниченная или банальная, и обеспечивает тексту способность быть понятым на более высоком, всеобъемлющем, уровне. В прошлом эта претензия на объективность находила свое выражение в особом образе поэта с его аурой избранности и гениальности: поэт становился медиумом высших сил и очевидцем высшей реальности, который обладает способностью проникать в самые глубины человеческой души и владеет самыми тонкими нюансами человеческого языка. Поэт в этом смысле - это рапсод, которому Платон в «Ионе» приписывает божественное вдохновение.

Но если при таком понимании лирики допустить, что ее художественная форма нуждается в постоянном обновлении, то можно предположить два

${ }^{1}$ Cм. Wilpert (1989, S. 540).

2 Падучева (1996, с. 208).

3 Там же, с. 209. 
пути ее развития: один из них заключается в обновлении и совершенствовании традиционной поэтической формы, пример чему можно найти в сонете эпохи модерна, или - в наше время - в стихотворном палиндроме (Елена Кацюба) или «листовертне» (Дмитрий Авалиани), а второй - в отрицании этой формы, примером чего служит свободный стих. ${ }^{4}$

Русская поэзия в течении всего XX века шла по первому пути, а западная - по второму. Для того чтобы понять возможные причины такого различия, мы попытаемся сравнить развитие русской стихотворной формы с развитием стихотворной формы немецкой, польской и сербской. Выбор нами поэзии именно этих литератур основан на том, что именно он позволяет учесть некоторые важные языковые, поэтологические, политические и культурно-религиозные особенности, свойственные этим культурам.

Отметим пока лишь некоторые из них: в немецком языке, как и в русском, существует свободное сильное динамическое ударение, и немецкая поэзия, как и русская, основана на силлабо-тонической системе; в польском языке, напротив, присутствует фиксированное (парокситоническое) ударение, и в польской поэзии доминирует силлабический стих; в сербском языке представлено свободное музыкальное ударение, и в сербской поэзии силлабическая система имеет тенденцию к хорею. Польша и ГДР были членами Варшавского пакта, в то время как Югославия была неприсоединенной страной.

\section{1. Развитие стихотворных систем в $\mathrm{XX}$ веке}

\section{1. Русская поэзия}

Хотя в XVIII-XIX веках в русской поэзии прочно утвердилась силлаботоническая система, в период Серебряного века, который М. Гаспаров датирует 1890-1935 гг., «несиллаботонические эксперименты» становятся в ней заметной тенденцией и их число возрастает на 20\%. Большинство этих экспериментов связаны с использованием тонического стиха. Свободный стих, который иногда использовался Блоком, Гиппиус, Сологубом, Каменским, Хлебниковым, Гуро, Крученых и др., а также представителями «пролетарской поэзии», ${ }^{6}$ как в поэзии Серебряного века, так и в ранней советской поэзии 1920-х - начала 1930-х гг., оставался маргинальным явлением:

\footnotetext{
${ }^{4}$ Под свободным стихом мы понимаем стихотворную форму, которая не имеет размера, рифмы и регулярной строфики, но которая предполагает стиховую организацию текста. ${ }^{5}$ Гаспаров (2000, с. 307).

${ }^{6}$ Орлицкий (1995).
} 
После полосы экспериментов около 1920 г. (не только у Есенина или Хлебникова, но и у пролетарских поэтов) он почти начисто исчезает из употребления. Маяковский обращается к нему лишь однажды («1-е Мая», 1923). ${ }^{7}$

Тонический стих, которым в 1925-1935 гг. была написана почти четверть всей поэзии, в свою очередь приобретает в этот период несколько новый характер:

[...] большая часть ее - дольники, которые ближе всего к силлаботонике, ритм акцентного стиха становится строже и проще, из него выделяется даже переходная форма к дольникам - тактовик конструктивистов. ${ }^{8}$

В последовавший затем период советской поэзии (1935-1955) большинство авторов ориентируются на классические образцы и, прежде всего, на Пушкина. Отступления от силлабо-тонической системы занимает не более $12 \%$ всего корпуса стихов, а свободный стих почти исчезает даже из переводов:

Переводя верлибры прогрессивных зарубежных поэтов (Арагона, П. Неруды), переводчики 1940-х гг. то и дело привносят в них ритм и даже рифму. ${ }^{9}$

Только в период хрущевской оттепели, когда советские поэты начинают переводить западную поэзию ближе к оригиналу, ситуация несколько меняется:

[...] три четверти поэтов 1960-1970-х гг. хотя бы раз или два обращались к верлибру, но лишь немногие писали им систематически. В целом в это время на свободный стих приходится около $10 \%$ всех неклассических примеров - больше чем на акцентный стих. ${ }^{10}$

Но несмотря на это, эксперименты с отступлениями от силлабо-тонической системы продолжают оставаться и в этот период второстепенным явлением:

[...] в пору социалистического классицизма 1935-1980 гг. они стабилизируются на $12 \%$ (этот уровень одинаков и в сталинское время, и в хрущевскоепослехрущевское, когда, как известно, некоторым экспортным поэтам вроде Евтушенко и Вознесенского с их подражателями было позволено экспериментировать шире). ${ }^{11}$

По данным Ю. Орлицкого, в период с 1976 по 1980 год доля свободного стиха в поэтической продукции снова снижается на примерно 1\%:

[...] в 1029 поэтических книгах, выпущенных пятью основными крупнейшими

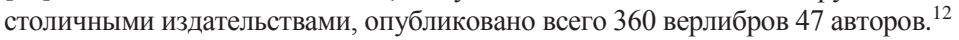

Даже в постсоветской России изменения в области стиха происходят очень медленно. Это ясно показывает исследование, проведенное Гаспаровым на основе текстов шести литературных журналов («Новый мир», «Знамя»,

\footnotetext{
${ }^{7}$ Гаспаров (2000, с. 282).

${ }^{8}$ Там же, с. 304.

${ }^{9}$ Там же, с. 282.

${ }^{10}$ Там же, с. 283.

${ }^{11}$ Там же, с. 307.

12 Орлицкий (2002, с. 388).
} 
«Москва», «Наш современник», «Новая юность», «Арион») за 1997 год. ${ }^{13}$ В среднем использование неклассических размеров снова возрастает в этот период на $20 \%$, хотя данные сильно колеблются в зависимости от направления журнала (от 3,5\% в «Нашем современнике» до $28 \%$ в «Арионе»). При этом 35-40\% приходится как на строгий дольник, так и на верлибр. Эта тенденция, как доказывает составленная автором данной статьи антология произведений 60 поэтов, возрастает в XXI веке: если у поэтов, родившихся с 1940 по 1960 год, ${ }^{14}$ силлабо-тоническая система явно преобладает и только немногие из них последовательно используют свободный стих, то многие поэты, родившиеся с 1960 по 1980 год, ${ }^{15}$ пишут преимущественно верлибром. Стремление к верлибру еще заметнее среди более молодых поэтов, родившихся после середины 1980 -х гг. и в $1990-е$ гг. $^{16}$ и вошедших в литературу после 2010 года. ${ }^{17}$ Тем не менее, метрическая система остается в русской поэзии и в XXI веке актуальной, и ее использование ни в коей мере не сводится к функциям реминисценции или иронии. Скорее, наоборот. Как отмечает Д. Давыдов:

Проблема, собственно, заключается в особой, внестиховой маркированности верлибра в культурной среде. ${ }^{18}$

\section{2. Верлибр в немечкой поэзии}

Как отмечает К. Вагенкнехт, первые элементы свободного стиха, «свободные ритмы» ${ }^{19}$ (freie Rhythmen), были введены в немецкую поэзию в середине

${ }^{13}$ Ср. и Ковалев (2013, с. 10): «В конце XX века [...] количество обращений к верлибрам, доля которых достигает 9,1\% от числа всех поэтических текстов, догоняет дольниковые формы - $12,1 \%$. При этом стоит отметить, что показатели верлибров, составляющих почти половину всех Нкл [неклассических форм] периода 1980-2000-х годов, лежат вне области влияния каких-либо классических компонентов метрического репертуара, что свидетельствует о перемещении центра тяжести в „диффузную зону смешанных пограничных форм“ (Федотов 1997, с. 297) русского стиха, стремительно набирающих силу и развивающихся иначе в начале XX столетия».

${ }^{14}$ Первый том антологии: Hodel (Hg., 2015).

15 Вторая часть антологии готовится к печати и должна выйти в свет в 2019 году.

${ }^{16}$ См. раздел 3.6 .

${ }^{17}$ Ср. раздел 3.7. Кроме верлибра наблюдается и «перестройка поэтического дискурса, ознаменованная выдвижением в центр литературного процесса маргинальных форм»: «Под этим названием выступают различные формы с нарушением метрической природы поэтического текста и выдвижением в качестве структурообразующих внетекстовых факторов - акростих, тавтограмма, палиндром, ономатопея, брахиколон, фигурные стихи, параллелизм, амебейные композиции, реверсивный стих и др.» (Ковалев 2013, с. 6).

18 Давыдов (2013).

19 Свободный ритм лишен размера и рифмы, но, в отличие от модернистского свободного стиха, обладает ярким ритмом и предполагает возвышенную интонацию. Граница между свободным ритмом и свободным стихом, однако, весьма относительна. 
XVIII века Фридрихом Клопштоком. ${ }^{20}$ Сначала они ассоциировались с античными формами оды. Они использовались поэтами «Бури и натиска», прежде всего молодым Гете, а затем Фридрихом Гельдерлином и Генрихом Гейне, которые постепенно освободили эту форму от ассоциации с античными образцами. Этот процесс был завершен Детлевом фон Лилиенкроном и Арно Хольцем, в результате чего «у поэтов-экспрессионистов появилась возможность писать стихи, вообще не связанные никаким размером». ${ }^{21}$

Тем не менее, развитие свободного стиха отнюдь не было в немецкой поэзии прямолинейным и было связано не только с национальной традицией. Сильным импульсом для него стали «Листья травы» Уолта Уитмена („Leaves of Grass“), чей французский перевод Жюля Лафорга был опубликован в журнале «Вог» (,La Vogue“) в 1886 году. Сильное влияние на развитие немецкого свободного стиха оказал также «освобожденный стих» (vers libéré) $^{22}$ французских символистов - Бодлера, Верлена, Малларме и Рембо. Другим важным фактором явились Т.Е. Ульм и Ф.С. Флинт, познакомившие в 1909 году с французским верлибром членов лондонского «Клуба поэтов» („Рoets Club“). Этот клуб стал, в свою очередь, центром движения за свободный стих в поэзии англо-американского имажизма, который в свою очередь оказал влияние на таких поэтов как Т.С. Эллиот, Эзра Паунд и Эми Лоуэлл. Разумеется, это только отдельные важные моменты: свободный стих развивался в творчестве широкого международного круга поэтов и критиков. Одним из первых примеров влияния французского верлибра на немецкую лирику стало, среди прочего, стихотворение Штефана Георге «Позднее лето» (1890). ${ }^{23}$

Вагенкнехт связывает этот процесс с общим отказом модернизма от традиции, который помимо свободного стиха находит свое выражение в отказе от любой строгой художественной формы, будь то разрушение строфики сонета (Бертхольд Брехт) или растягивание строк, при котором рифма отступает на задний план (Эрнст Штадлер, Франц Верфель, Брехт) ${ }^{24}$ Д. Броер отводит здесь особую роль Ницше, чья «переоценка всех ценностей» касалась также нормативных форм поэзии. ${ }^{25}$ В письме Карлу Фуксу (зима 1884 / 1885) Ницше противопоставляет «разухабистый икт» немецкой поэзии античному квантитативному стихосложению. В 1888 году он пишет Фуксу:

Эти два вида ритмики совершенно противоположны в их изначальной направленности и происхождении. Наша варварская (или германская) ритмика

\footnotetext{
${ }^{20}$ Wagenknecht (2007, S. 117-119).

${ }^{21}$ Там же, S. 125.

22 Освобожденный стих (vers libéré) отличается ослаблением метрических правил благодаря произвольному количеству слогов в строке и подвижной цезуре.

${ }^{23}$ Breuer (1991, S. 262).

${ }^{24}$ Wagenknecht (2007, S. 124 f.).

${ }^{25}$ Breuer (1991, S. 231, 247).
} 
понимает ритм как чередование равномерных напряжений аффекта (икта) и расслабленных безударных слогов [...] Наш ритм - это выражение аффек$m a$, в то время как античная ритмика, ритмика времени, стремится подчинить себе аффект и до известной степени его уничтожить. ${ }^{26}$

Как отмечает Броер, эти слова Ницше помогают понять, почему он не видел принципиальной разницы между поэзией и прозой. ${ }^{27}$

Тот факт, что такие поэты, как Стефан Георге, Гуго фон Гофмансталь, Райнер Мария Рильке или Рудольф Борхард, продолжали писать классическими размерами, Броер объясняет как эксперимент сознания с уходящей в прошлое формой. ${ }^{28}$ Поиск экспрессионизма в области формы Броер также толкует как результат «дезориентации и разлада „Я“», который в конечном счете приводит к освобождению от традиционных норм. Правда, это освобождение не сразу делает силлабо-тоническую поэзию чем-то маргинальным. Поэты конца 1940-х - начала 1950-х гг. (Пауль Целан, Гюнтер Айх, Петер Хухель) все еще ориентируются на строгую античную или романтическую форму стиха. Но в течение 1950-х гг. все они постепенно отказываются как от нее, так и от формальных языковых ограничений, все более разрушая при этом конвенциональные ожидания читателя. ${ }^{29}$

В качестве примеров дальнейшего развития немецкой поэзии после 1965 года следует назвать такие явления, как венская звуковая поэзия, поздний берлинский сюрреализм, поэзия хеппенинга (ср. «звуковые стихи» Эрнста Яндля), агитационная поэзия и противостоящая ей поэзия новой субъективности (Николас Борн, Ф. С. Делиус, Михаель Крюгер, Йоханнес Шенк, Юрген Теобальди, Роман Риттер) или развитие лирической традиции Брехта в поэзии ГДР. ${ }^{30}$ Одним из исходных пунктов всех этих феноменов можно назвать манифест Ойгена Гомрингера «от стиха к констелляции» (1954), в котором сторонник «конкретной поэзии» требовал актуализации поэтической формы перед лицом наступления экономического рационализма, ведущего к упрощению языка:

Стихотворение в метрической форме - это либо историческое явление, либо, если оно написано сегодня, художественная реминисценция. Оно больше не является ориентиром и образцом для языка, напротив, его специальный язык существует вне языка живой жизни. ${ }^{31}$

\footnotetext{
${ }^{26}$ Nietzsche (1960, S. 1315). Перевод здесь и далее мой. Р.X.

${ }^{27}$ Breuer (1991, S. 235).

${ }^{28}$ Там же, S. 125.

${ }^{29}$ Там же, S. 372.

${ }^{30}$ Там же, S. 397-401.

${ }^{31}$ Gomringer (1972, S. 154).
} 


\section{3. Польская и сербская поэзия}

В польской поэзии, в целом силлабической, свободный стих развивался в общих чертах примерно так же, как и в поэзии немецкой, в целом силлаботонической. Уже в период «Млада Польска» восходящий к эпохе барокко «нерегулярный стих» начинает в отдельных случаях, в первую очередь в творчестве Станислава Выспяньского, превращаться в «свободный стих» (wiersz wolny). ${ }^{32}$ По-настоящему он находит свое развитие в поэзии «краковского авангарда» и, в частности, в творчестве Тадеуша Пайпера, Юлиана Пшибося и Яна Бженковского. ${ }^{33} \mathrm{O}$ ситуации во второй половине XX века Л. Пжоловска пишет следующее:

Для остальных 50 лет наиболее значимое явление в области версификации расширение свободного стиха, а вследствие того - вытеснение метрического стиха [...] свободный стих преобладает, метрический стих является формацией маркированной $[\ldots] .^{34}$

В сербской поэзии, которую в ХX веке следует рассматривать как часть единого штокавского языкового и культурного пространства, освобождение от силлабо-тонической традиции происходит столь же последовательно, как и в польской. Свободный стих, который уже в XIX веке занимает определенное место в творчестве Воислава Илича, Сильвия Страхимира Кранчевича, Лаза Костича и Милеты Якшича, ${ }^{35}$ получает сильный импульс для своего развития в результате переводов, в частности «Листьев травы» Уолта Уитмена, появившихся в журнале «Босанска вила», и уже перед первой мировой войной получает статус новой поэтической программы, сформулированной и апробированной на практике ${ }^{36}$ Святославом Стефановичем. Важным фактом для укрепления позиций верлибра в сербской поэзии явился сборник Милана Чурчина «Письма», вышедший в 1906 году. Для сербских символистов, писавших в рамках как силлабической, так и силлабо-тонической систем, верлибр остается, впрочем, все еще маргинальным явлением. Йован Дучич вообще не использует его, а Алекса Шантич применяет свободный стих лишь в 11 из своих 606 стихотворений. ${ }^{37}$ Но после первой мировой войны, с выходом на сцену поколения таких поэтов, как Антун Бранко Шимич, Иво Андрич, Мирослав Крлежа, Милош Црнянский или Растко Петрович, свободный стих быстро находит свой путь и уже никогда не теряет в штокавском культурном пространстве своего доминирующего положения. Это, в частности, ясно доказывает поэтиче-

\footnotetext{
${ }^{32}$ Pszczołowska (2001, s. 301).

33 Там же, s. 346.

34 Там же, s. 355.

${ }^{35}$ Cp. Škreb / Stamać (1986, s. 323).

${ }^{36}$ Мы применяем понятие «штокавский» по отношению к языковой системе, которую обычно называют сербохорватской.

${ }^{37}$ Porobić (2010, s. 436).
} 
ская антология «Сто граммов души», в которой представлены произведения 28 сербских поэтов, родившихся между 1940 и 1960 гг. ${ }^{38}$ Лишь немногие из них пишут стихи с определенным размером, причем в каждом случае их силлабические или, что реже встречается, силлабо-тонические размеры воспринимаются как нарочитый прием, несущий особую функцию: иронию (Милан Милишич, Джордже Сладое), имитацию народной песни (Исмет Реброня, Милослав Тешич), реминисценцию религиозных текстов (Райко Петров Ного) или подражание детским стихам (Мирослав Цера Михаилович).

\section{2. Причины сохранения силлабо-тонической системой ведущей роли в русской поэзии}

Любое объяснение того факта, что метрическая система сохраняла ведущие позиции в русской поэзии на протяжении всего XX века и отчасти сохраняет их до сих пор, будет, разумеется, до известной степени спекулятивным. В первую очередь, хочется назвать причины политического характера, но совершенно очевидно, что их нельзя признать достаточными, так как политические условия в СССР не сильно отличались от политических условий в ГДР или Польше. В то же время политический фактор явно не следует полностью игнорировать. Однако наряду с ним существовали и другие аспекты данной проблемы, которые мы и рассмотрим сначала.

\section{1. Языковые причиньл}

\subsection{1.}

Славянские языки являются флективными языками и потому допускают, как правило, относительно свободный порядок слов. Это обстоятельство позволяет достаточно легко переставлять слова в строке в зависимости от их звучания и ритма без какого-либо ущерба синтаксису. Такая возможность в немецком языке сильно ограничена. Еще более ограничена она в английском и французском языках.

\subsection{2.}

Поэзия на языках с сильным динамическим ударением имеет тенденцию к акцентному стихосложению, при котором ударение в слове совпадает с сильной долей стопы. ${ }^{39}$ Среди четырех рассматриваемых нами языков эта тенденция особенно заметна в немецком и русском, и неслучайно силлабическая традиция, не различающая ударные и безударные слога, пред-

\footnotetext{
${ }^{38}$ Cm. Hodel (Hg., 2011).

${ }^{39}$ Cp. Küper (1988, S. 117).
} 
ставлена в этих языках очень слабо. Музыкальное ударение ${ }^{40}$ существующее в штокавском языке, напротив, малосовместимо с акцентным стихосложением, так как при нем ударные слога могут быть по-разному интонированы. Выделяются четыре типа ударения: долгое восходящее, долгое нисходящее, краткое восходящее и краткое нисходящее. К тому же по долготе и краткости различаются не только ударные, но и безударные слоги. Поэтому неслучайно уже в XIX веке были предприняты попытки создать на штокавском языке силлабо-тоническую поэзию по античному образцу с чередованием долгих и кратких слогов. Штокавская силлаботоника колеблется между акцентным и квантитативным стихом, оставаясь в целом в тени господствующей силлабической системы. Возможности рифмы остаются при музыкальном ударении и чередовании долгих и кратких гласных также весьма ограниченными: например, pâs («пояс»; долгое нисходящее ударение) и päs («пёс»; краткое нисходящее ударение) или gòle-bòlē (последнее «е» носит долготу) воспринимаются как недостаточная рифма.

Что касается ударения в польском языке, то Б. Бартничка и Б. Ханзен пишут о нем так:

Ударение в польском языке чаще всего рассматривается как динамичное и фиксированное. Динамичность означает, что ударный слог должен артикулироваться с особым напряжением дыхания. Но при этом звук до определенной степени повышается, а слог удлиняется. Поэтому некоторые лингвисты рассматривают польское ударение как музыкальное. ${ }^{41}$

\subsection{3.}

Как польский язык с его фиксированным (парокститоническим) ударением, так и немецкий со свободным ударением, которое в одном и том же слове становится постоянным (ср. Báum - Báumes), имеют по сравнению с русским языком с его свободным подвижным ударением (ср. мост, на моcmy) гораздо меньше возможностей подбирать слова в соответствии с требованиями размера и рифмы. Особенно ограничены эти возможности в польском языке: мужская рифма возможна в нем только для односложных слов. Определенные ограничения существуют и в штокавском языке, поскольку в новоштокавском языке ударение чаще всего падает на первый слог. Поэтому в штокавском ямбе с цезурой как правило присутствует второй полустих, который является чисто трохеическим. ${ }^{42}$

\footnotetext{
40 При музыкальном ударении звук усиливается не за счет напряжения дыхания, а за счет вариации высоты звука (китайский язык) или движения тона (штокавский).

${ }^{41}$ Bartnicka / Hansen (2004, S. 78 f.).

${ }^{42}$ Cр. ямбические одиннадцатисложники Йована Душича: Porobić (2010, s. 391).
} 


\subsection{4.}

Славянские флективные языки располагают гораздо большими возможностями по сравнению с немецким, английским и французским для создания грамматической рифмы. Особую роль играет то, что ударение в славянских языках может падать на суффикс или окончание. В немецком языке, за исключением -ei (Liebelei), это возможно только в словах иностранного происхождения: Praktikant(in), Student, Veterinär, praktikabel, rigoros, spazieren и др. В польском языке, наряду с отчасти подобными примерами (cp. praktykántka, studéntka), есть все же гораздо больше слов, пригодных для грамматической рифмы (myślimy / robimy, półmiskami / gromadami). Тем не менее, возможности польского языка в этой области по сравнению с русским достаточно скромны: ведь в русском языке ударение может падать как на суффиксы глаголов, так и на окончания множественного числа существительных -bl, -u, -a/я(ma), окончания предложного падежа $-e,-u,-y,-a x / я x$, окончания полных и кратких форм прилагательных, уже не говоря о возможности создавать дактилические и гипердактилические рифмы со словами на -а́емый, -а́нная, -а́емая, -а́вщаяся и формами принадлежности на -ич, -


ком языке отличается от этого понятия в русском и польском и звучит так:

[это] рифма между основами двух слов или формами одного и того же слова без учета их созвучия: bekleiden / kleidet. $^{43}$

\subsection{5.}

Важным фактором является также статистическое соотношение ударных и безударных слогов. Если в русском языке ударение падает в среднем на каждый третий слог, ${ }^{44}$ то в немецком - на каждый второй, а в штокавском на каждые два с половиной слога. ${ }^{45}$ Это обстоятельство обусловлено средней длиной слова, которая в русском языке составляет 2,2, в то время как в немецком $-1,7$, а в английском ${ }^{46}-1,4,{ }^{47}$ и именно оно создало в русской культуре уже в эпоху классицизма предпосылки для использования пиррихия. Если в четырехстопных хореях Ломоносова третий икт реализован в $58 \%$, то в первой половине XIX века это число падает до 43,6\%. А у младшего поколения поэтов 1820-1840-х гг. реализованный третий икт в четы-

\footnotetext{
${ }^{43}$ Wilpert (1989, S. 350 f.).

44 По данным Станкевича (Stankiewicz 1960, с. 79) соотношение ударных и безударных слогов в русской поэзии и прозе составляет 2,8 .

${ }^{45}$ Porobić (2010, s. 147-150).

${ }^{46}$ О влиянии этого обстоятельства на английскую метрическую поэзию Кюпер пишет: «В английском языке ударения встречаются чаще, чем раз в два слога. В результате в английском двухсложном размере не только сильные, но и слабые доли неизбежно оказываются под ударением» (Küper 1988, S. 117).
}

${ }^{47}$ Fucks (1968, S. 80). 
рехстопном ямбе составляет всего $35 \%{ }^{48}$ Двусложный размер звучит порусски гораздо спокойнее, не так монотонно, и не производит эффекта барабанной дроби, как в немецком, ${ }^{49}$ а трехсложный размер в русском языке более соответствует естественной речи и может быть построен гораздо легче. ${ }^{50}$

В целом, можно констатировать, что русский язык по сравнению с немецким, польским и штокавским располагает большим количеством средств для создания вариативного силлабо-тонического стиха, который находится в созвучии с естественным языком.

\section{2. Эстетические причинь}

В своей «Поэтике» Аристотель определяет поэзию как отклонение от господствующих и привычных языковых форм (tò parà tò kýrion) с помощью «необычных» или «чуждых» (xenikòn) элементов. К таким элементам он относит глоссу (например, слово из другого диалекта), растяжение (например, удлинение слога) и метафору. ${ }^{51}$ В этом смысле приближение стиха к прозе может рассматриваться как один из подобных элементов или как, согласно Лотману, значимый «минус-прием», который предполагает, что метрический стих воспринимается как привычная языковая форма. ${ }^{52}$

Можно предположить, что метрическая традиция, ${ }^{53}$ возникшая в русской поэзии только в середине XVIII века, еще не исчерпала себя в рамках русской культуры, как это произошло в немецкой, польской или штокавской ${ }^{54}$ культурах, где эта традиция восходит к Ренессансу. Можно также заметить, что чисто языковые особенности русского языка, о которых речь шла выше, дают больше возможностей для различных инноваций в рамках силлабо-тонической системы и позволяют эффективно использовать такие приемы, как использование нетрадиционных размеров, полиметрия, вариативная длина строк, дактилические, неточные или диссонансные рифмы, вариативная строфика и т.д. Более того, эти языковые особенности позволяют создавать стихи, которые, оставаясь метрическими, все же приближа-

${ }^{48}$ Гаспаров (2000, с. 318).

${ }^{49}$ Cp. Žirmunskij (1925/1966, p. 80-85).

${ }^{50}$ Küper (1988, S. 118).

${ }^{51}$ См. Aristoteles (1994).

52 Лотман (1969, с. 120-121). Ср. также «Стих и поэзия должны рассматриваться как творчески используемая система ограничений, накладываемых на обычный язык» (Якобсон 1985, с. 257).

${ }^{53}$ Короткий период силлабического стиха в русской поэзии пришелся на вторую половину XVII века и был представлен, прежде всего, Симеоном Полоцким (1629-1680). Силлабическая поэзия была, однако, вытеснена силлабо-тонической в XVIII веке.

${ }^{54} \mathrm{~B}$ штокавском языке метрическая традиция связана с фольклорной поэзией. 
ются по своему звучанию и эстетическому эффекту к прозе. Это происходит благодаря использованию таких приемов, как несоответствие границы слова границе стопы, расширение пиррихия и спондея, несоответствие структуры фразы структуре стиха, редукция стилистически возвышенной инверсии, введение разговорной лексики и синтаксиса и др. Так, даже в «неоклассический» период советской поэзии меняется характер и природа четырехстопного хорея: если в стихах старшего поколения советских поэтов, родившихся до 1910 года, первый икт реализован в 58,2\% всех случаев, то у более молодого поколения, родившегося после 1910 года, это число падает до $50,9 \% .5$

Прием удлинения строки также встречается уже в советский период и находит в постсоветский период свое дальнейшее применение.

Поэтому было бы в принципе неверно сказать, что сохранение классического стиха накладывает на русскую поэзию какие-то серьезные ограничения в области формы или препятствует новаторству. Неслучайно силлаботонической системы придерживаются не только официальные советские, но и многие оппозиционные поэты: от Ахматовой и Мандельштама до Бродского и Кибирова. И может быть отчасти поэтому та «необычность высказывания» и то отклонение от привычных норм в духе идей Аристотеля остаются в литературноцентричной России XX века областью лирики, тогда как на Западе они стали прерогативой других видов искусства - в первую очередь поп-музыки.

В приведенном ниже письме А. Еременко утверждает, что именно классическая форма стиха делает возможной метафору, которую он, вслед за Аристотелем, считает одной из основ поэзии. ${ }^{56} \mathrm{M}$. Айзенберг исходит из того, что метрический стих - это особое состояние речи, внутри которого может быть как своя норма, так и возможность эту норму нарушить, в то время как верлибр, будучи в принципе свободным от норм, такой возможности не дает. ${ }^{57}$ Сходные аргументы в пользу классического стиха выдвигает и Д. Воденников, который видит в классическом стихе многообразие форм и, следовательно, защиту от инерции, которую не дает верлибр. ${ }^{58}$

\footnotetext{
${ }^{55}$ Гаспаров (2000, с. 318).

${ }^{56}$ См. раздел 3.1.

${ }^{57}$ См. раздел 3.4 .

${ }^{58}$ См. раздел 3.2 .
} 


\section{3. Политические и идеологические причинь}

\subsection{1.}

История русского стиха в XX веке дает уникальную возможность понять, какое влияние имел в СССР чисто политический аспект на такую, вроде бы отвлеченную область, как стихосложение, и какой след он в ней оставил. В первую очередь это относится к «неоклассическому» периоду 1935-1955 гг. Советская цензура, которая и до 1935 года препятствовала публикации написанных верлибром произведений Хлебникова и Заболоцкого, в этот период укрепления сталинской диктатуры делает канонизацию не только содержания, но и формы одной из своих главных задач. В основе этой канонизации лежит официально провозглашенное положение о единстве содержания и формы, согласно которому недопустимы любые формальные эксперименты:

Стиховедение начала века рассматривало стиховую форму (ритм, рифму и пр.) как самостоятельный эстетический возбудитель. Теперь такой взгляд осуждается как формалистический. ${ }^{59}$

В критике утверждается мнение, что свободный стих несвойствен духу русского языка и противен традициям русской поэзии. Это получает даже идеологическое обоснование: именно в это время свободный стих становится господствующей стиховой формой в поэзии Западной Европы и Америки и для прямолинейных критиков превращается в символ упадочной буржуазной культуры, наглядное выражение распада личности. ${ }^{60}$

Если в 1928 году Маяковский в обращении к «Галопщику по писателям» с презрением писал о поэтах-эмигрантах «Одни / хорей да ямбы», ${ }^{61}$ то теперь ямбы и трохеи становятся едва ли не одним из отличий реального социализма.

Впрочем, как раз Маяковский, который сразу после революции провозглашал верлибр «правомерной формой пролетарского искусства», ${ }^{62}$ может служить примером того, что свободный стих отвергался советской поэзией отнюдь не только по политическим причинам. Футурист и адепт пролетарской поэзии, сам он писал не силлабо-тоническими, но и не свободными стихами.

Здесь следует упомянуть также созданные в классической форме произведения Ахматовой, Цветаевой, Мандельштама и Пастернака, которые были написаны «в стол», то есть вообще без оглядки на цензуру. Тот факт, что эти поэты работали в основном с метрическими формами, можно объяснить их ориентацией на культуру дореволюционной России. Подобные аргументы можно привести и в отношении таких неофициальных поэтов позднего периода советской истории, как Иосиф Бродский, Виктор Кривулин, Сергей Стратановский, Елена Шварц, Юрий Кублановский, Ольга Се-

\footnotetext{
${ }^{59}$ Гаспаров (2000, с. 269).

${ }^{60}$ Там же, с. 282.

${ }^{61}$ Там же, с. 270.

62 Орлицкий (1995).
} 
дакова, Сергей Гандлевский и др., которые также использовали главным образом силлабо-тоническую систему, хотя их поэтические формы существенно отличаются от форм официальной советской поэзии. Очевидно, что использование свободного стиха, которое, возможно, более четко противопоставило бы этих поэтов официальной советской культуре, вступило бы в противоречие с их стремлением сохранить русскую классическую традицию. А. Сен-Сеньков, кстати, рассматривает это стремление к непрерывности культуры как «проклятие великой классической русской литературы», предопределившее ее «ужасающую провинциальность». ${ }^{63} \mathrm{He}$ менее критически высказывается по этому поводу С. Завьялов, который приписывает неофициальному культурному сопротивлению в СССР «реваншистский характер». ${ }^{64}$ Исходя из подобных положений, можно увидеть в силлабо-тонике символ тотального контроля, существовавшего в обоих политических лагерях. Но не отбрасывая полностью подобное толкование, следует все же поставить вопрос о том, насколько исчерпывающим оказывается здесь чисто политическое объяснение. Ведь и в первые два десятилетия XX века, когда верлибр распространился в поэзии Европы и США, в России, несмотря на общий либеральный климат, позиции силлабо-тоники оставались непоколебимы.

Тем не менее, остается бесспорным, что с помощью цензуры, издательской политики или системы присуждения премий советский официоз вплоть до падения коммунистического режима оказывал массивное влияние на литературу во всех ее аспектах и формах. Как подчеркивает Орлицкий:

Поэты, плодотворно и интересно работавшие в середине века с этой формой стиха - Д. Хармс, С. Нельдихен, В. Мазурин, Г. Оболдуев - оказались практически вычеркнутыми из живой литературы. Только в конце 1950-х - начале 60-х годов свободный стих вновь выходит из подполья. Правда, ненадолго: официальный идеологический запрет с него, вроде бы, снят, однако продолжает действовать ничуть не менее строгий редакторский, вкусовой барьер. Редкие публикации свободных стихов В. Бурича, В. Солоухина, К. Некрасовой, Н. Рыленкова сопровождались резко отрицательной официальной критикой - несмотря даже на то, что в те же годы, не афишируя этого, публикуют свои «опыты верлибра» такие мэтры советской поэзии, как Н. Ушаков, И. Сельвинский, К. Симонов, Е. Винокуров, Д. Самойлов, Б. Слуцкий, А. Вознесенский, Л. Озеров, О. Шестинский, В. Боков, А. Яшин - как видим, авторы самых различных творческих ориентаций. ${ }^{65}$

Силлабо-тоника не только доминирует в таких альтернативных неоклассических художественных направлениях, как неоакмеизм (Арсений Тарковский, Бэлла Ахмадулина, Александр Кушнер, Евгений Рейн и круг Иосифа Бродского и Виктора Кривулина) или необарокко (Иван Жданов, Елена

${ }^{63}$ См. раздел 3.5 .

${ }^{64}$ См. раздел 3.7.

65 Орлицкий (1995). 
Шварц, Александр Еременко, Виталий Кальпиди), в 1960-1980-х гг. она становится основой для постмодернистской поэзии. В творчестве Пригова, Кибирова или Лимонова она уже не является знаком продолжения традиции, а становится средством для ее иронического переосмысления на уровне формы. Классические стихотворные формы, будь то столь популярный в официальной советской поэзии трехстопный анапест или пушкинский четырехстопный ямб, производят в стихах Кибирова или Пригова эффект палимпсеста и провоцируют в читателе двусмусленную дистанцию к известному образцу. Однако, как раз московский концептуализм, формально оставаясь в силлабо-тонической сфере, создает важную предпосылку для развития верлибра: он делает классический стих маркированной, узнаваемой формой.

\subsection{2.}

В своей статье «Наизусть: о мнемоническом бытовании стиха» Михаил Гронас рассматривает еще один любопытный аспект советской культуры. Гронас отмечает, что в конце XIX века школьная практика заучивания наизусть была подвергнута резкой критике как на Западе, так и в России, в том числе со стороны Льва Толстого. Это критическое отношение вначале оказало влияние и на революционную педагогику первых лет Советской власти, однако оно оказалось недолгим: вскоре советская школа полностью вернулась к традиционной методике.

В первые годы после революции большевистские педагоги, наследуя реформаторам XIX века, предсказуемо ополчились против механического заучивания и объявили запоминание наизусть формой буржуазного гнета. Но в начале 1930-х годов, с упрочением государственного аппарата и усилением идеологического контроля над образованием, заучивание поэзии было заново открыто в качестве эффективного инструмента внушения советским детям чувства национальной и идеологической общности. ${ }^{66}$

По мнению Гронаса, практика заучивания наизусть в советской школе становится важным средством всеобщей индоктринизации:

Запоминаемый текст, следовательно, может восприниматься как когнитивное вторжение, чужой голос, поселившийся в сознании выучившего, и, следовательно, как потенциальный плацдарм для индоктринации или «идеологической обработки». ${ }^{67}$

Гронас, однако, отмечает, что заучивание наизусть служило для распространения не только выдержанных в духе официальной идеологии текстов, но и текстов, этой идеологии чуждых, например, стихов Ахматовой.

Для нас важно отметить, что независимо от идеологических целей «мнемоническому бытованию поэзии» гораздо лучше соответствует легко

\footnotetext{
${ }^{66}$ Гронас (2012).

67 Там же.
} 
запоминаемая ритмичная классическая стихотворная форма, чем свободный стих.

\subsection{3.}

Скидан, опираясь на идеи Джорджо Агамбена («Оставшееся время: Комментарий к „Посланию к римлянам“»), ${ }^{68}$ связывает верлибр с процессом секуляризации западного общества и противопоставляет ему советскую поэтическую практику как пример десекуляризации или ресакрализации советского общества. ${ }^{69}$ Даже если применить здесь понятие «сакральный» с известной долей условности, очевидно, что культ личности Сталина был тесно связан с ритуалом и церемониальностью, неотъемлемой частью которых была и силлабо-тоническая поэзия. Не последнюю роль играл при этом и официально насаждаемый культ Пушкина.

\subsection{4.}

Если пойти дальше, можно связать концепцию ресакрализации со многими концепциями русской культуры, которые выдвигают в ней на передний план духовность, иррациональность или религиозность и противопоставляют их материализму, рационализму и прагматизму Запада. ${ }^{70}$ Оценка этих качеств может быть различной: регрессу и изоляции («День опричника» Владимира Сорокина) противостоит позитивный консерватизм («Санька» Захара Прилепина).

Под этим углом зрения советский период русской истории предстает как закономерный этап развития русского общества и культуры в целом. Вопрос о том, действительно ли эта культура противостоит западной или - по крайней мере, после второй мировой войны - напротив, является ее частью, остается открытым, в том числе и в отношении свободного стиха.

\section{3. Русские поэты о свободном стихе}

Приведенные ниже письма представляют собой ответы восьми русских поэтов (А. Еременко, Д. Воденников, А. Монастырский, М. Айзенберг, А. СенСеньков, А. Скидан, С. Завьялов и А. Родионов) на следующий вопрос:

${ }^{68}$ См. Agamben (2000).

${ }^{69}$ См. раздел 3.6.

${ }^{70}$ А. Родионов подчеркивает также роль все еще актуальной русской народной поэзии с ее «скоморошьим, частушечным характером» (см. раздел 3.8.).

${ }^{71}$ Все авторы дали свое согласие на публикацию здесь приведенных отрывок писем. 
Уважаемый господин ...,

пишу Вам в связи с докладом и научной статьей о том, почему в русской поэзии по сравнению с другими европейскими литературами (английской, немецкой, польской, сербской, хорватской) в высокой мере сохранился именно классический стих (с размером и рифмой). Как вы объяснили бы, почему Вы (или другие поэты) пишете (пишут) в той или иной форме?

\section{1. Александр Еременко ${ }^{72}$}

Я думаю, что в нашей традиции верлибр и классический стих - это просто разные жанры. Я не знаю примеров, чтобы поэт писал рифмованно и вдруг как с какого-то перепугу стал писать верлибром. И, за редчайшими исключениями, те кто пишет верлибром - просто либо не умеют писать (кто из них, на пари, сможет написать сонет на двух рифмах? никто) вообще, либо не ощущают «второго дна», глубины рифмованного стиха. Французов, например, с их фиксированным ударением, понять как-то ещё можно... Но ведь были и Рембо, и Бодлер... Но, повторяю, те кто сейчас пишет на русском верлибром, просто не умеют писать в рифму. Да и верлибром-то не могут. Да и те, кто пишут рифмовано - тоже не умеют писать толком. Все их поэзии - в основном рифмованные мысли и не более того.

Да нашей поэзии всего-то 200 лет. Какой там верлибр, пусть сначала толком рифмовать научатся. Хотя я думаю, что верлибр для нас - неперспективен. Ведь ему противопоказана - метафора. А без неё нет поэзии, если она не самоцель.

\section{2. Дмитрий Воденников ${ }^{73}$}

Я думаю, что это происходит, потому что дает возможность написать полисистемный текст. Когда, например, верлибр в пределах одного стихотворения перерастает в рифмованный, а потом опять становится верлибром.

Таким образом получается как бы стереоскопическая картинка.

Или, чтоб было понятней, как бы документальный фильм с неожиданной игровой сценой. Или сложноорганизованная песня, где ритмическая основа вдруг перебивается размытым туманным фрагментом-монологом, уходящим опять в жесткий ритм.

Условные сравнения можно продолжить.

Итог один: это возможность еще больше расшатать инерционность стиха. Потому что как ни крути если перед нами только верлибр, это тоже своего рода инерция.

А пишущий идет за дыханием (и правдой) и инерция ему противопоказана.

72 Письмо от 29/04/2016. Письма публикуются в соответствии с датой их получения, цитируются непосредственно ответы на поставленный вопрос, орфография и авторский стиль в основном сохранены.

73 Письмо от 29/04/2016. 


\section{3. Андрей Монастырский ${ }^{74}$}

Мне не очень понятна та проблема, о которой вы пишете. Лично я никогда не разделял значимо поэтические формы на рифмованные строфы и на верлибр. У меня много стихов как в форме с рифмами, так и в форме верлибра. Главное мое сочинение - «Поэтический мир» 1976 года - написан именно верлибром [...]. Также и ранние стихи, например, сборник «Для двуногого друга» 1972 года написан верлибром [...]. Да, я пишу последнее время (несколько лет) шуточные стихи-импровизации в чатах и мейлах для друзей, которые написаны в рифму. Но это совсем не принципиально!

\section{4. Михаил Айзенберг $2^{75}$}

В русской поэзии у верлибра сложная и не слишком завидная судьба. Удачи имеются, их даже много, но они как-то не на слуху, и не складываются в систему. Это именно что отдельные удачи. Часто они принадлежат будущим прозаикам. Те, видимо, лучше чувствуют необходимый верлибру интонационный сдвиг: сложение разных по природе ритмических импульсов, дающее совершенно другое направление.

Стихи - не сумма признаков, а особое состояние речи. Отказ от таких признаков - это, скорее, освободительный жест, а не реальное освобождение. Можно считать верлибр нормальной поэтической формой, но как эту норму нарушить? (А это необходимо: поэзия не следует нормам). И верлибристам, и сторонникам регулярного стиха надо каждый раз что-то делать, чтобы их вещи как-то отличались от «стихов»: всякий раз заново исхитряться ради возможности того, что называется „tour de force“ - какого-то прорыва, выражения силы, но вместе с тем и какого-то трюка, выполненного с помощью средств. Понятно, что возникает желание применить прогрессивные технологии и решить эту проблему кардинально. Загвоздка в том, что верлибры в массе своей еще больше похожи друг на друга, чем вещи с регулярной основой. Видимо, в искусстве не бывает, чтобы кардинально и раз и навсегда.

Вопреки названию, русский верлибр крайне редко предоставляет реальную свободу слова. Как правило, речь верлибриста или неестественно напряжена, или непоправимо расслаблена. Для точного сочетания напряженности и легкости здесь необходим особый поэтический темперамент. Один из редких примеров безусловной удачи - стихи покойного Сергея Кулле, одного из членов т.н. «филологической школы». Его верлибр заразительно естественен. Стихи Кулле как будто и не собирались быть именно верлибром, просто оказались им по каким-то своим причинам. (Видимо, стихи становятся свободными, когда перестаешь отмечать их место в видовой классификации). Нечто подобное можно сказать и о стихах Леонида Шваба.

\footnotetext{
${ }^{74}$ Письмо от 30/04/2016.

75 Письмо от 3/05/2016.
} 


\section{5. Андрей Сен-Сеньков ${ }^{76}$}

Мне кажется, причины две. Первая - проклятие великой классической русской литературы. Многим сложно прикончить сидящего внутри Пушкина или Мандельштама. Второй же причиной является ужасающая провинциальность большинства современных русских поэтов, не знающих и не желающих знать о происходящем в поэтическом пространстве современной Европы и Америки и живущих по стереотипным, устаревшим много десятилетий назад, представлениям, что есть поэзия. Впрочем, есть счастливые исключения, когда поэты работают с традиционными формами на высочайшем уровне.

\section{6. Александр Скидан ${ }^{77}$}

В последние годы баланс между верлибром и регулярным стихом заметно выровнялся, в первую очередь за счет младшего поколения (середины - конца 80-х - 90-х г.р.), которое в основном использует как раз свободный стих. Но в целом, если брать все современное поэтическое поле, включая и непрофессиональных авторов, пожалуй, с констатацией доминирования регулярного стиха можно согласиться. Думаю, это происходит в силу культурной памяти старших поколений и восходит к тому времени, когда знание стихов наизусть выполняло функцию своего рода «социального коммуникативного кода», а сам статус поэта - и поэзии - обладал повышенной символической ценностью. О причинах этого, в том числе идеологических, хорошо написал Михаил Гронас в статье «Наизусть: о мнемоническом бытовании стиха» [...] Не со всеми положениями этой работы я готов согласиться, но это хорошая точка отталкивания для разговора.

Историко-философски фундированный подход к этой проблеме можно найти в книге Джорджо Агамбена «Остающееся время», в главе, посвященной отказу от рифмы у позднего Гельдерлина. Агамбен связывает этот отказ с атеологией, с тем, что с «уходом богов» стихотворение перестает быть сотериологической машиной, моделью мессианского времени. Иными словами, с секуляризацией западноевропейского сознания. Исходя из гипотезы Агамбена, в России такой секуляризации не произошло. Напротив, в советскую эпоху сфера культурного производства - сам процесс создания и публикации поэтического текста, его прохождения через цензуру - были сакрализованы даже больше, чем в годы, предшествовавшие Октябрьской революции. Побочным эффектом такой сакрализации было то, что знание и передача запрещенных, неофициальных поэтических текстов также оказались связаны с устной традицией, запоминанием.

Сам я практикую и свободный стих, и регулярный, выбор всякий раз происходит ситуативно. Зачастую я использую смешанные, гибридные формы, это дает дополнительную степень свободы.

\footnotetext{
${ }^{76}$ Письмо от 3/05/2016.

77 Письмо от 4/05/2016.
} 


\section{7. Сергей Завьялов ${ }^{78}$}

Действительно, в западноевропейской поэзии после Первой мировой войны свободный стих стал занимать всё более и более значительное место, а после Второй мировой войны вытеснил регулярный стих на периферию, тогда как в России даже в последнее десятилетие XX века, несмотря на крушение советской жизни и советской эстетики, сопровождавшееся попыткой интегрироваться в современное культурное пространство, бо́льшая часть поэтов оставались верны традиции вековой давности.

Ситуация, схожая с Западной Европой 1920-х - 1930-х, приходится в России на 1990-е - 2000-е: Генрих Сапгир, Всеволод Некрасов, Геннадий Айги, Аркадий Драгомощенко, Лев Рубинштейн, Шамшад Абдуллаев, Александр Скидан, бескомпромиссно отказавшиеся к этому времени от рифм и размеров, принадлежат к первому ряду русских поэтов конца XX - рубежа XXI веков. О выходе же свободного стиха на доминирующие позиции можно говорить в связи с новым поэтическим поколением, отчетливо заявившим о себе в 2010-е. Думаю, что приблизительно через десятилетие этот переход окончательно завершится.

Почему же он так затянулся?

Я думаю, дело тут в том, что сопротивление политическому режиму приобрело в позднесоветской культуре пассеистский или даже реваншистский (вернуться в Российскую империю Серебряного века) и эгоцентристский (русская культура так прекрасна, что может быть самодостаточной) характер, что породило в 1970-е годы поэтическое явление, которое я называю ретромодернизмом. Наиболее ярко он проявился у поэтов петербургского Самиздата (Леонид Аронзон, Виктор Кривулин, Елена Шварц, Александр Миронов, Олег Охапкин), а в Москве - у Ольги Седаковой, Михаила Айзенберга, поэтов групп «СМОГ» (Леонид Губанов, Владимир Алейников, Юрий Кублановский) и «Московское время» (Александр Сопровский, Сергей Гандлевский, Бахыт Кенжеев).

Ретромодернизму оказалось по силам то, с чем не могла справиться советская цензура. Он на треть века удерживал повестку дня в русской культуре в стороне от общеевропейской проблематики, и русская поэзия как ничто другое чутко на это реагировала.

Что касается моей собственной позиции, то она с первых же публикаций в ленинградском Самиздате (1985 год) заключалась в последовательном отказе от регулярного стиха. Я мог ориентироваться на высокий модерн, минимализм, концептуализм, но не на русский Серебряный век, мог вести диалог с древнегреческой лирикой и финно-угорским фольклором, мог полемизировать с последователями школы языка, но не бесконечно пародировать социалистический реализм.

\section{8. Андрей Родионов ${ }^{79}$}

Поэты в России заняты самыми разными поэтическими практиками и болееменее в курсе того, что происходит в литературе Европы и Америки. Тем не

\footnotetext{
${ }^{78}$ Письмо от 12/05/2016.

${ }^{79}$ Письмо от 9/05/2016.
} 
менее действительно - больше нигде в мире ритм и рифма не воспринимаются столь серьезно и не преподносятся с такой помпезностью, как в России.

Связано это, во-первых, с семьюдесятью годами социализма и господствующим в литературе принципом социалистического реализма. С физическим устранением или выдавливанием в эмиграцию всех, кто этому принципу не соответствовал. Это очевидный факт, и я не буду долго на нем останавливаться.

Во-вторых, и это кажется мне важнее, господство регулярного стиха связано со скоморошечьим, частушечным характером народной поэзии. Эта насмешливая или печальная песенная форма до сих пор воспринимается многими поэтами в России как живой, актуальный язык, который находит свой отклик и в университетских аудиториях, и в клубах, и в театре. И если мы ведём разговор не об элитарном искусстве, а о поэзии улиц - то автору, чтобы быть услышанным, надо писать в рифму, соблюдая привычные народу ритмы.

Поэтому каждый поэт в России, будь он экспериментатор, модернист, постмодернист, создатель нового эпоса или репер, обязательно имеет в виду и работает с классическими размерами девятнадцатого и даже восемнадцатого века.

Итак, поэтическая форма - это важный компонент образа автора, который возникает у читателя при чтении лирического произведения. Она не только представляет собой конструктивный элемент манифестации авторского голоса в тексте, но и связывает этот текст с определенной традицией. Ответы восьми поэтов позволяют прийти к заключению, что выбор поэтической формы определяется тем, какую позицию по отношению к традиции занимает тот или иной автор и какое место для себя он в ней видит. Выбор поэтической формы - это условие творческой идентичности.

\section{Литература}

Гаспаров, М. (2000): Очерк истории русского стиха. М.

Гронас, М. (2012): Наизусть: о мнемоническом бытовании стиха. Пер. с англ. А. Вдовина // Новое литературное обозрение. 114, 2012. http://magazines.russ.ru/nlo/2012 /114/g24-pr.html (2/08/2016).

Давыдов, Д. (2013): Приключение верлибра (фестиваль как повод взглянуть на свободный стих со всех сторон) // Арион. 3, 2013. http://magazines.russ.ru/arion/2013/3/ 21d.html (2/08/2016).

Ковалев, П. (2013): Русский верлибр XX века и проблемы его изучения // Уральский филологический вестник. 2, 2013. 6-20.

Лотман, Ю. (1969): Структура художественного текста. М.

Орлицкий, Ю. (1995): Русский верлибр: мифы и мнения // Арион. 3, 1995. 85-92. http://magazines.russ.ru/arion/1995/3/monolog1.html (2/08/2016).

Орлицкий, Ю. (2002): Стих и проза в русской литературе. М.

Падучева, Е. (1996): Семантические исследования. Семантика времени и вида в русском языке. Семантика нарратива. М. 
Федотов, О. (1997): Основы русского стихосложения: Метрика и ритмика. Учебное пособие. М.

Якобсон, Р. (1985): Ретроспективный обзор по теории стиха // Якобсон, Р.: Избранные работы. М. 239-269.

Agamben, G. (2000): Il tempo che resta. Un commento alla Lettera ai romani. Torino.

Aristoteles (1994): Poetik. Griechisch / Deutsch. Stuttgart.

Bartnicka, B. / Hansen, B. et al. (2004): Grammatik des Polnischen. München.

Breuer, D. (1991): Deutsche Metrik und Versgeschichte. München.

Fucks, W. (1968): Nach allen Regeln der Kunst. Diagnosen über Literatur, Musik, bildende Kunst - die Werke, ihre Autoren und Schöpfer. Stuttgart.

Gomringer, E. (Hg., 1972): konkrete poesie. Stuttgart.

Hodel, R. (Hg., 2011): Hundert Gramm Seele. Serbische Poesie aus der zweiten Hälfte des 20. Jahrhunderts. Leipzig.

Hodel, R. (Hg., 2015): Vor dem Fenster unten sind Volk und Macht / За окном внизу народ и власть. Russische Poesie der Generation 1940-1960. Leipzig.

Küper, Ch. (1988): Sprache und Metrum. Tübingen.

Nietzsche, F. (1960): Werke in 3 Bdn. B. 3. München.

Porobić, S. (2010): Ispitivanje razvoja versifikacije u poeziji Bosne i Hercegovine. Zagreb / Sarajevo.

Pszczołowska, L. (2001): Wiersz polski. Wrocław.

Škreb, Z. / Stamać, A. (1986): Uvod u književnost. Zagreb.

Stankiewicz, E. (1960): Linguistics and the study of poetic language. In: Sebeok, Th. (ed.): Style in language. Cambridge, Massachusetts. 69-81.

Wagenknecht, Ch. (2007): Deutsche Metrik. Eine historische Einführung. München.

Wilpert, G. von (1989): Sachwörterbuch der Literatur. Stuttgart.

Žirmunskij, V. (1925 / 1966): Introduction to Metrics: The Theory of Verse. The Hague. 


\section{Юрий Орлицкий (Москва)}

\section{Соотношение лирического субъекта и типа стиха в «вариативном» творчестве Сергея Завьялова и Максима Амелина}

В условиях традиционного стиха (для русской поэзии - рифмованной строфически организованной силлаботоники) проблема соотношения лирического субъекта и используемых для его выявления типов версификации решается достаточно однозначно: стиховые средства оказываются практически индифферентными к субъектной природе произведения и по сути дела просто помогают выявить ее. Другое дело - современный русский стих, располагающий широчайшим спектром выразительных средств как на метрическом, так и на звуковом и строфическом уровнях организации ритмического целого.

Но сначала необходимо оговорить понимание лирического субъекта, из которого мы будем исходить. В русской традиции его сфоррмулировала Лидия Гинзбург в книге «О лирике», где, исходя из предложенной Ю. Тыняновым в статье о Блоке ${ }^{1}$ категории, последовательно использует словосочетание «лирический субъект» как синоним «лирического героя» (напр., «Лирическая поэзия - далеко не всегда прямой разговор поэта о себе и своих чувствах, но это раскрытая точка зрения, отношение лирического субъекта к вещам, оценка»; «Лирическое переживание или размышление отнесены теперь к личности (разумеется, обобщенной); изменилось тем самым и возросло значение лирического субъекта»; «Лирический субъект может быть зашифрован - пейзажем, предметом, другими персонажами, эпизодом, диалогом, сценой, размышлением, скрепленным с частным участком жизни. Автор присутствует, но он присутствует как лирическое отношение к вещам» ${ }^{2}$ ).

Наиболее последовательно этот подход развивает И. Роднянская в статье «Лирический герой» для «Лермонтовской энциклопедии», рассматривая эволюцию этого явления в творчестве поэта («Лирический субъект ранних стихов Лермонтова, казалось бы, являет типичное для романтиков тождество искусства и жизни, но это тождество - не сознательно выводимое из художественно-философской концепции, а первичное, „дилетантское“ результат не стилизации жизни, а „долитературной“ неискушенности поэзии»; «Переход от эпических певцов к лирическому субъекту совершается через песню Узник, в которой все психологически интимное и конкретно

\footnotetext{
1 Тынянов (1921).

${ }^{2}$ Гинзбург (1974, с. 5, 43, 44).
} 
подмеченное сплавлено с фольклорно всеобщим, так что тема заточения удалена от лирич. биографии и опосредована анонимностью „песенного“ лица»; «постановка и ориентация „поющего“ лирического субъекта начинает меняться: он уводится, во-первых, за социально-групповые границы „поколения“ и „образованного круга“ и, во-вторых, от обязательного драматич. контакта с сиюминутной „,олпой“ слушателей»; «Об этой готовности Лермонтова двигаться сразу в двух направлениях и свидетельствует „двойной“ принцип построения лирического субъекта в стихах последних лет» ${ }^{3}$.

В свете принципиально другой традиции - бахтинской - рассматривают субъектную организацию лирического произведения Б. Корман ${ }^{4}$ и его последователи, в первую очередь - С. Бройтман ${ }^{5}$; именно на нее опирается в своей «Нарратологии» Вольф Шмид ${ }^{6}$. В рамках этого подхода понятие «лирический субъект» не используется, однако речь ведется о соотносимых с ним «субъекте сознания» и «субъекте речи»; при этом «лирический герой» понимается Корманом как «один из субъектов сознания, характерных для лирики» ${ }^{7}$.

Именно в перспективе двух этих традиций мы предлагаем рассмотреть практику двух поэтов - Сергея Завьялова и Максима Амелина, наиболее активно использующих в своем творчестве разнообразные формы метрики и строфики, что предполагает, на первый взгляд, определенные сложности для однозначной идентификации субъекта развернутого лирического высказывания. В первую очередь это относится к обращению этих авторов к таким архаическим по своему генезису стиховым формам, как силлабический стих, логаэды и гексаметр, одическая и сапфическая строфа, которые Завьялов и Амелин не просто используют в своей лирике, но и радикально видоизменяют, прежде всего с ориентацией на господствующий в современной мировой поэзии свободный стих. При этом стих обоих поэтов сохраняет явную лирическую доминанту, что не позволяет рассматривать их «вариативную» поэзию как явление стилизации.

Так, С. Завьялов в большинстве своих произведений отчетливо апеллирует к античности или фольклору, демонстрируя тем самым видимое устранение авторской субъективности и стремление к делиризации, объективизации повествования.

Например, поэма «Рождественский пост» (2009) на первый взгляд строится в основном по принципу коллажа документального материала, раскрывающего высокую трагедию Ленинградской блокады. Текст состоит из семи частей, названных в соответствии с семью днями - шестью суббота-

\footnotetext{
${ }^{3}$ Роднянская (1981).

${ }^{4}$ Корман (1977, с. 508-513; 1992, с. 172-189).

${ }^{5}$ Бройтман $(1997,2001,2004)$.

${ }^{6}$ Шмид (2003).

${ }^{7}$ Корман (1992, с. 179).
} 
ми и праздничной средой - с 29 ноября 1941 г. по 7 января 1942 г., знаменующими начало и конец Рождественского поста самой страшной первой блокадной зимы. Все семь картин выстроены строго по десятичленной единой схеме, для демонстрации которой приведем описание одного дня:

1

29 ноября 1941 года, суббота.

Погода:

Температура воздуха в Ленинграде минус 9-11 градусов;

облачно, пройдет кратковременный снег;

ветер переменных направлений, 3-7 метра в секунду; атмосферное давление 762 мм ртутного столба; относительная влажность $96 \%$.

Первая недъля Рождественскаго поста:

Старый стиль 16 ноября. Память:

Апостола и еvангелиста Матөея.

Праведнаго Фулвіана, князя Еөіопскаго.

Монастырскій уставъ:

Сегодня, а также въ воскресеньђ, вторникъ и четвергъ - разрьшается рыба.

Въ понедъльникь - горячая пища безъ масла.

Въ среду и пятницу - сухояденіе.

Карточки продовольственные. Литера «И»:

Карточка на хлеб на ноябрь месяц.

Купоны на 29 число:

Первый купон - 50 граммов

Второй купон -50 граммов

Третий купон -50 граммов.

Четвертый купон -50 граммов.

Согласно постановлению Военного Совета Ленинградского фронта № 00409 от 19 ноября 1941 года установлены новые нормы обеспечения населения хлебом.

Карточка на крупу и макароны, рыбу и рыбопродукты на ноябрь месяц:

Купон на крупу № $24-25$ граммов. Отоварен в понедельник 24 ноября. Купон на рыбу № 3 - 100 граммов. Отоварен в понедельник 24 ноября.

Карточка на мясо и мясопродукты на ноябрь месяц: 
Купон № 16 - 25 граммов.

Отоварен в пятницу 28 ноября.

Карточка на жиры на ноябрь месяц:

Купон № 24 - 10 граммов.

Отоварен в понедельник 24 ноября.

Карточка на сахар и кондитерские изделия на ноябрь месяц:

Купон № 16 - 50 граммов.

Отоварен в пятницу 28 ноября.

Я сказал:

А еще в другой раз

у меня будет такой специальный шкаф:

в одном месте ржаной хлеб

в другом месте пеклеванный хлеб

в другом месте карельский хлеб

в другом месте французская булка

в другом месте городская булка

в другом месте хала

Ты сказала:

Котя приходил и говорит:

Сделай ты мне, Шура, винегрет.

Котя, ну из чего же я тебе сделаю винегрет?

Он сказал:

Алиментарная дистрофия - патологический процесс, который с клинической стороны следует рассматривать как особую нозологическую единицу. Я.Л. Рапопорт выдвинул гипотезу о ее гастрогенном происхождении. Опираясь на современные представления о многообразной секреторной, экскреторной и инкреторной функции слизистой оболочки желудка и ее роли в нервногуморальной регуляции жизненных процессов, автор считает нарушение метаболизма слизистой оболочки желудка ведущим звеном в патологенезе алиментарной дистрофии.

Она сказала:

Я лежу больная, а они все только жрут и жрут, жрут и жрут.

Вы сказали: 
О как величествен был снегопад на закате этого дня

Эти хлопья что стирают приметы пространства

Это исчезновение линий утрата теней

угасание звуков

Они сказали:

Вчера ночью части Южного фронта советских войск под командованием генерала Харитонова прорвали укрепления немецких войск, и, грозя им окружением, ворвались с северо-востока в Ростов и заняли его. В боях за освобождение Ростова от немецко-фашистских захватчиков полностью разгромлена группа генерала Клейста в составе 14-й и 16-й танковых дивизий, 60-я моторизованная дивизия и дивизия СС «Викинг». Противник оставил на поле боя свыше 5 тысяч убитыми. Захвачены большие трофеи, которые подсчитываются.

И мы воспгли на утренг:

Величить душа Моя Господа, и возрадовася духъ Мой о Бозъ Спась Моемъ. ${ }^{8}$

Как видим, следом за документальной фиксацией даты, вынесенной в заглавие поэмы, следует такая же, на первый взгляд, абсолютно безоценочная информация о погоде названного дня. Однако вскоре мы понимаем смысл этого рамочного элемента, который можно определить одним словом - «холодно». А указание на место действия - Ленинград - вносит дополнительные уточнения: во-первых, описываемые ниже события происходят во время блокады, а во-вторых - в самые холодные и сырые ее дни.

Более того: от недели к неделе погода последовательно ухудшается, нарастает мороз (до 30 градусов) и влажность (до 100\%). Если посмотреть реальные сводки погоды этого времени, таких показателей в тогдашнем Ленинграде не было: это художественный вымысел Завьялова, и на этом «документальном» пятачке создающего апокалиптическую картину надвигающейся всеобщей гибели.

Следующая часть тоже на первый взгляд выглядит совершенно нейтральной, объективно-документальной: она включает обозначение дня по старому стилю, указание святых, чье поминовение приходится на конкретные дни года, а также рекомендации к питанию по монастырскому уставу на конкретные дни: здесь впервые появляется ключевой для поэмы концепт еды (точнее, ее острого дефицита). Тут тоже возникает сложная коллизия: с одной стороны, можно противопоставить добровольный отказ от необходимого питания, продиктованный монастырским уставом, и вынужденный отказ, вызванный отсутствием продуктов в городе; с другой стороны, можно сопоставить монастырские ограничения с блокадными и тем самым - самих блокадников монахам, святым людям.

8 Завьялов (2010, с. 61-64). 
Самая обширная часть каждой главки - «Карточки продовольственные. Литера „И“» - с документальной точностью описывает карточки иждивенцев апогея блокады; для того, чтобы усилить впечатление о скудости полагающегося этой категории ленинградцев пайка знаменитые 125 граммов блокадного хлеба разбиты на купоны по 25 граммов, как это и было на самом деле; точно так же описаны и ежедневные порции остальных продуктов.

После этого начинается собственно «фикционная» часть поэмы, по форме напоминающая пьесу, действующие лица которой названы личными местоимениями, за которыми скрываются индивидуализированные персонажи: Я - сошедший с ума и бредящий будущими запасами разнообразных припасов человек, мысленно раскладывающий продукты по шкафам (условно говоря - сын); Ты - тоже потерявшая рассудок женщина (условно - мать, из простых), озабоченная в первую очередь голодом членов своей семьи; Она скорее всего, соседка семьи по коммунальной квартире, судя по речи, из интеллигенции, тоже безумная; Вы - еще один квартирный сосед, поэт, сочиняющий стихи о прекрасном мире природы возвышенным стилем и внешне выстраивающий полустроки своего изысканного верлибра как псевдологаэды (кстати, так поступал в своих ранних стихах и сам Завьялов; здесь же он, по собственному признанию, имел в виду погибшего в блокаду переводчика Горация А.П. Семенова-Тян-Шанского, на что прозрачно намекает замена в последней главе авторского четверостишия подлинной строфой римского классика). Наконец, два следующих участника драматургической части снова возвращают нас к документальному слову: под именем Он следуют цитаты из запрещенной в советское время медицинской книги «Алиментарная дистрофия в блокированном Ленинграде» (Ленинград,1947) - кроме последнего фрагмента, взятого из другого источника, тоже документального; под отчуждающим Они - из подлинных сводок Совинформбюро (цитируются, как указывает Завьялов в комментарии, «по газете „Правда“ за 1941-1942 годы»).

Завершает же портрет каждого из дней отрывок из канонических православных молитв («и мы воспели на утрене»), дающийся в старой орфографии; для шести первых суббот это текст из Всенощной (утреня) - Песнь Пресвятой Богородицы, являющаяся положенным на музыку евангельским текстом: Лк.: 1, 46-55), в последней главе - из Рождественской Литургии (Праздничный кондак).

Как уже говорилось, восемь частей каждой главы написаны по новой, две, связанные с реалиями досоветской истории, - по соответствующей ей дореформенной орфографии, что задает тексту глубокую временную перспективу. Первые шесть дней (субботы) описаны однотипно, и это создает страшное унылое однообразие; завершающая глава отличается от предыдущих принципиальным изменением текста: мороз и влажность достигают максимальных величин, в календарной части ничего не говорящие атеистам имена святых заменят известное всем «Рождество Господа Бога и 
Спаса нашего Іисуса Христа»; «Поста нътъ: разрђшеніе на вся»; раздел карточек открывается радостным сообщением:

Исполком Ленинградского городского совета депутатов трудящихся разрешил продажу по январским продовольственным карточкам в счет существующих месячных норм. ${ }^{9}$

Он вместо медицинского труда цитирует другой документальный источник:

За последнее время число случаев трупоедства в Ленинграде резко сократилось, однако еще значительно и идет исключительно за счет похищения трупов и трупных частей с кладбищ, ${ }^{10}$

а Она - «Ленинградскую правду»:

Она сказала:

А я пойду сегодня в кино.

В кинотеатре «Спартак»-

кинокартина Большая жизнь.

В кинотеатре «Правда» -

кинокартина Музыкальная история.

В кинотеатре «Молот»-

кинокартина Сто мужчин и одна девуика». ${ }^{11}$

$\mathrm{Bce}$, кроме апокалиптической погоды, свидетельствует вроде бы о переменах к лучшему, изображенных, правда, с аристотелевской «трагической иронией», однако все живые персонажи к этому времени уже умерли или расстанутся с жизнью в ближайшие дни.

Мы видим, как в поэме Завьялова переплетаются подлинные исторические прозаические цитаты, прозаические же, но выполненные в основном стихоподобной версейной строфой квазидокументальные речи большинства персонажей и стихотворные (написаны свободным стихом, маскирующимся под античный) речи поэта и подлинные цитаты из богослужебных текстов. Такая прозиметрическая многоголосица позволяет автору, сохраняя видимость документальности, сочетать ее с образцами высокой поэзии - как традиционной, так и авторской.

Таким образом, креативная активность лирического субъекта в поэме смещается с традиционных форм выражения авторской позиции на формальный уровень - отбор стиховых средств и аранжировку «материала», в качестве которого используется вполне определенная историческая («Рождественский пост»), нарочито квазиисторическая («Берестяные грамоты», «Четыре хороших новости») или литературная «реальность» (,Elegiarum Fragmenta“, „Horatii Paraphrases“, «Переводы с русского»); на поверку однако большинство объективизированных текстов демонстрирует вполне традиционную лирическую природу, а лирический субъект демонстративно просвечивает через квазиобъективного нарратора.

\footnotetext{
9 Завьялов (2010, 86-87).

10 Там же, с. 88.

11 Там же.
} 
Соответственно в других квазиисторических циклах Завьялова аналогичным образом искусно имитируются мордовские фольклорно-этнографические материалы, тоже представляющие сложный гибрид написанных стихоподобной версейной прозой (с «библейской» нумерацией строк-строф), легко допускающей такую имитацию, но при этом поддерживающей высокий по сравнению с обычной прозой градус художественности, и собственно прозаического, ритмически нейтрального нарратива:

После сего избрал Азор и других семьдесят учеников и послал их по двое пред лицом Своим во всякий город и во всякий поселок городского типа, и во всякий райцентр, даже и до всякого сельсовета.

1. И были это Ордань-буе и Атяшево, Найманы и Кочкурово,

2. а также Ичалки и Кемля в Земле Эрзянской.

3. И были Потьма и Явас, Салазгорь и Пишля,

4. а также Пурдош и Сивинь в Земле Мокшанской.

5. А еще Пикшень и Яз, Арзамас и Алатырь в уделе Пургазовом,

6. а также Чембар и Поим, Наровчат и Камешкир в уделе Пурешевом.

7. И Саран Ош с предместьями его: Атемаром, Посопом, Лямбирем.

8. И Пенза с предместьями ее: Шемышлеем, Рамзаем, Ардымом.

9. И ты, Обран Ош, Нижний Новгород, отец городов мордовских, высоко вознесен рог твой.

10. Да сбудется реченное через вострубившую тюштянову тораму:

И ты, земля Буртасова, вдоль тянущихся степями шоссе, там, за Сурой, и ты, лесной народ на Цне, семя Мещерское, блудящий на стезе русской веры, даже вы увидели свет Независимости, и се - всем сидящим в тени смертной воссиял он. ${ }^{12}$

Здесь перед нами - безусловно авторский, напрямую исходящий от лирического субъекта текст, однако имитирует он «альтернативное» мордовское Писание, то есть традиционное сакральное версе, что тоже позволяет автору «прятаться» за объективизированным, и к тому же нарочито эпизированным повествованием.

Сложнее всего происходит дело с третьей группой завьяловских циклов, ориентированных на литературную реальность: как античную, так и русскую классическую.

Вот до боли знакомое русскому читателю стихотворение Горация в новом переложении, завершающее цикл Завьялова «Declamationes Horatianae. Carmina versibus liberis expressa. Декламации на горацианские темы (свободным стихом)» (1999-2001):

$$
\text { \#5 (III.30) }
$$

Exegi monumentum aere perennius

regalique situ pyramidum altius,

quod non imber edax, non Aquilo impotens

12 Там же, с. 57. 
possit diruere aut innumerabilis annorum series et fuga temporum.

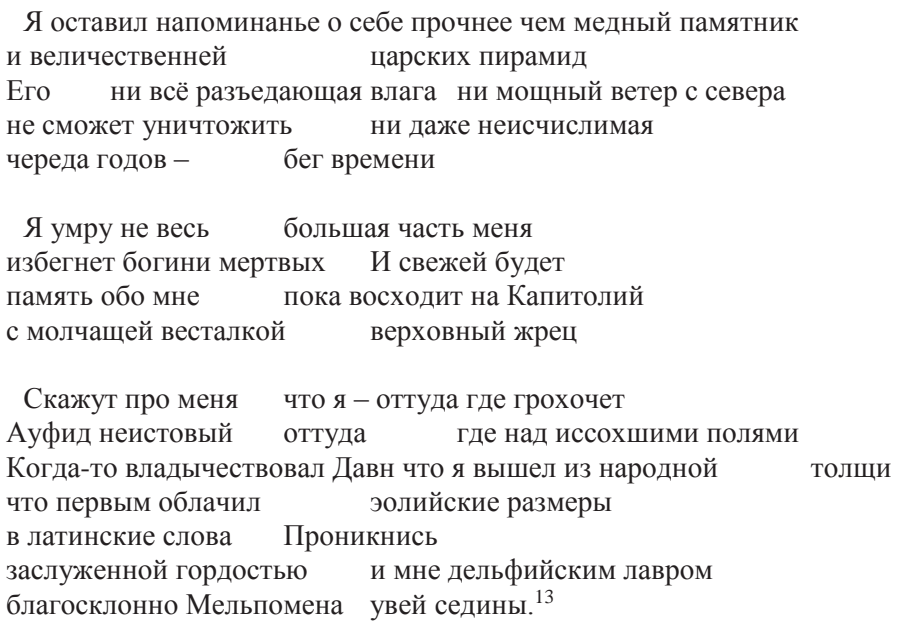

Обратим внимание на «комплектность» завьяловского текста: он начинается заглавием цикла, в котором обращается внимание на то, что входящие в него стиха написаны не античным, а свободным стихом; кроме того, в названии обращает на себя слово «декламации», а не переводы, хотя именно в последнем качестве большинство стихотворений оказывается вполне адекватным: современному поэту важно подчеркнуть, что он именно исполняет (декламирует) свой перевод, выполненный не адекватным авторскому типом стиха.

Далее следует номер стихотворения по установленному порядку, что еще более отстраняет нас (и поэта!) от латинского оригинала, а потом пять первых строк оригинала, продолжающие настраивать нас на восприятие чужого текста. Наконец, следует сам перевод, выполненный, как и обещал автор, верлибром, однако не совсем обычным: все его строки, кроме двух, при помощи пробелов разбиты на два полустишия, а две даже на три неравные части, как это нередко делается при записи переводных логаэдов, - то есть, Завьялов подчеркивает, что перед нами современный свободный стих, графика которого, однако, ориентирована на античные стандарты, но при этом не следует за античным оригиналом.

Нетрудно заметить, что Завьялов, так же, как остальные русские предшественники, не просто переводит классическое стихотворение Горация, но и несколько видоизменяет его, что вкупе с объемным заголовочным комплексом позволяет говорить о сложном по структуре новом тексте, со-

13 Завьялов (2003, с. 117). 
зданном «по образцу» латинского, но при этом заметно от него отличающимся, что и характерно для декламации (то есть, исполнения, а не воспроизведения первоначального текста).

Все это показывает, что знаток античного и современного стиха Завьялов делает в своем стихотворении (и цикле в целом) особый акцент на создаваемой им ритмической конструкции вновь создаваемого целого, творцом которого из «готового» материала оказывается лирический субъект; немаловажно и то, что современный русский читатель, которому это стихотворение в первую очередь адресовано, воспринимает его на фоне как минимум трех хрестоматийных версий перевода-подражания: ломоносовского, державинского и пушкинского, знакомым всем со школьной скамьи (в зависимости от степени продвинутости читателя круг текстов должен возрастать, включая и собственно переводы, стремящиеся к академической точности, как давние, так и новые, и многочисленные вольные интерпретации сюжета «Памятника», ставшего для нашей словесности архетипическим).

В отличие от Завьялова Максим Амелин внешне выстраивает свое повествование в традиционном лирическом модусе, от лица канонического лирического субъекта. Однако именно использование экзотических стиховых средств, ориентированных на искушенного в русской и мировой поэзии читателя, показывает недостаточность такого понимания субъектного строя большинства его стихотворений.

Так, даже используя традиционную для русской поэзии рифмованную силлаботонику, строфически оформленную в катрены с перекрестной рифмовкой, Амелин может демонстративно усложнить и эту форму:

Нежно-розовый нехотя исчезает под густо-лиловым, зазеваешься, кажется, и не сыщешь дороги туда,

где случайная музыка не успела с умышленным словом

разминуться, развстретиться, где в открытое море суда

под союзными флагами выступают воинственным клином, где вернуть не получится безъязыкой стране голоса, всё в сгустившихся сумерках по иным протекает причинам и последняя светлая поглощается тьмой полоса. ${ }^{14}$

Приведенное выше стихотворение написано вполне обычным для русской лирики анапестом, однако, во-первых, достаточно редкой «длинной» его вариацией - пятистопной и цезурированной, но кроме этого на цезуре обнаруживается регулярное наращение, что делает ритмический облик стихотворения крайне необычным; при этом лирический субъект отчетливо демонстрирует нам эту необычность, отвлекая внимание от вербального смысла произведения.

${ }^{14}$ Амелин (2012, с. 87). 
Еще более усложненной выглядит субъектная структура силлаботонического (шестистопный цезурированный ямб) стихотворения Амелина «Эротический центон, составленный из стихов и полустиший эпической поэмы М. Хераскова “„Россияда““ в подражание Дециму Магну Авсонию», восприятие которой предполагает непременное обращение к обширному претексту, данному в комментариях; обращение к нему показывает, что все стихотворение составлено из фрагментов «чужого» текста (о чем свидетельствует и его справедливое наименование центоном; в конечном комментарии к стихотворению даны все контексты использованных в нем фрагментов, строк и полустрок):

Какую песнь мне петь? каким писать пером? -

Готовься к дивному повествованью, лира!

Перед усыпанным звездами алтарем,

О Муза! петь хощу блаженствы здешня мира

И нежности любви. - Трудясь наедине,

Уже я получил за слабый труд награду.

Стихотворенья дух! чего бояться мне? -

Услышав грома звук, начать тотчас осаду. ${ }^{15}$

Здесь вопрос о лирическом субъекте решается еще сложнее: фактически перед нами - два текста, причем автором обоих является известный поэт XVIII века, из поэмы которого наш современник собрал свой центон, а затем снова «собрал» локальные контексты всех его строк. Можно сказать, что у стихотворения два полноценных лирических субъекта, биографически разделенных двумя веками; при этом их роль в создании текста очень различна: можно сказать, Херасков «сочинил слова» для центона (и для своей поэмы, разумеется, но здесь это парадоксальным образом оказывается не так важно), а Амелин построил из них принципиально новое (в том числе и по основному пафосу - эротическому вместо героического) произведение.

Привлекает к себе внимание также силлабический и квазисиллабический стих Амелина, от которого русский читатель изрядно поотвык; обращение к нему также отвлекает внимание от голоса лирического субъекта и переносит его на экзотически звучащую, тем более в союзе с причудливо перемешанной лексикой разных столетий, стиховую речь. Силлабику Амелин использует и в своих многочисленных переводах: так, если для «правильного», как он считает, воспроизведения на русском языке ритмики той части знаменитого стихотворения Н. Бараташвили «Мерани», которая написана силлабическим двадцатисложником (в Грузии этот стих называется «чахрухаули» по фамилии поэта 12 в. Чахрухадзе и его состав $-5+5+5+5)$, он выбирает счетверенный силлаботонический пятисложник с дактилическим

15 Амелин (2011, с. 91). 
окончанием, то для чередующихся с ними 14-сложников он использует тот же размер («малый размер Бесики», поэта XVIII века, состав - 5+4+5). ${ }^{16}$

По мнению Амелина, грузинские размеры не силлабические в точном смысле, а скорее стопно-силлабические, единицей стиха в них является закрытая стопа от 3 до 9 слогов, ударение находится либо на предпоследнем слоге, либо на третьем от конца.

Пример счетверенного пятисложника амелинского перевода выглядит так:

Рассекай ветра, разрывай дожди, над вершинами да провалами

Мчи, взмывай и мне, торопливому, дни пути сжимай всеми силами!

Не пугайся же, быстролетный мой, ты ни жара, ни хлада лютого,

И наездника изможденного, но отважного не жалей твого!

Что ж, пускай родной край оставлю я, пусть лишусь друзей да товарищей;

Не увижу пусть ни родителей, ни возлюбленной, слух ласкающей, -

Где стемнеет ли, рассветет ли где, той земле и стать мне отчизною;

Лишь со звездами я попутными поделюсь своей сердца тайною! ${ }^{17}$

а вот как выглядит переводная силлабика Амелина:

Отголосок чувств - стон сердечный - я морским волнам

И восторженной скачке, страстной и лихой предам!

Мчи, Мерани, в даль устремляясь безграничную,

И развей мою бегом бурным думу мрачную! ${ }^{18}$

Очевидно, что в этом новом переводе - в отличие от предшествующих, сильно олитературенных и приспособленных к русской классической традиции - отчетливо слышны ритмы русских имитаций (кольцовских в первую очередь) народного стиха и ранней русской досиллаботонической поэзии. В этих условиях лирический субъект переводного текста дистанцируется и от субъекта оригинала (что неизбежно при переводе), и от субъектов традиционных переводов, выступавших как простые двойники переводимого автора.

Характерно, что сам автор пишет об этом так:

Многолетний опыт перевода античных поэтов и, прежде всего, Пиндара, подсказывал мне, что стоит только найти метрико-ритмическое соответствие, как все слова сами станут на свои места. Если вся европейская поэзия традиционно переводится на русский эквиметрически, с той или иной долей условности, то почему грузинской быть исключением из правила? И не только грузинской, но и, например, всей персидской, писавшейся по системе аруз, которая есть не что иное, как квантитативная система, родственная древнегреческой. В смысле адекватности передачи метрических особенностей, действительно, всю персидскую поэзию стоило бы перевести заново, отыскивая соответствия, изобретая размеры. На мой взгляд, переводное сти-

16 Там же, с. 416-417.

17 Там же.

${ }^{18}$ Там же, с. 420-421. 
хотворение не должно быть совершенно русским, в нем обязательно должно оставаться нечто чужеродное, инозвучащее. ${ }^{19}$

Как уже говорилось, очень часто новации Амелина ориентированы на основной тип современного мирового стиха - верлибр, что в русской читающей среде тоже до сих пор представляется новацией. Поэтому даже вполне традиционное по смыслу стихотворение представляет лирического субъекта - именно в сочетании с избранной им для высказывания новационной формой - как минимум в двойственном статусе, условно говоря, новатора и архаиста в одном лице:

ЛИРА

В антикварном отделе

книжного магазина «Москва» на Тверской, куда я часто захаживаю, мне попалась - буквально на днях одна любопытная книга:

«Опыт о русском стихосложении» Востокова, 1817-го года.

Александр Христофорович по молодости лет истинным был пиитом, изысканным и чрезвычайно изобретательным, воспевал мужскую - в античных формах любовь и дружбу, а потом, остепенясь, Поэзию бросил и женился на Филологии.

Редкий - ручаюсь экземпляр единственного издания (хоть и черным по белому, что второе), с которого, собственно, началась наука о русском стихе, в полукожаном переплете, без корешка, стоит 20.000 рублей.

Однако не тем он ценен, а тремя - на переднем форзаце слева прежних последовательными надписями владельцев:

Сергея Михайловича Бонди, Сергея Павловича Боброва, Михаила Леоновича Гаспарова и пометами на полях.

Знатоки и ценители тонкостей стиховых с отвлеченной своей наукою переместились к Востокову - медлительно рассуждать

19 Там же, с. 419. 
о размерах, рифмах и строфах,

а ты на продажу выставленной оказалась, обветшалая, не переданная никому

Лира стиховедения!

$2007^{20}$

Активно использует свободный стих Амелин и в своих переводах. Вот пример такого стиха, написанного современным вьетнамским поэтом Ву Суан Хыонг (род. 1956), с умножением лирического субъекта (автор и переводчик, представитель восточной культуры и западной темы, древней стиховой традиции и верлибра и т.д.):

\section{САКСОФОН}

Саксофон

твой голос уже звучит -

в небе приметы вечера -

пробираясь неспешно теснинами арок...

вот вырвался ветер окрашен в цвета воспаленных закатов из переполненной клетки грудной, где трепещет, вздуваясь, пара легких листов

траектории ветра - синусоиды, спирали - дыхания струи эволюции циклы - в твоих изгибах

глухие стены воздвиглись

в желтых и серых пятнах

твоя душевная боль острее там, где садится солнце

Ночь -

амфитеатр Древнего Рима,

испанская арена -

тебе не страшно, когда в налитых кровью очах быка

отражены бесчувственные глаза самодовольного человека...

не настаиваешь, не плачешь

только дрожишь порывам глубинной мелодии в такт

Представь, что твое лицо стало ликом земли

искаженным разломами разлук

разделением эпох отхода и наступления моря

Голоцен

Плейстоцен

отпечатки шагов первых тварей с человеческим обличьем...

Нет, это не зов трубы, побуждающей к бою солдат!

не печальные всхлипы флейты вслед идущим в последний путь!

${ }^{20}$ Там же, с. 232-233. 


\author{
Саксофон \\ твой голос еще звучит - \\ в небе приметы вечера - \\ пианино умолкло, затих последний аккорд
}

все временное отступает, покоряясь ритму судьбы

перед бессрочным покоем таинственного безмолвия... ${ }^{21}$

Говоря о верлибре, нельзя не отметить и разнообразной плодотворной деятельности Амелина по разысканию и популяризации ранних форм русского стиха, отчетливо перекликающихся с новейшими; так, им был открыт и частично опубликован возможно самый первый русский верлибрист М. Собакин, автор стихотворения «Благополучное соединение свойств, потребных к правлению великих империй, в высокоторжественный день восшествия на престол всепресветлейшия и непобедимыя Государыни Императрицы Анны Иоанновны, самодержицы всероссийския, при радостном восклицании с удивлением всеподданнейше представленное от обретающагося в Санктпетербурге при Шляхетной академии юношества» (1738):

О благополучный день! твое светлое сияние

Возбуждает и призывает все наши чувства к удовольствию,

Позволь чтоб мы последовали нашей радости,

Влей в наши сердца твое сокровище.

Предложи, о радостный день! нам твое довольство,

Да от твоего богатства познаем изобилие,

И да щастливейшим тебя днем назовем в России;

Объяви нам славы твоея источник:

Тебя прославляет и хвалит неисчетное число

Тех людей, которых благополучие произошло от твоего света,

И на которых тобою послано Божие благословение:

От тебя заимствует слабый их свет свое сияние $[\ldots]^{22}$

Впервые после многолетнего забвения привлек Амелин внимание и к другой книге, содержащей многочисленные примеры раннего русского свободного стиха (правда, как и в случае Собакина, не осознаваемых в качестве таковых) - духовных стихов русских старообрядцев, собранных в книге Т. Рождественского. ${ }^{23}$

Вообще, Амелин проявляет большой интерес к так называемому народному стиху, причем не в собственно фольклорной форме, а в преломленном через опыт исследователей-имитаторов начала XIX века (в первую очередь, того же Востокова); особого внимания в свете нашей проблемы заслуживает недавняя поэма «Соловецкая страда», каждая часть (песнь) которой написана собственным метром, схема которого (тоже как у Восто-

\footnotetext{
21 Там же.

${ }^{22}$ Собакин (1738, с. 12).

${ }^{23}$ Амелин (2011, с. 359-366).
} 
кова) помещается автором перед текстом, а сам он строится в соответствии с авторским пониманием метрики русских лирических народных песен как стопо-силлабической, как и у грузин:

ПЕСНЬ ТРЕТЬЯ. ПЕРЕСЧЕТ МОНАСТЫРСКИХ ПУШЕК

СОЛОВЕЦКИЙ МОНАСТЫРЬ, 29 ЯНВАРЯ 1676

\begin{abstract}
$\times \cup-\cup \times \mid \times \times$
Как в обители стал хозяйничать учинить велел каковые суть? и послал двоих для той росписи изобученных
\end{abstract}

Оба знатчика Пересчитывать Перемеривать да чернилами $\cup-\cup \times \mid \times \times \times \cup-\cup \|$

Соловецкой, взысканной сам Иван Мещеринов, пересчет с пристрастием сколько их в наличии? вологодских знатчиков Бориса Савельева хитростям в неметчине

начали расхаживать в точности наличные их стволы да взвешивать в свой черёд почёркивать и опустошённой, грозный воевода, пушкам да пищалям: на которых башнях? пушечного дела с Назарьевым Климом, своего искусства.

по стенам и башням, пушки да пищали, по тяжести ядра, на белой бумаге. ${ }^{24}$

В основе метра этой песни лежит, как видим, девятистопный хорей с двумя обязательными цезурами с наращением на второй из них и с регулярными переакцентуациями на третьей части строки.

Таким образом, лирический субъект этого произведения также оказывается многолик: это и современный поэт, пишущий историческое произведение, и изображаемый им русский поэт XVII века, описывающий события недавнего прошлого и бывший, возможно, их непосредственным участником, и искушенный знаток теории и истории русского стиха, способный оценить версификационную изощренность возникающего на его глазах текста.

Еще более интересно устроены амелинские вариации на темы русских имитаций античного стиха, гексаметров и логаэдов. В отличие от многих отечественных авторов как прошлого, так и настоящего, по сути дела упрощающих гексаметр до шестстопного дактиля, Амелин вполне сознательно использует богатейшие ритмические возможности этого вариативного по своей природе стиха («первого русского дольника», как называл его М. Гаспаров), никогда не забывая при этом грандиозную предысторию этого типа стиха. Именно поэтому в его «Рождественский коллаж» вторгается фрагмент из «Метаморфоз» Овидия:

С мертвыми надо шутя живым вести разговоры, слово за слово, но передразнивать их никакого смысла нет. Итак, приступим. Болтливый Овидий! мне Вергилием будь и через круги превращений

\footnotetext{
${ }^{24}$ Цит. по рукописи из архива М. Амелина (не опубликовано).
} 
переведи меня, - не замедлю и я с переводом:

«Так как Пигмалион преступную жизнь провождавших видывал жен, возмущен пороками, коих в достатке ихней природа душе дала, - холостой, не женатый

жил, - пребывала его без соучастницы спальня. По белоснежной меж тем кости, удивляя искусством, резал, стараясь придать черты, каких ни одной из жен не врождалось, свое питая созданье любовью.

$[\ldots]$

Остановиться бы хоть на миг, закурить сигарету, дух перевести, размыслить, посомневаться: точен мой перевод с латыни? нет ли? - но точно, я не соперник тебе, изгнанник Римский, с тобою нечего мне делить, посему, пожалуй, продолжим: [...]

Вижу, ты прикорнул - ни всхлипа, ни храпа - на самом интересном для нас, телами стиснутых, месте; спишь без задних ног (так только бесплотные тени забываются сном), убаюкан гекзаметром скифским.

Bсе, что снится тебе, пред моими глазами застыло, проплывая: сидит, обложенный свитками, некто в мятой накидке, доску, покрытую воском, истертым ковыряя крючком при свете неярком лампады, -

пишет коряво: «...рожден... (слова неразборчивы) ...имя...» Свет внезапный слепит ему глаза голубые, новая в небе звезда, просияв на Востоке, пространство заполняет собой, застопоря время. Сидящий

замер (как будто не спит, но шевельнуться боится), устремленным вдаль созерцает видение взором, жадные света зрачки расширены, в них - как на снимке отпечатлена удивительная картина:

[...]

$1994-1998^{25}$

В этом стихотворении вторым лирическим субъектом оказывается Овидий в нарочито осовремененном переводе Амелина. В другом своем опыте переводе «Одиссеи» - современный поэт воздерживается от модернизации лексики; в предисловии к публикации он пишет:

${ }^{25}$ Амелин (2011, с. 90-94). 
Мне хотелось сохранить в нем архаическую непосредственность оригинала и в то же время показать современность его звучания, передать сложность и простоту Гомеровых поэтических выражений и при этом не соскользнуть в голимую прозу [...] Мне хотелось, чтобы внимание было сосредоточено больше на фонетической и ритмической фактуре перевода.

Гекзаметр по-русски я рассматриваю как дольник с мужской или женской цезурой на шестиударной основе, в котором любое ударение, кроме предцезурного и последнего в строке, может быть опущено и стать мнимым или подразумеваемым, как это обычно происходит в русских дольниках. Основной ритмический закон оригинала: в каждых трех соседствующих стихах ритмический рисунок повторяться не должен. Он создает необходимую вариативность, мешающую быстрому засыпанию при чтении или прослушивании. В своем переводе я постарался этот важный закон соблюсти. ${ }^{26}$

Вот как выглядит начало «Песни первой», в которой мы, благодаря подробному предисловию, вынуждены искать выражение как минимум трех лирических субъектов: собственно автора, его современного переводчика и знатока античной и русской метрики:

Муза, вещай мне о муже испытанном, кто поскитался много с тех пор, как поверг священную Трои твердыню, грады многих племён повидал и нравы изведал, много и на море вынес напастей сердцем отважным, спутникам и своей душе взыскуя возврата.

Но не сберёг всё равно сопутников, сколь ни старался, собственным погубили они себя безрассудством, ибо, глупцы, коров Гелиоса Гипериона

съели, за что у них возвращения день он и отнял.

Что-нибудь нам и о том, богиня, дщерь Зевса, поведай. ${ }^{27}$

Примерно то же происходит и с амелинскими логаэдами, которые поэт использует как в своих переводах (Катулла, Приаповой книги и т.п.), так и в оригинальной лирике. Напомним знаменитое стихотворение Амелина, написанное после завершения работы над переводами Катулла; стихотворение написано русской имитацией стопного римского логаэда - фалекия, каждая строка которого традиционно представлялась как последовательность двух анапестов и двух ямбов:

Мой Катулл! поругаемся, поспорим, просто так посидим - с Фалерном туго; ничего, - как-нибудь и с этим горем: поглядимся, как в зеркало, друг в друга.

На, кури. Что не спрашиваешь, кто я? где? когда? почему усов не брею? и слежу через стекла за тобою? В гости к сумрачному гиперборею

${ }^{26}$ Амелин (2013, с. 138).

27 Там же, с. 139. 
ты попал. Не видение, не морок мы с тобой, если хочешь, если надо, чай заварим из трав, лимонных корок и съедим по полплитки шоколада.

Ты, наверно, лет десять не был в Риме: тоги нынче не в моде - на смех курам. Да, таким же - с глазами голубыми, долговязым, но статным, белокурым -

я тебя представлял, когда в тетради от бессмертия к жизни - строки сами проступали. - Давай, союза ради, мой Катулл, обменяемся сердцами! ${ }^{28}$

На первый взгляд, применительно к этому стихотворению можно говорить об одном, вполне традиционном лирическом субъекте, соотносимый с современным автором. Однако не менее важным оказывается здесь адресат, которого поэт XX века вводит в свой мир, описывая его реалии; по сути дела, Катулл является в стихотворении вторым лирическим субъектом, идентификация которого во многом происходит при помощи употребленного в стихотворении редкого типа стиха, созданного в подражание античному.

Активно использует Амелин и логаэдические строфы разных типов: как воспроизводящие античные строфы, так и авторские. Пример последнего:

Поспешим

стол небогатый украсить

помидорами алыми,

петрушкой кучерявой и укропом,

чесноком,

перцем душистым и луком,

огурцами в пупырышках

и дольками арбузными. - Пусть масло,

как янтарь

солнца под оком, возблещет

ослепительно. - Черного

пора нарезать хлеба, белой соли,

не скупясь,

выставить целую склянку. -

Виноградного полная

бутыль не помешает. - Коль приятно

${ }^{28}$ Амелин (2011, с. 27). 
утолять

голод и жажду со вкусом! -

Наступающей осени

на милость не сдадимся, не сдадимся

ни за что. -

Всесотворившему Богу

озорные любовники

угрюмых ненавистников любезней.

$1992-2000^{29}$

Здесь лирический субъект проявлен как собственно в гастрономической идиллии, у русского читателя непременно вызывающую в памяти стихотворение Державина «Приглашение к обеду», ставшего прототипом всех стихотворений этого типа, так и в типе стиха, реализующем давний призыв того же Востокова к активизации логаэдических метров.

Из других античных по генезису строф Амелин использует также одическую, причем в том виде, в котором ее применяли русские поэты XVIII века (интересно, что и здесь Амелин обращается к стиховедческой рефлексии, вспоминая о выбранном размере - четырехстопном ямбе):

КЛАССИЧЕСКАЯ ОДА В.В. МАЯКОВСКОМУ

Зам. председателя Земшара!

вознагражден за гертруды,

ходи по лезвию пожара

и битому стеклу воды

свободно, без препон и пошлин,

иль стой на площади, опошлен, в потеках жертвенной мочи, лишь в сумрачное время суток кучкующихся проституток, смотри, В.В., не потопчи.

Смотри, в слепящее рекламой многоочитое табло неосторожно, самый-самый! ножищей в тысячу кило не звездани, В.В., навылет, a то напополам распилят и переплавят на металл. Ломая молниями строчки, о свежестиранной сорочке и памятнике кто мечтал?

Ты, друг всего и вся на свете и лучший враг всего и вся, из тех апартаментов в эти

29 Там же, с. 44-45. 
переливающегося,

ты, для горилл и павианов,

как вывернутый Жорж Иванов

для павианов и горилл,

поверивших, что солнце - люстра,

но, слава Богу, Заратустра

так никогда не говорил.

В четырехстопном ямбе трудно

сложить сочувственную речь

тебе, как тонущее судно

от гибели предостеречь, -

ни славы нет, ни силы класса,

ни рябчика, ни ананаса...

Стань, кем ты не был, кем ты был, останься, - старцем и подростком, всех шумных улиц перекрестком

и жеребцом для всех кобыл!

$1997-1998^{30}$

К одической строфе, одновременно активизирующей память об античной классике, русском XVIII веке и веке Серебряном (благодаря обращению к раскованной тонике) Амелин обращается и во вполне лирическом на первый взгляд стихотворении, смысл которого, однако, неизбежно усложняется именно благодаря упоминавшейся уже «мультипликации» лирического субъекта:

Сложного сложнее, простого проще, то неповоротлива, то шустра,

громоздясь на горы, врываясь в рощи, языками яростными костра ласково крутя, шевеля глумливо, рушится стремительная с обрыва и встаёт целёхонька, как ни в чём не бывало, плотная и сквозная, сведуща во всём, ничего не зная, собственным себя подопря плечом.

Сопредельным странам грозя набегом, мир даруя прочим издалека, Ноевым взлетающая ковчегом над водой под самые облака, раздаётся вширь обоюдокрыла, весть о том, что будет и есть и было, претворить пытается в кровь и плоть всех существ, замешанных на соблазнах, потому что в лицах и видах разных праведную любит её Господь. ${ }^{31}$

${ }^{30}$ Там же, с. 96-97. 
В еще одном своем оригинальном произведении Амелин тоже апеллирует одновременно к нескольким традициям - это визуальная «Запоздалая ода Екатерине Великой, императрице и самодержице всероссийской, при воззрении на зыбкое отражение в луже памятника ея, что на Невском проспекте в Санкт-Петербурге, декабрьским вечером 2006 года» ${ }^{32}$ :

Тебе,

царице

северной

сей

державы,

дерзну ли хвалу

вознести после стольких

величия полных певцов,

уже до меня все награды,

всю славу себе стяжавших?

Ни перстней, ни табакерок,

усыпанных алмазами, не жду!

Легко воспевать и выгодно

живых, сребра и злата от них,

высоких чинов и званий взыскуя,

верный доход сулящих владельцу

имений, и прочих благ и стяжаний,

устойчивых и непреложных! Любой

певец о том помышляет с надеждой

тайной иль явной, но обоснованной.

Суд над правителями посмертный

вершат беспристрастные летописцы,

дабы все по своим расставить местам

и должное всем воздать:

кто выспрь возлетел воздушным шаром,

кому упасть случилось ниже некуда,

чья кровь пролилась безвинно, чей сдавленный

в горле затих крик, на свободу так и не вырвавшись,

лепет любовный кого за ступенью ступень

по шаткой лестнице взомчал до верху самого,

откуда весь мир, возможный и зримый

как на ладони зерно конопляное видится,

о ком сперва безмолвствовать, потом рассказывать

повелено было на каждом углу, наоборот ли,

переставив наречия временные. Лиц и событий

истинная соразмерность при помощи

увеличительных и уменьшительных стекол

выявляется всенепременно. Мне же,

не летописцу, но певцу позднорожденному,

по созвучию научившемуся слова подбирать

и по мере укладывать, строй и порядок, предписанный

сводом правил неколебимых, безжалостно и хладнокровно

разрушающему, ради создания и утверждения новых,

свой приговор выносить издалека не пристало. В защиту

повелительницы премудрой части моря и суши той,

от которой и нынешний сколок иль клок, после всех переделов оставшийся, зрится немыслимым и восприятия чувственного

за гранью находящимся, немстительной ко врагам быть желавшей, справедливой ко подданным и милостивой, насколько возможно,

\footnotetext{
${ }^{31}$ Там же, с. 192.
}

${ }^{32}$ См. анализ: Rutz (2016). 
здесь и сейчас воздвигается, Екатерина! речь непредвзятая мной.

О могущественная владычица, окруженная сонмом великолепных

мужей и жен, заставивших трубы и лиры согласно звучать повсюду,

ибо только достойным достойные служат честно! Се непроглоченный

львом пучинным в лесу щегловитом, се луне надломивший рога, се хищных

птиц всех мастей ощипыватель догола, се мира заключитель долгожданного,

се бесстрашный по лужам соленым ходок, се счастливый разитель во бранном

поле и на ложе, се державной реки воспитатель, се расплодительница мысленных

стад и чувственных стай, се деяний свершенных и подвигов отдаленным потомкам

возвеститель правдивый в творениях стройных, премудрый свидетель и соучастник

великих событий, поскольку вне таковых речетворческий дар не вполне раскрывается.

Ничтожен пиит, коль на долю его прозябание выпало при бездарных и недальновидных

властителях, окруженных алчной сворою и ненасытной. Что ему остается? Дышать

равномерно дыханием прежде дышавших и с тихой тоскою смотреть обреченно

на искаженное отражение памятника твоего, самодержица, в мутном

декабрьском зерцале, поразительно напоминающем рваными

очертаниями своими нечто знакомое с детства: карту ль,

на которую ставить нельзя, медведицу ли большую,

семизвездием блещущую бесстрастно

сквозь пространство

и время. ${ }^{33}$

Наконец, в собственно античной, переводной «Пиндарова пифийская двунадесятая оде Мидасу из Акраганты, цевничему» Амелин точно воспроизводит строфику греческого оригинала:

Строфа 1

Молю, блесколюбице, тя, краснейшая градов земных, где Персефоны престол, чья над Акрагантой стада пасущей обитель - горы верх стройной, о владычице, сей благосклонно принять изволь от любимца богов и смертных Мидаса венец Пифийский достославного, кто всей победитель Эллады в том искусстве, некогда изобретенном Палладой, что сплела вой Горгон надрывный дерзостных, Афиной. ${ }^{34}$

Но для нас интересен не только этот опыт, но и его отражение в опыте самого поэта - его «Пространной оде на новотысячелетие», построенной по пиндаровской трехчленной схеме (строфа-антистрофа-эпод, где первые два элемента имеют однотипную логаэдическую структуру, а третья ритмически противопоставлена им):

Строфа 1

Лира с облупленной позолотой! что приумолкла ты? - Поработай,

${ }^{33}$ Там же, с. 222-223.

34 Там же, с. 396. 
верный словам задавая лад,

следуя замыслу,

вспрянь ото сна, наполни ладони

тяжестью некой, - лихие кони

в небо распахнутое взлетят,

страха не ведая,

в небо Пиндара и Вакхилида

с опустошенной земли, без вида,

в недре дремучем таящей клад,

медленно зреющий.

Антистрофа 1

Значит ли это хоть что-то? - Что-то

значит. - Последняя позолота

пылью на пальцы налипла пусть,

пусть оболочкою

их несмываемою покрыла, -

тьмой управляющие светила,

напрочь забытые, наизусть

прежде известные,

внемлют напевам, звенящим надо

всею вселенной, коей громада

избранным в радость, прочим во грусть

превелелеплена

Эпод 1

тем прозорливым Зодчим,

что естество

вмиг

для бытия выстроил

люботвореньем отчим

из ничего,

стих

произнеся мысленно

шероховатый, - вот чем

здание во-

здвиг

без чертежа Сущего. ${ }^{35}$

Здесь перед нами - сложное псевдологаэдическое построение, основанное на чередовании стоп дактиля и хорея и соблюдении строгой силлабической дисциплины. Соответственно, если рассматривать этот текст с точки зрения его субъектной организации, имеет смысл опять-таки выделять в нем сложное взаимодействие нескольких субъектных структур.

35 Там же, с. 157-158. 
Как мы видим, у Амелина лирический субъект проявляет себя крайне разнообразно и изощренно. Так, его авторские (то есть, не следующие античным образцам и их традиционным русским имитациям) логаэды создают отчетливое субъектное «двухголосие», продиктованное или наличием двух равноценных лирических субъектов (например, современного автора и Катулла [«Мой Катулл! поругаемся, поспорим...»], переведенного Амелиным наряду с Пиндаром, Горацием и Гомером), или совмещением лирического нарратора, вожделенно повествующего о соблазнительных гастрономических реалиях современной жизни и своем отношении к ним, и ориентированным на античный прообраз «голоса» сложной, но структурно четкой логаэдической строфы («Поспешим / стол небогатый украсить / помидорами алыми...», «Изваяние Силена в Капитолийском музее»).

Особенно характерно это прослеживается в одах Амелина, ориентированных на различные варианты одического стиха (от хвалебных, анакреонтических и визуальных в духе восемнадцатого столетия до полностью утративших свою структурную идентичность «од» Серебряного века).

Подводя итоги, скажем, что в современной поэзии, ориентированной на сложный стиховой плюрализм, на многослойную гетероморфность ритмического строения, лирический субъект оказывается неизбежно нагружен, кроме традиционных, рядом новых, собственно структурирующих текст и одновременно организующих его память функций, что позволяет говорить об определенной мультисубъектности многих произведений, особенно ориентированных на читателя-интеллектуала.

\section{Литература}

Амелин, М. (2011): Гнутая речь. М.

Амелин, М. (2012): Случайная музыка // Знамя. 10, 2012. 87-89.

Амелин, М. (2013): Гомер. Одиссея. Песнь 1. Пред. и пер. М. Амелина // Новый Мир. 2, 2013. http://magazines.russ.ru/novyi_mi/2013/2/g9.html (6/06/2018).

Бройтман, С. (1997): Русская лирика XIX - начала XX века в свете исторической поэтики (субъектно-образная структура). М.

Бройтман, С. (2001): Историческая поэтика. М.

Бройтман, С. (2004): Теория литературы. / Соавт.: Тамарченко Н. Д., Тюпа В. И. В 2 тт. М.

Гинбург, Л. (1974): О лирике. Л.

Завьялов, С. (2003): Мелика. М.

Завьялов, С. (2010): Речи. М.

Корман, Б. (1977): О целостности литературного произведения // Известия ОЛЯ АН СССР. 36 (6). 508-513.

Корман, Б. (1992): Целостность литературного произведения и экспериментальный словарь литературоведческих терминов // Корман, Б. Избранные труды по теории и истории литературы. Ижевск. 172-189. 
Роднянская, И. (1981): Лирический герой // Лермонтовская энциклопедия. M. http://febweb.ru/feb/lermenc/lre-abc/lre/lre-2581.htm (08/08/2018).

Собакин, М. (1738): Совет добродетелей о поздравлении всеавгустейшия персоны Ея Императорского Величества Анны Иоанновны, самодержицы всероссийския, в день высочайшаго Ея рождения 28 дня генваря, сочинен стихами в Санктпетербурге, чрез Михаила Собакина, Шляхетного кадетскаго корпуса подпрапорщика, 1738 года. Печатано при Императорской Академии Наук. СПб.

Тынянов, Ю. (1921): Блок и Гейне // Об Александре Блоке. (Редактор не указан.) Петроград. 235-264.

Шмид, В. (2003): Нарратология. М.

Rutz, M. (2016): Maxim Amelins „Verspätete Ode an Katharina die Große...“: Das Potential der literaturhistorischen Retrospektive // Stahl, Henrieke / Korte, Hermann (Hgg.): Gedichte schreiben in Zeiten der Umbrüche Tendenzen der Lyrik seit 1989 in Russland und Deutschland. Leipzig. 327-369. 


\section{Федор Двинятин (Санкт-Петербург)}

\section{Современные поэты-«не-поэты»: от позиции и текста к субъектности 1}

В последнее десятилетие (срок достаточно условный), как кажется, обнаружилась одна тенденция, имеющая отношение к современной (текущей) русской поэзии; впрочем, возможно, точнее было бы говорить о наборе перекликающихся частных тенденций. Основное наблюдение состоит в следующем: теперь, чтобы воспринимать панораму текущей российской поэзии в целом, а также сумму ее предполагаемых высших достижений, недостаточно учитывать творчество только тех авторов, которые представляются поэтами и публикуют стихи, которые просвещенный читатель ждет от номинальных поэтов; нужно - хотя бы «боковым зрением» - учитывать тех авторов, которые фактически не спешат занять вакансию поэта, которые ведут себя не как поэты и пишут не совсем так, как пишут современные «собственно поэты» - но при этом (иначе ведь и не стоило бы о них говорить) пишут и публикуют тексты, значительные в смысловом и техническом отношении, претендующие на оценку по самым серьезным критериям. Начинать разговор об этой тенденции (тенденциях) и об этих автоpax непросто, не хватает устоявшихся концепций и терминов; поэтому поначалу, возможно, лучше ограничиться отдельными наблюдениями и вводными рассуждениями.

Можно предположить, что поэт как таковой, автор, считающий себя, ощущающий себя собственно поэтом, живущий жизнью поэта - преимущественно и определяет себя как поэта в первую очередь, как прежде всего поэта. Тот, кто ставит свое поэтическое призвание на второе место в списке ролей или реализаций, уже не вполне разыгрывает роль поэта как такового. Номинальному поэту положено жить литературой, поэзией. Предполагается, что он ищет всяческих возможностей печататься в ведущих (или хотя бы доступных ему по статусу) журналах, издательствах, с недавних пор - на признанных поэтических сетевых ресурсах; участвует в жизни поэтических фестивалей, салонов, кабаре, в публичных чтениях и т.д.; входит в формальную группу, сообщество, либо противопоставляет себя всем сообществам, но как отдельную единицу поэтической жизни, и, как правило, в любом случае вовлечен в сеть связей - дружеских, нейтральных или

\footnotetext{
${ }^{1}$ Исследование выполнено при поддержке гранта РФФИ № 18-012-00570 «Топика постриторической эпохи: теория и практика», выполняемого в Санкт-Петербургском государственном университете.
} 
враждебных - с другими поэтами. Этой более внешней, социальной стороне соответствуют и особые признаки текстов: в положительной или отрицательной форме поэт реализует параметры текущей литературной ситуации: отвечает на запросы, участвует (в форме манифестов или самой поэтикой своих произведений) в полемиках и борьбе школ, отзывается на новинки, на колебание поэтического вкуса и литературную моду, в самых сильных случаях - создает эту новую поэтику или новую моду. Существование вне всех основных парадигм текущей поэзии (а их, видимо, всегда больше, чем одна, иногда - немало), игнорирование тенденций текущей литературной ситуации выдает полемическую (или менее полемическую и более естественную) фигуру поэта-«не-поэта»: поэта по характеру и значительности текстов, не-поэта - по социальному, окололитературному поведению и по специфической маргинальности текстов sub specie текущей литературной ситуации.

Современных русских поэтов-«не-поэтов» можно, кажется, отыскать среди: 1) успешных прозаиков, публикующих стихи как составную часть большой и (условно говоря) амбициозной прозы; 2) поэтических переводчиков лучшего разбора, печатающих, кроме переводов, и оригинальные тексты; 3) авторов, сполна реализовавшихся в какой-либо иной деятельности, каковая и есть их основная профессиональная идентификация, но при этом пишущих и публикующих стихи высокого качества - последняя оговорка исключает дилетантские опыты тех или иных «значительных людей»; для осторожности можно ограничиться крупными учеными; 4) блогеров, популярных или относительно популярных в сетевых сообществах и иногда (редко) известных только под своими никами; 5) авторов, известных (в тех же блогах и социальных сетях) своими ироническими миниатюрами, текстами в форме языковой и литературной игры, обращением к «бытовым» (имеется в виду современный быт) литературным жанрам. Применительно к одному автору графы этой классификации нередко пересекаются.

В качестве примеров «прозаиков» могут быть названы Андрей Бабиков, исследователь текстов Набокова и автор романа «Оранжерея», ${ }^{2}$ в состав которого вошли стихотворения, мотивированные фабулой и повествовательной конструкцией книги, ${ }^{3}$ и Олег Постнов, в романе (или сборнике) которого «Поцелуй Арлекина» ${ }^{4}$ есть подобные же стихотворные фрагменты. Роли прозаика, переводчика, филолога почти заслоняют собственно поэта в Романе Шмаракове (романы «Овидий в изгнании», «Каллиопа, дерево, Кориск», «К отцу своему, к жнецам», «Книга скворцов», переводы Клавдиана, Иосифа Эксетерского, Вальтера Мапа, Пруденция и др.), публиковавшего, однако, в составе своей прозы и в сетевых источниках поэ-

\footnotetext{
${ }^{2}$ Бабиков (2011).

${ }^{3}$ См. более раннюю публикацию: Бабиков (2007).

${ }^{4}$ Постнов (2014).
} 
тические тексты высокого достоинства. Переводчик ${ }^{5}$ и известный ученый (математик) Алексей Кокотов печатает также оригинальные стихотворения. $^{6}$ Крупный филолог, публицист и переводчик Алексей Любжин - автор книг «Сльпой. Поэма о Гомерђ» и «Сирень Таврическаго сада». ${ }^{7}$ Выдающийся физик Михаил Кацнельсон - автор двухтомника «Стихотворения». ${ }^{8}$ Огромной популярностью в филологических, литературных и сетевых кругах пользуются иронические, игровые и совершенно серьезные поэтические тексты филолога, эссеиста и прозаика Михаила Безродного - он печатает их в своих книгах, ${ }^{9}$ периодических печатных и сетевых изданиях и в своем блоге. Буквально только что были изданы избранные поэтические и прозаические «мелочи» Владимира Мошкевича, более десятилетия публиковавшиеся в блогосфере и социальных сетях: «Совершенные пустяки. 2005-2016». ${ }^{10}$ Кажется, есть основания включить в рассматриваемый круг как будто не принадлежащего ни к одной из перечисленных рубрик Алексея Ушакова ${ }^{11}$ и далее, хотя бы отчасти - уже более близких к собственно поэтической роли авторов, таких, как, например, Олег Комков и Глеб Михалев. (В принципе, некоторыми особенностями своей позиции и поэзии близок перечисленным авторам священник и поэт Сергей Круглов, но его автора семи стихотворных книг, номинанта престижных премий, предмет обсуждения статусных критиков - конечно, нельзя считать «не-поэтом», избегающим поэтического статуса, несмотря на явную вторичность роли поэта. Этот пример предупреждает о нечеткости границ и обилии переходных случаев). Основным клубом некоторых из рассматриваемых здесь авторов служит - или служила - платформа „LiveJournal“, где публиковались и отчасти продолжают публиковаться Безродный, Шмараков, Кокотов, Любжин, Кацнельсон, Мошкевич, филолог и редактор Владислав Николаенко и др. Не все и не у всех, но многие у многих состоят в друзьях и ведут беседы - о поэзии и не только.

Прототипы перечисленных явлений в русской литературной культуре более или менее ясны. Это, например, фигура «поэта-дилетанта», как Тынянов в известной статье определяет Тютчева. Эта формулировка могла вызывать несогласие у других исследователей поэта, но дело в данном случае не в том, насколько она исчерпывающе точна, а в том, что нечто существенное все же схватывает. На протяжении практически всей своей судьбы таким же поэтом-«не-поэтом» должен был ощущать себя И. Аннен-

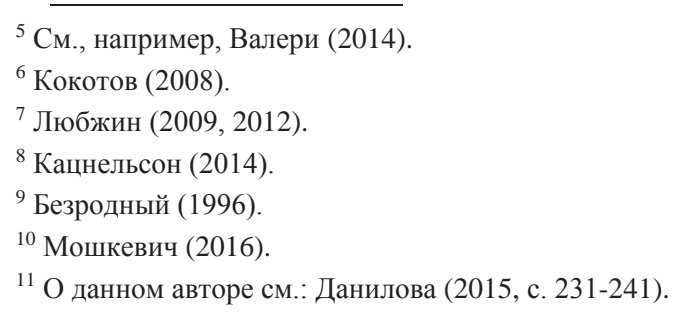


ский. «Стихи в составе прозы» в более близкой перспективе уводят к «Между собакой и волком» Саши Соколова, в более отдаленной - к «Доктору Живаго» Пастернака и опытам Набокова (например, в «Даре»). «Стихи прозаика» - не столь влиятельное явление в русской традиции, в отличие от «прозы поэта» (относительно хорошо изученной), даже в случаях Бунина, Мережковского, Белого, Набокова и Вагинова налицо постепенный и неполный переход поэта на прозу, а не «стихи прозаика». Их примером могли бы быть вирши, придуманные Достоевским для капитана Лебядкина. «Поэзия переводчика», несколько консервативная, технически изощренная, чуждая литературной актуальности (Für Wenige и для вечности) - напротив, пронизывает собой русскую стихотворную культуру XX века. «Канонизация» такой фигуры, прорыв носителя такого амплуа в высший поэтический эшелон - это, конечно, послевоенная поэзия Арсения Тарковского, ее издательская судьба и читательская рецепция; многие черты такой фигуры разыгрывал М.Л. Гаспаров, без немногочисленных оригинальных стихов которого теперь почти непредставима история русской интеллектуальной поэзии конца века; для некоторых современных авторов принципиальна ориентация на Сергея Петрова (1911-1988), крупного переводчика и поэта, чьи переводы в позднее советское время печатались, а оригинальные стихи - нет. Можно указать также на (различные по значению и судьбе) фигуры Михаила Лозинского, Константина Липскерова, Сергея Шервинского, Владимира Державина, Семена Липкина, в новейшее время - Владимира Микушевича и Евгения Витковского. Если говорить о гуманитариях недавнего поколения, очевидно вспоминаются стихи (почти всегда «дилетантские» в смысле реализуемого культурного амплуа, но не формальных и смысловых достоинств) В. Г. Адмони, С. С. Аверинцева, Вяч. Вс. Иванова и уже упомянутого М. Л. Гаспарова. В старой литературной культуре можно найти и прототипы фигуры поэта-шутника-«блогера», автора ценимых первоклассными знатоками стихотворных импровизаций, эпиграмм, буриме и проч., с их технической виртуозностью и при этом с особой ролью в эволюции поэтического языка и стиха: можно вспомнить Сергея Соболевского и, хотя бы отчасти, Ивана Мятлева.

При исчислении языковых, стиховых, интертекстуальных и смысловых стратегий перечисленных современных поэтов почти не удается сформулировать особенности, характерные для всех названных: речь скорее идет о преобладаниях и тенденциях. Нужно принимать во внимание, что значительная часть этих поэтов так или иначе знает друг друга, они пребывают в дружеском и отчасти публичном общении, но, во-первых, это само по себе не доказывает их внутреннего родства; во-вторых, это общение может иметь цепочечный («кирпичный», по слову Н.С. Трубецкого) характер; в-третьих, в некоторых других случаях имеет место почти полная взаимоизоляция. 
Тем не менее можно попытаться перечислить некоторые схождения, имеющие отношение к реконструируемой субъектности поэтов описываемого «облака». ${ }^{12}$

Стратегии конструирования субъектности в текстах поэтов-«не-поэтов», в принципе, могут быть перечислены по привычным рубрикам: речевая характеристика (языковые модели), цитатный пласт (интертекстуальность), персонажно-масочные построения.

На графическом уровне наиболее заметной особенностью ряда перечисленных авторов (Любжин, Николаенко, отчасти Кокотов) является последовательное использование дореформенной орфографии, в «гротовской» (кодификатор акад. Я.К. Грот, конец XIX века) или даже до-гротовской версии. В области фоники заметна тенденция - как в «серьезных», так и в игровых и полуигровых стихотворениях - к использованию богатых и многочисленных звуковых повторов, паронимирования и анаграммирования, с опорой как на достижения поэтического авангарда, так и на архаические и классические тенденции звуковой организации текста. В разнообразных стиховых решениях перечисленных авторов выделяется резко преобладающая тенденция к использованию традиционных, классических форм стиха, к строгому соблюдению стиховых конвенций. Так, преобладает силлаботоника, а среди силлаботонических размеров (при интересе некоторых авторов к романтическим трехсложникам) особым вниманием пользуются ямбические размеры, особенно Я4, Я5 (например, в сонете) или Я6 (особенно в форме александрийского стиха); характерно ритмическое разнообразие Я4 - например, повышенное использование редких форм; в большинстве текстов рифмы точные и строгие, а если используются неточные рифмы, то, по заветам Маяковского и Пастернака, неточность компенсируется богатством «левой» части рифмы, ее оригинальностью и лексической неожиданностью и т.д. В области лексики характерна не слишком резкая, но последовательная ориентация на сохранение (а не вымывание) классического поэтического словаря с его широтой и традиционной основой и на два (условно говоря) вида лексического расширения - архаическое, восходящее к лексическому богатству поэзии и прозы XVIII начала XIX вв. и более ранних эпох, и специальное, подразумевающее ввод в поэзию редких слов, терминов, лексических раритетов, вплоть до гапаксов. Не чураясь, особенно в ироничных и игровых текстах, примет современной речи, изредка и бранных слов (только у некоторых авторов), рассматриваемые поэты в целом отказываются от ставки на сближение поэтической речи с повседневной, предпочитая не сплошной, а пунктирный и остраняющий вариант «обмирщения» (Мандельштам) стихотворного дискурса. Это же можно сказать и о поэтическом синтаксисе. Таким образом,

${ }^{12}$ В понимании субъектности следуем изложениям: Шталь (2016, с. 162-181); Азарова / Корчагин / Кузьмин / Плунгян (2016, с. 99-110). 
стратегии конструирования субъектности в области языка и поэтического слога могут быть суммированы в понятиях «сохранения, усложненияустрожения и дополняющего развития конвенции», «частичной архаизации» и «независимости от господствующих поэтических тенденций».

Эти же наблюдения, как кажется, подтверждает и интертекстуальная перспектива поэтических текстов обсуждаемых авторов. В том филологическом сообществе, к которому принадлежит большинство из этих авторов, неслучайно такой популярностью пользовались изыскания и очерки, составившие двухтомную «Летейскую библиотеку» А.Л. Соболева, ${ }^{13}$ - настоящий синодик «пропущенных» по тем или иным причинам стихотворцев $\mathrm{XX}$ века, от довольно безнадежных до по-настоящему значительных. Столь же предсказуем интерес к линии (если это «линия») Ходасевича и Набокова - одинокого консерватора и поэта-прозаика со своим представлением о поэтической иерархии. Маркирован оказывается и XVIII век, причем и здесь выбираются не самые ожидаемые имена - прежде всего Херасков и Муравьев. Внутриязыковые межтекстовые параллели продолжаются в межъязыковых и межлитературных: античная, средневековая и ренессансная поэзия у Шмаракова и Любжина, фарси и чагатайский тюрки у еще одного автора этого круга, дружеские и профессиональные контакты с исследователями древнеиндийской и шумеро-аккадской традиций - характерное для XX века расширение творческих связей русской поэзии с древностью и востоком удерживается в этой среде. Но интертекстуальные отсылки не ограничиваются знаками преемственности, наряду с этим рекрутируется очень широкая «упоминательная клавиатура» формул, контекстов, отдельных строк и ключевых мотивов классической и модернистской поэзии; монтаж подтекстов может тяготеть к центонному типу построения. Кроме того, используются разные типы травестийности - например, «перепев» в понимании И.Г. Ямпольского (восходящем к Тынянову). Своего рода негативная интертекстуальность проявляется в (как кажется) почти полном отсутствии положительных отсылок к поэзии современников и недавних предшественников - «номинальных» поэтов, в практически полном игнорировании текущей профессиональной поэзии. (Это только неподтвержденная гипотеза, но возможно, многие из перечисленных авторов более или менее сознательно рассматривают традиционные поэтические институты, причем равно - официозные, нонкомформистские и альтернативные - как находящиеся в кризисе, как монополизированные отдельными группами или, говоря шире, определенными профессиональными и социальными моделями, вместе же с ними, возможно, - и саму «номинальную» поэзию. Будучи, по-видимому, вполне амбициозными в отношении своего творчества, рассматриваемые авторы не амбициозны в плане захвата историко-культурной инициативы - таково основное отличие от авангарда).

${ }^{13}$ Соболев (2013). 
Речевые клише современности, запоминающиеся фрагменты политического и публицистического дискурсов, саркастически цитируемые обороты современной литературы (причем скорее прозы), киноцитаты и сетевой фольклор также могут вовлекаться в гетерогенный поэтический текст, но, соседствуя с другими цитатами и общим речевым строем текста, обнаруживают свою побочную роль: быть источником прозаического контраста или переформатироваться преобладающей «классической» рамкой текста.

Переходя к архетекстуальному в понимании Ж. Женетта, можно заметить особую роль в рассматриваемой поэзии твердых форм и связанных с ними поэтических жанров, причем как традиционных и высоких, так и новых, модных в сети, и используемых как в высокой, так и в игровой поэзии: сонеты, хокку, лимерики, так называемые «пирожки» (и их дериват «порошки»); может практиковаться жанр «бескрылки», родственный салонно-литературному буриме. Для многих из рассматриваемых авторов характерна ориентация на ироническую поэзию, бытовые литературные формы и игры, поэтическое остроумие, высокопрофессиональную и не вполне серьезную стиховую стилизацию. Восходящее к А. К. Толстому и кругу Хармса использование плохого письма, графоманских приемов, сдвинутого языка принадлежит к числу допустимых и практикуемых приемов. Образцы ролевой или исповедальной лирики могут встречаться, но преобладает поэзия либо безличная (третьеличная), либо с условным, иногда ироническим, образом субъекта, со стилизацией (архаизацией, либо, наоборот - и существенно реже - вульгаризацией) субъекта. У филологов и переводчиков чуть ли не самым заметным тематическим пластом субъектности в тексте оказывается профессиональный: медитации напрямую либо иллюстративные обыгрывания, посвященные языку вообще, поэтическому языку, стиху, поэтической технике, истории поэзии и всей литературы. Отсюда огромная роль метаязыковых и (авто)метаописательных текстов, уже названной интертекстуальности, образцов «филологической поэзии». Для прозаиков характерна сложная игра с передачей фикционального авторства (и, значит, хотя бы отчасти субъектности) стихотворения персонажу, но при этом более или менее близкого к автору. Прямое проявление авторских воззрений осуществляется скорее в негативной форме, как отказ от исповедания ценностей, чуждых автору. (Некоторый мировоззренческий традиционализм характерен для большинства поэтов этого «облака». Среди них практически неизвестны просоветские симпатии, безоговорочная любовь к современному миропорядку, признание за авангардом статуса чего-то большего, чем одного из этапов поэтической традиции, сциентистский материализм, ощущение языка и традиционной культуры как «репрессивных» инстанций).

Итак, суммируя наблюдения, можно было бы выделить три основных признака субъектности поэтов описываемого «облака». Это «независимость», «мастерство» и «пассеизм». В кратких и условных формулировках 
может в значительной степени исказиться подлинное содержание определений. Так, определенная оппозиция к современности и настоящему времени не абсолютна, а «мастерство», говоря более развернуто, просто представляет собой стремление к как можно более полному контролю над всеми уровнями стихотворного текста, как поиск совершенства, разнообразия, полной нагруженности, изощренности на стиховом, звуковом, грамматическом, лексическом уровнях, в интертекстуальных стратегиях и проч. Что же касается «независимости», то это независимость от ролевых и социальных моделей поэта и поэзии, почти наверняка осуществляемая в надежде прорваться к «вечной и подлинной» поэзии через предполагаемые современные искажения и принижения: как кажется, описываемые поэты предполагают, что время благоприятствует «сторонней» роли, достоинству, сосредоточенности, «веселой науке» и «святому ремеслу».

\section{Литература}

Азарова, Н. / Корчагин, К. / Кузьмин, Д. / Плунгян, В. и др. (2016): Поэзия: Учебник. М. Бабиков, А. (2007): Стихи // Звезда. 6, 2007. 104-105.

Бабиков, А. (2011): Оранжерея. СПб.

Безродный, М. (1996): Конец цитаты. СПб.

Валери, П. (2014): Собрание стихотворений. Пер. с франц. А. Кокотова. М.

Данилова, Д. (2015): Благодать воз благодать. Алексей Ушаков // Вопросы литературы. 1, 2015. 231-241.

Кацнельсон, М. (2014): Стихотворения. Berlin.

Кокотов, А. (2008): Над черным зеркалом. М.

Любжин, А. (2009): Слъпой. Поэма о Гомеръ. М.

Любжин, А. (2012): Сирень Таврическаго сада. М.

Мошкевич, В. (2016): Совершенные пустяки. 2005-2016. М.

Постнов, О. (2014): Поцелуй Арлекина. СПб.

Соболев, А. (2013): Летейская библиотека. М.

Шталь, Х. (2016): Опыт философского обоснования мета-теории поэтического субъекта: современное прочтение Генриха Барта // Азарова, Н. / Бочавер, С. (ред.): Поэтический и философский дискурсы: история взаимодействия и современное состояние: Сб. ст. М. 162-181. 


\section{Марко Саббатини (Пиза)}

\section{Лирическое «мы» в творчестве Виктора Кривулина 1990-х гг. (анализ на примере книги стихов «Концерт по заявкам»)}

В данной работе речь пойдет о тематическом развитии субъектной структуры в поэзии Виктора Кривулина 1990-х гг. В начале этого десятилетия, в исторически иное время, в его творчестве особое внимание привлекает сборник «Концерт по заявкам». Произведения, представленные в этом издании, передают острое ощущение уходящей в прошлое позднесоветской культуры, что приводит к новому соотношению лирических «я» и «мы». Социальная и интеллектуальная характеристика этих субъектов особо важна для понимания творчества позднего Кривулина. Отклонение от «нормативного», старого типа композиции подчеркивает новую манеру стихосложения поэта и особое развитие его субъективности. Вопрос о лирическом субъекте в позднем творчестве Кривулина специально еще не рассматривался. Необходимо заметить, что именно в сборнике «Концерт по заявкам» коллективный субъект играет решающую роль в определении культурного пространства поэта. Неудивительно, что имплицитное лирическое «мы» в стихотворениях «Блудный сын», «Что рифмовалось», «Концерт по заявкам» отличается от обобщенного «мы» в текстах «Охота на мамонта», «По Твоему слову», «Пока мы изобретали рай» и т.д., при этом сохраняются основные черты поэтической историзации и культурного проекта Кривулина. Цель данной работы - проанализировать самые значительные тексты, выражающие наиболее ясно позицию автора и роль его лирического «мы».

Поэтическое творчество Виктора Кривулина конца 1980-х и начала 1990-х гг. требует особого внимания и отдельного подхода при его анализе. Еще в начале 1980-х гг. неомодернистская лирика имела для Кривулина преимущественное значение, но в середине десятилетия приоритеными для поэта становятся общественные проблемы. Он предчувствует, что все изменения советского строя эфемерны. Перестройка не освобождает андеграунд от новой риторики старой власти. Перед поэтом со всей остротой стоит не только вопрос о будущем «второй культуры», но и о судьбе своего собственного творчества. Новая эпоха не позволяет Кривулину добиться литературного признания у широкой аудитории читателей; интеллектуализм его неомодернистской петербургской поэзии очевидно уступает московскому концептуализму. ${ }^{1}$

\footnotetext{
${ }^{1}$ См. Берг (2011).
} 
Кривулин, всегда ощущавший себя частью культурного и литературного процесса, испытывает чувство отчужденности по отношению к новой эпохе. Отсюда рождается необходимость иных мотивов и прочих изменений в индивидуальной манере письма, о чём свидетельствует новый для него жанр «лирической публицистики», как в цикле «Новое зрение» (1986) и в «Стихах из Кировского района» (1987-1988). Последний цикл стихов был опубликован в 1990 году в первом номере журнала «Вестник новой литературы». В нем обращает на себя особое внимание стихотворение «Дочь Колымы» (1987-1988), в котором через игру лирических субъектов «мы» и «я» поэт показывает больное состояние «жидко-болотной культуры» и косвенно ставит вопрос о самосознании народа на переломе эпох. ${ }^{2}$

До чего это грустно, что - побочная дочь Колымы -

расправляет свои запоздалые крылья вполнеба словесность

над немыми людьми, составлявшими некогда «МЫ»

их бесчисленных «я», умножаемых как бы на вечность.

До чего это грустно, что сегодня возможно сыграть

поощрительный реквием и, не рискуя ни сердцем, ни шкурой, помянуть за полводкой из тел человеческих гать, намощенную щедро над жидко-болотной культурой. ${ }^{3}$

В конце 1980-х гг., когда наступает время распада советского быта и культуры, и в поэзии, и в экспериментальной прозе Кривулина преобладает постмодернизм. ${ }^{4}$ Согласно словам А. Житенева, выходом из творческого кризиса для поэта становится «качественное изменение языка, впитавшее опыт московского концептуализма». ${ }^{5}$ Несмотря на то, что у Кривулина присутствует некое скрытое разочарование в современном радикальном, экспериментальном и «свободном» от цензуры искусстве, именно в нем он ищет для себя ответ, выход или просто новый эстетический компромисс. По мнению Б. Дубина, в эту эпоху сложно найти следы литературного процесса. ${ }^{6}$ Несмотря на все это, сборник стихов «Концерт по заявкам» (1988-1993) является фундаментальным этапом в трансформации кривулинского поэтического языка. Как ни странно, он сочиняет большинство текстов именно в тот период, когда вся литературная ситуация сильно изменилась. ${ }^{7}$ Эта лирика, написанная в непредсказуемых культурных условиях, проявляется и в новых для поэта формах «растворения» субъекта.

\footnotetext{
${ }^{2}$ Шейнкер (2001, с. 234); ср. Саббатини (2014, с. 47).

${ }^{3}$ Кривулин (1990, с. 106).

${ }^{4}$ Lukšić (2002, c. 274).

5 Житенев (2011, с. 15-18).

${ }^{6}$ См. Дубин (2001).

${ }^{7}$ Ср.: «Период, за который литературная ситуация сильно изменилась, по-моему, уместился в три, много - четыре года, примерно с конца 1987 по конец 1990 - начало 1991го» (Дубин 2001, с. 148).
} 
Итак, на примере стихотворения «Что рифмовалось» ${ }^{8}$ можно сразу отметить имлицитное, предполагаемое местоимение «мы» в первой строке («Под рифму ставили: душа, духовный, Боже»), а в начале второй строфы («и ставили под рифму, под Господь») - скрытое присутствие лирического «я»: образный ряд описания - настолько подробный и яркий, что свидетельствует явно о личном переживании повествователя. ${ }^{9}$ Несмотря на это, в «Концерте по заявкам» редко слышится эхо квазиромантической ностальгии лирического героя о «Детях полукультуры» или некая мифопоэтическая отсылка к героическому «мы» Второй культуры 1970-х гг., хотя она и есть:

\section{$[\ldots]$}

мы были краями провинцией были границей

дрожащей - мы были подполье и шелест

но если оглянешься - что за прекрасные лица!

какая же в них тишина - тишина и господство. ${ }^{10}$

Название этих стихов «4'33”» (1978) отсылает читателя к музыкальному трехчастному сочинению Джона Кейджа; в концепции американского композитора содержанием трёх фрагментов тишины являются те звуки окружающей среды, которые будут услышаны им и публикой во время «исполнения» сочинения. В соответствии с идеей Кейджа, Кривулин абсолютизирует паузу и подчеркивает ее равноправие со звуком: согласно словам Сергея Завьялова, «именно этот конфликт между авторским текстом и его подчиняющимся произволу обстоятельств бытованием вдохновляет поэта». ${ }^{11}$ К этому приёму Кривулин обращается и в сборнике «Концерт по заявкам», ${ }^{12}$ что становится очевидным в первом же стихотворении, открывающем книгу:

по струнной плоскости народного оркестра

посты рогатки будки ворота́

с армейской звездочкой - такая простота

что нету человеческого средства

ни защититься от нее ни оторваться

а тут еще малороссийский альт

приподымается и забирает выше

границ водоразделов наций -

${ }^{8}$ См. Кривулин (2001a, с. 65).

${ }^{9} \mathrm{Cp}$.: «Горькая ирония и скепсис направлены в стихотворении не на внешнего адресата, а по-прежнему на лирического героя, границы „я“ “ которого становятся все более зыбкими: „я“ включается в „мы“. Однако „мы“ здесь - сообщество уже не единомышленников, но отчужденных друг от друга людей» (Саббатини 2007, с. 715).

${ }^{10}$ Кривулин (1988, с. 48).

11 Завьялов (2001, с. 249).

${ }^{12}$ Иванов (2011, с. 354-355). 
и от Урала до Савойских Альп

гуляет радио переполняя ниши

звукоубежища подполье слуховое

где прячутся остатки тишины

без электричества - коптилки зажжены

и пламя слабое, живое

с малейшим дуновением дрожит. ${ }^{13}$

«Концерт по заявкам» - это любимый жанр советской радиожурналистики, использующий музыкальные произведения по заявкам радиослушателей. Этот жанр, чуждый поэту, дает повод для метафорической тематизации культурного подполья (щели, убежища), где больше не удается спрятаться от всепроникающей и властной повседневности. Подобное ощущение усиливается благодаря интертекстуальной семантической нагрузке: строки «И от Урала до Савойских Альп / гуляет радио переполняя ниши» отсылают к мандельштамовскому: «Я пью за военные астры, за все, чем корили меня: / За барскую шубу, за астму, за желчь петербургского дня. // За музыку сосен савойских, Полей елисейских бензин, / За розы в кабине ролс-ройса, за масло парижских картин» (1931). ${ }^{14}$ В мире, переполненном хаотическими, иногда анахронистическими звуками, «остатки тишины» являются желаемой паузой для лирического «я/мы», необходимым кислородом для героя подполья.

В первых стихотворениях книги «Концерт по заявкам» присутствует тема музыки, песен, концерта. Как показывают тексты «Голое исполнение» и особенно «Филомела» - с ее отсылкой к мифопоэтическому безмолвию, - сюжет возникает от столкновения сквозных музыкальных мотивов с ощущением замолкания голоса лирического героя или с тишиной окружающей среды.

за высоким порогом слуха

в акустическом завтра метель завывает

и поэтому в горле становится гулко и сухо

и такая вокруг тишина какой не бывает $[\ldots]^{15}$

Здесь нужно еще заметить, что сама структура книги содержит в себе музыкальную концепцию. ${ }^{16}$ Почти все кривулинские сборники 1990-х гг. строятся по принципу четырехчастной симфонии. По словам поэта, композиционно речь идет о симфонии, в основе которой лежит соответствующая структурная единица, - «симфонический стих».

Я, говоря о таких вещах, о которых я раньше обычно не говорил, и именно как они построены - то есть построены симфонии. Основная часть, медленная часть, быстрая часть и финал. Аллегро. Allegro vivace, да? Ну. Это не

\footnotetext{
${ }^{13}$ Кривулин (2001a, с. 4).

${ }^{14}$ Мандельштам (1990, с. 174).

${ }^{15}$ Кривулин (2001a, с. 6).

${ }^{16}$ Фатеева (2010, с. 27).
} 
vivace, да, последняя часть у меня обычно такая, скорее мрачная. Здесь то же самое, но для всех моих книг характерно то, что, как правило, после них идет некий прозаический кусок - тоже четырехчастный, который как бы повторяет эту композицию в зеркальном... так построен «Концерт по заявкам», так построена книга «Предграничье», так построены несколько книг. ${ }^{17}$

Таким образом, структура сборника вполне соотвествует этому симфоническому принципу, а заглавие «Концерт по заявкам» придает ему еще большую музыкальную и семантическую глубину. Сборник состоит из четырех частей: три книги стихов («Концерт по заявкам», «Блудный сын», «У окна») и один прозаический текст - «Охота на мамонта, или Нищета Петербурга на фоне ленинградского нищенства». Это вполне зеркальная структура: сначала идет основная поэтическая часть, а в конце следует послесловие автора, «которое является своего рода антиключом к тому вот, что сообщалось в книге». ${ }^{18}$ Можно проанализировать использование сходного построения текста на примере «Охоты на мамонта» (1992). Здесь повторяется столкновение огромной, но как бы замороженной культуры с повседневным уродством и ужасом бытовой реальности.

если совсем откровенно - так не было учителей

племя преподавателей с палками и камнями

разыгрывало охоту, остервенелые, злей

чем грубая шерсть на шее кусачая в холода $[\ldots]^{19}$

Примечательна риторическая концовка стихотворения: «Палки летели камни... что они сделали с нами!» ${ }^{20}$ В послесловии сборника «Концерт по заявкам» обращает на себя внимание кривулинское толкование этого стихотворения: прозаические размышления поэта о мамонте расширяют неожиданные возможности интерпретации. В имплицитную оппозицию «мы» - поколение советских людей и «они» - представители власти (т.е. племя учеников / племя учителей), поэт включает и город-мамонт, но уже в качестве амбивалентного ролевого героя:

Мамонт был не что иное, как город. Он возвышался надо мной, преследовал своими остекленелыми глазами. Он охотился за мной. ${ }^{21}$

Объединяя роль охотника и жертвы, Мамонт символически занимает промежуточную позицию, растворяя противопоставление субъектов «мы / они». Интересно заметить, что в толковании метафоры мамонта Кривулин снова намекает на символику безмолвия и тишины города:

Холодный и нищий Ленинград, между тем был переполнен смыслами и мифами - но ни о чем не мог поведать $[. .$.$] Он предпочитал не повторяться, но$ и молчать не умел. Он многоточил. ${ }^{22}$

\footnotetext{
${ }^{17}$ Кривулин (2011, с. 90-91).

18 Там же, с. 91.

${ }^{19}$ Кривулин (2001a, с. 11).

${ }^{20}$ Там же.

${ }^{21}$ Там же, с. 100.
} 
Многоточие для поэта, прежде всего, является приемом семантической фрагментации текстов, новой тенденцей размножения и растворения субъектности. Это только начало семантической интровертности и стилистического усложнения позднего Кривулина.

Говоря словами Пригова, читатель не находил в стихах Кривулина анекдота, простого сюжета, который можно запомнить и пересказать, а без анекдота так выходило - метафизический крючок не заглатывался. Пока еще волна антиинтеллектуализма не покрыла с головой российское общество, пока не все символические и реальные ценности были перераспределены, надежда на понимание оставалась. Но к середине 1990 -х все уже стало понятно. ${ }^{23}$

Кажется, что «тишина и господство» как таковые в поэтике Кривулина больше не находят место, они присутствуют только в диалектической борьбе с шумом внешнего мира. В финале текста «По Твоему слову», в толпе вокзала, лирическое «я» трансформируется в «они»: сама оппозиция «шума» и «молчанья» оказывается смещенной.

$[\ldots]$
и если все по слову Твоему -
то как читать, с конца или с начала?
я чувствую и не пойму
зачем я здесь и что бы означала
невидимая никому
та жажда Голоса, когда, ей-Богу, мало
любого сообщенья, даже так:
посадка объявляется! - пускай их
повалят на перрон, и опустеют залы...
ты слышишь? это н а с не отпускает
молчанье

Возвращаясь к музыкальной природе стихов Кривулина в ее соотношении с субъектом «мы», обратимся к стихотворению «Блудный сын», привлекающему особое внимание. ${ }^{25}$ Здесь опять возвращается мотив радио и радиоточки, настроенной на одну волну. Каждая из радиопередач играла определенную роль, будучи непременной принадлежностью советского быта. Люди просыпались с гимном в 6 утра. Далее слушали радио в общественном транспорте, в парке и т.д. Особенно от этого сопровождения страдали выросшие в коммуналках. Кроме «Концерта по заявкам» на советском радио была такая же по жанру радиопередача - «Рабочий полдень». Кривулин слушал эти передачи, смотрел новости по телевизору, но его интересовали и голоса «Би-би-си» и «Свободы». Он всегда обращал особое внимание на за-

\footnotetext{
22 Там же, с. 101.

${ }^{23}$ Берг (2011).

${ }^{24}$ Кривулин (2001a, с. 25).

25 Фатеева (2010, с. 26).
} 
явки радиослушателей, на массовое сознание и настроение народа, для него это было эффективным способом культурологического анализа страны.

Начало стихотворения «Блудный сын» («лепетание бабьего радио в парке») содержит цитату в постмодернистском духе, где ирония, пафос и языковая игра соединяются. ${ }^{26}$ Поэт имеет в виду строки Александра Пушкина «Раздается близ меня / Парки бабье лепетанье...» («Стихи, сочиненные ночью во время бессонницы») - и название сонета Иннокентия Анненского «Парки - бабье лепетанье». 27

лепетание бабьего радио в парке

в уцелевшей его сердцевине

ради Бога послушай:

Отец повторяется в сыне

только блудном

и там

на задах кочегарки

эта встреча - на ящиках сидя

слыша ветхое радио скворчущее в глубине

о налогах о жертвах о всякой и всяческой сыти

косит мизерный дождик по всей ненасытной стране

и голодному слуху далекая музыка брезжит ${ }^{28}$

Каламбурный характер текста включает очевидную библейскую отсылку: в повторении отца в блудном сыне имеется в виду новый поэт (Кривулин), который цитирует старого (Пушкина / Анненского). Их метафизическая встреча происходит в глубине некогда роскошного парка, где теперь находится кочегарка. Персонажи выстраиваются в некую временную последовательность (коллективный персонаж «поэт» с его сюжетом-историей), объединяются определенной пространственной рамкой (совместное пребывание в общественных локусах) или литературными, социокультурными связями и некоторой общностью их свойств. ${ }^{29}$ Здесь нужно еще подчеркнуть возможную ссылку на знаменитую картину Рембрандта «Возвращение блудного сына» (1666-1669), поражающую своим драматизмом. У Кривулина есть много стихотворений 1970-1980-х гг., связанных с эрмитажными картинами, достаточно вспомнить его известный цикл стихотворений «Галерея». Во второй части «Блудного сына» поэт описывает так же реальную встречу между «блудным» лирическим героем и интеллектуа-

26 Зубова (2000, с. 11).

27 Зубова (2010, с. 57).

${ }^{28}$ Кривулин (2001a, с. 50). Это стихотворение и весь одноименный цикл посвящаются Ольге Кушлиной. «Еще очень значимо для названия цикла „Блудный сын“ (весь написан осенью 1989, большая часть стихотворений - в октябре), что это одна из самых известных картин Эрмитажа. А вся книга, как сказано в послесловии, написана с оглядкой на Ленинград-Петербург» (из письма О. Кушлиной от 04/12/2015).

${ }^{29}$ Фарино (2004, с. 115). 
лом-кочегаром. Это обыкновенная сцена подпольного быта кривулинского поколения, «поколения дворников и сторожей». ${ }^{30}$ Встреча с «кочегарами» - отщепенцами культуры, жаждущими ее, - расширяет сюжет стихотворения и снова позволяет голосу ветхого радио выйти на сцену. В финале текста выделяется скрытая, но очевидная цитата: «косит мизерный дождик»это знаменитые стихи Маяковского: «Я хочу быть понят моей страной, / а не буду понят, - что ж, / по родной стране пройду стороной, / как проходит косой дождь». ${ }^{31}$ Владимир Маяковский тоже являлся изгоем, но другого рода: «блудный сын» истинной культуры, пытавшийся ее променять на социальный заказ. В стихотворении Кривулина описание процесса потери и обретения культуры оставляет ощущение неудовлетворенности, «тоски по мировой культуре». Здесь лирическое «я» блудного сына тоже превращается в коллективный субъект «мы» поэтов-изгоев (кочегары, Пушкин, Маяковский). Согласно Ю. Лотману,

так раскрывается напряжение в семантической структуре текста: монолог оказывается полилогом, а единство складывается из полифонии различных голосов, говорящих на разных языках культуры. Вне поэзии такая структура заняла бы многие страницы. ${ }^{32}$

Неутолимая тоска лирического «мы» характеризует также и другие тексты сборника, как, например, «Пока мы изобретали рай», где поэт иронизирует над темой эмиграции. ${ }^{33}$

когда мы конструировали Запад

на сорока внутрисоветских языках

как некий Рай в эоловых руках

как Ханаан, какой не занят

никем - и только нам обетован, -

мы видели египетские казни

вокруг себя, но жили безопасней

обломова: схожденье на диван

святого духа с эмигрантским чтивом

портрет набокова с пурпурною каймой...

когда ходил Господь по нищенским квартирам

и призывал на родину, домой -

${ }^{30}$ Цитата из песни «Поколение дворников» Бориса Гребенщикова (альбом «Равноденствие», 1987).

${ }^{31}$ Маяковский, В. Я хочу быть понят моей страной... (цит. по http://www.wisdomcode. info/ru/poetry/authors/54568.html?page=2, 29/01/2018).

32 Лотман (2001, с. 116).

${ }^{33}$ В своем докладе «Компьютерно-лингвистические средства выявления субъективности в поэзии» (конференция «Типы субъекта и способы его репрезентации в новейшей поэзии (1990-2015)»; Институт языкознания РАН, Москва, 11/07/2016) Борис Орехов посредством графики и статистик продемонстрировал высокую повторяемость местоимения «мы» в творчестве В. Кривулина. 
в Европу, в Индию ли, в Палестину,

где пуп Земли, а мы всегда не там... ${ }^{34}$

Парафразируя содержание стихотворения, поэт намекает на мечты о прекрасной стране (эмиграция), благодатном центре мира, новом Ханаане, куда уносит Эол (самолет). В реальности же, как у Обломова, остается лежание на диване с запрещенной книжкой и замена действия мечтой о пупе земли (Ханаане), в то время как вокруг тяжелая и мрачная бытовая и социальная жизнь. Здесь имеет место блуждающий тип коллективного персонажа. Данный тип построен на несовпадении поставленной цели с действиями, непредсказуемо отклоняющимися от неё. Одна из функций этого блуждания и несовпадения раскрыта в конце стихотворения («а мы всегда не там...»): «создать при помощи случайностей картину глубокой закономерности». ${ }^{35}$

Стихотворения «Последняя книга», «Книги и люди», «Новый Раскольников» и «На празднике народов» являются примерами, где контаминация и растворение субъектов «я» и «мы» происходит на фоне петербургского литературного текста. ${ }^{36}$ Стихотворение «Книги и люди» (1993) является примером субъектного синкретизма: в 3-й строке - «полуослепшие книги тоже казались людьми» - «народ-палач / народ-жертва / книга-свидетель» берет на себя всю ответственность за собственную историю, за лирическое «мы» и за ролевого антигероя «он / они» («сосед / стукачи»).
худо, конечно, с какого конца ни возьми
но может быть, из-за того
полуослепшие книги тоже казались людьми,
и скрывали преступное с ними родство
прятали а если за стенкой затихал сосед -
бережно - как шуршит папиросный слой! -
обнажали какой-нибудь порфироносный портрет
полоску с гольбеиновой Пьетой ${ }^{37}$

В стихотворении «На празднике народном» рядом с мотивом послевоенной истории города выделяется автобиографический мотив. Для точного толкования субъекта здесь необходимо напомнить, что именно биографические реалии организуют композиционное единство текста. Как известно, родители Кривулина пережили блокаду. Еще до окончания войны Борис Афанасьевич Кривулин был направлен в Краснодон военным комендантом.

Мать, Евгения Львовна, выносила ребенка в Ленинграде. Выехала из города уже беременная Виктором, зачатым в блокаду. Она работала в военном гос-

\footnotetext{
${ }^{34}$ Кривулин (2001a, с. 67).

35 Фарино (2004, с. 356).

${ }^{36}$ См. Sandler (2007).

${ }^{37}$ Кривулин (2001a, с. 16).
} 
питале, под Краснодоном, в поселке Кадиевка (который потом стал называться город Стаханов), где и родился Виктор Кривулин. ${ }^{38}$

После войны возвращаться в Ленинград родители не хотели: слишком тяжелы были воспоминания о пережитом в блокаду. Но в возрасте пяти лет ребенок заболел, что дало осложнения на ноги, и они вернулись в Ленинград, потому что там было больше возможностей для лечения.

В комнате в коммуналке на Большом проспекте Петроградской стороны жили другие люди, отец Борис с пистолетом в руках отстоял свое право на жилье. ${ }^{39}$

напрасно я на празднике народном

ищу мистериальный поворот

на красный свет или назад к животным

или в неведомый перед

мне повезло в отличие от многих:

родители меня больного привезли

в Столицу Бывшую откуда всех безногих

неслышно вывезли на самый край земли

пустынны улицы... предчувствие парада

звук не включен еще, кого-то молча бьют

возле моей парадной - и не надо

иных предутренних минут

я знаю что прошла, пережита блокада

мы счастливы меня - я чувствую - возьмут

сегодня вечером туда, к решетке Сада

где утоленье голода - салют $^{40}$

Кроме автобиографического воспоминания в стихотворении снова предстает различие между молчанием («звук не включен еще, кого-то молча бьют») и шумом праздника, особенно - в финале текста: «где утоленье голода - салют». Именно здесь, на сдвиге между реальностью лирического героя (субъекта / зрителя) и иллюзией петербургской театральной сцены выделяется «экстатичная историчность» кривулинской поэтики. ${ }^{41} \mathrm{C}$ этой точки зрения, важно напомнить о финале публичного исполнения стихотворения «На празднике народном»: он позволяет нам понять его культурный масштаб и символическую ценность.

Его Кривулин прочел на митинге, посвященном празднику города, проходившем на Владимирской площади. Это было запоминающееся выступление [...] Стихотворение, передающее самоощущения мальчика-инвалида на фоне

\footnotetext{
${ }^{38}$ Из письма Ольги Кушлиной от 18/04/2015.

${ }^{39}$ Там же. Ср. Лотман (2002, с. 217).

${ }^{40}$ Кривулин (2001а, с. 10).

${ }^{41}$ См. Седакова (2001).
} 
злополучной истории родного города, с жалкими радостями праздников, обманывавших ложным коллективизмом, прозвучало как откровение. Кривулину кричали, аплодировали. Стихотворное мальчишечье ожидание большого торжества сливалось с жадным ожиданием перемен собравшихся тысяч взрослых людей. ${ }^{42}$

Таким образом, кривулинский текст девяностых годов приобретает иной «коллективный» характер: это новая поэтическая ориентация на фрагментацию коллективной памяти, которая стремится учесть декламационное задание и устный контакт с большой аудиторией. ${ }^{43}$ Согласно словам Юрия Лотмана,

[...] автор изменяет объем читательской памяти, поскольку, получая текст произведения, аудитория, в силу конструкции человеческой памяти, может вспомнить то, что ей было неизвестно. С одной стороны, автор навязывает аудитории природу ее памяти, с другой, текст хранит в себе облик аудитории. ${ }^{44}$

Если в послесловии «Концерта по заявкам» Кривулин подтверждает автобиографическую основу книги, выделяя особую роль семиотического пространства Ленинграда / Петербурга, ${ }^{45}$ то свои эстетические пристрастия он выражает в предисловии к последней книге «Стихи после стихов»: здесь он определяет «сквозные музыкальные темы» как «человеческое измерение истории». ${ }^{46}$ Уже в 1984 году поэт сочинял стихи под эгидой подобной концепции:

с утра беспрерывно играют по радио

одну серьёзную классику

шостакович шуберт шопен чайковский

даже брукнер

смерть начальства зачем соразмерна

с филармоническим залом?

лучшие музыканты европы

меломаны ручные ${ }^{47}$

В контексте кривулинской поэзии 1990-х гг. субъект все больше становится неопределенным пространством для воплощения поэтического эксперимента. Признаки подобной направленности были очевидны уже в 1970-е гг.: «в этой связи отказ от личностного рассматривается не как обеднение лирики»,

${ }^{42}$ Иванов (2011, с. 353$)$.

${ }^{43}$ Смирнов (2001, с. 42-43).

44 Лотман (2002, с. 174).

${ }^{45}$ См. Топоров (1995, с. 319$)$.

${ }^{46}$ Кривулин (2001b, с. 5-6). Ср. также: «Чтобы зазвучала музыка, внутреннее пространство должно освободиться от всего лишнего, личного. Кривулин лишает свое внутреннее пространство лирической персональности, превращая его в имперсональное, сакральное пространство - пространство храма, собора. А уже в соборе персональность возрождается на новом, более высоком (или более глубоком) уровне - когда открывается подлинная перспектива, проясняется подлинный смысл судеб и событий» (Кулаков 2011, с. 9).

${ }^{47}$ Кривулин (1999). 
так как «субъектность - это воплощенное зияние, бесформенность». ${ }^{48}$ Эта естественная эволюция субъектности соответствует характерному многоголосию творчества поэта. ${ }^{49}$ Все чаще у позднего Кривулина слово «я» и его превращение в субъект «мы» теряются между адресантом и адресатом, сливаются в неоглядном пространстве «своего» и «чужого» семантического поля. Это скорее соответствует идее автора о «безличном» субъекте, предполагавшем «апелляцию к коллективу и коллективному бессознательному». 50

Таким образом, выступая в качестве динамического, противоречивого элемента текста, субъект позднего творчества поэта является принципиально фрагментарным и утверждающим себя через сомнение: это своего рода (почти эпический) «субъект в процессе», ${ }^{51}$ который обнаруживает значительную способность к автономному и оригинальному существованию.

\section{Литература}

Берг, М. (2011): Кривулин и Пригов // Звезда. 10, 2011. http://zvezdaspb.ru/index.php?page=8\&nput=1721 (27/05/2016).

Бережнов, А. (Кривулин, В.; 1983-1984): Час тоски невыразимой // Обводный канал. 5, 1983-1984. 272-279.

Дубин, Б. (2001): Литературные журналы в отсутствие литературного процесса // Дубин, Б.: Слово - письмо - литература: очерки социологии современной культуры. М. 148-155.

Житенев, А. (2011): Образные коды «другой культуры» в поэзии Виктора Кривулина 1970-х гг. // Полилог. 4, 2011. 15-18.

Житенев, А. (2012): Поэзия неомодернизма. СПб.

Завьялов, С. (2001): Тишина и господство бессмертия // Новое литературное обозрение. 52, 2001. 249-254.

Зубова, Л. (2000): Современная русская поэзия в контексте истории языка. М.

Зубова, Л. (2010): Языки современной поэзии. М.

Иванов, Б. (2011): Петербургская поэзия в лицах. М.

48 Житенев (2011, с. 17).

${ }^{49}$ Иванов (2011, с. 301-305).

${ }^{50} \mathrm{Cp}$.: «Кривулин, констатируя, что в ХХ веке „человеческая личность последовательно и небезуспешно вытеснялась из поэзии на протяжении всего столетия“, обозначает три основных направления ее редукции: выход во „внеличное“, в мир „'не-я’ - предметов и феноменов культуры“, выход в „безличное“, предполагавший апелляцию к коллективу и коллективному бессознательному, выход в „надличное“, когда сквозь „я“ „Просвечивают высшие смыслы и внечувственные среды“» (Житенев 2012, с. 98). Ср. Бережнов [псевд. В. Кривулина] (1983/1984, с. 274).

${ }^{51}$ Ср.: «Оказывается, что речь субъекта (,я“") с необходимостью пронизана языком как носителем конкретного и всеобщего, индивидуального и коллективного одновременно» (Кристева 2004, с. 179). 
Кривулин, В. (1988): Стихи. В 2 тт. Париж / Л.

Кривулин, В. (1990): Стихи из Кировского района // Вестник новой литературы. 1, 1990. 98-107.

Кривулин, В. (1999): Через полтора десятилетия // Волга. 11, 1999. http://magazines.russ.ru/volga/1999/11/krivul.html (26/05/2016).

Кривулин, В. (2001a): Концерт по заявкам. Три книги стихов. СПб. http://www.vavilon.ru/texts/krivulin8-1.html (29/01/2018).

Кривулин, В. (2001b): Стихи после стихов. СПб.

Кривулин, В. (2011): Петербург - Москва - Петербург: два поэтических вечера Виктора Кривулина // Полилог. 4, 2011. 82-103.

Кристева, Ю. (2004): Избранные труды: Разрушение поэтики. Пер. с франц. Г. Косикова, Б. Нарумова. М.

Кулаков, В. (2011): Стихи после стихов // Полилог. 4, 2011. 8-14.

Лотман, Ю. (2001): О поэтах и поэзии. СПб.

Лотман, Ю. (2002): История и типология русской культуры. СПб.

Мандельштам, О. (1990): Сочинения в 2 тт. Т. 1.: Стихотворения. Переводы. М.

Саббатини, М. (2007): Стихотворение Виктора Кривулина «Что рифмовалось» (1990) рефлексия кризиса неофициальной культуры // Новое литературное обозрение. 83, 2007. 710-717.

Саббатини, М. (2014): Виктор Кривулин на переломе эпох. Заметки о смене поэтики во второй половине 1980-х годов // Вестник СПбГУ. 4, 2014. 44-50.

Седакова, О. (2001): Памяти Виктора Кривулина // Новое литературное обозрение. 52, 2001. 236-242.

Смирнов, И. (2001): Смысл как таковой. СПб.

Топоров, В. (1995): Миф. Ритуал. Символ. Образ. Исследования в области мифопоэтического. Избранное. М.

Фарино, Е. (2004): Введение в литературоведение. СПб.

Фатеева, Н. (2010): Синтез целого. На пути к новой поэтике. М.

Шейнкер, М. (2001): «...Гривастая кривая...» Виктора Кривулина // Новое литературное обозрение. 52, 2001. 230-235.

Lukšić, I. (2002): Время наступило: «Шмон» Виктора Кривулина // Russian Literature. 51, 2002. 273-293.

Sandler, S. (2007): A Poet Living in the Big City: Viktor Krivulin, Among Others. In: Boudreau, N. / O’Neil, C. (eds.): Poetics. Self. Place: Essays to Honor Anna Lisa Crone. Columbus, Ohio. 675-693. 



\section{Галина Заломкина (Самара)}

\section{Сопричастная субъективность в современной русской «непрозрачной» поэзии}

При всем разнообразии подходов к пониманию субъективности неизменно релевантным остается ее изолирующий характер. Субъективность, прежде всего, предполагает сугубо индивидуальное восприятие внешнего мира, уникальный опыт, сохраненный в сознании одного человека, доступный в своем своеобразии только ему и не подлежащий всеобъемлющей трансляции. Субъективность обусловливается квалиа человека - индивидуальными свойствами восприятия окружающего, «тем, как вещи выглядят для нас [...] особенностями сознательного опыта». ${ }^{1}$ Д. Деннетт выделил четыре признака квалиа, объясняющие отгораживающий характер субъективности:

Квалиа полагаются такими свойствами ментальных состояний субъекта, которые (1) невыразимы, (2) изначально присущи, (3) персональны, (4) прямо или непосредственно постижимы в сознании. ${ }^{2}$

Проблема замкнутости субъекта - одна из основополагающих тем поэзии, культивируемая вплоть до солипсизма, что стало особенно ощутимо в современных обстоятельствах поиска новых форм и предназначений поэтического слова. Однако обратное устремление - к преодолению барьеров субъективности - может быть обнаружено в новейшей русской поэзии, даже в ее «непрозрачной» области, по первому впечатлению, менее всего нацеленной на растолковывание квалиа.

Определение «непрозрачный» употребляется здесь по отношению к особому способу поэтического высказывания, обозначаемому исследователями как «трудная поэзия», ${ }^{3}$ «нелинейная поэзия», «ненарративная поэзия», ${ }^{4}$ «медленное письмо». ${ }^{5}$ Для поэтов этой стилистики (А. Драгомощенко, А. Парщиков, А. Глазова, Ш. Абдуллаев, А. Уланов, Н. Звягинцев, А. Сен-Сеньков, С. Снытко, С. Соловьев, Е. Суслова и др.) характерна многомерность взгляда, позволяющая пристально воспринять и приблизиться к пониманию сложности, тотальности и конечной непостижимости связей как во внешнем, так и во внутреннем мире. Основное свойство здесь - нелиней-

\footnotetext{
${ }^{1}$ Dennett (1988, p. 42). Перевод мой. Г.3.

2 Там же, p. 385.

${ }^{3}$ Edmond (2004, p. ii).

${ }^{4}$ Евграшкина (2015, с. 85).

5 Заломкина (2006).
} 
ность лирического сюжета, резко затрудняющая логическое, эстетическое и эмоциональное считывание смыслов, каковые многократно умножаются за счет разнообразных языковых техник остранения.

Механизмы прямой репрезентации в поэзии как одной из разновидностей современного искусства заменяются мощнейшим информационным сжатием $[\ldots]^{6}$

Дж. Эдмонд в определении «трудные поэты» (их творчество «обеспечивает альтернативу общепринятому поэтическому высказыванию») 7 объединяет А. Драгомощенко, Л. Хеджинян и Ян Ляня, принадлежащего к направлению, которое в китайском языке определяется как ,menglong“ - «туманный, неясный, смутный». Для уяснения сущности поэтического письма, о котором я говорю, здесь важна сема недостаточной понятности из-за неполной прорисованности деталей-смыслов, которые возможно увидеть / понять лишь отчасти, в остальном - достроить или отгадать. К. Корчагин употребляет определение «непрозрачный» в таком смысле в обозначениях «непрозрачная речь», «непрозрачность текста», «непрозрачный смысл». ${ }^{8}$

Подобного рода «темный дикт», ${ }^{9}$ как может показаться, мало приспособлен для преодоления неизбежной изоляции субъекта. Тем не менее попытка установления когнитивно-эмоционального контакта между двумя мирами сознаний, причем тесного, эмпатического, может быть обнаружена у вышеназванных поэтов. Формально она проявляется в употреблении грамматических форм первого лица множественного числа и, как представляется, выражает движение к специфической сопричастной субъективности выстраиванию взгляда, в котором невыразимые, независимые, несравнимые, непосредственные переживания внешнего мира двух индивидуумов могут вступать в диалог, взаимопроникать и становиться общими. Этот процесс можно рассматривать как лирическую разновидность интерсубъективности, которая, по Гуссерлю, априорна монадически-замкнутому сознанию, стремящемуся к обнаружению Другого, к восприятию опыта Чужого, к «вчувствованию» (Einfühlung). ${ }^{10}$

Использование местоимения «мы» в лирике нового и новейшего времени традиционно нацелено несколько иначе, прежде всего на обобщение опыта группы людей или человечества в целом. Употребление форм первого лица множественного числа в значении «,,я“ + ,я““ $\left(\right.$, ,не-я“), ${ }^{11}$ союз Я и Ты» ${ }^{12}$ носит номинальный характер и подразумевает формы вполне при-

\footnotetext{
${ }^{6}$ Суслова (2016, с. 379).

${ }^{7}$ Edmond (2004, p. ii).

${ }^{8}$ Корчагин (2012).

${ }^{9}$ Фридрих (2010, с. 72).

${ }^{10}$ Гуссерль (2005, с. 386).

11 Федоров (2008, с. 14).

${ }^{12}$ Носорева (2009, с. 204).
} 
вычной сопричастности, характерные для жанра любовного / дружеского послания. Частотность «мы» в «новой социальной поэзии» ограничивается обозначением «некой группы лиц, включая и говорящего, указанием на общность», ${ }^{13}$ то есть модификации привычной расстановки субъективностей не происходит.

Характерная для «непрозрачной поэзии» предельная индивидуализация восприятия ставит под вопрос возможность резонансного взгляда, совместного переживания:

Видим, как «мы» расслаивается на «я» уравнений времени $[\ldots]^{14}$

Мы, наше - скука и агрессия слипания. ${ }^{15}$

Но заострение внимания на негативных свойствах ощущения общности выводит «мы» из традиционного восприятия, маркирует его, детализирует механизмы сопереживания, подталкивает к поиску форм для него. В результате полностью вероятность ощущения эмоциональной и интеллектуальной совместности с другим не отрицается, развертываются специфические ее понимания:

Но ты и я - слишком отдельно. Ты со мной - нет, слишком уверенно там, где всегда свобода. Может быть, мое с твоим? предполагая, что я и ты сохраняем отдельность - но чем-то, входящим в нас, соприкасаемся - может быть, и пересекаемся? ${ }^{16}$

У Ш. Абдуллаева устойчива тема совместной прогулки или путешествия с другом, обеспечивающих контакт сознаний в неспешном созерцании, «в молчании братства», ${ }^{17}$ замирании в зазоре времени-пространства и дающих в результате совместный опыт изменения восприятия в сторону гораздо большей чуткости:

Замедляем шаг, зараженные тишиной.

И всюду

дышит Оно. Что-то.

Легкая длительность $[\ldots]^{18}$

В стихотворениях «Зверек» и «На стороне камней» эмпатия компании мальчишек, увидевших попавшее в капкан животное и коллекцию камней, не только сближает их квалиа, но и распространяется на объект восприятия:

Мы подбежали.

В его косых и розовых глазах вся местность уменьшалась.

И, ощутив нас,

${ }^{13}$ Северская (2015, с. 98).

14 Драгомощенко (2011, с. 23).

15 Уланов (2012, с. 21).

16 Там же.

${ }^{17}$ Абдуллаев (2003).

${ }^{18}$ Абдуллаев (1997). 
он закричал - казалось,

что это наша близость ему вонзилась в спину. ${ }^{19}$

Наконец

мы насмотрелись вдосталь, мы вроде бы насмотрелись вдосталь, но что-то невысказанное удерживало нас

и тянуло к ним, к соцветию камней. ${ }^{20}$

В результате «мы» объединяет субъективность наблюдающего с субъективностью наблюдаемого - неожиданной, труднозаметной, возможно, не существующей вовсе, а сконструированной. Создается эффект преодоления барьера квалиа:

[...] мы учимся видеть вне нас, где необретенное уже утрачено. ${ }^{21}$

Мы устремляем

бессмысленный, распыленный взгляд на дорогу, ухитряясь

не видеть ее, - может быть, именно так

она сама глядит на себя и вот-вот окажется невесомой,

как невидимый и чистый полет бесконечности,

которую мы тоже втянули в нашу игру:

там что-то есть, там нет ничего. Выбор

всегда за тобой. ${ }^{22}$

В текстах А. Драгомощенко дружеско-братский вариант со[вместного по]знания приобретает черты древнегреческого симпосия: вполне в рамках традиционных форм «говорящий отождествляет себя [...] с близкими друзьями $[\ldots] »,{ }^{23}$ игровым образом реставрируя архаическое растворение «я» в общности боевого отряда или дружеского круга.

Как бы то ни было,

в устье Исмена Периклимен настигает Амфиарая

(мы поднимается с мест. Ликуем, - победа, мы - Скопас [... $]^{24}$

Здесь, на пыльном, как дорога на Брацлав, балконе, с ненавязчивым Olarra Reserva, постоянным, как

элементы Эвклида, мы говорили о том, кто впервые

сумел написать: «Они взошли на корабль

крепкостнастный» $[\ldots]^{25}$

Сопричастность сознанию отца или сына воспринимается как атрибут утраченного родового сознания:

19 Абдуллаев (2003).

20 Там же.

${ }^{21}$ Там же.

22 Абдуллаев (1997).

${ }^{23}$ Носорева (2009, с. 205).

24 Драгомощенко (2011, с. 51).

25 Драгомощенко (2011, с. 35). 
Сегодня ночью

ты мне приснился. Шли сумерки [...]

Мы были вместе, как в древнем мире,

где суть не нуждалась в отчислениях вести $[\ldots]^{26}$

У А. Драгомощенко своеобразно работает философско-обобщающий смысл местоимения «мы», «когда местоимение указывает на всех, на неопределенное множество лиц». ${ }^{27}$ Констатации состояний мира и сознания, воспринимающего мир, носят остраняющий характер, проблематизируют привычки восприятия: лирический субъект, говоря «мы», делает читателя подчеркнуто сопричастным нелинейному, многомерному ходу мысли.

[...] мы как бы есть, но в самом сердце падения, повисшего на конце иглы $[\ldots]^{28}$

[...] если «сейчас» окружность, то где будем мы, когда туман слепящий настигнет к полдню $[\ldots]^{29}$

Сопричастность усложненной субъективности лирического героя может быть рассмотрена как психоделическое - измененное в сторону большей восприимчивости - состояние сознания, в котором трансформируются стандартные пространственно-временные координаты, кинетические закономерности, бесконечно малые и бесконечно большие величины смыкаются, элементы реальности предстают взаимопревращаемыми.

Слова их зеркальны. Не только слова, но и жесты.

Потому не в состоянии мы сдвинуться с места.

Потому на губах остывает паутина Атлантики,

А нам ее не смахнуть, поскольку мириады наречий

Текущих за пределы мгновения, уносят и нас,

Вместе с нами и с ними, не в след и не сразу $[\ldots]^{30}$

Наиболее традиционная разновидность контакта внутренних состояний, обусловливающая сопричастную субъективность в поэтическом тексте - в любовном чувстве - в «непрозрачной» поэзии подвергается расчленяющему обдумыванию, нацеленному на поиск настоящих, «работающих» форм такого контакта. В стихотворении А. Глазовой «мы» образуется в финале из разнообразных пониманий-модификаций «я» и «ты», мозаично преломляющихся, отражающихся друг от друга эхом, чтобы в конце концов улечься в гармоничное слияние «мы»:

как в тот раз, когда не я мне, не ты-ты,

не не-ты, не не-не-ты,

когда ты,

26 Там же, с. 349.

${ }^{27}$ Носорева (2009, с. 204).

28 Драгомощенко (2011, с. 130).

29 Там же, с. 69.

${ }^{30}$ Там же, с. 234. 
когда с третьей, с четвертой попытки,

ты сказал «ты»,

так коснулись теперь

моих, не немых, не ненемых,

мы

коснулись губами. ${ }^{31}$

В любовном взаимодействии лирический субъект переживает единение с другим, полную сопричастность, совместную «завернутость» и одновременно открытость, свободу по отношению к миру:

я плету нам бесцветный как голое тело

частый словно секунды ресниц

и ничей как наш парусник парус. ${ }^{32}$

В стихах Драгомощенко сопричастная субъективность любовников парадоксально соединяет слияние и разделение:

$[\ldots]$ каждый из нас напылением амальгамы $[\ldots]^{33}$

Перетекая друг в друга и в мир, они ощущают характерную драгомощенковскую «зернистость», отдельность всех составляющих.

Остальные формы - поодаль. Поры ветра.

Будь и ты всегда, где там, где слюна проторяет путь

черепичной осени, как все, как черепаховый гребень

воду у берега; милосердней также, поскольку «они»,

«в них», «мы» повсюду беспечно размечены нами,

словно черенками листьев, отточенных внутрь,

раскрыта до полудня пенная вода холода. ${ }^{34}$

$\mathrm{B}$ «размеченном» сопричастной субъективностью окружающем мире ячейки в каждой точке времени накладываются друг на друга иначе.

Нас разделяет пестрый искры миг

золою мотылька, расплавленного в копоть

свободной радугой ресниц.

Нас, разлучив, венчает вспышка век -

гарь десяти секунд глаз в совпаденьи $[\ldots]^{35}$

Для А. Уланова любовное взаимодействие оказывается, вероятно, единственным способом контакта двух восприятий и находит точное выражение в намеренном языковом искажении «Между мы»:

Мандариновая долька между четырех губ, вытекающий сок, холодная нить, спускаясь все ниже до новой встречи. Ты меня не считаешь, я поперек тебя не выйду. Между мы, между, мыши летучие, лягушки земноводные, рыбы двоякодышащие, улитки крылатые. [...] Осторожность движений - не чтобы

\footnotetext{
${ }^{31}$ Глазова (2008).

32 Там же.

33 Драгомощенко (2011, с. 273).

34 Там же, с. 269.

35 Там же, с. 414.
} 
не разбудить - для кого тогда? - чтобы не нарушить - не наружу. Голос ходит в двенадцати стенах. ${ }^{36}$

Как и в известном речении А. Рембо „Је est un autre“, при помощи «ошибочной» грамматики здесь заостряется внимание на необходимости переосмысления лирической субъективности, в данном случае - сопричастной: то, что есть у нас общего - одновременно что-то вне нас, в промежутке, где мы и пребываем, позиция вненаходимости позволяет избежать «слипания», не уничтожить самозамкнутость каждой из субъективностей.

Деконструирующий аграмматизм - действенное средство освежить явления языка, выражающие совместность ментальных процессов у двух субъектов, - использует и С. Снытко в прозопоэтическом тексте «Дьявол», представляющем собой любовный обмен вопросами и ответами, сюрреалистическая гетерогенность которых очищает любовный дискурс от избитости, снимает с любовной темы наслоения традиции:

Дьявол, растерзав телеграфный электрон иглы, воздвигает нашу обоюдную луну $[. .$.$] - Теперь у тебя восемнадцать глаз: на что предпочтешь обменять$ их? На солнце. Или твое сердце. ${ }^{37}$

Сопричастная субъективность порождается неполной проясненностью ролей в этом диалоге: реплики говорящих переплетаются, путаются, жизнь двух сознаний предстает как единый текст. Кульминация этого - наложение грамматических форм, создающее эффект наложения действий и интенций.

«Таковы же, - возражал я, - и конфигурации притяжения: извлеченные изпод земли, тип изделия - хронометр, еще пара шагов, и мы сможешь заглянул в глаза незнакомцу - г-ну живцу, упорно остывшему у окна», - хотел было, успев, сказать. ${ }^{38}$

Игра с местоимением, со временем и модальностью глагола приводит к тому, что в трех словах реализуются четыре варианта реальности: возможность совершения действия Другим, возможность совершения действия мной совместно с Другим; действие совершено Другим; действие совершено мной совместно с Другим. Концентрация вероятностей предуведомляется упоминанием хронометра и итожится двоякой сущностью того, на кого действие направлено - жив[ого мертве]ца, причем действие - заглядывание в глаза - также, как правило, нацелено на постижение внутреннего состояния Другого. Выстраивается характерная для «непрозрачной» поэзии модель любовной эмпатии - слияние, не лишающее автономности, взаимопроникновение, оставляющее часть самоощущения вне, созвучие, сохраняющее возможность (у)молчания. Последнее предложение текста:

Обезъединённых чем ${ }^{39}$

\footnotetext{
36 Уланов (2006, с. 241).

${ }^{37}$ Снытко (2014, с. 56).

38 Там же.

${ }^{39}$ Снытко (2014, с. 56).
} 
- содержит авторский окказионализм, соответствующе многозначный, описывающий сопричастную субъективность как объединенность-разъединенность-обездоленность.

В поэме С. Соловьева «стекло» необходимая отстраненность любовников, которая преодолевает сливающее, единящее притяжение, противопоставляется полному, мистическому единству Марии и ее сына на изображении в церкви:

А они вдаль глядят, и, похоже, даже не знают о том, что их двое.

Потому что они - одно. ${ }^{40}$

Воспоминание о нем возникает после размышлений о полной идентификации лирического героя с возлюбленной:

И какое-то выпавшее из времени тело - то ли в будущем, то ли в прошлом.

Худенькое, нерослое. И почему-то всегда, как только глаза прикрываю, голое, и - со спины. Мальчик. Лет двенадцати. Я. ${ }^{41}$

Но сразу вслед за констатацией подобной идентификации внутри святого семейства обозначается и освобождение из подобного состояния, искомое и достижимое в любви, в составлении разбегающегося «мы»:

Вот, что мы с тобой делали. Выламывались друг из друга, как из вязкотекучего зеркала.

$[\ldots]$

Вероятно, ты чувствовала, что я в тебе провоцировал. То, что, держась за руки, пятилось друг от друга. Мы. ${ }^{42}$

Сопричастная субъективность - нелогичная, разорванная, болезненная, противоречивая, пугающая, набухающая скачущими образами - разворачивается в координатах первозначимости языка в прозопоэтическом тексте С. Снытко «Внутри слова „мы“».

Терпеливо трепетавший в ожидании ласковой расправы, внимавший словам, едва успевавшим превратиться в запахи или шелест опустевшего сада: так быстро потемнело все вокруг, что не разобрать - обморок или финал, или триумф - или простая ошибка беспамятного почтальона. Над синевой ночи уже зрело одно настолько существенное, что в одинокой глубине бульвара забулькало что-то, имеющее непредсказуемые размеры и едва ощутимые последствия. Обычный больничный ужин, печеный песок, полголовы собаки, леденец-петушок, - съел с аппетитом и ждал сигнала к отбою, чтобы попасть наконец в чаемую пустоту. Терпеливое томление, скрывавшееся внутри слова «мыљ» - гласила записка, найденная поутру у ног распростертого аборигена. ${ }^{43}$

Ощущение «мы» здесь - источник трепета, «терпеливого томления», напряженного ожидания совпадения квалиа. Синестетическое перетекание

\footnotetext{
40 Соловьев (2005).

41 Там же.

42 Там же.

${ }^{43}$ Снытко (2014, с. 18).
} 
чувственных впечатлений в начале (слова превращаются в запахи, шелест, темноту), причудливые образы булькающего бульвара (фонетическая обусловленность) и больничного меню - способы отразить персональную уникальность, подвижность, невыразимость, укорененность в подсознании того, как мир воспринимается индивидуумом. Но находится ключ к трансляции квалиа - слово. Местоимение «мы» предстает кодом, заклинанием, само написание которого способно обеспечить сопричастную субъективность. Но оно, как всякое настоящее заклинание, опасно, и колдун-абориген, который с ним работает, может и не выжить.

Подытоживая, можно сказать, что в современной русской «непрозрачной» поэзии нащупывается приближение к сопричастной субъективности как к новому состоянию проницающего соприкосновения двух сознаний, тесного когнитивно-эмоционального контакта, в традиционном понимании недостижимого. Она принимает формы дружеского созерцания, боевой / родовой общности, психоделического вовлечения читателя, любовной эмпатии. Полная сопричастность сознаний, отгороженных от остального мира в любовном взаимодействии невозможна для «непрозрачных» поэтов без открытости окружающему, слияние парадоксально сочетается с разделением, что обеспечивает поддержание автономности каждой из субъективностей. Действенным средством переосмысления лирической субъективности предстает деконструкция языковых норм, превращающая слово из помехи сопричастности в запускающий ее код.

\section{Литература}

Абдуллаев, Ш. (1997): Медленное лето. СПб. http://www.vavilon.ru/texts/abdullaev1.html $(30 / 05 / 2016)$.

Абдуллаев, Ш. (2003): Неподвижная поверхность. М. http://www.vavilon.ru/ texts/abdullaev2-1.html\#1 (30/05/2016).

Глазова, А. (2008): Петля. Невполовину. М. http://www.vavilon.ru/texts/glazova3-6.html $(02 / 06 / 2016)$.

Гуссерль, Э. (2005): Картезианские медитации. Медитация V. Раскрытие сферы трансцендентального бытия как монадологической интерсубъективности // Гуссерль, Э.: Избранные работы. Пер. с нем. В. Куренного. М. 383-426.

Драгомощенко, А. (2011): Тавтология: Стихотворения, эссе. М.

Евграшкина, Е. (2015): Игры с перспективой и «полагание» субъекта: о дейксисе поэтического текста // Евграшкина, Е. / Шталь, Х. (сост./ред., 2018): Субъект в новейшей русскоязычной поэзии - теория и практика. Frankfurt am Main. 171-183.

Заломкина, Г. (2006): Подходы к пониманию медленного письма: Поэтика зазора в текстах Ш. Абдуллаева, А. Драгомощенко, А. Уланова // Рымарь, Н. (ред.): Граница и опыт границы в художественном языке. Вып. 4.: Поэтика рамы и порога: Функциональные формы границы в художественных языках. Самара. 369-380. 
Корчагин, К. (2012): В непрозрачной речи (О поэзии И. Шостаковской) // Новое литературное обозрение. $114,2012.283-288$.

Носорева, Т. (2009): Местоимение «мы» в поэзии Ф.И. Тютчева // Известия Российского государственного педагогического университета имени А.И. Герцена. 93, 2009. 203-207.

Северская, О. (2015): Субъект лирический или публицистический? (от чьего имени говорит новая социальная поэзия) // Евграшкина, Е. / Шталь, Х. (сост./ред.): Субъект в новейшей русскоязычной поэзии - теория и практика. Frankfurt am Main. 325-341.

Снытко, С. (2014): Уничтожение имени. М.

Соловьев, С. (2005): Новые стихотворения // TextOnly. 13, 2005. http://www.vavilon.ru/ textonly/issue13/soloviev.html (02/06/2016).

Суслова, Е. (2016): Модели информационного сжатия и проблема архивации знания в новейшей русской поэзии // Азарова, Н. / Бочавер, С. (ред.): Поэтический и философский дискурсы: история взаимодействия и современное состояние. М. 379-387.

Уланов, А. (2006): Между мы. М.

Уланов, А. (2012): Способы видеть. М.

Федоров, М. (2008): Роль личных местоимений в композиции произведений Ин. Анненского: автореферат дис. ... к. филол. н. М.

Фридрих, Г. (2010): Структура современной лирики: От Бодлера до середины двадцатого столетия. Пер. с нем. Е. Головина. М.

Dennett, D. (1988): Quining Qualia. In: Marcel, A. / Bisiach, E. (eds.): Consciousness in Contemporary Science. Oxford. 42-77.

Edmond, J. (2004): Writing on the Margins: The Experimental Poetry of Lyn Hejinian, Yang Lian, and Arkadii Dragomoshchenko. A thesis submitted in partial fulfillment of the requirements for the degree of Doctor of Philosophy in Comparative Literature, the University of Auckland. https://researchspace.auckland.ac.nz/bitstream/handle/2292/308/02whole. pdf? sequence $=12(12 / 02 / 2018)$. 


\section{Александра Третьякова (Трир)}

\section{Коммуникативные лирические отношения и способы выражения субъекта в поэзии Елены Зейферт (на материале сборника «Веснег»)}

Коммуникативные отношения в лирическом стихотворении всегда привлекали исследовательское внимание как важный аспект смыслообразования. Е. Козицкая определяет их как взаимоотношения «я» и «ты», взаимодействие их смысловых позиций. ${ }^{1}$ Не менее интересны они в пределах цикла, так как становятся здесь проявлением одной из граней авторской концепции. Раскрытие сущности «я», а также его отношения к окружающему миру и является особенностью лирического текста. Исследование лирической коммуникации в том или ином стихотворении способствует раскрытию сути лирики как особого рода литературы. При этом представляется необходимым анализ способов выражения образов субъекта, или адресанта, и лирического адресата, отношений людей и животных, вещей и их владельцев, человека и Бога. Материалом данного исследования послужил сборник стихотворений и верлибров «Веснег» (2009) Елены Зейферт, в который входят оригинальные стихотворения и поэмы на русском и частично на немецком языках, а также переводы на русский язык немецкоязычных стихотворений Райнера Марии Рильке, Эльзы Ласкер-Шюлер, Виктора Шнитке.

\section{Коммуникативные лирические отнотения}

И. Романова ${ }^{2}$ разработала методику, позволяющую выделить три типа коммуникативных лирических отношений:

1. Безлично-безадресный тип: субъект и адресат максимально скрыты; тематическая направленность на окружающий мир.

2. Эготивный тип: субъект находится в центре и без адресата; преобладание сосредоточенности на «я».

3. Апеллятивный тип: единое обращение к тому или иному эксплицитному адресату; выраженная направленность поэтического сознания на «ты».

Остальные коммуникативные формы носят смешанный характер: либо одна часть стихотворения построена по одному коммуникативному прин-

\footnotetext{
${ }^{1}$ Козицкая (2000, с. 171).

2 Романова (2007, с. 38-39).
} 
ципу, а вторая - по другому, либо один тип усложняется другим или даже двумя другими типами.

В сборнике «Веснег» преобладающим по численности является эготивноапеллятивный тип. В этих стихотворениях либо эготивный текст усложняется аппелятивными элементами, либо наоборот. При этом адресатом обращений лирической героини (чаще всего именно героини, а не героя) является некий или некая «ты» (A mbl Давид. Tbl статуя нагая; ${ }^{3}$ Tbl совершенна...); ${ }^{4}$ объекты и явления природы: животные (Tbl станешь весь из молока, / Щенячий мальчик, млечный bоy), ${ }^{5}$ солнце и луна (Sоппе беби зачем тебе бельй твой свет); ${ }^{6}$ снег (Tы закрой меня Schnее от людей от тепла и зольl). ${ }^{7}$ Особым (над)адресатом становится Бог. Помимо ряда стихотворений, восхваляющих Святое («Икона», ${ }^{8}$ «Богу», ${ }^{9}$ «Молитва» $\left.{ }^{10}\right)$, обращение к Богу проявляется в многочисленных произведениях: лирический субъект обращается к Всевышнему, критикуя общество (homo ludens (о Боже) - не homo ль ubludens, о люди?), ${ }^{11}$ в минуту отчаянья (Это ты посылаешь мне / или просто не можешь помочь? $)^{12}$ или восхваляя им созданный мир. Г. Ермошина подчеркивает, что для Зейферт главное даже не присутствие Бога в мире, а его присутствие в человеке - любом, каждом. ${ }^{13}$

Вторую по численности позицию занимает эготивный тип и третью апеллятивный тип. Лирическое «я» наиболее ярко представлено в стихотворениях второго типа, однако сосредоточенность на субъекте, а также его взаимоотношениях с окружающим миром и лирическим «ты» присутствует почти в 70\% проанализированных стихотворений цикла "Веснег" и является отличительной чертой поэзии Елены Зейферт.

\section{Способы выражения субъекта}

В ходе нашего исследования мы придерживались позиции С. Бройтмана, который определяет лирический субъект как «носителя речи, а также ос-

\footnotetext{
3 Зейферт (2009, с. 67).

4 Там же, с. 84.

5 Там же, с. 22.

${ }^{6}$ Там же, с. 33.

${ }^{7}$ Там же, с. 35.

${ }^{8}$ Там же, с. 11.

${ }^{9}$ Там же, с. 12.

10 Там же, с. 13.

11 Там же, с. 17.

12 Там же, с. 10.

${ }^{13}$ Ермошина (2009).
} 
новной (объемлющей) точки зрения на мир и оценки в лирическом художественном произведении». ${ }^{14}$ В соответствии с классификацией И. Романовой, ${ }^{15}$ мы выделяем следующие способы выражения лирического субъекта в тексте: «я» повествующее, «я» повествуемое, «мы» инклюзивное (я + ты - мы с тобой; ${ }^{16}$, «мы» эксклюзивное (представляет собой модель я + он / она или я + они $)^{17}$, а также в виде формулы ${ }^{18}$ я + все или мы $=$ мир. ${ }^{19}$

Исследуя разные формы проявления субъекта в произведениях Елены Зейферт, стоит отметить, что лишь две его формы, повествующая (принимающая на себя роль нарратора; при этом «я» имеет возможность быть авторским и персонажным) и повествуемая (говорящая форма субъекта, являющаяся одновременно и предметом описания лирического текста), ${ }^{20}$ встречаются в стихотворениях Зейферт. Безличная же его форма, не определяющая статус говорящего и описывающая какое-либо событие / действие, вряд ли вообще характерна для сборника «Веснег», а также для поэзии Зейферт в целом, так как именно личнылй характер является отличительной частью ее творчества. Безличная форма не описывает личность носителя сознания, сосредотачивает внимание читателя на том, что изображается, а не на том, кто изображает. Его присутствие выявляется лишь в его взгляде на происходящее, его жизненной и моральной позиции. ${ }^{21}$ Но даже если субъект не выражен грамматически (окончаниями глаголов, местоимениями и т.д.), его присутствие и черты характера отчетливо проявляются именно в этой позиции и видении вещей:

Полутораухий щеночек

(«Пустите, пустите в подъезд!»)

то кость после Лорда обточит,

то с птицами крошек поест...

Бедняжке и имя не дали

и кликали все вразнобой.

Бывало, камнями бросали,

а в общем... не брали с собой. ${ }^{22}$

Субъект не растворен в тексте, а «выдает» свой внутренний мир: он способен к сочувствию (полутораухий; бедняжка; влажные горошины) и сосре-

\footnotetext{
${ }^{14}$ Бройтман (2008, с. 112-113).

15 Романова (2007).

16 «Мы с тобою похожи, палач мой, как хохот на плач.» Зейферт (2009, с. 25).

17 «Волга! Mutter! И в тысяче мест / остаёмся мы Wolganigger.» Там же, с. 28.

18 «Кто мы? что мы? Мы все пылинки.» Там же, с. 70.

${ }^{19}$ Азарова (2017).

${ }^{20}$ Сергеева (2008, с. 250, 254).

21 Там же, с. 249.

22 Зейферт (2009, с. 19-20).
} 
доточен на страдании живого. Так поданный субъект сознания оказывается уже предметом изображения - «собственной темой», или субъектом-длясебя в терминологии С. Бройтмана. ${ }^{23}$ Д. Черашняя отмечает «столь естественную для автора книги „Веснег“ причастность к чужой жизни как к своей, неподдельную боль за все живое, страдающее, сиротствующее». ${ }^{24}$

Более четко субъект выявляется при анализе целого лирического цикла, поэтому следует рассмотреть и следующее стихотворение, одно из немногих с «псевдо-безличным» субъектом:

На стеклянной витрине киоска

в подземном переходе -

нарисованный Чебурашка.

Полуслепая нищая старушка,

принимая его за продавца,

просит милостыню...

«Сынок, на хлеб...» ${ }^{25}$

Опять же взгляд «скрытого» субъекта сосредотачивается на страдании полуслепой нищей старухи, которую не услышат ни бездушное стекло, ни нарисованный Чебурашка. Как название «Когда сжимается сердце», так и тройная аллитерация (полуслепая, принимая, просит), фокусирующие повествование на описании старушки, выражают сочувствие, сожаление и сострадание, открывая дверь во внутренний мир субъекта.

Таким образом, безличная форма субъекта не встречается в стихотворениях цикла «Веснег», так как субъект так или иначе проявляет себя. Названные примеры стоит, скорее всего, отнести к измененной форме повествующего способа выражения, который мы рассмотрим в дальнейшем.

Повествующий способ выражения лирического субъекта, способный позиционировать себя в пространстве и времени, определяя таким образом точку зрения, с которой ведется повествование, намного реже встречается в сборнике, ${ }^{26}$ нежели повествуемый. Это «я» может позиционировать себя как нарратор, предлагая свою точку зрения, давая эмоциональную оценку объекту описания. Этот тип субъекта может быть выражен местоимением первого лица единственного либо множественного числа, т.е. быть авторским, либо же персонажным, выраженным местоимением третьего лица единственного числа. ${ }^{27}$

${ }^{23}$ Ср. Каргашин (2015, с. 69).

24 Черашняя (2009).

25 Зейферт (2009, с. 150).

${ }^{26}$ Однако не личность говорящего является главной темой поэтического произведения, а внешний мир, включающий и других людей.

${ }^{27}$ Ср. Сергеева (2008, с. 250-251). 
Повествующая (а также повествуемая) форма эксклюзивного «мы» несколько раз встречается в сборнике Зейферт, например, в стихотворении «Бог. Новый Вавилон», в котором субъект, выраженный местоимением «мы», обращается к общечеловеческим проблемам веры, присутствия и поиска Бога на земле, а также роли поэта в нем, задавая при этом риторические вопросы: Господи, как смеем? Как смоем дерзость?28 Чаще речь идет о «мы» как «ты и я», но эта форма выражения скорее относится к повествуемому типу.

В следующем произведении встречаются оба местоимения «я» и «мы», то есть лирический субъект - одновременно само общество «мы» и в тоже время индивидуум «я», являющийся частью этого общества. Они объединены одной общей проблемой, которая становится объектом описания: серая, жалкая масса людей - общество потребления, толкущееся ежедневно в разноцветных автобусах-упаковках, жертва рекламы:

Автобусы раскрашены под пачку чая,

Под стиральный порошок, под кубики «Maggi».

Нас учат удивительному искусству перевоплощения.

Утром, в жарком запечатанном салоне,

Мы, жалкие чаинки, лежим друг на друге.

Вечером я - маленькая мятная карамелька,

В тесной коробке,

Завернута в нарядный бумажный фантик.

Пытаюсь озираться - чья обертка лучше?

На свидание спешу крупицей порошка $[\ldots]^{29}$

Критическая позиция субъекта, ярко выраженная уже с первых строк, особенно четко просматривается в сопоставлении $\boldsymbol{м ы , ~ ж а л к и е ~ ч а и н к и ; ~ я - к а - ~}$ рамелька в тесной коробке; я и любимый - (никчемные) одинаковые крупицы порошка; а также в последних строках Не хочу идти на пользу потребителю. / И никаких поездок, в которых субъект «я» (выраженный формой глагола) противостоит принуждению быть частью серого общества в цветном автобусе.

Лирическим объектом-персонажем стихотворения «Дверная ручка отслужила срок» миницикла «Нет имени у вещи...» становится старая дверная ручка:

Дверная ручка отслужила срок,

Но вечного не заслужила рая.

Мне память вещи подает урок,

И я в недоуменье замираю,

Касаясь круглой гладкости рукой,

\footnotetext{
28 Зейферт (2009, с. 7).

29 Там же, с. 156.
} 
Столь непривычной после деревянной

Шероховатости, что на покой

Легла в углу балкона безымянной. $[\ldots]^{30}$

Субъект одушевляет ее, говоря о ее верности, о ею заслуженном рае, раскрывая при этом такой взгляд на вещи: предметы и вещи для нее (него) обладают определенной степенью родства, когда они проживают общую жизнь со своим владельцем. Жизнь вещи - не абстрактное явление, а вполне определенная категория совместного бытия. Вещи преданы, они зависимы от своего хозяина, им не дано права на свободную от него жизнь, на личный голос, поэтому они становятся частью его бытия. ${ }^{31}$

Перейдем к последнему, самому весомому в сборнике типу лирического субъекта - повествуемому. Говорящее Я является носителем сознания и стоит при этом в фокусе изображения. В центре внимания его состояние, его отношение к миру. Такое «я» представлено в сборнике разными способами:

- непосредственно через «я», возникающее в большинстве стихотворений цикла и наиболее ярко представленное в повествуемой форме;

- через глагол-предикат в 1-ом л. ед. ч.: не забываю, открываю, спешу, подхожу - при отсутствии местоимения (см. последний пример);

- как «другой» со стороны в 3-ем л.: Он мускулист, силен, готов к броску; ${ }^{32}$ Девочка лет четырех; ${ }^{33}$ До утреннего кофе он спешил открылть; ${ }^{34}$ Казахстанской Золушке здесь невмоготу; ${ }^{35}$

- с помощью местоимения второго лица «ты»: Beдb mbl умеешь лстить; ${ }^{36}$ А ты Давид. Ты статуя нагая; ${ }^{37}$

- метонимически, через духовные и телесные составляющие: головешки рук; ${ }^{38}$ знак бесконечности; ${ }^{39}$ сердчее-ястребенок; ${ }^{40}$ молчание ${ }^{41}$ облик твой - виртуальные буквы $;^{42}$ мой зрачок - чужеземеи.. ${ }^{43}$

${ }^{30}$ Там же, с. 41.

${ }^{31}$ Ср. Ермошина (2015).

32 Зейферт (2009, с. 15).

33 Там же, с. 148.

34 Там же, с. 63.

35 Там же, с. 28.

36 Там же, с. 73.

37 Там же, с. 67.

38 Там же, с. 33.

39 Там же, с. 38 .

40 Там же, с. 85.

${ }^{41}$ Там же, с. 95.

42 Там же, с. 61.

43 Там же, с. 62. 
В эготивном, а также эготивно-апеллятивном виде лирических отношений преобладает выражение субъекта через «я». Далее по убывающей следуют способы выражения с помощью «ты» и третьего лица. При этом метонимический способ является вспомогательным во всех коммуникативных типах. Духовные и телесные составляющие, посредством которых лирический субъект выражает себя, значимы для всего поэтического цикла. В группу лексических наименований, обозначающих духовные, интеллектуальные и эмоциональные составляющие, входят следующие:

- душа: а душа моя, сжавшись до километра боли; ${ }^{44}$ дай пристанище моей душе ${ }^{45}$; две души истомились в груди; ${ }^{46}$

- молчание / немость - крик: дыхание немых молитв ${ }^{47}$ немая немка, ${ }^{48}$ онеметь на время стихам $;^{49}$ Я кричу на языке Слова:50 от бессилия плакать в голос; ${ }^{51}$

- воспоминание: Я помню, как Гончар меня лепил, ${ }^{52}$ я помню, как кружилась голова ${ }^{53}$ забыв о былой своей людности ${ }^{54}$ я ярко помню. ${ }^{55}$

Группа наименований телесных составляющих представлена следующими лексическими единицами:

- руки / пальцы: свои корни руками латаю;56 обугленных рук моих тыл, $5^{57}$

- губы / рот: рот, вмещуающий два языка.;8 пепел губ твоих; ${ }^{59}$ а рот как грог; $; 0$

- глаза: по твоим голове и глазам ${ }^{61}$ ни губ, ни глаз любовного питья. ${ }^{62}$

44 Там же, с. 23.

45 Там же, с. 13.

46 Там же, с. 26.

47 Там же, с. 14.

48 Там же, с. 23.

49 Там же, с. 27.

${ }^{50}$ Там же, с. 48.

51 Там же, с. 65.

52 Там же, с. 91.

53 Там же.

${ }^{54}$ Там же, с. 131.

55 Там же, с. 79.

56 Там же, с. 27.

57 Там же, с. 32.

58 Там же, с. 22.

59 Там же.

60 Там же, с. 50.

61 Там же, с. 31. 
Как видим, метонимический способ выражения субъекта способствует раскрытию его внутреннего мира. ${ }^{63}$

Анализ произведений «Веснег» позволяет выявить определенную целостность субъекта, поскольку наблюдаются некоторые так или иначе повторяющиеся его черты: уже ранее описанное сострадание всему живому превознесение и восхищение.

Вещь так беспомощна, безропотна, верна,

что хочется ей в ноги поклониться

и влить в нее созвучие сполна,

и за грехи людские повиниться. ${ }^{64}$

$[\ldots]$

Нынешнего счастья дождавшись,

Теплая, сплетенная с тобою,

Прошлому скажу: «Дождь мой! Да, в жизнь

Ты принес покоя и прибоя». ${ }^{65}$

$[\ldots]$

Кроме того, лирический субъект Зейферт - в вечном поиске, а точнее, познании Всевышнего, сближении с ним:

Взаимная любовь на Земле - зернышки,

протянутые мне, жалкой, в ладошки Богом...

...Господи, родненький,

неужели ты хочешь забрать их?..

Или - еще горше!!!

Я должна их вернуть сама? ${ }^{66}$

Неотъемлемой чертой героя / героини является также языковая, немецкорусская «раздвоенность», попытка соединения в себе двух традиций ${ }^{67}$ :

Саша, я ищу среди развалин

Старого Берлина красный флаг.

И не кремль - коричневый рейхстаг!

Немец иль фашист - мой старый враг,

Vaterland - хорош, но федерален. ${ }^{68}$

${ }^{62}$ Там же, с. 51.

${ }^{63}$ Ср. Романова (2009, с. 97).

${ }^{64}$ Зейферт $(2009$, с. 43$)$.

${ }^{65}$ Там же, с. $46-48$.

${ }^{66}$ Там же, с. 71.

${ }^{67}$ В предисловии сборника Олег Федотов заостряет внимание именно на этом факте: «Вся художественная система книги Елены Зейферт возвращает нас к заглавию «BECHEГ - BECHER - ЧАША». Слова двух языков пристально всматриваются друг в друга, взаимодействуют и высекают новые неожиданные смыслы, призывая читателя приникнуть к полной чаше сотворчества». 
$[\ldots]$

Русской крови ни капли в жилах,

А язык до восторга родной!

Четверть красной семитской застыла

В трех четвертых густой - голубой. ${ }^{69}$

$[\ldots]$

Рот, вмещающий два языка.

Отче, Vater, скажи, чья дочь я? $[\ldots]^{70}$

При этом в обеих формах выражения субъекта, повествующей и повествуемой, проявляются биографические отсылки к самой Елене Зейферт, иногда конкретные («Маме. Спаси Бог. С.А. Зейферт», ${ }^{71}$ «Отец И.Ф. Зейферту», ${ }^{72}$ $\left\langle\right.$ ЕЗ» $\left.{ }^{73}\right)$, чаще же - косвенные. Глубокая православная религиозность Зейферт особенно ярко выражается в субъектах эготивно-апеллятивного типа. Здесь вера тесно связывается с творчеством, «тканием» стихотворений. Писатель становится поэтом именно в процессе поиска божественного слова, восстанавливая текст как мир из обрывков, обломков разбившейся речи. ${ }^{74}$

- Господи, дай ребеночка!

На колени ложится белый лист.

Рождается стих.

Бог слышит все. ${ }^{75}$

Еще одной параллелью между лирическим субъектом и поэтом становится проблематика раздвоенности русско-немецкого. Она просматривается в ряде стихотворений: «Александру Абезгаузу в Германию», ${ }^{76}$ «Верлибр: Вера в Лиебе» (Я сумасшедшая русская оттуда, где была сумасшедшей немкой), ${ }^{77}$ ср. также русской крови ни капли в жилах, а язык до восторга родной. ${ }^{78}$

Итак, мы установили, что в стихотворениях книги Елены Зейферт «Веснег» преобладают произведения эготивно-апеллятивного типа лирической коммуникации, а также повествуемая форма субъекта. Он занимает ведущее место в сборнике, и хотя способы выражения его разнообразны, способ проявления через местоимение «я» преобладает.

\footnotetext{
68 Там же, с. 23-24.

69 Там же, с. 27.

70 Там же, с. 29.

71 Там же, с. 77.

72 Там же, с. 78.

73 Там же, с. 38.

${ }^{74}$ Ср. Ермошина (2015).

75 Зейферт (2009, с. 13).

76 Там же, с. 23.

77 Там же, с. 25.

78 Там же, с. 27.
} 


\section{Литература}

Азарова, Н. (2017, в печати): Новые проблемы старого мы // Russian literature. http://natalia-azarova.com/pdf/we_new.pdf (25/07/2018).

Бройтман, С. (2008): Лирический субъект // Тамарченко, Н. (отв. ред.): Поэтика: словарь актуальных терминов и понятий. М. 112-113.

Ермошина, Г. (2010): Елена Зейферт. Веснег. В поисках божественного слова // Знамя. 5, 2010. http://magazines.russ.ru/znamia/2010/5/er27.html (10/04/2017).

Зейферт, Е. (2009): Веснег: Стихи и переводы. М.

Каргашин, И. (2015): Проблемы типологии субъектных структур в лирике О. Мандельштама // Новый филологический вестник. 1 (32), 2015. 68-74.

Козицкая, Е. (2000): Своеобразие субъектно-объектных отношений в лирике А. Блока // Сура. 4, 2000. 171.

Романова, И. (2007): Поэтика Иосифа Бродского: Лирика с коммуникативной точки зрения. Смоленск.

Романова, И. (2009): Проблема лирической коммуникации в раннем творчестве Татьяны Бек // Вестник Удмуртского университета. 3, 2009. 92-100.

Сергеева, Ю. (2008): К вопросу о коммуникативной структуре лирического произведения // Вестник Тамбовского университета. 11, 2008. 248-253.

Черашняя, Д. (2009): Вечно незаконченное. Отзыв о книге «Веснег». http://leinonen.ucoz.com/Druziya/EZeifert/BECHEr_rezensionen.html (10/04/2017). 


\section{Анна Гаврилюк (Трир)}

\section{Формы субъектности в современной украинской гражданской поэзии}

В последнее время активно меняются роль и гражданская позиция поэта в Украине ${ }^{1}$. Поэт формирует общественное мнение людей, переосмысливая в своих стихотворениях животрепещущие социальные темы. Проблема лирического субъекта тесно связана с вопросами сознания и самосознания автора, когда идет речь о соотнесенности творческой деятельности с ее индивидуальным или коллективным агентом.

В статье будут рассмотрены формы субъектности в современной украинской гражданской поэзии, а также показаны способы репрезентации лирического субъекта, которые раскрывают нераздельность коллективного и индивидуально-авторского «я». Применяя типологию лирических субъектов Б. Кормана ${ }^{2}$ и С. Бройтмана ${ }^{3}$, необходимо различать следующие субъектные формы: автор, лирическое «я», лирический герой, ролевой герой. Все эти субъектные формы присутствуют в выбранных для анализа стихотворениях современных украинских поэтов. Акцент поставлен на исследование индивидуального и коллективного начал.

Роль поэта и поэзии в Украине

Вопросы о роли поэта и поэзии в Украине и о наиболее популярных формах субъектности особенно актуальны в современной украинской поэзии, временные рамки которой определены политической ситуацией конфликта с Россией (2013-2017). Особый статус поэта в Украине и его гражданская позиция, которая отображается в поэзии, часто формируют мнение общественности. По мнению немецкого поэта Макса Чоллека, «поэты в Украине имеют ,звездный“ статус». ${ }^{4}$

1 По просьбе автора в статье сохранен предлог «в» в сочетании с хоронимом «Украина». Прим. ред.

${ }^{2}$ Корман (1986).

${ }^{3}$ Бройтман (1999).

${ }^{4}$ Deutsche Welle: „Wo Dichter wie Stars gefeiert werden“ (http://www.meridiancz.com/de/ dw-wo-dichter-wie-stars-gefeiert-werden/, 09/07/2018). Перевод с немецкого и украинского здесь и далее мой. А.Г. 
Будь то новые или старые поклонники поэзии: все они знают имена известных поэтов страны, как Юрий Андрухович или Сергей Жадан, но и такого молодого поэта как Андрей Любка. Когда я говорю, что я делаю что-то с Андреем Любка, даже люди, которые не имеют ничего общего с литературой, говорят: «Вау, Андрей Любка, это здорово». Этого никогда бы не случилось в Германии. ${ }^{5}$

В Украине поэты занимают более высокое положение в обществе, чем в Западной Европе. Они считаются интеллектуальными голосами общества. «В глазах народа поэт по-прежнему тот, от кого вы ожидаете чего-то существенного, какого-то важного сообщения», - говорит известный украинский поэт и прозаик Юрий Андрухович. По его словам, «в Германии поэзия сейчас очень разнообразна, очень изысканна, и в то же время она не имеет такой широкой аудитории, как здесь, в Украине» ${ }^{6}$.

Рейтинг самых известных современных украинских писателей возглавляет поэт Лина Костенко (с показателем узнаваемости в 42\%), после нее с существенным разрывом - авторы массовых романов Ирэна Карпа (15\%) и приключенческой литературы Василий Шкляр (12\%). 5 из 18 наиболее известных современных писателей являются также известными поэтами (27,7\% от всего числа узнаваемых авторов). Чтение произведений этих авторов колеблется от 1 до 24\%. Если проанализировать статистику книжных и литературных мероприятий за 2012 год (на основе анонсов портала «Друг читателя»), то обнаружим, что около 35\% (34,48\%) - это события, посвященные поэзии в самых разнообразных вариантах. ${ }^{8}$ Принимая во внимание тот факт, что некоторые мероприятия в форме книжных выставок, круглых столов, награждения премиями или определения литературных рейтингов могут предусматривать наличие в перечне поэтических книг, определенного участия поэтов, то этот процент будет еще выше. ${ }^{9}$ Эти показатели свидетельствуют о том, что современная украинская поэзия имеет общественное звучание и значение, а современные поэты имеют довольно большую аудиторию.

\section{Гражданская поэзия в Украине}

Гражданская поэзия играет центральную роль в традиции украинской литературы. С появлением второго сборника стихотворений Т. Шевченко «Три года» (1845-1847) можно говорить о возникновении в украинской словесности острых социальных мотивов в гражданской поэзии. В творче-

\footnotetext{
${ }^{5}$ Там же.

${ }^{6}$ Там же.

${ }^{7}$ Шелухин (2013).

${ }^{8}$ Там же.

${ }^{9}$ Там же.
} 
стве таких крупных украинских поэтов, как И. Франко, Л. Украинка, Е. Маланюк, В. Стус, С. Жадан и др., доминируют стихотворения на гражданские темы. Гражданская поэзия - условное название лирических произведений, в которых особо актуальными являются социальные и национальные мотивы. Это определение также отражает функции гражданской поэзии в Украине. В нашей работе мы опираемся на понимание гражданской поэзии, которое дает Максим Амелин, утверждая, что

гражданская поэзия - не что иное, как рифмованная публицистика, ритмизованный физиологический очерк, разделенное на строфы воззвание. Она процветает только тогда, когда в обществе что-то не так, выполняя коммуникативную функцию, никому кроме нее в данное время не доступную. Она оказывает огромное влияние на современное ей сознание и почти полностью забывается в потомстве. Политическая тирания, общественные неустройства, социальное неравенство порождают гражданскую поэзию, становятся основными ее темами, а по своем исчезновении грозят исчезновением и ей. ${ }^{10}$

Данная трактовка гражданской поэзии сходна с современным пониманием гражданственности в украинской поэзии.

Гражданская поэзия способствует формированию национального сознания и достоинства (Т. Шевченко, П. Тычина, Д. Павличко, П. Кулиш, И. Франко, Л. Украинка, О. Олесь, песни сечевых стрельцов, В. Симоненко, В. Стус и др.), развитию национальных тенденций (сборник «Вежі» [Башни] О. Ольжича), утверждению общечеловеческих ценностей. ${ }^{11}$ Она не только показывает позицию гражданской ответственности автора, но и существенные черты ментального сознания (при затяжной российскокавказской войне в XIX в. Т. Шевченко обращался к свободолюбивым горцам: «Борітеся - поборете!» [Боритесь - поборете!]). ${ }^{12}$

Для гражданской поэзии характерна сильная позиция субъекта, при помощи которой автор имеет возможность выразить собственную политическую позицию. Вопрос о субъекте гражданского высказывания важен, «поскольку делая - более или менее осознанно - такое высказывание, поэт тем самым входит в политическое пространство, где неминуемо возникает вопрос о его социальной и политической идентичности» ${ }^{13}$. Отчетливо артикулированные представления субъекта как особенность отличают не только украинскую, но и русскоязычную гражданскую поэзию, начиная с ее истоков в творчестве Н. Некрасова ${ }^{14}$. Сильная позиция субъекта очевидна не только в лирических произведениях одного из основоположников россий-

\footnotetext{
10 Амелин и др. (2002).

${ }^{11}$ Гетьманець (2003).

12 Там же.

13 Абдуллаев (2010).

${ }^{14}$ См. подробнее: Саженина (2014).
} 
ской гражданской лирики, ${ }^{15}$ но даже и в тех поэмах Некрасова, в которых однозначное выражение позиции автора сосуществует с развитым эпическим началом. ${ }^{16}$ Творчество Некрасова в значительной степени сформировало тип гражданской лирики, существовавший в пределах советской литературы, а также и за пределами России и Украины, например, в наследии С. Габиева. В дальнейшем влияние некрасовской лирики сочеталось с более явной опорой на гражданские мотивы в традиции А. Пушкина («О, если б голос мой умел сердца тревожить...»), М. Лермонтова («Люблю отчизну я, но странною любовью...») и Ф. Тютчева («Умом Россию не понять...»). Традиционная гражданская поэзия значительно повлияла на творчество современных поэтов: Д. Быкова, Е. Емелина, Е. Фанайловой ${ }^{17}$ и др.

Поэзия последних пятнадцати лет мощно развивалась благодаря Интернету и социальным сетям. Гражданская поэзия особенно актуальна в современном украинском литературном дискурсе. На литературных фестивалях часто присутствует секция гражданской поэзии. Так, например, на международном фестивале поэзии «Киевские лавры» 2014 г. была секция «Поэт и гражданин. Баррикады или башни из слоновой кости? Гражданская позиция литератора в смутные времена» ${ }^{18}$, в которой поэты говорили о поэзии, политике и гражданственности.

Говоря о гражданской сетевой поэзии, следует отметить, что важным фактором в социальных сетях являются образы поэта и его частного лица. Посредством таких социальных сетей как Facebook, Vkontakte, YouTube, Twitter, на которых широко представлена и поэзия, генерируются формы, в которых сливаются собственно лирические субъектные формы с медийными и автобиографическими, связанными с гражданской позицией поэта. Основной характеристикой современной украинской поэзии в сети является публицистичность. Акцент ставится на акт гражданского поведения и немедленный отклик на важнейшие события современности, которые осмысливаются эстетически.

Выступления и поэтические перформансы в рамках украинских фестивалей поэзии таких современных поэтов, как Юрий Андрухович и Сергей Жадан, представляют их, с одной стороны, как личностей, с другой стороны как поэтически оформленных субъектов. Современный поэт соотносит свое лирическое Я с обществом, отображая таким образом его актуальное состояние. В саморепрезентации лирического субъекта особенно важно отношение между «я» и коллективным «мы». По мнению Максима Амелина,

\footnotetext{
${ }^{15}$ См.: Гасанов (2011).

${ }^{16}$ См.: Саженина (2014).

${ }^{17}$ См.: Ермакова (2012).

${ }^{18}$ См. подробнее: Фанайлова (2014).
} 
лирическая поэзия есть дело частное, и оперирует она в основном личными местоимениями единственного числа. Гражданственность - общественное, множественное. $^{19}$

Таким образом, коллективное «мы» особенно важно для гражданской поэзии. Формально это может быть выражено напрямую. Например, в стихотворении Б. Херсонского четко прослеживается коллективное «мы»: «Сейчас мы это видим, но куда $м ы$ раньше глядели? / А раньше мы не глядели, все думали - обойдется» ${ }^{20}$; или в стихотворении С. Жадана: «І ми стоїмо під пекучим небом / і не можемо зайти на власні подвір'я. / Наші міста загусають медом. / В наших вітальнях літає пір'я» ${ }^{21}$ [И мы стоим под палящим небом / и не можем зайти на собственный двор / Наши города загустевают медом. / В наших гостиных летают перья]. Однако формы «мы» и их отношения с «я» строятся по-разному.

Среди многообразия сетевой поэзии для анализа формы субъекта под аспектом «мы» и «я» были отобраны отдельные произведения из творчества Евгении Бильченко, Сергея Жадана и Бориса Херсонского. Критериями выбора поэтов и их ключевых стихотворений были следующие факторы: популярность, высокий рейтинг и узнаваемость поэтов в социальнополитическом медиадискурсе Украины; активное использование социальных сетей (Facebook, Vkontakte, YouTube) в качестве платформы саморепрезентации и быстрого распространения своих поэтических текстов среди широких масс населения; языковой фактор как гражданская позиция. Среди выбранных поэтов Жадан - украиноязычный автор, Бильченко и Херсонский - русскоязычные. Следует отметить, что творчество украиноязычных и русскоязычных поэтов анализируется в работе как часть единой украинской литературы. Этот факт, который в Украине не всегда очевиден, активно обсуждается как в литературных, так и в политических кругах. ${ }^{22} \mathrm{~B}$ выбранных текстах представлены разные формы соотношения «я» и «мы». Мы ограничиваемся тремя репрезентативными формами, не претендуя на исчерпывающую типологию.

Коллективное «мы» в стихотворении Сергея Жадана «Откуда вы черные птицы, с какого неба?»

Наряду с украинскими поэтами, которые занимают или проукраинскую, или пророссийскую гражданскую позицию и отображают ее в стихотворе-

\footnotetext{
19 Амелин и др. (2002).

${ }^{20}$ Херсонский, Б. «Все любят войну, в которой почти никто не погиб»; запись в Facebook от 19/03/2014 (https://www.facebook.com/borkhers/posts/762650133769815, 09/07/2018).

${ }^{21}$ Жадан (2016, с. 12-13).

${ }^{22}$ См. об этом: Кузьмин (2007).
} 
ниях, существуют поэты, которые пытаются быть политическими и поэтическими посредниками между этими двумя позициями. Среди них можно назвать Сергея Жадана.

Жадан является одним из самых известных представителей «новой социальной» и гражданской поэзии. По словам поэта из Луганска, Константина Скоркина:

Жадан - это человек, который смог стать катализатором перемен. Он стал человекомостом между Востоком и Западом. Я помню выступления Сергея Жадана в Доме актера в Харькове, в зал нельзя было попасть, люди стояли в проходах, выступавшие с ним швейцарские поэты пережили культурный шок - «на наши выступления приходит 5-10 человек». ${ }^{23}$

Жадан является поэтом-медиатором, который поддерживает литературные связи между украиноязычной и русскоязычной поэзией в Украине.

В стихотворениях Жадана политические и социальные события осмысливаются в какой-то мере в антипропагандистской и часто в антиполитической манере. Его поэзия и проза всегда носили социальный характер. Три последних сборника поэзии - «Месопотамия» (2014), «Жизнь Марии» (2015), «Тамплиеры» (2017) - переполнены как остро социальными проблемами, так и мифологическими и архетипическими мотивами.

Сборник стихов «Жизнь Марии» (2015) появился как художественная реакция на военные события и является в конечном итоге попыткой их художественно осмысления. ${ }^{24}$ Одно из самых известных произведений Жадана из сборника поэзии «Жизнь Марии» - стихотворение «Звідки ти, чорна валко, пташина зграє?» ${ }^{25}$ [Откуда вы черные птицы, с какого неба?]. Стихотворение написано в форме диалога между жителями одного из городов на Донбассе («черные птицы») и капелланом («отче»). Война, дегуманизация общества, другие социальные катаклизмы, а также рефлексии ролевых субъектов здесь трактуются символически, через эпизоды общения со священником и Богом. По словам современного украинского поэта Олега Коцарева,

важная вещь у Жадана - это сопереживание. Оно лежит в основе большинства стихов. Имеется в виду и сопереживания с врагом и его сторонниками, или, лучше тут сказать, с Другими. У поэта, как и у его героя-капеллана, для каждого найдется хотя бы слово. ${ }^{26}$

Автор поляризует противостояние между «своими» и «чужими» и вводит субъект коллективного «мы».

23 «Перемены на Восточном фронте: интервью СТАНа немецкой прессе»: http://tisk.org.ua/?p=19806 (09/07/2018).

${ }^{24}$ См.: Мельничук / Хорошков (2016).

25 Жадан (2015, с. 10-13).

${ }^{26}$ Коцарев (2014). 
Наше місто було з каменю та заліза.

У кожного з нас тепер у руці дорожня валіза.

У кожній валізі попіл, зібраний під прицілом.

Тепер навіть у наших снах пахне горілим. ${ }^{27}$

Наш город был из железа и камня.

Мы пришли, чемоданные ручки, сжимая руками.

У каждого в чемодане пепел, собранный под прицелом.

$\mathrm{B}$ наших снах навсегда теперь пахнет горелым. ${ }^{28}$

Это коллективное «мы» в форме диалога рассказывает в прошедшем времени о горестях военных действий, о судьбе беженцев из Донбасса. Если обратиться к теории Кормана, можно установить, что в стихотворении лирическое «мы» является не индивидуальным носителем сознания, а выступает как член некоего единства, и внимание читателя, как следствие, фокусируется на том, что объединяет людей с разными политическими взглядами. ${ }^{29}$ Жители Донбасса покинули свои земли, спалив там свои церкви и разрушив все до основания: «- Ми, капелане, мешканці міста, якого немає». ${ }^{30}$ Священник не может их утешить ничем, кроме обещания, что все будут наказаны: виновные, невинные - и те, кто безразличен. Последняя строка стихотворения принадлежит священнику: «Якби ви знали, як нам усім не пощастило» ${ }^{31}$ [Если б вы знали, как всем нам не повезло]. Здесь важно буквальное прочтение текста: людям из Донбасса не повезло быть просто здесь и сейчас. В тексте все как будто очевидно: у людей нет никаких надежд, им не повезло - и они снимают с себя ответственность за происходящие события.

У Сергея Жадана война не является следствием необдуманных действий, она просто сумма случайных, никак не прогнозируемых обстоятельств. Поэтому и наказаны будут все, потому виновных, по сути, нет. В тоже время черные птицы, потерянное наследство, пророк, который не имеет ответов, все эти образы здесь являются скрытыми цитатами из Библии: «Удел Мой стал у Меня, как разноцветная птица, на которую со всех сторон напали другие хищные птицы». ${ }^{32}$ Более того, все стихотворение Жадана является перепевом Книги пророка Иеремии, одной из самых черных и обнадеживающих одновременно, и указание на нее можно найти в стихотворении:

\footnotetext{
27 Жадан (2015, с. 10).

${ }^{28}$ Перевод стихотворения здесь и далее - Е. Муляровой, запись в LiveJournal от 08/02/2015: http://kat-bilbo.livejournal.com/ 1516494.html (26/07/2018). Орфография и пунктуация сохранены. Прим. ред.

${ }^{29}$ См. подробнее: Корман (1986).

${ }^{30}$ Жадан $(2015$, с. 10$)$.

31 Там же.

${ }^{32}$ Книга пророка Иеремии (Иер. 12: 9): https://www.bible-center.ru/ru/bibletext/synnew_ru /jer/12:9 (09/07/2018).
} 
Чому саме ви потрапили до темних потоків?

Потрібно було уважніше читати книги пророків.

Потрібно було оминати пекельні діри.

Для мирянина головне - не бачити в дії символи віри. ${ }^{33}$

Объяснить, почему вы в эти черные воды попали?

Да потому что надо было читать пророков, а вы не читали.

Обходить надо было адские дыры.

Для мирянина главное - не увидеть в действии символы веры.

Можно спросить, почему же пророк в стихотворении Жадана превращен в капеллана? Это может быть способом соединить «библейскую» реальность с «исторической». Капеллан по определению совмещает духовный сан с военными обязанностями, безальтернативно редуцируя обе свои ипостаси.

Пам'ятаєте, що сказано в пророків про біль і терпіння, про птахів, які падають на міста, мов каміння?

Ось саме тоді й починаються, власне, втрати.

В кінці - там взагалі погано, не буду навіть розповідати.

Яка між нами різниця? Як між приголосними й голосними.

Всі готові сприймати смерть, якщо це буде не з ними.

Ніхто й ніколи в цьому житті не омине розплати.

Я завжди говорю про це своїм, коли не маю чого

сказати.

Я не знаю нічого про неминучість спокути.

Я не знаю, де вам жити і як вам бути.

Я говорю про те, що кожному з нас властиво.

Якби ви знали, як нам усім не пощастило. ${ }^{34}$

Помните, что у пророков сказано про боль и терпенье.

Про ставших камнями птиц, оборвавших пенье.

Собственно, вот тогда-то и начинается этот парад потерь.

Все закончится плохо, лишь это скажу теперь.

Между нами какая разница? Как между гласными и согласными.

«Смерть это то, что бывает с другими» - вы пели напрасно.

В этой жизни расплаты никому и никогда не избежать

Вот, что я говорю своим, когда мне нечего больше сказать.

Искупление неизбежно, но я ничего об этом не знаю, похоже.

Где вам жить и как быть, я не знаю тоже.

Всяк человек, да опасно ходит, под босыми ногами - стекло.

Если б вы знали, как всем нам не повезло.

33 Жадан (2015, с. 13).

34 Там же. 
Капелланство или военное священство играет одну из важнейших ролей в ходе военного конфликта на Востоке Украины. ${ }^{35}$ В вооруженные формирования Украины вошли уполномоченные представители от главных церквей Украины: Украинской православной церкви Киевского патриархата, Украинской православной церкви Московского патриархата, Украинской автокефальной православной церкви и Украинской греко-католической церкви. ${ }^{36}$ Взаимодействие разных религиозных движений во время конфликта способствует толерантности в среде воюющих. Автор стихотворения подчеркивает именно эту функцию капелланов - призвание к духовным ценностям, а не только поддержку боевого духа солдат.

Во второй части стихотворения появляется ролевое «я» в образе священника-капеллана и вытесняет субъект коллективного «мы» в первой части.

- Добре, давайте я розкажу вам, що таке втрата.

Звісно, всіх винних чекає гідна розплата.

I невинних вона, до речі, теж чекає потому.

Вона чекає навіть тих, хто взагалі ні при чому. ${ }^{37}$

- Ладно, давайте я расскажу, что такое утрата.

Что, конечно, же всех виноватых ожидает расплата.

Впрочем, и невиновных она настигнет, но позже.

И даже тех, кто вообще не причем, не минует тоже.

Здесь ролевое «я» поучает читателя, а образы Иисуса, Бога, мотивы искупления, греха, расплаты, спасения, благой вести придают стихотворению Сергея Жадана сходство с притчей. Роль Жадана в роли посредника между пророссийскими и проукраинскими взглядами раскрывается в стихотворении через фигуру священника-капеллана. Группа, представленная коллективным «мы», а также апеллятивным обращением «вы» символизирует мирных жителей Донбасса, которые оказались вовлеченными в военный конфликт, но которые в тоже время находятся за пределами политики и идеологии. При помощи религии автор пытается уравновесить конфликтные группы и установить посредничество между ними.

\section{Субъектная множественность в стихотворении Евгении Бильченко «Кто Я?»}

Другую форму лирического субъекта в гражданской поэзии можно увидеть в стихотворении украинского поэта Евгении Бильченко «Кто Я?», которое часто рассматривается в медийном пространстве как «гимн Майдану». Относительно неизвестный автор из Киева, Евгения Бильченко написала сти-

\footnotetext{
${ }^{35}$ Владыченко (2014).

36 Там же.

${ }^{37}$ Жадан (2015, с. 13).
} 
хотворение о событиях на Евромайдане на русском языке. Оно приобрело свою популярность благодаря социальным сетям. Это стихотворение было размещено как пост на Facebook 21 февраля 2014 года. ${ }^{38}$ Пользователи социальных сетей цитировали стихотворение, размещали его на страницах Facebook (2755 перепостов на 05/07/2018), в персональных блогах, в Twitter и LiveJournal, читали его на YouTube (17611 просмотров на 05/07/2018). Это стихотворение стало более известным под названием «Я мальчик» из-за первой строфы: «Я - мальчик. / Я сплю, свернувшись в гробу калачиком. / Мне снится футбол. В моей голове - Калашников. / Не вовремя мне, братишки, пришлось расслабиться!» ${ }^{39}$. В социальных сетях возникла немедленная реакция как от украиноязычной, так и от русскоязычной аудитории, которые по-разному восприняли стихотворение. Разнообразие жестких ответов и комментариев характеризует обсуждения в пространстве Facebook, LiveJournal и персональных блогах.

Индивидуально-авторское в стихотворении Бильченко становится коллективным и в действительности: на сцене Евромайдана и в социальных сетях стихи цитировались анонимно, лицо автора не имело значения. Это стихотворение показывает четкое распределение разных персонажей по социальным ролям (мальчик, мама, девочка-врач, священник, поэт, роди$н а$, Бог). И здесь не индивидуальность, а именно роль выступает на передний план, приглашая читателей к отождествлению. Все персонажи говорят от первого лица и плавно переходят друг в друга:

Я - мама.

О фартук вытерев руки мыльные,

Звоню на войну я сыночке по мобильному.

Дитя не берет! Приедет, - огрею веником!

«Его отпевают», - слышу ответ священника...

Я - батюшка.

Я собор свой открыл под госпиталь

И сам в нем служу медбратом, помилуй Господи!

Слова для души, что чреву - пуд каши гречневой:

За это крестил поэта я, пусть и грешен он...

Я - просто поэт.

Я тоже стою под пулями.

Кишка, хоть тонка, как лирика Ахмадулиной,

Но все ж не настолько, чтобы бояться красного:

Нужнее стихов сегодня - мешки с лекарствами $[\ldots]^{40}$

\footnotetext{
38 Бильченко, Е. «Кто я?»; запись в Facebook от 21/02/2014 (https://www.facebook.com/ yevzhik/posts/633031300065317, 09/07/2018).

${ }^{39}$ Там же.

${ }^{40}$ Там же.
} 
Персонажи являются также узнаваемыми личностями, получившими известность благодаря медиа. Например, в строках «Я - девочка-врач. / Я в шею смертельно ранена. / В моем городке по небу летят журавлики. / И глушат Wi-Fi, чтоб мама моя не видела, / Как я со своим любимым прощаюсь в Твиттере» $^{41}$ автор отсылает к истории медсестры Олеси Жуковской, которая во время Евромайдана работала волонтером-медиком и была ранена снайпером в шею. Она стала известна своим постом в Твиттере («Я умираю» ${ }^{42}$ ), который молниеносно распространился в интернете. То есть автор стихотворения намеренно обращается к медийным личностям, которые хорошо известны обществу, показывая этим, что, с одной стороны, это был реальный человек, а с другой - один из множества людей, стоявших на Евромайдане.

В стихотворении «Кто я?» украинское общество показано в состоянии разрыва и кризиса. Умерший мальчик метонимично представляет молодых людей, убитых во время Евромайдана. По словам Е. Байдаловой, «судьба мальчика сопричастна с судьбой любого другого человека и в итоге трансформируется в онтологическое умирание-воскрешение Бога». ${ }^{43}$ Здесь прослеживается протомифический сюжет об Отце и Сыне, который раскрывается в конце стихотворения:

Я - Бог.

И я тоже - Папа. Сынок Мой Ласковый

У вредины в классе детский отнял Калашников.

Сказал, мол: «Ни-ни!» - и прыгнул без парашютика...

Спи, золотко.

Спи, Мой Мальчик.

Я Воскрешу Тебя. ${ }^{44}$

Субъектная организация в стихотворении Бильченко представлена множеством «я», в которых отображаются разные социальные роли, а также личности, ставшие медийными знаменитостями во время Евромайдана, что приглашает читателя / слушателя к отождествлению. На основе идентификации с персонажами стихотворения выстраивается коллектив людей, связанных чувством страдания и сострадания, однако в нем личности не сливаются друг с другом, «я» не превращается в «мы».

\footnotetext{
41 Там же.

42 См.: Цензор.НЕТ. «Снайпер стрелял в безоружных граждан: в шею ранена молодая медсестра-волонтер» от 22/02/2014 (http://censor.net.ua/p271739, 09/07/2018).

${ }^{43}$ Байдалова (2015, с. 66).

${ }^{44}$ Бильченко, Е. «Кто я?»; запись в Facebook от 21/02/2014 (https://www.facebook.com/ yevzhik/posts/633031300065317, 09/07/2018).
} 
Лирическое «Я》 в стихотворении Бориса Херсонского «Все любят войну, в которой почти никто не погиб»

Одним из известных русскоязычных поэтов в Украине с ярко выраженной гражданской позицией является поэт Борис Херсонский. Во время Евромайдана поэт занял проукраинскую позицию и активно писал стихотворения на актуальные гражданские темы.

После событий 2 мая 2014 года в Одессе Борис Херсонский вошел в число координаторов Форума одесской интеллигенции, одной из задач которого стала попытка объединения расколовшегося гражданского общества города. ${ }^{45}$

В поэтических сборниках «Месса во времена войны» (2014, издан в СанктПетербурге) и «Открытый дневник» (2015) Херсонский опубликовал свои стихотворения, которые сначала появлялись на его странице в Facebook. Его поэтическое творчество наполнено философским переосмыслением социальных проблем, пафосом борьбы против диктатуры, борьбой за свободу личности. Херсонский - активный пользователь социальной сети Facebook (25759 подписчиков) и ведет также персональный блог на платформе LiveJournal, где он регулярно публикует свою поэзию и активно отвечает на комментарии пользователей. Как пишет сам автор, социальные сети являются для него «личным „лирическим дневником“» ${ }^{46}$.

Херсонский формирует общественное мнение в социальной сети Facebook посредством постов на острые социально-политические темы. В качестве примера можно назвать сетевую дискуссию Херсонского на тему «нового» тоталитаризма в Украине, которую развязала полемическая статья Евгении Бильченко «Страх» на онлайн-портале Информационного агентства ЛІГАБізнесІнформ ${ }^{47}$. Ответом на статью Бильченко была заметка Херсонского «Тоталитаризм в Украине? Чего нет, того нет» в социальной сети Facebook и еe репост на портале Информационного агентства ЛІГАБізнесІнформ ${ }^{48}$. Идеологические противостояния поэтов в Украине в социальных сетях стали частым явлением после событий на Евромайдане и по сегодняшний день. Они формируют сообщества и группы, которые активно обсуждают как острые социально-политические проблемы, так и поэтическое творчество авторов.

Стихотворение «Все любят войну, в которой почти никто не погиб» появилось впервые на персональной странице Херсонского в социальной се-

\footnotetext{
45 Деменок (2015).

46 По данным страницы Б. Херсонского на Facebook (https://www.facebook.com/ borkhers?fref=nf, 09/07/2018).

${ }^{47}$ Бильченко (2017).

${ }^{48}$ Херсонский (2017).
} 
ти Facebook 19 марта 2014. ${ }^{49}$ Пользователи сети Facebook сделали 347 перепостов его стихотворения, и некоторые из них комментировали его в стихотворной форме, цитируя стихотворение Булата Окуджавы «Ах, война, что ж ты сделала, подлая» (1958): «[...] У порога слегка помаячили / и ушли за солдатом солдат... // До свидания, мальчики! Мальчики, / постарайтесь вернуться назад» ${ }^{50}$.

Позже сетевое стихотворение Херсонского вошло в сборник поэзии «Месса во времена войны», посвященный событиям на Майдане и войне на Востоке.

Все любят войну, в которой почти никто не погиб.

Толпятся на площадях и кричат гип-гип-ура, и еще раз - гип-гип-ура, и снова - гип-гип-ура! я - старый мальчик, я это видел вчера.

Будь я ребенок, я б тоже скакал, закусив губу, но я - старый мальчик, я видел все это в гробу, в белых тапочках, в царской мантии, в золотой мишуре. Будь я маленький мальчик, я бы в это играл во дворе.

Но я - старый мальчик, я видел эту толпу. У отчизны звезда не там, где положено, а во лбу, отверстие влажное - до самых височных долей. Хорошо, когда есть стена, а у стены - мавзолей,

хорошо, когда классная площадь во-от такой ширины, что на ней может столпиться худшая часть страны.

Взгляд толпы не различает зарево и зарю.

Я - старый мальчик. Знаю, о чем говорю. ${ }^{51}$

Это стихотворение перекликается с выше рассмотренным стихотворением Евгении Бильченко «Кто я?», но показывает совсем другую форму субъекта. Субъект в стихотворении называет себя «старым мальчиком», что стилистически является оксимороном; это также и цитата позднеантичного и средневекового топоса senex puer. Автор намеренно использует этот мотив для того, чтобы показать оппозицию между мальчиком-«двухтысячником», которому снится футбол, как у Бильченко, например, и старым мальчиком-«шестидесятником», который пережил тоталитаризм Советского Союза. Символами Советского Союза здесь выступают «мавзолей», «классная площадь». При замене всего двух букв в слове меняется его семанти-

49 По данным страницы Б. Херсонского на Facebook (https://www.facebook.com/ borkhers?fref=nf, 09/07/2018).

${ }^{50}$ Окуджава (1989).

${ }^{51}$ Цит. по: Херсонский, Б. «Все любят войну, в которой почти никто не погиб»; запись в Facebook от 19/03/2014 (https://www.facebook.com/borkhers/posts/762650133769815, 09/07/2018). 
ческое значение, так что вспоминаются Красная площадь, где проходят парады, собираются «толпы», которые автор ассоциирует с «худшей частью страны», и героизация советского прошлого: «хорошо, когда классная площадь во-от такой ширины, / что на ней может столпиться худшая часть страны». Субъект поэтического высказывания преодолевает опыт советского прошлого. Согласно Житеневу, «одной из важнейших черт современного литературного процесса является актуализация идеологического, связанная с радикальным переосмыслением советского опыта» ${ }^{52}$.

У Херсонского идеологическим является переосмысление советского прошлого и сопоставление его с современной историей. Примерами могут послужить его последние стихи, которые автор разместил в социальной сети Facebook, например, прямая параллель с исторической фигурой Сталина в стихотворении «Минута ненависти»: «Верните Сталина в мавзолей. Только без реставрации. // Какой он сейчас в земле - пусть лежит на потеху свету» ${ }^{53}$. В стихотворении «Начало войны» Херсонский сравнивает два оппозиционных лагеря во Второй мировой войне - Красную армию и немецких фашистов: «Не все ли равно: и тот - бандит, и этот бандит. // Но бандиты столкнулись лбами. И нам „наш“ бандит милей. // Он называл нас братьями, забравшись на мавзолей, он раздавал награды над разоренной страной // и стояли стреляли заградотряды у защитников за спиной» ${ }^{54}$.

В поэтическом тексте Херсонского присутствует мотив «мудрого старика», который проявляется в образе «старого мальчика». Он наделен определенным жизненным опытом и способен наблюдать за общественными переменами на сломе двух поколений. Такая позиция автора актуализирует социальный аспект содержания этого стихотворения, а также тему молодого и старого поколения в украинском обществе. Субъект стихотворения, в котором говорит сам поэт, выступает как учитель общества. Внимание здесь уделяется молодому поколению, которое не знакомо с историей своей страны и которое не пережило период Советского Союза. Это поколение изображено в стихотворении как «толпа», которая воспринимает современную историю и не воспринимает опыт старшего поколения: «Взгляд толпы не различает зарево и зарю. / Я - старый мальчик. Знаю, о чем говорю».

В отличие от двух выше рассмотренных стихотворений, субъект у Херсонского не приглашает к отождествлению, а занимает дистанцированную позицию и отгранивает себя от адресатов. Эта форма напоминает образец гражданской поэзии с противопоставленностью «поэта и толпы» ${ }^{55}$ в ро-

\footnotetext{
52 Житенев (2011).

53 Херсонский, Б. «Минута ненависти»; запись в Facebook от 30/07/2018 (https://www. facebook.com/borkhers/posts/762650133769815, 09/07/2018).

54 Херсонский, Б. «Начало войны»; запись в Facebook от 22/07/2018 (https://www. facebook.com/borkhers/posts/762650133769815, 09/07/2018).

${ }^{55}$ См., к примеру, стихотворение А.С. Пушкина «Поэт и толпа».
} 
мантической литературе. Этот субъект не предпринимает активных действий, чтобы изменить ситуацию, а остается ее наблюдателем и критическим комментатором, а также выступает в качестве наставника общества. Это «я» соотносится с самим автором, о чем сигнализирует публикация стихов в социальной сети Facebook, и является рупором политического голоса поэта. Актуализируя сущность гражданской поэзии, Херсонский использует роль поэта по моделям девятнадцатого века: поэт есть учитель общества и носитель ее совести.

\section{Bblвodbl}

В заключение необходимо отметить, что значение поэта в Украине за последние четыре года (2014-2018) колоссально возросло и стало более видимым, чем раньше. Автор формирует мнение общественности и посредством своего творчества общается с читателем, создавая особое коммуникативное пространство. Лирический субъект в гражданской поэзии нацелен на рецепцию реальных событий, а также на формирование национальной идентичности общества и развитие критического сознания.

Проанализировав отдельные стихотворения современных украинских поэтов на гражданские и политические темы, мы выявили в них разные формы субъектности. В первых двух примерах отсутствует ожидаемый в гражданской поэзии сильный субъект, говорящий от первого лица: Жадан заменяет «я» голосом коллективного «мы», которому противопоставляется ролевой субъект священника-капеллана; у Бильченко («Я - мальчик») выстраивается собирательное «я» голосов разных лиц с функцией отождествления. У Херсонского («Я - старый мальчик»), наоборот, находим типично гражданский поэтический субъект, выступающий как автобиографически понимаемый поэт-мудрец, который критикует и учит общество.

\section{Литература}

Абдуллаев, Е. (2010): Террор, война и... Новая гражданская лирика в поисках языка, темы и субъекта. Дружба народов. 2, 2010. http://magazines.russ.ru/druzhba/ 2010/2/ab14.html (01/08/2018).

Амелин, М. / Бек, Т. / Николаева, О. / Пригов Д.А. и др. (2002): Поэзия и гражданственность // Знамя. 10, 2002. http://magazines.russ.ru/znamia/2002/10/konfer.html (09/07/2018).

Байдалова, Е. (2015): Современная украинская политическая поэзия в Интернете // Славяноведение. 6, 2015. 63-66.

Бильченко, Е. (2017): Страх // ЛІГАБізнесІнформ. http://blog.liga.net/user/ebilchenko/ article/25968.aspx (09/07/2018). 
Бройтман, С. (1999): Лирический субъект // Чернец, Л. (ред.): Введение в литературоведение. Литературное произведение: Основные понятия и термины. М. 141-153.

Владыченко, Л. (2014): Опыт внедрения военного священства (капелланства) в Вооруженных силах Украины // Схід. 1, 2014. 180-185.

Гасанов, И. (2011): Идеи и образы гражданской лирики Некрасова в творчестве С. Габиева // Вестник Социально-педагогического института. 1 (2), 2011. 1-5.

Гетьманець, М. (2003): Сучасний словник літературознавчих термінів. Харьков.

Деменок, Е. (2015): Борис Херсонский: вписываем главу в историю новых времен. http://www.www.ruslo.cz/index.php/arkhiv-zhurnala/2016/03-2016/item/304-boriskhersonskij-vpisyvaem-glavu-v-istoriyu-novykh-vremen (09/07/2018).

Ермакова, Д. (2012): Равенство лирического субъекта с нацией (на материале поэзии Е. Фанайловой) // Уральский филологический вестник. 4, 2012. 75-83.

Жадан, С. (2015): Життя Марії. Книга віршів і перекладів. Чернівці.

Жадан, С. (2016): Тамплієри. Чернівці.

Житенев, А. (2011): Идеологическое и медиальное в «новой социальной поэзии» // Вестник Татарского государственного гуманитарно-педагогического университета. 2 (24), 151-154. https://cyberleninka.ru/article/v/ideologicheskoe-i-medialnoe-v-novoysotsialnoy-poezii (09/07/2018).

Корман, Б. (1986): Лирика и реализм. Иркутск.

Коцарев, О. (2014): Про Війну і Майдан. Вийшли чотири збірки відомих поетів України різного віку, мов та естетики.

http://texty.org.ua/pg/article/editorial/read/61319/Pro_Vijnu_i_Majdan_Vyjshly_chotyry_z birky?a_srt=\&a_offset=7 (09/07/2018).

Кузьмин, Д. (2007): К восточнославянскому единству? Поэтический фестиваль «Киевские лавры» // Новое литературное обозрение. 86, 2007. 376-382.

Мельничук, И. / Хорошков, М. (2016): Рецепція євангелічного міфу у поетичному просторі Сергія Жадана.

http://konferencjabielsko.blogspot.de/2016/05/blog-post.html (09/07/2018).

Монгайт, А. (2015): Война по-одесски. Кто угрожает жителям за проукраинские взгляды и как Одесса готовится к бомбежкам // Телеканал «Дождь». https://tvrain.ru/ teleshow/reportazh/vojna_po_odesski_kto_ugrozhaet_zhiteljam_za_proukrainskie_vzgljad y_i_kak_odessa_gotovitsja_k_bombezhkam-383048/(09/07/2018).

Окуджава, Б. (1989): Избранное. Стихотворения // Московский рабочий. http://militera. lib.ru/poetry/russian/okudzhava/01.html (09/07/2018).

Саженина, Е. (2014): Лирическая событийность в поэме Н. А. Некрасова «Кому на Руси жить хорошо». Вестник Томского государственного университета. 385, 2014. 42-49. https://cyberleninka.ru/article/v/liricheskaya-sobytiynost-v-poeme-n-a-nekrasova-komuna-rusi-zhit-horosho (09/07/2018).

Фанайлова, Е. (2014): Поэзия Майдана // Радио «Свобода». http://www.europalibera.org/ a/25387539.html (09/07/2018).

Херсонский, Б. (2017): Тоталитаризм в Украине? Чего нет, того нет // ЛІГАБізнесІнформ. http:/www.liga.net/opinion/317689_totalitarizm-v-ukraine-chego-net-togo-net.htm (09/07/2018).

Шелухин, В. (2013): Більше не поезія // ЛітАкцент. http://itakcent.com/2013/12/13/bilshene-poezija/ (09/07/2018). 


\title{
Ольга Северская (Москва)
}

\section{Субъект лирический или публицистический? (от чьего имени говорит новая социальная поэзия)}

\begin{abstract}
Некогда запретные, самовосхваление и самодемонстрация ставят знак равенства между «Я» и «другими», между «Я-субъектом» и «Я-объектом», между внутренней интимной сферой «Я» и сферой «Я», рассчитанной на публику и предназначенной для публики. Человек, ранее разъединенный, теперь заново объединяется - ему возвращается его целостность, его истинная демократичность.
\end{abstract}

Ежи Фарино ${ }^{1}$

Новый виток в истории развития русской поэзии, на котором она закономерно переходит от эстетической своей модели к острой социальности, ${ }^{2}$ совпадает с возрастанием социально-протестных настроений в артистической среде, так называемого «артивизма», ${ }^{3}$ что выражается, прежде всего, в сближении поэтического и публичного, политического дискурсов и медиатизации поэтической дискурсивной практики. ${ }^{4}$ В 2000 -е гг. европейские поэты начинают использовать политические мотивы в лирике, и российские - не исключение: 5 это П. Барскова, К. Медведев, А. Скидан, М. Сухотин, Е. Фанайлова и другие авторы рубрики «Новая социальная поэзия» журнала «Новое литературное обозрение», а также поэты-публицисты Д. Быков, И. Иртеньев и Л. Каганов, чьи тексты, ретранслируемые массмедиа, включаются в общий контекст политической коммуникации, в диалог между властью и оппозицией. Это с необходимостью ставит вопрос: от чьего же имени говорит новая социальная поэзия? И вопрос этот представляется достаточно принципиальным: лирическим или (медийно)публицистическим видится читателям, исследователям и критикам ее речевой субъект?

\footnotetext{
${ }^{1}$ Фарино (2004, с. 112).

2 Эпштейн (2000, с. 159).

${ }^{3}$ Lindgaard (2005).

${ }^{4}$ Подробнее об этом: Зайцева (2010); Северская (2011, 2012, 2014).

${ }^{5}$ Северская (2015).
} 
Поэтическое «я» глазами критиков

То, что сегодня налицо трансформация поэтической субъективности, уже не новость.

В. Вестстейн, например, наблюдая явную «эпизацию лирики» ${ }^{6}$, замечает, что имплицитные речевые субъекты сегодня в ней преобладают над эксплицитными:

Die Abwesenheit des lyrischen Ich in der russischen Gegenwartsdichtung kann tatsächlich als ein Trendbruch mit der Vergangenheit betrachtet werden. Wenn man das Inhaltsverzeichnis der Ausgaben russischer Dichtung des neunzehnten und zwanzigsten Jahrhunderts aufschlägt - [...] dann kann man konstatieren, dass fast immer eine Anzahl von Gedichten mit ,Я“ [Ich] anfängt, oder dass ,Я“ schon in der ersten Verszeile genannt wird ${ }^{7}$.

Das Ich des Dichters, der lautere lyrische Ausdruck, habe keine Bedeutung mehr ${ }^{8}$.

В этом выводе он опирается как на собственный опыт интерпретатора, так и на материалы дискуссии, инициированной несколько лет назад журналом «Знамя».

С. Чупринин, начавший эту дискуссию утверждением о превращении проникнутого личным опытом лирического «я», доминировавшего в частотном словаре русской поэзии на протяжении не одного столетия, в «я» некого «наблюдателя и воспоминателя», ${ }^{9}$ нашел немало сочувственных откликов. Приведем наиболее показательные.

Во-первых, речь шла о проникнутости поэтического высказывания личным опытом, который читатель мог бы принять как свой, а значит, об ответственности автора «за слова». Б. Кенжеев, посетовав, что «вместе с „я“ (откровенным или скрытым) исчезают накал, страсть, радость и безысходность», констатировал:

Мало кто сегодня готов отвечать за базар. [...] Удивительное свойство нынешней цивилизации - ее анонимность. ${ }^{10}$

М. Степанова, говоря о «фиктивных фигурах авторства», конкретизировала:

Вымывание «я» из стихотворных сборников и антологий, анонимные и псевдонимные проекты, опыты говорения голосами, опыты присоединения чу-

${ }^{6}$ Weststeijn (2016, S. 146-147).

7 Там же, S. 143.

${ }^{8}$ Там же, S. 146.

9 Чупринин (2012).

10 Там же, курсив автора, О.С. Это удивительным образом перекликается с ранее высказанным наблюдением М.Н. Эпштейна: «На каком-то решающем сломе истории „я“ обнаружило свою ненадежность, недостоверность, предательски ускользнуло от ответственности - ответственность взяли на себя структуры. Социальные, знаковые [...]» (2000, с. 131). Мысль о маскировке «я» как тактике ухода от ответа найдем и у А. Зайцевой $(2010$, с. 50). 
жого слова [...], речь, зависшая, как дирижабль, над границей персонального и безличного - детали большой картины. ${ }^{11}$

И. Роднянская предпочла термин «лирическая псевдонимия» и заметила, что современная лирика - это преимущественно «призма авторского сознания» [...] личная «призма» преломляет показания чувств и придает неповторимую избирательность впечатлениям, но не пропускает сквозь себя цепь лирических признаний, слагающихся в повествование о «судьбе поэта», ${ }^{12}$

ей вторил Л. Оборин, согласно которому «поэты отказываются говорить и становятся оптикой». ${ }^{13}$

Во-вторых, особый интерес представляют высказанные в этой дискуссии мнения не столько об «уходе», сколько об «отступлении» авторского «я» в угоду читателю. Например, А. Родионов заметил:

Читателю непонятно, как кто-то в наше время вообще может говорить «я» и что-то там чувствовать, поэтому личности в искусстве пора натянуть на голову балаклаву $[\ldots] ;{ }^{14}$

\section{А. Скворцов предположил:}

Современные авторы, стремящиеся к «объективизму», демонстрируют не пренебрежение читателем, а, напротив, деликатно-уважительное отношение к нему; ${ }^{15}$

а М. Степанова поделилась убеждением:

Мыслить свою речь как общую - или обращенную к некоей общности, нашаривающую ее в темноте - значит избавлять ее от всего избыточного, от всего частного или собственного. ${ }^{16}$

Нечто похожее прозвучало и в предшествовавшем дискуссии интервью Г. Дашевского, ${ }^{17}$ который постулировал возможность социального (связанного с мыслью об уникальном целом) и романтического (проникнутого уникальностью собственного «я», как бы «отзеркаленного» поэтом) читательских прочтений поэзии:

У стихов нет своего сообщения: [...] потому что в конечном счете о чем они говорят - решаешь ты. ${ }^{18}$

И это очень интересное наблюдение: возможно, сегодня лучше говорить не столько о редукции «образа автора», сколько о его невостребованности, а следовательно, игнорировании его текстовых «примет» читателем, которому социальное сегодня важнее индивидуального.

\footnotetext{
11 Там же.

12 Там же.

13 Там же.

14 Там же.

15 Там же.

16 Там же.

17 Дашевский (2012).

${ }^{18}$ Там же.
} 
Что касается собственно социальной поэзии, то к ней весь этот спектр мнений еще более применим. М. Майофис, говоря о новом типе поэтического высказывания о политике, подчеркивает: автор (лирический герой) остро и активно реагирует на явления и события в социально-политической сфере, при этом лирическое «я» превращается в «я» свидетеля политических событий, которые «драматизируются» за счет соотнесения политических образов с системой поэтических констант и архетипов. ${ }^{19} \mathrm{M}$. Липовецкий считает, что «правильнее говорить не о политизации лирики, а о политике лирического субъекта, находящей свое воплощение во всех составляющих поэтического высказывания», ${ }^{20}$ и хотя он имеет в виду лишь поэтику Е. Фанайловой, представляется возможным отнести это к новой социальной поэзии в целом, которая также

строит новую субъективность - политическую в том числе - на парадоксальном основании внутренних противоречий, на отчаянной интериоризации «внешних» конфликтов, на переживании социально отвратительного не как чужого, а как своего (что ни в коей мере не предполагает примирения и оправдания). ${ }^{21}$

Как следует из приведенного обзора, при всей афористичной привлекательности высказываемых положений о диалектике имплицитного и эксплицитного, субъективного и объективного, своего и чужого, лирического и эпического, поэтического и политического, литературная критика грешит известным импрессионизмом и скорее констатирует факты, чем классифицирует их и объясняет. Постараемся восполнить этот пробел, но прежде чем перейти к анализу поэтических текстов, обратимся к теории и договоримся о терминах.

Образ автора, лирический субъект (герой), автор в публицистике и медиа

Отталкиваясь от определения В.В. Виноградовым образа автора как «идейно-стилистического фокуса целого», «концентрированного воплощения сути произведения», объединяющего всю представленную в нем систему речевых структур, но не всегда выраженного эксплицитно, ${ }^{22}$ современные исследователи производные термины «лирический субъект» и «лирический герой» нередко употребляют синонимично. Некоторые отождествляют «лирического героя» с образом поэта, его художественным «двойником», вырастающим из текста лирических композиций, - четко очерченной фигурой с психологически отчетливым внутренним миром, а иногда и с

\footnotetext{
${ }^{19}$ Майофис (2003).

20 Липовецкий (2013, с. 310). Курсив автора, О.С.

${ }^{21}$ Там же, с. 321.

${ }^{22}$ Виноградов (1971, с. 118).
} 
определенными чертами пластического облика, ${ }^{23}$ другие же видят в нем объективированный субъект лирического сознания, открыто стоящий между читателем и изображаемым миром. ${ }^{24}$ Как представляется, двусмысленности можно избежать, если говорить в обоих случаях о так называемом «лирическом ,я“»: по определению Г. фон Вильперта, это

Я, первое лицо единственного числа, в лирическом стихотворении - пере-

живающий, чувствующий и высказывающийся субъект. ${ }^{25}$

При этом оказывается существенным, что статус лирического «я» подобен статусу «я» языкового. Последнее является знаком без референта, а потому на уровне речи и текста такое «я» может присваиваться любым говорящим, делая лирическое высказывание одновременно и сугубо личным, и анонимным, «ничьим». ${ }^{26}$ Именно это и позволяет лирическому «я» быть мерилом как авторской, так и любой иной речевой субъективности, зеркально отражая иные «я» - «другие» или «многие», также выраженные местоимениями.

Если разговор от первого лица считается конституирующей чертой лирики, то публицистический стиль также иногда определяется как лирический, т.е. субъективно авторский. Так, мэтр журналистики А.А. Аграновский утверждал:

Настоящая публицистика лирична. [...] Лирична она в том смысле, что автор берет на себя смелость выступить со своими переживаниями, навеянными жизнью общества. ${ }^{27}$

В образе автора в публицистике принято выделять две составляющие: социальную и частную, ${ }^{28}$ в чем можно видеть параллель с подразделением лирического «я» на объективную, предназначенную для публики («яобъект»), и субъективную, внутренне-интимную («я-субъект»), ${ }^{29}$ или же поэтическую и человеческую (иногда представленную метонимически как «сердце», «душа», «разум», «совесть», «духовное начало» и т.п.) $)^{30}$ ипостаси, способные вступать друг с другом в диалогические отношения. Не случайно в перечне типов публицистической языковой личности ${ }^{31}$ с пропагандистом, полемистом, репортером, аналитиком соседствует художник.

В медийном пространстве «образ автора» трансформируется в «авторское начало»: под ним понимается «смысловая часть текста, в которой

\footnotetext{
${ }^{23}$ Роднянская (1987, с. 185).

${ }^{24}$ Корман (1981, c. 45-46).

${ }^{25}$ Wilpert (2001, S. 545 f.).

26 Фарино (2004, с. 154-155).

27 Аграновский (1980, с. 9).

${ }^{28}$ Солганик (2003, с. 528).

${ }^{29}$ Фарино (2004, с. 112).

${ }^{30}$ Ковтунова (2005, с. 26).

${ }^{31}$ Солганик (2003, с. 528).
} 
проявляется речевое поведение автора и его рефлексия по поводу своего текста»;32 оно получает выражение с помощью целого спектра средств «от имплицитных модусных показателей до самостоятельных метавысказываний». ${ }^{33}$ Т.В. Шмелева указывает на то, что сегодня авторское начало в медийных текстах минимализируется: автору предлагается скорее отсутствовать, чем присутствовать в своем тексте; ${ }^{34}$ он превращается в «корпоративного субъекта», используя эллипсис, обобщенно-личные и страдательные конструкции, метонимическую персонификацию, различные средства «маскировки», в том числе с помощью чужих текстов, соположенных в медиапространстве, но несовместимых в пространстве культурном. ${ }^{35}$ Интересно, что и в поэзии, и в медиасфере сегодня одновременно действуют два разнонаправленных вектора: раскрепощение «я», вызванное эссеизацией обеих областей, ${ }^{36}$ и его подавление, сведение до анонимности.

Таким образом, налицо известный параллелизм развития субъективности поэтического, публицистического и медийного текстов и интерференция соответствующих дискурсивных практик. На это обращают внимание и сами поэты: например, М. Амелин называет гражданскую поэзию «рифмованной публицистикой», ${ }^{37}$ а П. Арсеньев утверждает, что «задача [...] художника должна заключаться в том, чтобы [...] революционизировать медиа». ${ }^{38}$ Как публицистику расценивают политизированную поэтическую речь и журналисты и литературные критики. ${ }^{39}$ Поэтому интересно проанализировать, что общего у новой социальной поэзии и наиболее авторски отмеченного медийного речевого жанра, и понять, действительно ли «авторское начало» в новых текстах конституируется скорее публицистическим, нежели лирическим субъектом.

\section{Публицистичность поэзии, поэтичность публицистики}

Прежде всего, сходство обнаруживается в политико-идеологическом модусе подачи материала. Референтной основой поэтического высказывания становятся политические реалии: явления, факты, события и их действующие лица, так называемые политические деятели и активисты. В «новой

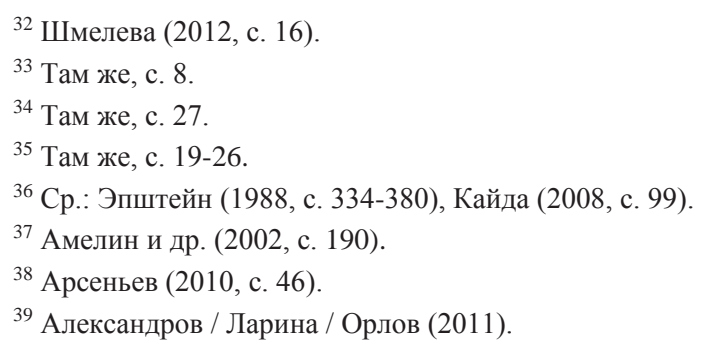


социальной поэзии» это, как правило, реалии, осмысленные и вербально представленные в личном и публичном дискурсивном пространствах.

В некоторых случаях поэт описывает политические события, в которых сам принимал непосредственное участие. Это касается, прежде всего, К. Медведева, рассказывающего, например, в красках о «походе на мэрию» и подчеркивающего свою роль в коллективе соотношением местоименных форм множественного и единственного числа - включением авторского «я» в конкретно членимое и абстрактное множества:

нам согласовали антифашистский митинг, но не согласовали шествие.

мы с правозащитником Пономаревым пошли разбираться в мэрию.

Пономарев был очень зол. я его слегка сдерживал [...], ${ }^{40}$

или об участии в защите Химкинского леса. ${ }^{41}$

В других случаях референтом является некое историческое событие, имевшее общественно-политический резонанс. Например, блокада Ленинграда в «Сделанность (ленинградские картины)» П. Барсковой, где описываются «город-смерть», «воспаления бомбардировщиков», «изверженья зениток» и конкретная история любви, представленная в «аккуратных», «несколько простодушных» воспоминаниях - документе, «пересказываемом» aвтором. $^{42}$ Или же высадка человека на Луну в стихотворении Ю. Лейдермана «20 июля 1969», в котором упоминаются Кеннеди, Брежнев, Путин, а также Наполеон (это прецедентное имя к тому же имплицирует представление «о наполеоновских планах» как одной из реалий советской эпохи):

Полет американцев на луну

как бросок перчаткой в Советский Союз, - президент Кеннеди сказал, ${ }^{43}$

- «бросок перчаткой» упоминается в тексте несколько раз, и каждый раз появляется некий ответ на «космический» вызов: «могли послать ракету не послали», «звездное равнодействие социализма», «тыканье бедер в Луну Юли с Леной (т.е. девочек из дуэта «Тату», О.С.)». ${ }^{44}$

Это может быть и имевший место в действительности разговор политического толка, как в стихотворении И. Померанцева, где воспроизводится полилог автора «с Великим Американским Поэтом, / его миловидной женой / и маленьким американским поэтом», ${ }^{45}$ в ходе которого обсуждаются «фашистский режим» (политический и коммерческий), американский «Президент и его команда», «ФБР», «политическое убежище» и многое другое. Каждая из тем обнаруживает несовпадение точек зрения на то, что

\footnotetext{
${ }^{40}$ Медведев (2011). Курсив мой, О.С.

41 Там же.

42 Барскова (2010).

43 Лейдерман (2010). Курсив мой, О.С.

44 Там же.

${ }^{45}$ Померанцев (2009).
} 
удостаивается «криков», «воплей», «камлания», «потрясающей акустики», а что - «мертвой тишины»:

- Знаете, Майкл, у вас есть стихи о том, как американская солдатня

в 1954 году у побережья Исландии расстреляла сто китов,

так, забавы ради.

- А, эти стихи нравились Вознесенскому.

- Мне тоже нравятся. Но вот какая незадача:

$\boldsymbol{y}$ нас это делали с людьми, и более основательно.

- Ага. Я буду размышлять. ${ }^{46}$

Заметим, что «я»-субъект в этом тексте представлен имплицитно, подразумеваясь в эксплицитных образах американских поэтов «от мала до велика» («они»-субъекты, каждый из которых выступает в определенный момент как «ты-» и даже «я»-субъект) и имплицитном же образе поэта-автора, который обозначен на поверхностном текстовом уровне корреляцией местоименных форм (мне - у нас - у вас), отражающей также сопоставление фактов с определенной точки зрения.

В качестве референтной может рассматриваться ситуация, имевшая место в действительности и отраженная в СМИ, иными словами, первичная референция осуществляется к медиатексту, как, например, у Х. Закирова в «Дневнике 2010 года: июнь», где авторское начало обнаруживается в следующих за местоимением «я» модусных глаголах (автор читает, вспоминaеm), в омонимии форм предлога «судя» и деепричастия «судя» (от еще одного модусного глагола: «судить», с помощью которого имплицируется авторская логика и оценочность), а также в использовании синтактического и смыслового параллелизма в представлении фрагментов медиакартины мира и реальности:

\section{Я читаю статью}

о том, как на юге Киргизии насиловали и убивали узбечек именно потому, что они узбечки.

$[\ldots]$

Там,

под мириадами звезд, прошлым летом

грабили, жгли, убивали, поливали свинцом

безоружных защитников глинобитных кварталов,

родной махалли, своего

дома. Помню подобное в Фергане,

лет двадцать назад, когда $и$ у нас

безумная, озверевшая толпа

шла с дубинами, утыканными гвоздями, со списками, где имена

и адреса турков-месхетинцев, и лишь некоторых, немногих

спасли их соседи-узбеки. Больше спасли солдаты,

но здесь, в Киргизии, судя по тексту, милиция и армия

(речь, безусловно, не обо всех) шли вместе с толпой. ${ }^{47}$

46 Там же. Курсив мой, О.С. 
Политико-идеологический модус подачи материала - важнейший, но не единственный признак публицистичности текста: среди них, определяя публицистику как особый стиль и особый тип дискурса, Н.И. Клушина называет также социальную оценочность и открытую авторскую позицию, предполагающую прагматическую направленность на адресата, которая проявляется в выборе экспрессивных выражений с высоким потенциалом воздействия. $^{48}$ В публицистической поэзии именно авторская позиция предопределяет выбор идеологем и экспрессивных средств с ярко выраженной оценочностью.

Идеологемы, т.е. вербально-ментальные стереотипы, по Н.И. Клушиной, ${ }^{49}$ представлены в рассматриваемых текстах достаточно широко.

У авторов «новой социальной поэзии» можно встретить такие идеологизированные концепты, как «Империя», «война с фашизмом», «борьба с „культом личности“», «языковой тест», «узники Болотной площади», «гражданская оборона», «война», «пространство переворота», «ребрендинг», «гомофобия», «толерантность», «далекое ближнее зарубежье» и многие другие. Можно отметить и появление «медиалогем», например: «жесткий трэшак в прайм-тайм», «трупы в новостях», «криминальные сводки», «увидеть в новостях» и т.п.

Что касается идеологизированных образов, то самый популярный из них это, пожалуй, «гастарбайтер», который оказывается в центре внимания сразу трех поэтов - К. Чухрова, ${ }^{50}$ Г. Беневича, ${ }^{51}$ Р. Осминкина ${ }^{52}$. При этом «гастарбайтер» становится настоящим лирическим героем, «двойником» поэта.

Оценочность, как и в публицистике, достигается за счет употребления лексем с положительными или отрицательными языковыми коннотациями, а также за счет иронии - и в случае использования ее в языковой игре, например:

мы все гастарбайтеры в мире,

$[\ldots]$

и веке, в котором мы только гости -

работники на мировом погосте,${ }^{53}$

и в случае интерпретации описываемой ситуации в ироническом ключе с помощью параллелизма, как в следующем отрывке:

\footnotetext{
47 Закиров (2012а). Курсив мой, О.С.

${ }^{48}$ Клушина (2008, с. 42).

${ }^{49}$ Клушина (2008, с. 73).

50 Чухров (2013).

${ }^{51}$ Беневич (2014).

52 Осминкин (2012).

${ }^{53}$ Беневич (2014). Курсив мой, О.С.
} 
[...] у воображаемого рабочего должен быть воображаемый поэт который пишет ему одному

о том какой он трудолюбивый могучий честный

и как на нем все зиждется

тем самым воображаемый поэт сам становится

могучее честнее трудолюбивее! ${ }^{54}$

Ирония делает высказывание двуплановым: первый план, как замечает Н. И. Клушина, рассчитан на «неискушенных людей, которые понимают речевое сообщение однозначно», 55 второй же представляет собственно иронию, переносное значение, контрастное по отношению к буквальному. Нужно заметить, что ирония в публицистической поэзии становится главным приемом формирования социальной оценки. И одним из способов выражения оценки является карнавальный пастиш с ироническим преодолением цитируемого «авторитетного мнения», которым особенно успешно пользуются Д. Быков, И. Иртеньев и Л. Каганов: ссылка на «авторитет», его слова в данном случае сродни говорению от имени другого, речевая «маска», в прорезях которой (если продолжить метафору) можно увидеть истинное авторское лицо. ${ }^{56}$ Поэзия опять же заимствует прием выражения оценки у публицистики, которая использует квазицитирование ${ }^{57}$ в целях манипуляции общественным сознанием.

\section{Речевые субъекты новой сочиальной поэзии}

Анализ коммуникативной рамки текстов русской «новой социальной поэзии» показывает, что политически окрашенное поэтическое высказывание чаще всего оказывается ответом на некий не персонифицированный вызов со стороны общества:

Вот несущие конструкции, мне говорят, вот мир, говорят, повернутый к тебе задницей. Что ты на это скажешь? ${ }^{58}$

Стихотворение может строиться как серия ответов на вопросы, которые могут быть заданы кем угодно - обществом, сторонним собеседником, автором (например, читателю, реальному собеседнику или самому себе):

что это было? чеченский след

привел к нарушениям процедурным

внутри силового ведомства [...]

что это было? менты винтят

демонстрантов на потускневших кадрах

\footnotetext{
${ }^{54}$ Осминкин (2012).

55 Клушина (2008, с. 198-199).

${ }^{56}$ Северская (2015).

${ }^{57}$ Клушина (2008, с. 110-111).

58 Закиров (2012b).
} 
из хроники Перестройки [...]

что это было? фабричный люд

после банкротства завода ищет

работу на стороне $[\ldots]$ и т.д. ${ }^{59}$

В приведенном примере постоянно повторяющийся вопрос уравнивает общественное-политическое и частное в жизни поэта:

что это было? засахарен мед

в трехлитровой банке от перекисших

огурцов $[\ldots]$

что это было? декседрин иль прозак

кислородное голодание вызвали, ${ }^{60}$

диалог и внутреннюю коммуникацию, а совпадая по форме со сленговым «(И) что это было?» (употребляющимся в отношении чего-то странного, того, чего быть не должно), становится знаком удивления, за которым следуют размышления о том, как такое вообще возможно, предположения о причинах «загадочного явления» и поиски путей решения стоящей за ним проблемы. Правда, в рамках процитированного текста ответа на вопрос так и не находится:

что это было? и было ли что и будет ли что-нибудь, и бу-бу-бу-бу [... $]^{61}-$

все уходит в слова, у которых также нет авторства, они образуют многоголосый хор, в котором каждый голос привносит свое видение ситуации.

Заметим, что тактика повторения (полу)риторических вопросов - сегодня одна из наиболее употребимых и в публицистике, и в ретранслируемом медиа публичном политическом дискурсе.

Что касается позиции говорящего, то она выражается по-разному.

И.И. Ковтунова обращает внимание на то, что «я» может звучать от имени другого ${ }^{62}$ или отождествляться с лицом из «определенной социальной группы, к которой поэт заведомо не принадлежит». ${ }^{63}$ Неоднозначным бывает и лексическое выражение «образа автора»:

Автор (лирическое я) может быть выражен не только первым лицом, но и вторым (при автоадресации) и третьим (при отчуждении я). ${ }^{64}$

В роли говорящего может выступать персонаж, который прячется за брутальной, эпатажной речевой маской, как, например, в поэзии В. Нугатова, который, по словам Т.С. Потаповой,

говорит «за» поколение и социум, оставаясь фигурой, локализованной «здесь и сейчас», но не вполне проявленной как индивидуальность. ${ }^{65}$

\footnotetext{
${ }^{59}$ Голынко-Вольфсон (2010).

60 Там же.

61 Там же.

${ }^{62}$ Ковтунова (2005, с. 35).

63 Там же, с. 43.

${ }^{64}$ Там же, с.70. Курсив автора, О.С.
} 
Впрочем, В. Нугатов примеряет не только различные маски, но и использует разные указания на общность (порой экзотические: «лэцгоу олл чугэва» $\left.{ }^{66}\right)$, в том числе и местоимение «мы», обозначающее некую группу лиц, включая и говорящего, - «мы пропагандируем поэзию [...] стихи [...] интеллектуальную составляющую» ${ }^{67}$ :

они нас сериалами

а $\mathrm{Mbl}$ их толерантностью

они нас гомофобией

а мыл их культуркой

они криминальными сводками

а $M b l * * * * *$ литературоведческим анализом. ${ }^{68}$

Местоимение «мы» довольно широко используется в «новой социальной поэзии» (нередко с указанием на социальную общность, к которой принадлежит автор текста в реальности или возможном мире текста):

А $\mathrm{Mbl,} \mathrm{левые,} \mathrm{не} \mathrm{чувствуем} \mathrm{твердо} \mathrm{никаких} \mathrm{своих} \mathrm{прав,}$

разве что эфемерное право на утопию, ${ }^{69}$

как и соответствующие первому лицу множественного числа глагольные формы:

преодолеем отделение от реальной жизни и пассивности

организуем свое неповиновение в творчестве [...]

Mbl сами творцы своей судьбы

мы пришли сюда, чтобы жить ${ }^{70}$

о, чтобы было, к чему отнестись

с пониманием,

входим в огонь $[\ldots]$

в воздух, которым дышать невозможно. ${ }^{71}$

Поэтический дискурс в этом испытывает влияние политического: в речи политиков сегодня преобладают «мы»- и «вы»-формы (у Путина в совокупности это $70 \%$ употреблений, у Медведева - 76\%), ${ }^{72}$ в то время как в норме в лирической поэзии преобладать должны «я»-формы, соотносимые с лирическим субъектом.

Часто встречаются неопределенно-личные и обобщенно-личные формы:

${ }^{65}$ Потапова (2012, с. 237).

${ }^{66}$ Нугатов (2011).

67 Там же.

${ }^{68}$ Там же.

${ }^{69}$ Медведев (2011).

${ }^{70}$ Осминкин (2013). Курсив мой, О.С.

71 Чарыева (2014). Курсив мой, О.С.

${ }^{72}$ Алышева (2012, с. 11). 
бывает хочется сказать товарищи и господа хватит подчиняться

все на баррикады ${ }^{73}$

захочешь написать о рабочем классе

придешь на завод

а там нет никакого рабочего класса

одни хипстеры шарятся ${ }^{74}$

против читателя,

против тебя,

вообще человека, [...]

ложь, ложь, ложь ${ }^{75}$

$T b l$ бы смог пройти мимо Чечни, повстречай $m b l$ ее в коридоре? ${ }^{76}$

Местоимение «я» обычно имеет расщепленную референцию, которая определяется как соотношением автора и лирического героя, так и внутри авторского «я» - диалектикой социальной и индивидуальной его ипостасей, что можно показать на примере «По дороге на защиту Химкинского леса $[\ldots] »$ К. Медведева, в котором Т.С. Потапова справедливо отмечает совмещение «агитационного порыва и мучительной рефлексии»: ${ }^{77}$

По дороге на защиту леса $я$ думал о бессилии, обсасывал в уме старую идею о том, что использование оружия это признак бессилия.

вот об этом $\boldsymbol{я}$ думал.

Когда нам навстречу выдвинулся полк ОМОНа и все ошалели, но уже не от философского, а от вполне земного человеческого бессилия, $\boldsymbol{я}$ с восторгом вспомнил идею из одного анархистского манифеста о том, что мол размышлять о пацифизме может только тот, кто владеет оружием, вот бы нам оружие подумал $\boldsymbol{я}$, мы бы здорово порассуждали о пацифизме, и вдруг в этой высшей точке нашего бессилия появилось оружие: наши ряды раздвинулись и из самой гущи студентов-пацифистов, пропащих интеллигентов и местных пенсионеров застрекотал пулемет. Омоновцы падали как подрубленные деревья Химкинского леса. Но все-таки главное чтоб революции не было - сказала Женя Чирикова, когда мы стоя над кучей трупов пытались сообразить что же делать дальше.

\footnotetext{
${ }^{73}$ Осминкин (2013). Курсив мой, О.С.

74 Там же. Курсив мой, О.С.

${ }^{75}$ Рымбу (2013). Курсив мой, О.С.

76 Тихомиров (2001, с. 112). Курсив мой, О.С.

${ }^{77}$ Потапова (2012, с. 234).
} 
Во время октябрьской революции было убито меньше народу, чем сегодня, сказал $\boldsymbol{s}^{78}$

Казалось бы речь здесь идет о конкретном общественно-политическом событии: защите Химкинского леса, участниками которого были присутствующие в тексте как персонажи, с одной стороны, «студенты-пацифисты, пропащие интеллигенты и местные пенсионеры», с другой стороны, «полк ОМОНа», «омоновцы». Однако видение события противоречит его медиатрактовке: в новостях сообщалось об избиении протестующих омоновцами, в тексте же, напротив, «омоновцы падали как подрубленные деревья Химкинского леса», а участники пикета стояли «над кучей трупов». И это не единственное проявление авторского начала, авторской точки зрения.

К. Медведев использует практически все известные специалистам по поэтике и медиологам стратегии усложнения образа автора: ${ }^{79}$ ссылки на источники информации («один анархистский манифест»), косвенную речь («идея о том, что [...]: использование оружия это признак бессилия, размышлять о пацифизме может только тот, кто владеет оружием», ср. авторскую реплику в воображаемом диалоге: «вот бы нам оружие подумал $\boldsymbol{я}$, мы бы здорово порассуждали о пацифизме», с дальнейшей реализацией темы «бессилия» и «оружия»), чужой голос прямой речью, который, благодаря лексическому повтору сопрягается с голосом автора («Но все-таки главное чтобы революции не было - сказала Женя Чирикова [...] Во время октябрьской революции было убито меньше народу, чем сегодня, сказал $я$ »), использование глаголов ментальной сферы, переводящих реальный план в воображаемый и наоборот («вот бы нам оружие подумал я [...] и [...] застрекотал пулемет»).

Авторское «я» включается не только в различные общности («я»субъект может прятаться за местоимением «мы»: «вот бы нам [...], наши ряды раздвинулись, мы $[. .$.$] пытались сообразить что же делать дальше, но$ может и быть эксплицитно представленным участником диалога: я - Женя Чирикова). Автор обнаруживает свое присутствие и использованием форм прошедшего времени глаголов - как моделирующих предметный план, так и модусных глаголов ментальной сферы («думал», «обсасывал в уме», «вспомнил», «(тогда) подумал»), тем самым определяя свою речевую позицию в координатах актуализации высказывания «здесь» и «сейчас».

Преобладание обобщенно-личных форм обозначения позиции говорящего и разделение авторского «я» на социальное и индивидуальное, как представляется, свидетельствует о принципиальной диалогичности «новой социальной поэзии» и ее нацеленности на адресата, о чем, в принципе, говорят и эти строки Н. Денисовой: «читай $\boldsymbol{я}$ пишу / слушай $\boldsymbol{я}$ дышу», ${ }^{80}$ ко-

\footnotetext{
${ }^{78}$ Медведев (2011). Курсив мой, О.С.

${ }^{79}$ Ковтунова (2005, с. 45-69), Шмелева (2012, с. 11-12).

${ }^{80}$ Денисова (2012).
} 
торые как бы предлагают читателю и автору меняться ролями, приглашая «присвоить слова», совершив референтную замену.

Таким образом, «новая социальная поэзия» обнаруживает в себе все признаки нового публицистического стиля: насыщенность идеологемами, ярко выраженную социальную оценочность, формируемую, в частности, иронией и цитатой, авторскую субъективность и направленность авторской позиции на адресата, воздействие на сознание и подсознание которого с помощью эксплицитно и имплицитно представленных в тексте экспрессивных языковых средств становится главной задачей. Кроме того, эта поэзия полноправно участвует в политической коммуникации, отражая оппозиционные настроения общества и встраиваясь в массмедиа не только формально, но и заимствуя у политической коммуникации и СМИ некоторые дискурсивные особенности. И вместе с тем, при всей выраженной публицистичности, авторское «я» не теряет и лиризма, в предельном случае вмещая в себя (как и в классической поэзии) весь мир: как замечает Е. Фарино,

безреферентность, условность лирического «я» ведет тому, что реципиент такого высказывания легко принимает это «я» на себя, идентифицируется с ним. $^{81}$

А значит, лирическое начало поэтической субъективности как раз и предопределяет ее публицистическую функцию.

\section{Литература}

Аграновский, А. (1980): Своего дела мастер. Заметки писателя. М.

Александров, Н. / Ларина, К. / Орлов, А. (2011): Культурный шок: фельетонная поэзия (09.04.2011). http://www.echo.msk.ru/programs/kulshok/764191-echo/ (21/09/2016).

Алышева, Ю. (2012): Речевой портрет современного политического лидера. Автореферат... канд. дисс. Волгоград.

Амелин, М. и др. (2002): Поэзия и гражданственность // Знамя. 10, 2002. 189-207.

Арсеньев, П. (2010): Литература факта как последняя попытка назвать вещи своими именами // Транслит. 6/7, 2010. 37-52.

Барскова, П. (2010): Сделанностью // НЛО. 102, 2010. http://magazines.russ.ru/ nlo/2010/102/ba1.html (21/09/2016).

Беневич, Г. (2014): Поэма о гастарбайтерах // НЛО. 127, 2014. http://magazines.russ.ru/ nlo/2014/3/2b.html (21/09/2016).

Виноградов, В. (1971): О теории художественной речи. М.

Голынко-Вольфсон, Д. (2010): Что это было // НЛО. 106, 2010. http://magazines.russ.ru/ nlo/2010/106/vo1.html (21/09/2016).

Денисова, Н. (2012): Чоп-чоп // НЛО. 115, 2012. http://magazines.russ.ru/ nlo/2012/115/d2.html (21/09/2016).

${ }^{81}$ Фарино (2004, с. 155). 
Дашевский, Г. (2012): Григорий Дашевский: как читать современную поэзию / Записала В. Бабицкая. http://os.colta.ru/literature/events/details/34232 (21/09/2016).

Зайцева, А. (2010): Спектакулярные формы протеста в современной России: между искусством и социальной терапией // Неприкосновенный запас: дебаты о политике и культуре. 4 (72), 2010. М. 47-69.

Закиров, Х. (2012а): Три взгляда на Ферганские окрестности // НЛО. 113, 2012. http://magazines.russ.ru/nlo/2012/113/z2.html (21/09/2016).

Закиров, Х. (2012b): Le serpent rouge // НЛО. 113, 2012. http://magazines.russ.ru /nlo/2012/ 113/z2.html (21/09/2016).

Кайда, Л. (2008): Эссе: стилистический портрет. М.

Клушина, Н. (2008): Стилистика публицистического текста. М.

Ковтунова, И. (2005): Категория лица в языке поэзии // Красильникова, Е. (отв. ред.): Поэтическая грамматика. Т. І. М. 7-72.

Корман, Б. (1981): Целостность литературного произведения и экспериментальный словарь литературоведческих терминов // Финк, Л. (отв. ред.): Проблемы истории критики и поэтики реализма. Куйбышев. 39-54.

Лейдерман, Ю. (2010): 20 июля 1969 // НЛО. 101, 2010. http://magazines.russ.ru/ nlo/2010/101/le1.html (21/09/2016).

Липовецкий, М. (2013): «Есть смерти для меня...»: Политика субъективности в поэзии Елены Фанайловой // Шталь, Х. / Рутц, М. (ред.): Имидж, диалог, эксперимент - поля современной поэзии. München / Berlin / Washington. 309-323.

Медведев, К. (2011): «Поход на мэрию» и другие стихотворения // НЛО. 111, 2011. http://magazines.russ.ru/nlo/2011/111/me1.html (21/09/2016).

Майофис, М. (2003): «Не ослабевайте упражняться в мягкосердии»: Заметки о политической субъективности в современной русской поэзии // НЛО. 62, 2003. М. 323-339.

Нугатов, В. (2011): Пропаганда поэзии // НЛО. 107, 2011. http://magazines.russ.ru/ nlo/2011/107/nu2.html (21/09/2016).

Осминкин, Р. (2012): Текст, написанный после девяти дней работы строителем [...] // НЛО. 115, 2012. http://magazines.russ.ru/nlo/2012/115/o3.html (21/09/2016).

Померанцев, И. (2009): Мы сидели в ресторане Palffy Palace [...] // РЛО. 95, 2009. http://magazines.russ.ru/nlo/2009/95/po3.html (21/09/2016).

Потапова, Т. (2012): Новая социальная поэзия // Уральский филологический вестник. 4, 2012. 231-237.

Роднянская, И. (1987): Лирический герой // Литературный энциклопедический словарь. Под общ. ред. В. Кожевникова, П. Николаева. М. 185.

Рымбу, Г. (2013): Передвижное пространство переворота // НЛО. 124, 2013. http://www.nlobooks.ru/node/4140 (21/09/2016).

Северская, О. (2011): «Интеллектуал интеллектуалу шамбалит что-то про шамбалу...» (на каком языке современная поэзия говорит с интеллигенцией) // Никольский, С. Et al. (ред.): Проблемы российского самосознания: народ, интеллигенция, власть. Уфа. 371-379.

Северская, О. (2012): «Читатели газет»: поэтическая журналистика как новый феномен СМИ // Медиаскоп. 3, 2012. http://www.mediascope.ru/node/1132 (21/09/2016).

Северская, О. (2014): Поэтическая журналистика: поэзия в современных каналах массовой коммуникации // Векшин, Г. (отв. ред.): Методология и практика русского 
формализма: Бриковский сборник. Вып. II: Материалы международной научной конференции «II Бриковские чтения: Методология и практика русского формализма» (Московский государственный университет печати, Москва, 20-23 марта 2013 года). М. 274-279.

Северская, О. (2015): Новый публицистический стиль: поэтические и политические практики (на примере «политической» поэзии России и Германии) // Stylistika. 24, 2015. Opole. 141-162.

Солганик, Г. (2003): Публицистический стиль // Культура русской речи. Энциклопедический словарь-справочник. Под ред. Л. Иванова, А. Сковородникова, Е. Ширяева. M. 527-529.

Тихомиров, О. (2001): Что за символы нынче в чести? // Время «Ч»: Стихи о Чечне и не только. Сост. Н. Винник. М. 112.

Фарино, Е. (2004): Введение в литературоведение: учебное пособие. СПб.

Чарыева, К. (2014): Измененный покой // НЛО. 126, 2014. http://magazines.russ.ru/ nlo/2014/126/2ch-pr.html (21/09/2016).

Чупринин, С. (2012): Стихи без героя? Приглашение к дискуссии: А. Родионов, И. Волков, И. Роднянская, А. Алехин, Б. Кенжеев, А. Улюкаев, А. Скворцов, С. Львовский, Л. Оборин, М. Степанова // «Знамя». 11, 2012. М. 197-215.

Чухров, К. (2013): Метропоэма // НЛО. 120, 2013. http://magazines.russ.ru/ nlo/2013/120/ ch1.html (21/09/2016).

Шмелева, Т. (2012): Медийное речеведение: сборник статей [электронный ресурс]. Великий Новгород. http://www.novsu.ru/file/1145792 (21/09/2016).

Эпштейн, М. (1988): Парадоксы новизны. О литературном развитии XIX-XX веков. М.

Эпштейн, М. (2000): Постмодерн в России. Литература и теория. М.

Lindgaard, J. (2005): Artivisme. In: Vacarme. 31, 2005. Paris. 30-37.

Weststeijn, W. (2016): Das lyrische „Ich“ in der russischen Gegenwartsdichtung // Stahl, Henrieke / Korte, Hermann (Hgg.): Gedichte schreiben in Zeiten der Umbrüche. Tendenzen der Lyrik seit 1989 in Russland und Deutschland. Leipzig. 143-151.

Wilpert, G. von (2001): Sachwörterbuch der Literatur. Stuttgart. 



\section{Александр Уланов (Самара)}

\section{Радикальная индивидуализация опыта: субъект в поэзии А. Драгомощенко и А. Сен-Сенькова}

Литература является существенным средством самопостроения личности, причем это связано именно с активностью языка:

Поэма нас придумывает, придумывает того, кто ее пишет, и придумывает того, кто ее читает. Это этический акт, а не акт эстетический, активность личностной этики, активность языка. ${ }^{1}$

Поскольку восприятие мира и мышление осуществляются во многом (если не полностью) через язык, именно индивидуализация языка обеспечивает индивидуальность мышления субъекта, что особенно важно в современных условиях давления массовой культуры. Ряд стратегий, используемых в современной русской поэзии, недостаточно отвечают этой задаче. Ориентация на использование чужой речи или бытового опыта ведет к тому, что человек теряется в этих практиках, в реакции на социальное. Стратегия концептуализма решает критическую задачу противодействия идеологии, клишированности сознания. После концептуализма действительно, как отмечает М. Ямпольский, «чрезвычайно затруднительно, если и не смешно, эксплуатировать раздутое лирическое ,я“"». ${ }^{2}$

Однако концептуализм не затрагивает позитивную задачу построения субъекта иного типа. Поэтому представляется интересным рассмотрение иных путей - индивидуализации опыта на основе изменения взаимоотношений с предметами, языком и другим субъектом, примерами чего являются поэтики А. Драгомощенко и А. Сен-Сенькова. При всем различии поэтик этих авторов, можно предположить, что модель субъекта у них близка, в особенности в противопоставлении двух этих поэтов «новой искренности», постконцептуализму, «поэзии повседневности» и ряду других направлений в русской поэзии конца XX - начала XXI веков.

В явном виде («я») субъект у обоих поэтов практически отсутствует. Более того, можно найти декларации об отрицании субъекта:

я ненавижу «я», сидящее в том, что пишется, как заноза в фарфоровой копии ступни мальчика, изымающего занозу. ${ }^{3}$

\footnotetext{
${ }^{1}$ Meschonnic (2005, p. 257). Цит. по: Маричик (2012, с. 288).

2 Ямпольский (2003, с. 89).

3 Драгомощенко (2011, с. 249).
} 
Но представляется, что это связано с отрицанием не личности, а чрезмерного присутствия «я» в тексте, с отказом от модели субъекта, «для которой знание всегда было подавлением потенциальности и инаковости через схватывание, овладение, захват». ${ }^{4}$

В поэзии Драгомощенко и Сен-Сенькова возникает иной тип субъекта, не настаивающий на собственной персоне, на своем обладании, но оттого еще более индивидуализированный. Субъект для них является не данностью, но одной из проблем, одной из задач для построения. И эта задача решается с помощью поэзии. М. Ямпольский отмечает, что для Драгомощенко

поэзия - это область специфического отражения мира, в которой постепенно кристаллизуются инстанции Я (автора и читателя одновременно). ${ }^{5}$

И Драгомощенко, и Сен-Сеньков сводят к минимуму выражение собственных эмоций (понимая без иллюзий, насколько часто эти эмоции у человека клишированы) и стремятся увидеть окружающее в его своеобразии и переменах, насколько возможно, свободно от интересов и предубеждений смотрящего. Индивидуализации субъекта соответствует индивидуализация события, которое рассматривается как событие-вне-меня, а не событиедля-меня. Смотрящий отстраняется от себя, забывает о себе - но именно благодаря этому получает возможность увеличивать свой внутренний мир за счет увиденного:

меня больше там, где я о себе забываю. ${ }^{6}$

Это можно рассматривать как продолжение восходящей к Рильке концепции поэта как не выражающего себя, а слушающего мир. Сосредоточением субъективности становится индивидуальный стиль автора, его способ говорить и видеть. Субъект стремится быть как можно более бережным и незаметным.

Ты же посторонись, чтобы никого не задеть. ${ }^{7}$

Как быть еще незаметней?..

Как же приблизиться? ${ }^{8}$

Поскольку приближение возможно лишь из пространства уважения, невмешательства, незаинтересованного взгляда. Напряженно-внимательный и одновременно незаинтересованный взгляд позволяет видеть предметы в их яркости, подробности и взаимодействии.

В некоторых буквах есть отверстия, которые вырезаются изнутри тончайшим лезвием зеркала другой стороны листа. ${ }^{9}$

\footnotetext{
${ }^{4}$ Ямпольский (2000, с. 375-376).

5 Ямпольский $(2015$, с. 10$)$.

${ }^{6}$ Драгомощенко (2000, с. 15).

7 Драгомощенко (2011, с. 72).

${ }^{8}$ Там же, с. 78.
} 
Такое восприятие обусловливает внимание к малому и хрупкому. К тому малому, но близкому, что воздействует сильнее всего. Тем более, что индивидуальность проявляется именно в оттенках.

Ангел сигаретного пепла, то увеличивающегося, то уменьшающегося в размерах по мере того, как линии на ладонях заполняются. ${ }^{10}$

Можно отметить в данном фрагменте соответствие заполнения линий на ладони (линий жизни, судьбы) изменениям эфемерного сигаретного пепла.

Примечателен характерный для Драгомощенко и Сен-Сенькова принципиальный отказ от прямого высказывания, непосредственного описания, огрубляющего опыт в клише.

Среди множества трубочек памятника сибелиусу

есть одна

чтобы музыка

чувствующая себя возможной к описанию

могла уйти незамеченной. ${ }^{11}$

Поэт И. Жданов (порой включаемый в одну группу «метареалистов» с Драгомощенко) отмечал, что предмет или состояние могут быть уловлены при помощи именно косвенного зрения.

Если предмет неясен, гляди чуть в сторону, вскользь, и ты его увидишь полнее. Это физический факт. Так и в стихах: косвенным зрением нащупываешь, как бы обход такой делаешь, изгибаешь взгляд. А называние - это не то что даже умерщвление вещи, а... ${ }^{12}$

Фраза Жданова завершается именно многоточием - возможно, прямое называние казалось поэту настолько неподходящим, что он охарактеризовал бы его скорее непечатными словами.

Следует отметить, что и субъект возникает у Драгомощенко и СенСенькова косвенным образом, в процессе вхождения в новые отношения с другими субъектами, с предметами.

Речь остается средством наблюдения неочевидного опыта, однако это речь преобразованная. М. Перлофф отмечает, что

язык для Драгомощенко - не нечто, всегда уже использованное, присвоенное, предоформленное и предопределенное, каковым он является для американских [языковых] поэтов, видящих свою задачу в том, чтобы бороться с этим. Драгомощенко, наоборот, настаивает на том, что «язык не может быть присвоен, поскольку он не свершаем». ${ }^{13}$

${ }^{9}$ Сен-Сеньков (2001, с. 43$)$.

${ }^{10}$ Сен-Сеньков (2010, с. 82).

11 Там же, с. 74.

12 Жданов (1994, с. 13).

${ }^{13}$ Perloff (1991, p. 219). Цит. по: Павлов (2015, с. 293). 
Речь у Драгомощенко стремится не закостенеть, каждую секунду ставит себя под вопрос, но, тем не менее, длится, наращивает значения.

Что написано - не завершено, постоянно следуя к завершенью. ${ }^{14}$

Одновременно Драгомощенко осознает ограниченность любой речи, нащупывает ее границы, порой только указывая на предметы, на идущие от них ассоциации.

Ладонь, мотылек полудня, трещина на губе, любовная влага, ножа ничтожность, следы соприкосновенья возлюбленных - как нужное дополнение к модальности отсутствующих языков. ${ }^{15}$

Речь постоянно выясняет свои границы, отменяет себя, указывает на неречь. Внесловесное дополняет языки и создает новые.

Раздели на вино, крапиву, признание, а дальше говори на пальцах горячих камней. ${ }^{16}$

Очень большой объем предметов собран и в поэзии Сен-Сенькова. Предметы образуют цепочки образов, причем входят в них не только в наличном, но и в превращающемся состоянии:

[музыка] медленная настолько, что во время пауз инструменты успевают умереть. у них отрастают ногти и волосы, которые подстригают розовыми мягкими ножницами аплодисментов. ${ }^{17}$

Предметы не просто одушевлены, но связаны с людьми так, что ближе некуда.

[Рыба] плачет по ночам в стеклянную подушку словами от которых лодки умеют такое что рыбаки возвращаются к жёнам опустив глаза. ${ }^{18}$

Участвуя в человеческой жизни, предметы участвуют и в смерти тоже:

При внезапной смерти если поднести ко рту умершего зеркальце - оно, как упавшая записная книжка, закроется на всех отражениях сразу. ${ }^{19}$

При этом предметы не статичны, мир рассматривается как система нескончаемого числа форм, превращений, не заканчивающих себя ни в одной и, следовательно, не имеющих, не могущих иметь окончательного описания.

Есть - означает неустанную переходность. ${ }^{20}$

Переходность обеспечивается взаимодействием в промежуточности.

Фигура, которая интересует А. Сен-Сенькова, существует между, между двумя телами, как зона их встречи, события и судьбы. Такую зону промежуточности Мерло-Понти называл «плотью мира», чем-то не до конца

14 Драгомощенко (2000, с. 257).

15 Драгомощенко (2005, с. 29).

16 Там же, с. 53.

${ }^{17}$ Сен-Сеньков (2012, с. 117).

${ }^{18}$ Там же, с. 7.

19 Там же, с. 89.

${ }^{20}$ Драгомощенко (2013, с. 14). 
принадлежащим субъекту и не до конца принадлежащим внешнему миру.

Это именно зона промежуточности, перехода. ${ }^{21}$

Переходность дает не просто индивидуальность предмета и субъекта, но индивидуальность их мгновенных состояний, не равных друг другу. Непредвиденность превращений дает перспективу потенциальности.

Ничего себе не равно (сверчка фосфор),

ничто не предвидит себя (системы ветра). ${ }^{22}$

В мире, увиденном Драгомощенко и Сен-Сеньковым, все отменяет само себя и продолжается в другом. (Характерно, что и это может быть сопоставлено с Рильке, его вниманием к превращениям, его „Wolle die Wandlung“ [желай превращенья] из 12 сонета второй части «Сонетов к Орфею»). Таким образом, объектность оказывается текучей, непостоянной, однозначно не утверждаемой, и подразумевает такую же субъектность.

Буква птицы, буква огня, догадки буква

избраны, чтоб продолжаться друг в друге,

как рта и рук отзвук, тело стирая, открывает пальцам,

волокном пропуская слоения. ${ }^{23}$

Имеет значение и не появившийся предмет, не произошедшее событие. Одно из стихотворений Сен-Сенькова называется «Пантомима непоявившейся Афродиты». ${ }^{24}$ Взгляд поэта позволяет предмету - через включенность в связь с другими предметами - стать больше, чем он есть. Так, жемчужина приобретает способность к перемещению.

Жемчужина реагирует на звук и передвигается по направлению любого источника шума, будь то желток в яйце, стержень авторучки, исправляющей Ш на Щ, или время. ${ }^{25}$

Характерно, что мельчайшее, вызывающее это перемещение, добавление черточки к букве Ш, оказывается сопоставимым таким образом с огромностью времени. С другой стороны, множество усматриваемых индивидуальностей событий и моментов становятся основой индивидуальности субъекта. Задача поэта - поддерживать бесконечные превращения речи, которые и обеспечивают возможность личного высказывания и само существование личности. Тексты Сен-Сенькова создают впечатление «невозможности остановки бесконечного движения по лабиринту возможных смыслов движения, деконструирующего и обессмысливающего любые выстроенные из них системы». ${ }^{26}$

21 Ямпольский (2003, с. 90).

22 Драгомощенко (2000, с. 51).

23 Там же, с. 50.

${ }^{24}$ Сен-Сеньков (1996, с. 12).

${ }^{25}$ Сен-Сеньков (2001, с. 44$)$.

${ }^{26}$ Павлов (2007, с. 298). 
Это и есть описание самопостроения личности, постоянно ставящей себя под сомнение, отказывающейся застывать в готовых формах. При этом речь должна помнить о своей неокончательности. Окончательность была бы окончанием - смертью - и не только речи. С другой стороны, подвижность и перемена не исключают и постоянство как свой частный случай. Субъект ищет индивидуальный баланс текучести и определенности.

Можно в данном случае говорить и о джазовом принципе построения текста, тем более, что многие стихи Сен-Сенькова тематически связаны с джазом, в поэме «Тайная жизнь игрушечного пианино» он прямо говорит о джазовом Принципе Неопределенности. ${ }^{27}$

Драгомощенко и Сен-Сеньков не стремятся к комфортности привычноокончательного понимания, обнаруживая радость противоположного состояния:

Я не претендую также и на понимание, и более того, может быть, именно непонимание является моим последним удовольствием. ${ }^{28}$

Субъект выбирает жизнь в неточности, рассматривая недостаточность и незавершенность как свободу, потенциальность. Но реализация этой возможности требует точности. Поэтому поэзия Драгомощенко и Сен-Сенькова пропитана рефлексией. Дело речи (то есть поэзии) - сохранить человека или предмет на грани понимания, именно на грани, так как понимание до определенной степени возможно, оно является основанием действия, но претензия на совершенность понимания отрезает субъекта от мира как потока превращений.

Не называй даты, страницы, адреса, времени.

Но другое всегда иным из другого. ${ }^{29}$

И одновременно речь должна помочь

войти в отношения

с тем, что меняет поверхность ежемгновенно. ${ }^{30}$

Эту сложную задачу едва ли способны решить прямое высказывание или концептуалистский монтаж чужой речи. Поиск индивидуального представления осуществляется через ассоциативные механизмы, причем предмет или человек рассматриваются как динамические узлы связей.

Вполне вероятно, что дерево

поименовано чашей, воздух - сочетанием чисел, листвой расстоянием. ${ }^{31}$

${ }^{27}$ Сен-Сеньков $(1997$, с. 7$)$.

28 Драгомощенко (2000, с. 243).

29 Драгомощенко (2011, с. 29).

30 Драгомощенко (2000, с. 41).

31 Драгомощенко (2000, с. 58). 
Основанием для ассоциаций служит предметность. Представляется, что субъектность у поэтов, о которых идет речь, строится в значительной степени с помощью субъектностей, существование которых для традиционной лирики невозможно - из субъектностей предметов. В традиционной поэзии стакан или пчела получают субъектность только метафорически в рамках олицетворения или аллегоризации.

Соприкосновение с внесловесным расширяет возможности языка. У Драгомощенко практически отсутствует оппозиция природного и культурного, книга Башляра является таким же действующим событием, как вода:

Так вот из чего состоим, если изъять влагу, башляра, сны, слизь. ${ }^{32}$

У Сен-Сенькова практически во всех сборниках стихов текст активно взаимодействует с графическими образами. Можно предположить, что поэтика Драгомощенко более ориентирована на язык и познание, у Сен-Сенькова - на предметы и восприятие, но у обоих авторов оба направления дополняют друг друга. В первой же книге Сен-Сенькова «Деревце на склоне слезы» (1995) стихи имеют эпиграфы из Лиотара, де Бовуар, Пруста, Фрейда, Набокова, Лейбница, Кокто, Гюисманса, Понжа, Паунда, Рильке - и это лишь на первых 12 страницах. У Драгомощенко движение к вопросам о возможности высказывания, описания часто начинается от предмета, порой выносимого в заглавие текста («Настурция как реальность»).

Речь, основанная на ассоциациях, позволяет уловить черты другого субъекта как индивидуальности.

Ты вообще - репейник,

матрица уподобления в устье цвета,

налет зернистый на языке, кислотная забава

послеполуденного расписания. ${ }^{33}$

- и это только данное «ты», и более никто. Такая речь позволяет уловить и динамику перемен.

Мы слагались из зеркальных брызг, проточной воды, глиняного ила и тяжелых ночных снов ${ }^{34}$

- таков состав «нас» в данное мгновение. Сен-Сеньков также стремится создать меняющийся портрет ускользающего момента, настаивая на индивидуальности мгновения и взгляда:

твой голос-

вокальная пирамидка

(это я написал вчера)

а это я написал сегодня:

твой голос-

32 Драгомощенко (2011, с. 50).

33 Драгомощенко (2005, с. 24).

${ }^{34}$ Драгомощенко (2011, с. 13). 
тельце

невидимки-ошеломления ${ }^{35}$

Внимание к другому субъекту в его постоянно меняющейся индивидуальности и потенциальности, развитие восприимчивости при наблюдении оттенков, хрупкого, малого служат основаниями этики взаимодействия с другим человеком, одновременно предельно близким в интенсивности отношений и предельно удаленным в независимости и недоступной окончательному пониманию неисчерпаемости. Драгомощенко и Сен-Сенькову свойственна ощутимая эротичность текстов, причем эрос также рассматривается как свободная встреча с равным субъектом, а не овладение им. Любовь, душевное тепло проявляются не в демонстративной страсти, но в личной скрытости.

И не высаживай мак, и не говори, что любишь ${ }^{36}$

- потому что словесное может быть дополнено несловесным, потому что любовь либо ясна из несловесного, либо отсутствует. М. Ямпольский отмечает, что у Драгомощенко любовь «описывается не как слияние, а именно как отслоение тел, как их расхождение». ${ }^{37}$

Разделение выделяет лицо любимого из общей слитности. Но в опыте Драгомощенко и Сен-Сенькова нет антиномичных оппозиций, разделение - одновременно близость. И рефлексия не убивает эротику - скорее наоборот, делает ее более интенсивной, соответствующей сложности, накопленной в современной личности. Радикальная индивидуализация ведет не к холоду, а к головокружительной концентрации чувства.

Тогда снова к тебе, не написать - тебе в воздухе;

дым, тебе легче письму, и зеленый, как щавель,

выдохнуть, - весны чернь, когда задыхаешься

и вино катится из руки, и перекусываешь воду, где закидывается голова... ${ }^{38}$

Любовь остается горением.

Возрастает скорость, намагничивая мозг,

словно разматывая клубок, и конец нити вспыхивает. ${ }^{39}$

Предметы остаются помощниками и при встрече с любимым человеком.

Где лучше глазами с тобой встречаться. В зените?

Там зияние вселяет надежду, совершенно-слепяще.

Либо в низинах, где ты и туман не отличны ни в чем. ${ }^{40}$

35 Сен-Сеньков (1995, с. 9).

36 Драгомощенко (2005, с. 53).

37 Ямпольский (2000, с. 365).

38 Драгомощенко (2005, с. 46).

39 Драгомощенко (2000, с. 157).

40 Драгомощенко (2005, с. 34). 
Любимый человек - одновременно и близость, и удаленность свободы и возможности.

Как хранится в каком-то отделе мозга «любовь»,

рядом с другим, возле стекла, но другому ни имени,

а есть расстояние, а к нему ни губой, ни глазом. ${ }^{41}$

«Ты» - постоянное ускользание, которое только и может обеспечить свободу. Любовь - подвижность и перемена, а они неизбежны без потери. Отказ от возможности потери был бы отказом от подвижности, провалом в монотонное существование, которое ранит даже деревья, тем более - человека.

Точно так же в проект «любви» заложена энергия потери как вдохновляющая затаенность опыта, не замыкающегося ни на одном выборе, понятии, определении знания, что - не-сбыточно, не-бывает, не подлежит быванию (иному предлогу), как если бы оно намеренно опережало собственное предощущение; тогда говорится «любовь» или другое, если моросит либо если с Гавани несет листву и спящих птиц сквозь кроны натянутых струной, израненных монотонностью деревьев. ${ }^{42}$

Применительно к Драгомощенко, М. Ямпольский говорит об «эросе касания», который «описывается как эфемерная встреча тел, расположенных в разных измерениях, и соприкасающихся в единой точке, чтобы затем разойтись ветвями в четвертом измерении - времени». ${ }^{43}$

При этом движение фразы у Драгомощенко и Сен-Сенькова медленно и бережно. Что, кроме всего прочего, - свойства эротики. Так едва ли не всякое косвенное описание оказывается эротичным.

Субъект неизбежно сталкивается с вызовами истории и идеологии - и представляется, что накопленная у Драгомощенко и Сен-Сенькова индивидуализация речи, опыта, сознания позволяет субъекту ответить на эти вызовы. Противодействие идеологии осуществляется через эстетику. Ассоциации позволяют увидеть даже в авангардной фотографии связь с породившей ее тоталитарной идеологией. Руки спортсмена на фотографии Родченко

не согнуты

отрезаны по локоть

человеческими ножницами вспотевшего изнутри комсомола. ${ }^{44}$

Восприятие истории через ассоциативные механизмы способствует многомерности ее понимания. Так, у А. Сен-Сенькова некоторые из русских царей

находили что-то свое

внутри серой жидкой бомбы невы

не взрываясь

от ее медленных терактов ${ }^{45}$

41 Там же, с. 46.

42 Драгомощенко (2013, с. 94).

43 Ямпольский $(2000$, с. 365$)$.

${ }^{44}$ Сен-Сеньков (2010, с. 57). 
Ведь и политика является движением в многомерном пространстве, попыткой выбора наименее худшего в неопределенном, а не уничтожением однозначно определенного зла в черно-белом мире.

Отношения с Богом у такого субъекта также строятся чрезвычайно личным образом. Поскольку в мире Драгомощенко и Сен-Сенькова нет абсолютных координат, Бог воспринимается порой весьма скептично. Но именно этот скепсис открывает возможность для тепла личного отношения. Во всяком случае, Бог рассматривается как зависящий от человека не в меньшей степени, чем человек от него.

белому богу скучно в африке

и когда к нему приходят

$\mathrm{OH}$

прячется за дверь

развлекается

притворяясь ребенком

и меняя голос

говорит

«не могу открыть.

родителей нет дома» ${ }^{46}$

Драгомощенко и Сен-Сеньков стремятся уловить мир в максимально доступной степени многообразия, предполагая, что именно такое восприятие, несмотря на его сложность и затрудненность, обеспечивает реальную поддержку личности. Л. Горалик отмечает, что тексты Сен-Сенькова вынуждают «поверить не в существование иной реальности, но - что гораздо мучительнее - в многослойность и неочевидность реальности привычной». ${ }^{47}$

Это же можно сказать и о текстах Драгомощенко. Яркость и многосторонность взгляда Драгомощенко и Сен-Сенькова развивают индивидуальность и в читателе. Это приглашение ему развивать собственный взгляд, отказавшись от повторения не только клише, но и того, что предлагает поэт. А. Цветков-младший замечает, что «регулярно читая Сен-Сенькова, разучиваешься повторять и с середины цитаты начинаешь гнуть ее в новую сторону». ${ }^{48}$

Личное для субъекта, который возникает в поэзии А. Драгомощенко и А. Сен-Сенькова - это напряжение внимательности и ответственности, открытость, понимание неокончательности любого смысла, неуниверсальности любого решения. Радикальное усложнение речи и опыта позволяет субъекту говорить о тех оттенках перемен и восприятий, которые высказать невозможно - о которых, однако, необходимо говорить, поскольку это поз-

\footnotetext{
${ }^{45}$ Сен-Сеньков (2006, с. 14).

46 Там же, с. 18.

${ }^{47}$ Горалик (2006, с. 4).

${ }^{48}$ Цветков (2010, с. 10).
} 
воляет увидеть динамику предмета, его соприкосновений и перемен, сохранить во встреченном человеке, предмете, событии не только его индивидуальность, но и возможность.

Таким образом, можно предположить, что в современной литературе (в частности, в поэзии А. Драгомощенко и А. Сен-Сенькова) формируется новая модель субъекта, противостоящая как модернистской (где субъект оказывается навязывающим свой взгляд), так и постмодернистской (где субъект представлен как сумма чужих голосов, в которой он растворяется). В новой модели субъект рассматривается как индивидуальность взгляда, речи, опыта, готовая слушать и взаимодействовать с другими индивидуальностями, сохраняя их свободу.

Разумеется, поиски такой модели субъекта не относятся только к русской литературе. Здесь, в первую очередь, следует указать на работы Мориса Бланшо, его концепцию множественности (и частичности) вариантов соприкосновения, внимание к подвижности и неустойчивости языка, к потенциальности события, которое сопровождается настоянием на возможности реализации невозможного и противоречивого через встречающую речь, осторожным и многосторонним приближением к человеку или предмету, согласием на дистанцию и неполноту, этикой, отошедшей от «золотого правила» «обращайся с другим так, как хочешь, чтобы обращались с тобой», учитывающей текучую индивидуальность Другого и предлагающей обращаться с Другим так, как требует именно его индивидуальность, как бы это ни было сложно. Бланшо отмечает, что текст - это не описание, «не отчет о событии, но само событие». ${ }^{49}$

Это полностью соответствует поэзии Драгомощенко и Сен-Сенькова, в которой текст - событие встречи с индивидуальностью человека или предмета, событие развертывания значений и связей в открывающемся пространстве возможного, формирования пишущего (а вслед за ним и читающего) субъекта. Не случайно, что, несмотря на хронологию, Ж. Деррида охарактеризовал Бланшо как находящегося уже за постмодернизмом. Представляется, что Драгомощенко и Сен-Сеньков также развивают модернистское понимание субъекта, сохраняя осознание его индивидуальности и устремленности к новизне, но дополняя полученным в постмодернизме пониманием неокончательности и множественности истин и точек зрения, отказом от попытки занять господствующее положение, вниманием к равноправному диалогу с другими субъектами (среди которых оказываются и предметы).

Событие стихотворения в этом случае является практикой индивидуализации, поиском способа жить в меняющемся мире. При этом автор стиха не стремится к непосредственной коммуникации с читателем, но предлага-

\footnotetext{
49 Бланшо (1997, с. 13).
} 
ет его вниманию свой способ смотреть, существовать, которым читатель может воспользоваться в меру собственных возможностей и желаний.

Построение нового субъекта требует немалых и радикальных усилий по самоотстранению, напряженной внимательности, отказа от комфортной устойчивости и определенности, выработки личной речи, позволяющей уловить мир в его многообразии и переменности. Слова о мучительности в ранее приведенном высказывании Л. Горалик не лишены основания. Но эти усилия оправданы тем объемом бытия, с которым автору (и с его помощью читателю) удается войти в соприкосновение. Разумеется, мир не свободен от боли и безнадежности.

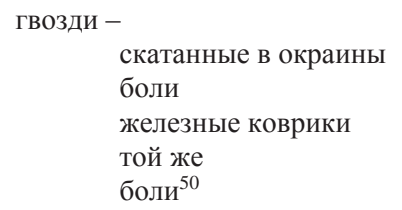

Но мир делится с субъектом настолько большим количеством впечатлений огромной яркости, что не может быть рассматриваем как враждебный в целом. У Драгомощенко и Сен-Сенькова нет иррационального ужаса или жалоб на несовершенство мира - и есть немало слов о счастье.

восклицательный знак - след, оставленный подпрыгнувшей от счастья точкой ${ }^{51}$

Счастье, свойственное предметам и речи, приходит от них и через них к человеку, осознающему его - и себя - через них.

Если взглянуть на этот же вопрос со стороны общества, представляется, что именно попытки формирования субъекта, способного воспринимать современный мир в его накопленной сложности, реагировать на вызовы этого мира, требующие индивидуальных решений в каждом случае, делают «сложную» литературу не просто актуальной, но крайне необходимой для современного общества. Сможет ли общество, тяготеющее к более очевидной литературе, это осознать?

\section{Литература}

Бланшо, М. (1997): Пение сирен // Бланшо, М.: Последний человек. Пер. с фр. В. Лапицкого. СПб. 5-16.

Горалик, Л. (2006): Книга, написанная императором на зернышке дикого риса через 5/6 секунды после того, как в его покои ворвалась вооруженная охрана // Сен-Сеньков, А.: Заостренный баскетбольный мяч. Челябинск. 3-7.

${ }^{50}$ Сен-Сеньков (1995, с. 5$)$.

51 Там же, с. 19. 
Драгомощенко, А. (2000): Описание. СПб.

Драгомощенко, А. (2005): На берегах исключенной реки. М.

Драгомощенко, А. (2011): Тавтология. М.

Драгомощенко, А. (2013): Устранение неизвестного. М.

Жданов, И. (1994): Интервью // Сегодня. 26/2/1994. 13.

Маричик, Ю. (2012): Море черных чернил. М.

Павлов, Е. (2007): Зеркало во рту // Новое литературное обозрение. 88, 2007. 297-303.

Павлов, Е. (2015): Тавтологии Драгомощенко // Новое литературное обозрение. 1 (131), 2015. 289-301.

Сен-Сеньков, А. (1995): Деревце на склоне слезы. М.

Сен-Сеньков, А. (1996): Живопись молозивом. М.

Сен-Сеньков, А. (1997): Тайная жизнь игрушечного пианино. М.

Сен-Сеньков, А. (2001): Танец с женщиной, которая немного выше. М.

Сен-Сеньков, А. (2006): Дырочки сопротивляются. М.

Сен-Сеньков, А. (2010): Бог, страдающий астрофилией. М.

Сен-Сеньков, А. (2012): Колено-локтевой букет. М.

Цветков, А. (2010): Сведения об авторе // Сен-Сеньков, А.: Бог, страдающий астрофилией. М. 5-16.

Ямпольский, М. (2000): Поэтика касания // Драгомощенко, А.: Описание. СПб. 355-378.

Ямпольский, М. (2003): Дзен-барокко // Новое литературное обозрение. 62, 2003. 89-98.

Ямпольский, М. (2015): Из хаоса (Драгомощенко: поэзия, фотография, философия). СПб.

Meschonnic, H. (2005): Henri Meschonnic, la pensee et le poeme. Sous la dir. de G. Dessons, S. Martin, P. Michon. Paris.

Perloff, M. (1991): Noticings. In: Sulfur. 29, 1991. 219. 



\section{Катина Бахарова (Трир)}

\section{Субъект в онейрических текстах Ольги Седаковой и Елены Шварц (сравнительный анализ) ${ }^{1}$}

Ольгу Седакову и Елену Шварц связывала длящаяся десятилетиями интеллектуальная дружба, ${ }^{2}$ нашедшая свое выражение также и в поэзии обеих. Они находились в поэтическом диалоге друг с другом, посвящая друг другу стихи и выражая свое мнение о произведениях других. ${ }^{3}$ Кроме того, они используют похожие мотивы и фигуры (в основном библейские), а также формы художественного произведения (например, псалом), а их тексты обнаруживают многообразные тематические точки соприкосновения. Так, например, для их лирики характерно особенно сильное тяготение к метафизическим темам. Обеих интересуют формы перехода между имманенцией мирского и трансцендентностью Бога. К религиозно-мистическим темам они подходят с позиции христианской веры, являющейся чем-то сугубо личным, выходящим за рамки канонов.

\section{Сон и сновидение как топос в поэзии О. Седаковой и Е. Швари}

Тематическим полем, общим для обеих писательниц, является сон как поэтический топос, в рамках которого происходит переход из реального мира в мир метафизический. ${ }^{4}$ Нужно отметить, что общая тема сновидений находит индивидуальную реализацию в поэтических мирах Седаковой и

${ }^{1}$ Перевод с немецкого Татьяны Ушаковой.

${ }^{2}$ Седакова упоминает 35-летнее общение со Шварц, см. Седакова (2010b, с. 568).

${ }^{3}$ См. об этом у Марии Хотимски: „Sedakova and Shvarts maintain friendly but distant relations. The poets were aware of each other's work, and [...] they often rely on poetic dialogue to underscore the uniqueness of their own poetics and to create individual interpretations of the poetic tradition" (Khotimsky 2007, p. 738).

${ }^{4}$ Хотимски рассматривает сновидения как один из множества общих мотивов, которые встречаются в творчестве обеих поэтесс: „In writing about their own creative development, both Sedakova and Shvarts tend to single out the events of spiritual biography and devote particular attentions to marginal states of consciousness: dreams, revelations, visions. The more personal and introverted the poets' self-recollection, the more striking the manifestations of poetic allusion and creative dialogue. [...] Both poets underscore the opacity of dreams, suggesting the limits of vision and understanding - the themes that Sedakova and Shvarts explore in their poetic works“ (там же, p. 739-740). 
Шварц. Их онейрические произведения навеяны личными переживаниями и собственным стилем творческого выражения. ${ }^{5}$

Стихи о снах пера Седаковой можно сопоставить с ее биографической ситуацией, изменяющейся со временем. Поэзия Седаковой на раннем и среднем этапах ее творчества отличается некой скрытой практикой веры, компенсацией религии. Показательно, что число стихов уменьшается по мере либерализации России, в то время как она начинает публично отстаивать свои религиозные взгляды. После смены политического курса страны мотив сна, занимающий центральное место в раннем творчестве, тоже практически отсутствует.

Совершенно иначе эта ситуация выглядит у Елены Шварц, для которой характерна творческая непрерывность: мотив сна присутствует неизменно и сохраняет свое особо важное значение. Прочие расходящиеся поэтические признаки накладывают свой отпечаток и на лирику обеих поэтесс о сне, например, в отношении языкового оформления (так, ясность языка у Седаковой противопоставляется языковому оформлению Шварц, напоминающему стиль барокко) или выбора тем (преобладание определенных мотивов и жанров, как, например, колыбельная песня у Седаковой в противопоставлении разнообразию тем и жанров у Шварц).

Елена Шварц пишет стихи вплоть до своей смерти в 2010 году, причем, в отличие от Седаковой, стихи, вдохновленные темой сна, неизменно присутствуют в ее творчестве. Дальнейшим отличием является разнообразие литературных жанров у Шварц. Помимо стихов, преобладающих в ее творчестве, она писала также драматургические, очерковые тексты, рассказы, короткие афоризмы и изречения, а также дневники, в которых частично присутствует мотив сна. Кроме того, она оставила заметки о снах.

${ }^{5}$ Стефани Сандлер обобщает разницу в поэтических и жизненных путях Седаковой и Шварц: „Еlena Shvarts absorbs her terrors almost matter-of-factly, while Ol'ga Sedakova tries to contain her fears within religious and philosophical truths. [...] Shvarts writes in broken rhythms, grotesque images, and a painful sense of existential aloneness. [...] Sedakova writes in syncretic clusters of images, able to imitate the syntax of neoclassical odes in one poem and then to echo the music of Russian spiritual rimes (dukhunnye stikhi). [...] Shvarts gives us a world where connections to others are always fraught with danger; but Sedakova speaks for a small community of intellectuals, expecting her readers to recognize quotations from Dante Alighieri, Rilke, Charles Baudelaire, or John Keats. Lexically, her poetry is deceptively simple, balancing a restricted vocabulary with frequent abstractions; [...] Shvarts, with her more theatrical poses, seems less accessible, but her poems can have the exceptional immediacy of a light drama. [...] The differences between Sedakova and Shvarts are also profound - in tone, in range, in the very idea of poetic experimentation and poetic career. Sedakova has long been a scholar, translator, teacher, and poet; her poems exude a sense of hard work. Shvarts, by comparison, has boasted that she writes hers in the bathtub and, especially in the 1980s, she was a self-styled bad girl of contemporary Russian poetry“ (Sandler 2001, p. 475-476). 
Елена Шварц выбирает иной подход к представлению снов в своих стихах, нежели Седакова. Самым явным отличием от Седаковой является вид сновидений: Шварц поэтически реализует конкретные признаки реального переживания сновидения. С этим связано различие в изображении субъекта. Лирический субъект в сновидении у Седаковой «перемещается» в различные фигуры и перенимает их перспективы видения, Шварц же опирается на реальные проявления чувства «Я» в сновидении, а также на расщепление между «Я» в сновидении и его демонстрацией в различных формах проявления, которые сами могут порождать сон, однако без перемещения инстанции субъекта или его перспективы в другие фигуры. ${ }^{6}$ Другим свойством реальных снов, используемым Шварц, является люцидное (осознанное) «Я» в сновидении, при котором сознание во сне «не засыпает». Кроме того, субъект сна у нее является частью мира имманентного, который не представляется пронизанным трансценденцией, как это имеет место у Седаковой. Напротив, как показала Хенрике Шталь, Шварц следует поэтике трансцендирования. ${ }^{7}$

Самое четкое различие на тему сна в поэзии Седаковой и Шварц прослеживается в механизме изображения и в поэтических функциях лирического субъекта. Ниже противопоставляются существенные формы проявления и функции лирического субъекта сна в стихах обеих поэтесс с целью выявить различия в их представлении субъекта. Анализ будет осуществляться за счет сравнения двух аспектов, касающихся субъекта сна как композиционного центра и как центра изображения. Спашивается, каким является субъективный способ выражения в текстах, и как субъект позиционируется между миром сна и бодрствования.

Например, стихотворение Шварц «Окна во сне» выявляет такое расщепление субъекта сна:

Окна во сне

В глубоких облаках - квадратное окно,

Сосновою стружкой пахнет оно,

И что-то в нем трепещет - как в прихожей,

Волнуется - пылинок столб взовьется,

(Бывает так) -

Когда любовь за дверью мнется

С для подаянья кружкой.

Скорей, скорей

${ }^{6}$ Расщепление субъекта в поэзии Е. Шварц констатирует и Александр Скидан: «У Шварц субъект высказывания раздроблен на множество голосов, подчас растворен в хтонической стихии, раздираем ею [...] и обращается к „иррациональному“, телесному, экстатическому опыту, к альтернативным, маргинальным (в научную, „расколдованную“ эпоху) традициям, таким как оккультизм и алхимия» (Скидан 2013, с. 55).

${ }^{7}$ См. Шталь (2016). 
(Как пахнет золотою стружкой)

Подай же ей.

В глубоком облаке овальное окно -

В нем плещется лиловый сумрак -

Как то бывает с зеркалами,

Когда жильца несут

Вперед ногами.

Я вижу окна в облаках,

О сколько окон - их!

Кровь завела вдруг октоих,

И мозг мой закружился весь -

Как голубиный древний стих -

Как будто бы я здесь. ${ }^{8}$

Описанные в стихотворении сны сначала передаются без разграничения видящего сны лирического «Я» и «Я» рассказчика; «Я» в сновидении и рассказчик едины. Сцены сновидения, описываемые в первой и в начале второй строфы, фокусируются на окнах, располагаемых в облаках и одновременно имеющих концентрическую пространственную конструкцию, причем объекты в их центре определить невозможно. При этом субъект, переживающий сновидение, не осознает себя и ограничивается передачей сновидения, описываемого так, как он его видит, т.е. своим восприятием. Самосознающего субъекта в данном случае нет.

Несмотря на это, данный субъект одновременно способен создавать свои собственные картины сна: он порождает сравнения и ассоциации с тем, что он смутно видит в окне. Эти сравнения и ассоциации далее реализуются в новом отрезке сновидения - во второй половине первой строфы. Первоначально наблюдаемая сцена, в которой окно находится в центре внимания, сменяется сценой попрошайничества, в которой лирическое «Я» участвует и при этом наблюдает само за собой. Таким образом, призыв («скорей») и обращение посредством использования глагола в повелительном наклонении («подай») направлены на собственное «Я» в этом сновидении.

Однако, парадоксальным образом, в этой строфе есть второй, скрытый голос субъекта, введенный в скобках и отстраненный от остального текста за счет своего свойства осознавать собственные мысли. Этот голос подхватывает элементы из сна и, оценивая, ссылается на них. Этот второй голос субъекта включается независимо от центральной инстанции рассказчика сна. Поэтому можно предположить, что в этом случае речь идет о внутреннем ходе мыслей переживающего «Я», что типично для сновидения. В рамках «Я», воспринимающего сон, возникает инстанция «Я», эмоционально и умственно реагирующая на пережитое во сне. Эта инстанция «Я» связана со сном, однако не ставится полностью под контроль изначального

${ }^{8}$ Шварц (2008, с. 31). 
«Я» в сновидении. Децентрализация личности является феноменом, обозначаемым в эмпирически-психологическом исследовании сновидений как «расщепление „Я““ в сновидении». ${ }^{9}$ В этом случае для видящего сон доступны две различные формы «Я», которые, однако, воспринимаются как его идентичное «Я». Размещенное в скобках дополнение репрезентирует такую вторую форму «Я».

Позиционирование субъекта сна в стихах Седаковой происходит подругому. Стихотворение «Детство» имеет специфическую композиционную структуру, в которой события сна передаются как воспоминание и сопровождаются сменой перспективы.

Детство

Помню я раннее детство и сон в золотой постели.

Кажется или правда? кто-то меня увидел, быстро вошел из сада и стоит улыбаясь.

- Мир - говорит, - пустыня.

Сердце человека - камень.

Любят люди, чего не знают.

Ты не забудь меня, Ольга, а я никого не забуду. ${ }^{10}$

Действие сна подается из перспективы ребенка, причем посредством воспоминаний опыт сна взрослого лирического героя делается его собственным. Взрослый лирический герой с самого начала выделен эксплицитным и интенсивным употреблением личного местоимения «я» в первой строке стихотворения. Вводная инверсия сосредоточивает внимание как на процессе воспоминания (глагол «помню» в первом лице стоит перед местоимением «я» и открывает стихотворение), так и на взрослом лирическом герое, так что весь сон помещен в рамки воспоминаний и тем самым нераздельно связан со взрослым лирическим героем, чье имя «Ольга» названо в тексте и, как следствие, отсылает нас к самой поэтессе.

Но логический субъект во сне ребенка не является субъектом, видящим собственное содержание сна или вспоминающим о нем позже. Ведь вспоминающее «Я» перемещено в перспективу фигуры, идентифицируемой как Христос, как показала Хенрике Шталь. ${ }^{11}$ «Я» говорит и воспринимает про-

\footnotetext{
${ }^{9}$ CM. Siebnthal (1984, S. 231).

${ }^{10}$ Седакова (2010a, с. 183).

${ }^{11}$ Шталь (2016).
} 
исходящее со своей перспективы, не с перспективы ребенка, который, собственно, олицетворяет прошлое «Я» рассказчицы. Пространственная перспектива переворачивается. Кроме того, мужчина является исполнителем всех действий, так что теперь он берет на себя роль субъекта, и ребенок, которого он видит и с которым он начинает говорить, становится объектом его действий.

Это стихотворение также демонстрирует состояние субъекта, типичное для стихов Седаковой о сне. У нее субъект находится в переходной фазе между бодрствованием и сновидением. В этом так называемом гипнагогическом состоянии засыпающий все еще находится под влиянием внешних впечатлений, однако не осознает их. Также и бодрствующее сознание при этом не полностью теряет свою силу. В этом случае гипнагогическое состояние приводит к тому, что вспоминающее лирическое «Я» не может провести четкую границу между сновидением и сознательно пережитым.

Такое состояние не имеет места в творчестве Шварц в явном виде. Напротив, она предпочитает люцидный сон, который во сне распознает сновидение как сновидение.

Например, стихотворение «Сон как вид смерти» показывает субъект в тройственной форме: в местоимении «я», в относящемся к нему глаголе в первом лице единственного числа, и в повторении этой конструкции. Лирическое «Я» осознает свое состояние сна и передает содержание сновидения напрямую из сна. Таким образом, осознание того, что собственная личность находится во сне, указывает на состояние так называемого люцидного сна, при котором видящий сны знает, что он видит сон, и в отдельных случаях он даже может управлять событиями во сне.

Сон как вид смерти

Я сплю, а череп мой во мне

Вдруг распадается на части -

Уходят зубы в облака

Чредою умерших монашек.

А челюсть, петли расшатав,

Летит туда, где Орион

И поражает филистимлян

Там ею яростный Самсон.

Я сплю, а смерть моя во мне

Настраивает свой оркестр -

Прыжки ее легки,

Вся распрямляется, как древо

Или как поле для посева,

И костию моей берцовой

Взмахнув играет в городки

И разбивает позвонки. 
Но к утру с окраин мирозданья

Кости, нервы, жилы, сочлененья

Все слетаются опять ко мне. Сознанье

Просыпаясь удивится, что не тень я,

Собирая свои жалкие владенья,

Что еще на целый зимний день - я.

Просыпаюсь и молюсь - вернитесь, кости,

Вас еще не всех переломали,

Кровь, теки в меня с Луны, с Венеры,

Я хочу пролить тебя на землю,

Ведь еще меня не распинали. ${ }^{12}$

Восприятие собственного «Я» может подчеркиваться также за счет чрезмерного акцентирования физических ощущений, как, например, боли. Здесь применяются две похожие композиционные структуры, предваряющие события во сне одним и тем же способом: «я сплю, а...», причем дальнейшее описание сна также однозначно производится субъектом (используется притяжательное местоимение «мой/моя»). Следующее за этим физическое разобщение люцидного лирического «Я» в третьей и четвертой строфах противопоставляется восстановлению единства тела. Этот процесс совпадает с пробуждением и восстановлением состояния бодрствования.

Несмотря на свое крайне физиологичное восприятие тела, а, возможно, именно благодаря ему, лирическому «Я» во сне удается уничтожить телесность и, таким образом, достичь трансценденции, причем бодрствование возвращает его к имманенции. Первые две строфы выдвигают на первый план различные части тела лирического «Я» (череп, зубы, челюсть, петля, позвонки, берцовая кость), связанные глаголами, выражающими разрушение: «распадается», «уходят», «расшатать», «разбивает». Субъект видит и чувствует, как его покидают части тела, которые все больше и больше начинают жить своей жизнью, пока они в последней строке первой строфы уже вовсе не принадлежат ему: челюсть теперь в руках Самсона и используется им для победы над филистимлянами. Во второй строфе телесное воплощение лирического субъекта полностью подчинено смерти. Она принимает живой образ («прыжки ее легки»), она получает символы жизни (древо, поле) и «использует» остатки «Я» в игре в городки. Таким образом, лирический субъект лишается своей телесности, и он осознает это и передает свои ощущения из сна. Разделение духа и тела производится в сновидении, осознаваемом как сон.

В свою очередь, третья и четвертая строфы противительным союзом «но» и картиной утра предваряют процесс пробуждения. Части тела снова ставятся в центр внимания (строка 18: кости, нервы, жилы, сочленения), однако они сопровождаются глаголом, указывающим на восстановление

12 Шварц (2008, с. 161). 
тела (слетаются). До наступления дня тело лирического «Я» снова полностью «собирается»: строка 20 - «не тень я», строка 22 - «я».

Так, лирический субъект выступает в двух различных формах: физически разрушенным и трансцендированным во сне и телесно восстановленным и имманентным в состоянии бодрствования. ${ }^{13}$ Лирический субъект осознает себя в обоих этих состояниях, то есть его сновидение является люцидным.

У Седаковой же субъект, видящий люцидные сны, полностью отсутствует. Вместо этого в некоторых стихах она, напротив, выдвигает в центр внимания бессознательный сон. Здесь она внедряет повествовательную инстанцию, рассказывающую о спящей фигуре (см. «Алатырь», «Легенда десятая. Иаков»).

В таких стихах, например, глубокий сон стилизируется как мистическое событие, доступное только трансценденции и ее носителю, спящему человеку, и которое уклоняется, таким образом, от инстанции повествователя. Здесь сон представляется как средство единения Бога и человека, причем это переживание характеризуется прежде всего отсутствием интерсубъективности. Примером этому служит стихотворение «Легенда десятая. Иаков»:

Легенда десятая. Иаков

Он быстро спал, как тот, кто взял

хороший посох - и идет

сказать о том, как он искал,

и не нашел, и снова ждет;

что он следит, как пыль стоит,

не окружая никого,

что небо, круглое на вид,

не свод, а куб - и он гремит,

и сердце есть внутри него.

Он спал и спал, зажав в руке

едва надкушенный кусок

пространств, гремящих вдалеке,

и тьмы, бегущей на восток.

Другие жили, как поток.

А он не мог сглотнуть глоток

от новостей - и спал, как мог,

спал исчезая, спал в песке,

спал, рассыпаясь, как песок, -

и Бог,

который ждать не мог,

13 Мотив физической боли встречается в поэзии Шварц так часто, что его можно назвать центральной поэтической концепцией. Cp. Кёнёнен: „In Švarc's poetic philosophy these mysteries [of devine and pain - К.Б.] are inseparable: knowledge of the devine cannot be attained without pain and suffering, which is always illustrated with violent, physical overtones“ (Könönen 2014, p. 415). 
изнемогая падал в нем,

охваченный внезапным сном. ${ }^{14}$

При первом взгляде присутствие Иакова ссылает на библейский сюжет, хотя здесь отсутствуют такие ключевые элементы соответствующей сцены, как лестница и ангелы. Имплицитный рассказчик утверждает, что Иаков спит, но без указания на сюжеты его снов, так что сон его остается для нас недоступным. В другой части стихотворения рассказчик рисует нам лицо, тщетно стремящееся к познанию мистического («как он искал, / и не нашел и снова ждет»). Наряду с проповедью, это лицо обладает и другими атрибутами пророка или мессии, такими как посох, поиск откровения и чистое сердце.

Во второй строфе изображено более глубокое погружение в сон. Ничто не может помешать Иакову спать, сон остается глубоким и всесильным, о чем свидетельствуют засыпание во время еды и шумное окружение. Человек из первой строфы, с которым проводится сравнение, и Иаков из второй строфы отделены от остального мира. Тогда как все живут, как река (строка 14), спящий описывается противоположными понятиями, символизирующими преходящее: пыль и песок.

Углубление Иакова в сон и особое значение его подчеркнуто посредством четырехкратного повтора глагола «спать», на ритмическом уровне впервые в стихотворении происходит отклонение от ритма (ранее выдержанного в ямбе), и глагол «спать» выделяется не только графически как первое слово строки, и синтаксически, но и интонационно. Сон владеет Иаковом так безраздельно, что он теряет свою телесную оболочку и, исчезая, превращается в песок.

Второе отклонение от ритма в девятнадцатой строке привносит укорачивание четырехстопного ямба: сон как опыт Бога. Несостоявшееся мистическое переживание в первой строфе, где Бога ищут намеренно и осознанно и где его не находят, продолжается теперь в рамках сна, в котором имманентное и трансцендентное объединяются. Столкновение с Богом происходит вне времени и пространства, и именно сон служит здесь путем к этому мистическому опыту.

Сон как средство единения человека и Бога проявляется прежде всего в отсутствии интерсубъективности этого переживания. В то время как мистический сон в стихотворении «Детство» передается через пересказ и визуализацию, мистический опыт во сне остается внутрисубъектным и непостижимым даже для самого субъекта.

Неудавшееся мистическое переживание первой строфы, где лирический герой намеренно и осознанно ищет Бога, но не находит его, удается, однако, далее в рамках сна, когда трансценденция и имманенция объединяются в сновидении. Объединение миров трансцендентного и имманентного про-

${ }^{14}$ Седакова (2010a, с. 130). 
исходит, таким образом, в строго индивидуальных рамках собственного сна, содержание которого не может быть пересказано.

Мотив состояния сна присутствует и у Шварц, однако в очень ослабленной форме. Процесс сна является второстепенным явлением, основывающимся на пассивности и спокойствии и порождающим содержание сновидения, которое ни в коем случае не представляется событием, непроницаемым для повествовательной инстанции. Состояние является только физической рамкой описываемого позже сновидения. В отличие от Седаковой, у которой сон проходит без сновидений и не осознается, и, таким образом, не поддается описанию, содержание сна у Шварц поддается интерсубъективному описанию.

$\mathrm{COH}$

В печи сияющей, в огромном чреве

Нерожденный Пушкин спал -

Весь в отблесках огня и отсветах светил,

Два месяца всего назад зачатый -

Уже он с бородой

Или как после тифа был.

В черном, стриженый, сквозящий,

И как пирог он восходил,

И широко раскрытыми глазами

Смотрел в огонь, лежал, кальян курил.

Шумели ангелы, как летний дождь, над ним,

Вливались в уши, вылетали в ноздри,

Ленивый демон прятался в углу,

Их отгонял, как мух, как туча звезды.

Он зорок был, бессонен - потому,

Чтоб с цепкостью ко тьме младенец шел во тьму... ${ }^{15}$

Подводя итоги, можно сделать вывод, что различаемые формы лирической субъектности в сновидении у Ольги Седаковой и Елены Шварц можно сопоставить с помощью двух аспектов: изображения лирического субъекта и его эмпирические сходства с действительным состоянием сна. В то время, как лирический субъект у Седаковой является открытой, проницаемой инстанцией, допускающей смену перспектив и, таким образом, трудно поддающейся конкретизации, то у Шварц конструкция субъекта концентрируется на самом субъекте, причем субъект принимает различные формы: дифференцированно думающей картины собственного «Я» и люцидного лирического «Я». Так, ее представление субъекта связано с конкретными переживаниями или формами «Я» в сновидении, которым свойственны различные ступени восприятия самого себя, степени самоанализа, а также внутреннее расщепление инстанции субъекта.

${ }^{15}$ Шварц (2002, с. 73). 


\section{Литература}

Седакова, О. (2010а): Стихи. М.

Седакова, О. (2010b): L'antica fiamma. Елена Шварц // Она же: Poetica. M. 567-579.

Скидан, А. (2013): Сумма поэтики. М.

Шварц, Е. (2002): Сочинения в пяти томах. Т. 1. СПб.

Шварц, Е. (2008): Сочинения в пяти томах. Т. 3. СПб.

Шталь, Х. (2016): «пока тебя это не коснулось». Имманентность трансцендентности: поэтологические размышления о мистических и духовных аспектах поэзии Ольги Седаковой // Сандлер, С. / Хотимска, М. / Криммель, М. (изд.): Стихи, смыслы, истолкования. М. 252-292.

Khotimsky, M. (2007): Singing David, Dancing David: Olga Sedakova and Elena Shvarts Rewrite a Psalm. In: The Slavic and East European Journal. 51, 4, 2007. 737-752.

Könönen, M. (2014): Manifestations of the City and the Self in the Poetry of Elena Švarc: The Spell of Gnosticism. In: Russian Literature. 76 (4), 2014. 407-426.

Sandler, S. (2001): Scared into Selfhood: The Poetry of Inna Lisnnianskaia, Elena Shvarts and Ol'ga Sedakova. In: Slavic Review. 60 (3), 2001. 473-490.

Siebnthal, W. von (1984): Die Wissenschaft vom Traum. Ergebnisse und Probleme. Berlin. 



\section{Валерий Гречко (Токио)}

\section{Лирический субъект в поэзии минимализма}

Вот, глядите, я пишу:

Трёхпарусные кеды.

Собирайтесь, объясняйте,

Литературоведы. ${ }^{1}$

Разговор о минимализме приходится начинать с предуведомления: готовой дефиниции минимализма у нас нет. С терминологической неопределенностью этого понятия сталкиваются практически все исследователи, изучающие поэзию минимализма. Так, Сергей Бирюков отмечает, что «при обращении к минимализму в наших условиях приходится учитывать, что сам термин не разработан», ${ }^{2}$ а Юрий Орлицкий говорит о соблазне «объявить минимализм непознаваемой вещью в себе, явлением, с неизменным успехом ускользающим от любого осмысления». ${ }^{3}$ Среди многочисленных попыток хоть как-то уложить разнообразные поэтические явления в рамки строгих дефиниций, в общем, можно различить два магистральных направления: одно связывает минимализм с количественным измерением и говорит о том, что минимализм - это эстетика малых форм, другое же обращает внимание на качественную сторону, относя к минимализму проявления «любой стилистической строгости» (,,any stylistic austerity“汭 или же минимального воздействия на материал, когда, говоря словами Всеволода Некрасова, «художник сводит счеты с художничаньем». 5 Попытка примирить эти две позиции и найти какой-нибудь общий знаменатель для разнообразных проявлений минимализма, которую предпринимает, например, Юрий Орлицкий, предлагающий взять в качестве универсального основания «аномально минимальное количество в тексте чего бы то ни было», ${ }^{6}$ также потенциально не свободна от возражений, так как имплицитно включает в себя понятие «норма», видимо, противопоказанное искусству в особенности современному.

1 Бонифаций (1998, с. 18-19).

2 Бирюков (1997, с. 290).

3 Орлицкий (1997, с. 342).

4 Baker (1988, p. 9).

5 Журавлева / Некрасов (1996, с. 314).

${ }^{6}$ Орлицкий (1997, с. 342). 
И все же мы будем говорить о минимализме, применяя эвристический подход, который позволяет оперировать понятиями даже в том случае, когда их логическое определение представляется затруднительным. А за рабочее определение примем перефразированное стихотворение поэта-минималиста Всеволода Некрасова:

Минимализм есть

Минимализм есть

Минимализм есть минимализм ${ }^{7}$

Чтобы понять особенности функционирования лирического субъекта в минималистской поэзии, важно обратиться к более общей проблеме коммуникативной природы лирики. Согласно принятым классификациям, лирика является одной из основных форм поэтического творчества. Как видно из самого слова, она развилась из пения и декламирования стихов под аккомпанемент лиры. Этимологическое указание на лиру не будет излишним, так как характер этого музыкального инструмента определил и характер лирической поэзии. Лира обладает негромким, камерным звучанием, к тому же на лире певец мог исполнять стихи под собственный аккомпанемент (что невозможно, например, с духовыми инструментами - это различие тематизируется в мифе о несчастном пастухе Марсии).

Если обратиться к определениям лирики в различных словарях, то вызывает удивление, насколько они сами «лиричны». Так, двухтомная «Литературная энциклопедия» говорит о том, что под лирикой понимается «вид поэтического творчества, который представляет собой раскрытие, выражение души», и доверительно сообщает, что «лирические стихи всегда - цветы», а лирика - это «преимущественный сосуд чувства». ${ }^{8}$ «Поэтический словарь» Квятковского понимает под лирикой род поэзии, где «находят воплощение самые глубокие и задушевные переживания поэта». ${ }^{9}$ Немецкие авторы также не отстают в поэтичности, „Kleines literarisches Lexikon“ определяет лирику как «непосредственное поэтическое воплощение человеческой встречи с миром», ${ }^{10}$ что, очевидно, отсылает нас к Гегелю, видевшему в лирике «созвучие внешнего и души, возбужденное им настроение, сердце, как оно чувствует себя в таком окружении». ${ }^{11}$

7 Некрасов (1991, с. 5).

8 Подольский (1925, с. 407-409).

9 Квятковский (1966, с. 145).

${ }^{10}$ Rüdiger / Koppen (1966, S. 244).

11 Гегель (1971, с. 515). Понимание лирики как вида литературного творчества, в центре которого находится личность поэта (лирического субъекта) и его мировосприятие, продолжает жить и в современном литературоведении (см. следующие определения: «Лирика - один из трех основных родов литературы, выдвигающий на первый план субъективное изображение действительности: отдельных состояний, мыслей, чувств, впечатлений автора» (Белокурова 2006, с. 76); «стихи, которые сосредотачива[ются] на 
Если убрать из этих определений обращения к душе, настроению и сердцу и перевести их в более нейтральные семиотические термины, то сущность лирики можно будет сформулировать как передачу субъективной авторской модели мира. В лирике внимание концентрируется не на том, что произошло, а на том, как воспринимается автором какая-то ситуация, как он выстраивает связь явлений и своих внутренних состояний и т.д.

При таком понимании лирики важно обратить внимание на два момента. Во-первых, это модель, т.е. до известной степени упрощенный и субъективный конструкт, созданный с познавательной целью, а именно с целью познания определенного аспекта более сложной системы (в данном случае мира). Во-вторых, лирика, как и любое искусство, предполагает передачу этой модели другому, т.е. является частным случаем коммуникации. (То, что в некоторых случаях получателем является сам автор, не меняет сути дела - автокоммуникация также является разновидностью коммуникации в широком смысле). Таким образом, лирику можно рассматривать как процесс передачи (или, если угодно, навязывания) адресату субъективной модели мира автора.

Все эти теоретические рассуждения звучат вполне приемлемо, пока мы не обратимся к современной поэзии, в частности, к поэзии минимализма. Возьмем, например, следующее стихотворение Всеволода Некрасова:

(1)

Нить и нить

И нить и нить

И нити нити нити нити

Нити нити нити нити

Нити нити

Не тяните

Не тяните 12 $^{12}$

чувствах и ощущениях поэта» (Азарова и др. 2016, с. 21)). Однако нужно отметить, что в последнее время наметились и другие подходы, которые, в частности, исходят из критики самого понятия «субъект» (Bürger / Bürger 2000) и более не рассматривают субъектную перспективу в качестве конститутивной составляющей лирики (Zymner 2009). Трудность этого вопроса приводит к тому, что некоторые авторы и вовсе отказываются от сущностного определения лирики, прибегая к приему «от противного» или используя лишь формальные критерии (см. характерный пассаж: „It is difficult to give a definition of lyric poetry. The lyric poem can be contrasted to the narrative poem, which tells a more elaborate story; or it can be defined on the basis of its length" (Mikics 2007, p. 172-173)). Рамки данной статьи не позволяют нам подробно рассмотреть эту проблему, ее содержательный обзор и анализ читатель найдет в публикациях: Lamping (2011), Stahl (2017).

12 Некрасов (1991, с. 5). 
Подходя формально, перед нами все признаки полноценного стихотворения: наличие метра и даже рифмы, графическое оформление с разбивкой на строки, начинающиеся с заглавной буквы и т.д. Выражено также отношение субъект-адресат, присущее лирике. Хотя участники коммуникативного акта не обозначены прямо через личные местоимения, все же наличие императива «не тяните» ясно указывает на коммуникативную структуру. Однако как насчет передачи «субъективной модели мира»? Представляется, что все попытки как-то семантизировать призыв «не тянуть нити» и найти за ним скрытый смысл будут выглядеть натянутыми. Очевидно, что стихотворение прежде всего демонстрирует звуковое сходство, возникающее при произнесении слов за счет редукции гласных и сдвига словоразделов, а также полисемию выражения «не тяните».

Еще более трудный пример представляют собой стихи, в которых формальные и звуковые моменты сведены к минимуму:

(2)

А обои можно пообдирать ${ }^{13}$

Является ли это лирикой? И имеют ли подобные стихи какую-либо специфику относительно выражения субъекта?

Оставив пока проблему о принадлежности подобных стихотворений к лирике за скобками, обратимся к вопросу об их коммуникативной структуре. Если рассматривать лирическое стихотворение как определенный вид сообщения, включенного в акт коммуникации, то, следуя известной схеме Якобсона, ${ }^{14}$ можно говорить о наличии по крайней мере шести компонентов: отправителя, получателя, кода, сообщения, контекста и канала передачи.

Однако в отличие от схемы Якобсона, в которой коммуникация рассматривается в общем виде, коммуникативная схема лирического стихотворения нуждается в ряде уточнений. Дело в том, что ситуация лирического стихотворения (и литературы вообще) представляет собой то, что в лингвистике называется «неканоническая коммуникация». В отличие от канонической коммуникативной ситуации, предполагающей общение «лицом к лицу», автор и читатель литературного произведения общаются не непосредственно - они могут быть разделены во времени, пространстве, не разделять коммуникативный контекст и т.д. ${ }^{15}$ К тому же надо учитывать и психологический аспект. Лирика представляет собой передачу / навязывание личностной модели автора читателю, что при излишней прямолинейности, естественно, может вызывать ответное психологическое сопротив-

\footnotetext{
13 Бонифаций (2000).

14 Якобсон (1975, с. 198).

15 Подробнее о различии «канонической» и «неканонической» коммуникации см.: Lyons (1977, р. 637-638), Падучева (1996).
} 
ление со стороны последнего. Чтобы нивелировать пространственно-временной барьер и нейтрализовать психологическое сопротивление, в стихотворении автор обычно выступает не от своего имени и обращается не к реальному читателю. Конструируются лирический субъект и адресат, между которыми и осуществляется коммуникация. Такое опосредование позволяет автору в известной степени дистанцироваться от передаваемого сообщения и сконструировать тот образ, который он желает придать себе в данный момент (до известной степени это можно сравнить с множественными виртуальными идентичностями, которые могут принимать пользователи при анонимном общении в Интернете). Читателю же ситуация подобной опосредованной коммуникации позволяет легче, без психологического отторжения отождествляться с лирическим субъектом или адресатом и тем самым апперципировать модель мира, содержащуюся в сообщении.

В качестве содержания сообщения (у Якобсона „message“) в лирической коммуникации выступает авторская модель мира. Этот «месседж» получает свою материальную реализацию с помощью кода, который, по сравнению с естественным языком, дополнительно организован посредством набора правил и ограничений (таким образом, являясь, по Лотману, вторичной моделирующей системой, надстроенной над системой естественного языка). ${ }^{16}$

Кроме того, важным компонентом лирической коммуникации будет являться эстетический контекст, понимаемый как совокупность эстетических норм и установок, в которых осуществляется данный акт лирической коммуникации.

Нетрудно убедиться, что почти все элементы этой схемы являются постоянными, неотчуждаемыми составляющими акта лирической коммуникации. Если перед нами стихотворение, то у него есть автор и реципиент (хотя бы в интенции), которые внутри стихотворного текста входят в контакт друг с другом через посредство лирического субъекта и адресата. Текст имеет некоторое материальное вербально-визуальное выражение и находится в определенном эстетическом контексте.

Единственный компонент, который может быть элиминирован - это сам «месседж». На первый взгляд это кажется странным, ибо именно «месседж», т.е. авторская модель мира, «душевный мир поэта», до недавнего времени так или иначе присутствовал в классических определениях лирики как ее важнейшая характеристика, а функция лирики определялась как передача этого месседжа читателю. Однако если мы представим себе все остальные компоненты акта лирической коммуникации в виде некой машины, вспомогательного устройства для передачи месседжа, то увидим, что как раз машина-то и является первичной - если машина или какойлибо ее компонент отсутствует, то передача чего бы то ни было станет не-

16 См. Лотман (1998, с. 19-20). 
возможной. Если же машина работает, хотя и без месседжа, то возможны разные варианты - она может работать на холостом ходу, демонстрируя совершенство своих движений, передавать сообщения, отличные от лирического месседжа и т.д.

Беглого взгляда на современную поэзию будет достаточно, чтобы увидеть, что в значительной ее части, в особенности в поэзии минимализма (как это было в вышеприведенных примерах), месседж утрачивает свою роль. Автор больше не видит своей задачи в том, чтобы транслировать читателю свою модель мира, да и сам читатель не ждет от автора каких-либо откровений. В причины этого явления мы сейчас вдаваться не будем, отметим лишь, что данная тенденция характерна не только для поэзии, но и для современного искусства вообще и часто обобщенно описывается как ситуация постмодерна.

Что же может передавать наша машина? В чем может состоять содержание и функция лирической коммуникации, если изъять из нее месседж? Очевидно, что возможным решением окажется раскрытие потенциала самой машины, актуализация и эксплуатация возможностей различных компонентов коммуникативной схемы. Рассмотрим эти случаи подробнее, обращая, в частности, внимание на выражение субъектности.

1. Актуализация возможностей языка. При просмотре различных сборников и антологий минимализма бросается в глаза большое количество произведений, эксплуатирующих звуковую сторону языка (как это было и с приведенным выше стихотворением Некрасова): звуковые повторы, парономазии, палиндромы и др. Очевидно, что с функциональной точки зрения здесь речь идет не столько о передаче «душевных состояний поэта» или его модели мира, сколько о демонстрации потенций языкового материала и мастерства поэта по его препарированию. Подобного рода «формальные фокусы» восходят к той линии авангарда, для которой семантически ориентированные искания типа мифопоэтики Хлебникова отходят на второй план, а доминирующим оказывается синтаксический вектор, ориентированный на комбинаторику и пермутацию (условно говоря - линия Крученых). Заложенная в ней установка на условность языкового знака («ложь») и игру нашла свое новое развитие в эпоху постмодернизма с его демонстративным отрицанием онтологических, «фундаментальных» истин и отказом от претензий на мессианскую роль автора. В результате мы имеем дело с явным усилением тенденции к комбинаторно-манипулятивным формам поэзии, которые нередко реализуются в технике минимализма.

С точки зрения выражения субъектности можно отметить, что так как в подобных случаях семантическая в своей основе функция передачи «субъективной модели мира» снимается, то и субъектность оказывается не релевантной. 
Но даже в тех случаях, когда она формально выражена, она не является существенной - употребление местоимений «я», «ты», дейктических маркеров и других «эгоцентриков» ${ }^{17}$ оказывается продиктовано чисто звуковой логикой. Выражающие субъектность элементы здесь так же вероятны, как и другие элементы текста:

(3)

Вот сила типа кухарки марксистов

Вот с искрами крах у капиталистов ${ }^{18}$

Очевидно, что причину употребления слова «вот» в этом палиндроме нужно искать не в дейктическом указании, косвенно обозначающем субъект, а в звуковой логике, по которой звуковой фрагмент «вот» лишь перевернутое окончание «тов».

В типологическом отношении подобные «звуковые фокусы» составляют особую группу и очевидным образом выпадают из понятия «лирика», даже в его расширительном толковании. Столь явная редукция функциональной стороны к чисто звуковым эффектам заставляет некоторых исследователей исключать их и из категории «чистого минимализма». ${ }^{19}$

2. Актуализация отсутствия месседжа. Эксплуатировать можно не только присутствие какого-либо элемента, но и его отсутствие. Привлекая внимание к отсутствию того, что обычно составляет сущность лирической коммуникации, автор демонстративно нарушает читательское ожидание. Интересно отметить, что подобные случаи часто реализуются в форме подчеркнуто прямого обращения лирического субъекта к адресату и их интеракции:

(4)

А это что, тоже стихотворение?

Да. Стихотворение.

Да ну тебя. ${ }^{20}$

Открыто сообщается, что в стихах не содержится никакого месседжа или же подчеркивается неспособность его выразить:

(5)

отдельные мои произведения

не представляют собой

ничего особенного ${ }^{21}$

17 Подробную типологию и анализ свойств эгоцентрических единиц языка см. в: Падучева (2013).

18 Авалиани (1995).

19 См., например, противопоставление «игрового минимализма» и «чистого минимализма», проводимое в работе: Степанов (2008).

20 Бонифаций (1998, с. 19).

21 Ахметьев (1990, с. 37). 
(6)

Европа двумя войнами

насильственно привязала нас

к своему ритму

что еще сказать - не знаю 22

Интересным видом игры на отсутствии месседжа являются случаи метакоммуникации - сообщения о месседже, которого в действительности нет:

(7)

Я так думаю.

Свое мнение я хотел бы

изложить в стихах

Они перед вами. ${ }^{23}$

или описание месседжа вместо него самого:

(8)

это стихотворение

передает не только состояние

но и устремление ${ }^{24}$

3. Актуализация эстетического контекста. Еще одной группой минималистских текстов является то, что можно назвать крайним минимализмом случаи почти полного (а иногда и действительно полного) отсутствия вербальной или визуальной выраженности, доходящей до чистого листа бумаги. Ведущая, по крайней мере в России, свое происхождение от Василиска Гнедова, эта линия получила свое продолжение, например, в так называемой вакуумной поэзии Ры Никоновой, есть подобные примеры у Всеволода Некрасова, спорадически появляются они и у других авторов.

Разрушая принятые представления о «нормальном стихотворении» и противопоставляя его принятому эстетическому контексту, автор провоцирует читателя, ставя его перед вопросом о границах искусства, о минимальной степени выраженности эстетического объекта. Естественно, что подобные произведения будут оставаться действенны до тех пор, пока они выделяются на фоне существующего эстетического контекста.

К этим случаям крайнего минимализма примыкают и эксперименты с итеративной техникой, когда крайне ограниченное количество элементов текста повторяется - в потенциале - бесконечное число раз. ${ }^{25}$ Сюда же можно отнести и случаи не количественного, а качественного разрушения принятых эстетических представлений - демонстративного элиминирова-

\footnotetext{
22 Там же, с. 11.

23 Там же, с. 27.

24 Там же, с. 65.

25 См., например, тексты Германа Лукомникова «40 раз по разу» и «100 тысяч почему», состоящие из многократного повторения одного единственного слова (Лукомников 1997, c. 266).
} 
ния всякой претензии на сообщение какого-то «знания о мире», модели мира автора и т.д., или же имитация месседжа в пародийном ключе:

(9)

Крапива

Красива.

$* * *$

Мел

Бел. $^{26}$

(10)

в нашем микрорайоне

есть магазин

где принимают банки

из-под майонеза

но не больше трех. ${ }^{27}$

4. Актуализация связки субъект-адресат. Приведенный выше пример с «обоями» (2) очень характерен и в другом отношении. Здесь нет модели, которую надо передать, но есть коммуникативная ситуация. Хотя «месседж» этой коммуникации подчеркнуто нулевой, остается коммуницирующий субъект, вступающий в прямой контакт с адресатом. Актуализация связки субъект-адресат вообще весьма характерна для рассматриваемых примеров и происходит в самых разных формах:

а. Подчеркивание коммуникативных ролей, где систематически перебираются все актеры акта коммуникации:

(11)

я выдох

ты вдох ${ }^{28}$

Я не Палах

Ты не Палах

$\mathrm{A} \mathrm{OH}$

Палах?

$\mathrm{A} \mathrm{OH}$

Палах

Он Палах

А ты не Палах

И я не Палах 29

б. Инверсия субъекта и адресата, где последний выступает в активной роли спрашивающего:

\footnotetext{
26 Там же, с. 265.

27 Ахметьев (1993).

28 Ахметьев (1990, с. 13).

29 Некрасов $(1979$, с. 3$)$.
} 
(12)

а вы уверены

что вы

именно это

хотели сказать

$?^{30}$

в. Синтез субъекта и адресата, демонстрация их слияния:

(13)

Я - это ты ${ }^{31}$

Я Я Я Я Я Я Я Я Я Я Я Я

Т T T T T T T T T T T T

Ы Ы Ы Ы Ы Ы Ы Ы Ы

T T T T T T T T T T T T

Я Я Я Я Я Я Я Я Я Я Я Я

ы ы ы ы ы ы ы ы ы ${ }^{32}$

г. Наконец, проверка коммуникативной связи:

(14)

правильно ли вы

меня понимаете ${ }^{33}$

Любопытно заметить, что отношения субъекта и адресата часто актуализуются в форме их явной или скрытой полемики, в которой субъект подвергается явной «снижающей» стилизации. Обычно это роль ничего не умеющего, никчемного человека, «наивного автора», что сближает его с персонажами примитивистской поэзии:

(15)

мое творчество в целом

есть портрет

заурядного человека ${ }^{34}$

как человек

я не уверен

как поэт

я не умею ${ }^{35}$

Я маленький человек.

Пишу маленькие стихи.

30 Ахметьев (1990, с. 23).

31 Никонова (1997, с. 281).

32 Ахметьев (1990, с. 14).

33 Там же, с. 52.

34 Там же, c. 37.

35 Там же, с. 54. 
Хочу написать одно, выходит другое.

.................... 36

бесконечны как кишки

из меня ползут стишки ${ }^{37}$

Иногда же субъект, наоборот, стилизуется в качестве высокомерного и страдающего манией величия персонажа, нападающего на читателя:

(16)

Во избежанье недоразумений

Предупреждаю, что я гений. ${ }^{38}$

Что ни читатель, то дебил...

Я пошутил! Я пошутил! ${ }^{39}$

Главное иметь нахальство знать, что это стихи. ${ }^{40}$

Вероятно, эти навязчивые и несколько невротические перепады между защитной и наступательной стилизацией субъекта свидетельствуют о том, что тема взаимоотношения с читателем является болезненной и для реального автора. Можно себе представить, что для поэта, пишущего в радикальной технике минимализма и демонстративно удаляющего месседж из своих произведений, встречи с реальными читателями были не всегда приятны - читатель часто не в состоянии дифференцировать между «сниженным» лирическим субъектом и реальным автором. ${ }^{41}$ Интересно, что, повидимому, и самому автору иногда бывает трудно отделить себя от лирического субъекта и он воспринимает замечания по отношению персонажей своих стихов как выпады в свой адрес. Характерна в этом отношении реакция первопроходца техники минимализма Всеволода Некрасова, который до конца своих дней не мог простить Михаилу Эпштейну того, что тот назвал героя некрасовских стихов «маленьким человеком наших дней» и сравнил его с гоголевским Акакием Акакиевичем. ${ }^{42}$

Подведем некоторые итоги. Сокращение или полная элиминация месседжа, ставшая характерной для современной ситуации в искусстве, имеет

36 Сатуновский (1995, с. 369).

37 Бонифаций (1998, с. 18).

38 Бонифаций (2000).

39 Там же.

40 Сатуновский (1992).

41 О патологическом стремлении читателя перенести на реального автора свойства субъекта лирической поэзии см.: Левин (1998, с. 466).

42 См. об этом: Янечек (2009, с. 208). 
своим следствием важные изменения, которые коснулись функциональной и формальной стороны искусства.

1. В области лирической поэзии исчезновение такой базовой для нее функции, как передача авторской модели мира адресату, ведет к повышению значимости элементов самого передаточного механизма - связки между субъектом и адресатом, языка, а также эстетического контекста. Когда из поэзии уходит месседж, обнажается коммуникативная схема, и интеракция участников становится ее ведущим содержанием. В результате парадоксальным образом элиминация месседжа ведет к усиленному проявлению субъектности (пожалуй, кроме случая «языковых фокусов»).

2. Поэзия приобретает вторичный характер - она отсылает к нормативной, канонической лирике и отталкивается от нее. Можно сказать, что в известном смысле она паразитирует на распространенных представлениях о том, какой должна быть эталонная лирическая поэзия. Тем самым она интересна, пока представление о норме еще является распространенным, и возможна до тех пор, пока это представление не изменилось. В случае, если в дальнейшем безмесседжные формы поэзии сами станут нормой, поэтическая практика должна будет искать новые пути, возможно - возвращение в поэзию месседжа в каком-то новом виде. Но в общем такая ситуация не является спецификой только современной поэзии - любое искусство в своей эволюции использует зазор между нормой и ее нарушением.

3. Хотя поэзия сама по себе уже содержит в себе тенденцию к сокращению объема (как об этом красноречиво свидетельствует и немецкое слово „Dichtung“ - «уплотнение, сгущение»), все же месседж, модель, передаваемая читателю, нуждается в некоторой пространственно-временной протяженности. Однако поэзия без месседжа, функция которой заключается лишь в демонстрации механизма коммуникации, в большом объеме не нуждается, для нее достаточно лишь обозначить компоненты передаточного механизма. Поэтому представляется, что элиминация месседжа может объяснить и то необычайно широкое распространение минималистских форм и жанров, которое мы наблюдаем в современной поэзии.

\section{Литература}

Авалиани, Д. (1995): Пламя в пурге. М. http://www.vavilon.ru/texts/avaliani1-p.html (30/07/2017).

Азарова, Н. и др. (2016): Поэзия. Учебник. М.

Ахметьев, И. (1990): Миниатюры. Сборник стихов. Arbeiten und Texte zur Slawistik. Bd. 47. München.

Ахметьев, И. (1993): Стихи и только стихи. Избранные стихотворения 1968-1992 гг. М. http://www.vavilon.ru/texts/ahmetiev1.html (30/07/2017). 
Белокурова, С. (2006): Словарь литературоведческих терминов. СПб.

Бирюков, С. (1997): О максимально минимальном в авангардной и поставангардной поэзии // Новое литературное обозрение. 23, 1997. 290-293.

Бонифаций (1998): Из избранного // Цирк «Олимп». 33, 1998. 18-19.

Бонифаций (2000): Избранное. http://www.vavilon.ru/bgl/bon1.html (30/07/2017).

Гегель, Г. (1971): Эстетика. В 4-х тт. Т. 3. М.

Журавлева, А. / Некрасов, В. (1996): Пакет. М.

Квятковский, А. (1966): Поэтический словарь. М.

Левин, Ю. (1998): Лирика с коммуникативной точки зрения // Левин, Ю.: Избранные труды: Поэтика. Семиотика. М. 464-482.

Лотман, Ю. (1998): Структура художественного текста // Лотман, Ю.: Об искусстве. СПб. 14-285.

Лукомников, Г. (1997): Стихотворения // Новое литературное обозрение. 23, 1997. 264-267.

Некрасов, В. (1979): Стихотворения // Ковчег. 4, 1979. 3-7.

Некрасов, В. (1991): Справка. М.

Никонова, Ры (1997): Стихотворения // Новое литературное обозрение. 23, 1997. 281-283.

Орлицкий, Ю. (1997): Минюме // Новое литературное обозрение. 23, 1997. 342.

Падучева, Е. (1996): Семантические исследования. М.

Падучева, Е. (2013): Эгоцентрические единицы языка и режимы интерпретации // Компьютерная лингвистика и интеллектуальные технологии. Вып. 12. Т. 1. 538-555.

Подольский, Ю. (1925): Лирика // Литературная энциклопедия: Словарь литературных терминов. Ред.: Н. Бродский и др. В 2-х тт. Т. 1. М. 407-414.

Сатуновский, Я. (1992): Хочу ли я посмертной славы. Избранные стихи. М. http://www.vavilon.ru/texts/satunovsky1-3.html (30/07/2017).

Сатуновский, Я. (1995): Из неопубликованного // Новое литературное обозрение. 14, 1995. 367-369.

Степанов, А. (2008): Минимализм как коммуникативный парадокс // Новый филологический вестник. 2 (7), 2008. 5-28.

Якобсон, Р. (1975): Лингвистика и поэтика // Структурализм: «за» и «против». М. 193-230.

Янечек, Д. (2009): Всеволод Некрасов и русский литературный концептуализм // Новое литературное обозрение. 99, 2009. 201-209.

Baker, K. (1988): Minimalism: Art of Circumstance. New York.

Bürger, P. / Bürger, C. (2000): Das Verschwinden des Subjekts. Das Denken des Lebens. Fragmente einer Geschichte der Subjektivität. Frankfurt a. M.

Lamping, D. (Hg., 2011): Handbuch Lyrik. Theorie, Analyse, Geschichte. Stuttgart.

Lyons, J. (1977): Semantics. Vol. 1-2. Cambridge.

Rüdiger, H. / Koppen, E. (Hgg., 1966): Kleines Literarisches Lexikon. Bern / München.

Stahl, H. (2017): Towards a Historical Typology of the Subject in Lyric Poetry. In: Journal of Literary Theory. 11 (1). 125-135.

Zymner, R. (2009): Lyrik. Umriss und Begriff. Paderborn. 



\section{Кирилл Корчагин (Москва)}

\section{Возвращение мерцающего субъекта: московский концептуализм и поэзия 2000-2010-х годов 1}

Концептуализм можно считать одним из центральных направлений русского искусства второй половины XX века. Со времен авангарда и его незаконнорожденного наследника социалистического реализма ${ }^{2}$ это был первый эстетический проект, предлагавший общие принципы одновременно для многих искусств и обладавший международным резонансом, несмотря на определенные различия в региональных вариантах этого движения. ${ }^{3} \mathrm{Co}-$ ветский концептуализм был относительно широким интеллектуальным и артистическим движением, вовлекавшим различные группы авторов и отдельных художников, подчас довольно слабо связанных друг с другом. Хорошо известно, что специфика этого движения состояла в не имевшей прецедентов со времен исторического авангарда рефлексии над методами и путями нового искусства.

Можно сказать, что ядром этого достаточно широкого круга были те поэты и художники, деятельность которых была освещена философом и теоретиком искусства Борисом Гройсом под именем «московского романтического концептуализма», ${ }^{4}$ хотя на практике круг причастных к движению художников и поэтов мог быть значительно шире. 5 Более того, со време-

${ }^{1}$ Исследование выполнено при поддержке РГНФ (проект № 15-24-06003 «Типология субъекта в русской поэзии 1990-2010-х гг.»).

${ }^{2}$ Ср.:«Социалистический реализм создавали не массы, а от их имени - вполне просвещенные и искушенные элиты, прошедшие через опыт авангарда и перешедшие к социалистическому реализму вследствие имманентной логики развития самого авангардного метода, не имевшего к реальным вкусам и потребностям масс никакого отношения [...] В сталинское время действительно удалось воплотить мечту авангарда и организовать всю жизнь общества в единых художественных формах [...]» (Гройс 2013, с. 26-27).

${ }^{3}$ Об американском концептуализме в поэзии см., например: Fitterman / Place (2010); Perloff (2010); Golston (2015).

${ }^{4}$ Гройс (1993, с. 260-274).

${ }^{5}$ Кроме работ Бориса Гройса богатый материал по самоописанию концептуалистского круга представляют документации группы «Коллективные действия», издававшиеся сначала в самиздате, а потом типографским способом под названием «Поездки за город» (1980-2009), самиздатские «Сборники МАНИ» (1986-1991) и «Папки МАНИ» (19811984). Различные версии концептуализма могли довольно сильно отличаться друг от друга: так, программа Д.А. Пригова во многом была противоположна программе Всеволода Некрасова и во многом даже Бориса Гройса. Я позволю себе пренебречь этими 
нем концептуалистское движение расширялось, захватывая и тех авторов, что были близки к первоначальному кругу, но по-другому воспринимали наследие исторического авангарда (как Всеволод Некрасов), и тех, что изначально не имели связей с движением, но со временем взяли на вооружение практиковавшиеся концептуалистами методы письма (как Александр Скидан или Василий Ломакин). ${ }^{6}$ Ретроспективно концептуализм представляется не только одним из наиболее заметных наследников исторического авангарда, но и движением, чей опыт оказался в наибольшей степени принципиален для младших поколений поэтов и художников, вынужденных отвечать на вызовы концептуализма уже после того, как он в своем первоначальном виде сошел со сцены.

Воздействие концептуализма на младших художников и поэтов можно сравнить с вирусом: концептуальные практики словно бы заражают более традиционное искусство и преображают его до неузнаваемости. При этом вирус концептуализма «мутирует» со временем: реакция на этот вирус у поэтов и художников середины 2010-х годов совсем не такая, как у поэтов и художников середины 1990-х. Более того, в 2010-е годы многие практики, характерные ранее только для концептуализма, становятся общими, разделяемыми всеми без исключения авторами, принимающими во внимание интеллектуальный и артистический ландшафт второй половины XX века. Таким образом, вирусную метафору можно продолжить: каждый вирус, встречающийся в природе, способен к множественным мутациям и изменениям - он меняет свои ДНК и РНК для того, чтобы лучше приспособиться к окружающей среде, к постоянно совершенствующейся иммунной системе живых существ. Вирус может быть разрушителен для организма, но, в то же время, реакция на него помогает иммунной системе стать сильнее, учитывать большее количество внешних «вызовов». Именно поэтому в современной поэзии и современном искусстве опыт концептуализма учитывается большим количеством авторов - настолько большим, что их едва ли возможно обозреть внутри одной статьи. В этой статье я буду обращаться лишь к русскому поэтическому концептуализму, оставляя за скобками работу художников и музыкантов, а также работу концептуалистов и их последователей в других странах. Я попытаюсь проследить, какие именно черты концептуализма оказались наиболее устойчивы к воздействию «иммунной системы» литературы и каким именно образом они преобразовывали русскую поэзию на протяжении последних двадцати лет.

крайне важными различиями, обращаясь, прежде всего, к ядру концептуалистского круга - Пригову и Рубинштейну. Подробнее об этой рефлексии, не совпадающей во многих деталях с гройсовским прочтением концептуализма, см.: Кукулин (2014); Житенев (2014, 2015).

${ }^{6}$ См. Корчагин (2013a). 
1.

В рамках одной статьи сложно проследить, как именно концептуализм менял облик современной поэзии, но основные траектории, по которым шло это изменение, проследить все же можно. В связи с этим важно различать приемы, элементы поэтики, практики, обычно ассоциирующиеся с концептуализмом, и существовавшую в поэзии разных представителей этого движения структуру поэтического субъекта. У самих концептуалистов (прежде всего, Д.А. Пригова, Льва Рубинштейна и Андрея Монастырского) определенные приемы обуславливали определенный тип поэтической субъективности и наоборот, но далеко не у всех их последователей это происходило таким же образом.

Свойственный концептуалистской поэзии тип субъективности довольно хорошо описан исследователями - прежде всего, на материале стихов Д.А. Пригова, однако он актуален далеко не только для этого поэта. Такая субъективность может быть описана через понятие мерцания: это понятие упоминается в «Словаре терминов московской концептуальной школы», где ему, однако, не посвящено отдельной статьи. Наиболее развернутую характеристику «мерцания» мы встречаем в вокабуле «Незалипание»:

НЕЗАЛИПАНИЕ - двойственное отношение к своему «Я», своему месту в мире, своему занятию, которое лучше всего определить как своеобразное «мерцание»: то ты попеременно находишься внутри всего этого, то снаружи. Это «мерцание» происходит постоянно, в одном и том же ритме - то ты сохраняешь свой «идентитет», то теряешь его; то совмещаешь себя со своей профессией или делом, то - в следующее мгновение - оставляешь их. ${ }^{7}$

В дополнительном словаре Д. А. Пригова слово «мерцание» встречается еще один раз уже в другой вокабуле:

ВЛИПАНИЕ - погружение в определенный стиль или дискурс до полной идентификации с ними (как раньше говорили: автор умирает в тексте), в отличие от стратегии мерцания. ${ }^{8}$

Конечно, этот словарь пародирует научный дискурс, как и многие другие тексты концептуалистов, однако нельзя не заметить, что даже в этом пародическом словаре «мерцание» оказывается среди фундаментальных понятий концептуалистской практики: оно не определяется через другие понятия и выступает как само собой разумеющееся, базовое. Действительно, структуру субъекта в поэзии Пригова достаточно удобно описывать через «мерцание»: субъект Пригова на протяжении одного текста, как правило, несколько раз «переключается» между различными модусами речи, различными дискурсами, «влипая» (погружаясь) в каждый из них. Такое «влипание», однако, никогда не бывает достаточно продолжительным - до-

\footnotetext{
${ }^{7}$ Монастырский (1999 (сост.), с. 62-63). Выделение здесь и далее - мое, КК.

${ }^{8}$ Там же, с. 192.
} 
вольно скоро субъект переходит к следующему дискурсу, в силу чего создается впечатление, что вся присутствующая в этих стихах речь «не принадлежит» субъекту, представляет некую внешнюю по отношению к нему инстанцию. Такое «овнешнение» собственной речи помогает Пригову обращаться с любым дискурсом как с внеположной субъекту речью и, тем самым, критиковать этот дискурс. ${ }^{9}$

Этот эффект мог достигаться разными способами: наиболее очевидный из них - это монтирование фрагментов «чужой речи» друг с другом, в результате чего единый голос субъекта перестает существовать, раскалываясь на множество подчас диссонирующих голосов. Среди классиков концептуализма к такому способу организации речи чаще всего прибегал Лев Рубинштейн. ${ }^{10}$ Другой способ - сосредоточить внутри внешне цельного субъекта различные, выглядящие противоположными характеристики (это как раз и был метод Пригова). Оба этих способа «децентрализации» субъекта в несколько измененном виде получили продолжение в последующей поэзии, и для них обоих принципиальна характеристика речи субъекта как «отчужденной»: во всех случаях поэты настаивают на том, что субъект говорит не своими (или не вполне своими) словами. ${ }^{11}$

Эта проблематика находилась в центре внимания поэтов, которые отталкивались от концептуализма Пригова и Рубинштейна. Одной из первых наиболее последовательных попыток такого отталкивания была деятельность ряда авторов, дебютировавших в середине 1990-х годов, чья творческая практика была описана Д.В. Кузьминым под именем постконцептуализма. ${ }^{12}$ Согласно Д.В. Кузьмину, эти поэты возвращались «к классическому представлению о поэте как субъекте индивидуального высказыва-

${ }^{9}$ См. Липовецкий (2013); Корчагин (2013b).

${ }^{10}$ См. Аронсон (2007); Липовецкий (2008); Кукулин (2015, с. 29-31, 430-434).

${ }^{11} \mathrm{C}$ проблемой использования «чужой речи» связаны также две проблемы, имеющие большую историю в литературе XX века. Первая из них - это проблема монтажа, который начинает активно использоваться в литературе примерно одновременно с укреплением кино как искусства. Вторая - проблема использования документальных свидетельств в литературе. И монтаж, и документальность в равной мере использовались концептуалистами и многими их последователями (в диапазоне от Михаила Сухотина до Станислава Львовского) и часто воспринимаются как характерные именно для концептуалистских творческих стратегий. Причина этого, по-видимому, в том, что эти две стратегии организации текста лучше всего приспособлены для «децентрирования» субъекта и способны «автоматически» порождать ситуацию «мерцания». Подробнее о монтаже и документальности в поэзии см.: Kukulin (2010). Также о «чужой речи» в новейших поэтических практиках см.: Лехциер (2016).

12 Как выяснилось позднее, эта попытка преодоления концептуализма была не последней в российской литературе, и по этой причине для простоты дальнейшего изложения это движение я буду обозначать как П1. 
ния», ${ }^{13}$ но механика этого возвращения была крайне специфична. Поэты $\Pi^{1}$ действовали в ситуации множественности окружающих их дискурсов, и эти дискурсы впитывались их поэзией так же, как ранее поэзией Пригова, однако они пытались «подчинить» все эти разнообразные дискурсы какойто одной управляющей ими инстанции. Внешне это действительно похоже на возвращение к целостному, «центрированному» субъекту, однако на практике у поэтов $\Pi^{1}$ этот процесс никогда не доходил до конца, вследствие чего их стихи также были заполнены «чужой речью» так же, как стихи их предшественников концептуалистов. Субъект $\Pi^{1}$ был един интенционально, но фактически оставался мерцающим и расщепленным.

Для того чтобы лучше понять эту механику нужно обратится к понятию «новой искренности», которое возникло внутри концептуалистского круга и исторически предшествовало постконцептуализму, обозначая примерно тот же набор практик и стратегий организации субъекта. Автор этого понятия, Д.А. Пригов, неоднократно упоминал его в различных текстах и, по всей видимости, считал «новую искренность» законной частью собственной творческой стратегии. Своего рода «сократическое» определение «новой искренности» было дано Приговым в разговоре с Михаилом Эпштейном:

В чем заключается проблема новой искренности? В том что она - не искренность, а новая искренность. Искренность заключается в том, что вообще моя деятельность очень далека от наивности. Она предполагает, что все эти модели поведения суть культурные конструкты. Поэтому если ты точно угадываешь дискурс, скажем, искренности какого-то высказывания, то для человека они, собственно говоря, моментально служат триггерами, включателями этой самой искренности. ${ }^{14}$

Понятие «новой искренности» было присвоено $\Pi^{1}$ и во многом не сохранило то теоретическое значение, которое в него вкладывал Пригов, однако сыграло значительную роль в образовании того типа субъективности, который был свойственен этой поэзии. Исходя из текста Пригова, субъекта $\Pi^{1}$ можно описать таким образом: над «мерцающим» субъектом Пригова создавалась своеобразная «надстройка», своего рода суперсубъект, который не просто «включает» «искренность» в нужный момент, но подобно суперэго в психоанализе требует последовательно удерживать эту искренность, не сбиваясь на другие дискурсы и модальности. Однако - и здесь аналогию с психоанализом можно продолжить - субъект, для которого переключение между различными дискурсами происходит естественно, начинает избегать «искренности» в тот момент, когда внимание суперсубъекта ослабевает. Он, пользуясь терминологией «Словаря московской концептуальной школы», влипает в определенный дискурс.

\footnotetext{
${ }^{13}$ Кузьмин (2001).

${ }^{14}$ Пригов / Эпштейн (2010, с. 69).
} 
Поэтика $\Pi^{1}$ предстает в известном смысле телеологичной: процесс письма становится процессом обуздания той разноголосицы, что окружает субъекта, и неудивительно, что точкой в этом процессе становится ситуация, при которой суперсубъекту все же удается остановить «мерцание» подчиненного ему субъекта. Именно по этой причине два наиболее последовательных представителя $\Pi^{1}$, Дмитрий Воденников и Дмитрий Соколов, достигнув успеха в борьбе с «мерцанием», в конечном счете отказались от поэзии, уйдя в дневниковые жанры (как Воденников) или в журналистику (как Соколов). Крайне показательным свидетельством этого процесса может служить последний цикл стихов Соколова «Стихи про арабов и постмодернистов», где эксплицитно излагается программа преодоления наследия концептуализма:

Во власть идут по доброте, там нет людей плохих.

Я буду делать все, как все, и заставлять других.

Мы слишком разные цветы, такие не цветут.

А вдруг арабы не придут, арабы не придут?

А вдруг не крикнет муэдзин, не крикнет муэдзин?

Мы все друг друга доедим, друг друга доедим.

Мы все не значим ничего, не значим ничего.

Убей, убей в себе свой дар, попробуй без него. ${ }^{15}$

$\Pi^{1}$, конечно, не ограничивался этими двумя поэтами. Среди других ярких представителей этого течения можно указать на Кирилла Медведева, который реализовывал приведенную выше схему несколько иным образом, как бы акцентируя избыточный контроль над субъектом, осуществляемый некой внешней силой (это отмечает и Д.В. Кузьмин). ${ }^{16}$ При этом дальнейшая эволюция Медведева, связанная с переосмыслением наследия московского концептуализма и обращением к политической поэзии, увела его достаточно далеко от $\Pi^{1}$, сделав одним из центральных авторов второй волны постконцептуалистского движения - $\Pi^{2}$.

Интересно, что $\Pi^{1}$ мог вызывать реакцию со стороны авторов, принимавших в известном смысле более «традиционную» версию концептуализма. Здесь показателен пример Валерия Нугатова, поэта, один из периодов творчества которого был практически целиком посвящен своеобразной борьбе с $\Pi^{1}$, при которой мишенью для поэтических атак становился именно тот суперсубъект, что возникает в поэзии $\Pi^{1} .{ }^{17} \mathrm{C}$ точки зрения Нугатова попытка произвести «искреннее» высказывание не просто обречена на провал (с этим бы согласились и сами представители $\Pi^{1}$ ), но приводит к

\footnotetext{
${ }^{15}$ Соколов (2000-2004).

${ }^{16}$ См. Кузьмин (2001).

${ }^{17}$ См. Корчагин (2009); Арсеньев (2013).
} 
своеобразному эскапизму и аполитизму, не свойственному историческому концептуализму. Нугатов в книге „fAKE“ (2009) и ряде написанных после нее стихотворений последовательно доводил эту тенденцию до абсурда, чтобы наглядно показать тот символический и экзистенциальный крах, к которому приводила практика $\Pi^{1}$ :

мне говорят

что мои нынешние стихи

похожи на стихи кирилла медведева

только хуже

или лучше

но это не важно

[...]

на самом деле я больше люблю шарля бодлера

и его стихи

но мне никто не говорит

что мои стихи

похожи на стихи шарля бодлера

даже не говорит что похожи но хуже

и мне обидно ${ }^{18}$

Поэзия Нугатова явилась провозвестником того глубокого кризиса, в котором прибывал $\Pi^{1}$ и который разрешился радикальным перерождением одного из центральных авторов этого движения - Кирилла Медведева, во многом отступившего на позиции исторического концептуализма, актуализировав свойственные ему приемы и структуру субъекта как инструменты политической критики. ${ }^{19}$

\section{2.}

Повторное обращение к опыту концептуализма в $\Pi^{2}$ было связано с необходимостью создания новой политической поэзии, для которой концептуалистское устройство субъекта неожиданно оказалось наиболее подходящим. Причины этого, по-видимому, лежат в самом устройстве интеллектуальной и публичной жизни в России 2000-2010-х годов: современный российский интеллектуал существует в ситуации, когда ни один политический дискурс не может удовлетворить его полностью и, в то же время, испыты-

\footnotetext{
${ }^{18}$ Нугатов (2009, с. 37).

${ }^{19}$ См. Корчагин (2012); Bozovic (2014). Возможно, у кризиса П1 были и внутрилитературные причины: для поэтов П1 была принципиальна активность исторического концептуализма (в лице, прежде всего, Д.А. Пригова и Льва Рубинштейна), который выступал для них как своего рода литературный Другой. Но со смертью Пригова и уходом Рубинштейна в публицистику присутствие этого Другого, по всей видимости, чувствовалось поэтами П1 всё меньше, исподволь разрушая структуру субъективности, актуальную для их поэзии.
} 
вает необходимость взять один из имеющихся дискурсов на вооружение, воспринять его «как свой», не утрачивая при этом критической дистанции по отношению к нему. Некоторые исследователи связывают такое положение дел с общими изменениями в европейской мысли - с тем, что «[3]ападная философия прошла путь от критики чистого разума до критики коммуникативного разума», ${ }^{20}$ видя в новейшей постконцептуалистской поэзии прямое отражение этих процессов.

То, как Пригов описывал стратегию «мерцания», почти дословно повторяет описание этой ситуации за одним лишь уточнением: если для исторического концептуализма «мерцание» было инструментом дезавуирования идеологии (не только идеологии позднего советского общества, но и, например, идеологии «частной жизни» как в «новой искренности» Пригова), то для $\Pi^{2}$ оно выступало способом напомнить об условности любого политического дискурса при сохранении его как основы для коммуникации и взаимопонимания: другими словами, критика дискурса или присущих ему идеологем не аннулирует сам дискурс - он продолжает служить источником общезначимых смыслов.

Кроме Кирилла Медведева среди авторов, принадлежащих $\Pi^{2}$, можно выделить таких поэтов, как Антон Очиров, Роман Осминкин, Павел Арсеньев. Наиболее показательным примером здесь может служить поэзия Павла Арсеньева, который выступает не только как практик, но и как теоретик новой поэзии, а также как редактор альманаха «Транслит», где появляются стихи многих авторов, работающих в ключе новой постконцептуальной поэзии. Арсеньев определяет жанр создаваемых им текстов как «реди-риттен» (ready-written), однако с поэтикой московского концептуализма эти тексты связаны, пожалуй, более отчетливо, чем с классическими «реди-мейдами». Действительно, в центре таких текстов - фрагмент «чужой», уже готовой и заданной речи, однако этот фрагмент не берется в неизменном виде и не становится строительным блоком в более пространном коллажном тексте, а скорее реконструируется, его внутренняя логика проясняется поэтом, доводится до наиболее отчетливой формы, выявляющей то, насколько шаткими оказываются идеологические основания подобного высказывания - даже если это высказывание описывает собственную практику поэта:

Я молодой поэт-активист-гражданин,

И я спешу использовать любое воздушное пространство

для языкового упражнения,

утверждая необходимость прямой связи

жизни и искусства,

и выбираю для выставки

невинные строки из творчества советского диссидента,

${ }^{20}$ Лехциер (2016, с. 154). 
к творчеству которого не питает нежности

разве что самый равнодушный и черствый ребенок. ${ }^{21}$

На первый взгляд, эти стихи представляют практику самого Арсеньева в подчеркнуто ироническо-остраненном ключе: это выражается и в избыточности тех характеристик, которые поэт применяет к себе (nоэт-активист-гражданин), словно бы переписывая от первого лица восторженные аналитические тексты, посвященные его собственной деятельности и деятельности его единомышленников, и в преувеличенности эпитетов (самый равнодушный и черствыц̆ ребенок), и в синтаксической тавтологичности (строки из творчества советского диссидента, к творчеству которого $[\ldots])$ и т.д. Все эти приемы можно встретить уже в поэзии Д.А. Пригова, и у старшего поэта они также служили одним из центральных инструментов, маркирующих стратегию «мерцания»- то, что в тексте происходит подспудная критика используемого дискурса. Однако в случае Арсеньева эта критика выглядит во многом парадоксально: если «мерцание» предполагало критику дискурса, которая ведет, в конечном счете, к тому, что этот дискурс перестает быть убедительным, то стратегия Арсеньева и ряда близких ему поэтов приводит к обратному результату - к еще большему утверждению этого дискурса, к тому, что он, метафорически выражаясь, получает своеобразный «иммунитет» против разрушающего его вируса концептуализма.

Такое преодоление концептуализма средствами самого концептуализма получило достаточно заметное развитие в поэзии 2010-х годов: в это время появилось сразу несколько молодых поэтов, которые вошли в литературу с этими установками и чье творчество практически сразу получило заметный критический резонанс (Эдуард Лукоянов, Никита Сунгатов, Ян Выговский). Одним из наиболее показательных примеров «младшего крыла» $\Pi^{2}$ можно назвать книгу поэта Никиты Сунгатова (2015), уже название которой - «Дебютная книга молодого поэта» - недвусмысленно свидетельствует о том, что автор учитывает опыт исторического концептуализма: эта фраза часто встречается в рецензиях на новинки поэтического книгоиздания, публикуемых в поэтическом журнале «Воздух», и ее использование в качестве названия поэтической книги должно говорить о внимании автора к тому литературному контексту, в котором он существует, и о его желании преодолеть присущую этому контексту речевую автоматизацию, выраженную помимо прочего в использовании клишированных формул и языковых шаблонов.

Сунгатов создает своего рода «метапоэзию», в которой фрагменты критического дискурса о современной литературе и новейшие поэтические практики совмещаются внутри одного произведения. Это делается для того, чтобы проблематизировать литературное поле в целом, обратить внимание читателя на то, что оно устроено нелинейно - как с точки зрения

${ }^{21}$ Арсеньев (2015, с. 53). 
участия в общественной жизни (вернее, неучастия - невозможности действительно «владеть умами»), так и с точки зрения его внутренней структуры. В обоих случаях главной мишенью поэта оказывается некритическое восприятие норм и конвенций, пронизывающих современную российскую литературу. Можно сказать, что в поэзии Сунгатова бурдьевистская программа «расколдовывания» литературы, сведения ее к набору социальных взаимодействий, оказывается исходной точкой для поэтического творчества, которое в чем-то подтверждает подобный редукционистский взгляд на словесность, а в чем-то отвергает его.

Для поэзии Сунгатова важно различие между «чужой речью» и документальностью, которое во многих концептуалистских и постконцептуалистских практиках смешивается: здесь нет непосредственного обращения к документальным свидетельствам (как в поэмах Станислава Львовского и Антона Очирова), хотя ряд используемых поэтом цитат вполне может быть однозначно атрибутирован. Эти цитаты нужны поэту не для того, что подчеркнуть связь текста с реальностью, но для того, чтобы создать впечатление полифонического звучания множества голосов - воспроизвести ту ситуацию «мерцания» субъекта, которая была так важна для исторического концептуализма:

ветеран второй чеченской войны

взялся писать актуальные стихи

например, такие:

подземная темнота

сквозь которую пробивается еле живой

голос

пули

Puxmep

noem

все друзья над ним смеялись

и восстали из могил

дружно к телу прикасались

шестикрылый серафим

мёртвые однополчане

говорили с ним во сне:

«все поэты лежат в дагестане, а не в чечне $»^{22}$

${ }^{22}$ Сунгатов (2015, с. 13). 
Как видно в этом небольшом стихотворении различные типы поэтических дискурсов монтируются друг с другом, не оставляя место для целостного субъекта, роль которого сводится к монтажу. Здесь противопоставлены два фрагмента, которые должны восприниматься как принадлежащие к различным поэтическим традициям - фрагмент, представляющий собой актуальные стихи, и, словно бы оспаривающий его, метрический фрагмент, написанный в более традиционном ключе. В обоих фрагментах, несмотря на их небольшой объем, в концентрированном виде представлены языковые шаблоны, благодаря которым эти фрагменты опознаются как принадлежащие двум разным и конкурирующим друг с другом поэтическим традициям. В первом случае это «поэтика смысловой дискретности», связанная с именами Пауля Целана и Геннадия Айги, ${ }^{23}$ оперирующая небольшим количеством базовых образов (темнота и голос как раз относятся к таковым); ${ }^{24}$ во втором - условно традиционная поэзия, воспроизводящая каноны XIX века (именно такие стихи с точки зрения здравого смысла должен писать ветеран войны). Отношение к обеим традициям у поэта двойственное: он показывает, что язык каждой из них клиширован и автоматизирован и что каждая из них может быть использована как фрагмент в концептуалистском монтаже. 25 Чтобы подчеркнуть монтажную природу текста, поэт усиливает характерные особенности тех поэтик, к которым он обращается.

Первый фрагмент становится «узнаваем» благодаря специфической синтаксической организации, привычным лексическим клише (темнота, голос, петь) - повышенная концентрация всех этих элементов структуры текста на пространстве шести коротких строк уже свидетельствует о том, что фрагмент подвергается ироническому остранению; еще более об этом свидетельствует немотивированное упоминание Святослава Рихтера, который, как известно, был пианистом, а не певцом, в силу чего строки Рихтер / nоет воспринимаются как указание на автоматизированную природу используемой поэтики, где разнородные и несочетаемые элементы начинают монтироваться друг с другом в силу инерционной и клишированной природы самого способа письма.

Второй фрагмент устроен похожим образом: так, алогичность сочетания первых двух строк (ведь чтобы друзья могли смеяться, они должна снача-

${ }^{23}$ См. Фатеева (2006, с. 13); Житенев (2012, с. 386).

${ }^{24}$ Азарова (2010, с. 180).

25 Интересно, что поэты московского концептуализма практически не использовали подобные узнаваемые, «авторские» поэтики (вроде поэтик Геннадия Айги или Аркадия Драгомощенко) в своих монтажных структурах. Единственным, но ярким исключением в этом смысле был Андрей Монастырский, который в ряде текстов создавал монтажные структуры именно на основе таких поэтик (прежде всего, в поэме «Поэтический мир» и тексте «Элементарная поэзия № 3»), что, по всей видимости, было связано со стремлением поэта к «информационной перенасыщенности» текста (Житенев 2012, с. 437). 
ла восстать из могил, а не наоборот) усиливается строкой шестикрыльй серафим, которая синтаксически и семантически не связана с предыдущими и последующими строками, но при этом функционирует как отсылка к хрестоматийному стихотворению Пушкина. Иронически остраненная природа этого фрагмента подтверждается и используемыми рифмами - бедными (смеялись - прикасались), а затем - неточными (могил - серафим).

Таким образом, внешне перед читателем почти чистый пример использования стратегии «мерцания». Однако случай Сунгатова, как и разобранный выше случай Арсеньева, показывает, что сообщение, вложенное в каждый из этих фрагментов, не аннулируется и дезавуируется, даже при том, что оба фрагмента прочитываются как элементы концептуалистского монтажа: таким образом, стратегия «мерцания» оказывается нагруженной совершенно иным смыслом, во многом противоположным той критической задаче, над решением которой работал московский концептуализм. Так, в приведенном стихотворении поэт сообщает, что, несмотря на клишированность и ограниченность совмещаемых дискурсов, каждый из них по-своему может быть выразителен и служить для передачи лирического сообщения, которое само по себе обладает иммунитетом к критическому вирусу концептуализма.

Здесь мы имеем дело с поэтической атакой на этический релятивизм, свойственный публичному полю в современной России, где множественность дискурсов и наличие в одном медийном пространстве многочисленных конкурирующих друг с другом точек зрения часто становится способом отказать истине в праве на существование. Стихи Сунгатова и Арсеньева утверждают ровно противоположное: наличие многих точек зрения должно, напротив, заставлять внимательнее подходить к поиску истины, анализировать каждую из них, чтобы прийти к некой суммирующей, подлинно истинной точке зрения. Можно сказать, что такие задачи в той или иной форме ставят перед собой все авторы $\Pi^{2}$.

Таким образом, «мерцающий» субъект концептуалистов для младших поэтов, судя по всему, был основным вызовом - таким фактом развития литературы, который не мог быть проигнорирован. Разные поэты отвечали на этот вызов по-разному: некоторые $\left(\Pi^{1}\right)$ попытались «приручить» этот тип субъекта, сделать его управляемым, другие $\left(\Pi^{2}\right)$ - поставить его на службу политической критики. Этими двумя вариантами, вероятно, не исчерпывается рецепция концептуализма - так, отдельного внимания требуют практики, прямо или косвенно связанные с творчеством Егора Летова, который предложил собственное понимание концептуализма, оказавшееся достаточно влиятельным для ряда поэтов конца 1970 - начала 1980-х годов рождения (для Виктора Іваніва, Шиша Брянского и других). ${ }^{26}$ Но уже то, насколько отличаются два рассмотренных ответа на вызов концептуализма, позво-

\footnotetext{
${ }^{26}$ См. подробнее: Кузьмин (2001); Давыдов (2000, 2003).
} 
ляет сделать вывод о том, что концептуалистская поэтика не только остается актуальной для российской поэзии, но и продолжает менять ее облик.

\section{Литература}

Азарова, Н. (2010): Язык философии и язык поэзии - движение навстречу (грамматика, лексика, текст). М.

Аронсон, О. (2007): Слова и репродукции (О поэзии Льва Рубинштейна) // Аронсон, О.: Коммуникативный образ (Кино. Литература. Философия). М. 215-230.

Арсеньев, П. (2013): «Выходит современный русский поэт и кагбэ нам намекает»: к прагматике художественного высказывания // Новое литературное обозрение. 124, 2013. 243-251.

Арсеньев, П. (2015): «Отзыв на одну провокационную выставку современного критического искусства» и другие реди-риттены // Транслит. 17, 2015. 53.

Гройс, Б. (1993): Московский романтический концептуализм. Утопия и обмен. М.

Гройс, Б. (2013): Gesamtkunstwerk Сталин. М.

Давыдов, Д. (2000): Русская рок-культура и концептуализм // Русская рок-поэзия: текст и контекст. 4, 2000. http://www.fedy-diary.ru/Gold/books-r/poeza4/32.htm (23/01/2018).

Давыдов, Д. (2003): Панк-памятник [О поэзии Егора Летова] // Новое литературное обозрение. 64, 2003. 313-316.

Житенев, А. (2012): Поэзия неомодернизма. СПб.

Житенев, А. (2014): Две модели концептуализма: Всеволод Некрасов и Борис Гройс // Галиева, Ж. (сост.): Пригов и концептуализм: Сб. статей и материалов. М. 271-281.

Житенев, А. (2015): Архивация как самолегитимация: Папки «МАНИ» // Житенев, А.: Emblemata amatoria: Статьи и этюды. Воронеж. 99-116.

Корчагин, К. (2009): Двойник читателя [О поэзии Валерия Нугатова] // Новое литературное обозрение. 95, 2009. 242-249.

Корчагин, К. (2012): Революция маски: о поэтике и политике Кирилла Медведева // ОpenSpace.ru. http://os.colta.ru/literature/events/details/35834/ (23/01/2018).

Корчагин, К. (2013a): Расщепленный прах [О поэзии Василия Ломакина] // Новое литературное обозрение. 120, 2013. 289-295.

Корчагин, К. (2013b): «Маска сдирается вместе с кожей»: способы конструирования субъекта в политической поэзии 2010-х годов // Новое литературное обозрение. 124, 2013. 225-238.

Кузьмин, Д. (2001): Постконцептуализм (Как бы наброски к монографии) // Новое литературное обозрение. 50, 2001. 459-476. http://www.litkarta.ru/dossier/kuzmin-postkonts/dossier_987/ (23/01/2018).

Кукулин, И. (2014): Д.А. Пригов и Всеволод Некрасов: два варианта эстетической утопии // Галиева, Ж. (сост.): Пригов и концептуализм: Сб. статей и материалов. М. 243-262.

Кукулин, И. (2015): Машины зашумевшего времени: Как советский монтаж стал методом неофициальной культуры. М. 
Лехциер, В. (2016): Поэзия в эпоху постметафизического мышления // Азарова, Н. / Бочавер, С. (сост., ред.): Поэтический и философский дискурсы: история взаимодействия и современное состояние: Сб. ст. М. 144-160.

Липовецкий, М. (2008): Паралогии: Трансформации (пост)модернистского дискурса в русской культуре 1920-2000-х годов. М. 326-341.

Липовецкий, М. (2013): Практическая «монадология» Пригова // Пригов, Д.: Монады. M. 10-45.

Монастырский, А. (сост., 1999): Словарь терминов московской концептуальной школы. М.

Нугатов, В. (2009): fAKE: Стихи 2004-2008. Тверь.

Пригов, Д. / Эпштейн, М. (2010): Попытка не быть идентифицированным (2004) [Беседа М. Эпштейна с Д.А. Приговым] // Добренко, Е. / Кукулин, И. / Липовецкий, М. / Майофис, М. (сост., ред.): Неканонический классик: Дмитрий Александрович Пригов (1940-2007). М. 52-71.

Соколов, Д. (2000-2004): СТИХИ ПРО АРАБОВ И ПОСТМОДЕРНИСТОВ http://www.guelman.ru/slava/texts/sokolov.htm (23/01/2018).

Сунгатов, Н. (2015): Дебютная книга молодого поэта. СПб.

Фатеева, Н. (2006): «Мельчайших слов счастливые согласия...» (о континуальной дискретности текстов Г. Айги // Орлицкий, Ю. / Азарова, Н. / Дерепа, Д. (сост.): Айги: Материалы. Исследования. Эссе: В 2 тт. Т. 1. 6-16.

Bozovic, M. (2014): Poetry on the Front Line: Kirill Medvedev and a New Russian Poetic Avantgarde. In: Zeitschrift für Slavische Philologie. 70 (1), 2014. 89-118.

Fitterman, R. / Place, V. (2010): Notes on Conceptualism. New York.

Golston, M. (2015): Poetic Machinations: Allegory, Surrealism, and Postmodern Poetic Form. Columbia.

Kukulin, I. (2010): Documentalist Strategies in Contemporary Russian Poetry. In: Russian Review. 69, 2010. 585-614.

Perloff, M. (2010): Unoriginal Genius. Poetry by Other Means in the New Century. Chicago / London. 


\section{Марк Липовецкий (Болдер)}

\section{«Цитатный» субъект: неоакмизм, концептуализм, пост-концептуализм}

Роль цитат и различных апроприаций в поэзии модернизма и постмодернизма обсуждалась не раз. ${ }^{1}$ По мнению этих исследователей, апроприация «чужого слова» в модернистской традиции воплощает новый тип мозаичной субъектности и особое понимание истории (теоретически артикулированное Ницше, Шкловским, Беньямином и Деррида), в соответствие с которым повторения прошлого не отменяют сингулярности нового, а оформляют ее. В то же время

quotational texts quote something that has not yet been said, some other beginnings. $^{2}$

Проясняя эту мысль, Патрик Грини, автор недавней книги „Quotational Practices", добавляет:

[...] the past matters not only because of what actually happened but also because of the possibilities that were not realized and that still could be. Quotation evokes these possibilities. By repeating the past, artists and writers may be attempting to repeat that past's unrealized future. ${ }^{3}$

Сравните:

Для Мандельштама все эпохи сосуществуют, прошлое еще предстоит открыть в будущем (ср. «сколько радостных предчувствий: Пушкин, Овидий, Гомер»), а резкий социально-культурный сдвиг способен оживить ощущение давно прошедшего. ${ }^{4}$

Иными словами, устанавливая с помощью цитатности личные отношения с культурной памятью, (пост)модернистский поэт одновременно заново изобретает историю, раскрывая ее нереализованные возможности. Разумеется, такие отношения с прошлым напрямую отражают и одновременно формируют субъектность.

Но дело не только в этом. По мнению Грини, сами отношения, выстраиваемые автором с «чужим словом» и чужим сознанием посредством цитат, содержат в себе почти утопическую модель субъектности. Исследователь сравнивает цитатность с тем, что Фуко называет „governmentality“:

\footnotetext{
${ }^{1}$ См., например, Oraić-Tolić (1990), Goldsmith (2011), Perloff (2010), Greaney (2014).

${ }^{2}$ Greaney (2014, p. 7).

${ }^{3}$ Там же.

${ }^{4}$ Левин / Сегал / Тименчик / Топоров / Цивьян (1974, с. 49).
} 
Governmentality directs flows and organizes heterogeneity with the aim of allowing the potential of these heterogeneous elements to be best realized. „To govern, in this sense, is to structure the possible field of actions of other" (Foucault). ${ }^{5}$

По мысли Грини,

Quotational writing, it seems, manages texts - rearranges, represents reuses them - just as governmentality manages body [...] Coextensive with governmentality are forms of resistance, ways to imagine ,alternate production of subjectivity“. 6

Ниже я попытаюсь схематично рассмотреть модели цитатного письма, сложившиеся в русской поэзии за последние 30-40 лет, обращая внимание на отмеченные функции цитатности по отношению к субъекту: (1) реализацию нереализованных исторических возможностей - как способ оформления (альтернативного - субъектного) исторического времени; и (2) поэтическую ,governmentality“ (или ее подрыв), структурирующую отношения «своего» и «чужого» сознаний и языков. Важно подчеркнуть, что эти модели сосуществуют, а не сменяют друг друга. Поэтому свои примеры я буду выбирать из стихов, написанных в 1990-2000-е гг.

1.

Нет сомнений в том, что в русской поэзии интенсивность цитатности и, шире, эксплицитных интертекстов, неуклонно возрастала со времен акмеизма. Фразы Ахматовой о том, поэзия сама «одна великолепная цитата», и Мандельштама о «цитате-цикаде» стали литературоведческими штампами, начиная с рубежа 70-80-х гг. Именно тогда в журнале «Литературное обозрение» развернулась масштабная дискуссия о «плодах просвещения», а точнее, о цитатах и аллюзиях в советской поэзии. Сам этот количественный подъем свидетельствовал не о падении оригинальности поэзии (как утверждали рассерженные критики), а об актуализации именно модернистских концепций субъектности и историчности, унаследованных от акмеизма.

Можно утверждать (разумеется, сильно огрубляя), что в 70-80-е гг. складываются две контрастные модели цитатности: одна связана с неоакмеизмом, а другая с концептуализмом. Неоакмеизм, который охватывает как подцензурную поэзию (Кушнер, Ахмадулина, Самойлов), так и андеграунд (Бродский, Кривулин, Шварц, Стратановский), обращается с цитатой как с аллегорией исторической памяти. Цитата или, вернее, цитатность как свойство поэтического стиля становится важнейшим средством «реконструкции истории в условиях, „когда акции личности в истории падают“». ${ }^{7}$

${ }^{5}$ Greaney (2014, p. 14).

${ }^{6}$ Там же.

7 Левин / Сегал / Тименчик / Топоров / Цивьян (1974, с. 42). 
Как писали авторы классической статьи 1974-го года о семантической поэтике акмеизма:

Авторское я здесь оказывается равновеликим культуре, природе, истории, соответственно, самые интимные признания и автоописания воспринимаются как голос универсального человеческого начала в данной уникальной культурно-исторической природной ситуации. ${ }^{8}$

Цитата в неоакмеизме всегда имеет автора и позволяет установить личные диалогические отношения между современным текстом (или поэтом) и автором цитаты, как правило, уже принадлежащим истории. Цитата понимается как осколок некоего спрятанного или погибшего «логоса»; через цитатность современный неоакмеист утверждает свою повторимо-сингулярную субъектность, одновременно «вписывая» себя в культурно-исторический контекст и выговаривая свое неповторимое место в нем. Понятно, что сверхзадачей этой модели цитатности было восстановление разрушенной советской эпохой непрерывности культуры (о чем Бродский говорил в своей Нобелевской речи).

В поздних вариантах неоакмеизма, сохраняясь в общих чертах прежней, ситуация несколько меняется. Попробую продемонстрировать, что я имею в виду, на нескольких примерах из поэзии С. Стратановского и В. Кривулина. В стихах Стратановского из сборника «Тьма дневная» восстановление непрерывности культурной истории не воспринимается автором как идеальная цель, а переживается, скорее, как печальная данность. Потенциальность, скрытая в цитатах, уже успела развернуться в современной истории, не отменяя первоначальное значение цитаты, но накладывая на него сегодняшнее, иногда тривиализирующее, иногда зловещее значение. См., например:

Вот Павка Чичиков -

вчера партаппаратчик

Теперь хозяин фирмы по продаже

Российских голых душ

в лимонный Сингапур. 9

\footnotetext{
8 Там же, с. 59.
}

Полагаю, эти принципы приложимы и к неоакмеизму, хотя и с некоторыми оговорками. Как показал С. Бирюков в докладе «Исторический авангард как субъект и объект неоавангарда», прочитанном на конференции „Grundlagen: Zur Theorie des lyrischen Subjekts im Kontext der neueren Dichtung / Основы: теория лирического субъекта в контексте новейшей поэзии“ (2.-6. November 2015, Universität Trier), аналогичные принципы наблюдаются и в неоавангарде 1980-2000-х гг. Хотя в неоавангарде цитируется «классический» авангард начала XX века, в современном контексте сама эта процедура выступает как средство реконструкции исторической непрерывности, несмотря на то, что сами авангардные тексты стремятся прервать и начать заново традиционные поэтические и исторические нарративы.

${ }^{9}$ Стратановский (2000, с. 15). 


\section{Притча о двух врачах}

Вкалывать стал участковым врачом Разумихин

За копейки горбатиться, а Раскольников, скорбный романтик

Стал геронтологом

и смертельные дозы по сговору

Вкалывать стал старикам

дедам-бабкам недужным, ненужным

За солидные бабки ${ }^{10}$

Президент говорит:

«Наш великий Михайло Бахтин

Завещал, уходя,

и торжественно мы обещаем

Выполнять непреложно,

как бы ни был безбожно кровав

Карнавал всероссийский» ${ }^{11}$

В послесловии к сборнику Стратановского, Кривулин писал:

Первое же слово этой книги стихов - «псевдоморфоза» - отсылает читателя к Освальду Шпенглеру, оно своего рода ключ к тому, что и как сообщит нам «Тьма дневная». По Шпенглеру, «псевдоморфоза» обозначает видимые, внешние социокультурные изменения, которые, претендуя на радикализм, тем не менее не затрагивают внутренней природы той или иной культуры. ${ }^{12}$

Литературный текст, к которому - через имя персонажа - отсылает Стратановский, предстает при таком подходе некоей программой истории. Современный же поэт выступает как медиатор, а вернее, декодировщик, соотносящий литературный «код» с исторической реализацией. „Governmentality“ Стратановского направлена именно на литературу, а не на историю. Бедность литературной программы, по этой логике, отзывается в обедненном спектре исторических сценариев. В этом случае, Стратановский оборачивает на литературный первоисточник - и, разумеется, на стоящий за ним социокультурный дискурс - упрек в нереализованности потенциала, как это происходит, например, в стихотворении «Шариков - Преображенскому»:

А ведь я-то надеялся

Отсобачиться начисто -

Стать человеком вполне

Пусть кошколовом,

Но все же не уголовником

И не убийцей научным,

Живопыталой, как ты [...]

Сдох во мне человек,

${ }^{10}$ Там же, с. 38.

11 Там же, с. 41.

${ }^{12}$ Кривулин (2000, с. 175). 
и течет век посмертный

Век беспросветный, собачий. ${ }^{13}$

Смысл, зачеркнутый «Собачьим сердцем», достраивается Стратановским как возможность, утраченная историей. Его „governmentality“, таким образом, направлена на предельно полную реализацию смыслов - императивную, по его логике, для литературы.

Кривулин в своих поздних стихах несколько иначе выстраивает отношения между литературой и историей, а через них - субъектность и ,governmentality“. Показательно в этом отношении стихотворение «Миллениум на пересменке» из его последнего сборника «Стихи юбилейного года»:

кто пил из черепа отца

кто ел с чужой тарелки

но тоже не терял лица

не портил посиделки

и даже кто не ел не пил

а просто был допущен

стоять на стреме у перил

да кланяться идущим

на пир ли с пира ли где спирт

с бандитом жрал есенин

где мордою в салате спит

испытанный хозяин -

все, провожая каждый год

в небытие, к монахам, как радовались мы что вот живем под новым знаком год уходил а век торчал с новорожденным студнем в обнимку, и мороз крепчал и штамп стучал по судьбам он пропуск выписал себе в тысячелетье третье по блату, по глухой алчбе по страсти к малым детям

и, думаешь, после всего что он сплясал на цирлях отпустят беленьким его с переговоров мирных ${ }^{14}$

Все стихотворение представляет собой развернутый перифраз знаменитого стихотворения Тютчева «Цицерон» (1836):

Блажен, кто посетил сей мир

В его минуты роковые!

\footnotetext{
${ }^{13}$ Стратановский (2000, с. 97).

${ }^{14}$ Кривулин (2001, с. 51).
} 
Его призвали всеблагие

Как собеседника на пир.

Он их высоких зрелищ зритель,

Он в их совет допущен был -

И заживо, как небожитель,

Из чаши их бессмертье пил!

Мотив пира («на пир ли с пира») и допущенности («и даже кто не ел не пил / а просто был допущен») закрепляют эту связь через «рассеянную» цитату. Однако, помимо этого «рамочного» интертекста, стихотворение пронизано целым рядом других цитат.

Оно начинается с несколько измененной (скандальной) строчки поэтанационалиста Ю. Кузнецова: «Я пил из черепа отца» (1978). За ней следует перифраз первой строчки из стихотворения Высоцкого «Тот, кто с нею раньше был» (1962): «В тот вечер я не пил, не ел». Потом появляется перифраз Пастернака, соединяющий «талон на место у колонн» из «Красавица моя, вся стать» (1931) с мотивами из «Высокой болезни» (1923), знаменитой восторженным описанием Ленина: «И помню, в самый день торжеств, / Пошел взволнованный донельзя / К театру с пропуском в оркестр [...] / Проснись, поэт, и суй свой пропуск». Единственная маркированная именем автора искаженная цитата «где спирт с бандитом жрал есенин» отсылает к стихотворению «Да! Теперь решено, без возврата» (1922): «Я читаю стихи проституткам / И с бандюгами жарю спирт». Строфа «год уходил а век торчал / с новорожденным студнем / в обнимку, и мороз крепчал / и штамп стучал по судьбам» - интертекстуально связана с Мандельштамом и, в особенности, с мотивами стихотворения «Век мой, зверь мой...» (1924): через снижение «теплого хряща морей» и позвоночника века до «новорожденного студня» рядом с урезанной до «штампа» ходячей остроты о «мандельштампе». ${ }^{15}$ Наконец завершается стихотворение слегка трансформированной цитатой из «Маски египтянки» Блока из «Масок на улице» (1909):

Глаза смотрят так, что побеждают все лицо; побеждают, вероятно, и тело и все окружающее. Полное равнодушие и упорство устремления, вне понятий скромности, стыда или наглости; единственно, что можно сказать про эти глаза, это - что они смотрят и будут смотреть, как смотрели при жизни. Помыслить их закрытыми, смеженными, спящими - невозможно. В них нет ни усталости, ни материнства, ни веселья, ни печали, ни желания. Все, что можно увидеть в них, - это глухая ненасытная алчба; алчба до могилы, и в жизни, и за могилой - все одна и та же. Но никакого приблизительного удовлетворения этой алчбы не может дать ни римский император, ни гиперборейский варвар, ни олимпийский бог. Глаза смотрят так же страшно, безответно и томительно, как пахнет лотос. Из века в век, из одной эры - в другую эру. ${ }^{16}$

15 Такая «сборная» форма цитации характерна и для самих акмеистов. См. Майофис / Кукулин (2006).

${ }^{16}$ Блок $(1965$, с. 50$)$. 
Этот текст Блока читается как символическое выражение потенциальных возможностей России, открывшихся в начале века и, по логике Кривулина, безжалостно растраченных к концу миллениума. Живые глаза давно умершей египтянки, соединяющие эры, контрастно противопоставлены двойной смерти - питью из черепа отца, с которого начинается стихотворения. Хотя, кроме Есенина, в «Миллениуме на пересменке» авторы цитат не идентифицированы; для Кривулина, по-видимому, крайне важно и кому принадлежат цитируемые строки, и какова была позиция и судьба данного поэта. Как он сам говорил:

В основе нового поэтического слова лежит принцип свертки исторического опыта в личное слово. ${ }^{17}$

Именно через соотнесенность между цитатой и историей ее автора возникает в этом стихотворении второй план, в котором - невысказанно, но явно - раскрывается потенциал приводимой, на первый взгляд, «невинной» цитаты. Имена и личности, встающие за цитатами, и служат основанием для вынесения приговора веку.

Более того, даже датировки цитируемых произведений выстраиваются в четко сбалансированную временную перспективу: от конца XX века к его началу - что читается как судебное «дело», сопровождаемое при этом постоянно звучащим тюремным арго, которое тоже проходит определенную траекторию, достигая кульминации в «приговоре» веку, выраженном на языке тюрьмы. Таким образом, цитатность у Кривулина воплощает особую „governmentality“, сопоставимую с ритуалом суда. Каждая цитата и стоящий за ней автор служат свидетелями обвинения, но обвинения, исходящего не от абстрактного судьи, а от одного из заключенных (или от их группы): перед нами внутрикамерный суд равных над равным. Век осужден за то, что «сплясал на цирлях» - то есть унизился, предал себя, потерял достоинство перед властью. Именно этим приговором оборачивается тютчевская «допущенность» поэтов на пир всеблагих.

Однако, в целом, и пример Стратановского, и пример Кривулина подтверждают характеристику авторов статьи о «семантической поэтике» акмеизма:

Гетерогенные элементы текста, разные тексты, разные жанры [...] все скреплялось единым стержнем смысла, призванного восстановить соотносимость истории и человека. ${ }^{18}$

2.

Использование цитаты для обратной цели - разрушения стереотипных связей, предполагающих соотнесенность человека и истории, и обнажение их

\footnotetext{
${ }^{17}$ Каломиров (1986, с. 460).

18 Левин / Сегал / Тименчик / Топоров / Цивьян (1974, с. 51).
} 
мнимости и фиктивности, разрабатывается в концептуализме начиная с середины 70-х гг. Концептуалистская модель цитатности и апроприации представлена прежде всего Вс. Некрасовым, Д. Приговым и Л. Рубинштейном. В их текстах цитата всегда является анонимной, даже когда у нее есть узнаваемый автор. Цитата выступает у концептуалистов как симулякр исторической памяти, она полностью принадлежит современной культуре и является аллегорией или элементом ее «коллективного бессознательного». Путем апроприации поэт может демонстрировать «цитатный», а значит, безличный характер всего, что кажется личным, тем самым деконструируя модернистскую концепцию субъекта. Так происходит, например, у Всеволода Некрасова:

Музыкальная фраза
Слышали
Музыку

Боже ты мой

И какие же уши

Слушали

Музыку

Революции

Музыка музыкою ${ }^{19}$

Нас тьмы и тьмы

и тьмы и тьмы итьмыить мыть и мыть ${ }^{20}$

Унылая пора

очей очарованье

Приятна мне твоя

прощальная краса

да

как бы ни был

красив Шираз

еще раз

как бы ни был

красив Шираз

\footnotetext{
${ }^{19}$ Некрасов (2012, с. 158).

20 Там же.
} 


\section{а разве можно \\ быть \\ красивше нас \\ с вами ${ }^{21}$}

Цитата здесь на глазах обессмысливается, превращаясь в код, потерявший сообщение.

Другой путь - особенно характерный для Рубинштейна - это построение интонационно и ритмически выверенных композиций из «чужих» (или квази-чужих) слов и фраз, которые тем не менее передают неустойчивую, ситуативную, но несомненную сингулярность авторской субъектности. Как правило, «главный» интертекст честно указан в заголовке «картотеки» Рубинштейна: «Шестикрылый серафим» (1984) или «Сонет 66» (1987). Безусловно, каждый из переосмысляемых таким образом классических текстов оказывается больше самого себя - за каждым стоит определенная поэтическая мифология: оправдание поэзии через сакрализующую трансформацию поэта в «Пророке» или же через страдание и сострадание в «Сонете 66» Шекспира - с этими-то мифологиями Рубинштейн и работает.

Так, в «Шестикрылом серафиме» строчки, прямо или косвенно отсылающие к «Пророку», перемешаны с, казалось бы, посторонними фрагментами. Сами эти фразы тоже очень неоднородны: от «Да, и вы не Пушкин...» и «Есть много, друг Гораций, различных ситуаций...» до классических цитат и перифразов, вроде «Перстами легкими, как сон» или гоголевского, из «Шинели»: «Как будто ветер с четырех сторон...» Но, вспыхивая через неравные промежутки времени, фразы, прямо или ассоциативно связанные с темами Пушкина (призвания поэта, «высокого» искусства), тем не менее подготавливают последнюю карточку, которая читается и как обобщение сюжета всей композиции, и как обновленная версия истории смерти и воскрешения пушкинского пророка:

Невольно вскрикнув от внезапной боли,

Он повернулся на спину, затих...

И все вокруг затихло. Тишину

Ничто не нарушало, кроме капель

Дождя и голосов на переправе,

Торгующихся с лодочником. Тот,

Ссылаясь, очевидно, на погоду,

Накинуть требовал. Другие голоса

С ним спорили. И эта перебранка

Не кончится, казалось, никогда.

Потом он снова потерял сознанье.

И сколько так он пролежал - минуту,

Неделю, год, столетие - никто

Сказать не может. Но сияло солнце,

${ }^{21}$ Там же, с. 204. 
Когда он вновь открыл глаза и понял,

Что вновь родился... 22

В этом тексте Рубинштейна погружение в «шум языка» замещает торжественную встречу будущего пророка с шестикрылым серафимом. Но и у Пушкина, и у Рубинштейна поэт должен открыться всему в мире, и горнему и дольнему, и быть сметенным этим потоком - пережить смерть своего. Совсем не случайно процитированный выше, написанный белым стихом текст с последней карточки «Серафима», в сущности, совсем не пародиен. Рубинштейн, как я полагаю, стремится акцентировать параллели - а не расхождения - между пушкинской и своей версией смерти и возрождения субъекта; манифестацией этой рубинштейновской версии становится насыщенный мифологическими смыслами мотив переправы. Только там, где у Пушкина - «Бога глас», высшая гармония, там у Рубинштейна - «перебранка», неумолчный языковой хаос.

В качестве другого яркого и масштабного примера концептуалистской цитатности рассмотрим проект Пригова «Евгений Онегин Пушкина» (1992), который сам автор называл «одним из самых моих амбициозных проектов». Суть проекта состояла в переписывании всего текста «Евгения Онегина» с заменой всех эпитетов либо на «безумный», либо на «неземной». Как сам Пригов указывает в Предуведомлении, замысел проекта восходит к 70-м гг., когда такой акт переписывания понимался бы как перенос из поля официальной культуры в пространство самиздата. Осуществленный, однако, в начале 1990-х гг., проект приобрел совершенно иной смысл. С одной стороны, Пригов подчеркивает монашеское служение священному тексту, который, как знает автор, после его переписывания вряд ли будет кем-то прочитан целиком:

Наружу сразу же выходит аналогия с терпеливым и безымянным восторгом монастырских переписчиков. В наше время это работает, работает. Буквально несколько лет назад не работало, а сейчас - работает. Неожиданно обнаруживается как бы смирение и благоговение, как качества маркированного и отмечаемого с благосклонностью литературного поведения. Думаю, что вряд ли кто-либо сейчас подвигнется на прочтение слепого машинописного текста, к тому же, изданного неимоверное количество раз самым роскошнейшим образом и зачастую хранящегося в анналах личной памяти, если не целиком, то по частям или в виде отдельных выражений, строчек, слов. ${ }^{23}$

С другой, замена пушкинских эпитетов на «безумный» и «неземной» порождает эффект, который сам Пригов определяет как лермонтизация:

[...] будучи в полнейшей уверенности, что никто не подвигнется на прочтение хотя бы малой страницы этого текста, должен заранее отметить одну особенность этого издания - оно, вернее, он, текст то есть, как я люблю это теперь называть, он лермонтизирован. То есть он как бы прочитан глазами

22 Рубинштейн (2000, с. 384).

${ }^{23}$ Пригов (1992, с. 150). 
последующей (естественно, последующей после Пушкина) превалирующей романтической традиции (в смысле, Чайковского). ${ }^{24}$

По интерпретации М. Ямпольского:

[...] Пригова интересует механизм автоматизированной генерации текста, где вместо эпитетов чисто механически подставляется одно из двух выбранных им слов. Любопытно при этом, что эта бессмысленная, чисто механическая операция, по его мнению, должна вызывать в сознании читателя идею наивной искренности и восторга. Восторг - важное тут понятие. Это сильный аффект, но будучи аффектом, в системе Пригова, восторг приводит к абсолютной десемантизации своего выражения. Чем более выражен аффект, тем менее он содержателен. [...] В «онегинском» эксперименте Пригов, таким образом, касается глубинных механизмов творчества, в которых эмоции, аффекту отводится важное место. ${ }^{25}$

Думается, этим аспектом смысл приговской апроприации не исчерпывается. Благодаря заменам, Пригов разворачивает потенциал, скрытый в оригинале и уже раскрытый всей последующей романтической традицией. Совмещая оригинал и то, как он запечатлен культурой, автор «Евгения Онегина Пушкина» добивается яркого комического эффекта:

Безумный дядя честных правил

Когда безумно занемог

Безумствовать себя заставил

Безумней выдумать не мог

Его безумная наука

Безумная какая скука

Сидеть безумно день и ночь

Не отходя безумно прочь

Безумно низкое коварство

Полубезумных забавлять

Его безумно поправлять

Безумно подносить лекарство

Безумно думать про себя

Безумие возьмет тебя ${ }^{26}$

Пригов воссоздает, или вернее, симулирует безличный процесс апроприации пушкинского текста романтической традицией, которая, собственно, и определит дальнейшее функционирование «Евгения Онегина» в мировой культуре. Присвоенный традицией текст не только утрачивает авторство, но и становится абсурдным («безумным»), одновременно воплощая возвышенное («неземное»). Усвоение оригинального текста культурой и его канонизация в качестве поэтического образца, таким образом, достигается путем стирания субъектности и разрушения смысла. Масштабность проек-

\footnotetext{
24 Там же.

25 Ямпольский (2016, с. 159).

${ }^{26}$ Пригов (1992, с. 152).
} 
та переписывания «Евгения Онегина» соответствует работе истории - или вернее, предлагает ее действующую модель.

Собственно говоря, перед нами наиболее чистый - на русской почве пример того, что Ги Дебор и другие ситуационисты называли „détournement“. Основанный на таком воспроизводстве культурных стереотипов, при котором они превращаются в саморазрушительную самопародию, „détournement“", по Ги Дебору, представляет собой противоположность цитирования:

the antithesis of quotation, of a theoretical authority invariably tainted if only because it has become quoted. ${ }^{27}$

\section{„Détournement“" формирует}

the language of the critique of the totality, of the critique of history. Not some „writing degree zero“ - just the opposite. Not a negation of style, but the style of negation. [...] The defining characteristic of this use of détournement is the necessity for distance to be maintained toward whatever has been turned into an official verity [...] Détournement [...] is the fluid language of anti-ideology. ${ }^{28}$

The distortions introduced in the detourned elements must be as simplified as possible, since the main impact of a détournement is directly related to the conscious or semiconscious recollection of the original contexts of the elements. [...] There is not much future in the détournement of complete novels, but during the transitional phase there might be a certain number of undertakings of this sort $[\ldots]^{29}$

Все эти характеристики применимы к концептуалистской цитатности и в особенности к приговскому проекту. Как и в акмеизме, у Пригова «авторское $я$ здесь оказывается равновеликим культуре, природе, истории $[\ldots]{ }^{30}$ Однако, в эту равновеликость вписана дистанция и установка на критику истории и критику тотализирующей идеологии, наделяющей, к примеру, «Евгения Онегина» статусом возвышенного абсолюта. „Governmentality“, реализованная в «Евгении Онегина Пушкина» воплощает сопротивление, ибо обнажает насилие истории над субъектом и субъективными смыслами, выраженными в литературном тексте. Впрочем, и аспект насилия описан Ги Дебором в качестве характеристики ,détournement“:

the violence of détournement itself mobilizes an action capable of disturbing or overthrowing any existing order $[\ldots]^{31}$

Поэзия 2000-2010-х гг., которую, вслед за Д. Кузьминым, ${ }^{32}$ часто называют «постконцептуалистской», вместе с тем, впитала в себя и неоакмеисти-

\footnotetext{
${ }^{27}$ Debord (1995, p. 145-146).

${ }^{28}$ Там же, p. 144, 145.

${ }^{29}$ Debord / Wolman (1956).

30 Левин / Сегал / Тименчик / Топоров / Цивьян (1974, с. 59).

${ }^{31}$ Debord (1995, p. 146).
} 
ческие влияния. Во всяком случае, такие видные поэты последних десятилетий, как М. Степанова, Е. Фанайлова, П. Барскова, прошли школу неоакмеизма. Несколько схематизируя, можно сказать, что в поэзии этих лет происходит парадоксальный синтез неоакмеистской и концептуалистской моделей цитатности. С одной стороны, в поэзии этих лет «авторские» цитаты (П. Барскова, Е. Фанайлова, М. Степанова) встречаются так же часто, как и анонимные (С. Львовский, А. Родионов, К. Медведев, С. Завьялов). Однако и те, и другие, даже когда они взяты из исторических источников, выступают как аллегории современного состояния и сознания (см., например, цикл С. Львовского «Советские застольные песни» или «Четыре оперы» М. Степановой). Они не предполагают диалога с прошлым, так как прошлое выступает закрытым для подобных отношений и во многом непостигаемым, тем самым представляя собой форму трансцендентного (или абсурдного). Поэтому цитатность в стихах этого поколения направлена не столько на концептуализацию истории, сколько на оформление лирического субъекта. Очень показательна в этом отношении поэма С. Львовского «Чужими словами», в которой цитаты из литературы, новостей, блогов знакомых, формируют поток сознания лирического субъекта, что представляется развитием экспериментов Рубинштейна.

Вместе с тем, фрагментарный и цитатный характер лирического «я» является в этой поэзии предметом (само)анализа и проблематизации, как это видно, например, в таких строках Барсковой:

Невозможно помнить и понимать без учебника, без сравненья

Как (допустим) Марина ${ }^{33}$

Что это значит? Где я?

В этой фразе? Тень ли

Столетней давности

Так длинна, что пускает корни

Или душа, живущая в никотиновом горьком горле,

Столь труслива, что жаждет костылей, кислородной маски

Поддельного паспорта, на ночь сказки? ${ }^{34}$

Подобно концептуалистам, авторы этого поколения «анонимизируют» вполне индивидуальную цитату, превращая ее в означающее безличного дискурса - и одновременно, в знак сомнительности субъективного высказывания. Таково, например, стихотворение Андрея Родионова из его сборника «Звериный стиль» (2013):

Девочки пели в масках в церковном хоре

Богородица выгони путина вон

у Надежды Толоконниковой плакал ребенок

а Достоевский не велел, чтобы плакал он

\footnotetext{
${ }^{32}$ См. Кузьмин (2001).

${ }^{33}$ Имеется в виду Марина Цветаева.

${ }^{34}$ Барскова (2010, с. 40).
} 
и храм был страшен как панк-молебен

и их тогда отвели в тюрьму

красиво одетых нежных царевен

под масками слез не видать никому

все плакали тихо, но вой был жуток

и лишь далеко в кирпичном кремле

причастный к тайнам, плакал путин

на что Федор Михалыч как раз положительно смотрел ${ }^{35}$

При внешней непритязательности, стихотворение предлагает довольно сложную и остроумную систему цитат. Ритмико-мелодическая структура (за исключением последней строки) и отдельные строки («Девочки пели...», «И храм был страшен», «причастный к тайнам плакал...»), безусловно, цитируют стихотворение Блока «Девушка пела в церковном хоре» (1905). Но у Родионова Блок «подменен» Достоевским, выступающим в качестве эмблемы сентиментально-религиозного дискурса, как бы поглотившего оригинальный текст. В этом смысле Родионов воспроизводит приговский тип цитации. Неслучайно стихотворение заканчивается так называемой «приговской строкой»: «на что Федор Михалыч как раз положительно смотрел» (характерно, что в сборнике за этим стихотворением следует текст под названием «Д.А. Пригову»).

Однако Родионов идет несколько дальше, чем Пригов. В стихотворении также цитируется панк-молебен „Pussy Riot": «Девочки пели в масках в церковном хоре / Богородица выгони путина вон», и называется имя лидера группы - Надежды Толоконниковой. При этом конкретика художественного высказывания „Pussy Riot“ подменяется все тем же сентиментальным дискурсом, на этот раз пародирующим аргументы либеральной общественности. Иначе говоря, Родионов проецирует тот механизм поглощения индивидуального безличным, который предъявлен как антисмысл истории в приговском «Евгении Онегине Пушкина», на настоящее, в котором этот процесс происходит не в течение десятилетий или столетий, а моментально, по ходу суда над группой.

«Анонимизация» индивидуальной цитаты приобретает иную семантику в стихотворении Полины Барсковой «Пятое письмо о русской поэзии. Агон» из сборника «Сообщение Ариэля» (2011). Цитатой в строгом смысле слова здесь является только перечень рифм, автором которых является герой стихотворения:

Он вернул русской рифме

Ее самоё -

Точные

Внезапные

${ }^{35}$ Родионов (2013, с. 19). 
Бесстыдные

Смеющиеся

Рифмы

По каме ли по камере остынем пустыням замо́к замолк свобода слабо, да? ${ }^{36}$

Далеко не всякий филолог сходу опознает в этих рифмах стихи Высоцкого: «По Каме ли / по камере» из «Лекции о международном положении», «остынем / пустыням» из «Обо мне, о поездах и о пустынях», «Замо́к / замолк» из «Истории болезни. Ошибка вышла» и «свобода / слабо, да» из «К 15-летию Театра на Таганке». Затрудненность узнавания цитаты не случайна - Барскова последовательно акцентирует стертость и безличность в качестве отличительных свойств кумира:

Его простодушие, его хитроумие

Его власть, его слабость

Его заурядное лицо человека, постоянно заботящегося своим успехом,

Его ужас, его цепкость,

Плохие зубы, рот гузочкой,

Узкая грудь, маленькие и широконькие ступни.

Вместе с тем, те черты Высоцкого, которые могли бы спровоцировать моментальное «узнавание», даются почти зашифровано. Роль Дон Хуана в фильме М. Швейцера «Маленькие трагедии» (1979) метонимически заменена указанием на «любовника / с риторическим нутром / вроде каменной статуи». («Длань командора» тоже появляется в тексте, но раньше и в «дезориентирующем» контексте: «[...] сценические выходки, взгляды в камеру, / Всегда чрезмерные, тяжеловатые, ложащиеся на трепещущего партнера, / Как длань командора»). Песни Высоцкого из фильма С. Тарасова «Баллада о доблестном рыцаре Айвенго» (1982) вряд ли относятся к самым популярным его произведениях. Однако, именно Айвенго упомянут в тексте: «все мы смотрели до состояния сепии истертую копию айвенго». Ассоциация с уголовной культурой, сопровождавшая Высоцкого от ранних песен до роли Жеглова, заменена антитетической отсылкой к Шаламову: «Он мог притвориться уркой, / Червем-королем нар / Про́клятым проклятым / Писателем Шаламовым». И так далее.

В результате таких операций, с одной стороны, Высоцкий (поэт, а не актер) предстает как совокупность множества (в пределе бесконечного) субъектов: «Каменное его актерское нутро / Умело на бумаге вести существование - / Протею не снилось. / Словом, он мог превращаться во все». С другой стороны, итоговый результат оказывается граничащим с анонимностью: «[...] неопрятный необязательный коллаж [...] Так и стал Коломбиной, легонькой восковой куклой, / Агонизирующей под рокот агона в телевизоре [...]», «Народный любимец, баловень судьбы [...] оплаканный

\footnotetext{
${ }^{36}$ Барскова (2011, с. 28).
} 
олимпийской толпой» превращается в протеическое ничто; харизматичный и легендарный Высоцкий парадоксальным образом рисуется Барсковой и как «человек без свойств», и как концентрированное воплощение современной субъектности. Поэтому его «узнавание» и необязательно для восприятия стихотворения.

При этом у Барсковой «анонимизация» субъекта - выраженная через систему дезориентирующих цитат - не исключает субъектной перспективы. Высоцкий предстает в этом стихотворении как неотъемлемая (и возвращающаяся) часть личной истории героини - он ее «детский кумир»: «Как всегда бывало во времена смуты / Ей стал являться детский кумир»; «Когда-то, изнуренная пубертатной страстью, / Она вызнала о нем все, что умела». «Всеобщая история культуры», которую деконструирует Пригов, заменяется у Барсковой личной историей, в которой Высоцкий как харизматический символ безличности занимает свое, почти «соматическое», место. Именно эта невыразимая субъектность проступает, на мой взгляд, и в финале стихотворения - в описании смерти поэта:

Однако в своем последнем явлении к ней он был не при оружии,

Сам по себе.

Он сидел, улыбаясь,

Горячей, жалкой, прелестной улыбкой победителя,

Человека, быстрее всех прошедшего дистанцию,

Быстрее всех доведшего себя до состояния грезы

Сидел рядом

Смотрел мимо

Все повторял:

- Ласточка моя,

Еще совсем немного

Напряжение между разнообразно выраженными субъектностями, стирающими друг друга, и невыразимо пронзительной и неоспоримо сингулярной, несмотря на кажущуюся банальность, сценой смерти, представляется эмблематичным для всей поэзии постконцептуализма. Рождающийся в ней субъект лишен стабильности: он постоянно движется между полярными состояниями - безличной множественностью переживаемых субъектных состояний и единственностью личного опыта.

Анонимная / индивидуальная цитатность наиболее точно соответствует этой модели субъективности. „Governmentality“, предполагаемая этим типом цитатности, не только (как в концептуализме) моделирует формы сопротивления обезличивающей силе языка и истории, но и нацелена на поиски «альтернативных путей построения субъекта». Современный поэт одновременно обнажает работу этих сил и строит личную историю из, казалось бы, обезличенных цитат. Одновременность и параллельность этих 
операций и составляет тот «агон», который вынесен в название стихотворения Барсковой.

Рискну утверждать, что вариации этого агона можно обнаружить у многих современных поэтов, пишущих на русском, и что одним из устойчивых индикаторов воплощенной таким путем модели субъекта станет странная дезориентирующая цุитатность, синтезирующая акмеистический поиск надысторического смысла, устанавливаемого путем контакта цитат, и концептуалистского „détournement“, нацеленного на выявление и отстранение от насилия, скрытого в культуре.

\section{Литература}

Барскова, П. (2010): Прямое управление. СПб.

Барскова, П. (2011): Сообщение Ариэля. М.

Блок, А. (1965): Собр. соч. в 8-ми тт. Т. 5. Очерки, статьи, речи. М. / Л.

Каломиров, А. (1986): Двадцать лет новейшей русской поэзии (предварительные заметки) // Кузьминский, К. / Ковалев, Г. (сост.): У Голубой Лагуны: Антология новейшей русской поэзии в 5-ти тт. Ньютонвилль. 460-466.

Кривулин, В. (2000): Сквозь призму боли и ужаса // Стратановский, С.: Тьма дневная: Стихи девяностых годов. М. 175-181.

Кривулин, В. (2001): Стихи юбилейного года. М.

Кузьмин, Д. (2001): Постконцептуализм: Как бы наброски к монографии // НЛО. 50, 2001. 459-476.

Левин, Ю. / Сегал, Д. / Тименчик, Р. / Топоров, В. / Цивьян, Т. (1974): Русская семантическая поэтика как потенциальная культурная парадигма // Russian Literature. 7-8, 1974. 48-82.

Майофис, М. / Кукулин, И. (2006): Трансгрессивный неоклассицизм: О стихотворении А.А. Ахматовой «Вот это я тебе, взамен могильных роз...» (1940) // Баран, Х. / Иванов, Вяч. Вс. / Неклюдов, С.Ю. / Осповат, А. Л. / Поливанов, К.М. / Серебряный, С. Д. / Скулачёва, Т.В. / Шумилова, Е.П. (ред.): Стих, язык, поэзия. Памяти М.Л. Гаспарова. М. 373-399.

Некрасов, В. (2012): Стихи, 1956-1983. Вологда.

Пригов, Д. (1992): Евгений Онегин Пушкина // Берг, М.: Шинель Пушкина. М. / СПб. 149-227.

Родионов, А. (2013): Звериный стиль. М.

Рубинштейн, Л. (2000): Домашнее музицирование. М.

Стратановский, С. (2000): Тьма дневная: Стихи девяностых годов. М.

Ямпольский, М. (2016): Пригов: Очерки художественного номинализма. М.

Debord, G. / Wolman, G.J. (1956): A User's Guide to Détournement. Transl. by K. Knabb. http://www.bopsecrets.org/SI/detourn.htm\#1 (14/05/2018).

Debord, G. (1995): The Society of the Spectacle. Transl. by Donald Nicholson Smith. New York. 
Goldsmith, K. (2011): Uncreative Writing: Managing Language in the Digital Age. New York.

Greaney, P. (2014): Quotational Practices: Repeating the Future in Contemporary Art. Minneapolis / London.

Oraić-Tolić, D. (1990): Teorija citatnosti. Zagreb.

Perloff, M. (2010): Unoriginal Genius: Poetry by Other Means in the New Century. Chicago. 


\section{Александр Житенев (Воронеж)}

\section{Ready-made как опыт реконструкции лирического субъекта}

Критика представлений о субъекте как рациональной и целостной структуре, интерес к обезличенному высказыванию в современной поэзии не исключают попыток частично восстановить субъекта в правах. В этой связи особый интерес представляют опыты found poetry, где «найденность» допускает разные варианты авторского вмешательства в переструктурирование текста.

Стратегия ready-made может быть рассмотрена как опыт утверждения и одновременного снятия отчуждения, когда запрет на оценочность и первичность высказывания оставляет субъекту возможность выразить себя через отбор элементов и логику реорганизации чужого текста. Опыты такого рода тем более привлекательны, что позволяют выстраивать авторские стратегии вне оппозиций эксплицитно и имплицитно выраженной субъектности, противопоставления личностного и ролевого высказывания.

Исторически первые опыты такого рода ${ }^{1}$ соотносятся с московским концептуализмом и некоторыми практиками ленинградской «второй культуры». Используя термин ready-made по отношению к концептуализму, Е. Прощин отмечает, что слово здесь воспринимается как «некий готовый объект, происхождение которого может быть совершенно произвольным, однако в контексте авторской интерпретации его смысл означает расподобление прагматических связей». ${ }^{2}$ Близким образом, анализируя некоторые стихи А. Кондратова, определяет found poetry М. Павловец: в его понимании это «эстетизация речевых феноменов изначально внеэстетической природы путем их контекстуализации внутри художественного целого». ${ }^{3}$

На правах синонимичных или близких определения found poetry и readymade в 2000-е гг. применяются к широкому кругу явлений: в критических публикациях, рассматривающих разные формы работы с «готовым» сло-

\footnotetext{
${ }^{1}$ Новизна, конечно, относительна: манипуляции с чужим текстом имели место еще в авангардной прозе 1920-х: «Приему „монтажа“ или „коллажа“ в изобразительном искусстве в словесном искусстве и в определенных текстах и жанрах „литературы факта“ соответствует цитирование документальных материалов (бюрократические формуляры, отрезки из газет, бытовые тексты всякого рода) в контексте стилизованного повествования с установкой на „фиктивность“» (Hansen-Löve 1985, с. 32).

2 Прощин (2013, с. 241).

${ }^{3}$ Павловец (2014, с. 160).
} 
вом, можно встретить имена М. Нилина, ${ }^{4}$ В. Ломакина, ${ }^{5}$ П. Арсеньева, ${ }^{6}$ М. Галиной ${ }^{7}$ и др. При этом очевидно, что работа со словом как объектом в 1970-1980-е и в 1990-2000-е сопряжена с разными прагматическими установками и вариантами осмысления такой практики. Не претендуя на полноту картины, отметим несколько линий размежевания, связанных с пониманием ready-mades в близких исторических контекстах.

На рубеже 1970-1980-х гг. поэтический ready-made рассматривался как прием, призванный сделать очевидным пребывание субъекта в точке пересечения обезличенных голосов. Он обозначает профанированность поэтического слова, его вплетенность в бытовую речь и идеологическую коммуникацию и при этом выступает маркером художественной саморефлексии, создает ситуацию перехода текста из одного жанрово-стилевого регистра в другой.

Стратегия, в которой точкой отсчета оказывается фраза, перенесенная из внеэстетической реальности в эстетическую, была охарактеризована Л. Рубинштейном:

Концептуальное сознание предполагает в тотально «окультуренном» пространстве отношение к тексту как к объекту, а к объекту как к тексту. Что же касается проблем языка, то это скорее проблема языков, т.е. взаимодействие различных языковых пространств, различных жанров языка, в частных случаях - жанров литературы. Для концептуального текста вообще характерно жанровое или даже родовидовое смещение: бытовая речь в роли стиховой и наоборот; фрагмент прозы в роли стихотворной строки и наоборот и т.д. ${ }^{8}$

Стратегия, в которой исходным пунктом выступает книга как материальный объект, описана Ры Никоновой и С. Сигеем в пояснениях к «ирфаеризму». Исходя из мысли, что «прекрасное есть прекрасная основа для прекрасного», поэты обосновывают стратегию системного переозначивания, охватывающего как материальный, так и семантический уровень исходного текста: «ирфаеризм - это использование готовой формы в целях создания новой готовой формы», и он допускает «перемену целевого акцента», ряд «декон-

\footnotetext{
4 «Нилин [...] в ранних книгах даже не чуждается found poetry, публикуя в качестве стихотворений укладывающиеся в метр случайные разговорные реплики [...] или мелкие письменные тексты прикладного характера» (Кузьмин 2008).

5 «Ломакин фиксирует распад языка русской поэзии, ее финальное отсечение от означивания, от коммуникации, от диалога, от вдохновения (так многие из его поздних стихов написаны при участии компьютерной программы, перемешивающей собственные более ранние тексты поэта)» (Гулин 2014).

${ }^{6}$ «Павел Арсеньев сосредоточен на работе с чужой речью, балансируя на грани между found poetry и прямым высказыванием» (Корчагин 2011).

7 «В этом плане особо стоит отметить цикл „Препарируя Брема“, представляющий собой found poetry» (Горшкова 2013).

${ }^{8}$ Рубинштейн (1991, с. 233).
} 
струкций, дополнений и замещений», в которых книга - это объект, «смысл которого давно смыт до простого типографского набора». ${ }^{9}$

Рубеж 1980-1990-х гг. характеризуется внеидеологической трактовкой ready-made; на первый план выходит поиск новизны в остановившемся времени, исследование процессов валоризации высказывания, «мерцающей» субъективности, соотнесения обезличенности и эмоциональности текста.

Б. Гройс, говоря о ready-made как опыте «десакрализации традиции», считает правомерными его трактовки как «предельного акта художественного произвола», «критического анализа механизмов рынка» и проявления «подсознательных стратегий желания и языка», но сам считает наиболее значимым уничтожение-утверждение ауры:

Картина переживается как картина именно и прежде всего на пределе своего отчуждения, утраты своей ауры, достоинства и аутентичности [...]. Превращение картины в ready-made переживается теперь не как прогресс, а как утрата, и эстетизируется, под видом критики, именно как таковая. [...] Таковы же сегодня и тексты, если они используются в такой картине. ${ }^{10}$

В 2000 и 2010-е гг. с ready-mades связывается тематизация субъекта и креативности, этос «заимствования» и публичного предъявления «готового» текста, типология прагматических установок высказывания, параметры восприятия текста, построенного по принципу found poetry.

Н. Байтов, предлагая свое видение ready-made, акцентирует в нем прежде всего «присвоение вещи новым автором и измененный пафос авторства, творческого акта»; при этом, как явствует из его пояснений, «измененность» создается за счет нарушения структуры объекта и его помещения в другие смысловые ряды. Байтов ставит под сомнение «неокультуренность» объекта манипуляций и уделяет особое внимание манифестированию «найденности» текста; им же отмечается несовпадение ready-made и found poetry в отношении к материалу: если первый предполагает всего лишь создание экспозиционного пространства, то вторая - разделение в объекте ценного и профанного. ${ }^{11}$

Р. Осминкиным ready-made трактуется как «новая парадигма произведения искусства, сведенного к [...] прагматике и модальностям самого акта высказывания»; его характеристиками являются двунаправленность переозначивания (придание вещи статуса арт-объекта и разыскусствление произведения) и собирание субъекта в перформативном «арте-акте», предполагающем его включение в опыт коллективной чувственности. ${ }^{12}$ Абсолютизация реди-мейда, его трактовка как перформанса, идея обратимости

\footnotetext{
${ }^{9}$ Никонова / Сигей / Пригов (1983); ср.: Сигей (1983).

${ }^{10}$ Гройс (1993, с. 344-345).

${ }^{11}$ Байтов (2004).

12 Осминкин (2015).
} 
творческого акта делают концепцию Р. Осминкина наиболее радикальной из рассмотренных.

Акцент на проблематике авторства и креативности в современных концепциях ready-made делает правомерным исследование соответствующих поэтических опытов сквозь призму герменевтики субъекта. Понять, как тексты, организованные на этих основаниях, могут репрезентировать субъектность, можно, обратившись к анализу книги Андрея Черкасова «Домашнее хозяйство. Избранное из двух колонок» $(2015)^{13}$ и проекта Владимира Беляева «Таблички» (2015 - настоящее время). ${ }^{14}$

Возникшие независимо друг от друга, эти проекты имеют черты сходства: оба апеллируют к материалу, отражающему коллективный опыт (энциклопедия домоводства у Черкасова, многотиражные газеты у Беляева); оба предполагают работу с текстами, отодвинутыми в область прошлого (энциклопедия относится к 1959 г., газеты - к концу 1980-х - началу 1990х гг.); оба маркируют объектность исходного текста (Черкасов сохраняет расположение фраз на странице, Беляев наклеивает вырезки на деревянную основу); оба имеют сериальную структуру, допускающую произвольное комбинирование элементов.

Как явствует из авторского предисловия, А. Черкасов видит в энциклопедии домашнего хозяйства образ советского универсума, целостную картину действительности, преломленную через повседневность. F ound poetry - результат смысловых разрывов, замеченных в случайных сближениях рядоположных фрагментов текста. Гротескный образ - обретение, обесценивающее исходный материал.

Что было? «Краткая энциклопедия домашнего хозяйства» (1959), кем-то выброшенная и подобранная мной. [...] Что осталось? Фрагментированный поэтический текст, единственная связь слов в котором - их соседство в энциклопедии на двух соседних колонках в одной строке. Все лишнее стерто, выбелено. Оставленное - осталось на тех же местах, что и было. ${ }^{15}$

В. Беляев в интервью автору статьи иначе интерпретирует практику редимейда:

Материал отбирается стихийно. [...] Рамки выбора меняются от таблички к табличке. Где-то я ставлю себе задачу использовать как можно больший массив текстов разной направленности, где-то, наоборот, ограничить выбор од-

\footnotetext{
13 Черкасов (2015).

14 Фотографии объектов с написанным от руки или наклеенным текстом поэт выкладывает на своей странице в Фейсбуке с апреля 2015 г. (https://www.facebook.com/ profile.php?id=100002164561452\&sk=photos\&collection_token $=100002164561452 \% 3 \mathrm{~A} 230$ 5272732\%3A69\&set=a.430098183738997.98723.100002164561452\&type=3, 23/09/2016), и все цитаты приводятся по этому источнику; первое предъявление проекта в арт-пространстве связано с выставкой «Форматирование памяти»в петербургской галерее «Вертикаль» 30 апреля 2016 г.

15 Черкасов (2015, без пагинации).
} 
ной колонкой [...] «Табличка» - это вещь, артефакт, имеющий материальное измерение, в отличие от текста, который больше подвержен инфляции-дефляции [...] Табличка в этом смысле - попытка поймать воробья, сжать ветер, сделать слово-вещь, текстовую икону, в конце концов. [...] Табличка - это что-то, чему можно уделить большее время взгляда, избыть это время через взгляд и восстановить в правах пространство и память. [...] То есть, я представляю это - когда путники идут, разговаривают или молчат о своем, и шаги, путь, отмеряемый взглядом, актуализируют время ожидания и т.д. И вот они останавливаются у камня-сообщения, и пространство вокруг этого сообщения из прошлого растет, и время замедляется, и ветерок вечности тут как тут. [...] Найденность текста - да, я буду за то, что он даже не столько найден, сколько угадан. Как гадание по внешним знакам, как в древности гадание по костям птиц, так и здесь по обломкам текстов. Чья-то тревога, надежда - своя, чужая, общая в этой выборке просвечивает, и ты ее ловишь. ${ }^{16}$

Работа В. Беляева, таким образом, лишена строгой формальной заданности, в ней важны алеаторические эффекты, возникающие в текстовом массиве, объем которого постоянно меняется. Речь идет не о заимствовании отдельных фраз с газетной полосы, но о спонтанной реорганизации текстового целого под воздействием встреченных слов-сигналов. Создание found poetry соотносится с перформативными и ритуальными практиками, a результат творчества закрепляется в арт-объекте, который маркирует внеположность высказывания принятым формам бытования литературного текста. Исходный текст не уничтожается в новом, но отчасти передает ему свой эмоциональный импульс.

Различия в формулировке принципов работы с материалом и способах его контекстуализации предопределяют несовпадения в направлениях творческого поиска, его методах и результатах.

В работах В. Беляева «найденность» теста отражена преимущественно в медиуме, в его бумажной основе; фактически едва ли не в каждой «табличке» имеет место создание оригинального высказывания, возникшего в результате комбинирования коротких газетных вырезок. Связь с исходным контекстом здесь предельно ослаблена, газетный текст рассматривается как материал, исключающий любые диалогические отношения; в нем важен не смысл, но аура времени, отраженная в словесных формулах. Закономерным образом работе с газетами предшествовало создание «табличек» с текстами М. Еремина и Вс. Некрасова, обозначившими два ориентира: метафизическая формула-шифр и интонационная фразировка.

Эстетический код в «табличках» задан медиумом: фактурными эффектами, связанными с деревянной основой, и культурными коннотациями газетной типографики. В первом случае важны расположение текста (стандартное горизонтальное, задающее однозначный порядок чтения, или диагональное, допускающее нелинейные связи) и заполненность / незапол-

${ }^{16}$ Из интервью от 29/05/2016. 
ненность «ниши» под бумажный текст (который может состоять из «телеграммных» вырезок, сегментирующих фразы и отдельные слова, или текстовых блоков разной конфигурации). Во втором случае важны шрифтовой репертуар исходного материала (вызывающий ассоциации с официозными советскими изданиями) и относительный масштаб газетного текста, оперирование с курсивами, буквицами и другими формами выделения текста.

«Таблички» не составляют завершенного цикла, но лейтмотивы проекта вполне можно описать. Среди них прежде всего нужно назвать «событие» и «свидетельство». «Таблички» повествуют о движении «большого времени», об исторических переломах и сдвигах сознания: «Будущее извлекут из глубин античного храма / при свете настольной лампы / школьная карта дно свидетельств руины дна»; «мы горький хлеб свидетельств / кормежка про житье-бытье / мед и мир»; «Время - несостоявшийся беглец / Я стал ощущать его снова / под знаком / Это случилось / и / будет длиться».

Хоровому «мы» отведена роль исследователя движущих сил истории, с этим связаны мотивы стихии и оформленности субъекта внешними обстоятельствами: «мы видели / причины предыдущих существований»; «первый шаг / отменен / не оправдал ожиданий»; «жизнь / делает нас»; «вот мы / себя и выстрадали»; «письмо теснит скрывать / переступают / границы друг друга / оборачиваясь временами / стихия не принадлежать никому / внутри события». Субъект в цикле получает «топологическую» трактовку: это фокус восприятия и понимания; такой взгляд определяет появление мотива речи как медитативного инструмента, проявляющего шифры бытия: «Знаете, само слово исследует жизнь / Происходит то, что произошло. / Обретение непременного условия / эха бесконечно продолжающейся жизни / когда у нее появляются свои поводыри / И, может быть, самое важное слышать их работу»; «Куда? Куда зовет / спрятавшегося и заснувшего / сквозь сумерки дыхания / непроизнесенные, но слышимые / в дом уместившийся в голос „своего места“»; «Это же и есть человек / место жизни».

Если работа В. Беляева с чужим текстом «семантична» и предполагает многолинейную рефлексию над контекстом, из которого заимствуются словесные формулы, то практика А. Черкасова «синтаксична»: в ней важны эффекты, возникающие вследствие случайного соседства объектных и смысловых рядов. Абсурдная реальность, созданная блэкаутом, помещает в центр внимания единичное наблюдение, для которого любой контекст избыточен. Книга представляет собой собрание «атомарных фактов», серию проекций высказывания или действия.

Черкасов исследует альтернативные версии порядка, предлагая парадоксальные варианты категоризации вещей, выстраивания родовидовых и причинно-следственных отношений. Наиболее продуктивными моделями создания found poetry оказываются работа с эпитетом, создание перечислительных и противительных конструкций, а также генитивная метафора. Система трансформаций исходного текста имеет две координаты: это свя- 
зи слов, оказавшихся в одной строке, и связи строк, между которыми устанавливается ассоциативное соответствие. При этом переход из одной колонки в другую оказывается сродни стихотворной цезуре. ${ }^{17}$

Эпитет расширяет семантику слова («ультрафиолетовое варенье»), раздвигает пределы лексической сочетаемости («бытовой переживший супруг»), позволяет ставить рядом явления из разных рядов («пористые внесения», «жесткая вода вызывает сухость, мужскую, состоящую из пиджака и брюк»). Перечислительный ряд ставит под сомнение основания, позволяющие относить явления к определенному классу («женщины, еловые ветки», «смородину, клюкву, смерть»), ту же задачу решает общий эпитет или управляющее слово («специальный крот, сурок, тарбаган, суслик, хомяк, крыса»; «выступления артистов, радиопередачи наволочек и пододеяльников»), случаи противопоставления утверждают эквивалентность несоотносимого («или виноград / или ты»; «воротник; надевается поверх сарафана или государства»). Генитивная метафора в словосочетании создает эффект нормализованного абсурда («шкафы котлет», «занавеси швов», «усвояемость века»); отсутствие связей между объектами и предикатами в конструкциях с зависимыми словами обусловливает появление абсурдного гротеска («запонка подготовки человека», «капканы большого яда», «чувство страха, лицо его от больного животного»).

Изолированность случаев семантического слома делает невозможной не только целостную картину реальности, но и предметную представимость запечатленного в тексте ее фрагмента. Блэкаут Черкасова принципиально эллиптичен, для него характерны конструкции с незаполненными валентностями («внутри оранжевые пластинки») и номинативные формулы («в центре круга или квадрата времени / растения, стекла»). Это свойство позволяет говорить о текстах книги как открытом наборе возможностей восприятия и понимания.

Круг этих возможностей задан рядом устойчивых лейтмотивов, связанных с телесностью и уязвимостью. Черкасов акцентирует ограниченность восприятия («глаз делает речь менее внятной»), разбалансированность и болезненность существования («срезать у самого основания лицо / залить красным папиросы / [...] / соприкасаться с раной всего»), его занимает обостренно-чувственное восприятие реальности («выпуклые узоры и, реже, колючие кости»), осознание тщеты познания и действия («лучше изучить путем личного обследования и убить или ранить самого себя»).

Такой набор мотивов резко осовременивает исходный текст, заставляет прочитывать его в другой временной перспективе. В этом И. Соколовым была увидена суть эксперимента с реди-мейдом:

17 Все цитаты из книги Черкасова (2015) приводятся без указания страниц: книга представляет собой собрание листов без пагинации. 
Вроде бы перед тобой предельно отчужденный текст [...] тем не менее [...] каким-то образом поэтический опыт автора-миллениала в буквальном смысле прорастает из советского языка. [...] Этот опыт говорения через чужое как свое принципиален [...] перед нами не изощренный соц-арт, а индивидуализированная поэтическая речь, которая каждой своей точкой укоренена в сегодняшней действительности. ${ }^{18}$

Проделанный анализ позволяет сделать вывод о том, что редукция субъекта в практике поэтического ready-made сводится к запрету на предъявление «идеологически» структурированной картины мира и невозможности определения дистанции между субъектом речи и автором. Но это не означает, что рефлексивность и активность, традиционно соотносимые с субъектностью, здесь отсутствуют - напротив, они вынесены на первый план и явлены во множестве аспектов.

Субъект выступает в роли герменевта, он организует перспективу восприятия и создает траектории чтения, обнаруживая в пантекстуальной реальности конструкции, обладающие свойством автономии. Даже не проявляя себя в прямой оценке, субъект входит в новый текст со всей полнотой своего опыта, который дает о себе знать в принципах структурации реальности. Работая с «готовым» материалом, субъект проявляет себя как конструктор «резонансного пространства», в котором важна игра несовпадений между исходным и вторичным текстами, тематизация исторической и эстетической дистанции. Проявляя эту дистанцию, субъект выступает в роли изобретателя формальных структур, он утверждает свою креативность в разработке приема. В отдельных случаях субъект может стать предметом изображения, но как носитель «голоса» он помещен в область смещений, разделяющих литературный и внелитературный контексты, и его невозможно соотносить с автором реди-мейда.

\section{Литература}

Байтов, Н. (2004): Ready-made как литературная стратегия // Фатеева, Н.А. (ред.): Поэтика исканий, или Поиск поэтики. Материалы международной конференции-фестиваля «Поэтический язык рубежа XX-XXI веков и современные литературные стратегии». М. 209-215.

Горшкова, Е. (2013): Письма водяных девочек [Рецензия на кн.: Галина, М. (2012): Письма водяных девочек. New York] // Воздух. 1-2, 2013. 168.

Гройс, Б. (1993): Страдающая картина, или картина страдания // Гройс, Б.: Утопия и обмен. М. 337-346.

Гулин, И. (2014): Поэзия после человека: Игорь Гулин о новом сборнике Василия Ломакина // Коммерсантъ. 26/09/2014. https://www.kommersant.ru/doc/2569439 (12/02/2018).

${ }^{18}$ Соколов (2015, с. 324). 
Корчагин, К. (2011): [Рецензия на кн.: Арсеньев, П. (2011): Бесцветные зеленые идеи яростно спят. СПб.] // Воздух. 4, 2011. 226.

Кузьмин, Д. (2008): Между конкретизмом и мифотворчеством. http://www.litkarta.ru/ dossier/kuzmin-nilin/dossier_2566/ (6/05/2016).

Никонова, Ры / Сигей, С. / Пригов, Д. (1983): Манифест ирфаеризма // Транспонанс. 18, 1983. 19-23.

Осминкин, Р. (2015): От артефакта к арте-акту: реди-мейд как агент социального действия // Артикульт. 4 (20), 2015. 6-8.

Павловец, М. (2014): «Конкреции» Александра Кондратова как опыт русского конкретизма // Вестник СПбГУ. Сер. 9. Филология. Востоковедение. Журналистика. 4, 2014. 156-163.

Прощин, Е. (2013): Специфика субъектной персонификации в русской концептуалистской и постконцептуалистской поэзии (1960-1990-е годы) // Вестник Нижегородского университета им. Н.И. Лобачевского. Сер. Филология. 1 (2), 2013. 241-245.

Рубинштейн, Л. (1991): Что тут можно сказать. Личное дело №. М. 232-235.

Сигей, С. (1983): Концептуальный рэди-мейд // Транспонанс. 18, 1983. 87-90.

Соколов, И. (2015): Коробка очень расчлененных крыс // Воздух. 3-4, 2015. 323-326.

Черкасов, А. (2015): Домашнее хозяйство. Избранное из двух колонок. М.

Hansen-Löve, А. (1985): «Фактура», «фактурность» // Russian Literature. 17, 1985. 29-38. 



\section{Михаил Мартынов (Москва)}

\section{Особенности конструирования субъекта в «поэзии вычеркиваний» ${ }^{1}$}

«Поэзия вычеркиваний» представляет собой практику создания поэтического произведения путем удаления словесных или иных фрагментов из имеющих авторство текстов. Как правило, слова удаляются при помощи их закрашивания черным маркером, и с этим связано популярное название данной практики - блэкаут поэзия (blackout poetry). Такой способ «вычеркивания» хотя и распространен, но не является единственным. Фрагменты чужого текста иногда удаляются без использования черного маркера, например, при помощи специфического выбеливания. ${ }^{2}$ Иными словами, для «поэзии вычеркиваний» важным является не столько технический способ удаления текста, ${ }^{3}$ сколько возникающие при этом визуальные и смысловые эффекты и смещения.

В научной литературе исследователи уже обращались к осмыслению приема зачеркивания в поэтическом тексте, но их наблюдения были в основном ограничены примерами, в которых зачеркивание понималось как маркер поэтической вариативности. ${ }^{4}$ Идея вариативности в «поэзии вычеркиваний», как правило, вообще не имеет значения. Смещение языковой границы текста в сторону визуального, окрашенного в цвета негации, позволяет рассматривать эту поэзию в контексте восходящей к Ж. Батаю идеи о взаимосвязи искусства, насилия и смерти. В специфических практиках поэтического вычеркивания должен, по всей видимости, действовать осо-

${ }^{1}$ Исследование выполнено за счет гранта Российского научного фонда (проект №14-2800130) в Институте языкознания РАН.

А. Йоффе, Д. Серенко и А. Черкасов выразили согласие на публикацию цитат или фотографий в данной статье.

2 Так, например, построена книга Андрея Черкасова «Домашнее хозяйство. Избранное из двух колонок», в которой текст вычеркивается не при помощи черного маркера, а при помощи своеобразного компьютерного выбеливания из предварительно отсканированных страниц. Как объясняет автор, «все лишнее стерто, выбелено / оставленное осталось на тех же местах, что и было / порядок следования листов случаен и меняется в каждом экземпляре» (Черкасов 2015b).

${ }^{3}$ В рамках этой статьи мы не будем учитывать имеющиеся семантические различия между «вычеркиванием» и «выбеливанием». Наше основное внимание будет обращено только на производимое ими удаление текста и его роль в конструировании поэтической субъектности.

${ }^{4}$ Суховей (2008, с. 133). 
бый субъект, ключевые параметры которого мы попытаемся выявить в этой работе. Исследование будет построено в основном на анализе блэкаутов Андрея Черкасова и Дарьи Серенко и отдельных примеров других молодых российских поэтов.

«Поэзия вычеркиваний» в самых общих чертах близка реди-мейду, в котором основной ценностью для художника является не создание новых объектов или образов, а выбор из уже существующих и представление их в новом контексте. ${ }^{5}$ Поэтический реди-мейд часто определяется понятием «найденная поэзия» (found poetry), что подразумевает «вычитывание» как правило, в прозаическом тексте - «скрытой» поэзии.

Несмотря на близость к реди-мейду, «поэзия вычеркиваний» обладает некоторыми существенными отличиями. «Поэзия вычеркиваний» настаивает на своей творческой самостоятельности и отдельности от текстов, которые используются для вычеркиваний. В отличие от found poetry она не реализует идею коллективного творчества и двойного авторства. ${ }^{6}$ Например, книга «Домашнее хозяйство. Избранное из двух колонок» Андрея Черкасова, выполненная на материале советской энциклопедии, не является опытом сотворчества. Как замечает автор, «я работал с этим материалом так, как я работал бы со своими собственными стихами и с языком в целом». ${ }^{7}$

Кроме этого, новый текст в блэкауте связан с вычеркиваемым текстом семантикой насилия, и через насилие в блэкауте проглядывают важнейшие характеристики субъектности. Насилие, о котором идет речь, представляет собой не просто «организованное насилие поэтической формы над языком» (Р. Якобсон), а как бы изначальное негативное насилие, с которого, согласно Ж. Батаю, и начинается искусство. ${ }^{8}$ В элементарном жесте зачеркивания проявляет себя чистая, почти объективная, смерть, являющаяся как бы частью самой реальности и выводящая поэтическое слово за собственные пределы, то есть не просто за пределы уставших от повседневного использования образов, как у Р. Якобсона, а за границы любой готовой образности. Поэзия, согласно Ж. Батаю, хотя и «ведет от известного к не-

${ }^{5}$ В этом смысле практики реди-мейда вслед за Б. Гройсом можно рассматривать как инсталляции (Гройс 2006).

${ }^{6}$ Один из представителей found poetry, Джон Роберт Коломбо, «часто обозначает двойное авторство или в предисловиях к своим книгам пишет, что они есть плод целого коллектива авторов - в том случае, если поэзия найдена им, например, в Британской энциклопедии» (Байтов 2016).

7 См. выступление Андрея Черкасова на презентации книги «Домашнее хозяйство. Избранное из двух колонок» (Проект «Живое». Андрей Черкасов. Презентация книги: https://www.youtube.com/watch?v=p9sJnn9sHnI, 8/06/2016).

8 Ж. Батай отмечал, что «искусство - поскольку это несомненно искусство - идет путем последовательных разрушений. Поэтому инстинкты, которое оно высвобождает, - это садистские инстинкты» (цит. по Краусс 2003, с. 62). 
известному» и «разрывает в клочья мир известного», «в этом мире все же себя удерживает», то есть привязывает поэтический образ «к известному, которое и дает ему воплотиться». ${ }^{9}$ В жестком, неотменяемом вычеркивании блэкаута содержится семантика смерти, чистая деструктивность которой создает условия для расшатывания образной определенности и субъектности. Вычеркивание указывает также на то, что никакой текст не может занимать вневременной, исключительной позиции, и это означает отмену идеи интертекстуальности - текст не может быть всем. Если текст и отсылает к другим текстам, то только в аспекте уничтожения. ${ }^{10}$

Конструирование поэтического субъекта в блэкауте начинается с попытки его «растворения» в чужом тексте, то есть, по сути, с невозможного опыта, ведь именно это в блэкауте никогда и не удается. Заниматься вычеркиванием может кто угодно - например, дворник, когда он закрашивает неприличные слова на заборе. При этом, закрашивая какую-нибудь непристойность, дворник утверждает себя как дворник. В блэкауте, напротив, субъект вычеркивает не для того, чтобы утвердить в вычеркивании себя, но чтобы поставить себя под вопрос, то есть скорее обозначить то, чем он не является в вычеркиваемом тексте, - например, игроком, вычеркивающим только ради забавы, ${ }^{11}$ или даже поэтом, если вычеркивается поэтический текст, а поэзии предписана некоторая неизменяемая сущность. «Вычеркивание» обозначает горизонт вопросов: существует ли субъект блэкаута, действительно ли его можно увидеть в тексте?

Блэкаут производит игру видения / невидения, которая и делает возможным появление субъекта. Блэкаут начинается с вычеркивания, то есть с опыта отказа от смотрения, однако в итоге этот опыт оказывается необходимым для того, чтобы увидеть в тексте нечто, не запланированное им, некоторую избыточность. Само обнаружение поэтического субъекта происходит в таких невозможных местах текста, которые в обычном смысле существуют не для того, чтобы в них всматривались, - в обрывках слов при переносах, в местах между колонками статей в энциклопедиях, в «случайно» оставленных точках, запятых и других синтаксических знаках, в повторении заглавных букв, союзов или слов - в самой идее чистого повтора, оспаривающей установку на обязательную коммуникативность текста и др.

\footnotetext{
${ }^{9}$ Батай $(1997$, с. 252, 275).

${ }^{10}$ Ср. с двумя «достоверностями» Ж. Батая: «Мы не можем быть всем, в этом мире у нас вообще только две достоверности: эта и достоверность смерти» (там же, с. 11).

11 По этой причине блэкаут, используемый только в игровых целях, нельзя считать собственно «поэзией вычеркивания».
} 


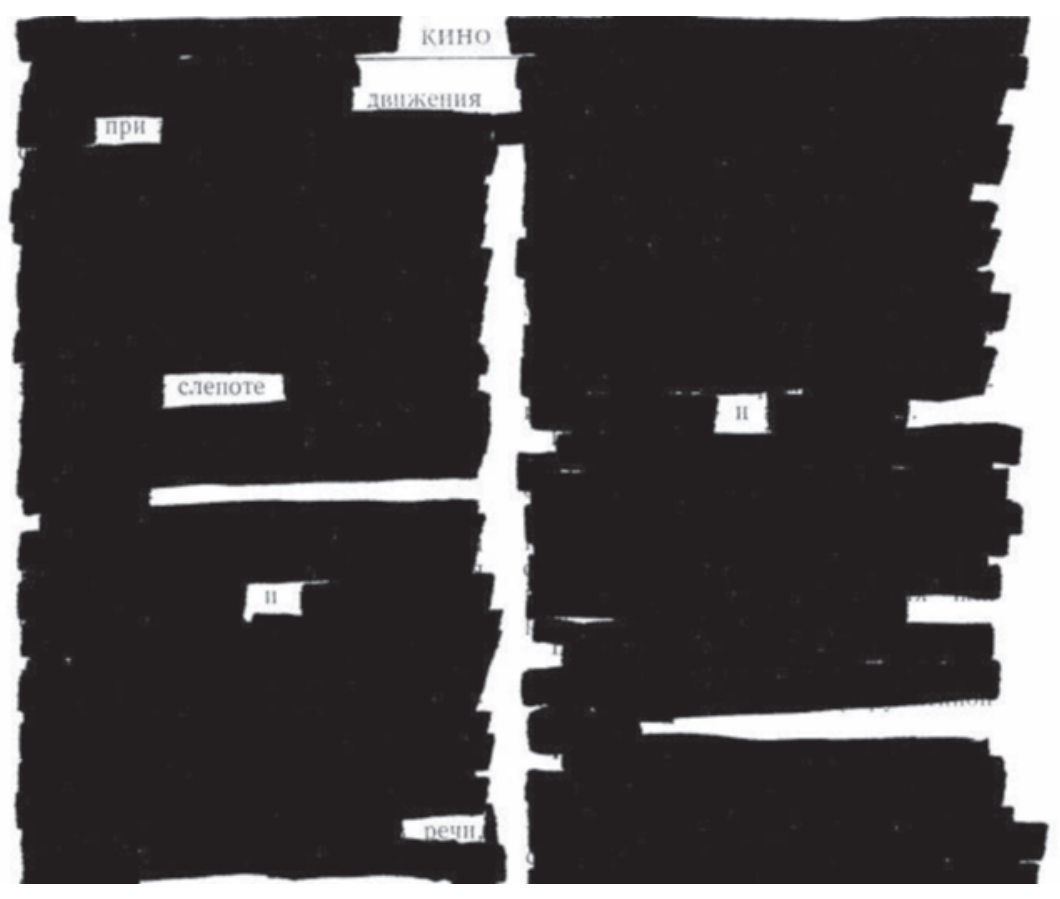






Moscow blackout session № 2. Why so serious?

(Андрей Акульиин, Мария Артамонова, Андрей Лермонтов, Дарья Лермонтова, Юлия Лермонтова, Екатерина Соколова, Андрей Черкасов, Ольга Черкасова, Наталия Юрова) 




Андрей Черкасов. «Блэкауты» ${ }^{12}$

В книге Андрея Черкасова «Домашнее хозяйство. Избранное из двух колонок» субъект действует в пространстве, образуемом в горизонтальном сгущении смыслов на границе двух соседних колонок реальной советской энциклопедии домашнего хозяйства, ${ }^{13}$ - то есть, по сути, в месте, не являющемся для энциклопедии местом высказывания. Название поэтической книги хотя и отсылает нас к некоторому условному домашнему хозяйству, но как раз четкая домашняя прагматика здесь обнаруживается в последнюю очередь. Субъект осваивает домашнее пространство, состоящее, например, из посуды, открытых полок, штепсельной розетки, пиджака и брюк, как пространство, невозможное для их будничного существования, то есть как освобожденное от готовых домашних смыслов и готовой субъективности.

\footnotetext{
12 Черкасов (2015a).

13 Речь идет о «Краткой энциклопедии домашнего хозяйства» 1959 года (Ревин (ред.) 1959), которая, как объясняет автор в предисловии, была «кем-то выброшена и подобрана мной» (Черкасов 2015b).
} 




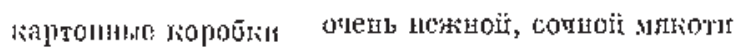

$$
\begin{aligned}
& \text { corpикасаться \& раной всего } \\
& \text { иметь отдельуую посуду с железныи крипами }
\end{aligned}
$$

закрывать пос и рот повлакой нз воздушшой әлектрической личи

правпло тормящей следует адземлять грозовым переклюдателем

для летения проводиой и штепсельной розеткой

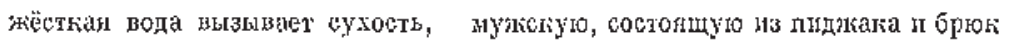

Андрей Черкасов. "Домашнее хозяйство. Избранное из двух колонок» ${ }^{14}$

Складывается впечатление, что блэкаут снабжен какой-то особой двойной оптикой, с помощью которой автор всматривается в вычеркиваемый текст не только для того, чтобы себя обнаружить, но также и для того, чтобы отметить места своего отсутствия в чужом тексте. Мысль о пустом месте автора в поэзии не является новой, и об этом, например, вслед за М. Фуко говорит Дж. Агамбен. ${ }^{15}$ Но поэтический блэкаут начинается с некоторого пространства, изначально занятого чьим-то жестким присутствием. И если субъект, как об этом говорит Агамбен, в поэтическом тексте «должен производиться каждый раз заново», ${ }^{16}$ то блэкаут добавляет к этому способы активного отсутствия субъекта, который, чтобы показать свое присутствие, должен каждый раз заново отмечать также и места отсутствия в чужом тексте.

Активное отсутствие субъекта означает скорее открытие незапланированных возможностей, чем создание конструкций, схватывающих некоторую данность и организовывающих «присутствие». Активное отсутствие в этом отношении имеет событийную природу. Как отмечает Ален Бадью,

[...] событие - это то, что заставляет проявиться возможности, которая была невидимой или даже немыслимой. Само по себе событие не является созданием той или иной реальности; оно - лишь создание возможности, оно открывает возможность. ${ }^{17}$

${ }^{14}$ В оригинале эти строчки, как правило, располагаются на отдельных страницах и выглядят как моностихи. (Черкасов 2015b).

${ }^{15}$ Агамбен / Скидан / Пензин / Новиков (2010, с. 6).

16 Там же, с. 7.

${ }^{17}$ Бадью (2013, с. 17). 
При этом событие «не подчиняется закону господствующих возможностей», и «быть готовым к событию - значит быть в таком состоянии духа, в котором порядок мира, господствующие силы не обладают абсолютным контролем над возможностями». ${ }^{18}$ Иными словами, событие - это вырывание возможности из невозможного, под которым в нашем случае можно понимать господствующий порядок речи, задающий параметры ее осмысленности. Событие - или, как мы отметили, активное отсутствие - есть такая возможность, которая не запланирована текстом и отсутствует в нем, но которая неожиданно прорывается сквозь его структурность. При этом речь идет именно об «отсутствии», а не «присутствии», потому что «присутствие» уже означает наличие некоторой «осмысленной вселенной», предсуществующего порядка, в котором любая возможность становится фактом, то есть перестает быть событием. ${ }^{19}$

Активность отсутствия означает, что оно не оппозиционально, что оно не выстраивается как противоположность присутствия. Возможность, которую открывает блэкаут, нельзя вывести из предшествующего опыта: например, возможность смысла, возникающего в пространстве между двумя колонками словарной статьи, нельзя вывести из ее прагматических установок.

Поле языка всегда размечено принадлежащими кому-то смыслами, и по этой причине, как мы думаем, поэтическая работа должна начинаться с производства активного отсутствия. В этом смысле поэзию в цуелом можно рассматривать как блэкаут.

Близкая идея высказывалась Михаилом Айзенбергом, правда, не по отношению к поэзии в целом, а по отношению к поэтике Николая Байтова. В одной из своих статей Айзенберг отмечает, что письмо Байтова есть

апофатическое письмо, существующее за границами стиля, выясняющее, что́ останется, если отказаться от всего общего, условного, риторического. Оно занято изъятием негодного по мере приближения к (предполагаемой) подлинности. Стирающее письмо (курсив наш - М.М.). И стирается не что-то прежде написанное, а как бы сам процесс письма. ${ }^{20}$

Любопытный пример поэзии как блэкаута можно наблюдать в творчестве Анны-Марии Альбиак (Anne-Marie Albiach), отдельные опубликованные тексты которой, если их сравнить с черновиками, выглядят как блэкауты. Так, например, сравнение черновых записей и напечатанных текстов, включенных в сборник „État“ (1971), наводит на мысль о том, что автор

\footnotetext{
18 Там же, с. 21.

${ }^{19}$ Близкую мысль о связи поэзии и события высказывает Наталия Азарова: «Событие это что́ поэзии. События не соотносятся - с и не трансформируются в случай и поэтому не типологизируются. Однако поэзия не всегда дотягивает до события» (Азарова 2016).

${ }^{20}$ Айзенберг (2011, с. 28).
} 
как будто вычеркивает собственный текст из черновика, ${ }^{21}$ который в этом вычеркивании уже и не является в полном смысле своим.

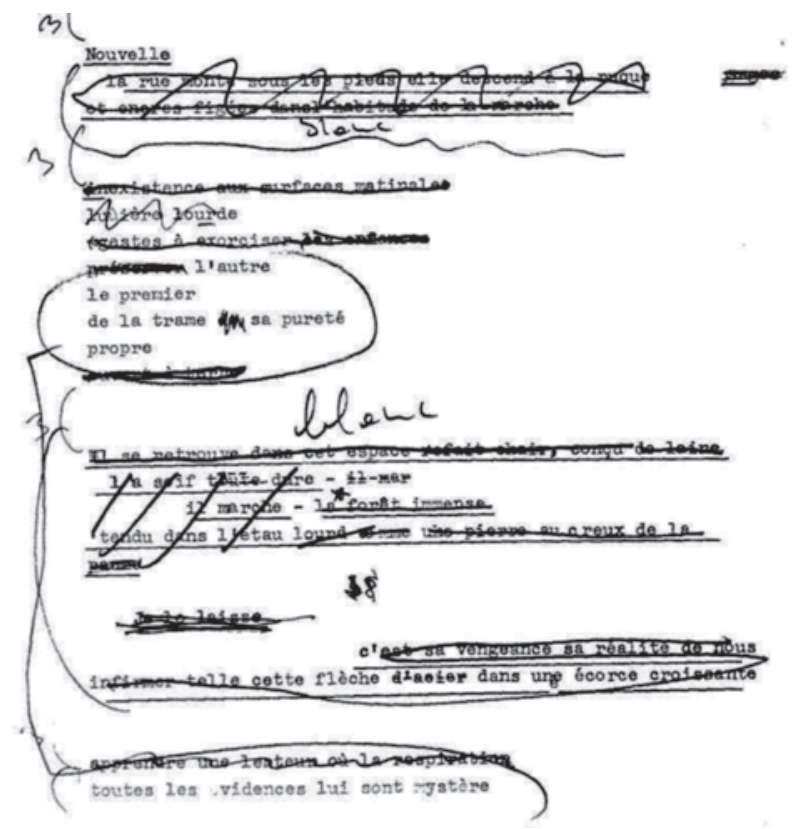

Черновик 22

${ }^{21}$ Автор благодарит Кирилла Корчагина, который поделился с ним этим наблюдением.

${ }^{22}$ Bernstein (2015). 


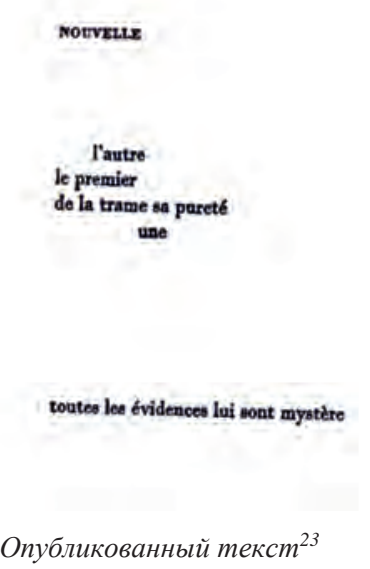

Отсутствие субъекта в «поэзии вычеркиваний» усиливается визуальной стороной - нетрудно заметить, что графически блэкаут напоминает структуру решетки. Это позволяет рассматривать «поэзию вычеркиваний» в контексте методологических установок Р. Краусс, согласно которой решетка является одной из ключевых идей авангардного искусства XX века. Идея решетки, согласно объяснениям Краусс, берет начало в трактатах XIX столетия по физиологической оптике, которые были проиллюстрированы решетками.

Для художника, который желал углубить свои познания о зрении при помощи науки, решетка представляла собой матрицу знания. Самой своей абстрактностью решетка выражала один из основных законов познания - разделение инстанции восприятия и «реального» мира. ${ }^{24}$

В начале XX века решетку открывают кубисты - П. Мондриан, К. Малевич и другие художники, для которых решетка была способом избавления от господствующей в искусстве установки на миметичность: «Решетка - это то, чем становится искусство, когда отворачивается от натуры». ${ }^{25}$

Идея решетки в блэкауте противопоставлена принципу классификации и таксономии. Решетка - это не таблица, накладывающая на мир определенную систему запретов и ограничений, и составляющая, согласно М. Фуко, ${ }^{26}$ суть дисциплинарной техники власти, но живая попытка высвечивания не схваченных «порядком дискурса» феноменов.

\footnotetext{
${ }^{23}$ Albiach (1971, p. 14).

${ }^{24}$ Kpaycc (2003, c. 25).

25 Там же, с. 19.

${ }^{26}$ См. Фуко (1999).
} 
В этом контексте идея решетки в блэкауте оказывается связана с политической проблематикой, с политическим субъектом. Блэкаут может быть использован для определенного политического манифестирования. Например, во время судебного рассмотрения дела участников московской передвижной антивоенной выставки $\{\mathrm{HE}$ МИР $\}$, поэт Дарья Серенко сделала несколько блэкаутов на страницах Уголовного кодекса. ${ }^{27}$ Участники выставки обвинялись в организации несанкционированного шествия: в марте 2016 года они прошли со своими работами по одной из московских улиц, расположенной недалеко от центра современного искусства «Винзавод», и были задержаны полицией.

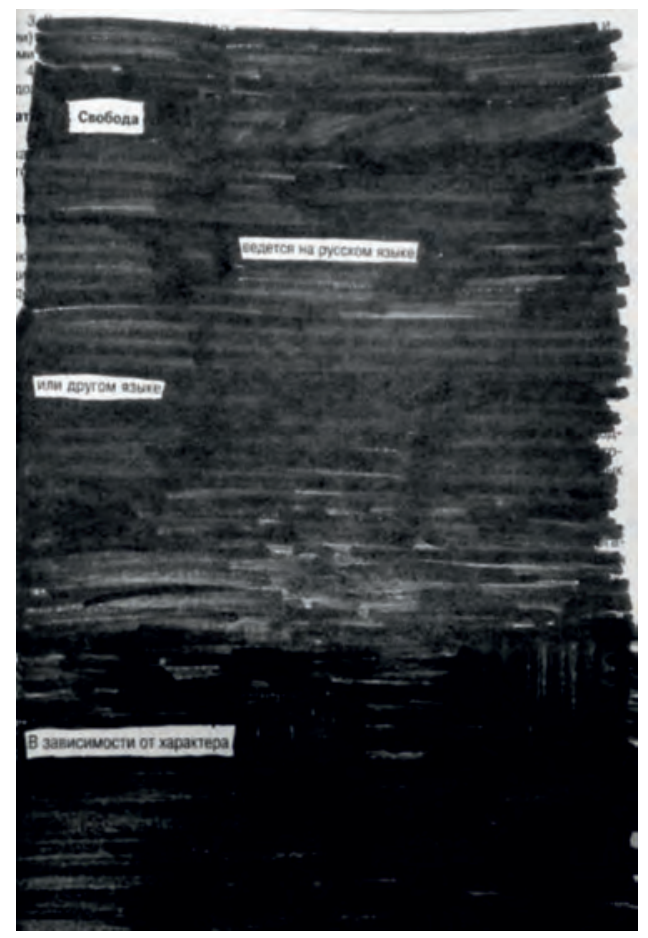

${ }^{27}$ Решетка блэкаута в этом случае символически может означать и пенитенциарную решетку. 


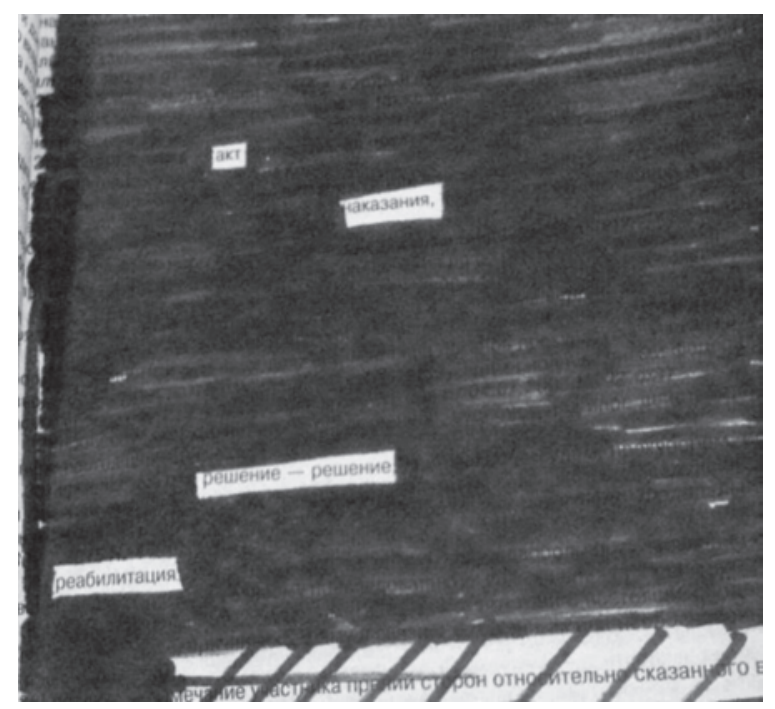

Блэкауты Дарьи Серенко, выполненные на Уголовно-процессуальном кодексе. 2016 г.

Важный смысл, который был невольно этим задержанием манифестирован, состоит в отсутствии права субъекта на так скажем «нулевое пространство», то есть свободное от действия регламентирующего закона. Любое место публичного пространства является политически обусловленным, его невозможно как бы впервые обнаружить и присвоить, поскольку одновременно с субъектом его открывает и присваивает власть. «Поэзия вычеркиваний» является поиском таких пустых мест, - нейтральных мест повседневности, в которых субъект получает право на собственное отсутствие. $^{28}$ В блэкаутах Дарьи Серенко эти места отмечены буквально пробелом - в них «наказание» должно как бы «утрачивать силу».

${ }^{28}$ В этом отношении блэкаут оказывается близок к идее психогеографии И. Щеглова. «Задача „психогеографа“ - заменить старые улицы города новыми. Дрейфуя по городу, надо переписать его как устаревшую книгу. Надо освободить город от жесткой сетки значений, навязанной ему. Надо сконструировать новые здания, где невозможно не быть влюбленным. Самая часто цитируемая фраза Щеглова: „Каждый будет жить в своем собственном соборе“» (Кузнецов 2003). 

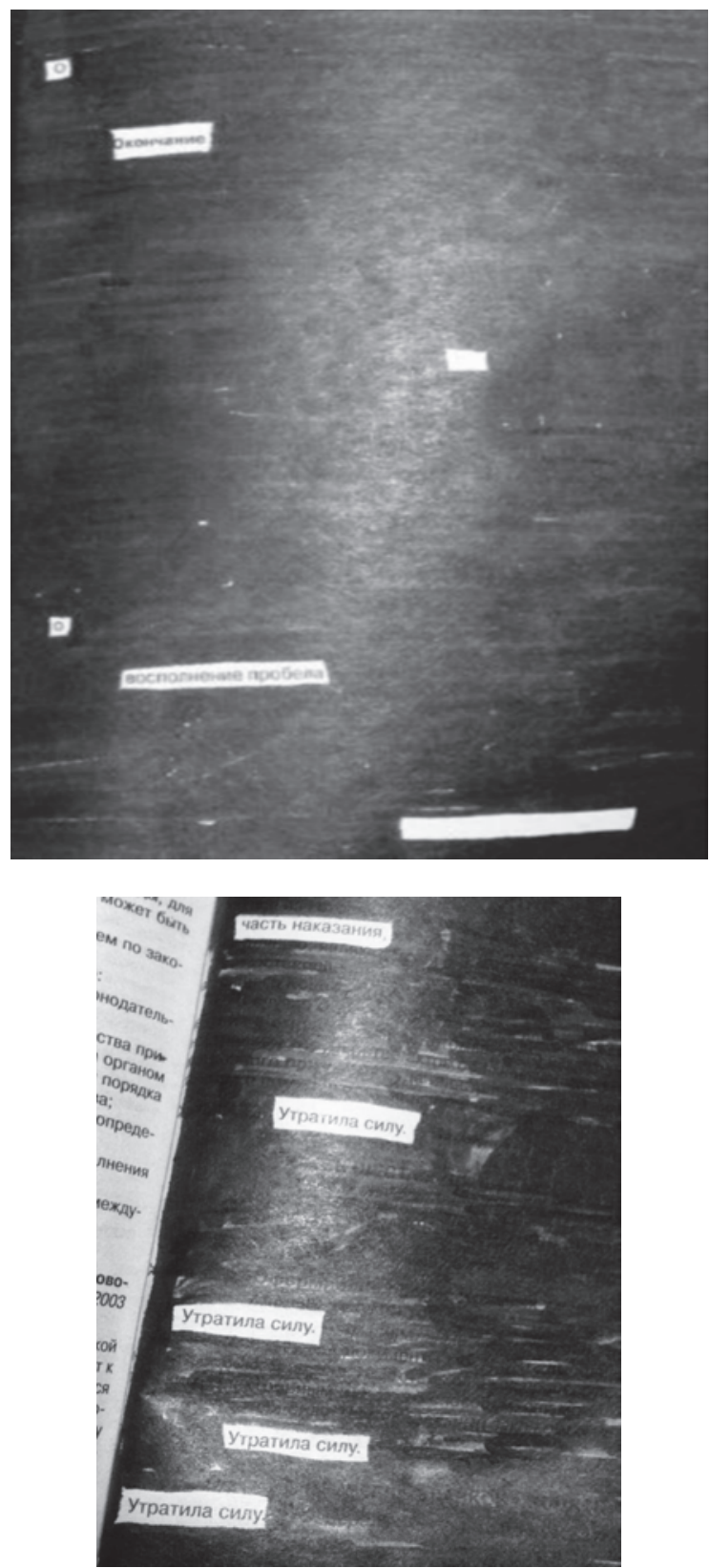

Блэкауты Дарьи Серенко, выполненные на Уголовно-процессуальном кодексе. 2016 г. 
Возможность таких мест чистой блэкаутной свободы субъекта заключена в самой идее решетчатого пространства, отрицающей, как на это указывает Р. Краусс, принцип перспективы ${ }^{29}$ и связанную с ним власть. Принцип перспективы лежит в основе организации мифологического пространства, что характеризует его как властецентричное. ${ }^{30}$ В мифе пространство возможно только в местах иерофаний, то есть в особых местах предельной концентрации и проявленности священного в мире. Полнота мифологической реальности обусловлена отношениями перспективы, то есть зависит от удаленности или приближенности к таким священным местам. ${ }^{31}$

Решетка блэкаута ничего не размечает с целью репрезентации какой-то иной реальности, и пространство здесь не имеет, как в мифе, привилегированных точек. Власть репрезентации как бы отменяется решеткой. ${ }^{32}$ В этом отношении блэкаут сближается с некоторыми практиками современного левого искусства, в котором критика политической репрезентации является одной из ключевых тем. Например, в работе Алисы Йоффе „Passe-port“ изображается дверной проем, края которого схвачены рамкой орнамента из российского паспорта.

Черный дверной проем выглядит как закрашенная страница паспорта и вызывает ассоциации с блэкаутом. Глеб Напреенко видит в этой работе критику идеи репрезентации, возможности политического представительства. ${ }^{33}$ Паспорт здесь никого не представляет, он не выполняет функцию удостове-

${ }^{29}$ Как отмечает Р. Краусс, «перспектива демонстрировала, каким образом реальность и ее репрезентация могут совпадать друг с другом, каким образом рисованный образ и его реальный прототип соотносятся друг с другом - как первый есть форма знания о втором. Все в решетке противостоит этому соотношению, с самого начала обрубает его. В отличие от перспективы, решетка не размечает пространство комнаты, пейзаж или группу фигур на плоскости картины. Если решетка что-то и размечает, то лишь саму поверхность холста» (Краусс 2003, с. 20-21).

${ }^{30}$ Под властью здесь понимается абсолютная божественная власть или власть как arche.

31 «Восприятие священного пространства делает возможным „сотворение Мира“: где в пространстве проявляется священное, там раскрывается реальное, и Мир начинает существовать» (Элиаде 1994, с. 46). Множество различных мифов повторяют эту основную космогоническую идею, связывая реальность Космоса с неким священным местом, центрирующая функция которого может передаваться образами столба, лестницы, горы, дерева, лианы (там же, с. 31).

32 Символически эту отмену выражает лишенная всякой перспективистской логики «решетка» П. Мондриана - «Композиция с Красным, Желтым, Синим и Черным» („Composition with Red, Yellow, Blue and Black“, 1921), удивительным образом совпадающая с композиционной структурой работы Веласкеса «Менины» (Аксенов 2013), которая, согласно известной интерпретации М. Фуко (Фуко 1994, с. 41-53), воплощает в себе перспективистскую логику власти.

33 См. лекцию Глеба Непреенко «О студии на Буракова, 27» из цикла «Древо современного русского искусства» в музее «Гараж» https://www.youtube.com/watch?v= sUOrUvYRBio (25/01/2018). 
рения личности: в том самом месте, где должна осуществляться коммуникация социального и индивидуального, находится пустое черное поле.

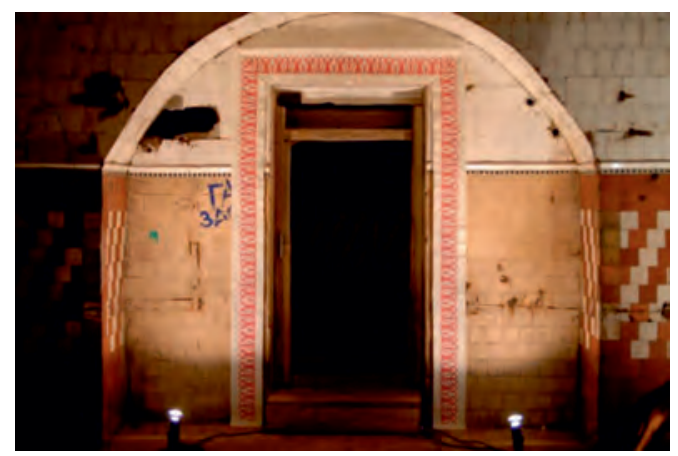

Алиса Йоффе. ,, Passe-port“, 2008.

В целом способы активного отсутствия субъекта в практиках блэкаута способны расширить возможности современной «левой поэзии», для которой проблема взаимоотношения субъекта и власти является существенной. Политическое содержание блэкаута усиливается также в его сближении с анархистской идеей отрицания. Как известно, еще М.А. Бакунин говорил о том, что «страсть к разрушению есть вместе с тем и творческая страсть!». ${ }^{34}$ При этом в самой «поэзии вычеркиваний» фигура политического субъекта не является центральной - блэкаут, прежде всего, связан с открытием и разработкой пространства поэтического. Блэкаут создает условия для активной незавершенности смысла: до конца никогда не ясно, закончился ли блэкаут и может ли он закончиться, не последует ли за первым блэкаутом еще один, который «вычеркнет» то, что осталось от первого. Всматриваясь в места, в которых может что-то активно отсутствовать, блэкаут не просто разрабатывает новые способы построения поэтической образности и субъекта, но пытается ухватить сами условия их возможности.

\section{Литература}

Агамбен, Дж. / Скидан, А. / Пензин, А. / Новиков, Д. (2010): «Поэтический субъект должен каждый раз быть произведен заново - только для того, чтобы затем исчезнуть»: диалог // Транслит. 8, 2010. 4-11.

${ }^{34}$ Бакунин (1935, с. 148). 
Азарова, Н. (2016): Мысли о поэзии. http://natalia-azarova.com/cgi-bin/index.pl?p=pensee (5/07/2016).

Айзенберг, М. (2011): Отзыв о поэзии Николая Байтова // Воздух. 1, 2011. http://www. litkarta.ru/projects/vozdukh/issues/2011-1/baitov-opinions/ (13/02/2018).

Аксенов, В. (2013): Философия квадрата, или К вопросу о семиотике формата в изобразительном искусстве // Фотожурнал. 2013. http://photo-element.ru/analysis/aks/aks.html $(28 / 07 / 2018)$.

Бадью, А. (2013): Философия и событие. Пер. с франц. Д. Кралечкина. М.

Байтов, Н. (2016): Readymade как литературная стратегия. http://www.levin.rinet.ru/ FRIENDS/BYTOV/statji/6.html (8/06/2016).

Бакунин, М. (1935): Реакция в Германии // Бакунин, М.: Собрание сочинений и писем. 1828-1876 гг.: В 4 тт. Т. 3. (Период первого пребывания за границей. 1840-1849). М. $126-148$.

Батай, Ж. (1997): Внутренний опыт. Пер. с франц. С. Фокина. СПб.

Гройс, Б. (2006): Топология современного искусства. Пер. с англ. А. Бобрикова // Художественный журнал. 61/62, 2006. http://xz.gif.ru/numbers/61-62/topologiya/ (8/06/2016).

Ревин, А. (ред., 1959): Краткая энциклопедия домашнего хозяйства: В 2 тт. М.

Краусс, Р. (2003): Подлинность авангарда и другие модернистские мифы. Пер. с англ. А. Матвеевой, К. Кистяковской, А. Обуховой. М.

Кузнецов, С. (2003): По ту сторону иметь и казаться: от Исидора Изу до Малколма Макларена, далее - везде // Новое литературное обозрение. 64, 2003. http://magazines.russ.ru/nlo/2003/64/kuz15.html (8/06/2016).

Суховей, Д. (2008): Графика современной русской поэзии: дис. ...канд. филол. наук. СПб.

Фуко, М. (1994): Слова и вещи. Археология гуманитарных наук. Пер. с фр. В. Визгина, Н. Автономовой. СПб.

Фуко, М. (1999): Надзирать и наказывать. Рождение тюрьмы. Пер. с франц. В. Наумова. М.

Черкасов, А. (2015а): Блэкауты // Воздух. 1-2, 2015. http://www.litkarta.ru/projects/ vozdukh/issues/2015-1-2/cherkasov/ (8/06/2016).

Черкасов, А. (2015b): Домашнее хозяйство. Избранное из двух колонок. М.

Элиаде, М. (1994): Священное и мирское. Пер. с франц. Н. Гарбовского. М.

Albiach, A. (1971): État. Paris.

Bernstein, Ch. (2015): Anne-Marie Albiach: Manuscript pages from „Etat“. http://jacket2.org/commentary/anne-marie-albiach-manuscript-pages-etat (8/06/2016). 